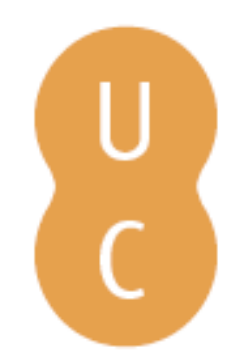

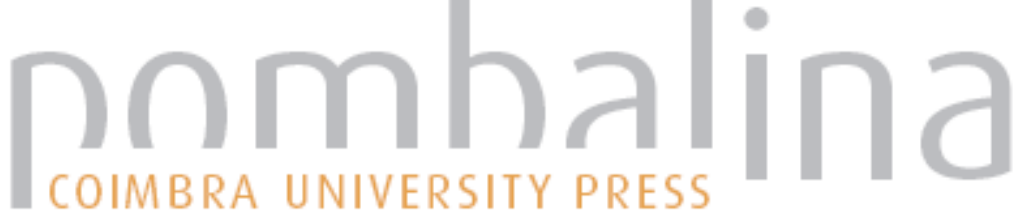

\section{Riscos e crises: da teoria à plena manifestação}

Autor(es): $\quad$ Lourenço, Luciano (coord.); Amaro, António (coord.)

Publicado por: Imprensa da Universidade de Coimbra

URL

persistente: URI:http://hdl.handle.net/10316.2/46014

DOI: $\quad$ DOI:https://doi.org/10.14195/978-989-26-1697-1

Accessed : $\quad$ 26-Apr-2023 13:30:04

A navegação consulta e descarregamento dos títulos inseridos nas Bibliotecas Digitais UC Digitalis, UC Pombalina e UC Impactum, pressupõem a aceitação plena e sem reservas dos Termos e Condições de Uso destas Bibliotecas Digitais, disponíveis em https://digitalis.uc.pt/pt-pt/termos.

Conforme exposto nos referidos Termos e Condições de Uso, o descarregamento de títulos de acesso restrito requer uma licença válida de autorização devendo o utilizador aceder ao(s) documento(s) a partir de um endereço de IP da instituição detentora da supramencionada licença.

Ao utilizador é apenas permitido o descarregamento para uso pessoal, pelo que o emprego do(s) título(s) descarregado(s) para outro fim, designadamente comercial, carece de autorização do respetivo autor ou editor da obra.

Na medida em que todas as obras da UC Digitalis se encontram protegidas pelo Código do Direito de Autor e Direitos Conexos e demais legislação aplicável, toda a cópia, parcial ou total, deste documento, nos casos em que é legalmente admitida, deverá conter ou fazer-se acompanhar por este aviso. 
LUCIANO LOURENÇO

ANTÓNIO AMARO

(COORDS.)
IMPRENSA DA

UNIVERSIDADE

DE COIMBRA

COIMBRA

UNIVERSITY

PRESS

\section{RISCOS E CRISES}

DA TEORIA À PLENA MANIFESTAÇÃO 
Este livro visa enquadrar o estudo dos diferentes tipos de risco que envolvem a intervenção dos agentes de proteção civil, ao mesmo tempo que procura especificar o significado, em língua portuguesa, de alguns dos principais conceitos associados à teoria do risco e contribuir para a definição da metodologia cindínica, concebida com um caráter holístico e, por conseguinte, diferente das análises parcelares feitas pelas ciências que para ela contribuem com metodologia própria das respetivas especialidades, quer se trate de ciências naturais, de ciências sociais e humanas ou de ciências económicas.

Deste modo e ao contrário destas ciências mais específicas, que apresentam uma visão mais especializada e, por isso, também mais parcelar dos riscos, as ciências cindínicas procuram concentrar-se no estudo global dos riscos, através de uma visão holística que abarca os diferentes tipos de manifestações porque se materializam.

Com efeito, apenas as ciências cindínicas possuem o conjunto dos riscos como objeto central e único de estudo, envolvendo todos os tipos e, também, as suas diferentes fases de manifestação, desde a prevenção até à recuperação das áreas onde se manifestaram e, ainda, os seus intervenientes, desde as personagens até às infraestruturas, ao contrário do que sucede com outras ciências que consideram os riscos mais como manifestações, as quais são estudadas apenas nos aspetos que dizem respeito à respetiva especialidade. Acresce que esta abordagem cindínica procura ser global e sistémica, isto é, tenta ter em linha de conta todos os elementos que explicam os diferentes tipos de risco, desde a sua origem: natural, antrópica ou mista, até às consequências provocadas pela sua manifestação, tanto nas pessoas, como nos seus bens e haveres.

Por fim, consideramos que a educação é a forma mais adequada para resolver os problemas resultantes da manifestação dos riscos, pelo que o conhecimento técnico-científico, materializado em diversos saberes, é fundamental para uma educação devidamente sustentada.

Por todas estas razões, a edição desta obra pretende dar um contributo para o saber cindínico e, através dele, para uma melhor educação e uma maior resiliência da população às manifestações de risco e, por conseguinte, contribuir para a redução do risco 
$R / 5005$

$$
\frac{\mathrm{I}}{\mathrm{U}}
$$




\section{Estruturas Editoriais}

Série Riscos e Catástrofes

Estudos Cindínicos

Diretor Principal | Main Editor

Luciano Lourenço

Universidade de Coimbra

\section{Diretores Adjuntos | Assistant Editors \\ Adélia Nunes, Fátima Velez de Castro \\ Universidade de Coimbra

\author{
Assistente Editorial | Editoral Assistant \\ Fernando Félix \\ Universidade de Coimbra
}

\section{Comissão Científica | Editorial BoArd}

Ana C. Meira Castro

Instituto Superior de Engenharia do Porto

António Betâmio de Almeida

Instituto Superior Técnico, Lisboa

António Duarte Amaro

Escola Superior de Saúde do Alcoitão

António Manuel Saraiva Lopes

Universidade de Lisboa

António Vieira

Universidade do Minho

Cármen Ferreira

Universidade do Porto

Helena Fernandez

Universidade do Algarve

Humberto Varum

Universidade de Aveiro

José Simão Antunes do Carmo

Universidade de Coimbra

Margarida Horta Antunes

Instituto Politécnico de Castelo Branco

Margarida Queirós

Universidade de Lisboa

Maria José Roxo

Universidade Nova de Lisboa

Romero Bandeira

Instituto de Ciências Biomédicas Abel Salazar, Porto

Tomás de Figueiredo

Instituto Politécnico de Bragança
Antenora Maria da Mata Siqueira

Univ. Federal Fluminense, Brasil

Carla Juscélia Oliveira Souza

Univ. de Sáo Joâo del Rei, Brasil

Esteban Castro

Univ, de Newcastle, Reino Unido

José António Vega

Centro de Investigación Forestal de Lourizán, Espanha

José Arnaez Vadillo

Univ.de La Rioja, Espanha

Lidia Esther Romero Martín

Univ. Las Palmas de Gran Canaria, Espanha

Miguel Castillo Soto

Universidade do Chile

Monserrat Díaz-Raviña

Inst. Inv. Agrobiológicas de Galicia, Espanha

Norma Valencio

Univ. Federal de São Carlos, Brasil

Ricardo Alvarez

Univ. Atlântica, Florida, Estados Unidos da América

Victor Quintanilla

Univ. de Santiago de Chile, Chile

Virginia Araceli García Acosta

Univ. Nacional Autónoma de México

Xavier Ubeda Cartañà

Univ, de Barcelona, Espanha

Yvette Veyret

Univ. de Paris X, França 
LUCIANO LOURENÇO

ANTÓNIO AMARO

(COORDS.)
IMPRENSA DA

UNIVERSIDADE

DE COIMBRA

COIMBRA

UNIVERSITY

PRESS

RISCOS E CRISES

DA TEORIA À PLENA MANIFESTAÇÃO 
EDIÇÃo

Imprensa da Universidade de Coimbra Email: imprensa@uc.pt

URL: http//www.uc.pt/imprensa_uc

Vendas online: http://livrariadaimprensa.uc.pt

COORDENAÇÃO EDITORIAL

Imprensa da Universidade de Coimbra

CONCEÇÃo GRÁFICA

Imprensa da Universidade de Coimbra

\author{
PRÉ-IMPRESS Ão \\ Fernando Felix \\ INFOGRAFIA DA CAPA \\ Mickael Silva \\ EXECUÇão GRÁFICA \\ KDP \\ ISBN \\ 978-989-26-1696-4
}

ISBN DIGITAL

978-989-26-1697-1

DOI

https://doi.org/10.14195/978-989-26-1697-1
Riscos - Associação Portuguesa de Riscos, PRevenção e Segurança TEL.: +351 239992 251; FAX: +351239836733
E-MAIL: RISCOS@UC.PT




\section{SUMÁRIO}

PREFÁCIO ................................................................................... 7

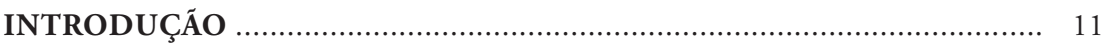

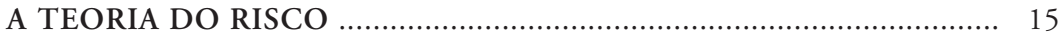

Alguns conceitos à luz da teoria do risco

Luciano Lourenço e A. Betâmio de Almeida ...................................... 17

Repensando os riscos, com um olhar desde o território

María Augusta Fernández Moreno ..................................................... 79

A visão do risco pela sociologia

Norma Valêncio

Uma classificação de riscos na óptica da proteção civil

Luciano Lourenço

AS QUESTÓES METODOLÓGICAS DA ANÁLISE E AVALIAÇÃO

DO RISCO EM DIFERENTES CIÊNCIAS

Questóes metodológicas da análise e avaliação do risco

Adélia Nunes e Fátima Velez de Castro

Modelos de gestão dos riscos e as políticas públicas

Alexandre Oliveira Tavares

PREVENÇÃO, SOCORRO E REABILITAÇÃO, OS TRÊS PILARES

DE SUSTENTAÇÃO DE UMA PROTEÇẪO CIVIL MODERNA

A gestáo do risco, como uma medida de prevençáo

A. Bento Gonçalves, A. Vieira, L. Martins, D. Pereira e J. Monteiro ..... 209 


\section{SUMÁRIO}

A gestão da catástrofe, como medida de resposta à crise

Salvador Almeida

Intervenção médico sanitária urgente em situaçóes de catástrofe. Análise e conceptualização

Romero Bandeira

Sistema de proteção e socorro em Portugal - Evolução e desenvolvimento

António Amaro

A recuperação emocional e o apoio psicológico às vítimas

Cristina Queirós e Fernando Passos

A gestão da pós-catástrofe, como medida de proteção e de mitigação da crise, bem como de aumento da resiliência

A socialização pós-catástrofe

Norma Valêncio 


\section{PREFÁCIO}

O propósito da RISCOS organizar uma série de livros sobre "riscos e catástrofes" surgiu da necessidade que sentimos de colocar à disposição dos interessados na temática dos riscos e das suas plenas manifestaçóes, as catástrofes (sejam eles professores, investigadores, estudantes, agentes de proteçáo civil ou cidadáos), algumas obras de qualidade, escritas em português, que deem a conhecer o que pensam e investigam alguns dos principais expoentes lusófonos das ciências cindínicas e da educação para a redução do risco, procurando criar um forum de discussão, que ajude a consolidar a terminologia científica que, em português, contribua para a construção desse edifício cindínico em que todos nos possamos rever.

A RISCOS, enquanto Associação de cidadãos, tem um importante papel a desempenhar na Proteção Civil, uma vez que, de acordo com o n. ${ }^{\circ} 1$ do Artigo $1 .^{\circ}$ da respetiva Lei de Bases, a proteção civil é uma atividade a ser desenvolvida pelo Estado, Regióes Autónomas e autarquias locais, pelos cidadãos e por todas as entidades públicas e privadas, como é o caso da RISCOS - Associação Portuguesa de Riscos, Prevenção e Segurança, com a finalidade de prevenir riscos coletivos inerentes a situaçóes de acidente grave ou catástrofe, de atenuar os seus efeitos e proteger e socorrer as pessoas e bens em perigo quando aquelas situaçóes ocorram.

Nesta conformidade, a RISCOS desenvolve diversas atividades com a finalidade de colaborar tanto na prevenção de riscos coletivos, como na atenuação dos efeitos das suas manifestaçóes. De entre essas atividades, uma das que reputamos de mais importantes diz respeito à criação de uma série de livros científicos e técnicos sobre "Riscos e Catástrofes", cujo primeiro volume, que se previu para abrir esta série, corresponde àquele que só agora se dá à estampa.

Todavia, por circunstâncias várias, desde atrasos na entrega de textos por parte de alguns autores a acontecimentos diversos que, entretanto, se sucederam e justificaram a publicação das obras já editadas, levaram a que a série se tivesse iniciado com a publicação de outras obras, pois já conta com cinco volumes editados, deixando também para mais tarde a publicação dos outros três tomos que, de igual modo, a deveriam ter iniciado, respetivamente sobre catástrofes naturais, catástrofes antrópicas e catástrofes mistas. 
Estas três obras deveriam ser organizadas dentro da lógica de subdivisōes apresentadas no capítulo 1.3., que trata da classificaçáo dos riscos, mas, como o ritmo de chegada dos textos foi muito diferente do inicialmente previsto, isso obrigou à reformulação desse plano, sobretudo para não atrasar mais a publicação dos capítulos dos autores que cumpriram com os prazos estabelecidos, razão pela qual a edição destes quatro volumes ficou comprometida no modelo previamente definido e foi necessário proceder a alguns ajustes, de modo a dar à estampa os capítulos que foram produzidos.

Em função desse atraso, a edição destes tomos acabou por vir a coincidir com a de outros volumes cuja publicaçáo estava prevista para mais tarde, mas que, entretanto, ficaram concluídos, pelo que as respetivas ediçôes irão processar-se alternadamente.

Por outro lado, a disseminação de conhecimentos técnicos e científicos que procuraremos fazer nesta série de livros, deverá ser seguida do necessário debate dos conceitos mais controversos, dando passos importantes para o amadurecimento do significado dos diferentes vocábulos, com o objetivo de implementar uma terminologia que possa vir a ser o mais consensual possível, de modo a permitir melhorar não só a qualidade do ensino e da prática pedagógica nas escolas, mas também a formaçáo e operacionalidade dos agentes de proteção civil.

Com vista à concretizaçáo deste propósito foram dados alguns passos significativos, tanto pelo Ministério da Administração Interna, através da Autoridade Nacional de Proteção Civil, em coedição com a Direção-Geral do Ordenamento do Território e Desenvolvimento Urbano e o Instituto Geográfico Português, bem como pelo Ministério da Agricultura, do Desenvolvimento Rural e das Pescas, através da Direção-Geral dos Recursos Florestais, atual Instituto de Conservação da Natureza e das Florestas, e, mais recentemente, pelo Ministério da Educação e Ciência, através da Direção-Geral de Educação e da Direção-Geral dos Estabelecimentos Escolares, que contaram com a colaboraçấo Autoridade Nacional de Proteção Civil, tendo instituído instrumentos orientadores muito importantes para a concretização desses objetivos, designada e respetivamente através de: (i) Guia metodológico para a produçáo de cartografia municipal de risco e para a criaçáo de sistemas de informação geográfica (sig) de base municipal, Lisboa, 2006; (ii) Guia técnico para elaboração do plano municipal de defesa da floresta contra incêndios; 
(iii) 2015 - Referencial de Educação para o Risco - Educação Pré-Escolar, Ensino Básico e Ensino Secundário, Lisboa, 2007.

Todavia, do nosso ponto de vista e como tivemos ensejo de manifestar após as respetivas publicações, estes instrumentos foram infelizes no posicionamento do conceito perigosidade, uma vez que alteraram a sua posição na sequência hierárquica da teoria do risco, adulterando o seu significado usual em português e introduzindo, por isso, alguma entropia na lógica em que deve assentar a teoria do risco e que, na nossa óptica, enquanto náo for corrigida, por muito que isso possa custar aos organismos que procederam à sua difusão, continuará a enfermar e a distorcer a realidade e, por conseguinte, a compreensão daquilo a que se convencionou chamar "teoria do risco".

A publicação do Referencial de Educação para o Risco, teria permitido resolver interna e serenamente esta situação, mas percebemos que as entidades supramencionadas não tiveram a humildade científica necessária para discutir o correto posicionamento desse conceito, porventura em resultado do incómodo que tal decisão acarretaria, pelo que se perdeu essa excelente oportunidade e, por conseguinte, não nos resta outra alternativa que não seja a de tentarmos divulgar uma outra opinião, um entendimento diferente do significado desse conceito, deixando ao leitor a decisão de optar pela perspetiva que considerar mais correta.

Neste contexto, a série está aberta à pluralidade das opinióes expressas pelos autores que nela queiram colaborar, sem fundamentalismos nem radicalismos, mas defendendo naturalmente os seus pontos de vista, com o objetivo de prosseguir um caminho sustentado numa lógica racional, que aponte para um modelo objetivo, que siga uma linha de rumo coerente, clara, bem definida e, em simultâneo, suficientemente abrangente, de modo a que todas as diferentes ciências que contribuem para a cindínica nele se possam rever, estando naturalmente aberto a todos os contributos que possam ajudar a melhorá-lo e a enriquecê-lo.

Ao longo dos anos em que temos vindo a desenvolver investigação científica, percebemos que a educação é a forma mais adequada para resolver os problemas com que qualquer país se possa debater e que o conhecimento técnico-científico, materializado em diversos saberes, é fundamental para uma educação devidamente sustentada, pelo que a proposição de esta nova série também pretende dar um 
contributo para o saber cindínico e, através dele, para uma melhor educação e uma maior resiliência da população às manifestaçóes de risco e, por conseguinte, contribuir também para a reduçáo do risco.

Coimbra, 10 de junho de 2018

Luciano Lourenço 


\section{INTRO D UÇÃO}

\section{Luciano Lourenço \\ Departamento Geografia e Turismo, CEGOT e RISCOS, Universidade de Coimbra (Portugal) ORCID: 0000-0002-2017-0854 luciano@uc.pt}

A edição desta obra, que foi pensada para ser a primeira e, por conseguinte, para abrir a nova série "Riscos e Catástrofes", foi concebida para fazer o enquadramento desta série na chamada Cindínica, a ciência que estuda os riscos naturais, antrópicos e mistos, bem como a prevenção das suas plenas manifestaçôes, as catástrofes.

Como é sabido, o termo provém do vocábulo grego Kyndinos, que significa "perigo", uma vez que a manifestação dos riscos normalmente acarreta perigo para as sociedades, quer seja diretamente para as pessoas, quer diga respeito aos seus bens.

Este termo foi ganhando consistência durante o último quartel do século passado, tendo sido definido nessa época, mais precisamente na década de noventa, altura em que foi popularizado por George-Yves Kervern, através da sua célebre obra Éléments fondamentaux des Cindyniques, publicada em 1995 e traduzida para português nesse mesmo ano.

Nesta publicação, o signatário além de enquadrar a problemática associada ao estudo dos riscos, especificou o significado de alguns dos principais conceitos, bem como definiu a metodologia desta nova disciplina concebida com um caráter holístico, completamente diferente das análises parcelares feitas pelas outras ciências que também estudam os riscos numa perspetiva mais especializada, quer se trate de ciências naturais, de ciências sociais e humanas ou, mesmo, de ciências económicas.

Com efeito, ao contrário destas ciências mais específicas, que apresentam uma versão especializada mas parcelar dos riscos, as ciências cindínicas procuram concentrar-se no estudo global dos riscos, através de uma análise e visão holística desta temática. De facto, apenas as ciências cindínicas possuem os riscos como objeto central e único de estudo, envolvendo todos os tipos e as diferentes fases de manifestação dos riscos, desde a prevenção até à recuperação das áreas onde se manifestaram, bem como os seus intervenientes, desde as personagens às infraestruturas, ao contrário do que sucede com as outras ciências que consideram os riscos mais 
como manifestaçôes, as quais são estudadas apenas nos aspetos que dizem respeito à respetiva especialidade.

Acresce que esta abordagem cindínica procura ser global e sistémica, isto é, tenta ter em linha de conta todos os elementos que explicam os diferentes tipos de risco, desde a sua origem: natural, antrópica ou mista, até às consequências provocadas pela sua manifestação, tanto nas pessoas, como nos seus bens e haveres.

Ora, pela sua dupla formação, tanto em ciências da natureza, no domínio da geografia física, como em ciências sociais, na componente da geografia humana, os geógrafos estão particularmente bem posicionados para se interessarem pelas ciências cindínicas, tanto mais que a geografia, enquanto ciência de síntese e ponto de convergência de vários saberes, lhes permite materializar, de forma muito particular, as implicaçóes espaciais, sociais e ambientais dos riscos e das suas plenas manifestaçôes, as catástrofes, nos diferentes territórios.

Com efeito, a sua formação na componente física, permite-lhes serem particularmente sensíveis aos processos que estão subjacentes ao desenrolar dos diversos fenómenos naturais que podem originar riscos, procurando situá-los no tempo e no espaço, já que a maior ou menor severidade dos danos por eles causados resultará dessa localização, bem como da intensidade com que o fenómeno se vier a manifestar.

Por outra parte, a componente humana da sua formação, deixa-os particularmente preparados não só para a análise dos fenómenos que desencadeiam riscos antrópicos, mas também e sobretudo para interpretarem a vulnerabilidade das sociedades e das infraestruturas que ficam expostas à manifestaçáo do risco, decorrentes da respetiva fragilidade e das eventuais capacidades de antecipação e de resposta, outro aspeto fundamental a ter em conta na avaliação desses danos, outro papel para o qual também estão habilitados, pelo que não será de estranhar que muitos geógrafos se tenham dedicado ao estudo dos riscos.

Acresce que a sua formação em ordenamento do território lhes permite fazer leituras precisas sobre o modo como os territórios devem estar ordenados para uma adequada gestão dos respetivos riscos, através das medidas cautelares consideradas necessárias e que, entre outras, passam por medidas estruturais, que decorrem do zonamento em diferentes níveis de risco, e por medidas conjunturais, designadamente de informação, sensibilização e educação. 
Com efeito, ao longo dos anos em que temos vindo a desenvolver investigação científica, percebemos que a educaçáo é a forma mais adequada para resolver os problemas com que qualquer país se possa debater e que o conhecimento técnico-científico, materializado em diversos saberes, é fundamental para uma educação devidamente sustentada, pelo que a proposiçấo desta nova série também pretendeu dar um contributo para o saber cindínico e, através dele, para uma melhor educação e uma maior resiliência da populaçáo às manifestaçóes de risco e, por conseguinte, contribuir para a reduçáo do risco.

Porque possuem esta visão holística e pela sua capacidade de realizar sínteses, os geógrafos estáo bem posicionados para liderar equipas cindínicas em que a intervençáo de outros profissionais especializados (das engenharias à sociologia, da geologia à história, da economia ao jornalismo, da química à antropologia, da medicina à informática, para referir apenas algumas das ciências intervenientes) é essencial, para levar a bom porto uma correta gestáo dos riscos, a fim de prevenir a sua manifestação e, sobretudo, a minimizaçấo das suas nefastas consequências, sempre que eles vierem a manifestar-se, por não ter sido possível evitar essa sua manifestação.

Talvez por essa razão também náo será de admirar que grande parte dos autores dos capítulos, tanto deste livro como dos seguintes, além de associados da RISCOS, muitos deles sejam também doutorados em geografia. Obviamente que não se trata de uma condição sine qua non, pois há diversos autores especialistas de outras áreas científicas e foram convidados outros que declinaram os convites, mas apenas denota essa maior propensão dos geógrafos para se dedicarem ao tratamento deste temas, razão pela qual é desta área científica que surgiu a maior parte dos autores, mas a série está naturalmente aberta à participaçấo de todos quantos nela queiram publicar os resultados da sua investigação científica na área das ciências cindínicas.

Feito o convite, aguardamos pelos vossos contributos, na expectativa de que esta série possa vir a publicar muitas obras e, assim, possa servir para educar e, através da educação, contribuir para a redução do risco. 
(Página deixada propositadamente em branco) 
A TEORIA DO RISCO 
(Página deixada propositadamente em branco) 


\section{ALGUNS CONCEITOS À LUZ DA TEORIA DO RISCO* RISKS. SOME CONCEPTUAL ASPECTS}
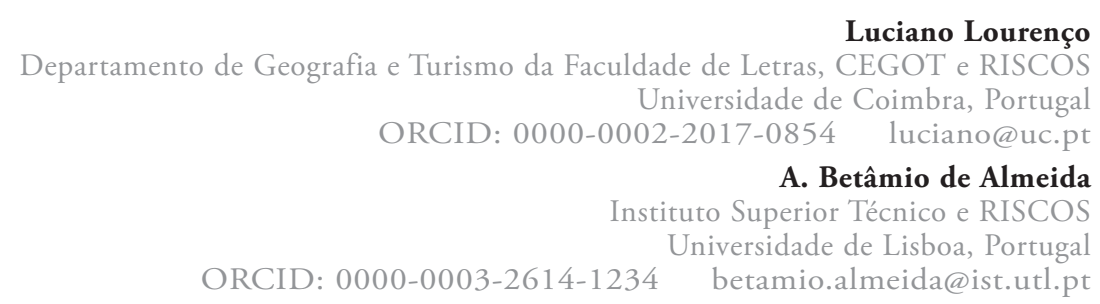

Sumário: A teoria do risco assenta em três conceitos base: risco, perigo e crise, termos que nem sempre, em português, são utilizados de acordo com o seu significado etimológico. Por sua vez, em linguagem técnica, o uso de alguns vocábulos assume um significado específico, mas nem sempre são usados corretamente pelos técnicos. Acresce que outros conceitos são referidos com frequência e a despropósito, mas que por serem ditos com total à vontade, até parece que estão corretos. Este texto visa apresentar o nosso ponto de vista e o entendimento que temos sobre vários destes conceitos, tratados à luz da teoria do risco e integrados no ciclo da catástrofe, numa abordagem voltada para o socorro e a emergência, numa lógica que se enquadra na análise e gestão de riscos em proteção civil.

Palavras-chave: Risco, perigo, crise, análise de riscos, gestão de riscos e de crises.

\footnotetext{
* Este texto resulta da reflexâo que temos vindo a fazer sobre alguns conceitos aplicados às ciências cindínicas, correspondendo assim a uma versão revista e ampliada dessa contextualização apresentada em trabalhos anteriores (Lourenço, 2014 e 2015).
} 


\begin{abstract}
The theory of risk is based on three basic concepts: risk, danger and crisis, terms that are not always used in Portuguese in keeping with their etymological meaning. In technical language, however, certain words should be used for their specific meaning but they are not always used correctly by technicians. In addition, other concepts are often used inappropriately but because they are spoken with total ease, they in fact seem to be correct.

This text aims to present our point of view and our understanding of several of these concepts, examined in the light of risk theory and included in the disaster cycle in an approach focused on relief and emergency, in a rationale of analysis and risk management in civil protection.
\end{abstract}

Keywords: Risk, danger, crisis, risk analysis, risk and crisis management.

\title{
Introduçáo
}

Todos sabemos que as palavras estâo sujeitas a modificaçôes, a evoluçóes, tanto na forma como no sentido, e que os seus campos semânticospodem restringir-se ou dilatar-se no decurso dos tempos. Mau é que, por vezes, evoluam num dado sentido por lapso, incúria ou má interpretação.

A. Machado Guerreiro (1987)

Muito tem sido escrito sobre o entendimento, em língua portuguesa, de alguns conceitos associados à terminologia dos riscos e o assunto está longe de estar encerrado. Com efeito, não estamos de acordo com algumas interpretaçóes dadas a determinados vocábulos que, na nossa opinião e em linguagem comum, têm um significado diferente daquele que lhes é atribuído por alguma terminologia científica, como é o caso de perigo, do mesmo modo que, em linguagem técnica, o uso de alguns termos assume um significado específico mas que, frequentemente, os técnicos não usam corretamente e de que, entre outros, são exemplo: incidente, 
em vez de ocorrência, fogo, quando se referem a incêndio, supressão, no lugar de extinção, reabilitação, que se associa à intervenção de emergência, e recuperação, que corresponde à intervenção de consolidação e reconstrução, decorrendo durante mais tempo, com intervenções de médio e longo prazo. Por último, outros conceitos são referidos a despropósito, como é o caso das condiçôes climatéricas, termo que, para além de corresponder a um galicismo, em substituição das condiçóes climáticas, normalmente é mencionado a propósito das designadas condiçóes meteorológicas adversas, relativas a um determinado tipo de tempo muito específico e que, por corresponderem a situaçôes excepcionais, pouco têm a ver com o clima "normal" a que pretendem aludir.

Para esta difusão, menos correta, muito têm contribuído alguns jornalistas, ávidos de sensacionalismo, bem como alguns políticos, sedentos de mediatismo, e também vários operacionais, em busca de aparente modernidade e inovação, ou, ainda, outros utilizadores que, por desconhecimento, usam estes conceitos de forma menos apropriada, mas que, face à força da sua repetição, nos meios de comunicação social ou nas açôes de formação de operacionais, entraram na moda e, inconscientemente, passam a ser usados com um significado diferente do etimológico e que, por isso, consideramos menos correto.

Contrariando um pouco essas tendências, este texto apresenta o nosso entendimento sobre estes e outros conceitos, tratados à luz da teoria do risco e integrados no ciclo da catástrofe, sendo abordados numa lógica de proteção civil, voltada tanto para o socorro e a emergência, como para a prevenção e a recuperação.

A difusão desta nossa opinião, ainda que por vezes possa ser contrária à que se encontra instalada, visa levar o leitor a refletir sobre o assunto, de modo a que depois, conscientemente, possa optar pelo significado que, para determinado conceito, lhe pareça fazer mais sentido em língua portuguesa.

Com efeito, consideramos que a reflexão e a discussão científica do significado dos termos, que por vezes até evolui com o tempo, são uma das caraterísticas do ensino superior e da investigação universitária e, por conseguinte, entendemos que não devemos abdicar delas, tanto mais que ao considerar o significado dos termos usados pelos operacionais, na linguagem da emergência e do socorro, entendemos que deverá ser o mesmo que lhe é atribuído 
pelos cidadáos comuns, o que, de facto, atualmente não sucede com alguns vocábulos e que, na nossa óptica, não existe nenhuma razáo que leve a que tal não possa ser corrigido.

Para nós, seria muito mais cómodo "alinhar" com o sistema instituído, abdicando do papel interventivo que os cidadáos devem ter na sociedade e, mormente, em proteção civil, mas como tal náo se coaduna nem com a nossa forma de pensar, porque somos defensores do princípio de melhoria contínua, nem com o nosso modo de estar em sociedade, onde entendemos dever ser cidadáos participativos, náo podemos deixar de continuar a alertar para aquilo que, na nossa modesta opiniāo, pode e merece ser melhorado.

Já depois de termos redigido este capítulo, foi dado à estampa um importante documento sobre Science for disaster risk management 2017. Knowing better and losing less (K. Poljanšek et al., 2017) que, pontualmente, contém uma ou outra interpretação diferente daquelas que aqui são apresentadas. Todavia, como refere Betâmio de Almeida (2018, p. 165) a propósito desse documento "o rigor científico e a harmonização de conceitos e metodologias nem sempre estão conseguidos" razão pela qual não nos sentimos obrigados a seguir na íntegra todas as propostas aí apresentadas, se bem que, na generalidade, este documento constitua um excelente instrumento de divulgação da gestão das plenas manifestações de risco, ou seja, de catástrofes.

\title{
A teoria do risco
}

\author{
"O risco, objeto social, define-se como a percepção do perigo, da \\ catástrofe possivel."
}

Yvette Veyret (2007)

Atendendo a que o conceito "risco" teve mais do que um percurso epistemológico e etimológico, e foi sendo enriquecido com diferentes dimensóes ou escalas e através de diferentes domínios de aplicação, em particular durante o séc. XX, é natural que existam diferentes pontos de vista sobre este conceito. 
No final do século XX e no século XXI, o risco passou a ser considerado, utilizado, calculado, incorporado e gerido por, praticamente todas as disciplinas científicas e ramos do saber, bem como pelas mais diversas organizaçóes e finalidades. Da atividade dos seguros, à gestáo de empresas, à economia, à atividade financeira, à geografia, engenharia, sociologia, psicologia, direito, proteçâo civil, medicina, biologia, ética, estratégia militar ou de segurança... até à comunicação social e à política, o "risco" passou a ser incorporado e depurado consoante a experiência de cada disciplina ou a força do utilizador. Em aplicaçôes e contextos dos mais diversos, a gestão do risco passou a ser adoptada, em muitas situaçóes, como um instrumento de decisão e de política.

Já entrados no século XXI, há uma tendência para uma convergência de definiçóes. As instituiçóes internacionais como as Naçóes Unidas, a OCDE, o Banco Mundial, a EU, bem como as normas técnicas (eurocódigos) contribuíram para haver um espectro muito mais estreito de definiçóes.

No entanto, o conceito risco ainda se localiza entre uma percepção subjetiva ou social, relativamente difusa, ampla e plástica, até uma posiçáo limite de grandeza quantificável e quase tornada objetiva como a adoptada na análise quantitativa do risco.

Num trabalho precursor, que intitulou "La dimension des faits et la théorie $d u$ risque", apresentado ao Seminário "Risques naturels, risques technologiques. Gestion des risques, gestion des crises", que decorreu em Saint-Valery-sur-Somme, de 2 a 7 de outubro de 1989, Lucien Faugères (1990) fez o enquadramento de diversos conceitos, a partir dos quais se lançaram os fundamentos da teoria do risco.

Todavia, apesar de depois desse Seminário muito se ter escrito sobre o assunto, poucas vezes este e outros trabalhos que nele foram apresentados constam das referências bibliográficas dos textos dedicados a esta temática, muito provavelmente por terem sido redigidos em francês e por não se encontrarem disponíveis na internet.

No entanto, esta menção ao trabalho de Lucien Faugères parece-nos fundamental em qualquer estudo que aluda à teoria do risco, na medida em que nele se hierarquizaram claramente os conceitos de risco, perigo e crise, ao contrário do que sucede em muitos outros trabalhos onde, por vezes, alguns destes termos se confundem, porventura em resultado da dificuldade de traduçâo de certos vocábulos, 
como, aliás, muito recentemente foi comprovado por diversos especialistas (Rebelo, 2014; Pedro, 2014, Lourenço, 2014).

Pela nossa parte, apenas pretendemos dar mais uma contribuiçáo ${ }^{1}$, no sentido de ajudar a clarificar aquilo que entendemos por cada um destes termos, dentro da tal sequência hierarquizada e num quadro de intervenção dos vários agentes de proteção civil, uma vez que o modelo conceptual que está subjacente a essa hierarquização visa a sua aplicação prática em termos operacionais, independentemente do tipo de agente interveniente (serviços de proteção civil, bombeiros, forças de segurança, ...), tanto na análise de riscos, como nas situaçóes concretas em que eles se manifestam.

Assim, mais do que apresentar o estado da arte sobre a matéria em apreço, visamos contribuir para clarificar aquilo que os portugueses tradicionalmente entendem como sendo o significado de alguns conceitos usados na linguagem da emergência e do socorro e que, por transliteraçóes e traduçóes menos corretas associadas à divulgação científica de alguns conceitos, tem vindo a ser deturpado, gerando alguma confusão, tanto mais que ao ser vertida em documentos oficiais, ela acaba por se instalar, mas tal não significa que esse uso, apesar de institucional e, até, legalmente consagrado, esteja correto em português corrente.

\footnotetext{
${ }^{1}$ A questấo terminológica é um assunto que sempre nos preocupou e, por isso, após a publicação do Guia Metodológico para Elaboração do PMDFCI (DGRF, 2006), o primeiro autor redigiu uma pequena nota que intitulou "Perigos das cartas de risco" (Lourenço, 2008), onde descreveu algumas das razóes pelas quais náo concorda com o uso que tem sido dado ao conceito de perigosidade. Depois disso, outras publicaçóes oficiais (Julião et al., 2009; Saúde et al., 2015) têm insistido no uso desse e de outros termos, razão pela qual entendeu não dever deixar cair este assunto.

Com efeito, já muito antes dessa nota e a seu pedido, o grande divulgador da teoria do risco em Portugal, o falecido Professor Doutor Fernando Rebelo, abordou na conferência de abertura do II Encontro Pedagógico sobre Risco de Incêndio Florestal, Coimbra, 21 a 23 de Fevereiro de 1994, o tema "Risco e Crise. Grandes Incêndios Florestais" (Rebelo, 1994), onde, numa primeira intervenção, clarificou "os conceitos de risco, perigo e crise e a sua aplicação ao estudo dos grandes incêndios florestais". Depois, no ano seguinte, voltou ao assunto, publicando esta conferência na revista Biblos, da Faculdade de Letras da Universidade de Coimbra (Rebelo, 1995).

Aliás, os temas "risco, perigo e crise" passaram a ser recorrentes nos anos subsequentes em diversas publicaçóes desse autor, de entre as quais mencionamos: F. Rebelo 1996, 1997a, 1997b, 1998, 1999, 2001a, 2001b, 2008, 2010, 2013 e 2014, obras onde não só podem ser encontrados mais argumentos a favor desta sequência, mas também e, sobretudo, porque nelas eles estáo expostos de forma bem mais eloquente do que a presente, razão pela qual se mencionam, pois, também eles, raramente são referidos nos estudos redigidos em português sobre esta temática.
} 
Ora, como é em português que comunicamos e como a linguagem de socorro e emergência é usada tanto pelos operacionais como pelos cidadãos comuns, seria conveniente que a utilização de qualquer termo tivesse o mesmo significado, independentemente de ser usado pelos operacionais ou pelos cidadãos.

A título de exemplo, podemos referir que o cidadão comum sabe distinguir muito bem e de forma bem pragmática as situaçóes em que ele está em risco, daquelas outras em que pode correr perigo, pelo que as expressóes "estar em risco" e "correr perigo" assumem significados bem distintos e, por conseguinte, devem implicar abordagens e medidas, tanto de prevenção como de segurança, bem diferentes.

Assim, esta nossa reflexão irá partir da existência, na linguagem comum, de um limiar que marca a transição do "risco" para a "crise" e que, na nossa perspetiva, corresponderá ao "perigo" efetivo. Neste contexto, a crise é entendida como sendo a plena manifestação ou realização do risco, admitindo-se que, até então, o risco está latente e o perigo é uma hipótese e, por conseguinte, pode nunca se manifestar, ou seja, pode nunca representar perigo efetivo, uma vez que este só acontece quando o risco se manifesta. Desta forma, o "perigo" está indelevelmente associado à manifestação do risco e, por conseguinte, ele é indissociável do início da crise.

De facto, se o risco é algo que está mais ou menos distante da manifestação, o perigo é algo que está muito próximo dessa manifestação e, por conseguinte, só deveremos falar de perigo quando a manifestação do risco, ou seja, a crise, está mesmo iminente. Deste modo, o perigo poderá ser comparado a uma linha amarela, a qual não deverá ser nunca transposta, pois corresponde ao limiar de transição que marca a passagem do risco para a crise. Por outro lado, ao contrário do risco, o perigo é normalmente acompanhado por sinais que alertam para a iminência da manifestação do risco, ou seja, significa que as pessoas e/ou os seus bens e haveres deixam de estar em risco para passarem a correr perigo efetivo.

Com efeito, se a linha amarela for transposta, deixaremos de estar na situação de risco, que podemos fazer corresponder à cor verde ou amarela consoante o valor do risco, para passarmos ao estádio seguinte, correspondente à manifestação desse risco, ou seja, à crise, a qual pode ser representada pela cor vermelha. Ora, se tal ocorrer, isso significa que o risco se está a manifestar e, como consequência, corre-se perigo efetivo. 
Deste modo, o perigo está assim presente durante todo o desenrolar da crise, embora de forma diversa, pois regista particular acuidade durante a manifestação do processo em causa (sismo, inundação, deslizamento, incêndio, explosão, colapso de edifício, queda de avião, choque de comboios, ação terrorista, convulsão social, epidemia, ...) e, depois, poderá permanecer por muito mais tempo, em resultado dos efeitos da crise desencadeada pela manifestação do processo inicial, e que, nestes casos, até pode evoluir para outro tipo de perigos, sobretudo de natureza social.

Pelas consequências que acarreta, a linha amarela não deverá ser transposta, uma vez que marca a passagem do risco para a crise. Todavia, sempre que não é possível evitar franqueá-la, a linha amarela serve de aviso para evitar danos maiores, sobretudo nos casos em que a velocidade da manifestação do processo possa não ser muito rápida.

Ora, em determinadas situaçóes, como sucede, por exemplo, nos riscos de inundação, quando existe uma cultura das cheias e, por conseguinte, se sabem interpretar os sinais de alerta por elas transmitidos, ou, então, quando a sua prevenção funciona e se emitem avisos à população sobre as atitudes a tomar e sobre o que deverá ser feito em concreto em função de cada situação específica, o que fará com que, nestes casos, tanto o número de vítimas como os prejuízos materiais sejam substancialmente reduzidos.

De facto, nessas circunstâncias, a maior parte das vezes é possível retirar as pessoas e os seus bens dos locais suscetíveis à manifestação do risco de inundação, ou, pelo menos, acondicioná-los de modo a que não sofram danos avultados. Atuando desta forma, apesar do processo inerente ao risco se ter manifestado, como se reduziu a vulnerabilidade da população e dos seus haveres, os prejuízos serão muito minimizados.

Posteriormente, durante o lapso de tempo em que o risco se manifesta, correspondente à antes mencionada cor vermelha, e que é muito variável em função do tipo de risco, normalmente pouco haverá a fazer, salvo proteger vidas, razão pela qual importa prevenir essas situaçóes, através da análise e gestão dos respetivos riscos, para evitar danos maiores e, mais tarde, ter de remediar aquilo que não se preveniu.

Por conseguinte, esta nossa reflexão não se limita a uma análise de riscos, já de si complexa, mas procura integrá-la no designado "ciclo da catástrofe", ainda bem mais complexo, pois é a forma de também nela incluir a componente da crise, a 
qual implica uma visão mais global do risco, pois pressupõe a sua manifestação, que se traduz em consequências e se minimiza através da adequada resposta das forças de socorro, que evita danos ainda maiores, bem como de uma imediata boa reabilitação e, ainda, da necessária e posterior recuperação da área afetada, situação que normalmente se arrasta no tempo.

Por isso, se a mitigação do risco for, como parece e deverá ser, o objetivo da análise e gestão do risco, então teremos de integrar nesse processo as três fases do ciclo da catástrofe, ou seja: (i) a fase de pré-catástrofe, correspondente ao "antes", isto é, ao período anterior à manifestação e que, naturalmente, deverá ser de preparação, prevenção e de previsão; (ii) a fase de socorro e de reabilitação, correspondente ao "durante", e que diz respeito à resposta perante as diferentes atuaçóes de emergência; (iii) a fase de pós-catástrofe ou de recuperação, que diz respeito ao "depois" e durante a qual será necessário reconstruir a área afetada, dotando-a de condiçóes de maior segurança do que as existentes antes da crise, através da redução das vulnerabilidades existentes.

Deste modo, a teoria do risco desenvolvida por diversos autores (Faugères, 1990; Hadjiconstantinou, 1990; Moustafa, 1990; Rebelo, 1995, 1996, 1997b, 2014) assenta, como foi antes referido, em três conceitos-chave: risco, perigo e crise, que constituem a trilogia-base da teoria do risco e do ciclo da catástrofe.

A clara distinção entre risco, perigo e crise é uma das traves mestras da teoria do risco. Convocando Aristóteles, podemos aplicar os conceitos de ser em potência (o risco) ou de ser em ato (perigo e crise).

Esta distinçáo parece estar de acordo com a opiniáo do jurista Dr. Miguel Nogueira de Brito, especialista em Direito Administrativo, quando afirma que: "a uma noção objetiva de perigo opóe-se um conceito subjetivo de risco" (in Carla Amado Gomes, 2012, cap. VII). Ele cita um jurista alemão que considera que: "o perigo é a condição a que o curso objetivo normal dos acontecimentos conduz, com suficiente probabilidade e num horizonte de tempo determinado, levando a que uma determinada situação ou comportamento causem danos a um determinado bem protegido". É interessante esta consideração do termo subjetivo, pois parece associar-se à percepção e ao conceito de probabilidade, uma vez que o termo objetivo corresponderá a uma suficiente probabilidade. Sendo assim, os conceito de perigo e de risco devem ser 
caracterizados por uma avaliação ex ante, uma vez que em Direito a consideração de perigo e de risco é muito sensível e complexa, tanto mais que só muito recentemente o risco passou a ser tido em conta, muito por efeito dos riscos ambientais.

Um outro termo que, por vezes, se associa ao risco é o de ameaça, enquanto sinal ou manifestaçáo que leva a acreditar na possibilidade de acontecer alguma coisa, que provoca dano. Por isso, enquanto tal, é um risco que, eventualmente, se revestirá de perigo se vier a ser concretizada, isto é, se e quando se manifestar.

Todavia, o risco e a crise, sendo esta a manifestaçấo daquele, são dois os conceitos fundamentais. $\mathrm{O}$ perigo, ainda que mencionado, aparece como elemento secundário, ao contrário do que tem sucedido em Portugal, onde a "perigosidade" prevalece sobre o "risco", o que não parece lógico, na medida em que o perigo é uma emoçáo sentida e quase instintiva, pouco racional, enquanto que, pelo contrário, o risco é uma construção muito racional e convencionada.

Com base neste enquadramento e no que à teoria do risco diz respeito, far-se-á de seguida a contextualizaçấo e a hierarquizaçáo de alguns dos conceitos mais usados em ciências cindínicas e em operações de proteção civil.

Risco

O risco corresponde, no dizer de Lucien Faugères (1990, p. 53), a um "sistema complexo de processos cuja modificação de funcionamento é susceptivel de acarretar prejuizos diretos ou indiretos (perda de recursos) a uma dada população". Trata-se de uma definição simples, mas simultaneamente completa, pois comporta os processos inerentes à manifestação de determinado risco (Rebelo, 1995), bem como a incerteza que decorre do "é susceptível" e, ainda, as consequências que o risco comporta para uma dada população (Betâmio de Almeida, 2011), plasmadas no acarretar prejuízos, e que, naturalmente, serão maiores ou menores em função da vulnerabilidade dessa população.

De facto, a incerteza sobre o desfecho, traduzida no "é susceptível", significa que pode, ou não, vir a manifestar-se. Assim sendo, neste último caso nunca haverá perigo, razão pela qual não nos parece fazer sentido mencionar a perigosidade 
neste contexto, uma vez que ela pode nem sequer existir. Por isso, entende-se o risco como algo de potencial, que pode vir a manifestar-se ou não e, nessas circunstâncias, parece-nos que ele deverá situar-se a montante do perigo. Assim sendo, a perigosidade não deveria fazer parte integrante do risco, já que decorre dele e, por conseguinte, é-lhe posterior, situando-se, por isso, a jusante do risco.

Podemos dizer, por exemplo, que o risco de incêndio florestal está presente, em grande parte do ano, nas florestas mediterrâneas. Todavia, raramente há perigo de incêndio. Ele só ocorre na presença de trovoadas secas ou, então, quando o ser humano usa inopinadamente o fogo no ambiente florestal. Nestes casos, o perigo passa a estar iminente e quando, de forma involuntária ou deliberadamente, o ser humano deixa de controlar o fogo, o perigo passa a ser real, o risco de incêndio manifesta-se e a crise acontece.

A Norma ISO 31000:2009 - Risk Management. Principles and Guidelines, vertida para a NP ISO 31000:2013 - Gestão do Risco. Princípios e Linhas de Orientação, define Risco como sendo o "efeito da incerteza na consecução dos objetivos". Nesta perspetiva, o risco assenta, fundamentalmente, na incerteza e nos efeitos, ou seja, nos danos decorrentes do potencial perigo antecipado, associado e identificado no processo em análise ou numa percepção.

Há autores que defendem que o conceito de risco implica a quantificação da incerteza através de probabilidades (Frank Knight, 1921), o que implica que a incerteza seja do tipo aleatório ou pseudoaleatório (com probabilidades empíricas ou lógicas), pelo que a incerteza epistémica ficaria de fora. Atualmente, com as formas generalizadas de probabilidades, talvez se possa abranger a quantificação dos dois tipos de incerteza.

Para as Nações Unidas, o risco resulta da "combinação da probabilidade de ocorrência de um evento com as suas consequências negativas" (ISDR, 2009, p. 25), definição que segue de perto a do ISO/IEC Guia 73, em que a palavra «risco» tem duas conotaçóes distintas: normalmente, em linguagem popular, a ênfase é colocada no conceito de acaso, de azar ou de possibilidade, de que é exemplo «o risco de um acidente». Por sua vez, em termos técnicos, a ênfase é posta, quase sempre, nas consequências, avaliadas em termos de "perdas potenciais», decorrentes de algum motivo particular, local e período. 
Estes aspetos levam-nos a pensar em algumas interrogaçóes clássicas na interpretação de fenómenos geográficos (e não só!), designadamente as de saber, neste caso, não só onde, quando e como, mas também porque é que os riscos se manifestam? A resposta às três primeiras questóes tem a ver com aquilo que poderemos chamar a severidade da manifestação de determinado processo, ou seja, com a maior ou menor violência inerente à atuaçáo do fenómeno ou processo envolvido. Por sua vez, o porquê, diz respeito à outra parte da explicação, muito condicionada pelo ser humano e que, genericamente, designamos por vulnerabilidade, conceitos que desenvolvemos a seguir.

\section{Severidade}

A severidade reúne a resposta às três questóes antes colocadas (onde, quando e como?) e que, embora mereçam análise individualizada, através da suscetibilidade (onde), probabilidade (quando) e intensidade (como), poderão ser agrupadas sob o denominador comum da severidade que acompanha a manifestaçáo dos processos potencialmente perigosos.

Com efeito, porque se trata, essencialmente, de identificar e caraterizar as causas inerentes a um determinado tipo de processos que leva a uma manifestação de risco, a qual se traduz pela maior ou menor violência dessas manifestaçóes, optámos por lhe chamar severidade, em substituição do termo perigosidade, pois nem sempre essa manifestação acarreta qualquer perigo, mormente nos níveis de baixa severidade, pelo que não nos parece fazer sentido usar um termo que nos parece inapropriado para identificar essa condição.

O termo severidade, do processo ou do cenário de análise, que se propóe para ser adotado em vez de perigosidade, caracteriza a probabilidade de ocorrência e a sua intensidade, enquanto propriedade obrigatoriamente implícita no valor da probabilidade, bem como suscetibilidade de ocorrência, ou seja a possibilidade lógica e física de um cenário acontecer.

Contudo, o vocábulo severidade poderá incluir também, de modo implícito, uma avaliaçáo da importância provável dos danos resultantes do impacte do processo em pessoas ou em bens materiais, com base no valor da intensidade do processo. 
Contudo, essa avaliação não é correta nesta componente do risco, uma vez que ainda é independente das consequências do processo. Com efeito, existe uma separação formal entre a caracterizaçáo do processo ou do cenário e os danos a eles associados.

De facto consideramos que, em condiçóes normais, um qualquer processo, seja ele a chuva, o frio, o calor, o caudal dos rios, ... ou, até, o próprio ser humano, não pode ser considerado um perigo ou um processo perigoso. Pelo contrário, na maior parte das condiçôes, esses processos até são benéficos. Então, se assim é, porquê chamar-lhes perigosos ou perigos?!

O exemplo das avalanches é, porventura, um dos mais elucidativos. Normalmente, não ouvimos falar das avalanches, enquanto processo natural, pois elas náo despertam qualquer interesse mediático, por não acarretarem qualquer perigo. Então porque chamar-lhes "perigo" ou caraterizar a sua "perigosidade" quando ela é inexistente?

As avalanches são efetivamente notícia quando entra a outra componente do risco, a vulnerabilidade, no que diz respeito à exposição, ou seja, à presença do ser humano, quer enquanto pessoas concretas (alpinistas, turistas, ...), quer através de infraestruturas construídas para o seu apoio: pistas de sky, hotéis e outras que, quando se encontram expostas ao processo natural, o transformam em risco e, nestas circunstâncias, podem acarretar perigo para as pessoas e os seus bens.

Fica, pois, claro que os processos naturais em si não são perigosos, pois fazem parte da evolução natural, razão pela qual entendemos que estes processos não devem ser chamados de "perigos". Como vimos neste exemplo, o processo só se pode tornar perigoso se existir presença ou atividade humana, pois são elas que o valorizam, mas como nem sempre tal acontece, entendemos que os processos não deverão ser tratados como sinónimo de perigo, ainda que, por vezes, a sua manifestação possa acarretar perigo e, por essa razáo possam ser designados por processos potencialmente perigosos.

\section{Sinais de perigo}

Aliás, os sinais de perigo avisam-nos da probabilidade de manifestaçáo iminente dos respetivos riscos, pelo que deveremos tomar medidas especiais de pre- 
caução no sentido de as evitar ou, pelo menos, de minimizar as consequências dessas manifestaçóes. São disso exemplo, os conhecidos sinais de aviso de perigo de vida ou de morte, associados às redes de distribuição de energia elétrica em alta voltagem (fig. 1).

Com efeito, corre-se perigo de vida, como se referia inicialmente, quer na versão mais técnica (fig. 1 - A), quer na imagem mais expressiva (fig. 1 - B), embora a incessante busca de inovação e de vocábulos fortes levou a que a manifestação do risco fosse substituída pela sua consequência, a morte, tendo então passado a designar-se por perigo de morte (fig. 1 - C), cuja simplificação levou à simbologia de uso mais recente (fig. 1 - D).

Ainda que não tenha diretamente a ver com os conceitos, entendemos deixar uma nota relativa à sinalética associada aos riscos, pois tem sofrido uma grande evolução, designadamente ao tender para uma certa uniformização, cujos critérios são fixados através de normas, tanto ISO, da Organização Internacional de Normalização, como CIE, da Comissão Internacional de Iluminação, que entre outros aspetos definem as caraterísticas colorimétricas e fotométricas dos materiais.

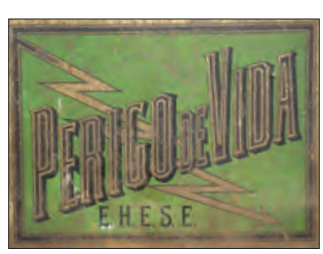

A

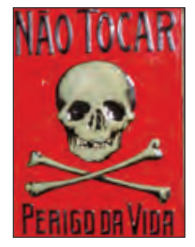

B

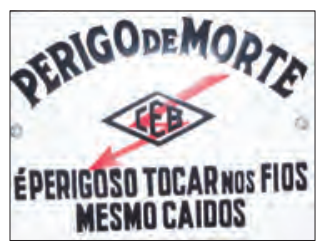

C

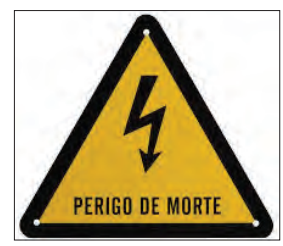

$\mathrm{D}$

Fig. 1 - Alguns dos mais vulgarizados sinais que avisam para a existência de situações de perigo associado às redes de distribuiçáo de energia elétrica em alta voltagem: A e B - Placas da antiga EHESE - Empresa Hidroeléctrica da Serra da Estrela, alertando para o Perigo de Vida; C - Placa da ex-CEB - Companhia Eléctrica das Beiras, alertando para o Perigo de Morte (Fotografias do autor, obtidas no Museu Natural da Eletricidade, antiga Central Hidroelétrica da Senhora do Desterro); D - Sinalética posterior.

Fig. 1 - Some of the most common signs that warn of dangerous situations associated with high voltage electricity distribution networks: $A$ and B - Old EHESE signs - Serra da Estrela Hydroelectric Company, warning of a threat to life;

$C$ - Sign used by the former CEB - Companhia Eléctrica das Beiras, warning of the danger of death (Photographs by the author, obtained at the Natural Electricity Museum, former Hydroelectric Centre of Senhora do Desterro); D - Subsequent sign. 
Desde logo, no espectro mais lato da sinalização de segurança, podemos considerar quatro diferentes tipos de sinais, que sáo usados em função das circunstâncias específicas a que dizem respeito e que, respetivamente, podemos designar por sinalização:

- Ótica - que inclui as chamadas cores de segurança, os sinais de segurança, a linguagem gestual e os avisos de segurança e de limitação;

- Acústica - que é feita através de campainhas, sirenes, alarmes e verbalmente;

- Olfactiva - que se realiza através da inoculação de aditivos em gases inodoros para que a sua presença seja detectada;

- Táctil - que usa recipientes rugosos para determinadas substâncias ou, então, para ser detetada por cegos.

Em termos de modelos de sinalização, podemos utilizar, separadamente ou em conjunto, diferentes modalidades, tais como:

- Cores e Placas;

- Luzes e Sons;

- Comunicação verbal e gestual.

As características a que, em Portugal, devem obedecer estas diferentes modalidades encontram-se bem definidas (Decreto-Lei n. ${ }^{\circ}$ 141/95 e Portaria n. ${ }^{\circ}$ 1456-A/95). A título de exemplo, mencionamos as referentes às placas de sinalizaçáo, que deverão ser: (i) de metal; (ii) simples; (iii) com dimensōes padronizadas; (iv) colocadas em locais de boa visibilidade; (v) bem compreensíveis de entendimento; (vi) sem nada na frente, como plantas ou postes, que dificulte a sua visão. Depois, se o risco desaparecer, é essencial retirar a placa sinalizadora. Por outro lado, há placas que exigem adição de luminosidade ou sinais acústicos, como luzes noturnas de contraste correto e alarmes.

As placas têm por objetivo a fácil e rápida compreensão dos sinais de segurança, através de um simples olhar e sem confusão possível, pelo que têm símbolos e cores diferentes consoante o seu significado (QuAdros I a IV).

Desde logo, sendo esta a informaçáo óptica normalizada, não se percebe porque é que a Autoridade Nacional de Proteção Civil não a respeita, designadamente na definição dos Estados de Alerta da Proteção Civil, uma vez que o nível mais baixo, 
QUADRO I - Usos das cores de segurança (Fonte: Adaptado de IDICT).

TABLE I - Use of safety colours (Source: Adapted from IDICT).

\begin{tabular}{|c|l|l|}
\hline \multicolumn{1}{|c|}{ Cor } & \multicolumn{1}{|c|}{ Uso } & \multicolumn{1}{c|}{ Indicaçóes } \\
\hline \multirow{2}{*}{ Vermelho } & Sinais de Proibição & Atitudes perigosas \\
\cline { 2 - 3 } & Alarmes & Stop, pausa, dispositivos de corte de emergência \\
\hline & $\begin{array}{l}\text { Material e equipamento de } \\
\text { combate a incêndios }\end{array}$ & Indicação e localização \\
\hline $\begin{array}{c}\text { Amarelo ou } \\
\text { Amarelo-alaranjado }\end{array}$ & Sinais de Aviso & Atençáo, precaução, verificaçáo \\
\hline \multirow{2}{*}{ Verde } & $\begin{array}{l}\text { Sinais de Salvamento ou } \\
\text { de Socorro }\end{array}$ & $\begin{array}{l}\text { Portas, saídas, vias, material, postos, locais } \\
\text { específicos }\end{array}$ \\
\hline & Situaçóes de Segurança & Regresso à normalidade \\
\hline Azul & Sinais de Obrigação & $\begin{array}{l}\text { Comportamento ou ação específica, obrigação } \\
\text { de utilizar EPI }\end{array}$ \\
\hline
\end{tabular}

QUADRO II - Cores de segurança, de contraste e dos símbolos usados nas placas

(Fonte: Adaptado de IDICT).

TABLE II - Safety colours, contrast colors and symbols used on signs

(Source: Adapted from IDICT).

\begin{tabular}{|c|c|c|}
\hline Cor de Segurança & Cor de Contraste & Cor dos Símbolos \\
\hline Vermelho & Branco & Preto \\
\hline Amarelo & Preto & Preto \\
\hline Verde & Branco & Branco \\
\hline Azul & Branco & Branco \\
\hline
\end{tabular}

correspondente ao alerta "Normal" tem associada a cor verde, quando deveria ser a azul e, pelo contrário, o nível seguinte, correspondente ao alerta "Especial" azul, deveria ser verde, no respeito pela padronização existente e há muito consagrada. Bastaria uma simples troca de cor para adequar os seus Estados de Alerta à normalização, universalmente aceite.

Um dos conjuntos de sinais com que estamos mais familiarizados diz respeito à sinalização de trânsito, que informa e orienta os utilizadores das vias, garantindo um trânsito mais organizado e seguro para os condutores e para os peóes, e contempla os conhecidos sinais de perigo, de formato triangular, com orla vermelha. 
QUADRO III - Forma geométrica dos sinais de segurança e respetivo significado (Fonte: Adaptado de IDICT).

TABLE III - Geometric shape of safety signs and their meaning (Source: Adapted from IDICT).

\begin{tabular}{|l|l|}
\hline Forma geométrica & \multicolumn{1}{|c|}{ Significado } \\
\hline & Sinais de Obrigação e de Proibição \\
\hline & Sinais de Perigo \\
\hline & Sinais de Emergência, de Sinalização e Sinais Adicionais \\
\hline
\end{tabular}

QUADRO IV - Combinaçóes de formas e de cores e seu significado nos sinais (Fonte: Adaptado de IDICT).

TABLE IV - Combinations of shapes and colours and their meaning in signs (Source: Adapted from IDICT).

\begin{tabular}{|c|c|c|l|}
\hline \multirow{2}{*}{ Cores } & \multicolumn{3}{|c|}{ Formas } \\
\cline { 2 - 4 } & & & \\
\hline Vermelho & Proibição & ---- & Material de luta contra incêndios \\
\hline Amarelo & $-\ldots--$ & Atenção-Perigo & ----- \\
\hline Verde & $-\ldots--$ & ---- & Informação ou instrução. \\
\hline Azul & Obrigação & ---- & $\begin{array}{l}\text { Situação de segurança. } \\
\text { Dispositivos de emergência. }\end{array}$ \\
\hline
\end{tabular}

Além destes, congrega ainda os sinais de:

i. Obrigação, redondos e de fundo azul;

ii. Proibição, redondos, com orla vermelha;

iii. Informação, quadrados ou retangulares de fundo azul;

Tipologia análoga também passou a ser usada na chamada sinalização de segurança e saúde no trabalho, cuja legislação antes mencionada estabelece prescriçóes mínimas para este tipo de sinais, que podem ser agrupados do seguinte modo: 
- Proibição, aqueles sinais que proíbem determinado comportamento, pretendendo impedir que ele seja susceptível de colocar em risco a segurança de um ou mais indivíduos. Sáo circulares e possuem fundo branco, símbolo a preto, margem e faixa a vermelho (fig. 2).

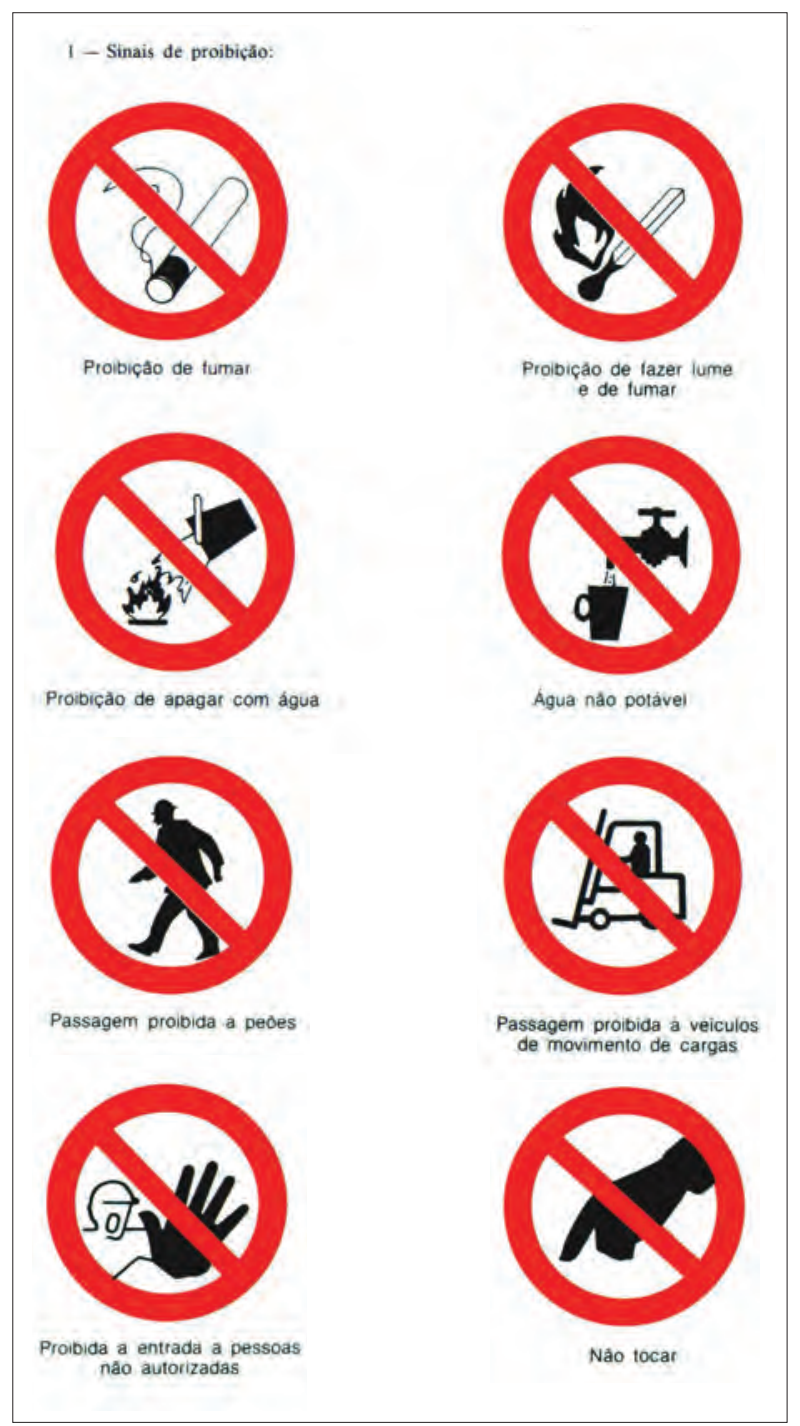

Fig. 2 - Exemplos de sinais de proibição (Fonte: Portaria n. ${ }^{\circ}$ 1456-A, 1995, p. 7734-5). Fig. 2 - Examples of prohibition signs (Source: Ordinance No. 1456-A, 1995, pp. 7734-5). 
- Aviso (por vezes, impropriamente designados de sinais de perigo), são sinais que advertem para a existência de locais e de materiais com diversos riscos, pelo que visam alertar o trabalhador para que ele tenha controlo sobre tudo o que esteja a fazer e não se prejudique nem prejudique ninguém. São apropriados e obrigatórios em situaçôes e locais que exigem atenção, cautela, precaução, ou afirmação de que algo é perigoso, evitando assim acidentes de trabalho e outras consequências graves. São triangulares, com fundo amarelo, pictograma e margem a preto (fig. 3 ).

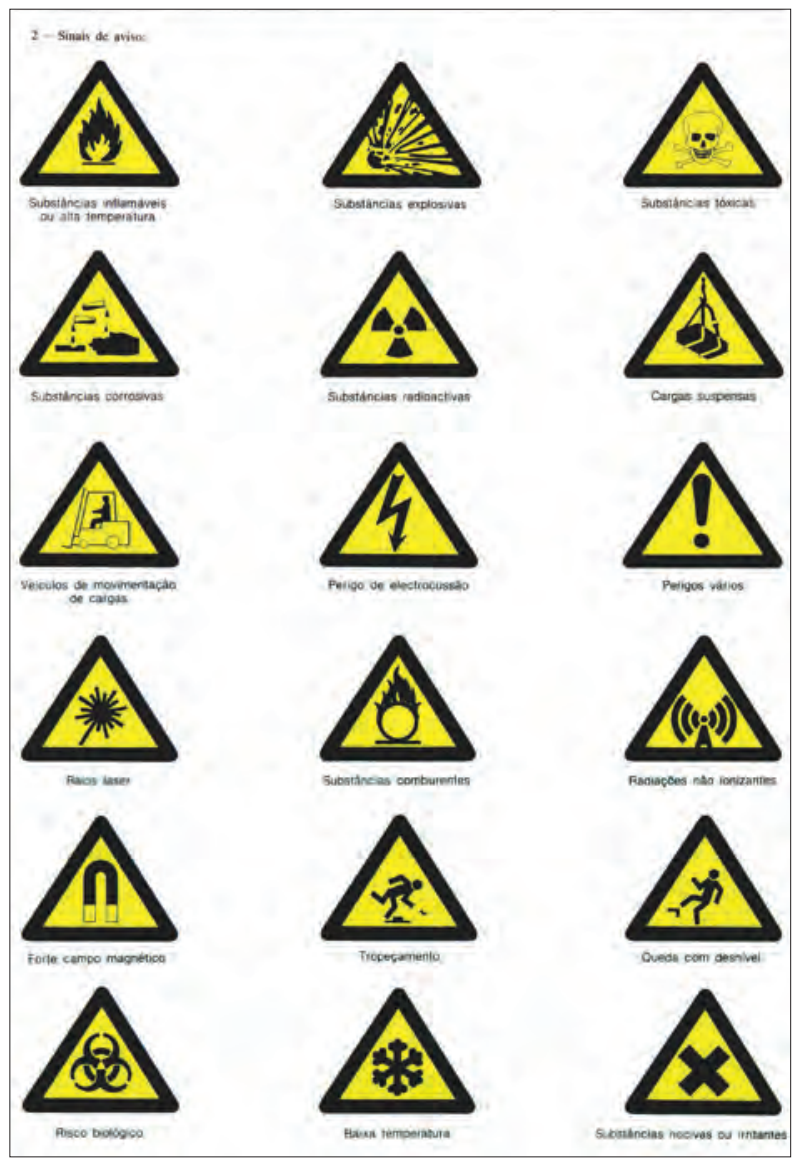

Fig. 3 - Sinais de aviso (Fonte: Portaria n. ${ }^{o}$ 1456-A, 1995, p. 7734-6).

Fig. 3 - Warning signs (Source: Ordinance No. 1456-A, 1995, pp. 7734-6). 
- Obrigação, aqueles sinais que impóem um certo comportamento, tendo por objetivo indicar as açôes que obriguem a utilização de determinado equipamento de proteçáo individual (EPI) de acordo com o pictograma inserido no respetivo sinal, a fim de evitar acidentes de trabalho que possam causar danos ao trabalhador acidentado e à empresa. Apresentam forma redonda, com o fundo azul e o símbolo a branco (fig. 4).

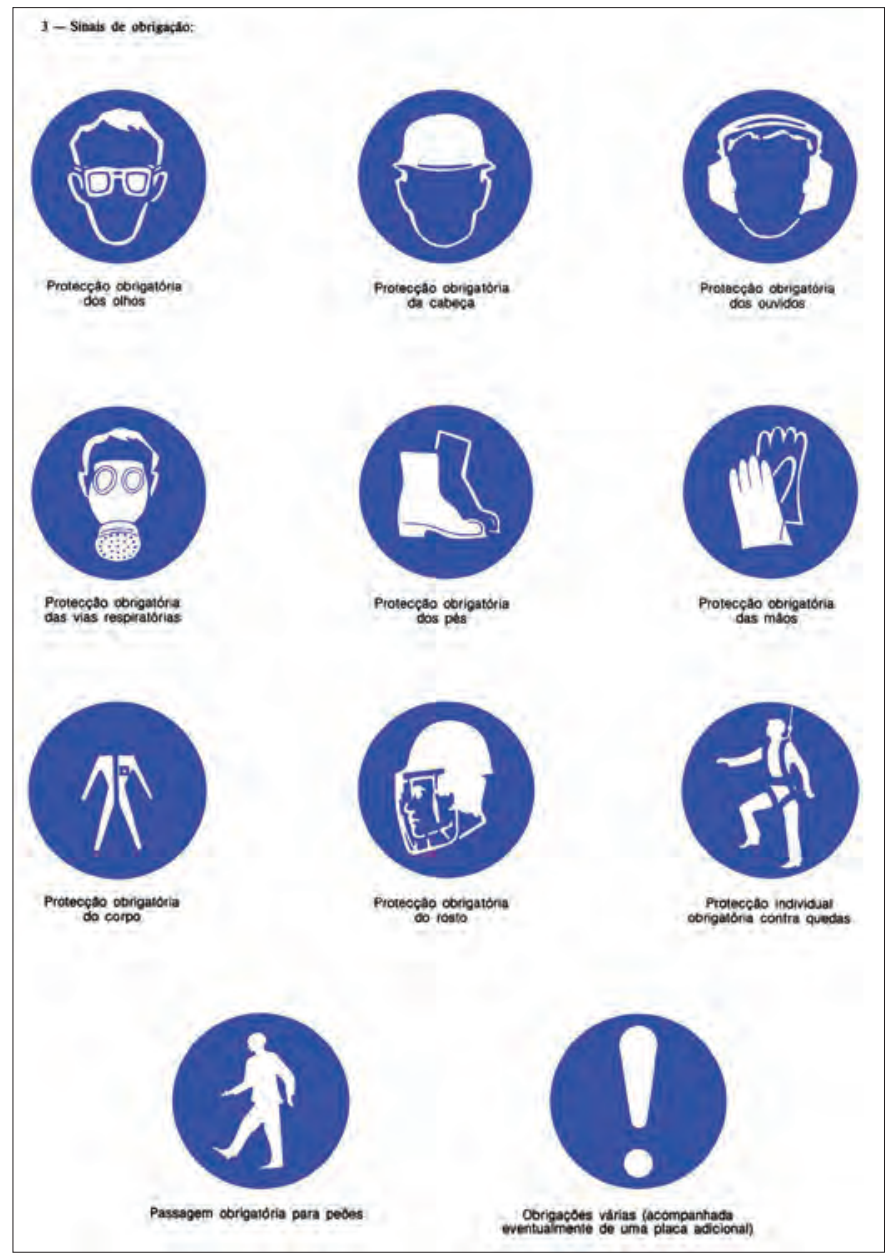

Fig. 4 - Exemplos de sinalização de obrigação (Fonte: Portaria n. ${ }^{\circ}$ 1456-A, 1995, p. 7734-7).

Fig. 4 - Examples of mandatory signs (Source: Ordinance No. 1456-A, 1995, pp. 7734-7). 
- Salvamento ou de socorro (emergência), os sinais que dão indicação sobre saídas de emergência, direçóes de fuga, Sáo úteis para guiar trabalhadores e visitantes para as saídas corretas, oferecendo capacidade de fuga. Têm por objetivo criar condiçôes para que trabalhadores e/ou visitantes duma qualquer infraestrutura circulem em segurança. São quadrados ou retangulares, com fundo verde e símbolo a branco (fig. 5).

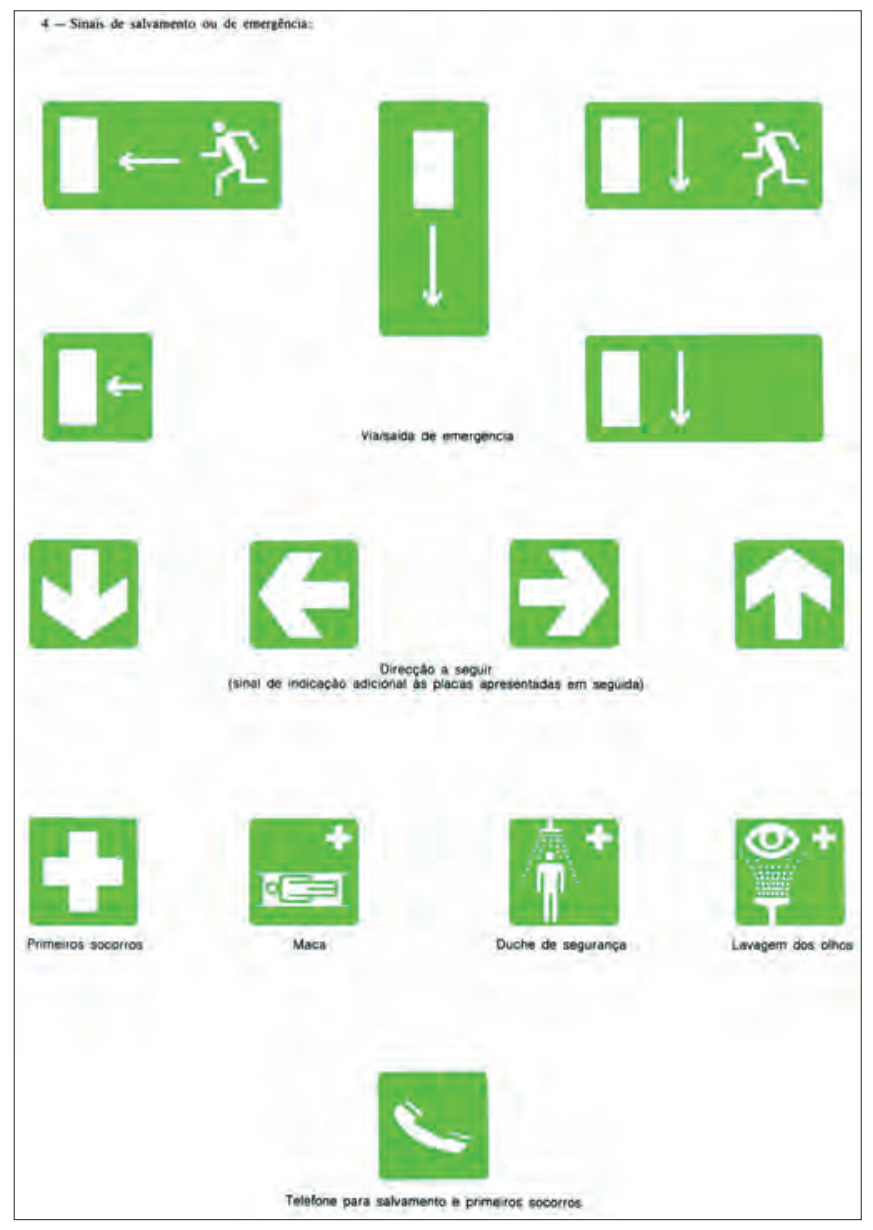

Fig. 5 - Sinalização de salvamento ou de emergência (Fonte: Portaria n. ${ }^{\circ}$ 1456-A, 1995, p. 7734-8).

Fig. 5 - Rescue or and emergency signalingsigns (Source: Ordinance No. 1456-A, 1995, pp. 7734-8). 
- Indicação (informação), aqueles sinais que dáo indicaçôes não abrangidas pelos anteriores, tais como os referentes a meios de socorro e salvamento, como seja a localização de algum equipamento útil em situaçóes de emergência, por exemplo, o material de combate a incêndios. Neste caso são quadrados, com fundo vermelho e pictograma a branco (fig. 6).

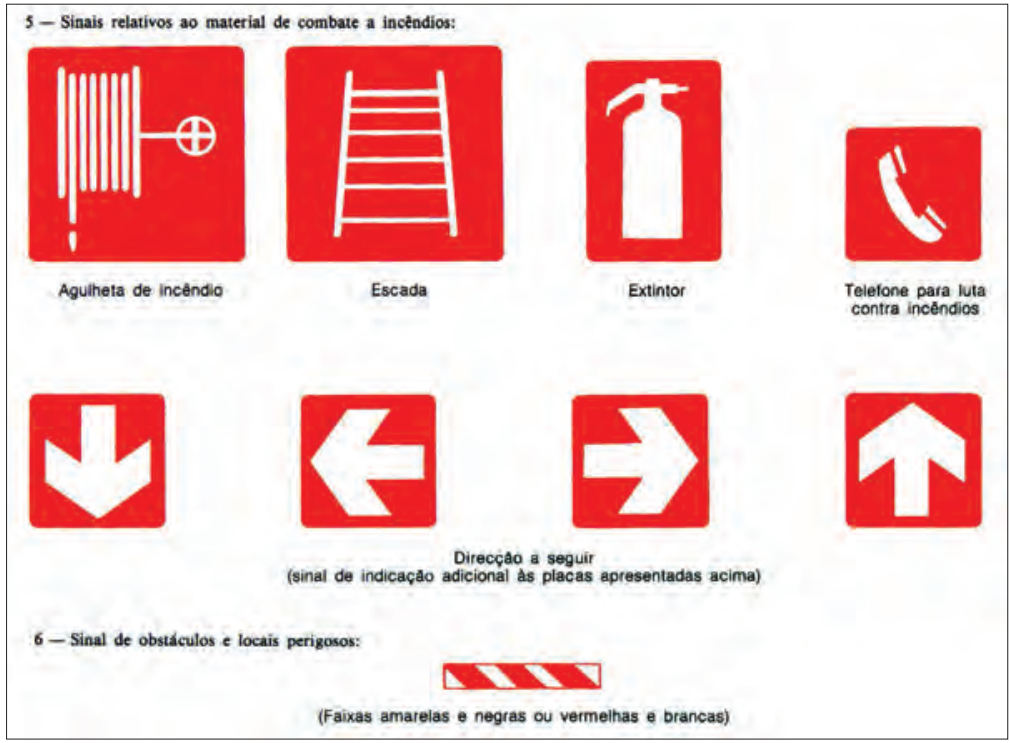

Fig. 6 - Sinais relativos ao material de combate a incêndio (Fonte: Portaria n. ${ }^{\circ}$ 1456-A, 1995, p. 7734-9).

Fig. 6 - Fire-fighting material signs

(Source: Ordinance No. 1456-A, 1995, pp. 7734-9).

Também o Regulamento (CE) n. ${ }^{\circ} 1272 / 2008$, do Parlamento Europeu e do Conselho, de 16 de dezembro de 2008, visou harmonizar os avisos internacionalmente reconhecidos relativos à classificação, rotulagem e embalagem de substâncias e misturas perigosas, tendo substituído os anteriores símbolos negros, sobre fundo laranja, por losangos vermelhos (QuADro V).

Por outro lado, alguns dos sinais inicialmente associados ao trânsito foram transpostos para outras situaçôes, como é o caso do relativo à queda de pedras das barreiras das estradas (fig. 7), para indicar outros locais onde também há perigo de 
quedas de blocos e que, por isso, passaram a ser utilizados noutras situaçôes análogos às das estradas, nomeadamente para sinalizar as arribas junto a praias onde ocorrem desmoronamentos, em cuja base por vezes até há interdição de passagem/ permanência por se admitir que existe perigo real de derrocada.

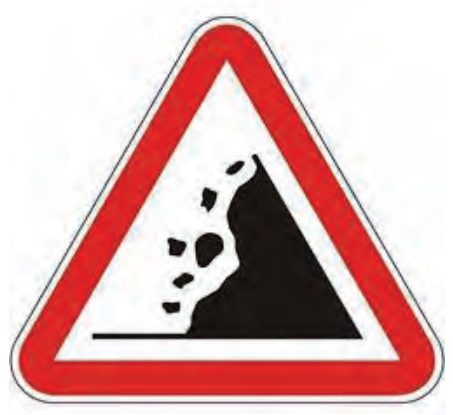

Fig. 7 - Sinal que avisa para a existência de situaçóes que acarretam perigo de queda de pedras, seja nas barreiras das estradas, seja nas arribas do litoral ou outras.

Fig. 7 - Warning signs for danger of rock fall, whether on roadblocksat roadsides, on coastal cliffs or otherwiseelsewhere.

Uma das situaçôes mais noticiadas, em termos de arribas litorais, sucedeu em 21 de agosto de 2009, na praia Maria Luísa, no Algarve, quando morreram cinco pessoas, e depois se repetiu na madrugada do dia 27 de agosto de 2015 e, novamente, a 7 de Agosto de 2016.

De facto, as arribas são, por natureza, instáveis e podem cair sem aviso prévio, ou seja, considera-se que o perigo está iminente e, por isso, é real, ao contrário das situaçôes de risco, em que as possíveis manifestaçóes podem estar distantes ou, até, nem ocorrerem, razáo pela qual se recomenda que na base das arribas seja mantida uma distância de segurança, correspondente a uma vez e meia a sua altura.

Com efeito, entendemos que o perigo corresponde à fase final do risco e ao início da crise, fazendo a transição entre ambos, motivo que nos leva a associar a perigosidade a estas circunstâncias, não devendo por isso ser tratada como uma componente do risco, já que corresponde ao seu final. 
QUADRO V - Exemplos de sinais que avisam sobre a existência de situaçóes específicas de perigo, respetivamente indicadas para cada um deles (Adaptado de https://echa.europa.eu/pt/chemicals-in-our-life/clp-pictograms).

TABLE $\boldsymbol{V}$ - Examples of signs warning of specific hazards, as indicated (Adapted from https:/lecha.europa.eulen/chemicals-in-our-lifelclp-pictograms).

\begin{tabular}{|c|c|c|}
\hline Sinalética em uso & Símbolo anterior & Descrição \\
\hline & inexistente & $\begin{array}{l}\text { Contém gás sob pressão e há risco de explosão sob a ação } \\
\text { do calor, ou } \\
\text { Contém gás refrigerado e pode provocar queimaduras ou } \\
\text { lesōes criogénicas. }\end{array}$ \\
\hline & & $\begin{array}{l}\text { Explosivo instável, havendo perigo de: } \\
\text { - Explosão em massa; } \\
\text { - Irojeçôes; } \\
\text { - Incêndio, sopro ou projeçốes; } \\
\text { Explosão em massa, em caso de incêndio. }\end{array}$ \\
\hline & & $\begin{array}{l}\text { Contém comburente e pode provocar ou agravar incêndios, ou } \\
\text { Contém produto muito comburente e há perigo de incên- } \\
\text { dio ou de explosão. }\end{array}$ \\
\hline & & $\begin{array}{l}\text { Gás inflamável ou extremamente inflamável, ou } \\
\text { Aerossol inflamável ou extremamente inflamável, ou } \\
\text { Líquido e vapor facilmente inflamáveis, ou } \\
\text { Sólido inflamável. }\end{array}$ \\
\hline & & $\begin{array}{l}\text { Produto corrosivo para os metais, que provoca queimaduras } \\
\text { na pele e lesóes oculares graves. }\end{array}$ \\
\hline & & $\begin{array}{l}\text { Substância que provoca irritação das vias respiratórias, } \\
\text { sonolência ou vertigens, reação alérgica cutânea, irritaçáo } \\
\text { ocular grave e irritaçâo cutânea. } \\
\text { É nociva por ingestão, por inalação e em contacto com a pele. } \\
\text { Prejudica a saúde pública e o ambiente, ao destruir o ozono } \\
\text { na alta atmosfera }\end{array}$ \\
\hline & & $\begin{array}{l}\text { Substância que é mortal por ingestáo, inalaçáo e em contac- } \\
\text { to com a pele. } \\
\text { É tóxica por ingestấo, inalaçáo e em contacto com a pele. }\end{array}$ \\
\hline & inexistente & $\begin{array}{l}\text { Produto que afeta os órgãos e que pode afetar a fertilidade e } \\
\text { ser mortal por ingestáo e penetraçấo nas vias respiratórias. } \\
\text { Suspeito de provocar cancro e anomalias genéticas. } \\
\text { Quando inalado, pode provocar sintomas de alergia ou de } \\
\text { asma ou dificuldades respiratórias. }\end{array}$ \\
\hline & & $\begin{array}{l}\text { Substância muito tóxica para os organismos aquáticos e } \\
\text { com efeitos duradouros. }\end{array}$ \\
\hline
\end{tabular}




\section{Suscetibilidade}

Saber onde ocorreram anteriores manifestações de um determinado tipo de risco, permite identificar a sua localização geográfica e proceder à distribuição espacial dos eventos que ocorreram e, por conseguinte, estimar as áreas mais suscetíveis a essa ocorrência, caraterística que permite localizar o fenómeno no espaço e se costuma designar por suscetibilidade.

Assim, a suscetibilidade poderá ser considerada como a possibilidade lógica e/ou física de ser atingido por um acontecimento. Com efeito, na seleção e definição dos cenários, a possibilidade é muito relevante. Por vezes, perde-se tempo com cenários que uma análise mais cuidadosa pode concluir que são física ou logicamente impossíveis.

A identificação de áreas espaciais "susceptíveis", porque possuem um conjunto de pessoas e bens nessas áreas que possam vir a ser afetadas por um processo, em princípio sem quantificação probabilística, estará dependente, se entendermos a distribuição espacial com uma dimensão probabilística resultante da incerteza na ocorrência, da maior ou menor propensão para essas determinadas áreas serem atingidas.

\section{Probabilidade}

Por sua vez, saber quando foi que esses fenómenos se manifestaram, ajuda a situar os fenómenos ao longo do tempo, histórico ou geológico, e inferir da eventual possibilidade da sua repetição, que pode ser traduzida em termos da probabilidade de ocorrência do processo em análise e, por isso, tem a ver com a sua localização no tempo.

Assim, o conceito de probabilidade envolve a ocorrência de eventos especiais relativamente aos eventos possíveis em determinadas circunstâncias, assumindo um significado de possibilidade, ainda que incerta, de mudança.

Por isso, sempre que possível, deve concentrar-se nesta componente a probabilidade total do evento, ou seja, o início da ocorrência com determinada intensidade e as sucessivas probabilidades, condicionadas ao evento inicial, encadeadas até ao local alvo. 
Todavia, no contexto de uma análise quantitativa rigorosa, o valor da probabilidade resultante deverá incidir também sobre os valores dos danos estimados ou previstos nos bens e pessoas, em função da sua exposição e fragilidade ou capacidade de resistência, bem como da intensidade do processo (energia no impacto), que se apresentam a seguir.

\section{Intensidade}

Definida a localização no espaço e a possibilidade no tempo, importa agora saber como é que o fenómeno se manifesta, conhecimento que é fundamental para estimar as consequências, em caso de repetição de situações análogas. Trata-se, pois, de analisar algumas características inerentes ao fenómeno em apreço, normalmente traduzidas pela sua intensidade, que exprime o grau de atividade ou de energia do processo em causa, e se expressa através de unidades de medida, designadamente em termos de percentagem, graus ou velocidade, valores que são quase sempre determinantes para a explicação dos danos causados resultantes do impacto do processo.

"Sendo assim, a resposta a estas três questóes, ajuda a explicar os processos envolvidos, pelo que, na nossa ótica, o termo 'processo[s]potencialmente perigoso[s]' será o mais adequado para agrupar este conjunto de características. Todavia, sabemos que em termos de literatura, nos países de expressão latina, muitas vezes ele tem vindo a ser expresso por 'perigosidade', o que náo nos parece correto, tendo em conta a sequência lógica e hierarquizada dos conceitos apresentados. Assim, na falta de um vocábulo português que expresse não só o modo como decorrem, mas também as características associadas a estes processos, chegámos a propor o de 'processualidade, para indicar as caraterísticas associadas à manifestação dos processos e, assim, substituir o atualmente usado" (Lourenço, 2014, p. 64).

No entanto, como as consequências das manifestaçóes de processos potencialmente perigosos resultam de um jogo de dados com resultados incertos, como diz o ditado popular, do azar (hazard) de "estar no sítio errado" (o que tem a ver com a localização no espaço - suscetibilidade), "à hora errada” (ou seja, com a localização no tempo - probabilidade) e, sobretudo, da intensidade das forças atuantes em cada manifestaçáo. Sendo 
assim, não há dúvida de que existe uma relação direta com a(s) causa(s) que está(ão) na origem do respetivo processo, pelo que, no conjunto e na nossa ótica, estas caraterísticas podem ser agrupadas na severidade de atuação dum determinado processo.

Nesta linha de raciocínio, Christofoletti (1990, p. 147) traduziu Natural Hazard por "Azares Naturais" e definiu-os como eventos que, por fazerem a interface entre sistemas naturais e utilizadores dos sistemas socioeconómicos, são considerados como azares, na medida em que são incertos e ocasionam prejuízos e mortes a seres humanos. Todavia, esta tradução, apesar de mais próxima do sentido etimológico, não foi bem aceite na terminologia portuguesa, tendo vários autores optado pela tradução por "Perigos Naturais” e, por isso, referência à "perigosidade”, impropriamente do nosso ponto de vista, uma vez que pretendem caraterizar a severidade da manifestação do processo.

\section{Vulnerabilidade}

Passando à última das interrogaçóes, o porquê dos danos ou perdas, será porventura a mais complicada em termos de resposta, uma vez que resulta de um conjunto de circunstâncias que podem ser agrupadas sob a designação de vulnerabilidade, a qual, no entender das Naçóes Unidas, corresponde às "características e circunstâncias de uma comunidade que a tornam suscetivel aos efeitos nocivos do processo" (ISDR, 2009, p. 30).

Todavia, esta definição torna-se tão abrangente que entramos noutra dimensão ou escala, ou seja, o termo vulnerabilidade deixaria de participar diretamente na definição do risco quantitativo.

Com efeito, a definição não quantitativa do risco, nomeadamente em algumas disciplinas como a sociologia e a psicologia social, centrou-se e centra-se muito na vulnerabilidade. Há livros célebres em que a definição do risco quase se confunde com vulnerabilidade social: "Por 'vulnerabilidade' entendemos ser a característica de uma pessoa ou de um grupo de pessoas de ter capacidade para antecipar, enfrentar, resistir e recuperar do impacto de um evento natural perigoso" (Wisner, et al., 1994).

Neste contexto, é dada muita ênfase aos fatores que retiram resistência às comunidades face a uma catástrofe. Assim, as escalas superiores da vulnerabilidade não cor- 
respondem a escalas de valores tangíveis dos danos mas, eventualmente, a uma escala de hierarquia convencionada, mais abrangente nas prioridades de intervençáo social ou de planeamento, sem necessidade de cálculos rigorosos.

A problemática das alteraçôes globais, muito incertas, veio justificar uma gestão de vulnerabilidades em detrimento de uma gestão de riscos, atendendo a que as probabilidades são difíceis de estimar de modo fiável. A gestáo de vulnerabilidades tenta, assim, minimizar perdas e danos seja qual for a probabilidade de ocorrência.

A vulnerabilidade é, pois, um conceito chave e tem havido muita discussão à sua volta (Poljanšek, 2017), bem como sobre os elementos que devem ser considerados como parte integrante da vulnerabilidade, uma vez que as diferentes definiçóes de vulnerabilidade abrangem um número muito elevado de factores que influenciam uma comunidade ou mesmo o Mundo (Birkmann, 2006) pelo que, também por isso, ela deverá integrar a análise de risco.

Do nosso ponto de vista, entendemos que a maior ou menor vulnerabilidade dos territórios e das comunidades, no sentido oposto ao da resistência (física, social, económica...) ao impacte de qualquer manifestação de risco, é dos parâmetros mais difíceis de determinar, pois depende essencialmente de três fatores, embora nem todos os autores os considerem como fazendo parte integrante da vulnerabilidade, e que dizem respeito à: exposição, sensibilidade e capacidade, tanto de antecipação como de resposta, pois são eles que, em grande parte, vão determinar as caraterísticas e a dimensão dos danos.

Sendo assim, os danos, ainda que tratados à parte por serem consequência e não parte integrante da vulnerabilidade, acabam por estar associados diretamente à vulnerabilidade que, em termos de cálculo, corresponde ao valor estimado dos danos em cada cenário.

Deste modo, a fórmula de cálculo poderá ter os factores que se entenderem ser pertinentes (localizaçáo, resistência estrutural e social, capacidade de antecipação e de resposta, hora do dia, dia da semana, mês do ano, idade das pessoas, rendimentos, sistema de aviso, plano de emergência, plano de evacuação, educação, etc.) mas, no final, traduzirá o valor dos danos quantificados ou o número de pessoas afetadas. 


\section{Exposição}

A exposiçâo diz respeito aos "elementos presentes nas zonas de risco - as pessoas e os seus bens e haveres - que, por esse motivo, ficam sujeitos a eventuais perdas" (ISDR, 2009, p. 15), ou seja, refere-se ao território, bens e pessoas expostas ao impacte do evento associado ao risco em apreço.

A identificação e caracterização espacial da exposição fica dependente da intensidade do processo, no âmbito de cada cenário em análise e, regra geral, depende do processo, físico ou estrutural, de propagação do fenómeno em causa.

Alguns autores (Almeida, 2011 e 2018) preferem tratá-la de forma independente, não a incluindo na vulnerabilidade, mas é fácil perceber que os efeitos nocivos do processo dependem, em grande parte, do maior ou menor grau de exposição dos diferentes elementos que estáo patentes ao processo, pelo que nos parece fazer sentido incluí-la como um elemento que integra a vulnerabilidade.

\section{Sensibilidade}

Por sua vez, a sensibilidade ou fragilidade, de acordo com Cutter (2011), corresponde ao nível e à extensão dos danos que os elementos expostos podem sofrer, em função das características intrínsecas desses elementos expostos, por exemplo, o tipo de materiais usados na construção, bem como do seu grau de proteção que, entre outros, envolve as infraestruturas de defesa. O conceito de sensibilidade pode ser considerado como semelhante ao da vulnerabilidade física.

\section{Capacidade}

Por último, a capacidade, quer de antecipação, quer de resposta, é um dos elementos que menos se integra nas análises de risco, apesar de ser um dos elementos primordiais para explicar muitas das diferenças registadas entre manifestaçôes que, à partida, poderiam ter consequências semelhantes mas que, depois, apresentam efeitos substancialmente diferentes, constituindo, por isso, frequentemente, a chave do sucesso de determinadas operaçóes, nomeadamente de gestão do risco e de crises. 
Sabemos da dificuldade em obter elementos fiáveis e dados estatísticos normalizados que permitam quantificar com precisão estas capacidades, mas isso não invalida que não se deva fazer um esforço no sentido de os obter e de introduzir esta componente nas análises de risco, quanto mais não seja para que, pelo menos, incluam uma avaliação de carácter meramente qualitativo.

Com efeito, a capacidade é entendida como sendo "a combinação de todas as forças e recursos disponiveis dentro de uma comunidade, na sociedade ou numa organizaçāo que possam ser utilizados para atingir os objetivos" (ISDR, 2009, p. 5-6). Ora, estes passam obviamente pela redução do risco a que essa sociedade está exposta (o que tem a ver com a capacidade de antecipação) ou, no caso de uma eventual manifestação, pela reduçáo dos danos que por ela possam ser causados (o que se consegue através de uma capacidade de resposta eficaz.

\section{Capacidade de antecipação}

Deste modo, a capacidade de antecipação, sendo anterior à manifestaçăo do risco, permite que nos preparemos previamente e, por isso, ela diz respeito à implementação de açóes e à realização de atividades que permitam reduzir danos, no caso do risco se vir a manifestar.

Ora, estas açóes e atividades passam tanto por medidas de prevenção, com vista a não só evitar essa manifestação mas também a minimizar os seus efeitos, no caso de ela se manifestar, como por medidas de protecção e de preparação para o socorro, designadamente a nível de infraestruturas, de modo a que este venha a atuar de forma adequada, com o objetivo de também reduzir os danos ao mínimo possível.

\section{Capacidade de resposta}

Por sua vez, a capacidade de resposta, embora tenha de ser dimensionada e preparada antecipadamente, só é chamada a intervir imediatamente após a manifestação do risco, também com o mesmo objetivo de reduzir os danos causados por essa manifestaçấo. 
Deste modo, a capacidade de resposta diz respeito às várias organizaçóes que integram a proteção civil, designadamente as forças de socorro e segurança, de emergência e assistência, com vista à prestação de socorro durante a ocorrência e à reabilitação a área afetada (intervenção de emergência), bem como à posterior recuperação dessas áreas (intervenção de consolidação/reconstrução) com o objetivo de minimizar os danos, caso volte a repetir-se a manifestação de risco.

Como é sabido, o socorro está organizado por forma a que o número de vítimas (sejam elas fatais, psicológicas ou físicas), bem como os danos por elas sofridos sejam sempre reduzidos ao mínimo possível. Todavia, para que seja possível obter este desiderato é fundamental estabelecer uma definição de prioridades, sobretudo para o tratamento/evacuação de possíveis feridos, que poderão ser muito graves, graves e ligeiros, os quais, por sua vez, deverão ter uma avaliação e um tratamento separado dos prováveis desalojados e desabrigados, e que, por sua vez, deverá ser ainda diferente daquele que estará reservado a eventuais desaparecidos.

No que respeita ao socorro de urgência, a capacidade de resposta, para ser eficaz, carece de prévia organização, formação e treino, aspetos que se revelam fundamentais para a eficiência do sistema de proteção e socorro no teatro de operaçóes. Normalmente, ela está mais organizada e vocacionada para prestar socorro em termos de açôes de "salvamento", relacionadas com os feridos, e de "busca" para encontrar soterrados e desaparecidos, do que para dar resposta eficaz às vítimas psicológicas e aos desalojados, que, assim, nesta fase inicial são, por vezes e compreensivelmente, deixados para segunda prioridade, mas isso não significa que, depois desses momentos iniciais, a fase de resgate, associada à busca e salvamento, não decorra em simultâneo com a de reabilitação.

Com efeito, nesta primeira fase, designada de reabilitação, a capacidade de resposta satisfaz normalmente as necessidades, uma vez que está relacionada com medidas de emergência e, normalmente, mobiliza ajuda internacional, pois trata-se de prestar assistência para suprir necessidades básicas vitais dos afetados, designadamente em termos de alimentação e alojamento provisórios, tendentes a minorar, no imediato, os impactes da crise.

Todavia, no que respeita a medidas de médio e longo prazo, designadas de recuperação, a capacidade de resposta deixa mais a desejar, se é que alguma vez se con- 
cretiza, sobretudo porque implica continuidade e persistência ao longo do tempo. $\mathrm{Na}$ realidade, estas medidas implicam uma série de aspetos complementares, com o duplo objetivo de, por um lado, atenuar as consequências da crise e, por outra parte, de minorar os efeitos de manifestaçôes futuras, os quais passam pela reconstrução dos bens e haveres destruídos, pela redução das vulnerabilidades e por programas de desenvolvimento, fundamentais para um rápido retorno à situaçáo de normalidade.

$\mathrm{Na}$ nossa perspetiva é fundamental ter em conta estes três aspetos: exposição, sensibilidade e capacidade, para se poder intervir em termos da reduçáo da vulnerabilidade, pois é a vulnerabilidade dos territórios, das comunidades e da sociedade, constituída pelos seres humanos e pelos seus bens e haveres, que liga obrigatoriamente os processos ao risco, pois "sem o homem não há risco, há outra coisa..." (Rebelo, 1999, p. 12).

Ora, o risco só é objeto de estudo porque acarreta consequências, sempre que se manifesta com alguma severidade. Embora essas consequências façam parte da crise, dado que ocorrem após a manifestação, em termos de avaliaçâao de risco podemos estimá-las e, por isso, é possível ter uma ideia dos danos que, eventualmente, se possam vir a ocasionar, dado que eles estáo intimamente associados às vulnerabilidades.

Assim, o dano potencial comporta dois aspetos que carecem de análise separada. Por um lado, trata-se de estimar as perdas humanas, traduzidas pelo número de vítimas, dado que não é possível contabilizar o valor económico da vida humana. Por outra parte, importa avaliar o valor económico das perdas materiais, ambientais ou funcionais que determinada manifestação de risco poderá ocasionar.

\section{Perdas humanas}

No que respeita às perdas humanas, trata-se de prever o número de vítimas, que, como vimos, poderáo ser de três tipos: 1 - fatais, correspondentes às vítimas mortais; 2 - físicas, que englobam tanto os feridos, com distintos níveis de gravidade (ferido grave, ferido leve, enfermo, mutilado, ...), como, num segundo conjunto, os desalojados, desabrigados e desaparecidos; 3 - psicológicas, aquelas que ficaram afetadas em termos psicológicos. 
De facto, nestas circunstâncias, os aspetos psicológicos e sociais, que, tantas vezes, ou não são tidos em consideração ou não lhes é dada a devida conta, são dos que deixam marcas mais profundas e duradouras nos diversos tipos de vítimas e, em particular, nos desabrigados, por estes verem a sua moradia totalmente destruída ou danificada irreversivelmente e por não contarem com uma rede social que lhes faculte um acolhimento circunstancial.

Do mesmo modo, essas marcas também ficam bem vincadas nos desalojados, que se veem despojados das suas raízes, dos seus afetos e das suas ligaçôes preferenciais com um espaço/território/comunidade que deixou de existir após a plena manifestação de risco que os afetou, ou a que deixaram de ter acesso, por esse espaço ter ficado profundamente transformado.

\section{Outras Perdas}

No que concerne às perdas materiais, ambientais e funcionais, poderá estimar-se o valor monetário ou estratégico do(s) diferente(s) elemento(s) exposto(s) ao risco, correspondente ao custo de mercado para a respetiva recuperação, naturalmente tendo em conta não só o tipo e as caraterísticas do elemento exposto, mas também outros fatores que poderão influenciar esse custo, tais como outras perdas económicas, diretas e indiretas, resultantes da cessação da funcionalidade, atividade ou laboração (Juliáo et al., 2009).

\section{Modelo Conceptual}

Após esta contextualização, e em síntese, o modelo de risco que propomos (fig. 8) resulta do cruzamento de processos naturais e/ou antrópicos, ou seja, da severidade, com as vulnerabilidades dos seres humanos e dos seus bens, pelo que o risco resultará da multiplicação da severidade pela vulnerabilidade:

Risco $=$ Severidade $x$ Vulnerabilidade 
Agrupando, numa perspetiva conceptual, a sequência dos conceitos apresentados e, na ótica de aplicaçáo operacional, permitindo o estabelecimento de diferentes níveis para cada risco em concreto (normalmente, em termos operacionais, consideram-se os indicados de 1 a 5), em resultado do modo de atuaçáo dos respetivos processos e tendo em conta as vulnerabilidades existentes, que incluem os danos estimados.

Nesta definição existe o propósito de estruturar um modelo de risco que permita hierarquizar tomadas de decisão, inerente a uma certa escala de decisão, através de valores numéricos (finais) discretos e sem dimensóes, variando de 0 a 1,0 a 10 ou 0 a 100, consoante a escala adotada, situando-nos assim num propósito de convenção, fora da definiçấo quantitativa e formal que, por vezes, é usada para diferentes cenários. Assim, o objetivo do modelo de risco proposto náo é o de quantificar o risco como valor expectável de danos estimados (análise quantitativa do risco).

Muitas vezes, o valor obtido converte-se numa escala de 0 a 5 , correspondente aos seis níveis de risco normalmente utilizados em termos operacionais e que, na prática, se reduzem a cinco, por não se considerar o nível mais baixo, o mínimo (fig. 8).

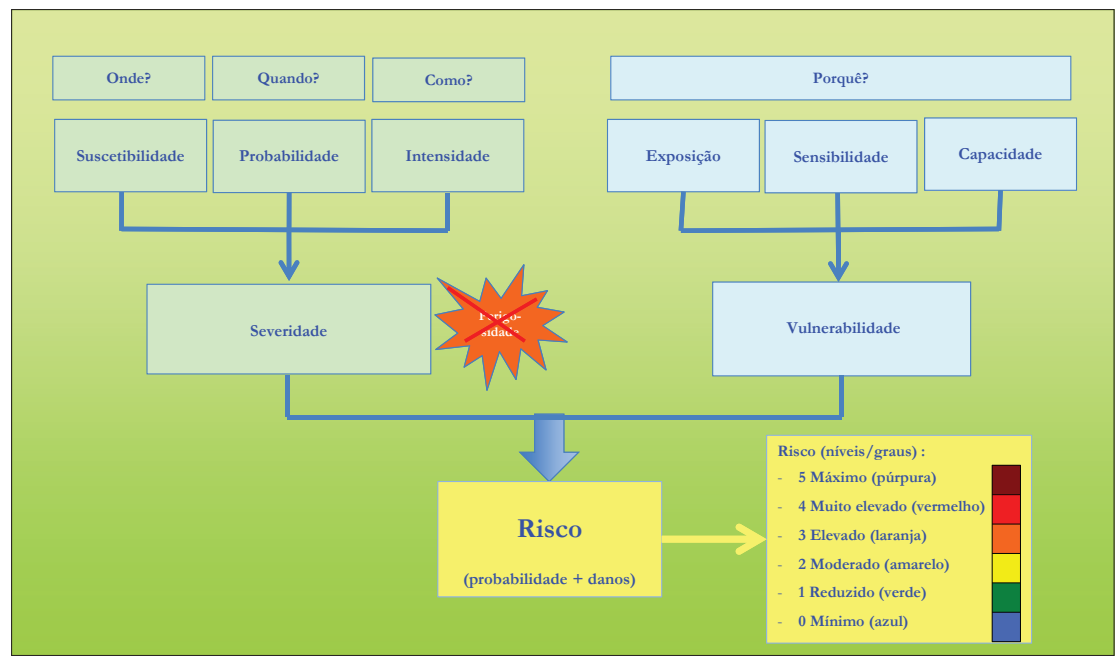

Fig. 8 - Modelo conceptual para estimar um determinado tipo de risco e sua tradução numa classificação para resposta operacional e previsão das possíveis consequências.

Fig. 8 - Conceptual model to estimate a certain type of risk and its expression as a classification for operational response and prediction of possible consequences. 


\section{Perigo}

O "perigo", como referimos anteriormente, é por nós entendido como uma espécie de limiar de transição entre o "risco" e a "crise" que marca, de forma indelével, o início desta, desempenhando um papel de soleira ou de patamar de transição entre ambos, ou seja, constitui a porta de entrada que marca o início da Crise.

Ora, se admitirmos que o perigo corresponde à situação em que o risco se manifesta, então ele será contemporâneo do início da crise, uma vez que esta corresponde à manifestação do risco. Com efeito, quando a manifestação do risco passa a estar iminente, ocorrem normalmente sinais de alerta, anunciadores da aproximação do perigo que, assim, passa a efetivo, durante o lapso de tempo em que o processo se manifestar, e que marca o início da crise, a qual poderá, depois, prolongar-se e apresentar outros "perigos", mas estes já não decorrem diretamente do processo inicial.

Por isso, o perigo é por nós entendido como algo fugaz, uma vez que tão depressa é potencial como está iminente, como, instantes depois, está a acontecer e, muito rapidamente, se pode transformar em algo que é passado (fig. 9), ao contrário

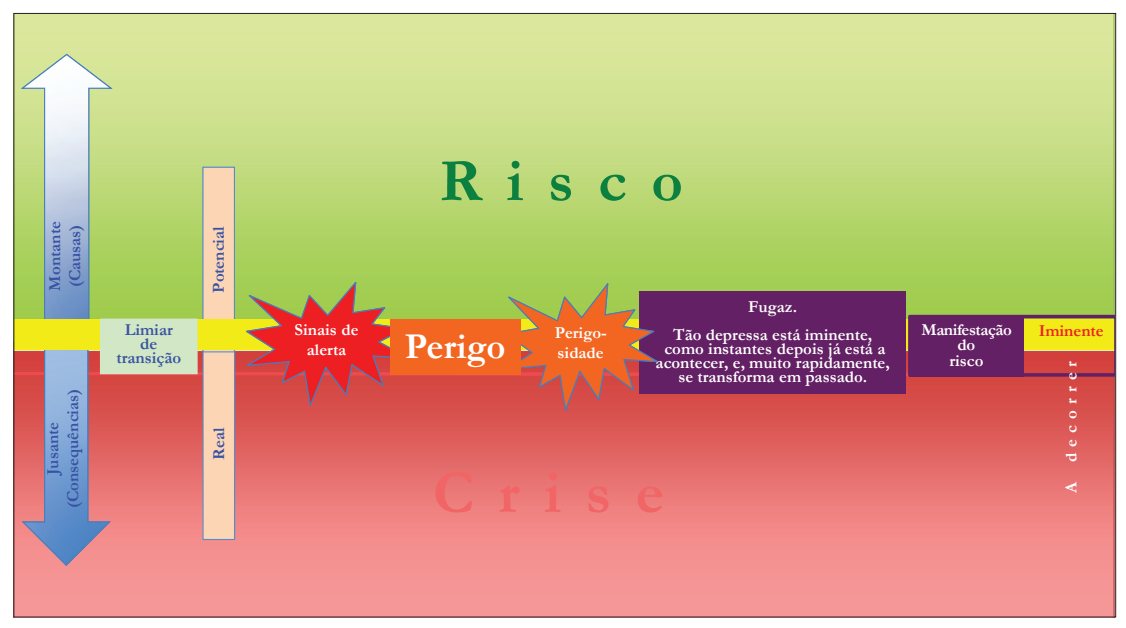

Fig. 9 - Representação esquemática do perigo, entendido como limiar de transição entre o risco, situado a montante e que por isso é potencial, e a crise, localizada a jusante, que é real.

Fig. 9 - Schematic representation of danger, taken as the transition threshold between the upstream, and therefore potential, risk and the downstream crisis, which is real. 
da crise, que pode permanecer por muito mais tempo, às vezes prolongando-se por vários anos, eventualmente com outros "perigos", mas que têm causas diferentes daquela que originou a crise.

Por outro lado, o perigo reconhece-se através de sinais de alerta, a que poderemos chamar perigosidade, ou seja, esta indica a qualidade do que é perigoso, dado que permite reconhecer a existência de perigo, exatamente através de sinais indicadores de que a manifestação do risco já está iminente e, por conseguinte, passou a acarretar perigo.

Ora, esses sinais variam consoante o tipo de risco que está prestes a manifestar-se. Por exemplo, no caso da manifestaçấo do risco sísmico, por vezes os cães ladram antes de acontecer o tremor de terra, por "sentirem" as ondas premonitórias, insensíveis ao ser humano, mas que são registadas nos sismógrafos.

Do mesmo modo, a manifestação do risco vulcânico é, muitas vezes, antecedida de sismos que alertam para uma atividade anormal nas câmaras magmáticas.

Um terceiro exemplo pode ser dado a propósito de algumas movimentaçóes em massa, cujos sinais dizem respeito ao aparecimento de fissuras na área que, mais tarde, irá ficar assinalada como tendo sido a "cicatriz de arranque" do deslizamento, ou seja, aquela que marca o local de arranque do material que foi destacado e deslocado.

Por fim, um último exemplo, diz respeita à rápida descida do nível do mar para cotas muito abaixo das habituais e que é sinal da posterior aproximação de ondas gigantes, conhecidas por maremotos ou tsunami.

Com estes exemplos de sinais de alerta, e muitos outros poderiam ser dados para outros tantos riscos, apenas pretendemos distinguir as situaçóes em que estamos em risco, mas em que nada de grave acontece, daquelas outras em que corremos perigo, nomeadamente quando estes sinais alertam para a iminente manifestaçáo do risco e que, quando ele se materializa e acontece, gera a crise, situação em que se corre efetivamente perigo.

Por isso, tanto Lucien Faugères (1990), ao mencionar que o perigo "caracteriza uma situação de desregulação do sistema que torna perceptivel e desencadeia toda uma série de reaçôes de defesa", como Yvette Veyret (2007), ao referir que "o risco, objeto social, define-se como a percepçấo do perigo, da catástrofe possivel”, deixam subenten- 
der o posicionamento antes mencionado, ou seja, como o limiar de transiçáo que marca o início da crise.

Deste modo, o perigo corresponde assim ao desencadear da manifestaçấo da crise, que nos é dado pelos sinais de alerta antes referidos, e por outros que nos sistemas de segurança são identificados por desvios, uma vez que não têm grande significado para a segurança, e por anomalias (fig. 10), que representam violação das situaçōes operacionais autorizadas, as quais, não pondo em risco a segurança, revelam deficiências nos sistemas (Lourenço, 2003, p. 91), um assunto a que voltaremos mais adiante.

Contudo, o perigo efetivo está associado ao desenrolar da crise. Assim, nos primeiros instantes, ele está diretamente associado à causa que originou a crise, mas nas horas (dias, meses ou anos) seguintes ele poderá continuar a manifestar-se, embora muito provavelmente já não esteja diretamente relacionado com a causa inicial, pois será devido sobretudo a causas antrópicas, designadamente à falta da capacidade de resposta para uma adequada recuperação da área afetada.

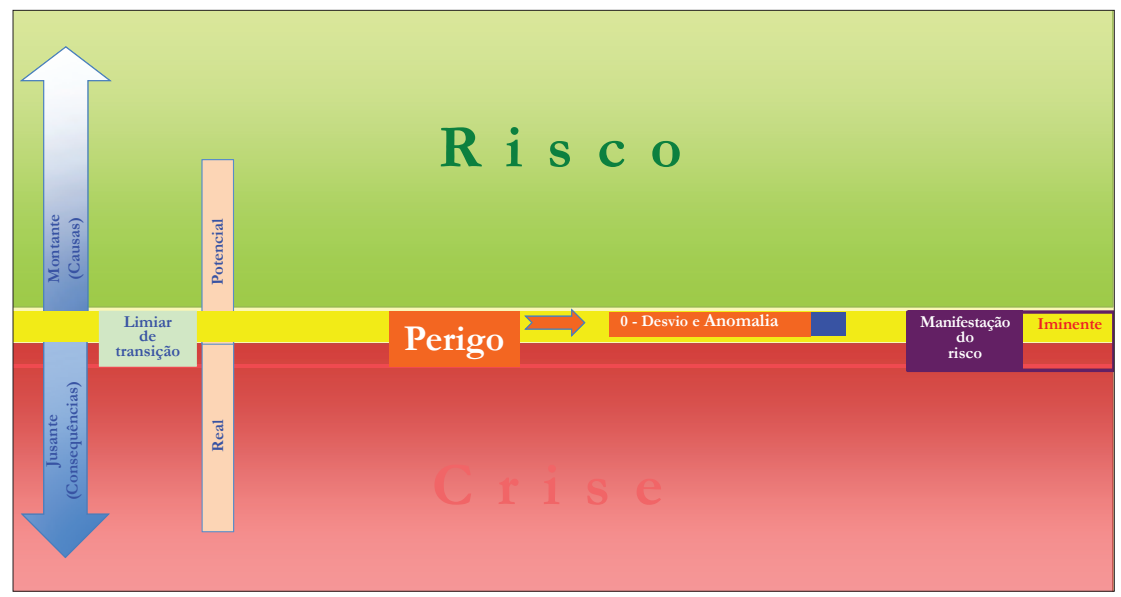

Fig. 10 - Esboço de representação do perigo, a marcar o final do risco e fazendo a transição para o início da sua manifestação, materializada na crise.

Fig. 10 - Danger represented as marking the end of the risk and making the transition to the beginning of its manifestation, in the form of crisis. 


\section{Crise}

A crise pode ser entendida, de forma simples, como a "plena manifestação do risco" e, por isso, as Naçóes Unidas entendem as crises como emergências, ou seja, como manifestaçóes de risco que requerem uma ação urgente (ISDR, 2009, p. 13), uma vez que foram ultrapassados os limiares normais de reação.

Por seu lado, Lucien Faugères (1990, p. 53) considerou que as crises ocorrem sempre que:

- as defesas, ou as tentativas de restabelecer o funcionamento anterior, se tornam inoperantes;

- certos limiares são ultrapassados;

- é iniciada uma escalada;

- o curso dos fenómenos em causa náo pode ser previsto ou controlado.

Este enquadramento permite que se desenrolem situaçóes muito diversificadas, pelo que nos parece fundamental distinguir essas situações, separando claramente as pequenas das grandes crises.

Todavia, antes disso, como é frequente encontrar associado às crises o uso de alguns termos que são entendidos com significados diferentes, entendemos dever contribuir para clarificar o seu uso junto dos agentes de proteção civil (que somos todos nós), pois se cada ciência atribuir um significado próprio a vocábulos que as outras usam com sentidos diferentes (e isso está a acontecer com o uso de alguns termos) criam-se claras dificuldades de entendimento, pois, apesar de se usar o mesmo termo, ele é entendido com diferentes significados pelos vários intervenientes, consoante sejam investigadores, operacionais, gestores, leitores, expectadores ou ouvintes.

Por vezes, quase se sente a necessidade de pedir a "tradução", ou melhor, a explicitação de determinados conceitos, devido à dificuldade de comunicação que o uso da mesma linguagem provoca, ao utilizar os mesmos vocábulos que são entendidos com significados diferentes pelos diferentes intervenientes nessas comunicaçóes/informaçóes.

Por isso, entendemos que os diferentes agentes de proteção civil (bombeiros, forças de segurança, forças militares, médicos e técnicos do INEM, decisores e técnicos dos diferentes organismos e serviços centrais e municipais, ...), bem como os professores, na qualidade de intervenientes ativos na educação para os riscos, os jornalistas e os políticos enquanto grandes divulgadores desses vocábulos, deveriam fazer um 
esforço para utilizar termos portugueses, adequados não só para exprimir os conceitos pretendidos, mas também para que sejam entendidos pela população, ou seja, pelos cidadãos que são a razão de ser da existência do sistema de proteção civil.

Ora, como não existe uniformidade nas classificaçóes dos diferentes tipos de ocorrências, apresentamos uma proposta que não só visa hierarquizar alguns dos termos mais usados em Proteção Civil, em função do número de eventuais vítimas e da importância dos danos ocasionados, mas também procura explicitar o significado que entendemos dever estar associado à utilização destes termos, a qual resulta de uma adaptação, simplificada, da Escala Internacional de Ocorrências Nucleares (AIEA/AEN, 1995), dado que esta classificação é demasiado minuciosa para uma aplicação mais geral.

\section{Ocorrências}

Este deverá ser o termo a usar em sentido genérico, para abranger todas as situações a seguir mencionadas, associadas a riscos e às suas manifestaçóes, independentemente da sua maior ou menor gravidade, ainda que, em sentido restrito, no domínio da proteção civil, signifique um evento que requer a intervenção especializada de equipas de socorro em caso de emergência (Silva et al., 2009). Sendo compreensível a lógica deste entendimento, porque incluem os falsos alarmes, já que estes implicam o acionamento de meios, de facto, estes não podem ser considerados uma verdadeira ocorrência, em sentido lato, pois o que houve efetivamente foi uma falsa informação e não uma manifestação de risco.

De todas formas, não há nenhum inconveniente em também considerar os falsos alarmes como ocorrências, pelo que a utilização deste termo deveria ser mais generalizada.

Assim, dentro dessa tal simplificação para a linguagem corrente da proteção civil, enquanto ponto de reunião e de encontro na aplicação dos diferentes saberes, se conseguíssemos uniformizar essa linguagem, estaríamos a prestar um bom serviço ao país, razão pela qual alertamos para esta realidade, embora estejamos conscientes de que não será fácil alterar rotinas definidas em diferentes organismos e disciplinas e mudar o que quer que seja sem ferir suscetibilidades, mas não devemos inibir-nos de ter esse papel "provocador" e de despertar consciências, por forma a corrigir aquilo que nos parece estar menos bem. 


\section{Pequenas crises}

Assim, do nosso ponto de vista, as pequenas crises traduzem-se quer por incidentes, em que não há necessidade de intervenção dos meios de socorro, quer por acidentes, em que apesar da intervenção dos meios de socorro dos bombeiros e, eventualmente, das forças de segurança, não apresentam gravidade, pelo que passam perfeitamente despercebidas e raramente são notícia, integrando-se nas situaçóes ditas de rotina. Estas situaçóes podem ser subdivididas em:

\section{Desvios e anomalias}

As ocorrências sem relevância para a segurança, que na Escala Internacional de Ocorrências Nucleares (AIEA/AEN, 1995) são classificadas abaixo da escala, sendo-lhe atribuído o nível zero, correspondente às situações de desvio (0). Segue-se-lhes o nível um, que faz parte dos níveis baixos e corresponde às anomalias (1), mas, por estas também não colocarem em risco a segurança, na nossa simplificação foram associadas ao grau zero (0), que assim agrupa estes dois níveis e que se associam a situações de risco mínimo (QUADRo I).

\section{Incidentes}

Os incidentes correspondem a episódios repentinos que reduzem significativamente as margens de segurança sem, contudo, as anular, pelo que apenas apresentam consequências potenciais para a segurança (Lourenço, 2003) ${ }^{2}$.

\footnotetext{
${ }^{2} \mathrm{Nem}$ todos os conceitos que agora se apresentam coincidem exatamente com os descritos no trabalho supramencionado porque, entretanto, com a publicação da nova Lei de Bases da Proteção Civil portuguesa (Lei n. ${ }^{\circ} 27$, de 3 de julho de 2006), alguns deles passaram a ter novo significado e enquadramento, como sucedeu, por exemplo, com o de calamidade. $\mathrm{Na}$ anterior Lei de Bases da Proteçáo Civil portuguesa (Lei n. ${ }^{\circ} 113$, de 29 de agosto de 1991) este termo correspondia ao nível hierárquico mais grave, acima da catástrofe, mas, com a publicação da nova Lei, passou a uma situação que "pode ser declarada quando, face à ocorrência ou perigo de ocorrência de algum ou alguns dos acontecimentos referidos no artigo 3. ${ }^{\circ}$ e è sua previsivel intensidade, é reconhecida a necessidade de adoptar medidas de carácter excepcional destinadas a prevenir, reagir ou repor a normalidade das condiçōes de vida nas áreas atingidas pelos seus efeitos".
} 
Assim, na simplificação que propomos, juntamos nesta categoria os outros dois níveis baixos da Escala Internacional de Ocorrências Nucleares, a saber: incidente (2) e incidente grave (3), chamando-lhe simplesmente incidentes (1), que normalmente estâo associados a situaçóes de risco reduzido (QUADRo I).

Aliás, a própria língua portuguesa traduz essa consciência do risco, pois quando se fala de "incidentes de percurso", entendem-se como coisas de somenos importância, razão pela qual tenho uma certa dificuldade em entender a vulgarização que alguns pretendem dar a este termo, usando-o tanto no sentido de ocorrência, como no de acidente.

\section{Acidentes}

Os acidentes são acontecimentos repentinos e imprevistos, provocados pela ação do ser humano ou da natureza, com danos significativos e efeitos muito limitados, no tempo e no espaço, susceptíveis de atingirem as pessoas, os seus bens ou o ambiente (Lourenço, 2003).

No entanto, uma outra forma de hierarquizar as manifestaçôes do risco poderá ser através do número de vítimas fatais que lhes estão associadas. Nesse sentido, André Dauphiné (2001) considerou os acidentes como o primeiro nível da escala, uma vez que eles podem apresentar danos avultados e envolver um número de mortos situado entre 0 e 9 .

De facto, em termos de consequências, estas manifestaçóes de risco, sem vítimas fatais ou com um reduzido número de mortos, nada têm a ver com aquelas que decorrem das plenas manifestaçóes de risco que, por assumirem maior gravidade, se traduzem em acidentes graves e catástrofes que correspondem às grandes crises, conforme apresentaremos a continuação.

Em termos da simplificaçáo que propomos, juntamos nesta categoria os primeiros dois níveis elevados da Escala Internacional de Ocorrências Nucleares, a saber: acidente, principalmente na instalação (4), e acidente com riscos fora da instalaçáo (5), a que chamamos simplesmente acidentes (2) e que normalmente podemos associar a situaçóes de risco moderado (QUADRo VI). 


\section{Grandes crises}

Por sua vez, as grandes crises implicam o acionamento do Sistema de Proteção Civil, pelo que correspondem, naquilo que é o nosso entendimento da Lei de Bases da Proteção Civil portuguesa (Lei n. ${ }^{\circ}$ 27/2006, de 3 de julho), aos acidentes graves e às catástrofes constantes dos n. ${ }^{o s} 1$ e 2 do Artigo $3 .^{\circ}$ e que se descrevem a seguir.

\section{Acidentes graves}

Os acidentes graves distinguem-se dos acidentes anteriormente descritos, pela maior gravidade das suas consequências, sendo entendidos como "um acontecimento inusitado com efeitos relativamente limitados no tempo e no espaço, susceptivel de atingir as pessoas e outros seres vivos, os bens ou o ambiente" (Lei n. ${ }^{\circ}$ 27, 2006).

Por sua vez, André Dauphiné (2001) na sua classificação refere-se a acidentes graves ou desastres quando o número de mortos se situa entre 10 e 99.

No entanto, esta associação dos acidentes graves aos desastres não deixa de ser curiosa, pois o vocábulo "desastre" é outro que também tem vindo a ser alvo de confusão, mercê da transliteração do termo disaster, dos autores anglófonos, em vez da sua tradução por catástrofe, dado que em português existem os dois termos, embora com significados diferentes.

Com efeito, referimo-nos frequentemente à existência de "um desastre de automóvel”, mas não é usual considerá-lo como sendo uma catástrofe. Pelo contrário, não hesitamos em considerar como catástrofes os terramotos com elevado número de mortos. Do mesmo modo, alguns grandes incêndios florestais que, durante dias consecutivos destroem milhares de hectares de floresta, queimam casas e, por vezes, até matam pessoas, devem ser considerados como catástrofes, entendidas como sendo "plenas manifestaçóes do risco" (Lourenço, 2015). Não podemos deixar de mencionar o entendimento que é dado ao termo "desastre" no Brasil que é equivalente ao da "catástrofe" em Portugal. 
Voltando à simplificação que propomos, esta categoria corresponderá a um dos níveis elevados da Escala Internacional de Ocorrências Nucleares, mais precisamente ao de acidente grave (3), e que normalmente se associa a situaçôes de risco elevado (QUADRo VI).

\section{Catástrofes}

$\mathrm{Na}$ atual Lei de Bases da Proteçáo Civil portuguesa, as catástrofes são entendidas como um fenómeno ou uma série de acontecimentos "susceptiveis de provocarem elevados prejuizos materiais e, eventualmente, vitimas, afectando intensamente as condiçóes de vida e o tecido socioeconómico em áreas ou na totalidade do território nacional' (Lei n. ${ }^{\circ}$ 27, 2006).

Por sua vez, no que à perda de vidas humanas diz respeito, e de acordo com a já mencionada obra de André Dauphiné (2001), consideram-se três tipos de catástrofes:

(i) A catástrofe propriamente dita, que se associa a um número de mortos variável entre 100 e 9999 ;

(ii) A catástrofe maior, com o número de mortos a variar ente 10000 e 99 999;

(iii) A supercatástrofe, com um número de mortos superior a 100 000, mas que pode ir até mais de um milhäo.

Em termos da Escala Internacional de Ocorrências Nucleares, o acidente muito grave (7), corresponde ao nível mais elevado dos chamados acidentes e que, em terminologia de proteçáo civil, é equivalente à catástrofe, a qual, de acordo com A. Dauphiné (2001), deverá incluir um número de mortos igual ou superior a 100 (cem), embora, em determinadas circunstâncias muito localizadas, possa corresponder a um número menor de mortos, mas, nesses casos, terá de afetar mais de mil (1 000) pessoas.

No entanto, se for declarado o estado de calamidade/emergência e solicitada a ajuda internacional, isso dever-se-á, certamente, a uma situaçáo bem mais grave do que a anteriormente descrita e, por conseguinte, parece-nos fazer sentido considerar as situaçóes de catástrofe subdivididas em dois subgrupos. 
No primeiro caso, designam-se simplesmente por catástrofe (ou catástrofe minor), que correspondem ao grau 4 e associamos a situaçóes de risco muito elevado (QUADRo VI).

Na segunda situação, dever-se-ão chamar grande catástrofe (ou catástrofe major), equivalente ao grau 5, que associamos a situaçóes de risco excepcional ou risco máximo (QUADRO VI).

Assim, a diferença entre estes dois níveis decorre, essencialmente, do facto do segundo tipo envolver, não só um maior número de vítimas e de pessoas afetadas, mas também de, por essa razão, ser decretado o estado de calamidade e solicitado o auxílio internacional. Com efeito, não nos parece que esta subdivisão se possa fazer tendo em conta exclusivamente o número de mortos, dado que há outras vítimas e danos que não podem deixar de ser tidos em conta, posto que são fundamentais para decretar o estado de calamidade e nem sempre são proporcionais ao número de mortos.

A análise comparativa da Escala Internacional de Ocorrências Nucleares com a da nossa proposta para uso dos Organismos de Proteção Civil, mostra claramente a diferença dos objetivos que estão subjacentes à definição dessas duas escalas e que se traduzem num claro estreitamento da base da nossa escala, que se reduz a metade dos

QUADRO VI - Níveis de risco em Organismos de Proteção Civil, comparativamente com os da Escala Internacional de Ocorrências Nucleares.

TABLE VI - Risk levels in Civil Protection Organizations relative to those of the International Scale of Nuclear Events.

\begin{tabular}{|c|c|c|c|c|c|c|c|}
\hline \multicolumn{4}{|c|}{ Organismos de Proteçáo Civil } & \multicolumn{4}{|c|}{ Escala Internacional de Ocorrências Nucleares } \\
\hline \multicolumn{2}{|l|}{ Grau } & Denominaçáo & Cor & \multicolumn{2}{|l|}{ Nível } & Designaçáo & Cor \\
\hline Máximo & 5 & Grande catástrofe & & \multirow{3}{*}{$\begin{array}{c}\text { Elevado } \\
\text { (Acidentes) }\end{array}$} & \multirow{2}{*}{7} & \multirow{2}{*}{ Acidente muito grave } & \\
\hline Muito elevado & 4 & Catástrofe & & & & & \\
\hline Elevado & 3 & Acidente grave & & & 6 & Acidente grave & \\
\hline \multirow{2}{*}{ Moderado } & \multirow{2}{*}{2} & \multirow{2}{*}{ Acidente } & & & 5 & $\begin{array}{l}\text { Acidente com risco fora } \\
\text { da instalaçáo }\end{array}$ & \\
\hline & & & & & 4 & Acidente na instalação & \\
\hline \multirow{2}{*}{ Reduzido } & \multirow{2}{*}{1} & \multirow{2}{*}{ Incidente } & & \multirow{3}{*}{$\begin{array}{c}\text { Baixo } \\
\text { (Incidentes) }\end{array}$} & 3 & Incidente grave & \\
\hline & & & & & 2 & Incidente & \\
\hline \multirow[b]{2}{*}{ Mínimo } & \multirow[b]{2}{*}{0} & Anomalia & & & 1 & Anomalia & \\
\hline & & Desvio & & $\begin{array}{l}\text { Abaixo da } \\
\text { escala }\end{array}$ & 0 & Desvio & \\
\hline
\end{tabular}


níveis da outra, e, em contrapartida, à manutenção do mesmo numero de classes nos níveis mais altos, por subdivisão do nível mais elevado da outra escala (QuAdro VI).

À guisa de síntese, diremos que uma situação de risco termina quando se inicia a de perigo, o qual dá início à manifestação desse risco, que se materializa através da crise, organizada em diferentes níveis de acordo com a respetiva severidade, os quais determinam diferentes protocolos de atuação, que se iniciam com a prevenção e a preparação, passando depois pelo resgate e tratamento das vítimas e terminam com a recuperaçâo da área afetada (fig. 11).

Feita esta descrição, voltemos às crises que habitualmente associamos às plenas manifestaçôes de risco e que correspondem a uma "situação delicada, em que por circunstâncias de origem interna ou externa, se verifica uma ruptura violenta da normalidade ou do equilíbrio dinâmico de um sistema, o que favorece a sua desorganização e descontrolo" (M. Silva et al., 2009, p. 17).

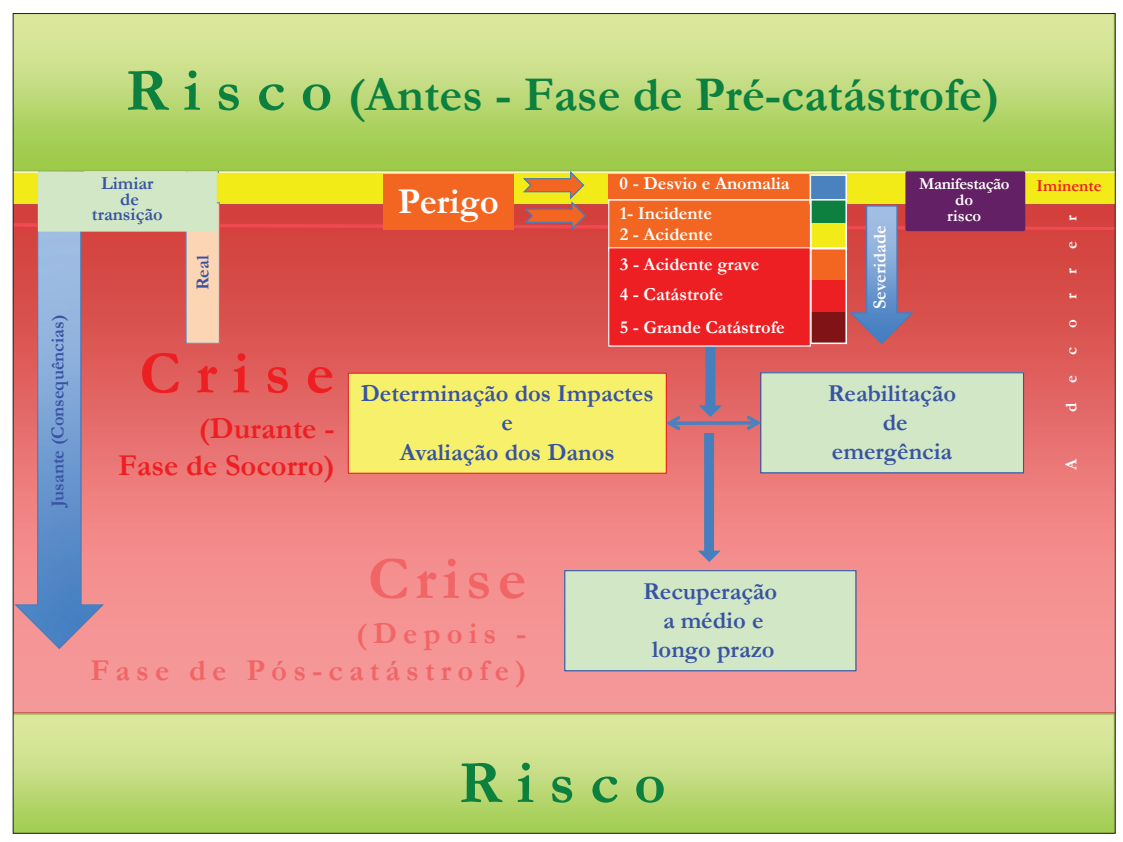

Fig. 11 - Esquema ilustrativo dos diferentes tipos de manifestaçôes de risco em associação com as fases do "ciclo da catástrofe".

Fig. 11 - Diagram showing the different types of risk manifestation in association with the stages of the "disaster cycle". 
Por outro lado, citando Farazmand (2001), "As crises envolvem acontecimentos e processos que acarretam ameaça severa, incerteza, um resultado desconhecido e urgência... A maioria das crises deixa marcas importantes nos individuos, organizaçôes e nas próprias naçôes. As crises podem ter diferentes origens, como actos de terrorismo (World Trade Center, de Nova Iorque), desastres naturais (Furacōes Hugo e Andrew, na Flórida), acidentes nucleares (Chernobyl), acontecimentos revolucionários (Greve Geral em Maio de 1968, em França), crises de negócio, e crises de organizaçâo... As crises consistem numa série de acontecimentos que destroem ou enfraquecem uma condição de equilibrio e a eficácia de um sistema favorecendo o seu descontrole dentro de um determinado periodo de tempo..."

Com efeito, são estas plenas manifestaçóes de risco que, normalmente, associamos às crises e que correspondem a uma situaçáo anormal e grave, traduzida pela incapacidade de agir sobre os processos e pela incerteza absoluta sobre o seu desenvolvimento e dos seus impactes.

Aliás, incerteza, insegurança e consequências são outros aspetos que, como vimos, não se podem desligar do risco e das suas manifestaçôes, as quais, por sua vez, estáo dependentes da intensidade de atuação do(s) processo(s), pelo que a construçáo do conceito de risco está, assim, intimamente ligado a estes fatores (Betâmio de Almeida, 2011).

\section{Resiliência e consequências das manifestações de riscos}

A determinação dos impactes e a avaliação dos danos devem iniciar-se imediatamente após a manifestação do risco, o que faz com que, por vezes, ainda ocorram durante a manifestação do risco, embora, quase sempre, só mais tarde é que se consegue concluí-las.

Não obstante, esses levantamentos são fundamentais para, numa primeira fase, se organizar a reabilitaçáo de emergência e, depois, são essenciais para se proceder à recuperação a médio e longo prazo, com vista à reconstrução da área afetada que, se for bem efetuada, poderá permitir intervir no território. Essa intervenção terá como objetivo exercer, no futuro, algum controlo sobre os processos 
naturais e as suas dinâmicas, e, muito em particular, sobre a sociedade, uma vez que "o ser humano, estando na origem dos riscos antrópicos, é produtor e gestor de tecnologias, de que decorrem riscos tecnológicos, e é gerador de conflitos, que estão na génese dos riscos sociais" (Lourenço, 2007, p.110). Além disso é, ainda, interveniente direto nos riscos mistos.

Ora, se esta intervenção a nível das causas é importante, mais imperioso se torna atuar também na redução das vulnerabilidades, por forma a que todo o conjunto seja mais resiliente e, deste modo, minimizando as consequências de futuras manifestações, fecha-se o ciclo da catástrofe. Como é sabido, ele começa com a existência de risco. Se, porventura, se passa à posterior emissão de sinais, isso torna evidente que a manifestação do risco está iminente, determinando a passagem ao estado de ao perigo, que dá início à manifestação do(s) processo(s) envolvido(s) que desencadeia $(\mathrm{m})$ a crise.

Por sua vez, a maior ou menor gravidade das suas consequências dependerá, por um lado, das vulnerabilidades existentes e do tempo durante o qual se manifestar o processo e, por outra parte, do tempo que demorar a recuperação da área afetada e da forma como ela vier a ser reconstruída, com o objetivo de a tornar mais resistente, ou, como sói dizer-se agora, mais resiliente (fig. 12).

\section{A exemplificação de situaçóes de Risco, Perigo e Crise}

Para que não restem dúvidas quanto ao significado que propomos para o uso dos três conceitos: risco, perigo e crise, vamos considerar quatro exemplos diferentes, sendo os dois primeiros relativos a manifestaçôes muito rápidas, embora as suas consequências se possam prolongar por vários anos. Por sua vez, os dois últimos, referem-se a situaçôes em que o tempo de atuação dos processos é mais demorado, mas, normalmente, com as consequências a perdurar por um tempo bem menor do que nos exemplos anteriores, embora também se possam dilatar por alguns anos, uma vez que o posterior retorno à normalidade está muito dependente, em todos os casos, da maior ou menor severidade da manifestação do processo envolvido e da elevada ou reduzida vulnerabilidade da área afetada. 


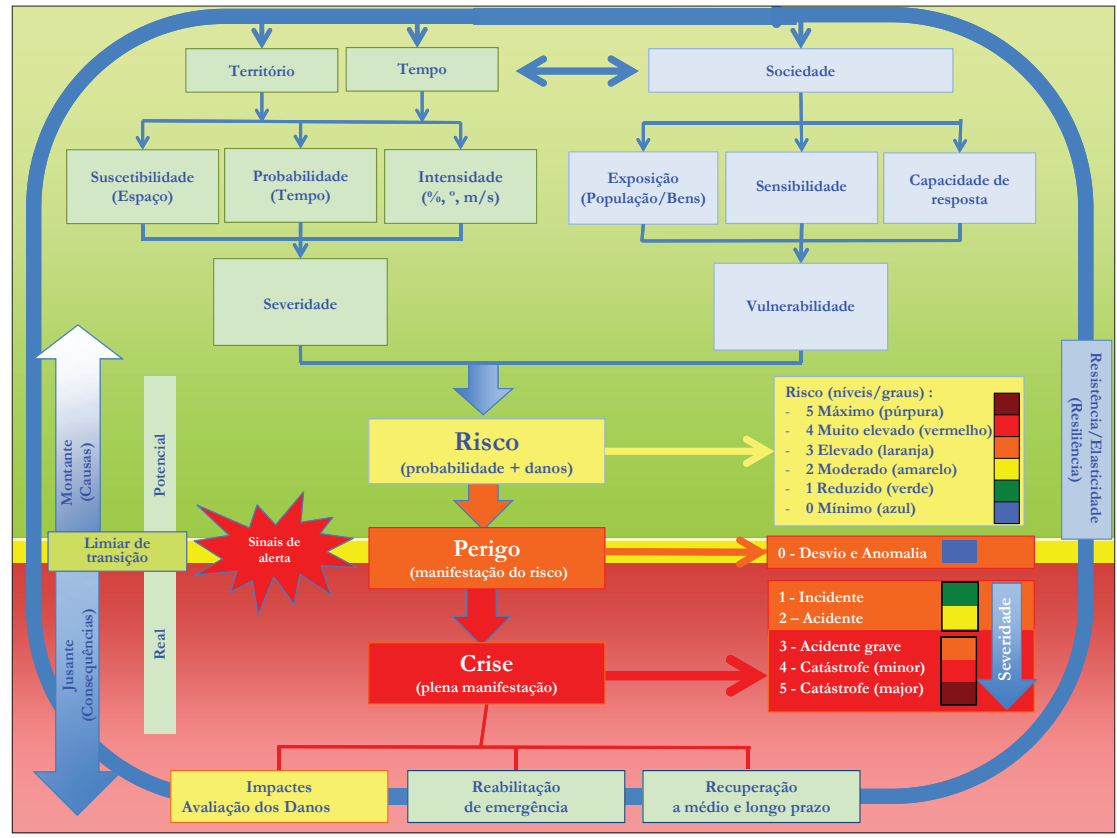

Fig. 12 - Modelo proposto para acompanhar a evolução da manifestaçấo de uma crise, através da análise de risco, avaliação do perigo e gestão da crise, com a posterior gestão do risco traduzida na fase de recuperação e que se deverá repercutir na redução do risco.

Fig. 12 - Model proposed to monitor the development of a crisis through risk analysis, risk assessment and crisis management, with subsequent risk management converted into the recovery phase, which should be reflected in risk reduction.

\section{Acidente de automóvel}

O primeiro exemplo refere-se a um risco antrópico e diz respeito a uma experiência frequentemente vivenciada por todos nós, correspondente a uma viagem de automóvel e que constituía o exemplo preferido pelo Prof. Fernando Rebelo para mostrar a articulação entre os conceitos de risco, perigo e crise, tendo-o descrito do seguinte modo:

"Pensemos numa viagem por estrada. Sabemos dos riscos que corremos quando entramos num automóvel — pode acontecer um acidente ou uma avaria, podemos adoecer... No entanto, só de vez em quando nos surge o 
sinal de perigo - na estrada, numa lomba, curvas apertadas, áreas inundáveis, áreas sujeitas a ventos, cruzamentos, obras ou, na própria viatura, o avisador de falta de água, de falta de óleo, de falhas nos travóes ou, ainda, em nós próprios, dores de cabeça, dores no peito, etc.; a ideia de perigo traz-nos sempre um sentimento de proximidade de algo que nos pode causar danos. Felizmente, a crise (que, neste exemplo, será o acidente, a avaria ou a doença) é rara, embora gostássemos que nunca acontecesse"

$$
\text { (Rebelo, 1999, p. } 4 \text { e 2001, p. 241). }
$$

Todavia, quanto se manifesta, pode ter consequências, físicas e psicológicas, que, por vezes, se fazem sentir durante toda a vida dos acidentados ou, mesmo, até podem conduzir à morte!

\section{Tremor de terra}

O segundo exemplo corresponde a uma manifestação muito rápida dum risco natural que, normalmente, dura apenas alguns segundos. Neste caso, entre muitas outras opçōes, algumas delas bem mais catastróficas, escolhemos um dos tremores de terra que foi registado nos sismógrafos do Instituto Geofísico da Universidade de Coimbra e que ocorreu a 24 de fevereiro de 2004, no Norte de África, tendo ficado conhecido por terramoto de Alhucemas.

Apesar de ter durado apenas escassos segundos, causou graves danos materiais e provocou a morte de pelo menos 560 pessoas, não tanto resultantes da manifestação do processo em si, mas mais da vulnerabilidade das construçôes, muitas das quais colapsaram e deixaram soterradas muitas vítimas.

Apesar da causa resultar de um processo natural, que se manifestou muito rapidamente, associaram-se-lhe outros riscos, de natureza antrópica, designadamente o colapso de algumas infraestruturas, devido à inexistência de construção antissísmica.

Por outro lado, a recuperaçáo levou alguns anos e, por conseguinte, as consequências desta manifestação prolongaram-se durante vários anos, período de tempo durante o qual, paulatinamente, se foi retornando à normalidade, ou seja, a uma situação semelhante à existente antes dessa plena manifestação de risco. 
Se, agora, procedermos à interpretação do respetivo sismograma à luz da teoria do risco, é possível inscrever nele os conceitos de risco, perigo e crise, à medida que foi decorrendo a "fita do tempo" (fig. 13) e, deste modo, tornar mais perceptível a aplicação concreta destes três conceitos.

Tratando-se de uma região sísmica, o risco está sempre presente, mas habitualmente não há perigo. Ele só ocorre quando há sinais de alerta, que são transmitidos pela chegada das ondas $\mathrm{P}$, alertando para a iminência da ocorrência, mas, como normalmente sucede, o lapso de tempo é muito curto. Neste exemplo também o foi, tendo correspondido apenas a cerca de um segundo antes da chegada das ondas S. Nestas condiçóes, não há oportunidade para tomar quaisquer medidas de prevenção, pelo que, em instantes, o perigo de iminente passou a real e o risco manifestou-se sob a forma de crise, a qual perdurou por bastante tempo, levando alguns anos até à total recuperação da área afetada.

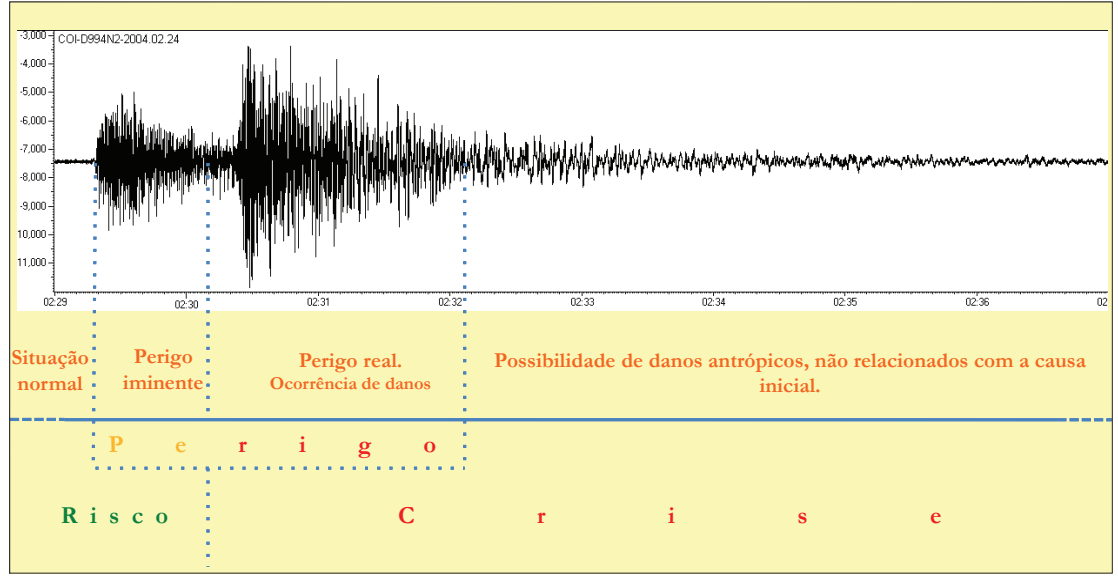

Fig. 13 - Sismograma do terramoto de Alhucemas (Marrocos), com magnitude $\approx 6,5$, registado pelo Instituto Geofísico da Universidade de Coimbra, em 24 de fevereiro de 2004, com a nossa interpretaçáo das fases de risco, perigo e crise

(Fonte: Instituto Geofísico da Universidade de Coimbra: http://www.astro.mat.uc.pt/novo/observatorio/site/sismologia.html).

Fig. 13 - Seismogram of the Alhucemas earthquake (Morocco), with magnitude $\approx 6.5$, registered by the Geophysical Institute of the University of Coimbra on February 24, 2004, with our interpretation of the phases of risk, danger and crisis stages

(Source: Geophysical Institute of the University of Coimbra http://www.astro.mat.uc.pt/novo/observatorio/site/sismologia.html). 


\section{Incêndio}

O terceiro exemplo diz respeito ao risco de incêndio e apresenta os três conceitos chave numa perspetiva um pouco diferente. Com efeito, neste caso, o processo tanto pode ter origem antrópica, designadamente nos incêndios urbanos e nos incêndios industriais, como ser misto, nomeadamente no que respeita aos incêndios florestais, já que são originados tanto por causas naturais como, sobretudo, por causas antrópicas.

Nestas condições, o risco de incêndio está mais associado ao chamado "risco de ignição", ou "de eclosão", ou ainda "de deflagração", pois não implica a ocorrência de incêndios, embora exista a probabilidade de eles se poderem vir a registar, desde que haja igniçóes, através de causas naturais ou de origem antrópica.

Por sua vez, o perigo de incêndio está mais associado ao "risco de propagação" ou "de progressão", o que já implica a prévia manifestação do risco de incêndio, pois decorre da existência de um foco de incêndio, cujo sinal de aviso foi dado pelo avistamento de fumo, e que tem condições para rápida propagação, de forma descontrolada, podendo transformar-se num curto espaço de tempo em grande incêndio, se, entretanto não for dominado.

Neste caso, é a existência duma combustão inicial que faz a passagem do risco para a crise. Digamos que enquanto o fósforo, ou o isqueiro, está aceso na mão do incendiário há risco de incêndio, mas o perigo está iminente. Depois, quando ele ateia o fogo, o risco manifesta-se e, nesse momento, o perigo deixou de estar iminente e passou a real, ao mesmo tempo que tem início a crise.

Deste modo, a crise de incêndio começa pela manifestação do risco, através do foco inicial, embora só seja habitual considerar como verdadeiras crises aquelas que correspondem às plenas manifestaçôes do risco, ou seja, aos grandes incêndios. Com efeito, normalmente todos eles começam por uma combustão controlada no tempo e no espaço, noção que corresponde ao conceito de fogo, para, depois, por qualquer razão se perder esse controlo inicial e a combustão passar a incontrolável, situação que já se designa por incêndio. Assim, a plena manifestação da crise corresponderá ao descontrolo do processo no espaço e a instalaçáo da crise ocorre quando esse descontrolo se prolonga no tempo (Lourenço, 2003). 


\section{Inundação}

O quarto e último exemplo, diz respeito ao risco de inundação, que se reporta a duas das mais importantes inundaçóes provocadas pelo rio Mondego, o rio que banha a cidade de Coimbra. Escolhemos este rio porque, na primeira delas, em janeiro de 1962, o rio corria em regime natural, livre, e na segunda, em janeiro de 2001, já se encontrava em regime regularizado, devido à construção, entre 1972 e 1982, do denominado Aproveitamento Hidroelétrico da Aguieira-Fronhas-Raiva.

Com efeito, a albufeira criada pela construção da barragem da Aguieira deveria servir, fundamentalmente, para regularizar os caudais e amortecer as pontas de cheia do rio Mondego e, ainda, para armazenar água para rega do Baixo Mondego. Por sua vez, a albufeira criada com a barragem das Fronhas destina-se essencialmente a controlar as cheias do rio Alva, um afluente do Mondego, que foi regularizado com a construção desta barragem, e também a desviar para a albufeira da Aguieira, através dum túnel, as afluências que chegam a este rio. Por último, a albufeira da Raiva constitui o contraembalse da central reversível de pé de barragem, instalada no escalão da Aguieira (Lourenço, 1986).

Deste modo, a comparação dos hidrogramas referentes às duas cheias permite mostrar não só a importância das albufeiras, criadas pelas barragens, no amortecimento das pontas de cheia, mas também, ao contrário do que muitos pensavam até então, que a construção destas barragens não foi suficiente para evitar importantes inundaçốes a jusante.

Assim, para a inundação de 1962, que ocorreu em regime natural, apresentam-se gráficos referentes a alturas de água em metros (m), na Ponte de Coja, sobre o rio Alva, bem como relativos a caudais do rio Mondego, em metros cúbicos por segundo $\left(\mathrm{m}^{3} / \mathrm{s}\right)$, na Ponte de Santa Clara, em Coimbra. O objetivo visa a ilustrar os dois parâmetros em que é usual quantificar as cheias fluviais: altura da água no leito, em $\mathrm{m}$, e caudais, $\mathrm{em} \mathrm{m}^{3} / \mathrm{s}$.

Ora, como habitualmente são as cheias que originam as inundaçôes fluviais, e uma vez que são estas as causadoras dos danos, é frequente considerar estes dois termos como sinónimos, embora, do ponto de vista hidrológico não o sejam, pois há inundações, mesmo as fluviais, que não são originadas por cheias, do mesmo modo que existem cheias que não provocam inundaçóes. 
Com efeito, do ponto de vista hidrológico, as cheias correspondem a um aumento rápido da altura da água (fig. 14-A) e, consequentemente, também do caudal do rio (fig. 14-B), ou seja, "são aumentos hidrométricos excepcionais, transbordantes ou não, que afectam, geralmente sem periocidade, o escoamento" (Loup, 1974). Por sua vez, as inundaçôes correspondem ao efeito de submergir certas áreas, ou seja, de as cobrir com água que transborda, pelo que consistem no transbordo da água para fora dos elementos que normalmente a contêm, quer eles sejam rios, o mar ou as galerias subterrâneas, tanto naturais como artificiais.

Mas, voltando ao Mondego e ao aproveitamento da Aguieira, que por também ter associada a produçáo de energia elétrica, a regularizaçáo dos caudais e o amortecimento das pontas de cheia nem sempre foi a prioridade e, por isso, mesmo em regime regularizado ocorreram inundaçóes, como sucedeu em 26-27 de janeiro de 2001, em resultado de uma longa sequência pluviosa ${ }^{3}$, e foi muito bem demonstrado por P. Cunha (2002) e depois, mais recentemente, tanto em 30 janeiro de 2009, como em 11 de janeiro de 2016.

Sobre o assunto gerou-se vasta polémica, mas apenas nos interessa analisar os hidrogramas, com o objetivo de neles inserir os conceitos que temos vindo a tratar: risco, perigo e crise.

Assim, as cheias que foram responsáveis pelas inundaçōes de janeiro de 1962, apresentaram, como seria lógico esperar, hidrogramas muito semelhantes nas duas estaçóes hidrométricas, com uma ponta de cheia bem vincada, que durou cerca de cinco dias. No caso da Ponte de Coja, se admitirmos que o rio transborda quando as suas águas alcançam dois metros de altura, verificamos que até ao dia 22 de dezembro as águas estiveram baixas e que passaram a aumentar a partir desse dia, o que fazia pensar que o perigo estaria iminente, embora, com a diminuiçáo sentida nos dias 27 e 28, se pudesse pensar que o perigo tinha passado e, desta vez, o risco náo se iria manifestar. Todavia, no dia 29 de dezembro, a altura da água voltou a subir e o risco de inundaçao manifestou-se no dia 30 , embora de forma não muito grave, pois a altura da água voltou a descer no dia 31 , o que levaria a pensar que a situação rapidamente retornaria à normalidade (fig. 14-A).

${ }^{3}$ Esta sequência provocou outras manifestaçóes de riscos, sobretudo deslizamentos, com avultados danos, sobretudo no Norte (Pedrosa et al., 2001) e Centro de Portugal (Lemos et al., 2001; Lourenço et al., 2001). 
No entanto, como a chuva voltou a cair com intensidade, a altura de água no rio subiu de novo, ao ponto de no dia 2 de janeiro, ter chegado a um dos valores mais altos de que há registo: 6,1 metros. No dia 3, o nível da água baixou para menos de 2 metros e foi altura de proceder à limpeza das áreas afetadas, embora sempre com receio de que a situação pudesse repetir-se, uma vez que a altura das águas se manteve próxima de 2 metros, até que, a partir do dia 16 começou a descer significativamente, levando a que no dia 20 se tivesse regressado à normalidade.

Deste modo, podemos afirmar que o risco de inundação se manifestou no dia 30 de dezembro e, a partir daí, a crise instalou-se até ao dia 20 de janeiro do ano seguinte (fig. 14-A).

Comparativamente com o exemplo do tremor de terra, o tempo durante o qual este processo se manifestou foi muito maior, cinco dias em vez de pouco mais de dois segundos, mas o processo de recuperação foi bem menor, 17 dias em vez de alguns anos, naturalmente porque, neste caso, os danos foram bem menos significativos.

Por sua vez, no exemplo do rio Mondego e considerando o valor de $500 \mathrm{~m}^{3} / \mathrm{s}$ como sendo o caudal a partir do qual ele transbordava em Coimbra (fig. 14-B), verificamos que a análise do hidrograma é muito semelhante à que acabámos de efetuar para o rio Alva, podendo considerar-se que estes dois rios apresentam regime do tipo torrencial, com uma resposta muito rápida à precipitação, mas que, depois, também depressa se desvanece, o que já não acontece em regime regularizado (fig. 14-C) e daí o interesse da análise comparativa destes gráficos.

Desde logo, as obras de regularizaçáo do rio Mondego, mais do que duplicaram o valor do caudal a partir do qual se passou a colocar a hipótese da inundaçáo controlada dos campos do Baixo Mondego, que ocupam 15000 hectares de terras agrícolas, uma vez que elas foram dimensionadas para conter o caudal da cheia centenária, avaliado em $1200 \mathrm{~m}^{3} / \mathrm{s}$ no Açude-Ponte de Coimbra, quando no exemplo anterior se consideraram apenas $500 \mathrm{~m}^{3} / \mathrm{s}$.

De facto, depois dessas obras e durante 15 anos, não se voltaram a registar inundaçóes, tendo-se perdido essa cultura e fazendo pensar que o risco tinha desaparecido. No entanto, no inverno de 2000/01 as barragens das Fronhas e da Aguieira foram incapazes de amortecer todas as pontas de cheia e as inundaçóes regressaram ao Baixo Mondego (Lourenço et al., 2017). 
Com efeito, a cota máxima de enchimento da barragem da Aguieira situa-se a 125 metros, tendo-se alcançado $124,52 \mathrm{~m}$ no dia 7 de dezembro, o que obrigou a aumentar o volume das descargas. Considerando, as leituras de caudais às 12 horas dos vários dias (fig. 14-C) o perigo esteve iminente nesse dia 7, chegando mesmo a gerar-se uma pequena crise, dado que o caudal máximo instantâneo alcançou 1613 $\mathrm{m}^{3} / \mathrm{s}$, o que fez com que tivesse havido transbordo para as margens. Parecia tratar-se duma situaçáo pontual, que náo voltaria a repetir- se, mas, a partir do dia 28 , os caudais voltaram a aumentar e o perigo voltou a estar iminente, se bem que, pouco depois, se tivesse admitido que ele estaria a passar, devido ao caudal ter voltado a descer nos primeiros dias de janeiro.

Todavia, apesar de no dia 4 de janeiro, o nível enchimento da barragem da Aguieira estar situado abaixo da cota de $120 \mathrm{~m}$ e de, no dia 6, ter aumentado até $124,03 \mathrm{~m}$, tal não foi suficiente para impedir nova inundação, desta vez um pouco maior do que a anterior. Nos dias seguintes, a Aguieira continuou as descargas controladas, razão pela qual a geometria das curvas descendentes destas cheias é mais suave do que a representada na fig. 14-B. Na manhã do dia 26, a cota de enchimento da barragem voltou a ser inferior a $120 \mathrm{~m}$, tendo estabilizado a 119,73 metros.

Mas, como continuou a chover, no final do dia 27 essa cota já tinha chegado de novo a 124,37 m, ficando a escassos $63 \mathrm{~cm}$ do galgamento, razão pela qual houve aumento das descargas, o que teve como consequência uma grande inundaçáo no dia 28 , causadora de numerosos danos, designadamente também porque, entre outras razóes, se tinha perdido a já mencionada "cultura das inundaçōes" e, por conseguinte, não se tinha feito qualquer prevenção.

O caudal máximo no Açude-Ponte de Coimbra atingiu o valor de $1941,9 \mathrm{~m}^{3} / \mathrm{s}$, tendo-se estimado que, em regime livre, alcançaria $2800 \mathrm{~m}^{3} / \mathrm{s}$, logo superior ao da cheia de 1962, cujo valor máximo se situou pelos $2457 \mathrm{~m}^{3} / \mathrm{s}$ (Cunha, 2002). Depois, o caudal voltou a baixar para valores "normais" para a época (fig. 14-C), mas os danos causados, nomeadamente devido ao rebentamento de diques marginais e de outras infraestruturas, obrigaram a uma recuperaçáo demorada, ao ponto de, decorrida uma dúzia de anos, algumas dessas infraestruturas ainda não terem sido totalmente recuperadas (Lourenço et al., 2017). 


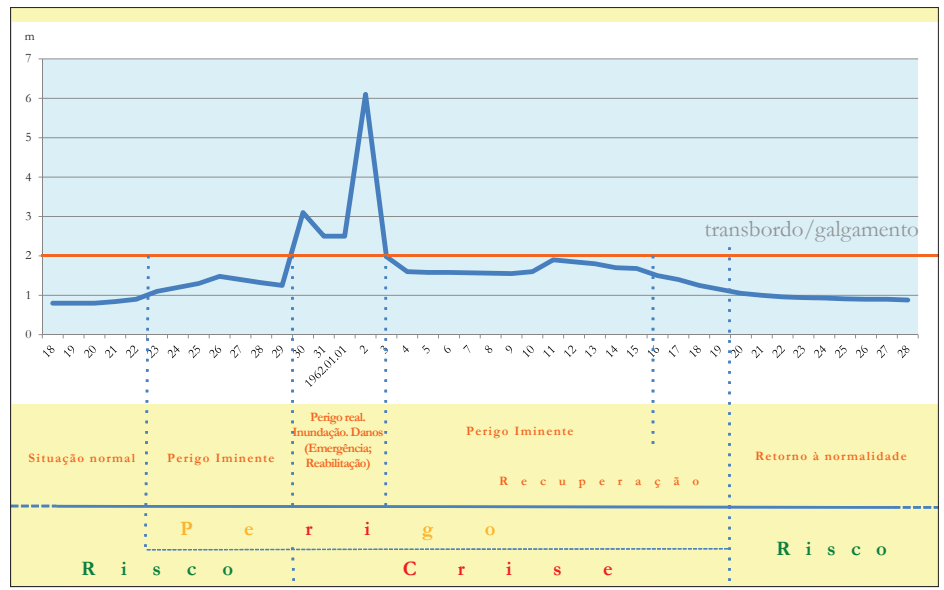

Fig. 14-A - Hidrograma da altura da água (m) do rio Alva, na Ponte de Coja (Portugal), referente à cheia de janeiro de 1962, com identificação das fases de risco, perigo e crise de inundação (Fonte dos dados: ex-Direcçáa Hidráulica do Mondego).

Fig. 14-A - Hydrograph of the height of the water $(m)$ of the River Alva river, inat the Ponte de Coja (Portugal), referring relating to the flood inof January 1962, with identification of the phases of risk, danger and flood crisis stages indicated (Data source: former Mondego Hydraulic Department).

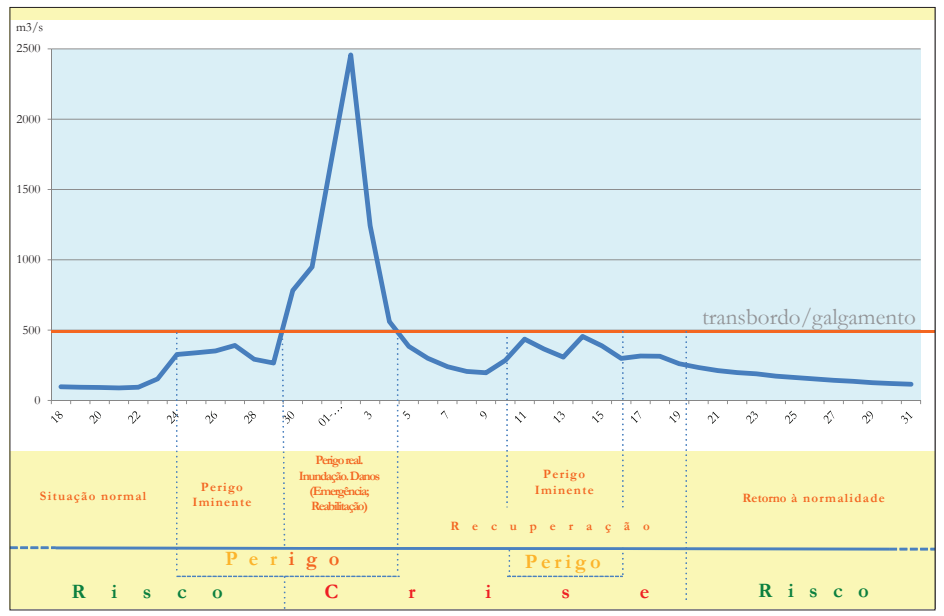

Fig. 14-B - Hidrograma do caudal $\left(\mathrm{m}^{3} / \mathrm{s}\right)$ do rio Mondego na Ponte de Santa Clara, em Coimbra (Portugal), correspondente à cheia, em regime livre, de janeiro de 1962, com identificação das fases de risco, perigo e crise de inundação (Fonte dos dados: DGSH, 1968, p. 26).

Fig. 14-B - Hydrograph of the river flow $\left(\mathrm{m}^{3} / \mathrm{s}\right)$ of the River Mondego river at the Ponte de Santa Clara, Coimbra (Portugal), corresponding relating to the flood, inunder a free regime, in January 1962, with the risk, danger and flood crisis stages indicated (Data source: DGSH, 1968, p.26). 


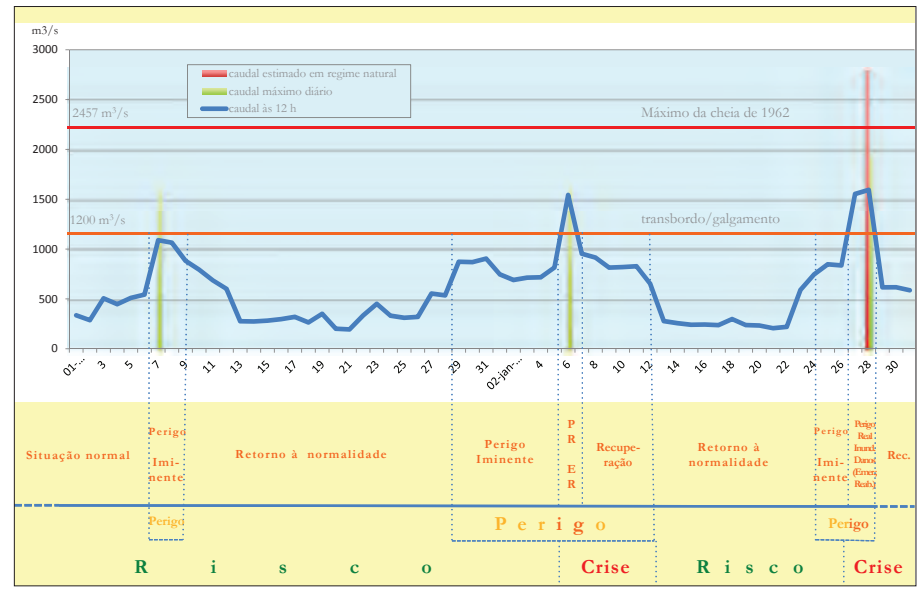

Fig. 14-C - Hidrograma do caudal $\left(\mathrm{m}^{3} / \mathrm{s}\right)$ do rio Mondego no Açude-Ponte da cidade de Coimbra (Portugal), em regime regularizado, de dezembro de 2000 e janeiro de 2001, com identificaçâo das fases de risco, perigo e crise de inundação (Fonte dos dados: ex-Instituto da Água).

Fig. 14-C - Hydrograph of the flow rate $(\mathrm{m} 3 / / \mathrm{s})$ of the River Mondego river inat the Açude-Ponte of inthe city of Coimbra (Portugal), in under a regularized regulated regime, December 2000 and January 2001, with the risk, danger and flood crisis staged indicated (Data source: former Water Institute).

Com a apresentação destes diferentes quatro exemplos, apenas pretendemos facilitar a percepção do modo como entendemos estes três conceito3s: risco, perigo e crise, e de como é que eles podem ser aplicados na prática a diferentes contextos, pois reconhecemos que nem sempre é fácil fazer a distinção entre eles.

\section{Conclusáo}

De acordo com Faugères (1990) e de forma simples, à guisa de síntese, diremos que: (i) o risco corresponde à probabilidade de ocorrência de acontecimentos danosos; (ii) o perigo resulta da proximidade iminente da manifestaçáo do risco; (iii) a crise corresponde à manifestação do risco fora do controlo do ser humano. Estes três conceitos constituem, pela ordem que foram apresentados, aquilo a que poderemos chamar a sequência temporal do risco e da sua manifestação como crise. 
Deste modo, procurámos efetuar uma reflexão conjunta sobre o significado destes três conceitos e, muito em particular, do seu significado em português. Aproveitando o ensejo, considerámos também outros vocábulos usados em ciências cindínicas, cujo sentido por vezes é desvirtuado em resultado de transliteraçōes, de traduçôes ou de usos menos corretos.

A ciência faz-se de reflexão, ao longo de um extenso caminho, em que se vão afinando os significados dos diferentes conceitos. Ao apresentarmos o nosso contributo para esta discussão, apenas pretendermos dar mais um passo na clarificação de alguns termos, mostrando um ponto de vista diferente e fazendo-o com a firme convicçáo de que em ciência não há verdades absolutas, pelo que não fugimos à discussão. Se defendemos o nosso ponto de vista é porque ele nos parece lógico. Todavia, deixamos a decisão ao leitor que, assim, mais informado, optará, de forma consciente, pelos termos que lhes pareçam mais adequados para exprimir as ideias que pretende expressar.

\section{Referências bibliográficas}

AIEA/AEN - AGÊNCIA INTERNACIONAL DE ENERGIA ATÓMICA E AGÊNCIA DE ENERGIA NUCLEAR (1995). Escala Internacional de Ocorrências Nucleares. Protecção Civil. Órgão do Serviço Nacional de Protecção Civil, Ano VII, II. a Série, N. o 5, Out-Jan., p. 31-33;

Almeida, A. Betâmio de (2011). Incertezas e Riscos. Conceptualização Operacional, Colecção Água, Ciência e Sociedade (APRH), Esfera do Caos. 237 p.;

Almeida, A. Betâmio de (2011). Risco e gestáo do risco. Questôes filosóficas subjacentes ao modelo técnico conceptual. Territorium 18, p. 23-31;

http://www.uc.pt/fluc/nicif/riscos/Documentacao/Territorium/T18_artg/Antonio_Betamio_de_Almeida.pdf

Almeida, A. Betâmio de (2018). Science for disaster risk management 2017. Knowing better and losing less. Territorium 25(I), p. 155-165;

http://www.uc.pt/fluc/nicif/riscos/Documentacao/Territorium/T25I_Artg/T25_I_Recensao4.pdf

Christofoletti, António (1990). Modelagem de Sistemas Ambientais. Editora Edgard Blucher, São Paulo.

Cunha, Pedro Proença (2002). Vulnerabilidades e risco resultante da ocupação de uma planície aluvial - o exemplo das cheias do rio Mondego (Portugal central), no Inverno de 2000/2001. Territorium, 9, p. 13-35;

http://www.uc.pt/fluc/nicif/riscos/Documentacao/Territorium/T09_artg/T09_artg02.pdf

Cutter, S. L. (Tradução de Victor Ferreira) (2011). A ciência da vulnerabilidade: modelos, métodos e indicadores. Revista Crítica de Ciências Sociais, 93, p. 59-69;

Dauphiné, André (2001). Risques et catastrophes. Observer - Spatialiser - Comprendre - Gérer. Paris, Armand Colin, 288 p.; 
Decreto-Lei n. ${ }^{\circ} 141$ (1995). Estabelece as Normas Técnicas de execução, Colocação e utilização da sinalização de segurança e saúde no trabalho. Diário da República (Portugal), n. ${ }^{\circ} 136$, I. ${ }^{a}$ Série-A, Imprensa Nacional - Casa da Moeda, de 14 de junho, p. 3848-3850;

DGRF-DIRECÇÃO-GERAL DOS RECURSOS FLORESTAIS (2006). Guia metodológico para elaboração do Plano Municipal/Intermunicipal de Defesa da Floresta contra Incêndios. DGRF, Lisboa, (4 vol.);

I. Introduçâo e Consideraçôes Gerais ao Guia Metodológico, 4 p.;

II. Caderno I - Plano de Acção, 47 p.;

III. Caderno II - Informação de Base, 51 p.;

IV. Apêndices, 36 p.;

DGSH - DIRECÇÃO-GERAL DOS SERVIÇOS HIDRÁUliCOS (Ministério das Obras Públicas da República Portuguesa) (1968). Anuário dos Serviços Hidráulicos, Hidrologia, 1961-1962. Lisboa, Imprensa Nacional, 296 p. + anexos;

Farazmand, A. (2001). Handbook of Crisis and Emergency Management. Taylor \& Francis. New York;

Faugères, Lucien (1990). La dimension des faits et la théorie du risque. Le Risque et la Crise, European Coordination Centre for Research and Documentation in Social Sciences, Foundation for International Studies, Malta, p. 31-60;

Gomes, Carla Amado (Coord.) (2012). A gestão do risco de catástrofe natural. Uma introdução na perspectiva do Direito Internacional. Capítulo I do livro Direito(s) das Catástrofes Naturais, Coimbra, Almedina, https://www.icjp.pt/sites/default/files/papers/catastrofes_naturais.pdf

Guerreiro, A. Machado (1987). Impacte e impacto. Correio da Natureza, Boletim do Serviço Nacional de Parques, Reservas e Conservação da Natureza, Lisboa, n. ${ }^{\circ}$ 1, p. 32.

Hadjiconstantinou, Georges (1990). Risques, crises et complexité. Le Risque et la Crise, European Coordination Centre for Research and Documentation in Social Sciences, Foundation for International Studies, Malta, p. 105-116;

IDICT - INSTITUTO DE DESENVOLVIMENTO E INSPEÇÃO DAS CONDIÇÓES DE TRABALHO (2001). Trabalho Seguro, Melhor Futuro - Educação/Formação para a Segurança, Higiene e Saúde no Trabalho. Módulo 10 - A sinalizaçáo de segurança: significado e normas de aplicação e utilizaçáo. http://www.prof2000.pt/users/eta/Bloco10.htm

ISRD - INTERNATIONAL STRATEGY FOR DISASTER REDUCTION (2009). Terminology on Disaster Risk Reduction. UNISDR - United Nations International Strategy for Disaster Reduction, Geneva, Switzerland, United Nations, 30 p.;

Juliāo, R. P.; Nery, F.; Ribeiro, J. L.; Branco, M. C.; Zêzere, J. L. (2009). Guia metodológico para a produção de cartografia municipal de risco e para a criação de sistemas de informação geográfica (SIG) de base municipal. Autoridade Nacional de Protecção Civil, DGOTDU/IGP, Lisboa, 91 p.;

Lei n. ${ }^{\circ} 113$ (1991). Lei de Bases da Protecção Civil. Diário da República (Portugal), n. ${ }^{\circ}$ 198, I. ${ }^{a}$ Série-A, Imprensa Nacional - Casa da Moeda, de 29 de agosto, p. 4501-4507;

Lei n. ${ }^{\circ} 27$ (2006). Lei de Bases da Protecção Civil. Diário da República (Portugal), n.o 126, 1. a Série, Imprensa Nacional - Casa da Moeda, de 3 de julho, p. 4696-4706;

Lemos, Luís; Lourenço, Luciano; Gonçalves, Carlos (2001). Movimentos em massa. Exemplos do Centro de Portugal. ENB, Revista Técnica e Formativa da Escola Nacional de Bombeiros, Sintra, no 18, p. 17-41; http://www.uc.pt/fluc/nicif/Publicacoes/Estudos_de_Colaboradores/PDF/Publicacoes_periodicas/ ENB18_2001_Movimentos_em_massa._Exemplo_no_Centro_de_Portugal.pdf

LOUP, J. (1974). Les eaux terrestres. Masson, Paris, 174 p.; 
Lourenço, Luciano (1986). Aproveitamento hidráulico do vale do Mondego. In Problemas do Vale do Mondego. Livro guia da excursão de 24 de setembro de 1986. IV Colóquio Ibérico de Geografia, Coimbra, p. 45-59; http://www.uc.pt/flud/nicif/Publicacoes/Estudos_de_Colaboradores/PDF/Livros_e_Guias/1986_IVColoquio_de_geo

Lourenço, Luciano (2003). Análise de riscos e gestão de crises. O exemplo dos incêndios florestais. Territorium, 10, p. 89-100; http://www.uc.pt/fluc/nicif/riscos/Documentacao/Territorium/T10_artg/T10_artg06.pdf

Lourenço, Luciano (2007). Riscos naturais, antrópicos e mistos. Territorium, 14, p. 109-113; http://www.uc.pt/fluc/nicif/riscos/Documentacao/Territorium/T14_artg/T14NNR01.pdf

Lourenço, Luciano (2008). Perigos das cartas de risco. Comentários ao modelo proposto no Guia Técnico para Elaboração do PMDFCI. Territorium, 15, p. 122-126; http://www.uc.pt/fluc/nicif/riscos/Documentacao/Territorium/T15_artg/T15NNR11.pdf

Lourenço, Luciano (2014). Risco, Perigo e crise. Trilogia de base na definiçáo de um modelo conceptual-operacional. In Lourenço, Luciano e Tedim, Fantina (Ed.) - Realidades e Desafios na Gestäo dos Riscos. Diálogo entre Ciência e Utilizadores, NICIF/FLUC, Coimbra, p. 61-72;

DOI: http://dx.doi.org/10.14195/978-972-8330-23-1_6

Lourenço, Luciano (2015). Risco, perigo e crise: Pragmatismo e contextualizaçăo. In Riscos de desastres relacionados à água: aplicabilidade das bases conceituais das Ciências Humanas e Sociais para a análise de casos concretos, Siqueira, Antenora; Valencio, Norma; Siena, Mari; Malagodi, Marco Antonio (Ed.).. São Carlos: RiMa Editora, p. 3-43. http://www.uc.pt/fluc/nicif/Publicacoes/Estudos_de_ Colaboradores/PDF/Livros_e_Guias/2015_RiscosDesastres_LL_.pdf

Lourenço, Luciano; Lemos Luís (2001). Consideraçôes acerca da movimentação em massa ocorrida na vertente poente da Ava . Elísio de Moura, em Coimbra, Territorium, Minerva, Coimbra, no 8, p. 93-108; http://www.uc.pt/fluc/nicif/riscos/Documentacao/Territorium/T08_artg/T08_artg08.pdf

Lourenço, Luciano; Tedim, Fantina (Ed.) (2014). Realidades e Desafios na Gestäo dos Riscos. Diálogo entre Ciência e Utilizadores, NICIF/FLUC, Coimbra, 97 p.; DOI: http://dx.doi.org/10.14195/978-972-8330-23-1

Lourenço, Luciano; Velez, Fátima; Cunha, Pedro Proença; Lima, Isabel Pedros de; Lima, João Pedroso de; Tavares, Alexandre (2017). Risco de Inundação no Baixo Mondego. Flood Risk in the Lower Modego. Livro-Guia da Visita Técnica n. ${ }^{\circ}$ 3. IV Congresso Internacional de Riscos. RISCOS - Associaçáo Portuguesa de Riscos, Prevençấo e Segurança, Coimbra, 75 p. ISBN 978-989-96253-8-9;

http://www.uc.pt/fluc/nicif/Publicacoes/Estudos_de_Colaboradores/PDF/Livros_e_Guias/ Ebook_VT3_Baixo_Mondego.pdf

Moustafa, Ehab M. (1990). Entre risque et crise. Le Risque et la Crise, European Coordination Centre for Research and Documentation in Social Sciences, Foundation for International Studies, Malta, p. 171-184;

Pedro, Isabel (2014). Riscos e Perigos em tradução. Consideraçôes sobre terminologia nas ciências cindínicas. In Lourenço, Luciano e Tedim, Fantina (Ed.) - Realidades e Desafios na Gestäo dos Riscos. Diálogo entre Ciência e Utilizadores, NICIF/FLUC, Coimbra, p. 55-60;

DOI: http://dx.doi.org/10.14195/978-972-8330-23-1_5

Pedrosa, A. Sousa; Lourenço Luciano; Felgueiras João (2001). Movimentos em massa. Exemplos ocorridos no Norte de Portugal. ENB, Revista Técnica e Formativa da Escola Nacional de Bombeiros, Sintra, no 17, p. 25-39; http://www.uc.pt/fluc/nicif/Publicacoes/Estudos_de_Colaboradores/PDF/Publicacoes_periodicas/ENB17_2001

Poljanšek, K.; Marín Ferrer, M.; De Groeve, T.; Clark, I. (Eds.) (2017). Science for disaster risk management 2017: knowing better and losing less. EUR 28034 EN, Publications Office of the European Union, Luxembourg, ISBN 978-92-79-60679-3, doi: 10.2788/842809, JRC102482.

Portaria n. ${ }^{\circ}$ 1456-A (1995). Regulamenta as prescriçóes mínimas de colocação e utilizaçáo da sinalizaçáo de segurança e de saúde no trabalho. Diário da República (Portugal), n. ${ }^{\circ}$ 284, I. a Série-B, Imprensa Nacional - Casa da Moeda, de 11 de dezembro, p. 7734-(2) a 7734-(11). 
Rebelo, Fernando (1994). Risco e crise. Grandes incêndios florestais. Actas, II Encontro Pedagógico sobre Riscos de Incêndio Florestal, Coimbra, p. 19-32;

Rebelo, Fernando (1995) . Os conceitos de risco, perigo e crise e a sua aplicação ao estudo dos grandes incêndios florestais. Biblos, 71, p. 511-527;

Rebelo, Fernando (1996). Alguns livros recentes sobre riscos, perigos e crises. Territorium, 3, p. 61-64; http://www.uc.pt/fluc/nicif/riscos/Documentacao/Territorium/T03_artg/T03_NNR06.pdf

Rebelo, Fernando (1997a). Risco e crise nas inundaçōes rápidas em espaço urbano. Alguns exemplos portugueses analisados a diferentes escalas. Territorium, 4, p. 29-47; http://www.uc.pt/fluc/nicif/riscos/Documentacao/Territorium/T04_artg/T04_Artg04.pdf

Rebelo, Fernando (1997b). O estudo dos riscos e das crises discutido em reunióes internacionais, Territorium, 4, p. 145-148; http://www.uc.pt/fluc/nicif/riscos/Documentacao/Territorium/T04_artg/T04_NNR04.pdf

Rebelo, Fernando (1998). Livros recentes sobre a problemática dos riscos e das crises. Territorium, 5, p. 75-79; http://www.uc.pt/fluc/nicif/riscos/Documentacao/Territorium/T05_artg/T05_NNR03.pdf

Rebelo, Fernando (1999). A teoria do risco analisada sob uma perspectiva geográfica. Cadernos de Geografia, 18, p. 3-13;

http://www.uc.pt/fluc/depgeo/Cadernos_Geografia/Numeros_publicados/CadGeo18/artigo01

Rebelo, Fernando (2001a). Os movimentos em massa na perspectiva da teoria do risco. ENB, Revista Técnica e Formativa da Escola Nacional de Bombeiros, 5 (17), Jan./Mar, p. 7-15;

Rebelo, Fernando (2001b). Riscos Naturais e Acção Antrópica. Coimbra, Imprensa da Universidade, 274 p. (2a edição revista e aumentada: Rebelo, Fernando (2003) - Riscos Naturais e Açãa Antrópica. Estudos e Reflexōes. Coimbra, Imprensa da Universidade, 286 p;

DOI: http://dx.doi.org/10.14195/978-989-26-0467-1

Rebelo, Fernando (2008). Um novo olhar sobre os riscos? O exemplo das cheias rápidas (flash floods) em domínio mediterrâneo. Territorium, 15, p. 7-14; http://www.uc.pt/fluc/nicif/riscos/Documentacao/Territorium/T15_artg/T15art02.pdf

Rebelo, Fernando (2010). Geografia Física e Riscos Naturais. Coimbra, Imprensa da Universidade, 215 p.; DOI: http://dx.doi.org/10.14195/978-989-26-0188-5

Rebelo, Fernando (2013). Crises e Catástrofes (ditas) Naturais. Reflexôes a partir de alguns casos registados em Coimbra. Proceedings of PNUM 2013, Coimbra, p. 93-108;

Rebelo, Fernando (2014). Terminologia do Risco. Origens, dificuldades de tradução e bom senso. In Lourenço, Luciano e Tedim, Fantina (Ed.) - Realidades e Desafios na Gestão dos Riscos. Diálogo entre Ciência e Utilizadores, NICIF/FLUC, Coimbra, p. 7-17;

DOI: http://dx.doi.org/10.14195/978-972-8330-23-1_1

Saúde, Anabela; Costa, Elsa; Fernandes, José Joaquim; Esteves, Maria José; Amaral, Maria Luísa; Almeida, Paula; André, Teresa Leandro (2015). Referencial de Educação para o Risco - Educação Pré-Escolar, Ensino Básico (1. ${ }^{\circ}, 2^{\circ}$ e $3 .^{\circ}$ ciclos) e Ensino Secundário, Ministério da Educaçáo e Ciência, Lisboa, 114 p.;

Silva, Miguel Correia da; Santos, Alexandra; Andresen, Maria (2009). Glossário de Proteção Civil, ANPC - Autoridade Nacional de Proteção Civil, 399 p.;

https://protecaocivil.files.wordpress.com/2011/01/glossario-31_mar_09.pdf;

Veyrey, Yvette (2007). Os Riscos: O homem como agressor e vítima do meio ambiente. Contexto, São Paulo, p. 320 .

Wisner, B., Blaikie, P, Cannon, T., Davis, I. (1994). At risk: natural hazards, people's vulnerability and disasters. Routledge, London and New York. 
(Página deixada propositadamente em branco) 


\title{
REPENSANDO OS RISCOS, COM UM OLHAR DESDE O TERRITÓRIO \\ RETHINKING THE RISK \\ FROM A TERRITORY PERSPECTIVE
}

\begin{abstract}
María Augusta Fernández Moreno
Pontifícia Universidade Católica de Ibarra, Equador, Centro de Investigação do Território, Transportes e Ambiente (CITTA), Portugal mariaaugusta_fernandez@yahoo.com
\end{abstract}

Se aceitamos o nosso papel como parte integrante de Gaia, os seus transtornos serão os nossos (Lovelock James)

Sumário: Partindo do território, faz-se uma abordagem aos riscos que são gerados na interação ser humano-natureza, com vista ao melhor ordenamento do território. Trata-se de uma abordagem ecocêntrica, com o objetivo de considerar os fenómenos naturais não como ameaças, mas sim como fazendo parte intrínseca do sistema território. Nesta perspectiva, o risco que se manifesta num território não é considerado um problema linear, logo, o seu estudo deve ter como ponto de partida a abordagem de sistemas. Por outro lado, considera-se que o processo de construção de risco só se consegue observar quando é analisado a nível local. Deste modo, quando nos aproximamos o suficiente, podemos observar que o território é constituído por uni-

\footnotetext{
${ }^{1}$ Tradução de Luciano Lourenço, a partir do original "Repensando los Riesgos desde el Territorio".
} 
dades territoriais de risco, ou seja, por células com funcionalidade e morfologia próprias, a que chamamos TRUE (territory risk ecocentric unit). Por último, a complexidade que resulta da integração de dados de natureza muito diferente, requer que os estudiosos do território trabalhem em equipes interdisciplinares para conseguirem modelar, de forma válida, os processos de risco no território.

Palavras-chave: Riscos naturais, território, ecocêntrico, sinergia, sistemas, unidade territorial.

Abstract: With a view to improving land management, the risks generated in the human-nature interaction are addressed from the standpoint of the territory. Under an ecocentric approach, natural phenomena are not seen as threats, but as intrinsic parts of the territory system. Risks that emerge in the territory are regarded as nonlinear problems and the systems approach is therefore proposed as the starting point for studying them. In addition, it is held that the risk construction process can only be observed when analysed at the local level. Thus, when we get close enough, we can see that the territory is composed of territorial at-risk units. We have named these TRUEs (territory risk ecocentric unit). They are regarded as cells with their own morphology and functionality. The complexity of integrating data of a varied nature requires researchers to work in interdisciplinary teams for modelling and validating risk processes in the territory.

Keywords: Natural risks, territory, ecocentric, synergy, systems, territorial unit. 


\section{Introduçáo}

Quando nos encontramos numa área geográfica muito dinâmica, onde se manifestam terramotos e furacóes ou quando estamos muito perto de um rio num dia de chuva forte, pensamos nas catástrofes que esses fenómenos naturais podem ocasionar. Mas, o que sucede quando um terramoto ou uma inundação ocorre numa área despovoada, ainda que possa, ou não, vir a ser ocupada no futuro? Ou, então, porque é que os egípcios interpretam as inundaçôes do Nilo como sendo benéficas, ou os povoadores dos Andes consideram as erupçóes vulcânicas como uma fonte de enriquecimento do solo? As respostas são óbvias, pois os fenómenos naturais não produzem apenas catástrofes. Por isso, falar do ser humano associado aos fenómenos naturais envolve diferentes interpretaçóes.

Assim, ao observar, com sentido de lugar, as interaçôes ser humano-fenómeno natural, a leitura das incertezas geradas por essa interaçáo, leva-nos a reconhecer que estas tanto se podem manifestar como riscos (perda potencial), como através de contribuiçóes benéficas para o território, pois quer os seres humanos, quer os fenómenos naturais, contribuem tanto para a vida como para os desequilíbrios de relaçôes mútuas. A partir desta abordagem e colocando-nos do lado do risco, reconhecemos que o território, como um todo, é o princípio e o fim do processo de construção de risco, para o qual contribuem não só os fenómenos naturais mas também o ser humano.

Deste modo, afastamo-nos do ponto de partida mais comum na abordagem dos Riscos Naturais, em que os fenómenos naturais são encarados como "a ameaça" e o ser humano é visto como "vulnerável" e, em vez disso, propomo-nos concentrar a atençáo no território, vendo as relaçóes ser humano-natureza desde um paradigma ecocêntrico.

Portanto, neste contexto, entende-se por território o espaço geográfico formado pelo conjunto ser humano-lugar, de acordo com a definiçáo de território proposta por Raffestin (2011: 112), ao afirmar que «o território reflete a multidimensionalidade da experiência territorial vivida pelos membros de um grupo, pelas sociedades em geral', ou seja, entendemos a natureza - portanto, os fenómenos naturais - como fazendo parte desse grupo. Na verdade, Milton Santos (1988: 27) reforça esta aborda- 
gem quando nos diz que "[...] embora os grupos humanos tenham o poder de modificar a ação de forças naturais, a natureza obriga estes grupos a adaptaçôes [...]".

Em conformidade- com o paradigma ecocêntrico queremos dizer, como foi sugerido por Lovelock (1983), que vemos o ser humano e a natureza em pé de igualdade, ambos como componentes do território e nele participando com as suas forças positivas e negativas, numa estreita relação simbiótica. Fazendo a análise deste ponto de vista, a priori não há culpados, isto é, o fenómeno natural não é a ameaça. Sendo assim, o risco é responsabilidade de quem o constrói e a sua construção é um processo sócio-natural. Neste contexto, a gestão do risco no território não trata de redistribuir os danos, nem de transferir o risco, mas sim de olhar à volta e, reconhecendo as particularidades de cada território, identificar as açóes, quer sejam naturais ou humanas, que melhoram as condiçóes de segurança mútua e, também, aquelas que contribuem para a desestabilização do território, assumindo, em consequência, as responsabilidades que daí advêm.

Alguns autores, especialmente todos os pensadores da Ecologia Profunda (Devall e Sessions, 1985; Næss e Rothenberg, 1989), argumentam que a relaçáo do ser humano com os fenómenos naturais se tornou num problema ético no Ocidente, enquanto que no Oriente, de acordo Gentelle (1993), e mais especificamente na China, uma catástrofe natural sempre foi entendida como um sinal de uma má relaçâo existente entre a sociedade e a natureza, reconhecendo-se que o problema prático reside na interpretaçáo, ou seja, na identificação dos processos e na correta atribuição de responsabilidades.

Ao analisar os riscos desde a perspetiva do território, através de uma leitura ampla e inclusiva, procuramos compreender as interaçôes que geram incertezas. Para as reconhecer, é necessário que, além de conhecer as componentes natural e antrópica do território, se reflita sobre as características de instabilidade dessas componentes, que mudam ao longo do tempo e do espaço e que, pelo seu dinamismo, geram incertezas. Se vivermos no mesmo lugar durante toda a nossa vida ou a ele regressarmos depois de um certo tempo, vemos as mudanças que vão acontecendo na paisagem, umas vezes de forma rápida e, outras vezes, lentamente. As causas podem ser muito diversas, sendo devidas tanto a fenómenos naturais, sejam extremos ou não, como ao ser humano, designadamente: o trabalho do agricultor no campo, 
a injeção de recursos que promova as obras de construção, a ação de fenómenos naturais quotidianos como a humidade, a chuva e a temperatura, ou de fenómenos mais raros, tais como terramotos, erupçôes vulcânicas, deslizamentos de terra, entre outros. São forças que, embora sendo diferentes na sua essência e na dinâmica temporal, pertencem ao mesmo território e todas elas, em conjunto, contribuem para moldá-lo. Assim, ao longo do tempo, vão-se gerando novas condições de estabilidade e de incerteza.

Jean-Paul Tricart (1981) no seu livro "A Terra Planeta Vivo", explica a íntima dependência entre o ser humano e o lugar, nomeadamente no prefácio, em que escreveu: "O funcionamento da vida só é possivel por meio de trocas permanentes com o ambiente. Isto ocorre tanto a nivel do mais simples ser unicelular como ao dos seres mais complexos, como é o ser humano. Para os homens, a solidariedade não é apenas biológica: o cérebro é influenciado pela percepção sensorial do meio, a fonte de informação que comanda a ação. Estar ciente da natureza viva do planeta Terra é mostrar como os fenómenos da vida se inserem no meio físico do globo e como o modificam, tanto nas suas características como na sua evolução".

A teoria da Gaia (Lovelock, 1983) deu-nos uma visão ainda mais completa da interdependência entre o ser humano e o lugar. Ela mostra-nos como a parte viva do nosso planeta é gerada na interface de contato dos sistemas terra-água-atmosfera, onde os processos são mais dinâmicos e onde há mais trocas de energia. Deste modo, biosfera, litosfera, hidrosfera e atmosfera estão intimamente interligadas e de tal maneira que formam um complexo sistema de interação energética que está constantemente à procura da homeostasia. Essa energia é usada para manter a homeostasia e, portanto, a vida, que se manifesta em fenómenos naturais.

\section{Os fenómenos naturais, do mesmo modo que o ser humano, são intrínsecos ao sistema território}

Tanto os fenómenos naturais como o ser humano estão constituídos por forças positivas e negativas ou, dito de outra forma, por forças complementares. Isto pode ser explicado através do princípio filosófico chinês do ying-yang: duas forças com- 
plementares compóem tudo o que existe e do equilíbrio dinâmico entre elas surge todo o movimento e a mudança. Assim, tanto os fenómenos naturais como os humanos apresentam esta dualidade, que se expressa de muitas maneiras. A dualidade a que nos referimos é como uma moeda, em que reconhecemos as particularidades de cada lado, mas que consideramos como um todo. De facto, os fenómenos naturais são favoráveis à vida humana, mas têm episódios que podem afetar os seres humanos. Por exemplo, a atmosfera, sob certas condiçóes químicas de temperatura, humidade e pressáo, garante a vida do ser humano, mas essa não é a sua única função, pois também apresenta eventos extremos, traduzidos em ondas de calor ou vagas de frio, em furacôes ou chuvas torrenciais, que sendo parte de sua própria natureza, também fazem parte do ser humano. As forças positivas do ser humano trabalham para garantir a permanência da espécie e proteger o planeta, mas as suas forças negativas também são capazes de destruir, quer a natureza, quer a si próprio. Exemplos suficientemente ilustrativos das forças negativas do ser humano podem ser dados através das atividades predatórias do ambiente, que estão ferindo a Terra, ou da sua capacidade de predador do próprio ser humano, nas guerras. Portanto, tanto a natureza como o ser humano são ao mesmo tempo ameaça e vulnerabilidade para o sistema território.

\section{Dos Riscos Naturais aos Riscos analisados a partir do Território}

A relação do ser humano com os fenómenos naturais tem evoluído ao longo da história. Na aurora da civilização, os riscos eram entendidos como oportunidades de solidariedade, tendo dado origem à criação de mecanismos de ajuda mútua para compartilhar as perdas registadas. Depois, até ao início da era industrial, o ser humano foi mantendo uma atitude natural de medo e de respeito pela natureza. Esta impunha as suas condiçôes e o ser humano adaptava-se-lhe.

Com o desenvolvimento tecnológico, o ser humano foi-se desadaptando da natureza e foi assumindo uma atitude mais de seu dominador, no afá de, por um lado, reduzir as perdas e de, por outro, aumentar os lucros. Mas isto não é tudo. Com efeito, o mercado de seguros também contribuiu para este processo, logo que os 
seguros deixaram de ser entendidos como uma forma de compartilhar as perdas e passaram a ser mecanismos de transferência de risco, em que a responsabilidade da recuperação dos danos é dada a um terceiro em troca de transaçóes monetárias, e, portanto, o indivíduo em risco foi deixando para segundo plano a necessidade de se adaptar para reduzir os riscos.

Neste contexto, a área de estudo conhecida como Riscos Naturais vai amadurecendo nos anos 90 do século passado, caracterizando-se por uma abordagem antropocêntrica em que a ameaça se traduz num fenómeno natural. Esta abordagem inspira-se na doutrina dos seguros, que diz que o risco não depende unicamente do segurado ou do beneficiário, mas também da exposição involuntária a uma ameaça e cuja manifestação dá origem a uma obrigação de compensar a perda (MAPFRE, s/d), como é demonstrado pelas definiçóes propostas pela ONU em 1979 (UNDRO, 1980). Pode então dizer-se que a relação com os fenómenos naturais passou do naturalismo e providencialismo ao antropocentrismo (Olcina Cantos, 2008).

$\mathrm{Na}$ literatura convencional que trata dos Riscos Naturais, o risco é entendido como sendo o resultado da conjugaçáo de dois factores: o processo natural e a vulnerabilidade. Geralmente, o fenómeno natural classifica-se de ameaça e os aspetos relacionados com o ser humano qualificam-se de vulnerabilidade. Quando Dauphiné (2001) se refere às vulnerabilidades social e individual, ou Brooks (2003) menciona a vulnerabilidade biofísica, ou Lavell (2003) considera as ameaças sócio-naturais, todos eles descrevem formas de fragilidade do ser humano na sua luta contra a natureza invasora, externa ao sistema social. Nesta perspectiva, o território só pode ser entendido como o campo de batalha.

Mas já não é esse o caso quando nos referimos à adaptação - como é entendida a partir do IPCC (Pachauri et al., 2014) - e ao ordenamento do território, dado que neste casos, o objetivo é contribuir para a ordem harmoniosa das relaçóes dos elementos que compóem o território. Por isso, na abordagem da problemática das relaçôes ser humano-fenómenos naturais, a perspetiva dos Riscos Naturais pode ser insuficiente.

Com efeito, enquanto o território atua como um sistema aberto, a maioria dos fenómenos naturais que nele se expressam são parte intrínseca desse mesmo território. Assim, um fenómeno natural pode ser ocasionalmente uma ameaça, o que torna este território ameaçador, e, ao mesmo tempo, constituir uma vulnerabilidade do sistema, 
porque ajuda a desestabilizá-lo. Por exemplo, a temperatura é uma característica da atmosfera e expressa-se dentro de intervalos a que o ser humano está adaptado numa determinada região particular, mas, por vezes, ultrapassa esses intervalos. Esta alteração da condição de temperatura da atmosfera é intrínseca ao sistema território. Ora, nesse mesmo território existem pessoas, muitas delas saudáveis, mas algumas com problemas respiratórios crónicos e, independentemente do seu estado de saúde, todas elas são parte integrante desse território, que possui casas, algumas das quais com boas condiçôes de isolamento, enquanto que outras não desfrutam delas. Então, quando às temperaturas excessivas se juntam outras forças negativas, tais como a falta de isolamento das casas e as pessoas com problemas respiratórios crónicos, isso faz com que o sistema fique desequilibrado. Portanto, podemos concluir que a temperatura extrema é mais uma vulnerabilidade desse território. Por isso, dizemos que todas as forças negativas das componentes do território são fatores de risco do sistema.

$\mathrm{Na}$ área de estudo dos Riscos Naturais é frequente situar os fenómenos naturais como sendo externos ao sistema ameaçado. Pelo contrário, quando olhamos para os riscos desde o território, os fenómenos naturais são parte intrínseca do sistema, pois são muito poucos os fenómenos naturais externos ao sistema território. Claro que isto depende do ponto em que se encontra o observador. A queda de uma meteoritos poderá ser considerada um fenómeno externo. Pelo contrário, não temos qualquer dúvida em afirmar que os fenómenos do sistema oceano-atmosfera, incluindo ondas de calor, vagas de frias e furacôes, fazem parte do território. As massas de ar pertencem aos territórios por onde vão passando. Por analogia com as aves migratórias, o fato de não estarem presentes durante todo o ano náo significa que deixem de pertencer ao território onde se reproduzem, onde se alimentam e onde descansam.

No mesmo território, estão presentes em simultâneo vários fenómenos naturais e, além disso, podem expressar-se com grande intensidade em diferentes momentos ou simultaneamente. Neste contexto, podemos dizer que o risco de um território é o resultado da combinação de todas as forças nele envolvidas, que estão em constante mudança, equilibrando ou desequilibrando esse território. Por exemplo, a cidade de Quito, no Equador, está localizada sobre um vulcão ativo, no contato de placas tectónicas e no cruzamento de várias falhas ativas locais e ainda recebe o impacto do fenómeno conhecido por El Niño. Ora o risco deste território constrói-se com todas as forças presentes nessa 
cidade montanhosa dos Andes, designadamente tendo em consideração os processos antrópicos, sociais e individuais, gerados por mais de dois milhôes de pessoas de diferentes culturas, bem como os processos naturais que resultam tanto da sua localizaçáo no Anel de Fogo Pacífico, como da influência do El Nino, entre outros. Os seus habitantes convivem com esses fenómenos naturais, porque eles são parte integrante do território e, por isso, são vistos como parte da sua experiência de vida. Ao ser inerente ao território, cada episódio natural extremo não é mau em si mesmo. Somente torna-se perjudicial pela dimensáo dos desequilíbrios que pode gerar no sistema quando associado a outros fatores humanos e naturais também desequilibrantes. Um evento insignificante pode ser o detonador de um processo de risco que estava em construçáo. $\mathrm{O}$ excesso de energia de um fenómeno conjuga-se com outras forças que se estão acumulando, sejam naturais ou antrópicas. Cabe aqui afirmar que, muitas vezes, a contribuição das forças antrópicas pode ser determinante para o desequilíbrio do sistema de território, transformando um cenário de risco num cenário de catástrofe.

Um exemplo clássico é a contribuição da atividade humana para as mudanças climáticas. No caso de terramotos, a sociedade também pode contribuir substancialmente para gerar o desastre, como aconteceu com o terramoto no Haiti entre 12 de Janeiro de 2010, de magnitude 7,0 Mw, onde foram registados danos muito superiores aos registados no sismo Chile, de 27 de fevereiro do mesmo ano e que foi de magnitude muito superior: 8,8 Mw (USGS, s/d). Sabe-se que as causas que marcaram essa diferença foram as condiçôes de vida do povo haitiano, uma vez que, antes do terramoto, numa escala de 177 países, o Haiti ocupava a posiçáo 149 no Índice de Desenvolvimento Humano das Naçôes Unidas, de 2009, enquanto o Chile ocupava a posição 44. Depois do terramoto, no Índice de 2015, o Chile subiu para a posiçáo 42 e o Haiti desceu para o lugar 163.

\section{O Risco analisado a partir do Território}

A leitura dos riscos, feita a partir do território, visa alcançar uma melhor compreensão das incertezas para fazer com que o ordenamento do território contribua para a adaptaçấo, ou seja, para uma ocupação sustentável do mesmo. 
O território é um cenário onde se desenrolam processos dinâmicos, no tempo e no espaço, que geram incertezas em resultado da interação ser humano-natureza. Os riscos estão na acumulação das forças negativas dessas interaçóes.

Portanto, no sistema território, o risco é uma construção sócio-natural e espaciotemporal que resulta da acumulação sinérgica de relaçóes desequilibradas entre os factores que a compóem.

Há vários fatores que interagem nos processos de construção de risco: físicos, biofísicos e antrópicos. Cada um deles é uma componente do território, daí que, na medida em que melhor conheçamos os fatores que estão envolvidos na dinâmica do território - que inclui os fenómenos naturais ao mesmo nível que os problemas sociais - poderemos fazer melhor gestão do risco que resultará num ordenamento mais sustentável do território.

O risco é, pois, um produto do sistema território. Para, numa abordagem sistêmica, ler os riscos do território recorremos a Haimes (2009), que sugere que a complexidade da análise de risco pode ser explicada a partir da teoria de sistemas, com é o caso da teoria Risk Scenario Structuring, introduzida por Kaplan e Garrick em 1981, que vamos referir a seguir como RSC e que explica a noção de risco através de uma trilogia:

$$
\text { Risco }=\{\text { cenário de risco, probabilidade, consequências }\}
$$

Das três componentes da RCS, o cenário de risco é o que serve para a abordagem territorial, pois permite-nos reconhecer o efeito sinérgico negativo que resulta da interação entre os fatores intervenientes no território. Quando o cenário de risco está definido, ele constitui a ferramenta para o planeamento territorial e para a predição de risco. O cenário é a base para o cálculo das probabilidades e das consequências, cujos resultados são utilizados, entre outros, no mercado dos seguros e da ajuda humanitária.

O cenário de risco é uma modelação geográfica da realidade. Como consequência, no estudo do risco desde o território, adquirem visibilidade as suas dimensóes fundamentais: o tempo e o espaço. Em contraste, a ameaça e a vulnerabilidade, embora presentes no sistema, deixam de ser as dimensóes que definem o risco.

No mesmo território, o risco é dinâmico e mutável. Com efeito, o risco é um processo contínuo que se vai definindo em função das alteraçóes que o cenário de 
risco vai sofrendo ao longo do tempo. Podemos dizer que o risco do território se lê através da reconstrução do processo histórico risco-catástrofes desse território. Portanto, para o caracterizar, fazem-se sucessivas leituras, de tal forma que o processo contínuo de construção do risco se vai retratando com vários cenários de risco dentro do período de investigaçáo. Trata-se duma reconstrução dos factos ocorridos e que foram traçando a trajetória do risco, tornando possível identificar as causas.

Outra característica do risco é a oportunidade. Esta pode ser vista como sendo oposta ao risco, no sentido de que o que é um risco para uns, é oportunidade para outros. Este conceito explica-se bem através do princípio chinês de yin-yang e a filologia do mandarim expressa claramente essa diferença (Mair, 2009). A visáo do Ocidente é muito diferente, em que a oportunidade pode ser vista como uma parte integrante do risco, ou seja, o risco cria oportunidades ou, dito de outra forma, corre-se um risco para aproveitar uma oportunidade (Banco Mundial, 2013). Por outro lado, a percepçáo de oportunidades e a percepção de ameaças são independentes, o que sugere que elas não representam necessariamente os polos de uma mesma construção (Krueger e Dickson, 1994; Wijkman e Timberlake, 1984). Em novembro de 1999, quando o Equador estava mergulhado numa recessão económica sem precedentes, o vulcão Pichincha entrou em erupção cobrindo de cinzas a cidade de Quito. Para as empresas comerciantes de equipamento de proteção, a erupção foi a oportunidade para colocarem os seus negócios de boa saúde, no entanto, para as empresas municipais significou uma despesa adicional para uma bolsa já suficientemente empobrecida. Finalmente, a forma como, a partir do território, se interpreta a dupla risco-oportunidade depende do ponto de vista do investigador, influenciado pelas condições do sujeito em risco.

Um outro aspeto a ter em conta é o de que a acumulação de forças negativas não ocorre em todo o território. Num terramoto, algumas casas caem e outras permanecem em pé. No mesmo território, uma inundação afeta alguns campos e outros não. Isto explica-se através da escala. Se observamos o território a nível regional, podemos falar da regiâo-risco, introduzida por Olcina Cantos (2008: 9), que a define como "um território de dimensóes conhecidas, afetado por um ou mais riscos naturais com incidência sobre a população, os assentamentos e as atividades nele instaladas, ao ponto deles assumirem uma das características geograficamente mais significativas desse espaço geográfico". 
Em vez disso, à escala local, podemos diferenciar as características geográficas específicas que definem os níveis de risco entre diferentes pontos da região-risco referida por Olcina Cantos. Mais ainda, é possível identificar os pontos mais frágeis, onde a probabilidade de materialização do risco é mais elevada. Assim, fazendo referência ao exposto, podemos identificar com antecedência as casas que podem cair num determinado terramoto e aquelas que vão permanecer em pé, ou o campo que será inundado e aquele que não o será. Agora, se além de observar o território a uma escala detalhada, o observarmos com a abordagem de sistemas, podemos ver os fatores que intervêm na construçấo dos seus riscos. De fato, o risco de cada sistema territorial está definido por fatores de ordem diversa: natural, social, sócio-natural, individual, etc. Além disso, se olharmos mais de perto, veremos que o sistema território está formado por subsistemas mais pequenos, compostos pelos mesmos fatores. E, estes subsistemas, por sua vez, estão compostos por subsistemas ainda menores e assim sucessivamente. Esta caraterística é conhecida na geometria fractal como invariável na escala (Mandelbrot, 1983; Sornette, 2006).

Para explicar a importância de desmontar um território de risco em pequenos subsistemas de risco, fazemos uso das catástrofes, uma vez que elas são a manifestação do risco. As bases de dados internacionais sobre catástrofes, tais como a EM-DAT ou a da Cruz Vermelha Internacional, entre outras, têm, geralmente, descriçôes de uma catástrofe para cada fenómeno natural que afetou o país, dando a ideia de que todo o país é uma grande área de desastre, e, portanto, de risco. Nestes casos, cada país é considerada uma regiäo-risco. Mas, se nos aproximarmos, descendo de escala e estudarmos a nível local, veremos que houve áreas afetadas e outras áreas que não o foram, o que proporciona uma leitura do risco completamente diferente. Só desta forma podemos ver que não se trata de uma só catástrofe, mas sim de muitas, resultantes da realidade do risco de cada subsistema que compóe esse território.

Vejamos um exemplo. Em 1997, o Equador sofreu as consequências de uma mega El Niño. Se consultarmos a descrição do perfil desta catástrofe do Equador, na base de dados EM-DAT, ela está registada como uma única catástrofe; mas se analisarmos a base de dados DESINVENTAR, que regista as catástrofes a nível local, concretamente a nível municipal para o caso do Equador, descobrimos que, para o mesmo território, a imprensa local registou cerca de 1840 manifestaçóes do 
mesmo fenómeno (DESINVENTAR, s/d). Assim pode verificar-se que, no território do Equador, havia uma grande quantidade de processos de risco instalados a nível local, sendo uns diferentes dos outros.

Portanto, ao observar o território com uma abordagem de sistemas, podemos desmontá-lo em subsistemas, a que chamaremos unidades territoriais de risco (TRUE de territory risk ecocentric unit). Então, no exemplo do Equador, podemos dizer que cada TRUE sofreu danos de forma diferenciada, em função das condiçôes próprias do risco de cada uma delas. Na verdade, na mesma janela de tempo, cada TRUE gera um nível de risco diferente do existente nas suas vizinhas, o que explica as diferenças nos níveis de dano sofrido.

\section{Unidades territoriais de risco}

Cada subsistema é uma célula com um diferente nível de risco. Chamamos célula à TRUE porque tem morfologia e funcionalidade próprias. Cada TRUE gera um nível de risco próprio. Embora os fatores sejam os mesmos para todas as TRUEs, as diferentes formas de interaçáo deles em cada uma das TRUEs fazem com que a manifestação de risco seja diferenciada. Assim, o território é um mosaico de células, cada uma com a sua vida própria (fig. 1). Portanto, o risco total dum território resulta da agregaçáo do risco das TRUEs que o compóem, atuando isoladamente ou produzindo efeito em cadeia. Podemos imaginar cada TRUE como uma pirâmide cuja base pode ser triangular, quadrangular, etc., dependendo do número de factores identificados e em que a sua altura indica o risco (fig. 2).

O risco no território é mutante, uma vez que é um processo que vai assumindo vários estados em função do tempo e do espaço. Assim, a variabilidade do risco no território pode ser encontrada através do estudo das mudanças de comportamento, ao longo do tempo, das TRUEs que o compóem. Esta noção faz das TRUEs entidades que podem ser usadas como um meio espaciotemporal de comparação, dentro do mesmo território ou em territórios diferentes.

Esta forma de abordar o tema, que reconhece um funcionamento próprio para cada TRUE, ao ser o resultado das forças que estão interagindo de forma conjugada 


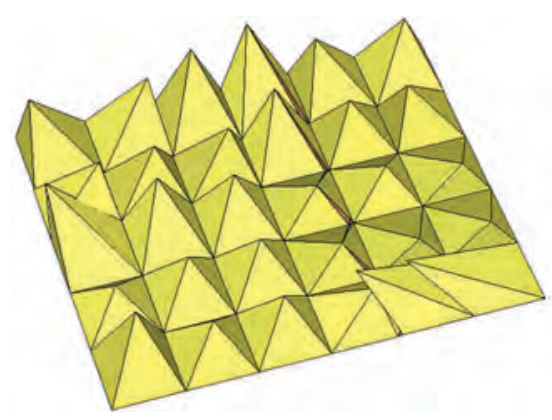

Fig.1 - O território pode ser observado como um mosaico de TRUEs. Cada TRUE tem o seu próprio nível de risco.

Fig. 1 - The territory can be seen as a mosaic of TRUEs. Each TRUE has its own level of risk.

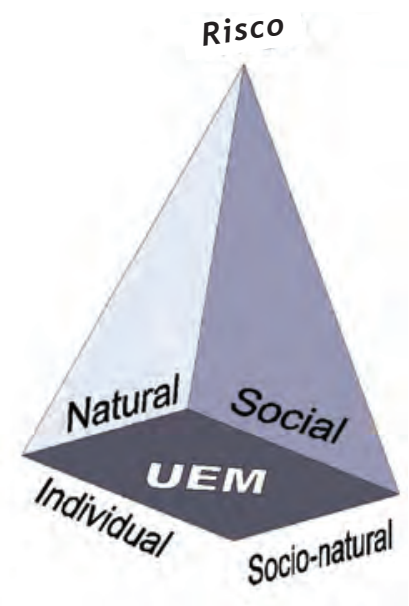

Fig. 2 - A TRUE é uma célula porque tem morfologia e funçôes. Todos os factores têm o mesmo peso.

Fig. 2 - A TRUE is a cell because it has morphology and functions. All factors have the same weightt.

em cada uma delas, representa uma maneira diferente de elaborar mapas de risco. Neste caso, não se trata de sobrepor mapas temáticos para identificar as vulnerabilidades ou para mapear o fenómeno natural como uma ameaça, mas trata-se antes de abordar a área de estudo através da desmontagem do território em TRUEs.

\section{Componentes da TRUE}

A TRUE pode ser definida através de três componentes: sujeitos em risco, fatores de risco e o espaço onde se relacionam.

Espaço onde se relacionam: começamos com a localização da TRUE. Chamamos Unidade Espacial Mínima (UEM) ao espaço onde se dão as relaçóes do sujeito em risco. Se estudarmos uma cidade, a UEM em que se baseia a TRUE pode ser o bairro, o quarteirão, o edifício, a casa, etc., dependendo da finalidade do estudo. Mas, as UEM também podem representar segmentos de trajetos e fluxos se forem 
abordados temas relativos a sujeitos móveis, em risco. Ao determinar o espaço sobre que assenta a TRUE, estamos a definir a escala de estudo e, consequentemente, o número de TRUEs que compóem o território que vai ser estudado para caraterizar um determinado sujeito que foi ou será afetado por um dado risco.

Falando em escala, surge a questáo da disponibilidade de dados à escala apropriada. Em estudos geográficos deste tipo, em que se trabalha na conjugaçâo de dados de naturezas diferentes - naturais e antrópicos - impóe-se uma atenção especial à diversidade das escalas. Por exemplo, os estudos geológicos tendem a ser regionais, ao passo que a informação sociodemográfica possui maior detalhe, como aquele que é facultado pelos censos, ou seja, a nível individual. Por conseguinte, a UEM definida para o estudo deve considerar a compatibilidade do nível de pormenor de todas as fontes consideradas.

Sujeitos em risco: Existem vários sujeitos em risco no mesmo espaço territorial. Saber qual ou quais são os sujeitos em risco a considerar, depende dos objetivos do estudo. Assim, se se tratar de população, o sujeito em risco poderá ser a população residente, a populaçáo economicamente ativa ou a saúde da populaçáo com menos de 10 anos. Se, porventura, tratarmos de património edificado, poderáo ser os edifícios do século XIX. Mas, as redes sociais também podem ser sujeitos em risco, pois constroem relaçôes e, portanto, constroem riscos. Podermos ainda considerar como sujeito em risco um curso de água, uma espécie da vida selvagem, etc. Vejamos um exemplo a grande escala. Numa fazenda existem vários sujeitos em risco: os proprietários, o gado, as culturas e outros. Os fatores que constroem o risco do sujeito proprietário sáo diferentes dos fatores do sujeito gado, embora o rendimento dos proprietários dependa da segurança dos seus gados. É que o risco dos proprietários náo é o mesmo que o risco do gado. Portanto, existe uma TRUE para cada sujeito considerado em risco. Consequentemente, no mesmo território, podem definir-se tantos tipos de TRUEs quantos os sujeitos que forem considerados.

Fatores de Risco: o sujeito, sendo o centro das relaçôes, determina os elementos que constroem o seu risco; por outras palavras, os fatores que definem a TRUE estáo dependentes do sujeito considerado em risco. Estes factores são as forças que interagem no território (fig. 3). Por exemplo, se o sujeito que estiver em risco forem plantaçôes de vinha, os fatores serão diferentes dos que consideramos quando o sujeito em risco for a saúde da população residente. 
O resultado do efeito sinérgico desses factores mostra o nível em que está ameaçada a estabilidade do sujeito em risco e, por conseguinte, a da TRUE. Cada fator está definido por um conjunto de variáveis selecionadas pelo investigador. Outros fatores, de caráter social, individual, do espaço construído, dos processos naturais e sócio-naturais e, até mesmo, a história dos danos desse território, podem definir a TRUE. De facto, os danos sofridos ao longo da história vão modificando o estado do sistema território e modelando a configuração do novo risco após uma catástrofe (Zilbert, 1996). Poderíamos considerar o fator social, de acordo com Rygel (2006), como sendo uma condição coletiva de risco que impede, imediata ou potencialmente, os grupos considerados de alcançar o seu bem-estar num contexto sócio-histórico e cultural concreto. Por outro lado, o fator individual pode ser definido como a existência de condiçóes e de comportamentos próprios a cada indivíduo que, pela capacidade individual para aplicar o conhecimento e os recursos que possui, os transforma, dando oportunidade à criação de atritos no sistema que fazem com que este se volte contra ele (Carballo e Bongiorno, 2007; Dauphiné 2001, Dercon, 2002). Por último, o fator natural seria definido como as condiçóes dinâmicas do ambiente natural, que são manifestaçôes de geração/consumo de energia e que tornam possível a existência de vida (Lovelock, 1983).

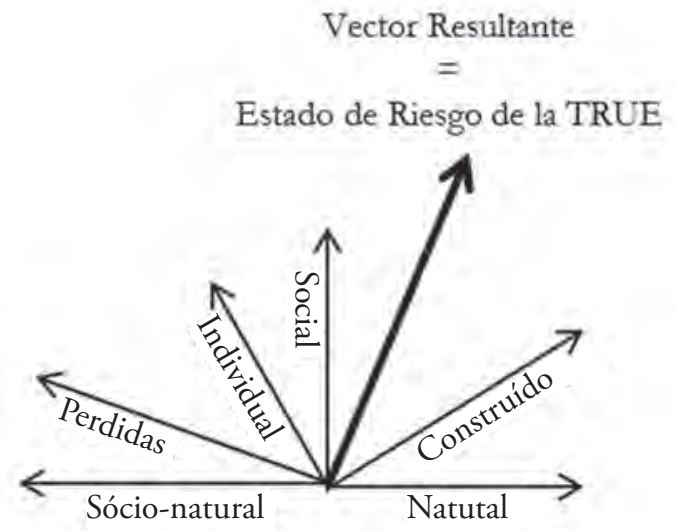

Fig. 3 - O vector resultante representa o estado de risco da TRUE, que resulta do produto do efeito sinérgico entre os factores de risco que a constituem.

Fig. 3 - The resulting vector represents the state of risk of the TRUE. It is the product of the synergistic effect of its risk factors). 
Se, por exemplo, o sujeito em risco é a saúde da população residente, podemos dizer que as ondas de calor e as vagas de frio, o empobrecimento da população, o trabalho ao ar livre, o envelhecimento, a falta de condiçóes de alojamento, entre outros fatores, póem em risco a saúde e, como consequência, a estabilidade geral da TRUE (Fernandez Moreno et al., 2014). Esses fatores são, simultaneamente, ameaças e vulnerabilidades, pois afetam diretamente o sujeito em risco e destabilizam o equilíbrio do sistema que é o garante da sustentabilidade do sujeito em risco.

\section{Características da TRUE}

- A UEM e os fatores da TRUE estão dependentes do sujeito em risco;

- Na mesma UEM podem existir sobrepostas tantas TRUEs quantos os sujeitos em risco considerados;

- Os fatores componentes da TRUE são os mesmos em todo o território estudado, mas interagem de forma diferente dentro de cada TRUE, produzindo um nível de risco próprio a cada uma;

- A TRUE apresenta uma escala invariável (Murphy, 1996), porque mantém a mesma estrutura em todas as escalas: nacional, regional e local;

- A escala da TRUE depende da finalidade do estudo e do sujeito em risco estudado;

- O risco de um território resulta da acumulação do risco das TRUEs que o compóem.

\section{Quantificação do risco}

Para quem está relacionado com a epistemologia dos Riscos Naturais, ao entender que cada fator é, em si mesmo, ameaça e vulnerabilidade, compreenderá que a diferença com aquela que é aqui proposta reside na abordagem ecocêntrica. Para colocá-la em termos práticos, parece-nos que para a adaptação e para o ordenamen- 
to do território, todos os fatores têm o mesmo peso, porque todos contribuem para a sinergia do sistema: o desequilíbrio de um fator significa o desequilíbrio de todo o sistema.

Isto leva-nos a refletir sobre a complexidade do território. Como Boisier (2003) sugere, a compreensão dos processos que se geram não é alcançável pelo seu somatório, mas sim pela simultaneidade que os faz aparecer, que os faz emergir. $\mathrm{O}$ estudo integrado do sistema de ser humano-natureza revela padróes complexos que não são necessariamente evidentes quando se estudam em separado (Liu et al., 2007; Byrne, 1998).

O risco é um processo contínuo de construção sócio-natural. Desde a teoria de sistemas, podemos dizer que o risco é um produto da sinergia do sistema (Malinietski, 2005), surge da dinâmica não linear de interaçôes locais desequilibradas entre os fatores $(F)$ envolvidos e, portanto, é um emergente sistémico (em que o todo é mais do que a soma das partes). Na verdade, o risco é um produto, que é diferente das componentes que integram o sistema de território. Assim, o risco de cada TRUE $(r)$ expressa-se como o resultado de uma função sinérgica $(f)$ dos factores contribuintes.

$$
r=f\left(\mathrm{~F}_{1}, \mathrm{~F}_{2} \ldots \mathrm{F}_{\mathrm{n}}\right)
$$

Ligado a este conceito encontra-se o de recursividade, que nos diz que, por sua vez, um sistema sinérgico é composto por subsistemas que também são sinérgicos. Portanto, o risco da totalidade do território $(R)$ seria o resultado da sinergia (f) entre as TRUEs $\left(r_{i}\right)$ que o compóem. Então, para conhecer o risco dum território a partir duma abordagem espacial, podemos expressá-lo por:

$$
R=f\left(\mathrm{r}_{\mathrm{i}}, \mathrm{r}_{(\mathrm{i}+1)} \ldots \mathrm{r}_{\mathrm{n}}\right)
$$

Além disso, o risco é um processo que é construído ao longo do tempo. Conhecê-lo ajuda a explicar as causas que o vão gerando. Para adicionar a dimensão tempo, é necessário construir cenários sucessivos da mesma TRUE em diferentes momentos $(t)$ do período estudado. Portanto, para cada TRUE, a evolução do risco seria expressa com a matriz

$$
r_{i}^{t}=\left[\begin{array}{ccc}
t 1 & t 2 \ldots & t n \\
r_{i 1} & r_{i 2} \ldots & r_{i n}
\end{array}\right]
$$


Portanto, o processo de construção do risco de todo o território (R) expressa-se como o resultado da função sinérgica de todas as matrizes de risco de todas as TRUEs, ao longo do período de tempo estudado.

Para resolver o problema, o primeiro desafio é trazer o pensamento do incrementalismo desarticulado de Lindblom e da simplificação cartesiana (Boisier, 2003) para a multidimensionalidade, a năo-linearidade, a complexidade, as características dos sistemas vivos, como é o caso do território. Trata-se de ver o mundo através de uma abordagem holística, ecocêntrica, diferente da tradicional separação entre ciências exatas e ciências sociais. Só desta forma é possível realizar um estudo de convergência antrópico-natural e fazer a sua abordagem por equipes multidisciplinares. Com efeito, é possível usar teorias e instrumentos existentes para a reconstrução do estado de cada TRUE ao longo do tempo. Partindo da teoria de sistemas e dependendo do grupo de pesquisa e do alcance que se pretenda dar à investigação, podem vir a usar-se outras teorias, tais como a teoria do caos, da sinergia, da lógica difusa (ou de Fuzzy), das catástrofes e do problema inverso, entre outras.

\section{Até que ponto a TRUE pode refletir a realidade do território?}

A resposta não está nas ferramentas disponíveis, mas sim no investigador. $\mathrm{O}$ rápido aumento da capacidade computacional permite que os problemas sejam abordados através de modelos organizados em muitas categorias. Como resultado, assistimos a um crescimento explosivo da quantidade de informaçôes produzidas por esses modelos. No entanto, também há um aumento concomitante da perda de procedimentos e de controlo de qualidade pelo que, frequentemente, os resultados obtidos são apresentados sem que tenham sido validados (Lynch e Davies, 1995).

Por outro lado, muitos modelos são preditivos, o que torna mais difícil a sua validaçáo. Mas a TRUE não exige um modelo preditivo, pois trata da reconstrução de cenários históricos, de reconstruçôes do passado. Conforme se discute no problema inverso, a partir das saídas ou outputs do sistema, podem encontrar-se as causas que alimentam os processos de risco. No caso da TRUE, aplica-se uma validaçáo de eventos já ocorridos e que é retroalimentada para obter uma melhor definição (fig.4). Portanto, para validar 
a TRUE é necessário ter em conta o nível de precisão que se pretende alcançar. A precisão é a ausência do erro sistemático e aleatório, o que em metrologia se conhece como fidelidade e precisão. Como sabemos, todos os modelos são, pela sua própria natureza, representaçóes incompletas do sistema de que pretendem ser modelo, mas, não obstante esta limitação, são úteis porque respondem a objetivos específicos. Assim, o nível de precisão que se alcança no desenho da TRUE é o que valida a robustez do modelo.

Doucet (1992) apresenta uma boa introdução à realização de testes de modelos, uma vez que faz a distinção entre confirmação do modelo (que mostra que ele é digno de ser credível, aceitável) e verificação do modelo (que mostra que ele é verdadeiro). Embora o risco no território seja não-linear, é conveniente rever a contribuição de Nelder e Wedderburn (1972) sobre modelos lineares, já que é uma fonte clássica de informaçóes sobre os métodos de criação de modelos estatísticos, onde se descrevem alguns princípios gerais para a implementação de modelos matemáticos, de que destacamos três dos princípios que devem nortear o criador de modelos: a) todos os modelos são erróneos, mas alguns são mais úteis do que outros; b) não há que comprometer-se com um único modelo, excluindo outros; c) deve verificar-se cuidadosamente o ajustamento de cada modelo aos dados.

Parece-nos necessário refletir sobre esta questão porque o facto de que convergirem dados físicos, biológicos e sociais para a modelação da TRUE, coloca os estudos geográficos como os casos mais complexos da matemática. De acordo com Hannah

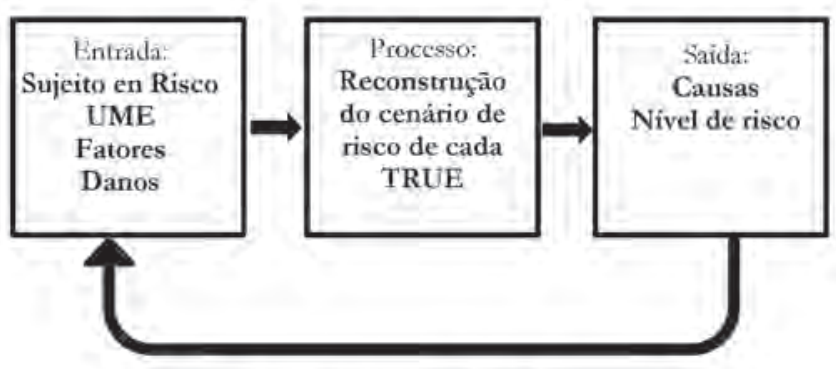

Retroalimentaçio: Validação

Fig. 4 - Validação do cenário de risco TRUE. Utiliza-se a história dos danos tanto para a validação como para a retroalimentação do modelo.

Fig. 4 - Validation of the TRUE risk scenario. Historical damage is used for validation and model feedback. 
(2007), para trabalhar com este tipo de simulação, em primeiro lugar é necessário a validação, ou seja, a avaliaçáo rigorosa do nível de confiança no modelo, a qual é crucial para aplicaçôes práticas; em segundo lugar, trata-se de um problema em aberto, o que significa que é preciso determinar a complexidade que se pretende alcançar; e, finalmente, porque são problemas multidisciplinares há, portanto, mais necessidade de integração. $\mathrm{O}$ processo de validação do modelo fornece a estrutura que permite conectar esses pontos. Além disso, Kelton e Law (2000) ao abordarem a questáo da criação de modelos de simulação, válidos, credíveis e devidamente detalhados, alertam para que alguns modelos podem não ser totalmente validados, mas em que é possível para validar individualmente as suas componentes. Assim, podem ser validadas separadamente, a concepção, os algoritmos, os processos informáticos e a funcionalidade (Dee, 1995).

\section{Conclusão}

A adaptação do ser humano à evoluçáo do nosso planeta requer formas de compreensão integradoras. A necessidade de seccionar o conhecimento foi necessária num dado momento da história do conhecimento, mas no presente, é possível abordar a relação ser humano-natureza como um problema único. Os riscos são um subproduto dessa relação, e, portanto, o seu estudo também requer uma abordagem integrada. No território os processos são não-lineares, portanto, logo é necessário realizar estudos de não-linearidade. Este é um bom momento, dado que existe conhecimento e capacidade para trabalhar multidisciplinarmente, ou seja, para dar respostas mais aproximadas à realidade. Pensamos que este é o caminho para a sustentabilidade, que se consegue através da mudança, traduzida no abandono da abordagem antropocêntrica para passar a acolher o paradigma ecocêntrico.

O risco é um tema que, pela sua complexidade, foi sistematicamente abordado de forma parcial e, muito em especial, os que aqui se referem especificamente, os riscos do território. Deixou-se aqui expressa uma nova proposta de abordagem para que, com as capacidades e os instrumentos existentes na atualidade, ela possa ser reformada, deformada, e se possível, colocada em prática por aqueles que se interes- 
sam pela interação ser humano-natureza, bem como pela procura do equilíbrio entre ambos e, portanto, pela compreensão das incertezas e dos desequilíbrios. Como diz Lovelock, é na interação que se gera a vida.

As células territoriais, subsistemas ou TRUEs, como se lhes queira chamar, têm a sua própria vida e precisam ser abordadas, não com dissecçóes que as matam, mas com estudos não-invasivos que respeitem e reconheçam a sua funcionalidade, vitalidade e decadência.

Ao longo desta proposta tentou-se mostrar a necessidade de alterar a categoria de ameaça de que gozam os fenómenos naturais desde a epistemologia dos Riscos Naturais, para passar a vê-los como parte intrínseca do território, ao lado do ser humano, numa perspetiva de adaptação e ordenamento do território.

\section{Referências bibliográficas}

Banco Mundial (2013). Informe sobre el desarrollo mundial 2014: Riesgo y Oportunidad. Retrieved from: h t t p : / / siteresources.worldbank. org/ EXT NWDR2013/ Resources/8258024-1352909193861/8936935-1356011448215/8986901-1380730352432/SPA_StandaloneOverview.pdf

Boisier, S. (2003). ¿ Y si el desarrollo fuese una emergencia sistémica. Revista Del CLAD Reforma Y Democracia, 27, 11-29.

Brooks, N. (2003). Vulnerability, risk and adaptation: A conceptual framework. Tyndall Centre for Climate Change Research Working Paper, 38, 1-16.

Byrne, D. S. (1998). Complexity theory and the social sciences: an introduction. Psychology Press.

Carballo, J., Bongiorno, M. (2007, May). Vulnerabilidad Individual: Evolución, Diferencias Regionales e Impacto de la Crisis. Argentina 1995 - 2005. Documento de Trabajo No 5.

Fernandes, P. J. da Silva (2013). A natureza e o homem: da contemplação à instrumentação - Dos antigos gregos a uma sociedade de riscos. Tesis de Doctorado. Universidad de Salamanca.

Dauphiné, A. (2001). Risques et catastrophes observer, spatialiser, comprendre, gérer. Paris: A. Colin.

Dee, D. P. (1995). A pragmatic approach to model validation. Coastal and Estuarine Studies, 1-1.

Dercon, S. (2002). Income risk, coping strategies and safety nets. Helsinki: United Nations University, World Institute for Development Economics Research.

DESINVENTAR. (s/d). Ecuador - Sis. de Inf. de Desastres y Emergencias. Retrieved April 6, 2016, from http://online.desinventar.org/desinventar/index.php?lang=spa

Devall, B., Sessions, G. (1985). Deep ecology. Salt Lake City: Gibbs Smith.

Doucet, P. (1992). Mathematical modeling in the life sciences. New York: E. Horwood.

Fernandez Moreno, M. A., Monteiro, A., Carvalho, V., Gonçalves, G. (2014). TRUE - Ecocentric Territory Risk Units: circulatory and respiratory diseases aggravation in Porto. Territorium, 21, 157-168. http://www.uc.pt/fluc/nicif/riscos/Documentacao/Territorium/T21_artg/T21_artg13.pdf 
Gentelle, P. (1993). China. In Os sentimentos da natureza. Lisboa: Perspectivas Ecológicas.

Giddens, A. (1990). The consequences of modernity. Cambridge, UK: Polity Press in association with Basil Blackwell, Oxford, UK.

Haimes, Y. (2009). On the Complex Definition of Risk: A Systems-Based Approach. Risk Analysis, 29(12), 1647-1654.

Hannah, C. (2007). Future directions in modelling physical-biological interactions. Marine Ecology Progress Series, 347, 301-306. http://doi.org/10.3354/meps06987

Kelton, W. D., Law, A. M. (2000). Simulation modeling and analysis. McGraw Hill Boston, MA.

Krueger, N., Dickson, P. R. (1994). How believing in ourselves increases risk taking: Perceived self-efficacy and opportunity recognition. Decision Sciences, 25(3), 385-400.

Lavell, A. (2003). La gestión local del riesgo: nociones y precisiones en torno al concepto y la práctica. In La gestión local del riesgo: Nociones y precisiones en torno al concepto y la práctica. Centro de Coordinación para la Prevención de los Desastres Naturales en América Central (CEPREDENAC); PNUD.

Liu, J., Dietz, T., Carpenter, S. R., Alberti, M., Folke, C., Moran, E., Pell, A. N., Deadman, P., Kratz, T., Lubchenco, J., Ostrom, E., Ouyang, Z., Provencher, W., Redman, C. L., Schneider, S. H., Taylor, W. W. (2007). Complexity of coupled human and natural systems. Science, 317(5844), 1513-1516.

Lovelock, J., trad. Rioja, A. (1983). Gaia: una nueva visión de la vida sobre la tierra. Hermann Blume.

Lynch, D., Davies, A. M. (1995). Quantitative skill assessment for coastal ocean models (Vol. 47). American Geophysical Union.

Mair, V. (2009). How a misunderstanding about Chinese characters has led many astray. Pinyin. Info.

Malinietski, G. G. (2005). Fundamentos matemáticos de la sinergética: Caos, estructuras y simulación por ordenado. URSS.

Mandelbrot, B. B. (1983). The fractal geometry of nature (Vol. 173). Macmillan.

MAPFRE. (2008). Diccionario MAPFRE de Seguros. MAPFRE. Retrieved from http://www.mapfre. $\mathrm{com} /$ wdiccionario/general/diccionario-seguros.shtml

MAPFRE. (s/d). Diccionario MAPFRE de Seguros. Retrieved June 16, 2016, from http://www.mapfre. $\mathrm{com} /$ wdiccionario/general/diccionario-seguros.shtml

Murphy, P. (1996). Chaos theory as a model for managing issues and crises. Public Relations Review, 22(2), 95-113.

Næss, A., Rothenberg, D. (1989). Ecology, community, and lifestyle : outline of an ecosophy. Cambridge; New York: Cambridge University Press.

Nelder, J. A., Wedderburn, R. W. M. (1972). Generalized linear models. Journal of the Royal Statistical Society. Series A (General), 370-384.

Olcina Cantos, J. (2008). Cambios en la consideración territorial, conceptual y de método de los riesgos naturales. Scripta Nova: Revista Electrónica de Geografía Y Ciencias Sociales, (12), 20.

Pachauri, R. K., Allen, M. R., Barros, V. R., Broome, J., Cramer, W., Christ, R., Church, J. A., Clarke, L., Dahe, Q., Dasgupta, P., Dubash, N. K., Edenhofer, O., Elgizouli, I., Field, C. B., Forster, P., Friedlingstein, P., Fuglestvedt, J., Gomez-Echeverri, L., Hallegatte, S., Hegerl, G., Howden, M., Jiang, K., Jimenez Cisneroz, B., Kattsov, V., Lee, H., Mach, K. J., Marotzke, J., Mastrandrea, M. D., Meyer, L., Minx, J., Mulugetta, Y., O’Brien, K., Oppenheimer, M., Pereira, J. J., Pichs-Madruga, R., Plattner, G. K., Pörtner, H. O., Power, S. B., Preston, B., Ravindranath, N. H., Reisinger, A., Riahi, K., Rusticucci, M., Scholes, R., Seyboth, K., Sokona, Y., Stavins, R., Stocker, T. F., Tschakert, P., van Vuuren, D., van Ypserle, J. P. (2014). Climate change 2014: synthesis Report. Contribution of working groups I, II and III to the fifth assessment report of the intergovernmental panel on climate change. IPCC. 
Raffestin, C., \& trad. França M.C. (2011). Por uma geografia do poder. Ática San Pablo.

Rizzi Cicci, S. (2006). El Riesgo. Retrieved March 31, 2013, from: http://www.monografias.com/trabajos40/el-riesgo/el-riesgo.shtml

Rygel, L., O'sullivan, D., Yarnal, B. (2006). A method for constructing a social vulnerability index: an application to hurricane storm surges in a developed country. Mitigation and Adaptation Strategies for Global Change, 11(3), 741-764.

Santos, M. (1988). Metamorfoses do espaço habitado: fundamentos teóricos e metodológicos da geografia.

Sornette, D. (2006). Critical phenomena in natural sciences: chaos, fractals, selforganization and disorder: concepts and tools. Springer Science \& Business Media.

Tricart, J., trad. Sánchez, M. (1981). La tierra, planeta viviente. Akal.

UNDRO - UNITED NATIONS DISASTER RELIEF ORGANIZATION (1980). Natural disasters and vulnerability analysis report of Expert Group Meeting (9-12 July 1979). Office of the United Nations Disaster Relief Co-ordinator. Retrieved from:

http://www.archive.org/stream/naturaldisasters00offi/naturaldisasters00offi_djvu.txt

USGS - UNITED STATES GeOlOGiCAL SURVEY (s/d). Earthquake Hazards Program. Retrieved from: http://earthquake.usgs.gov/earthquakes/eqinthenews/2010/

Wijkman, A., Timberlake, L. (1984). Natural disasters. Acts of God or acts of Man? Earthscan.

Zilbert, L. (1996). Guía de la Red para la Gestión Local del Riesgo II-Módulos para la Capacitación (ITDG). Lima: Versión. 


\title{
A Visáo do Risco pela SOCIOLOGIA RISK AS VIEWED BY SOCIOLOGY
}

\author{
Norma Valencio \\ Universidade Federal de São Carlos-UFSCar \\ norma.valencio@ufscar.br
}

Sumário: Na perspectiva sociológica, o risco está relacionado com as interaçôes sociais e representaçóes sociais. Assim, o contexto sociocultural é muito importante para explicar as origens desse problema. Através da menção a uma variedade de catástrofes ocorridas pelo mundo nas últimas décadas, o texto enfatiza o caráter econômico do espraiamento dessas ocorrências bem como a impossibilidade institucional de controlá-las.

Palavras-chave: Interação social, riscos, sociedade de risco.

\footnotetext{
Abstract: Sociology sees risk as being related to social interactions and social representations. Thus, the sociocultural context is very important to explain the origin of this problem. This paper uses a variety of disasters that have occurred in recent decades to highlight the economic character of these occurrences as well as the institutional impossibility of controlling them.
}

Keywords: Social interaction, risks, risk society. 


\section{Introduçáo}

O último século apontou para um cenário sombrio: o de incremento de riscos passíves de se materializarem não apenas em vultosas catástrofes como também através de inusitados tipos de catástrofes (Quarantelli, Lagadec \& Boin, 2007). Na perspectiva das Humanidades, os riscos estão longe de nascerem como algo palpável, pois derivariam do universo cultural de cada povo, subgrupo e indivíduo (Douglas e Wildavisky,1983); tratar-se-ia de um qualificativo sobre certos estados, operações e situações socioambientais, oriundo dos filtros classificatórios do mundo que são incorporados por meio dos processos, formais e informais, de ensino-aprendizagem aos quais o sujeito social está submetido em seu contexto de vida. Essa classificação não é estática, pois os conteúdos representacionais sobre a realidade concreta se alteram assim como promovem alteraçôes da própria realidade concreta. Vieses de classe social, de crenças religiosas, de ocupaçôes profissionais assim como de bases científicas podem dar direçôes muito distintas à definiçáo do conceito de risco ou ao reconhecimento de dada situaçáo como tal. Seja na sociologia como na antropologia, que tem como centro o estudo das interconexóes de diferentes sujeitos, comportamentos e culturas na escala micro ou macrossocial (Roberts, González de la Rocha, M. \& Escobar Latapí, 2013), o tema do risco adquire uma forte associação ao campo das representaçôes sociais. Essas iluminam as categorias de pensamento que regem o modo como a realidade é coletivamente apreendida e explicada. Ainda, as representaçóes sociais que se tornam o senso comum de um povo pautam as condutas ordinárias da vida social, seja estruturando as instituiçôes ou pondo em marchas as relações sociais de coesão ou conflito (Minayo, 1995).

Numa perspectiva sociológica de âmbito macrossocial, podemos considerar que os mais graves riscos contemporâneos derivem, direta e indiretamente, dos mecanismos de funcionamento, do ritmo e da abrangência do modo de produção capitalista. Há certo consenso científico de que esteja em curso mudanças climáticas globais e que as mesmas decorram de "fatores antropogênicos"; em essência, tais fatores se expressam através da história de dominância da dinâmica urbano-industrial no planeta, deflagrada pela Revolução Industrial, do que resulta 
a grande emissão de gases de efeito estufa (IPCC, 2014). Nos dias atuais, a indústria de grande porte e de alta tecnologia - especialmente, nos ramos nuclear, químico, biológico e automotivo -, que se expandiu sob a justificativa de melhoria da qualidade de vida da sociedade, avançou economicamente pelo globo devido a sua legitimação política. Isso levou à disseminação de produtos e processos que alteraram irreversivelmente o modo de vida urbano e rural planeta afora, mas cujos efeitos ambientais deletérios a técnica náo consegue deter. Os lugares e as pessoas se globalizaram (Santos, 1998) por meio de sua adesão à tecnificação ou convivência forçada com seus efeitos. Mas, a tolerância social para com os pontuais efeitos ambientais adversos tem resultado em que esses cresçam e se proliferem, propiciando preocupantes sinergias que, então, encontram um ponto de rutura que se manifestará em incidentes, acidentes ou catástrofes.

\section{Riscos incontroláveis}

O caso de Chernobil, ocorrido em 1986, demonstrou emblematicamente que a cultura organizacional industrial, tende a sobrestimar a sua capacidade de controle sobre os riscos que produz, suscitando os acidentes normais (Perrow, 1999), os quais extrapolam as fronteiras da planta industrial, do país de inserção e da geração que o presenciou diretamente. O caso de Bhopal, em 1984, já tinha apontado algo semelhante, sobretudo, em relação à relativa indiferença institucional, tanto empresarial quanto governamental, quanto ao destino de milhares de vidas que foram prejudicadas por morte imediata ou por danos permanentes à saúde, recrudescendo o sofrimento social (Das, 2000); o recorte de classe e etnorracial de desproteção civil repetiu-se no caso Katrina, ocorrido em agosto de 2005 (Bullard, 2006).

No caso dos tsunamis que ocorreram, em dezembro de 2004, em vários países asiáticos e africanos, elucidou-se a nova trama socioespacial dos riscos, que enodoa o 'lá' e o 'cá', uma vez que milhares de turistas estrangeiros estiveram entre os mortos e desaparecidos (Valencio, 2013). Por fim, o caso de Fukushima, em março de 2011, relevou que a sinergia entre diferentes hazards 
(naturais e tecnológicos) pode ampliar sobremaneira a abrangência territorial e social da devastação. Aos milhares de mortes e desaparecimentos, que foram testemunhados de maneira impotente pelo meio técnico e governamental japonês, acresceu-se a necessidade de evacuar milhares de famílais e acolhê-las em abrigos provisórios que, por perdurarem anos, revelaram-se não tão 'provisórios' assim, descortinando as falhas nas medidas recuperativas plenas.

A obsolescência planejada de artefatos e serviços na sociedade de consumo de massa bem como o aumento da circulação dessas mercadorias e dos fluxos de pessoas por todo o globo engendram indissociáveis efeitos benéficos e maléficos socioambientais. Tais efeitos vão da reificação da felicidade, traduzida no momento da aquisição da nova mercadoria - como a de sofisticados equipamentos de comunicação, que possibilitam que a vida virtual se torne mais envolvente do que a presencial -, à disseminação rápida de vírus que geram doenças graves e fatais em humanos e outros seres vivos e para os quais não há processos de cura eficazes. Esse contexto ambíguo foi o que Beck (1992) denominou como sociedade de risco, um processo global de saturação - em termos produtivos e relativo ao consumo -, que se assenta na imagem de propagação de bem-estar enquanto engendra o seu contrário, isto é, malefícios concretos e multidimensionais que deterioram a qualidade de vida. Em suas palavras, o conceito de sociedade de risco designa "uma fase da sociedade moderna, em que os riscos sociais, políticos, econômicos e individuais tendem cada vez mais a escapar das instituiçôes para o controle e a proteção da sociedade industrial' (Beck, 1997, p. 15). Porém, por um lado, esse controle e proteçáo, que deixam de ser público para serem privados, são mediados por relaçóes mercantis cuja rentabilidade depende do alardear de ameaças, pois a indústria da segurança se alimenta de medos reais ou presumidos; por outro lado, o avanço da produção de bens e de serviços através de megatecnologias, como na produção genética, na supermilitarização, na indústria química ou informática, corresponde a megaorganizaçóes que creem no controle total da situação, mas cuja envergadura aumenta a probabilidade de que 'algo dê errado' e quando isso ocorre, ficam em consideraçóes organizacionais setoriais insuficientes para lidar com a vida real, múltipla e complexa, na qual seus erros interferiram de maneira nefasta (Beck, 1997). 
Um caso recente, brasileiro, foi o do desastre relacionado ao rompimento de barragem de rejeitos da empresa Samarco, uma joint-venture das gigantes Vale e BHP Billinton. As preocupaçôes centrais da empresa com a dinâmica cíclica do mercado mundial de minérios e com a rentabilidade dos acionistas repercutiu numa frágil qualidade técnica dos procedimentos de deposição de rejeitos, num colapso das obras civis que resultou em prejuízos sócio ecológicos de grande monta ao longo da bacia do rio Doce (Milanez et al., 2015).

\section{Das incertezas manufaturadas ao desamparo radical}

Giddens (1991), por seu turno, denominou o contexto global atual como modernidade tardia, a saber, uma construçấo cognitiva com repercussôes na elevação das incertezas na vida prática. Ambos os autores, Giddens e Beck, convergem na identificação de um aumento da desconfiança pública nas práticas tecnológicas correntes dos diversos sistemas peritos - sejam eles empresariais ou governamentais -, especialmente, no que diz respeito às respectivas capacidades dos mesmos de neutralizar os perigos decorrentes de sua ação. Essa desconfiança pública pressiona para a reflexividade dos sistemas peritos (Giddens, 1991), isto é, para que esses exercitem a sua capacidade de autocrítica e de assimilação de críticas externas, reconhecendo seus erros e imperfeiçóes e, assim, reorientando os rumos de sua açáo. Quanto mais baixa a reflexividade de um sistema perito, mais a rigidez de sua visão de segurança gera intranquilidade para aqueles que com o mesmo convivem. Isto é, a resistência à mudança contribui no incremento das incertezas manufaturadas (Beck, 1999); dado que vivemos contemporaneamente em processos sociais não-lineares, a falsa crença de uma organização, pública ou privada, de que ela tenha um controle total sobre aquilo que faz ou que possa corresponder eficazmente às injunçôes externas suscita práticas cujas consequências socioambientais são imprevisíveis.

Convém, ainda, considerar que, se as organizaçôes se agigantam, o mesmo ocorre no caráter relacional das incertezas que essas geram no âmbito econômico, social e político. Isso pode ser levado ao paroxismo no entremear de uma crise 
no mercado em que as mesmas atuam, levando milhares de trabalhadores ao desemprego, com instabilidades nas estruturas decisórias institucionais governamentais e a resultante perda do sentimento de segurança e proteção por parte de diferentes estratos sociais, contribuindo para o aparecimento e proliferação de indícios de anomia social. Os riscos manufaturados apresentam esse caráter integrado porque a sua face mais visível, a que se associa ao progresso geral, também é triplamente articulada, incidindo não apenas sobre a vida econômica - no nível de emprego, nos impostos recolhidos aos cofres públicos - mas, sobre a vida política - financiando candidatos, cuja vitória garante políticas econômicas alinhadas com seus interesses - e sobre a vida social, especialmente, nesse particular, incidindo sobre a política de ciência e tecnologia voltada para a otimização das condiçôes de lucratividade dessas megatecnologias. Tais articulaçôes concorrem para que haja menos pressóes sobre essas estruturas e ouvidos moucos para com as denúncias de comprometimento da saúde e do bem-estar dos seres vivos; autoridades relutantes persistem, o quanto possível, na convivência com poluentes, contaminantes e resíduos, o que, por seu turno, gera aumento da carga de dejetos a serem despejados nos serviços de saneamento, no aumento da demanda por serviços de saúde, no desaparecimento de espécies silvestres, entre outros. Talvez, a questão de fundo seja a de que o estilo de vida predominante na modernidade recodificou, como um novo nicho (Ingold, 2011), a convivência com tais riscos através de cadeias, ciclos e fluxos ambientalmente insustentáveis (Turner, 1994); mas, com os quais a sociedade segue adaptando-se ao ponto de se esquecer das propriedades autofágicas desse processo. Assim, a performance de controle total sobre fatores ameaçantes, através do aumento das forças de vigilância, não corresponderia à real capacidade de fazê-lo (Irwin, 2001), sendo apenas recursos de acobertamento das fragilidades institucionais, prejudicando a pressão e o controle social sobre a situação alarmante (Douglas \& Wildavisky, 1983).

No nível microssocial, mascarar riscos é um comportamento social muito frequente porque viver sob um amplo horizonte de incertezas pode ser emocional e simbolicamente dilacerante, minando a ideia de sucesso em torno de conquistas materiais, sociais e existenciais que pautam a vontade de seguir em frente (Menezes, 2006). 


\section{Conclusão}

$\mathrm{Na}$ junção entre os contextos macro e microssociais, para se suplantar o desamparo coletivo - isto é, a falta de garantias do sujeito no mundo - o mundo urbano-industrial, travestido atualmente em sociedade de serviços, mantém a ilusão de que há controle institucional sobre forças adversas; escamoteia, com isso, a preocupante pulsão de morte por detrás de uma ordem social que endossa a capacidade destrutiva concentrada de certos agentes econômicos e políticos (Menezes, 2006). Portanto, o desvelamento desse desamparo coletivo exigiria procurar aquilo que está oculto sob a ordem estabelecida, ou seja, identificar a desordem que as instituiçóes escamoteiam. Tal busca seria mais exitosa através das margens da sociedade, onde o Estado constantemente falha (Das \& Poole, 2008) e onde se encontram as ricas experiências subjetivas daqueles, cujas vidas são feixes explícitos de inseguranças e vulnerabilidades (Kroll-Smith \& Gunter, 1998). Os desfiliados sociais sentem, de um modo desproporcional, as disfuncionalidades do progresso, pois suas vidas sáo tecidas por fios de precariedade material e física assim como de assédios morais e agravos emocionais que suscitam com frequência quadros patológicos, oriundos da forma limitada como as instituiçôes pensaram suas políticas de prevenção e precaução contra crises (Lieber \& Romano-Lieber, 2005). Entretanto, os sinais dos riscos costumam ser invertido pelas forças políticas e econômicas dominantes; os desfiliados sociais, ao invés de serem ouvidos, passam a ser apontados como sendo eles os fatores de risco. O discurso dominante adota um caráter moralizador, estigmatizando os "grupos de risco" que têm "comportamentos de risco", os moradores de "áreas de risco", que não têm "percepção de risco" e assim por diante, evitando assim o entendimento efetivo dos processos sociais estruturantes dessas debilidades (Cardoso, 2006), e as lógicas operativas que geram uma distribuição diferenciada de riscos (Lindell \& Perry, 2004).

Quanto maior a variedade e quantidade de riscos que possam se concretizar em catástrofes, mais necessário se torna o esforço de compreensão científica e técnica deste processo social através de uma escuta atenta das pessoas comuns que estão mais expostas (Kroll-Smith \& Gunter, 1998); com base em sua 
péssima qualidade de vida e vivência ambiental cotidiana desafiadora, essas pessoas poderão dizer o quáo confiáveis sấo as medidas protetivas ao seu dispor e o quão plausíveis são os planos de contigência aventados caso o pior venha a ocorrer com elas. Esse é um ponto de partida substantivo para procurar a verdade sobre os fatos ou tomar as providências cabíveis para reduzir as incertezas no horizonte, onde despontam nuvens cinzentas.

\section{Referências bibliográficas}

Beck, U. (1992). Risk society: towards a new modernity. Londres/Thousand Oaks/Nova Delhi: SAGE.

Beck, U. (1997). A reinvenção da política: rumo a uma teoria da modernização reflexiva. In: U. Beck; A. Giddens; S. Lash (Orgs.). Modernização Reflexiva: política, tradição e estética na ordem social moderna. São Paulo: EdUNESP, 11-71.

Beck, U. (1999). World risk society. Cambridge and Malden: Polity Press.

Bullard, R. (2006). Varridos pelo furacão Katrina: reconstruindo uma "nova” Nova Orleans usando o quadro teórico da justiça ambiental. In: S. Herculano; T. Pacheco (Orgs.). Racismo Ambiental. Rio de Janeiro: Fase, 126-147.

Cardoso, A. L. (2006). Risco urbano e moradia: a construção social do risco em uma favela do Rio de Janeiro. Cadernos IPPUR, Rio de Janeiro, 20, 27-48.

Das, V. (2000). Suffering, Legitimacy and Healing: the Bhopal case. In: S. Kroll-Smith, P. Brown $\&$ V. Gunter (Eds.). Illness and the Environment: a reader in contested medicine. New York University Press, 270-288.

Das, V. \& Poole, D. (2008). El Estado y sus márgenes: etnografias comparadas. Cuadernos de Antropología Social, 27, 19-52.

Douglas, M. \& Wildavsky, A. (1983). Risk and culture - and essay on the selection of technological and environmental dangers. Berkeley, Los Angeles, London: University of California Press.

Giddens, A. (1991). As consequências da modernidade. São Paulo: EdUNESP.

Ingold, T. (2011). Being Alive: essays on movement, knowledge and description. London and New York: Routledge.

IPCC- Panel Intergovernmental on Climate Change. Climate change 2014 - synthesis report, summary for policymarkers.Acedido em 04 de março de 2016 em: http://www.ipcc.ch/pdf/assessment-report/ar5/syr/AR5_SYR_FINAL_SPM.pdf

Irwin, A. (2001). Sociology and the environment: a critical introduction to society, nature and knowledge. Cambridge and Oxford: Polity Press and Blackwell Publishers Ltd.

Kroll-Smith, S.; Gunther, V.J. (1998). Legislators, interpreters, and disasters. In: E.L. Quarantelli (Ed.). What is a disaster? Perspectives on the question. Routledge: London and New York, $160-176$.

Lieber, R. R.; Romano-Lieber, N. S. (2005). Risco e precaução no desastre tecnológico. Cadernos de Saúde Coletiva, Rio de Janeiro, 13, 67-84. 
Lindell, M. K. \& Perry, R. W. (2004). Communicating environmental risk in multiethnic communities. California: Sage Publications, Inc.

Menezes, L. S. (2006). Pânico: efeito do desamparo na contemporaneidade - um estudo psicanalítico. São Paulo, Casa do Psicólogo.

Milanez, B. et al. (2015). Antes fosse mais leve a carga: avaliação dos aspectos econômicos, políticos e sociais do desastre da Samarco/Vale/BHP em Mariana (MG). (Relatório Final, mimeo) Juiz de Fora: UFJF.

Minayo, M.C.S. (1995). O conceito de representaçôes sociais dentro da sociologia clássica. In: P. Guareschi, P \& S. Jovchelovitch. 8.a ed. Petrópolis: Vozes.

Perrow, C. (1999). Normal accidents: living with high risk technologies. Princeton: Princeton University Press.

Quarantelli, E.L., Lagadec, P. \& Boin, A. (2007). A heuristic approach to future disasters and crises: new, old, and in-between. In: H. Rodríguez, E. L. Quarantelli \& R. R. Dynes (Eds.). Handbook of disaster research. Springer: New York, 16-41.

Roberts, B., González de la Rocha, M. \& Escobar Latapí, A. (2013). La cercana y distante relación entre la antropologia y la sociologia. In: V. Garcia Acosta \& G. de la Peńa (coords.). Miradas concorrentes. La antropologia en el diálogo interdisciplinario. México, D.F.: Centro de Investigaciones y Estudios Superiores em Antropología Social.

Santos, M. (1998). Técnica, espaço, tempo - globalizaçăo e meio técnico-científico informacional. São Paulo: Editora Hucitec.

Turner, J.H. (1994). Sociologia - conceitos e aplicaçôes. São Paulo: Makron Books.

Valencio, N. (2013). Nunca soubemos o que aconteceu...: a (in) capacidade pública em lidar com os riscos de desastres no contexto de globalização. In: L.F. Lourenço \& M.A. Mateus (Coord.). Riscos naturais, antrópicos e mistos - homenagem ao Professor Doutor Fernando Rebelo. Coimbra: Departamento de Geografia, Faculdade de Letras, Universidade de Coimbra. 
(Página deixada propositadamente em branco) 


\title{
UMA CLASSIFICAÇÃO DE RISCOS NA ÓTICA DA PROTEÇÃO CIVIL* RISK AND HAZARD CLASSIFICATION FROM THE STANDPOINT OF CIVIL PROTECTION
}

\author{
Luciano Lourenço \\ Departamento de Geografia e Turismo da Faculdade de Letras, CEGOT e RISCOS \\ Universidade de Coimbra, Portugal \\ ORCID: 0000-0002-2017-0854 luciano@uc.pt
}

Sumário: A inexistência, em Portugal, de uma classificação oficial dos riscos a que a Proteção Civil é chamada a dar resposta levou-nos, na sequência de trabalhos anteriores, a apresentar uma proposta que se baseia nos diferentes tipos de causas que podem estar na origem das diversas manifestações de riscos.

Assim, a grande divisão tem em consideração a origem de cada risco, ou seja, em função da causa que origina cada um deles, os riscos dividem-se em três grandes conjuntos: (i) naturais, quando a sua causa tem origem em fenómenos da natureza; (ii) antrópicos, quando essa origem resulta de ação humana; e (iii) mistos, quando a sua causa tanto pode ser de origem natural como devida a causa humana.

Depois, cada um deles, subdivide-se em subtipos que agrupam diversas categorias de causas específicas e, deste modo, chegámos à

\footnotetext{
* Este texto surge como corolário de uma reflexão sistemática que, sobre o assunto, temos vindo a fazer, o que permitiu ir afinando a classificação descrita em textos anteriores (Lourenço, 2003, 2007, 2014 e 2015) e que agora foram revistos e atualizados
} 
CLARICA, que não é mais do que uma proposta para classificação dos riscos e catástrofes.

Trata-se de uma classificação que, do nosso modesto ponto de vista, assenta numa lógica coerente e, por isso, poderá constituir um interessante contributo para a organização dos diferentes tipos de riscos que podem ser alvo de intervenção por parte dos agentes de proteção civil.

Palavras-chave: CLARICA, classificação de riscos, Riscos naturais, riscos antrópicos, riscos mistos.

Abstract: The absence in Portugal of an official classification of the hazards and risks to which Civil Protection is called to respond has led us, following previous work, to present a proposal that is based on the different potential causes of their various manifestations.

Thus, the major division takes into account the origin of each hazard/ risk, such that, depending on the cause, hazards and risks are divided into three major groups: (i) natural, when their cause stems from natural phenomena; (ii) anthropic, when the cause results from human action; and (iii) mixed, when the cause may be both of natural origin and due to human action.

Each group is then divided into subgroups of different categories of specific causes, and thus we have reached CLARICA, which is simply a proposed classification of hazards, risks and disasters.

This is a classification which, in our modest opinion, is based on a coherent rationale and could therefore be an interesting contribution to the organization of the various hazards and risks that may be targeted for intervention by civil protection agents.

Keywords: CLARICA, hazard and risk classification, natural hazards, man-made hazards, mixed hazards and risks. 


\section{Introdução}

A inexistência de uma classificação "oficial" dos riscos que se situam na área de atuação da proteção civil coloca problemas a quem pretende iniciar-se no estudo dos riscos, pois náo permite perceber como é que eles se hierarquizam, nem saber que relaçóes se podem estabelecer entre eles.

Com efeito, em função do objetivo que se pretenda tratar, é possível estabelecer e, por isso, encontrar diferentes classificaçóes de riscos, as quais normalmente aparecem organizadas em função de sectores de atividade ou de tipos específicos de riscos, designadamente: riscos no trabalho e nas empresas, também chamados de profissionais/ ocupacionais em grupos ou em ambiente laboral (físicos, químicos, biológicos, ergonómicos e de acidentes); riscos na atividade bancária; riscos financeiros; riscos ambientais (físicos, químicos e biológicos); riscos de agentes biológicos e por aí adiante.

Ora, em termos de intervenção da proteção civil interessaria tratá-los em conjunto, deixando naturalmente de fora aqueles que não envolvem a sua atuação, como por exemplo os financeiros e da atividade bancária, e, porventura, incluindo outros que não constem destas divisões mais generalizadas.

De facto, se pretendemos ter uma visão holística dos riscos, deveremos procurar classificá-los de modo a que todos possam ser incluídos nessa codificação, ainda que depois possamos tratar somente aqueles que têm a ver com determinado objeto de estudo e que, neste caso, envolvem a atuação dos agentes de proteção civil.

Sendo assim, a forma que nos parece mais prática para os analisar será a de os agrupar em função da sua génese, ensaiando depois a sua distribuição por subtipos de riscos, de modo a estabelecer uma tipologia que esteja sujeita a uma lógica de tratamento conjunto, decorrente dessa visão holística que importa ter sobre os riscos.

Quando temos em linha de conta a sua origem, os riscos e, por conseguinte, também as suas plenas manifestaçôes, que designamos de catástrofes, podem ser agrupados em: riscos e catástrofes naturais, riscos e catástrofes antrópicas e riscos e catástrofes mistas $^{1}$ (Lourenço, 2007).

${ }^{1}$ A Codificação de Desastre, Ameaças e Riscos (CODAR, 2000), em uso no Brasil, classifica os riscos em naturais, humanos e mistos. No entanto, alguns dos mistos, que tanto podem ter 
Com efeito, considera-se que os riscos têm origem natural quando o fenómeno que produz os danos tem a sua origem na natureza. De igual modo, consideram-se riscos antrópicos aqueles em que o fenómeno causador do dano tem a sua origem em açôes humanas. Por sua vez, designam-se por riscos mistos aqueles em que o fenómeno causador do prejuízo pode ter as duas causas, isto é, tanto pode ter uma origem natural como uma causa humana.

Porque as manifestaçóes dos riscos a seguir mencionados seráo objeto de tratamento específico, em próximos volumes desta mesma coleção, a sua caraterização não merecerá agora grande desenvolvimento, apenas se justificando uma ou outra nota para ajudar a compreender a subdivisão apresentada, na medida em que, depois, eles serão desenvolvidos nas ediçóes seguintes.

\section{Riscos Naturais}

Como é possível encontrar diversos fenómenos naturais que são capazes de produzir danos, eles poderão ser agrupados de várias formas. Na nossa perspetiva, uma forma lógica de os arrumar, é a seguinte:

\section{Riscos geológicos (geofísicos)}

Incluímos neste conjunto todos os riscos associados à geodinâmica interna e que podem apresentar duas grandes subdivisōes:

\footnotetext{
causa natural como humana, são apresentados em função da respetiva causa e não, em conjunto, como sucede na nossa classificação. De todas formas, em termos de subtipos, a CODAR apresenta uma classificaçáo bem mais detalhada do que aquela que indicamos, pelo que poderá ser usada como complemento, sobretudo para enquadrar alguns dos riscos que náo aparecem mencionados no texto que se segue.

Em Portugal e em outros países que pretendam adotar a classificação de riscos e catástrofes que propomos, ela poderá vir a ser designada pela sigla CLARICA.
} 


\section{Riscos tectónicos, também designados por Riscos sísmicos}

Incluem-se neste conjunto os riscos ligados à atividade das placas tectónicas e que se manifestam através de tremores de terra, também conhecidos por terramotos e sismos.

Quando a atividade tectónica se manifesta no oceano, podem desencadear-se ondas de grandes dimensôes, conhecidas por maremotos (tsunamis) que se irão manifestar, sobretudo, nas áreas litorais mais próximas do epicentro.

\section{Riscos magmáticos, também designados por Riscos vulcânicos}

Incluem-se nesta subdivisão os riscos que decorrem da atividade magmática e que se manifestam, principalmente, através de erupçóes vulcânicas e de fumarolas.

\section{Riscos climáticos e meteorológicos}

Neste apartado consideram-se os riscos associados aos diferentes tipos de clima (riscos climáticos) ou à variabilidade dos tipos de tempo (riscos meteorológicos), pelo que nele se incluem tanto os tufôes do Pacífico e os furacóes do Atlântico, como as chuvas torrenciais (de monçóes e outras), ou as avalanches e os degelos repentinos.

Ter deles conhecimento em tempo oportuno e observar os efeitos que provocavam era algo bastante difícil para os investigadores até há poucos anos. Pelo contrário, hoje é possível acompanhá-los em direto, através de imagens televisivas, que nos permitem não só observar o desenrolar destes fenómenos, mas também verificar as suas consequências nos instantes em que elas ocorreram ou, então, apenas algumas horas depois. Se isto representa uma grande vantagem, não deixa de introduzir alguma disparidade no processo de recolha de informação, fazendo com que o número atual de registos tenha uma precisão muito maior do que os recolhidos anteriormente, razão pela qual, quando analisamos e comparamos esses registos, o aparente 
aumento do número de fenómenos que normalmente se observa nos dados estatísticos dos últimos anos, poderá resultar mais deste maior rigor de apuramento, do que propriamente num real aumento do seu número, razão pela qual é necessário algum cuidado na hora de retirar ilaçôes.

Além disso, está na moda dissertar sobre "alteraçóes climáticas", como se elas tivessem sido a última descoberta da ciência. Todavia, muitas vezes, alguns desses oradores e investigadores desconhecem completamente a existência, o significado ou o comportamento da variabilidade dos tipos de tempo existentes dentro de mesmo tipo de clima, ou as grandes variaçôes que implicam as mudanças climáticas, que, afinal, sempre existiram e continuarão a existir ao longo dos tempos, pois, não sáo de agora, como alguns parecem ter descoberto, do mesmo modo que também não se limitam aos efeitos da atuação do ser humano, como outros pretendem fazer crer.

Por último, nos riscos meteorológicos, são de considerar aquelas situaçôes que, embora apresentem um carácter mais localizado, derivam de outras condiçóes meteorológicas, ditas adversas, tais como: secas prolongadas; vagas de frio e ondas de calor, chuvas intensas e chuvas continuadas; ventos muito fortes e geadas, sobretudo quando estas são tardias, pois são prejudiciais à agricultura, já que em época normal representam um perigo acrescido para a circulação automóvel.

Deste modo, todos os riscos que se podem incluir neste subtipo decorrem da existência de diferentes tipos de clima (riscos climáticos) ou da variabilidade dos sucessivos tipos de tempo (riscos meteorológicos).

Nos riscos climáticos poderiam incluir-se ainda outros tipos de riscos, como sejam os de erosão, de desertificação, ou de incêndio florestal, embora, por nem sempre serem devidos a causas exclusivamente naturais, devam ser antes considerados como riscos mistos, razão pela qual serão tratados mais adiante.

Algumas manifestaçóes de risco meteorológico, por serem sentidas, com maior ou menor acuidade, quase diariamente, passaram a estar na ordem do dia e, muitas vezes, não tanto pela gravidade das suas consequências, mas, táo somente, pelo incómodo ou desconforto que uma simples situação meteorológica pode ocasionar, factos que permitiram um impressionante desenvolvimento da previsão meteorológica, essencialmente numa perspetiva de prevenção e mitiga- 
ção dos efeitos de uma qualquer potencial plena manifestação de risco meteorológico, o que tem evitado muitos danos, apesar de que, pelo carácter localizado de algumas dessas manifestaçôes, a sua previsão nem sempre conseguir descer ao pormenor desejado.

Contudo, apesar dos grandes avanços da ciência nestes domínios, náo podemos esquecer o significado de algumas noçóes base, tais como as de escala, normal e variabilidade, que não devem ser confundidas, nem podem deixar de ser consideradas numa análise séria sobre este tipo de riscos. Caso contrário, transformaremos em catástrofes muitos dos fenómenos que apenas se afastam um pouco dos valores normais, pois ficam muito distantes das situaçóes excecionais que, essas sim, se manifestam catastroficamente.

\section{Riscos hidrológicos}

Os riscos hidrológicos abrangem todos aqueles que decorrem do excesso de água à superfície terrestre, comportando três subtipos que, sendo tecnicamente distintos, assumem a mesma aparência, pelo que, frequentemente, são confundidos e tratados como sendo um único:

\section{Risco de cheia}

Corresponde ao aumento brusco do caudal, ou da altura de água, num leito fluvial ou num outro qualquer canal com capacidade para transportar água.

Do ponto de vista hidrológico, as cheias identificam-se pela subida rápida da altura de água, que é acompanhada pelo rápido aumento de caudal e que, após a ponta de cheia, decresce de forma gradual e cada vez mais lenta, à medida que desce a altura de água, descrevendo uma curva assimétrica, que identifica o hidrograma típico das cheias.

Pelas diferentes consequências que acarretam, é importante distinguir as pequenas das grandes cheias fluviais. 


\section{Risco de inundação}

Consiste no transbordo da água para fora dos elementos que normalmente a contêm, quer seja o leito normal dos rios, a linha de costa dos lagos, mares e oceanos, ou os canais subterrâneos, naturais e artificiais.

Deste modo, todas as inundaçóes resultam ou de galgamentos, quer seja das margens dos leitos normais, quer seja da linha de costa, ou então, do esgotamento da capacidade de transporte e armazenamento das cavidades e galerias subterrâneas naturais, bem como dos colectores artificiais de águas pluviais.

Em função do tipo de canal que normalmente transporta ou armazena água, é possível distinguir quatro subtipos, a saber: risco de inundação fluvial, risco de inundação marinha e lacustre, risco de inundação cársica e risco de inundação rápida urbana.

O risco de inundação fluvial resulta normalmente de cheias, razão pela qual muitas vezes é confundido com o risco de inundação. Se, neste caso, estamos em presença da subida brusca da altura de água no leito normal, que num curto espaço de tempo transborda e cobre extensas áreas do leito de inundação, muitas vezes em resultado de precipitaçóes intensas, estas inundaçóes, por serem as mais frequentes e porque surgem de forma rápida, ao resultarem de cheias, confundem-se com elas e daí, existir uma relação direta entre ambas, a qual gera a dita confusão.

No entanto, não podemos esquecer que, além das inundaçóes rápidas, repentinas, também existem inundaçóes progressivas, cujo transbordo é mais lento, pois resultam de precipitaçóes prolongadas que, por náo serem tão concentradas no tempo, fazem subir a altura da água no leito de forma mais lenta e gradual. Ora, pelo facto dessa subida não ser rápida, estas inundaçóes, do ponto de vista meramente hidrológico, não podem ser consideradas como cheias, razão pela qual, em termos técnicos, se justifica distinguir os dois conceitos.

Além disso, as cheias fluviais, podem ser subdivididas em (i) monogénicas, quando se atribuem apenas a uma origem como, por exemplo, a precipitação intensa ou a rápida fusão da neve, que normalmente são súbitas, repentinas e rápidas; e (ii) poligénicas, resultantes de causas conjugadas, ou seja, de mais do que uma única origem e, por isso, mais do que uma ponta de cheia, como é o caso de precipitaçôes abundantes associadas à fusão da neve e que, quase sempre, dão azo a inundaçóes 
progressivas, com sucessivas pontas de cheia, sendo por isso bastante mais lentas e demoradas do que as anteriores.

\section{Risco de alagamento}

Ainda que seja pouco mencionado, não só porque produz efeito semelhante, mas também porque, quase sempre, coincide com o risco de inundação, leva a que habitualmente este seja confundido com aquele. Todavia, porque do ponto de vista hidrológico apresenta uma génese distinta, merece ser tratado em separado.

Corresponde, de igual modo, a uma acumulação de água em áreas aplanadas da superfície terrestre, mas resulta direta e exclusivamente da precipitaçáo, devido a dificuldades de escoamento superficial e de infiltraçáo, por saturaçấo dos solos e das rochas.

Sendo assim, não é devido a nenhum transbordo, ao contrário do que sucede com as inundaçóes, pelo que náo deverá ser confundido com estas.

\section{Riscos geomorfológicos}

Incluímos neste conjunto todos os riscos associados à geodinâmica externa e que podem resultar da atuação dinâmica, individual ou conjunta, de diversos processos, cujo fator desencadeante pode decorrer, entre outros, da abundância ou da intensidade da precipitação, da movimentação sísmica ou, até, simplesmente, da gravidade.

Estes riscos podem ser subdivididos em:

\section{Riscos de ravinamento}

O risco de formação de ravinas está normalmente associado á atuação da água da chuva, normalmente em resultado do abandono de solos agrícolas e florestais.

Por isso, uma ravina pode ser definida como sendo um canal com capacidade para transportar água, escavado pelo fluxo concentrado, embora de caráter tempo- 
rário, de água que, habitualmente, ocorre na sequência da ocorrência de chuvas intensas e durante o período de tempo em que estas decorrem, sendo suficientemente profundo (normalmente $>0,5 \mathrm{~m}$ ) para interferir com a lavoura normal e não ser por ela eliminado (Soil Science of America, 2008).

Além do abandono agrícola, algumas intervençóes humanas, incorretas do ponto de vista de conservação dos solos, bem como os incêndios florestais (Martins et al., 2017), têm contribuído para a formação de ravinas.

\section{Movimentaçóes em massa}

As movimentaçôes "em massa” e não "de massa”, como frequente e erradamente são referidas, implicam a deslocação em conjunto de todo o material que se movimenta, ou seja, "em massa”, por exemplo ao longo de uma vertente ou em parte dela, e não a sua movimentação individual, partícula a partícula, isto é, "de massa".

Este tipo de movimentos são, predominantemente, desencadeados por causas naturais, associadas a precipitaçóes intensas ou a precipitaçóes prolongadas, a sismos e à atividade vulcânica, mecanismos ou processos que podem ocorrer isoladamente ou em combinação. Todavia, a sua génese também pode estar associada à atividade antrópica. Muitas vezes, são causados ou agravados pela combinação das duas causas, como sucedeu em alguns casos por nós analisados (Lourenço, 1998, Lemos et al., 2001, Lourenço et al. 2001 e Pedrosa et al., 2001).

Ainda que, em geomorfologia, seja possível especificar vários subtipos destas movimentaçóes, indicamos os três que nos parecem mais importantes, por serem os mais generalizados e que, por isso, ocasionam mais danos.

\section{Desabamentos/desmoronamentos}

Os desabamentos, também chamados de desmoronamentos, correspondem a movimentos repentinos de quedas de grandes massas de rocha, de terra ou de ambas, que se desprendem em conjunto de arribas e de taludes íngremes, para a base 
dos mesmos, onde a massa deslocada normalmente se quebra com o impacte ${ }^{2}$ da queda, podendo rolar até à cota mais baixa da vertente.

Normalmente, sáo causados pela ação da gravidade, embora o crescimento de raízes e a presença de água ou de gelo (com a alternância de congelação e fusão) nas fissuras das rochas possa facilitar essas quedas (Rebelo, 2001). Outras causas, como o trabalho de sapa na base dos taludes, provocado quer por erosão regressiva associada a processos naturais dos rios, quer devido a atividades humanas relacionadas com escavaçóes para construção ou para manutenção de estradas, ou ainda terramotos e outras vibraçóes intensas podem dar origem a desmoronamentos (Highland e Bobrowsky, 2008).

A principal razão para considerar este subtipo separado dos seguintes reside no facto de ele poder ocorrer sem a presença de água, ao contrário do que sucede com os seguintes, onde a água se torna o principal fator desencadeante.

\section{Deslizamentos}

O termo deslizamento corresponde a um conceito genérico, usado para descrever não só o movimento de descida do solo, de rochas e de material orgânico, sob o efeito da gravidade, mas também a formação geológica resultante de tal movimento (Highland e Bobrowsky, 2008).

Trata-se de um processo de evoluçáo das vertentes, que faz parte da dinâmica natural de transformação da superfície terrestre, e que envolve: (i) um despreendimento, que normalmente fica assinalado pela cicatriz de arranque; (ii) o transporte da massa rochosa, solo e material orgânico que se desloca vertente abaixo; (iii) a sua deposiçấo ao longo ou na base da vertente.

Consoante a forma da superfície de rotura, curva ou plana, os deslizamentos designam-se, respetivamente, de rotacionais e de planares ou translacionais.

A principal causa dos deslizamentos é a saturação do solo e das rochas por água que pode ocorrer em resultado de chuvas intensas ou prolongadas, bem como do

\footnotetext{
${ }^{2}$ Impacte, enquanto substantivo, e não impacto, usado como adjetivo, de acordo com A. Guerreiro (1987).
} 
degelo e, ainda, de mudanças do nível de água na superfície, quer seja ao longo da orla costeira, quer ocorra nas margens dos lagos, barragens e outros reservatórios ou, ainda, em rios e canais.

\section{Fluxos de detritos}

Os fluxos de detritos são uma forma rápida de movimentação em massa, em que o solo, as rochas e, se existir, o material orgânico se misturam à água e formam lama que se escoa pela vertente abaixo. Os fluxos de detritos são, por isso, também designados por fluxos lamacentos devido à grande quantidade de partículas finas que podem conter.

Por vezes correspondem à parte terminal de deslizamentos que, ganhando água e velocidade, perdem a coesão interna e passam a fluxos de detritos, como sucedeu, por exemplo, em Frades, Arcos de Valdevez, a 7 de dezembro do ano 2000 (Pedrosa et al., 2001).

Com efeito, os fluxos de detritos são um tipo muito comum de evolução nas vertentes declivosas, sobretudo quando a vegetaçáo foi queimada, uma vez que, neste caso, se conjugam diversos fatores, que começam pela queima e perda de vegetaçáo dos taludes, passando pela alteração das propriedades físicas e químicas do solo, devido a essa quei$\mathrm{ma}$, até à posterior erosão pela água proveniente das precipitações que, frequentemente, incorpora matéria orgânica sobrante do incêndio (Lourenço et al., 2014).

\section{Riscos biológicos}

Estes riscos estão relacionados com desequilíbrios na biocenose que, normalmente, se traduzem nas chamadas pragas de animais e de plantas infestantes que acabam por eliminar as espécies autóctones.

Como é sabido, as espécies animais e vegetais originárias do território onde habitam dizem-se autóctones, nativas ou indígenas.

Por sua vez, a denominação "exóticas" lembra-nos que não são originárias desse território, tendo sido para ali transportadas e, por conseguinte, foram introduzidas em lugares distintos daqueles que são os seus locais de origem. 
Ora, quando introduzimos uma planta num ecossistema diferente daquele que corresponde ao do seu local de origem, pode ocorrer uma das três situaçóes seguintes: (i) encontra condiçóes inadequadas ao seu desenvolvimento e acaba por definhar e desaparecer; (ii) encontra boas condiçóes e, nesse caso, instala-se, passando a viver em harmonia com os demais seres vivos do ecossistema (estas espécies denominam-se alóctones, exóticas, intrusas, alienígenas ou estrangeiras); (iii) encontra condiçôes muito favoráveis, designadamente devido à ausência de predadores naturais e por apresentar vantagens competitivas em relação às espécies nativas, prolifera facilmente tornando-se invasora.

Ora, as espécies invasoras ou infestantes, ao possuírem uma elevada taxa de reprodução, são capazes de proliferar sem intervenção do ser humano, muito para além das áreas onde foram introduzidas, pelo que são consideradas pragas, como abordaremos a seguir.

\section{Riscos de pragas animais}

Como exemplo de alguns animais que podem constituir pragas, mencionamos os ratos domésticos, os morcegos hematófagos, os ofídios peçonhentos, os lagostins, os gafanhotos e as formigas.

Sem entrar em detalhes, é frequente distinguir as chamadas pragas maiores (ratos e ratazanas, pombos, ...), por serem constituídas por animais de maior porte, das denominadas pragas menores, por estes animais apresentarem tamanho mais reduzido (gafanhotos, escaravelhos, mosquitos, bactérias, vírus, nematóides, ...).

\section{Riscos de pragas vegetais}

As espécies vegetais que perturbam o normal funcionamento tanto dos ecossistemas como das atividades humanas constituem um risco, podendo transformar-se em pragas que podem pertencer tanto ao estrato herbáceo, como ao arbustivo ou ao arbóreo. 
As pragas de plantas tanto podem ser prejudiciais à pecuária, como à agricultura ou à silvicultura e, no caso de certas algas, são prejudiciais a diversas atividades costeiras, nomeadamente à piscicultura e ao turismo balnear. Quando muito desenvolvidas, algumas destas algas são genericamente designadas por maré vermelha, atendendo à sua coloração.

Além destas, existem diversas outras plantas, aquáticas e terrestres, algumas destas introduzidas com o objetivo de fixar taludes de aterros, na sequência da abertura de estradas, que devido aos incêndios florestais acabaram por se transformar em pragas, como é o caso das acácias, sobretudo das chamadas mimosas (Acacia dealbata) e das austrálias (Acacia melanoxylon) e aquém e além, ainda de Ailantos ou Espanta-lobos (Ailanthus altissima) e háqueas-picante (Hakea sericea), que assumem um comportamento de espécies invasoras e vão ocupando nichos que pouco a pouco proliferam, ocupando cada vez mais espaços com aptidão florestal (Lourenço, 2017), do mesmo modo que os canaviais (Arundo donax) se vão estendendo junto das linhas de água, ou o jacinto-de-água (Eichhornia crassipes) e a erva-pinheirinha, também chamada de pinheirinho-de-água (Myriophyllum aquaticum) invadem vastas superfícies aquáticas.

\section{Riscos Antrópicos}

Este conjunto de riscos diz respeito a fenómenos que causam danos em resultado da intervenção do ser humano, em função da sua própria evolução à face da Terra, podendo ser agrupados nos seguintes dois subtipos:

\section{Riscos tecnológicos}

Este subtipo de riscos resulta do desrespeito pelas normas de segurança e pelos princípios que não só devem reger a produção, o transporte e o armazenamento de certos produtos, mas que também envolvem o seu manuseamento ou o uso de determinadas tecnologias, dentro do necessário equilíbrio que terá existir entre a comunidade e o ambiente. 
Trata-se de um vasto conjunto de riscos que decorrem de situaçóes muito diversas relacionadas com o desenvolvimento industrial e a intensificação das trocas comerciais, sobretudo quando não existem preocupaçóes com o desenvolvimento sustentado e a proteção ambiental.

Pela diversidade deste tipo de riscos, é possível subdividi-los de várias formas, designadamente, agrupando-os em:

\section{Riscos associados aos meios de transporte}

O incremento da movimentação das pessoas, bem como das trocas comerciais, faz com que, cada vez mais, haja maior movimentação de tráfego aéreo, marítimo, fluvial, ferroviário e rodoviário, com riscos que decorrem quer do estado e das condiçóes da via, quer da robustez e do estado de conservação do meio de transporte utilizado, quer, ainda, do estado de saúde do respetivo condutor.

Deste modo, uma anormalidade em qualquer um destes três aspetos pode levar à manifestação do risco e a crise subsequente será tanto mais grave quanto maior for o número de pessoas ou de carga transportadas.

\section{Riscos inerentes à construção civil}

Este conjunto inclui diferentes tipos de riscos, não só de acidentes de trabalho durante a construção, mas também resultantes da destruição de obras de arte e de edificaçóes por problemas decorrentes tanto do substrato, como das fundaçóes ou, até, das estruturas, e que podem desencadear outros riscos, como é o caso da ruptura de barragens, que origina riscos de inundação a jusante.

\section{Riscos de incêndio (urbanos e industriais)}

A manifestação destes riscos é particularmente perigosa quando se manifesta em áreas particularmente sensíveis, como sejam as instalaçóes de combustíveis, óleos 
e lubrificantes (COL), ou nos meios de transporte, sobretudo marítimo e fluvial, bem como em fábricas e zonas industriais, ou em edifícios com grande densidade de utilizadores.

\section{Riscos de explosão e de extravasamento de matérias perigosas}

Este tipo de riscos decorre em resultado da extração, produção, armazenamento, transporte e utilizaçáo de diferentes tipos de matérias consideradas perigosas, nomeadamente materiais explosivos, produtos agrotóxicos, substâncias e equipamentos radioativos usados em medicina, em investigaçấo científica, na indústria e em centrais nucleares.

Por sua vez, o extravasamento de matérias perigosas pode dar origem a outros riscos, como sejam intoxicaçôes em ambiente familiar ou contaminação de sistemas de água potável, nomeadamente em poços e nas galerias subterrâneas conhecidas por minas de água.

Riscos de falha de recursos e sistemas essenciais, relacionados com elevadas concentraçôes demográficas

Quando as infraestruturas e os serviços essenciais não são compatíveis e adequados às elevadas concentraçóes demográficas existentes nas áreas urbanas, há riscos tanto de colapso e de falhas nos recursos hídricos e nos recursos energéticos, como de sobrecarga nos sistemas de resíduos sólidos urbanos ou de saneamento básico, passíveis de acarretar vários danos a essas populaçóes.

\section{Riscos sociais}

Este subtipo de riscos está associado à incapacidade do ser humano viver em harmonia tanto com o seu semelhante, dentro dos princípios de liberdade, igualdade e fraternidade, como com os ecossistemas urbanos e rurais, gerando desequi- 
líbrios nas diferentes inter-relaçôes humanas, sejam elas de natureza social, económica, política ou cultural.

Deste modo, é possível subdividir os diversos riscos sociais em vários subtipos, designadamente nos seguintes:

\section{Riscos associados a ecossistemas urbanos e rurais}

Incluem-se neste conjunto os riscos que não só podem gerar perturbação no normal funcionamento dos sistemas urbanos e rurais, originando incêndios urbanos e fluxos desordenados de trânsito, mas também podem contribuir para a delapidação do solo, quer através da desflorestaçáo/desmataçáo sem controlo e da má gestão agropecuária, quer por destruição deliberada da flora e da fauna, ou por acumulação de inertes sobrantes de mineração, e ainda, por deficiente organização de loteamentos urbanos e rurais.

\section{Riscos associados a convulsôes sociais}

As convulsōes sociais são cada vez mais frequentes e estáo associadas a causas muito diferentes, tais como: desemprego e subemprego generalizados, fome e desnutrição, migraçôes intensas e descontroladas, infância e juventude marginalizadas ou carentes, especulação, greves generalizadas, disseminação de boatos, tumulto e desordens generalizados, incremento dos índices de criminalidade e de assaltos, banditismo e crime organizado, colapso do sistema penitenciário, sabotagem e terrorismo, perseguiçóes e conflitos ideológicos, religiosos e raciais.

\section{Riscos associados a conflitos bélicos}

Os riscos que decorrem dos conflitos bélicos diferem entre si, em função das caraterísticas de cada tipo de conflito, que incluem desde guerras internas, civis e 
revolucionárias, até guerras convencionais, passando pelas guerrilhas, bem como açóes terroristas e criminosas.

Dentro destas, considera-se o risco NRBQ (Nuclear e Radiológico, Biológico e Químico) que, em termos de uso pacífico é um risco tecnológico, mas que, quando associado a açóes militares ou atos terroristas e criminosos, se considera como sendo um risco bélico. Ele passou a estar mais em voga depois dos trágicos acontecimentos ocorridos a 11 de Setembro de 2001, na cidade de Nova Iorque.

A contaminação resultante do emprego de substâncias radioativas ou de agentes biológicos e químicos pode fazer sentir-se a nível do solo, do ar, da água, dos alimentos ou dos objetos que consumimos e utilizamos, podendo atingir um elevado número de pessoas em simultâneo.

\section{Riscos Mistos}

Consideram-se mistos os riscos que resultam tanto de condiçóes naturais, como de ações antrópicas. Porque têm uma particular incidência sobre o ambiente, alguns autores preferem designá-los por riscos ambientais, se bem que esta designação seja bem mais abrangente, uma vez que ela deverá incluir todos os riscos que interferem com o meio geográfico, ou seja, com o ambiente, o que naturalmente engloba um número mais elevado dado que, em maior ou menor grau, a generalidade deles acaba por ter alguma interferência sobre o ambiente.

Por outro lado, esta adjetivaçáo não se preocupa com a origem desses riscos, isto é, com a causas que os desencadeiam, mas sim com as consequências, ou seja, com os efeitos que eles geram no ambiente, pelo que este esta subdivisão não se enquadra na lógica que apresentamos e que tem em conta o processo, o fenómeno causador do risco.

Do nosso ponto de vista, os riscos mistos podem ser subdivididos em:

\section{Riscos mistos de componente atmosférica}

De entre os riscos que se produzem no seio da atmosfera, aqueles que estão associados a causas naturais serão, porventura, os riscos menos frequentes, embora possam ter graves 
consequências, como é o caso dos riscos siderais resultantes do impacte de meteoritos. No entanto, as causas antrópicas contribuem de forma decisiva para aumentar as consequências dos riscos naturais de componente atmosférica, sobretudo porque a intervenção humana continua a aumentar e nem sempre ela é feita da forma mais correta, pelo que estes riscos merecem também uma referência, ainda que breve, subdividindo-os em:

\section{Riscos siderais}

Consideram-se riscos siderais aqueles que são provenientes do chamado espaço exterior ou espaço sideral, ou seja, o espaço que se desenvolve para lá da atmosfera terrestre. Do ponto de vista natural, incluiu os objetos que designamos por meteoritos e, do ponto de vista antrópico, os satélites e tudo o que tem a ver com a exploração do espaço, como se indica a seguir.

\section{Risco de impacte de meteoritos}

Apesar da sua baixa frequência, enquanto risco natural, o impacte de meteoritos pode ter das mais graves consequências, como terá sido o caso do que deu origem à cratera Chicxulub, com $180 \mathrm{Km}$ de diâmetro, que se encontra situada na Península de Yucatán, na América Central.

O impacte deste meteorito terá levado a que a Terra tivesse ficado envolta numa enorme nuvem de poeiras que, ao não permitir a penetração dos raios solares, deixou o planeta mergulhado na escuridão entre 1 e 3 meses e, essa falta de luz, terá causado a extinção de muitas plantas e animais.

Por sua vez, a colisão terá provocado grandes incêndios, que fizeram com que a temperatura aumentasse muito e que terão levado à quebra das cadeias de moléculas de azoto e hidrogénio e, depois, à sua reorganização, tendo levado à formação de ácido nítrico, responsável pelas chuvas ácidas.

Este contexto terá sido favorável a uma importante mudança climática, a qual poderá ter sido responsável pela extinção da maioria dos seres vivos então existentes à superfície da Terra. 


\section{Riscos inerentes à conquista do espaço}

Do ponto de vista antrópico, os riscos siderais resultam da exploração do espaço e estão associados à existência de satélites e das estaçóes orbitais, bem como dos processos inerentes à sua colocação e manutenção, os quais incluem o lançamento de foguetôes e as viagens espaciais.

De facto, tanto a crescente utilização da atmosfera pela aviação, comercial e militar, como do espaço exterior, sideral, apresenta consequências negativas para esses espaços, embora raramente sejam mencionadas, e que, além dos riscos referidos no parágrafo anterior, também podem interferir com vários outros de riscos, como é o caso dos que se mencionam a continuação.

Riscos de redução de espessura e/ou da existência de buracos na camada de ozono

Como é sabido, a camada de ozono constitui uma barreira ou um filtro que protege os seres vivos dos raios ultravioleta, deixando passar apenas uma quantidade muito pequena dessa radiação e que é útil à vida, por ser indispensável ao normal desenvolvimento dos ossos.

Todavia a redução da espessura e a existência de buracos nessa camada permite a passagem de raios ultravioleta em maior quantidade do que seria desejável, o que tem como consequência a exposição prolongada dos seres humanos a essas radiaçóes, causando-lhes anomalias e podendo levar ao aparecimento de cancro da pele, a deformaçóes, bem como à diminuição das defesas imunológicas, o que favorece o aparecimento de doenças infecciosas e, em casos extremos, pode conduzir à morte.

\section{Riscos de agravamento do efeito de estufa}

Sabemos que o efeito de estufa é essencial para a manutenção da vida na Terra, pelo menos tal qual a conhecemos. 
No entanto, a intensificação deste efeito deu origem ao chamado aquecimento global que, em parte, é provocado pelo aumento de emissóes dos chamados gases com efeito de estufa, tais como: vapor de água, dióxido de carbono $\left(\mathrm{CO}_{2}\right)$, metano $\left(\mathrm{CH}_{4}\right)$, óxido nitroso $\left(\mathrm{N}_{2} \mathrm{O}\right)$, ozono $\left(\mathrm{O}_{3}\right)$ e vários clorofluorcarbonetos.

Ainda que os ciclos de aquecimento e de arrefecimento tenham sido uma constante ao longo da história do Planeta, apesar de alguns pensarem que a Terra só recentemente começou a aquecer e apenas por influência antrópica, náo há dúvida de que essa evolução natural poderá ser agravada pela intervenção antrópica, cujos riscos que daí decorrem se irão manifestar sobre a biodiversidade e, em consequência, sobre a sociedade.

\section{Riscos de poluição atmosférica}

A poluição atmosférica diz respeito a mudanças que ocorrem na composição da atmosfera, através da contaminação por partículas sólidas, líquidos em suspensão, gases, material biológico ou energia, as quais provocam impactes em termos do ambiente ou da saúde humana.

Com feito, para além de prejudicar a saúde, a adição de contaminantes também provoca danos nos ecossistemas, além de poder produzir odores desagradáveis, interferir na visibilidade, reduzindo-a, e fazer diminuir a intensidade da luz.

A poluição atmosférica causa particular impacte no campo ambiental, por ter uma ação direta no aquecimento global, potenciar as chuvas ácidas e ser responsável pela degradaçấo dos ecossistemas.

\section{Riscos de chuvas ácidas}

Entende-se por chuva ácida qualquer forma de precipitação, desde que a sua acidez seja bastante superior àquela que resulta da simples dissolução do dióxido de carbono atmosférico $\left(\mathrm{CO}_{2}\right)$ na água precipitada.

É conhecido que a existência de precipitação ácida acarreta vários riscos, os quais se manifestam através de várias consequências adversas, nomeadamente para 
as florestas, as toalhas aquáticas de água doce e os solos, uma vez que matam as árvores, o plâncton, os insetos, os peixes e os anfíbios.

Por outro lado, também se revestem de efeitos nocivos para a saúde humana, além de que fazem aumentar a corrosão provocada pela atmosfera, danificando estruturas e equipamentos expostos ao ar.

\section{Riscos mistos de componente geodinâmica}

Este subtipo de riscos está relacionado com causas antrópicas e naturais, neste caso relacionadas com as forças associadas à geodinâmica interna e aos processos intervenientes na geodinâmica externa que atuam e se manifestam sobre a superfície terrestre.

Os subtipos mais frequentemente considerados, correspondem a:

\section{Risco de sismicidade induzida}

São várias as atividades humanas podem induzir sismos e, por conseguinte, provocar atividade sísmica. A atividade humana indutora de sismos pode traduzir-se de várias formas, designadamente através de: (i) construção de grandes barragens; (ii) aumento de carga sobre zonas específicas; (iii) exploração de hidrocarbonetos e de recursos hídricos subterrâneos; (iv) explosóes nucleares subterrâneas; (v) introdução de sobrantes, que não podem voltar a ser utilizados, em furos profundos.

\section{Riscos de erosão}

Os riscos de erosão resultam da atuação dos vários processos morfogenéticos, de origem hídrica, eólica ou química, que vão desgastando o solo e as rochas, deixando os materiais arrancados disponíveis para serem transportados e que, posteriormente, acabam por ser depositados, ficando acumulados. A ação antrópica, umas vezes por intervenção e, outras vezes, por omissão, também aparece como causa erosiva, 
dado que pode facilitar a intensificação desses processos morfogenéticos que, sem essa ação antrópica, teriam efeitos bem mais reduzidos, razão pela qual estes riscos devem ser considerados como tendo uma origem mista.

Convém recordar que, embora o conceito de erosão apareça, muitas vezes, associado apenas ao desgaste, desagregação, escavamento e destruição do solo e das rochas, tal não é correto, pois, como é sabido, o processo de erosão além do desmantelamento, implica também o transporte dos materiais arrancados e a sua posterior deposiçáo e acumulação, a qual poderá culminar, se lhe for dado tempo suficiente, na sedimentação (Martonne, 1909; Tricart, 1977; Strahler, 1981).

Deste modo, quando se trata de analisar riscos de erosão, devem ser consideradas as três fase do processo (desagregação, transporte e acumulação) e não, apenas, a primeira, correspondente à desagregação.

Assim, se tivermos em consideração o processo desencadeante, podemos subdividir este tipo de riscos em:

\section{Riscos de erosão hídrica}

O processo inicia-se com a pluviosidade, que vai dar origem à escorrência, a qual corresponde ao fluxo superficial que, em regra, ocorre quando o solo se encontra saturado de humidade.

A sequência de processos inicia-se, normalmente, com a chamada erosáo de salpico (splash) que corresponde ao destaque e movimentaçáo pelo ar de pequenas partículas de solo, causado pelo impacte das gotas de água da chuva quando embatem no solo.

Depois, uma parte dessa água pode infiltrar-se e a outra parte escoa-se à superfície do solo, originando a escorrência, que se costuma dividir em (Rebelo, 2001): (i) laminar, que ocorre quando a água corre uniformemente pela superfície como sendo um todo, uma lâmina que transporta as partículas minerais e orgânicas, sem formar canais definidos; (ii) difusa, que aparece quando a água da escorrência laminar passa a escorrer rapidamente, formando canais pequenos e anastomosados, podendo constituir pequenos sulcos; (iii) concentrada, a partir do momento em que 
os pequenos canais anastomosados se reúnem e instalam em sulcos bem marcados na paisagem, os quais constituem os canais elementares por que se iniciam as redes hidrográficas e que, depois, se vão reduzido à medida que a sua concentração aumenta e se vai organizando o escoamento superficial nas redes hidrográficas.

Normalmente, o poder erosivo vai aumentando para jusante, proporcionalmente à hierarquização da rede, mas depende de vários fatores que o influenciam tais como: a intensidade da chuva, a textura do solo, a existência de cobertura vegetal e de matéria orgânica, o maior ou menor declive da vertente ou do curso de água.

Todavia, mesmo quando pensamos nas formas de escorrência menos agressivas (laminar e difusa), os riscos de erosão podem ter consequências graves em termos de perda de solos agrícolas, razão pela qual não deverão ser menosprezados.

Em função do tipo de escorrência, podemos considerar também três tipos de erosão que lhes estão diretamente associados: (i) erosâo laminar, que corresponde à remoção, pela escorrência superficial, de uma fina e relativamente uniforme camada de solo; (ii) erosão em sulcos, corresponde a um processo que se observa frequentemente nos campos inclinados recentemente cultivados, onde se formam numerosos canais aleatórios com apenas alguns centímetros de profundidade; (iii) erosão em ravinas, que consiste no processo pelo qual a água depois de se concentrar origina canais estreitos que, por incisão vertical, removem o solo ou as rochas friáveis, até profundidades que, por vezes, são consideráveis.

As ravinas, através do remontar de cabeceiras por erosão regressiva, o qual se traduz no seu recuo e aprofundamento, evoluem frequentemente para barrancos que, em determinados tipos de rocha e em situaçóes específicas, podem atingir profundidades da ordem de 25 a 30 m (Bernardino et al. 2013; Fernandes et al., 2013).

Podemos referir ainda um outro tipo de erosão, que ocorre em solos que contêm camadas ricas em argila, uma vez que ela se expande quando humedecida e se contrai quando seca, formado estruturas subterrâneas semelhantes a uma rede de túneis, em forma de tubos (piping) e que se denomina erosão em túnel.

Além da erosáo pluvial que acabámos de descrever e é provocada pela retirada de material da parte superficial do solo pela água da chuva, podemos ainda referir a erosão fluvial, que dá sequência à anterior e corresponde ao desgaste efetuado pela água no fundo e nas margens do leito dos rios, a erosáo glaciar, que é desenvolvida 
pelos glaciares, em que a água se encontra no estado sólido, a erosão marinha, que corresponde a um longo e lento processo de atrito da água do mar com as rochas que vão cedendo lentamente transformando-se em grãos e a erosão por gravidade, em que, normalmente, a água vai como que empapando o solo ou as rochas e, depois, a gravidade origina a sua posterior movimentação em massa.

\section{Riscos de erosão eólica}

A erosão eólica é um tipo de erosão que está relacionada com a força do vento, o qual exerce uma ação sobre a superfície terrestre, retirando-lhe os fragmentos mais finos, normalmente constituídos por partículas de pequena dimensáo, correspondentes a siltes e areias, transportando-os para outros locais. Em consequência deste processo há modificação de dois ambientes, o inicial, de onde são retirados os pequenos fragmentos rochosos, e o final, onde ocorre a sua deposição.

Ora, os processos erosivos relacionados com a açáo dos ventos, podem agrupar-se em quatro tipos diferentes:

i. Corrosão, corresponde ao desgaste físico das rochas provocado pelo atrito e impacte das partículas que são transportadas pelo vento e que, paulatinamente, vai esculpindo as rochas, dando-lhe formas mais ou menos características. Este processo também pode ser realizado por ação da água, quer no estado líquido, quer sob a forma de gelo;

ii. Abrasão, designa um processo erosivo semelhante ao da corrosão, em que o desgaste das rochas é produzido pelo impacte e pelo atrito dos fragmentos, das partículas transportadas pelo vento. Este processo também pode ser desenvolvido por açáo glaciar, fluvial e marinha, designadamente através do movimento de vai e vem das ondas;

iii. Deflação, refere-se ao processo originado pelo vento que retira os fragmentos superficiais mais finos de um determinado local, fazendo com que nele apenas permaneçam os mais grosseiros, tais como seixos e calhaus, os quais, por vezes, se podem observar nos campos de dunas e nos desertos; 
iv. Deposição, diz respeito ao processo que leva à acumulação dos materiais transportados pelo vento, quando este perde a energia suficiente para os transportar. Após a deposição, processo também pode ser realizado por ação da água corrente e dos glaciares, os materiais depositados passam por um demorado e complexo processo, chamado diagénese, que permite a sua transformação em rochas sedimentares.

As dunas existentes quer nas regiôes costeiras do mundo inteiro, junto às praias, quer nos desertos são formaçôes devidas à ação da erosão eólica. Outra conhecida formação de origem eólica é o Loess, que é constituída por sedimentos depositados pelo vento e apresenta uma tonalidade amarelada.

\section{Riscos de erosão química}

A erosão química diz respeito a todos os processos químicos que ocorrem nas rochas. São vários os agentes que podem provocar alteraçóes químicas nas rochas, designadamente a água, a temperatura (frio/calor) e os compostos biológicos.

O tipo de agente envolvido na erosão química está muito dependente do clima da região, uma vez que em climas polares e em climas secos são as variaçốes da temperatura que mais contribuem para a desagregação das rochas, enquanto que nos climas quentes e temperados é a presença de humidade, de água e de dejetos orgânicos que, reagindo com as rochas, as desagregam.

\section{Riscos de desertificaçáo}

O risco de desertificaçẫo é, essencialmente, de origem natural, mas porque as suas causas também podem ter presente a ação antrópica, deverá ser considerado como um risco misto.

Com efeito, a Convenção das Naçôes Unidas de Combate à Desertificação (JOCE, 1998) entende por "desertificação" a "degradação da terra nas zonas áridas, semiáridas e sub-húmidas secas, resultantes de vários factores, incluindo as variaçôes 
climáticas e as atividades humanas", ou seja, a transformação de terras em atividade, com potencial produtivo, em terras que perderam a fertilidade e, paulatinamente, se transformam em desertos, devido a fatores naturais e antrópicos, pelo que este risco deverá ser considerado como sendo misto.

Merece ainda outra breve referência, porque alguns continuam a reduzir o significado do termo, associando-o apenas ao despovoamento do território e, por conseguinte, à ausência da populaçáa. No entanto, o risco de desertificaçáa apenas se identifica com os casos em que a persistência de situaçóes de seca vai criando condiçóes para que, paulatinamente, a expansão dos desertos se concretize. Todavia, só poderá ser considerado um risco misto quando, nas suas causas, também estiver presente a natureza antrópica.

\section{Risco de salinizaçáo}

O risco de salinização é um dos processos de degradaçáo do solo que ocorre quando aumenta a concentração de sais solúveis no solo para níveis prejudiciais às plantas. Se o aumento for de tal ordem que os sais passem a ser o elemento predominante, o solo perde algumas das suas funções e poderá levar à desertificação.

\section{Riscos de poluição}

O risco de poluição, seja da atmosfera, do solo, das águas continentais (superficiais e subterrâneas) e oceânicas (orlas costeiras e fossas oceânicas), é ao contrário do anterior, um risco quase exclusivamente de origem humana, no entanto, porque alguns fenómenos naturais, como é o caso dos vulcóes, também podem originar este tipo de risco, deverá considerar-se como risco misto.

De facto, este risco está muito relacionado com o desenvolvimento industrial, sobretudo quando a segurança industrial e a proteção do ambiente contra riscos de contaminaçáo nấo são tidas na devida conta, traduzindo-se, frequentemente, na libertaçáo de gases e/ou partículas que, durante mais ou menos tempo, permane- 
cem em suspensão na atmosfera, bem como na emanação de resíduos líquidos, efluentes da atividade industrial e doméstica e, ainda, na acumulação de resíduos sólidos, oriundos das mais diversas atividades.

\section{Risco dendrocaustológico ou de incêndio florestal}

A consideração deste subtipo de risco misto, merece ser destacado não só pela sua incidência em vastas regióes do mundo, e muito em particular Portugal, mas também porque é um dos mais preocupantes, dadas as suas frequência e magnitude em muitas dessas regióes.

Apesar de, na generalidade das situaçóes, corresponder a um risco de origem antrópica, voluntária ou acidental, também ocorre como risco natural, ainda que muito excepcionalmente atendendo à sua atual frequência, sendo, neste caso, provocado por faíscas emitidas por trovoadas secas, o que faz com que, por esta razão, deva ser considerado um risco de origem mista, dado não ser exclusivamente antrópico.

\section{Riscos mistos de componente biomédica ou do foro infecto-contagioso}

Este tipo de riscos resulta de desequilíbrios entre o homem e outros seres vivos (insectos, vírus, bactérias, fungos e outros microrganismos) e está associado a enfermidades mortais, epidemias e pandemias, originadas por causas biológicas. Deste modo, estão relacionados com doenças transmitidas por diversos tipos de vectores, designadamente os biológicos (vírus e bactérias), pela água e pelos alimentos, por inalação, através de sangue contaminado e de secreçóes orgânicas, ou por mais de um destes mecanismos.

Trata-se de um risco misto na medida em que o ser humano, ao ser contaminado por processos naturais, passa a ser também um agente transmissor e, por conseguinte, passa a estar na origem da difusão deste tipo de riscos, dando-lhe assim a dupla origem que leva a considerá-los como risco misto.

Este tipo de risco é muitas vezes agravado por deficiências várias sentidas pelos organismos promotores da saúde pública, que podem resultar ou ser agravadas em 
situaçóes de pauperismo, de desequilíbrio social e ecológico e de carência de estruturas de saneamento básico.

A subdivisão deste tipo de risco pode ser feita em função do respetivo agente transmissor, como se indica a seguir e se ilustra com alguns exemplos:

Riscos de transmissão por vectores biológicos (vírus e bactérias)

- Dengue;

- Febre amarela;

- Malária;

- Peste;

- Tripanossomíase africana (Doença do sono);

Riscos por ingestão de água e alimentos

- Cólera;

- Diarreias agudas;

- Febre tifóide;

- Intoxicaçóes alimentares;

- Hepatite a Vírus "A";

- Poliomelite.

Riscos de transmissão por inalação

- Coqueluche;

- Difteria;

- Gripe;

- Meningite meningocócica;

- Sarampo;

- Tuberculose. 


\section{Riscos por contágio de sangue contaminado e secreçôes orgânicas}

- Hepatite a Vírus "B" e "C";

- Síndrome da imunodeficiência adquirida;

\section{Riscos transmitidos por mais de um dos mecanismos anteriores}

- Raiva;

- Tétano;

- Ébola.

\section{Conclusão}

É vasta a panóplia de riscos a que os agentes de proteção civil são chamados a dar resposta, começando naturalmente pela sua prevenção, que deveria ser a grande aposta.

Contudo, nem sempre é possível evitar que esses riscos se manifestem e, então, transita-se para a fase seguinte à da prevenção e que diz respeito ao socorro.

Ora, quer para prevenir, quer para socorrer, é importante saber de que tipo de risco estamos a tratar.

Assim, para arrumar os diferentes tipos de risco, propôs-se uma classificação que os distribui em três grandes conjuntos, consoante a respetiva origem e, por sua vez, os subdivide em subconjuntos, de acordo com a natureza específica dos processos que envolvem cada um deles.

Pareceu-nos que esta proposta assenta numa lógica coerente e, por isso, esperamos que seja um contributo válido para ajudar a organizar o enquadramento dos diferentes tipos de riscos que podem ser alvo de intervenção por parte dos agentes de proteção civil.

Tratou-se, apenas, de uma apresentação sumária que contamos apresentar com maior desenvolvimento nos próximos volumes desta série. 


\section{Referências bibliográficas}

Almeida, A. Betâmio de (2011). Risco e gestão do risco. Questốes filosóficas subjacentes ao modelo técnico conceptual. Territorium 18, p. 23-31; http://www.uc.pt/fluc/nicif/riscos/Documentacao/Territorium/T18_artg/Antonio_Betamio_de_Almeida.pdf

Bernardino, Sofia; Lourenço, Luciano (2013). Obras de correção torrencial no controlo de situaçóes de erosão hídrica em Portugal. Exemplos da bacia hidrográfica do rio Pranto (Baixo Mondego). Territorium, Revista da Associação Portuguesa de Riscos, Prevenção e Segurança, Lousã, no 20, p. 115-132, ISSN 1647-7723. http://www.uc.pt/fluc/nicif/riscos/Documentacao/Territorium/T20_artigos/T20_Artigo10.pdf

CODAR - CODIFICAÇĀO DE DESASTRES, AMEAÇAS E RiSCOS (2000). In Politica Nacional de Defesa Civil. Anexo B. Secretaria da Defesa Civil, Ministério da Integração Nacional. Brasília, 53 p.; http://www.mi.gov.br/c/document_library/get_file?uuid=6aa2e891-98f6-48a6-8f47147552c57f94\&groupId=10157

Fernandes, Sofia Pires; Lourenço, Luciano (2013). A importância das obras de correçáo torrencial no controlo da erosão hídrica. Exemplos da bacia hidrográfica do rio Lis. Cadernos de Geografia no 32. Coimbra, p. 15-27, ISSN 0871-1623; http://www.uc.pt/fluc/depgeo/Cadernos_Geografia/Numeros_publicados/CadGeo32/Artigo_2

Guerreiro, A. Machado (1987). Impacte e impacto. Correio da Natureza, Lisboa, nº. 1, p. 32.

Highland, L. M.; Bobrowsky, Peter (2008). The landslide handbook - A guide to understanding landslides. Reston, Virginia, U. S. Geological Survey, Circular 1325, 129 p. https:/pubs.usgs.gov/circ/1325/

ISRD - INTERNATIONAL STRATEGY FOR DISASTER REDUCTION (2009). Terminology on Disaster Risk Reduction. UNISDR - United Nations International Strategy for Disaster Reduction, Geneva, Switzerland, United Nations, 30 p; http://www.unisdr.org/we/inform/publications/7817

JOCE - JORNAL OFICIAL DAS COMUNIDADES EUROPEIAS (1998). Convenção das Naçōes Unidas de Combate à Desertificação nos países afectados por seca grave elou desertificação, particularmente em África. n. ${ }^{\circ}$ L, 83, de 19 de Março, p. 003 - 035;

Julião, R. P.; Nery, F.; Ribeiro, J. L.; Branco, M. C.; Zêzere, J. L. (2009). Guia metodológico para a produçâo de cartografia municipal de risco e para a criaçấo de sistemas de informação geográfica (SIG) de base municipal. Autoridade Nacional de Protecção Civil, DGOTDU/IGP, Lisboa, 91 p.; http://catalogo.biblioteca.oasrs.org/cgi-bin/koha/opac-imageviewer.pl?biblionumber=22627

Lei n. ${ }^{0} 113$ - Lei de Bases da Proteç̧ão Civil. Diário da República (Portugal), n. ${ }^{\circ}$ 198, I. ${ }^{a}$ Série-A, Imprensa Nacional - Casa da Moeda, de 29 de agosto de 1991, p. 4501-4507;

Lei n. 27 - Lei de Bases da Proteç̧ão Civil. Diário da República (Portugal), n. ${ }^{0} 126,1 .^{a}$ Série, Imprensa Nacional - Casa da Moeda, de 3 de julho de 2006, p. 4696-4706;

Lemos, Luís; Lourenço, Luciano; Gonçalves, Carlos (2001). Movimentos em massa. Exemplos do Centro de Portugal. ENB, Revista Técnica e Formativa da Escola Nacional de Bombeiros, Sintra, $n^{\circ} 18$, p. 17-41;

https://www.uc.pt/fluc/nicif/Publicacoes/Estudos_de_Colaboradores/PDF/Publicacoes_periodicas/ ENB18_2001_Movimentos_em_massa._Exemplo_no_Centro_de_Portugal.pdf

Lourenço, Luciano (1998). O homem, causa próxima e principal receptor das trágicas consequências do deslizamento da Lousâ, Cadernos de Geografia, Coimbra, no. 17, p. 81-88;

http://www.uc.pt/fluc/depgeo/Cadernos_Geografia/Numeros_publicados/CadGeo17/artigo14

Lourenço, Luciano (2003). Análise de riscos e gestão de crises. O exemplo dos incêndios florestais. Territorium, 10, p. 89-100;

http://www.uc.pt/fluc/nicif/riscos/Documentacao/Territorium/T10_artg/T10_artg06.pdf 
Lourenço, Luciano (2007). Riscos naturais, antrópicos e mistos. Territorium, 14, p. 109-113; http://www.uc.pt/fluc/nicif/riscos/Documentacao/Territorium/T14_artg/T14NNR01.pdf

Lourenço, Luciano (2014). Risco, Perigo e crise. Trilogia de base na definiçáo de um modelo conceptual-operacional. In Lourenço, Luciano e Tedim, Fantina (Ed.) - Realidades e Desafios na Gestão dos Riscos. Diálogo entre Ciência e Utilizadores, NICIF/FLUC, Coimbra, p. 61-72;

https://digitalis.uc.pt/es/livro/risco_perigo_e_crise_trilogia_de_base_na_definiçẫo_de_um_modelo_conceptual_operacional

Lourenço, Luciano (2015). Risco, perigo e crise: Pragmatismo e contextualizaçẫo. In Riscos de desastres relacionados à água: aplicabilidade das bases conceituais das Ciências Humanas e Sociais para a análise de casos concretos, Siqueira, Antenora; Valencio, Norma; Siena, Mari; Malagodi, Marco Antonio (Ed.).. São Carlos: RiMa Editora, p. 3-43;

http://www.nesa.uff.br/wp-content/uploads/2017/02/Lourenço-Luciano.pdf

Lourenço, Luciano (2018). Incêndios florestais em Portugal continental. Degradação da paisagem ou reabilitaçáo após as cinzas? In Tedim, Fantina e Lourenço, Luciano (Ed.) - Os Incêndios Florestais: em busca de um novo paradigma. II Diálogo entre Ciência e Utilizadores, NICIF/FLUC, Coimbra, p. 9-30;

Lourenço, Luciano; Lemos Luís (2001). Consideraçôes acerca da movimentação em massa ocorrida na vertente poente da Ava. Elísio de Moura, em Coimbra, Territorium, Minerva, Coimbra, no 8, p. 93-108; http://www.uc.pt/fluc/nicif/riscos/Documentacao/Territorium/T08_artg/T08_artg08.pdf

Lourenço, Luciano; Nunes, Adélia (2014). O flagelo das chamas e a recorrência de eventos hidrogeomorfológicos intensos. O exemplo da bacia do rio Alva (Portugal). WATERLAT-GOBACIT Network Working Papers. Thematic Area Series SATAD - TA8 - "Water-related disasters: from trans-scale challenges to interpretative multivocality - Vol. 1 N. ${ }^{\circ}$ 1, p. $43-90$ (Print: ISSN 2056-4856; Online: ISSN 2056-4864); http://www.uc.pt/fluc/nicif/Publicacoes/Estudos_de_Colaboradores/PDF/Livros_e_Guias/2014_ WPSATADNo1_Artigo03.pdf

Martins, B.; Lourenço, L.; Lima, H. (2017). Açấo antrópica e risco de ravinamento: O exemplo da ravina do Corgo (rio Alva). Territorium, IUC e RISCOS, Coimbra, no 24, p. 221-234. http://www.uc.pt/fluc/nicif/riscos/Documentacao/Territorium/T24_Artg/T24_Artg16.pdf

Martonne, Emmanuel de (1909). Traité de Géographie Physique. Tradução portuguesa das edições de 1948 (I tomo) e 1951 (II tomo): Panorama da Geografia, Lisboa, Cosmos, Vol. I, 1953, 979 p.;

Pedrosa, A. Sousa; Lourenço Luciano; Felgueiras João (2001). Movimentos em massa. Exemplos ocorridos no Norte de Portugal. ENB, Revista Técnica e Formativa da Escola Nacional de Bombeiros, Sintra, no 17 , p. 25-39;

http://www.uc.pt/fluc/nicif/Publicacoes/Estudos_de_Colaboradores/PDF/Publicacoes_periodicas/ ENB17_2001

Rebelo, Fernando (2001). Riscos Naturais e Aç̧ão Antrópica. Coimbra, Imprensa da Universidade, 274 p. (2a edição revista e aumentada: Rebelo, Fernando (2003) - Riscos Naturais e Acção Antrópica. Estudos e Reflexöes. Coimbra, Imprensa da Universidade, 286 p;

https://digitalis.uc.pt/pt-pt/livro/riscos_naturais_e_acção_antrópica_estudos_e_reflexôes

Soil Science of America, 2008. Glossary of Soil Science terms. Soil Science of America, Madison, WI, p. 93. https://dl.sciencesocieties.org/publications/books/tocs/acsesspublicati/glossaryofsoils

Strahler, A. N. (1981). Physical Geography. Tradução espanhola, Geografía Física. Barcelona, Ed. Omega, 767 p.;

Tricart, Jean (1977). Précis de Géomorphologie, tome 2 - Dynamique générale, Paris, SEDES (3 vol.), 345 p. 


\section{AS QUESTÓES \\ METODOLÓGICAS DA \\ ANÁLISE E AVALIAÇÁO \\ DO RISCO EM DIFERENTES CIENCIAS.}


(Página deixada propositadamente em branco) 


\title{
QUESTÓES METODOLÓGICAS DA ANÁlisE E AVALIAÇÃO DO RISCO

\author{
METHODOLOGICAL ISSUES OF RISK
} \\ ANALYSIS AND ASSESSMENT
}

\begin{abstract}
Adélia Nunes
Departamento de Geografia e Turismo da Faculdade de Letras, CEGOT e RISCOS

Universidade de Coimbra, Portugal

ORCID: 0000-0001-8665-4459 adelia.nunes@ci.uc.pt

Fátima Velez de Castro

Departamento de Geografia e Turismo da Faculdade de Letras, CEGOT e RISCOS

Universidade de Coimbra, Portugal

ORCID: 0000-0003-3927-0748 velezcastro@fl.uc.pt
\end{abstract}

Sumário: Neste trabalho sistematizam-se os principais métodos de análise de risco, centrados nos processos de avaliação e de perceção. Particular ênfase é dada às etapas e métodos de análise e avaliação do risco, exemplificando o processo com um "estudo de caso", focado na avaliação do risco de incêndio florestal no NW de Portugal. No que se toca aos processos de perceçáo do risco, a metodologia centra-se, principalmente, na elaboração de inquéritos, pois é a partir destes instrumentos que ficam registadas e sistematizadas as impressóes percetivas dos indivíduos sobre a temática.

Palavras-chave: Análise de risco, metodologia de avaliação, perceção espacial, incerteza. 


\begin{abstract}
The main methodologies of risk analysis are systematized in this work, focused on the evaluation and perception processes. Particular emphases are given to the stages and methodologies of the risk analysis and evaluation, exemplifying the process with a "study case", focused on the wildfire risk assessment in the NW Portugal. Regarding to the processes of risk perception, methodologies focused on the elaboration of surveys will be approached, since it is from these instruments that the individuals' perceptions about the subject are recorded and systematized.
\end{abstract}

Keywords: Risk analysis, evaluation assessment methodology, spatial perception, uncertainty.

\title{
Introdução
}

Nas sociedades atuais, as populações exigem um elevado nível de segurança e bem-estar, bem como a preservação da qualidade do ambiente. Para que isso aconteça, torna-se necessário identificar os processos potencialmente perigosos e antecipar as suas possíveis consequências, de modo a minimizar os prejuízos, não só pela implementação das medidas de mitigação necessárias, mas também pela atuação a montante, no quadro do ordenamento do território, através da adequada localização das populaçóes e das atividades económicas (Julião et al., 2009).

Neste contexto, identificar, caraterizar e avaliar metodicamente os riscos naturais, antrópica e mistos que condicionam a segurança das comunidades são passos fundamentais no adequado desenvolvimento dos procedimentos de planeamento de emergência e de ordenamento do território (Julião et al., 2009; CNPC, 2014).

Assim, o acesso à informação sobre os riscos a que os cidadãos estão sujeitos, em cada área do território, é, para além de uma obrigação legal, uma ferramenta essencial para garantir a sensibilização da população em matéria de autoproteção e, deste modo, promover uma melhor aplicação do princípio da precaução, contribuindo para a adoção de medidas preventivas, antes do risco se manifestar, ou de mitigação das consequências no caso de este se vir a manifestar (CNPC, 2014). 
De acordo com as Naçôes Unidas, o risco resulta da "combinação da probabilidade de ocorrência de um evento com as suas consequências negativas" (ISDR, 2009). O risco corresponde, assim, a um "sistema complexo de processos cuja modificação de funcionamento é susceptivel de acarretar prejuizos diretos ou indiretos (perda de recursos) a uma dada população" (Faugères, 1990). Trata-se de uma definição aparentemente simples, todavia congrega grande complexidade pois integra os processos inerentes à manifestação de determinado risco (Rebelo, 1995), bem como a incerteza que decorre do é susceptivel e, ainda, as consequências que o risco comporta para uma dada população (Almeida, 2011; Lourenço, 2015), que, serão maiores ou menores em função da vulnerabilidade dessa população e dos seus bens.

A análise e avaliação do risco emergem, assim, como determinantes na sua gestấo, pois identificam e avaliam o risco que tem de ser controlado, minimizado ou aceite (Rot, 2008).

A Avaliaçáo Nacional de Risco, elaborada de acordo com as "Risk Assessment and Mapping Guidelines for Disaster Management" emitidas pela Comissão Europeia (documento SEC, de 2010, e 1626 final, de 21.12.2010) e adotada pela Comissão Nacional de Proteção Civil em janeiro de 2014 (CNPC, 2014) visa, precisamente, contribuir para esse objetivo. Nesta avaliação é realizada a identificação e caraterização dos riscos de génese natural, antrópica ou mista, suscetíveis de afetar o território nacional, assim como a descrição, para cada risco, do processo, metodologia, métodos e dados utilizados, estando a metodologia de análise centrada na avaliação da suscetibilidade e na cartografia dos elementos expostos, incluindo a estimativa do grau de gravidade dos danos potenciais e da probabilidade de ocorrência do risco.

Por outro lado, como refere Fonseca (2004), analisar as variáveis que podem ou não influenciar a forma como um risco é consciencializado implica ter em consideração "para além da probabilidade de ocorrência, a percep̧̧ão quanto ao grau de conhecimento ou informação existente, a capacidade de controlo, a magnitude das suas consequências, a quem beneficia, as implicaçōes no valor da propriedade na região, ou ao grau de confiança nos responsáveis pela sua produção, gestão e fiscalização, entre outros". Com efeito, a percepçâo do risco pode constituir-se como preditor consistente das respostas dos indivíduos e comunidades, em caso de acidente ou desastre, e deriva de um número alargado de fontes, distribuídas de variadas for- 
mas na população (Stoffle et al., 1991), influenciando a decisão e o comportamento individual (Siegrist e Gutscher, 2005).

Com o presente trabalho pretendem-se sistematizar os principais métodos de análise e avaliação de risco, assim como compreender os processos de consciência(lização) dos riscos e perceção dos perigos. Será dado particular ênfase às etapas e métodos de análise e avaliação do risco, exemplificando o processo com um "estudo de caso" centrado na avaliação do risco de incêndios florestal no NW de Portugal. No que se refere aos processos de consciencialização do risco será abordada a metodologia, centrada principalmente na elaboração de inquéritos, pois é a partir destes instrumentos que ficam registadas e sistematizadas as impressóes percetivas dos indivíduos sobre esta temática.

\section{Análise e avaliação de riscos}

\section{Formulação do Risco}

Das múltiplas fórmulas que podem ser utilizadas na avaliação do risco, uma das mais utilizadas congrega dois elementos principais: a existência de um processo ou fenómeno potencialmente perigoso (denominado na linguagem anglo-saxónica de hazard), o qual se pode expressar pela severidade da sua manifestação, e as caraterísticas dos elementos expostos a esse mesmo fenómeno - a vulnerabilidade.

\section{Risco $=$ Severidade $\mathbf{x}$ Vulnerabilidade}

Com efeito, os impactes da manifestação do risco dependem de múltiplas fatores ou caraterísticas (ISRD, 2009; CNPC, 2014; Lourenço, 2015);

- Susceptibilidade: relativa à propensão de uma determinada área para ser afetada por um determinado evento ou processo perigoso, através dos fatores de predisposição para a ocorrência dos processos ou acções, não contemplando o seu período de retorno ou a probabilidade de ocorrência; 
- Probabilidade: relacionada com a ocorrência de um processo ou acçáo com potencial destruidor, com uma determinada severidade, numa dada área e num determinado tempo;

- Intensidade: potencial destruidor do processo ou acçáo capaz de causar danos.

Assim a severidade refere-se à capacidade do processo ou acção para causar danos em função da sua magnitude, grandeza física, intensidade, grau, velocidade ou outro parâmetro que melhor expresse o seu potencial destruidor.

A análise da vulnerabilidade, ou melhor, das diferentes vulnerabilidades, depende, desde logo, do tipo de risco considerado, uma vez que diferentes processos perigosos afetam diferentes elementos, de distintos modos, provocando, também, diferentes reaçóes na busca de lhes resistir ou deles recuperar (Cunha, 2013).

Os dados e as técnicas utilizadas para a análise da vulnerabilidade dependem da abordagem conceptual definida. De acordo com padróes internacionais, estabelecidos pelas Naçôes Unidas (ISRD, 2009), a vulnerabilidade reflete as condiçôes determinadas por fatores físicos, sociais, económicos e ambientais ou por processos que aumentam a suscetibilidade de uma comunidade ao impacte de um processo potencialmente perigoso. Assim, em sentido lato, vulnerabilidade representa o potencial de perda (Cutter, 2011), que pode afetar diversos setores: social, económico, ambiental, institucional (Birkmann, 2006, 2013). Para além disso, a capacidade dos sistemas naturais e humanos absorverem as mudanças e recuperarem dos danos sofridos são fatores que influenciam o nível da vulnerabilidade de uma determinada comunidade ou sistema (Lavorel et al., 2007).

Oliveira et al. (2014) consideram que a vulnerabilidade expressa uma medida relativa do nível potencial de perdas e a sua avaliação pode resultar da combinação de 3 componentes (índices), que representam circunstâncias diversas:

- Exposição: presença de elementos; exemplo: população e respetivos bens;

- Sensibilidade: propensão dos elementos expostos para sofrerem determinado tipo e magnitude de danos;

- Capacidade de antecipação e de resposta: medidas e atividades de prevenção ou de resposta que influenciam a exposição ou a sensibilidade dos elementos. 
A manifestação do risco traduz-se, assim, pelas crises, que são consequências de eventos perigosos, cuja probabilidade de ocorrência é variável. As consequências são os efeitos negativos de uma ocorrência, expressos em termos de impactes humanos, económicos, ambientais e políticos/sociais.

\section{Métodos de avaliação do risco}

De acordo com a ISO 31010 (ISO sigla de International Organization for Standardization ou Organização Internacional para Padronização), no processo de análise e avaliação de riscos tenta responder-se às seguintes questôes fundamentais: o que pode acontecer e porquê (pela identificaçáo de riscos)? Quais são as consequências? Qual é a probabilidade de sua ocorrência futura? Existem fatores que mitigam as consequências do risco ou que reduzam a probabilidade do risco? O nível de risco é tolerável ou aceitável e requer tratamento adicional?

Esta Norma tem como objetivo refletir as boas práticas na seleçáo e utilização das técnicas para o processo de análise e avaliação de riscos. Assim, a abordagem completa do risco baseia-se na sequência de um conjunto de etapas principais: análise, avaliação e gestão (fig. 1).

O processo inicia-se, assim, com a identificação de risco, o qual se pode basear em evidências, tais como, bases de dados históricas; abordagens sistemáticas multidisciplinares de especialistas, com recurso a um conjunto estruturado de instruçōes ou perguntas; outras técnicas de apoio que podem ser utilizadas para melhorar a exatidão na identificação de riscos incluem o "brainstorming", o método Delphi ou a análise SWOT.

$\mathrm{Na}$ sequência, para definir um determinado nível de risco, os estudos dever-se-ão centrar na avaliação dos eventos potencialmente perigosos e nas condiçóes de vulnerabilidade existentes. $\mathrm{O}$ processo de avaliaçấo de riscos baseia-se numa avaliação de ambos e das suas caraterísticas, nomeadamente a localizaçáo, tamanho ou intensidade, frequência e probabilidade, assim como na análise das dimensóes físicas, sociais e económicas dos elementos expostos, a sua sensibilidade e capacidade de antecipaçáo e de resposta perante a manifestação do risco. Deve dar especial atençáo, igualmente, à capacidade de lidar com os cenários de risco e diferentes medidas para reduzir os impactes. 


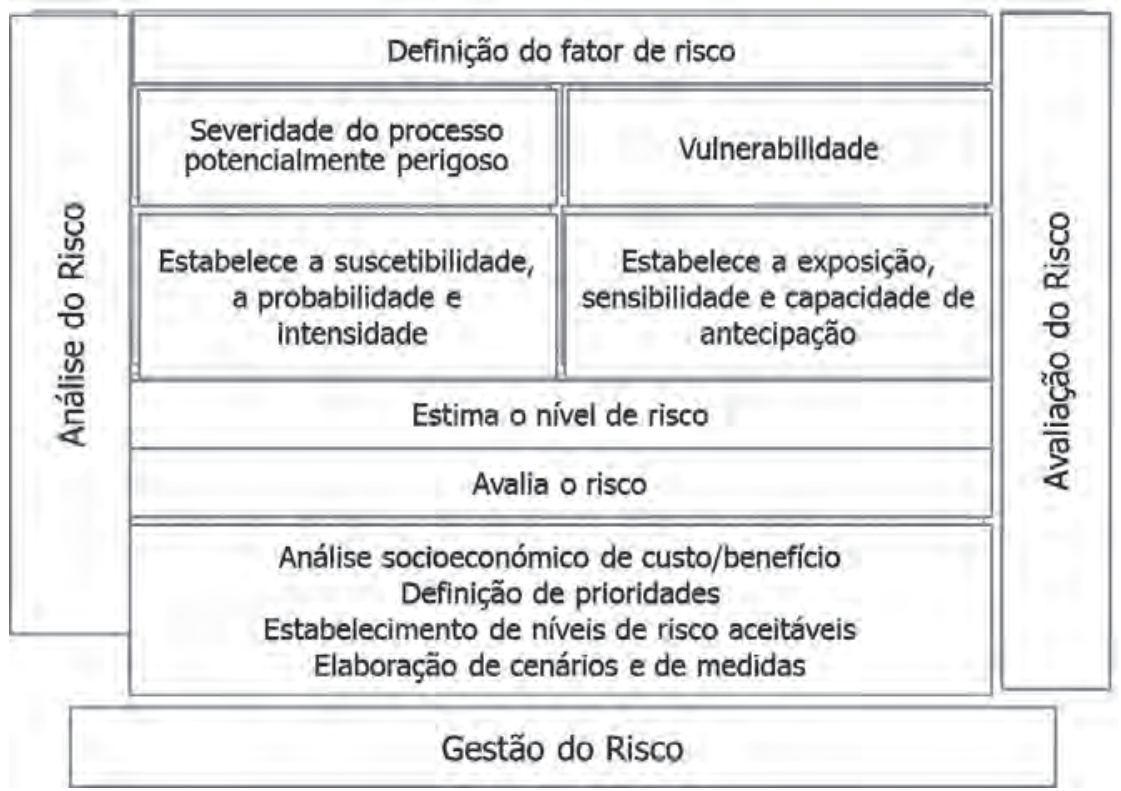

Fig. 1 - Principais etapas na abordagem ao Risco (Adaptado: Naciones Unidas/EIRD, 2004). Fig. 1 - Main steps in the approach to Risk (Adapted: United Nations / ISDR, 2004).

No processo de análise e avaliação do risco, os métodos utilizados são principalmente de cariz quantitativo ou qualitativo (Rot, 2008; Leal Martins e Lourenço; 2009). O grau de detalhe requerido dependerá sobretudo da disponibilidade de dados/variáveis confiáveis e das necessidades de tomada de decisão por parte dos órgãos decisores.

Métodos quantitativos (também denominados de probabilísticos): visam obter uma resposta numérica à estimativa da magnitude do risco, pelo que o cálculo da probabilidade faz apelo a técnicas sofisticadas de cálculo e ao recurso de bases de dados sobre o comportamento das componentes de análise que suportem a definição de um padrão de regularidade na frequência de determinados eventos. A quantificação de gravidade requer modelos matemáticos de consequências para possibilitar a simulação do campo de ação de um dado processo perigoso e o cálculo da capacidade agressiva em cada ponto desse campo de ação, por forma a estimar os dados esperados. Estes métodos possibilitam resultados objetivos, bem 
como a análise do efeito das medidas de controlo, utilizam linguagem objetiva e permitem a análise custo-benefício. No entanto, são mais complexos e morosos do que os seguintes, pois utilizam metodologias estruturadas (necessitam de bases de dados experimentais ou do histórico de fiabilidade e representatividade), precisam de elevada quantidade e informação específica, revelam dificuldade na quantificação da falha humana (erro de decisão, comunicação) e são bastante onerosos (recursos humanos com formação e experiência adequadas).

Métodos qualitativos: permitem a valoração do risco a partir de uma análise qualitativa. Baseiam-se num estudo sistemático das condiçóes, com vista a estimar a potencial severidade do dano (magnitude da gravidade) e a probabilidade de ocorrência, que podem ser efetuadas numa base qualitativa, tendo por exemplo elementos de comparação com o histórico de dados estatísticos, ou ainda, o que é esperado acontecer, de acordo com a opiniáo de especialistas. Estes métodos são mais simples do que o anterior, pois não requerem cálculos nem a identificaçáo exata das consequências, e são subjetivos por natureza, uma vez que dependem da experiência dos avaliadores, além de que não permitem análises de custo-benefício.

As principais vantagens e desvantagens de cada um destes métodos podem ser sistematizadas de forma comparativa (TABELA I).

TABELA I - Vantagens e desvantagens da utilização de métodos quantitativos e qualitativos na avaliação do risco.

TABLE I - Advantages and disadvantages of quantitative and qualitative methods in risk assessment.

\begin{tabular}{|c|c|c|}
\hline & Método quantitativo & Método qualitativo \\
\hline 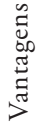 & $\begin{array}{l}\text { Fornece uma estimativa do risco mais precisa; } \\
\text { Facilita a análise e ajuda na identificação } \\
\text { de medidas de mitigação. }\end{array}$ & $\begin{array}{l}\text { Permite a determinação de áreas de risco } \\
\text { em menos tempo e com custos inferiores; } \\
\text { A análise é relativamente fácil e barata. }\end{array}$ \\
\hline 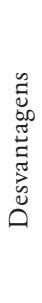 & $\begin{array}{l}\text { As medidas quantitativas dependem do } \\
\text { alcance e da exatidão para definir a escala; } \\
\text { Os resultados da análise podem ser pouco } \\
\text { exatos e confusos; } \\
\text { Os métodos normais devem ser enrique- } \\
\text { cidos com descriçôes para interpretação; } \\
\text { A análise conduzida por estes métodos } \\
\text { é geralmente mais cara, exigindo uma } \\
\text { maior experiência. }\end{array}$ & $\begin{array}{l}\text { Não utilizam medidas numéricas; } \\
\text { Na estimativa de perdas e danos a análise } \\
\text { é mais difícil; } \\
\text { A análise também é mais difícil na defini- } \\
\text { çáo de medidas de mitigação; } \\
\text { Os resultados tendem a ser genéricos e } \\
\text { aproximados. }\end{array}$ \\
\hline
\end{tabular}


Recolha, seleção, normalização e ponderação das variáveis/componentes do risco

Os dados utilizados para obter as variáveis representativas de cada parâmetro do risco podem ser provenientes de diversas fontes: estatísticas, cartográficas, produtos de deteção remota, disponibilizados através de entidades nacionais, europeias ou até mundiais. Nestas circunstâncias, a integração e a comparação dos elementos referentes aos processos potencialmente perigosos e aos fatores de vulnerabilidade são condicionadas pelo facto destes apresentarem distintas unidades de medida (proporçôes, taxas, índices), tornando imprescindível a sua normalização numa escala comum (Rashed e Weeks, 2003).

De acordo com Malczewski (1999), a normalização pode ser efetuada com recurso a vários métodos, como a escala linear de transformaçáo, as escalas de probabilidade ou as funçóes de valor/utilidade. Por exemplo, a normalização dos fatores com recurso as lógicas difusas compreende a passagem de um fator numa dada escala para a escala normalizada difusa, sendo que o resultado da normalização se traduz numa escala que varia entre 0 e 1 (Martins, 2010) ou entre 0 e 100.

$\mathrm{Na}$ sequência, torna-se necessário a seleção e a avaliaçáo do peso dos vários fatores/componentes a integrar no processo de avaliação do risco. A aplicação de métodos estatísticos, a análise multicritério (Martins, 2010) ou multivariada (análise de componentes principais ou a análise fatorial) (Oliveira et al., 2014) são algumas das possibilidades a serem consideradas para a ponderação das variáveis e para a avaliação da sua relevância, da qual resultará um índice composto.

Com efeito, a estimação do peso dos fatores/componentes visa determinar a importância relativa entre si. O pressuposto de que os fatores presentes possuem a mesma importância na avaliaçâao do risco é incorrecta, dado simplificar processos e relações de elevada complexidade. Estes métodos permitem a gestão da subjectividade de julgamento associado à estimação do peso dos fatores (Eakin e Bojorquez, 2008), visando a diminuiçấo da incerteza e do erro associados a este método de avaliação. 


\section{Matrizes de risco, escalas de análise e a sua representação cartográfica}

$\mathrm{Na}$ elaboração das matrizes de risco, quatro elementos fundamentais deverão ser tidos em conta: os níveis, as ponderaçóes, as escalas e as descriçóes. Todos estes elementos estão ligados entre si e deverão estar sempre devidamente justificados. Em primeiro lugar, devem ser definidos todos os fatores que se pretendem incluir na análise tanto da

probabilidade como da vulnerabilidade, assim como o método a aplicar. É importante que seja definido o menor número possível de fatores, ao mesmo tempo que se incluam todos os que se considerem como essenciais para a avaliação de riscos.

Niveis: A quantidade de níveis das várias matrizes pode ser igual ou variável. Não existe nenhuma regra que defina o número de níveis a serem considerados, verificando-se, por norma, o uso de 3, 4, 5 ou 6 níveis. Um menor número poderá originar uma estimativa pouco precisa, enquanto um número maior irá tornar as tabelas de cálculo demasiado grandes (figs. 2 e 3).

Ponderaçôes, escalas e descriçôes: Estas três caraterísticas são dependentes umas das outras. As ponderaçôes são os valores definidos para cada nível, posteriormente elementos de multiplicação entre fatores. A grande questão que se coloca reside nos valores a atribuir para a ponderação. Por regra, o valor de ponderação a ser aplicado no primeiro nível não deverá ser negativo ou “0”. O valor " 1 ”, apesar de válido, pode não ser aplicado por se tratar do elemento neutro da multiplicação, ou seja considerar a ponderação "1" num determinado nível, é o mesmo que não considerar esse nível, uma vez que não terá impacto na multiplicação com a ponderação do outro fator.

As escalas de cada tabela são individuais e fazem a correspondência entre os vários níveis. Podem ser regulares ou irregulares, desde que devidamente justificadas, e em total concordância com as descriçôes e com os valores de ponderação. A partir do primeiro valor de ponderação deve ser definida uma escala, influenciada pelas descriçôes, que dará origem às restantes ponderaçôes dos vários níveis da tabela.

As descriçóes de cada nível devem ser definidas à posteriori, tendo como principais influências o tipo de trabalho existente e o número de níveis pretendidos. As descriçôes devem ser diretas e coerentes, uma vez que, deparados com determinado risco, são as descriçóes que estão na origem da escolha do nível a que pertence a situação em estudo. 

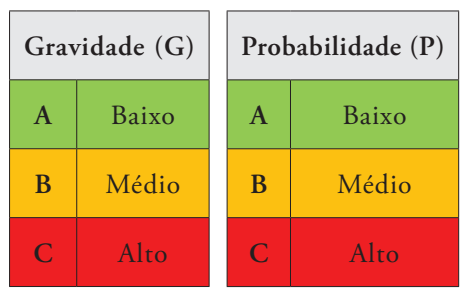

\begin{tabular}{|c|c|c|c|c|}
\hline \multirow{2}{*}{\multicolumn{2}{|c|}{$\mathrm{R}=\mathrm{G}^{*} \mathrm{P}$}} & \multicolumn{3}{|c|}{ Probabilidade $(\mathrm{P})$} \\
\hline & & A & B & $\mathrm{C}$ \\
\hline \multirow{3}{*}{ 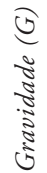 } & A & 1 & 1 & 2 \\
\hline & B & 1 & 2 & 3 \\
\hline & $\mathrm{C}$ & 2 & 3 & 3 \\
\hline
\end{tabular}

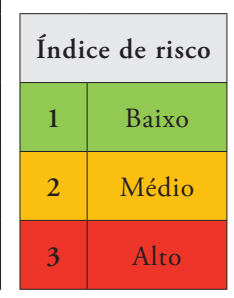

Fig. 2 - Exemplo de uma matriz de risco simples (Método de matriz simples Somerville), com três classes: escalas de Gravidade e Probabilidade; relaçáo entre gravidade e probabilidade e índice de risco (Fonte: Adaptado de Miguel, 2007).

Fig. 2 - Example of a simple risk matrix (Somerville's simple matrix method), with three classes: gravity and probability scales; relationship between severity and probability; risk index (Source: Adapted from Miguel, 2007).

\begin{tabular}{|l|c|c|c|c|c|}
\cline { 2 - 6 } \multicolumn{1}{c|}{} & \multicolumn{5}{c|}{ Probabilidade (P) } \\
\hline Impacto (I) & Baixa (1) & Média-Baixa (2) & Média (3) & Média-Alta (4) & Elevada (5) \\
\hline Crítico (5) & Moderado & Elevado & Elevado & Crítico & Crítico \\
\hline Elevado (4) & Moderado & Moderado & Moderado & Elevado & Crítico \\
\hline Moderado (3) & Baixo & Moderado & Moderado & Moderado & Elevado \\
\hline Baixo (2) & Muito baixo & Baixo & Moderado & Moderado & Elevado \\
\hline Insignificante (1) & Muito baixo & Muito baixo & Baixo & Moderado & Moderado \\
\hline
\end{tabular}

\begin{tabular}{|c|l|c|}
\hline Probabilidade & \multicolumn{1}{|c|}{ Impacto } & Grau de risco $\left(\boldsymbol{P}^{*} \boldsymbol{I}\right)$ \\
\hline Elevada (5) & Crítico (5) & Crítico $(\geq 20)$ \\
\hline Média-Alta (4) & Elevado (4) & Elevado $(\geq 13$ e $\leq 19)$ \\
\hline Média (3) & Moderado (3) & Moderado $(\geq 5$ e $\leq 12)$ \\
\hline Média-Baixa (2) & Baixo (2) & Baixo $(\geq 3$ e $\leq 4)$ \\
\hline Baixa (1) & Insignificante (1) & Muito Baixo $(\leq 2)$ \\
\hline
\end{tabular}

Fig. 3 - Matriz de risco, com 5 classes: relaçấo entre gravidade e impacto e grau de risco (Fonte: Adaptado de Barros, 2010).

Fig. 3 - Risk matrix, with 5 classes: relationship between severity and impact and degree of risk (Source: Adapted from Barros, 2010). 


\section{A incerteza na análise e avaliação do risco}

Uma grande dificuldade no tratamento do risco advém do facto dos acontecimentos futuros não ocorrerem exatamente da forma como os estamos a pensar no presente, devido aos muitos fatores de natureza incerta que intervêm no processo (Holton, 2004; Leal Martins e Lourenço, 2009, Betâmio de Almeida, 2014).

Como afirma Betâmio de Almeida (2014) a noção de risco é baseada numa subtil combinação entre conhecimento possível e a incerteza, pelo que o objeto e natureza da análise dos riscos, a incerteza nos resultados e dos elementos que servem de base a decisóes no âmbito da gestão dos riscos pode ser muito significativa e ter consequências relevantes. $\mathrm{O}$ mesmo autor acrescenta que a caraterização das incertezas inerentes ao processo de análise e avaliação dos riscos é cada vez mais uma exigência e tem vantagens evidentes: (i) mostra ao decisor que o conhecimento é incompleto ou impreciso e que as decisóes serão baseadas nos conhecimentos disponíveis, incompletos ou aleatórios; (ii) avalia e aprecia o grau de incerteza em causa e decide se o mesmo é aceitável ou não; (iii) permite saber atuar eficazmente (ou de um modo mais eficiente) para reduzir a incerteza resultante (através da identificação das fontes de incerteza mais relevantes para os resultados); (iv) permite separar as incertezas aleatórias das epistémicas para intervir (gerir) com eficácia no controlo de incertezas finais; (v) permite adaptar o processo de decisão ao tipo e valor das incertezas.

Klir (1995) refere que a insuficiência de informação é um dos principais fatores determinantes do grau de incerteza em dado sistema, assim como a introdução de informação de natureza irrelevante na sua análise e avaliação. No entanto, a quantidade de incertezas pode ser reduzida pela obtenção de novas informaçóes relevantes, como o resultado de algumas ações, tais como a observação de um facto novo, a execução de experiências, a obtenção de registos históricos, entre outros.

Em qualquer dos casos, a caraterização das incertezas envolvidas nos cálculos para avaliaçáo do risco deve ser levada a cabo tendo em vista uma tomada de decisão mais adequada com o grau de conhecimentos disponível. Sem uma análise das incertezas epistémicas embebidas nos cálculos, o aparente rigor dos resultados de uma avaliação quantitativa dos riscos pode conduzir a decisóes desproporcionadas. 


\section{Atualização e manutenção da cartografia de risco}

A cartografia de risco, ao produzir mapas temáticos, necessita de uma contínua manutenção e atualização, pois tanto a probabilidade como a vulnerabilidade são variáveis mutáveis, quer no tempo quer no espaço.

As mudanças ou variaçóes que se introduzem no risco e, portanto na sua representação em termos cartográficos, podem ter várias fontes ou procedências:

- A disponibilização de novas fontes de informação ou de dados mais atualizados;

- Avanço nos métodos de análise e representação;

- Mudanças e tendências nas variáveis condicionantes e desencadeantes dos riscos (severidade e vulnerabilidade);

- $\quad$ Outras (...)

\section{Estudo de caso: risco de incêndio florestal no NW de Portugal}

A ocorrência de incêndios florestais é uma das principais ameaças à sustentabilidade dos espaços florestais e à segurança das populações em Portugal e também noutras regiôes da bacia do Mediterrâneo (Nunes et al., 2015). O projeto PREFER ${ }^{1}$ pretendeu, através da disponibilização de informação harmonizada à escala europeia e atualizada sistematicamente com base em dados de satélite e tecnologias avançadas, a produção de cartografia aplicada a diversas fases de gestão de incêndios, nomeadamente na prevenção e preparação para situaçóes de emergência e na fase de recuperação pós-incêndios (Oliveira et al., 2014; Lourenço et al., 2014). A produção de cartografia de Risco de Incêndio foi da responsabilidade da Universidade de Coimbra, embora com a colaboração de outro parceiro, uma vez que o mapa de risco apresentado resultou da combinação de dois produtos PREFER: Mapa sazonal de probabilidade de ocorrência de incêndio e o Mapa de vulnerabilidade.

\footnotetext{
1 REFER: "Space-based Information Support for Prevention and Recovery of Forest Fires Emergency in the MediteRranean Area
} 


\section{Mapa sazonal de probabilidade}

O mapa sazonal de probabilidade de ocorrência foi desenvolvido para uma escala de longo prazo (quinzenal ou mensal). É baseado na observação da distribuição de incêndios nos dias anteriores à época de incêndios, nos mapas diários de probabilidade dos dias anteriores e no comportamento das condiçóes meteorológicas. O mapa sazonal de probabilidade fornece um índice de probabilidade de ocorrência de incêndios, de alta resolução, com uma escala temporal de 2 a 4 semanas (atualizado durante a época de incêndios) (fig. 4).

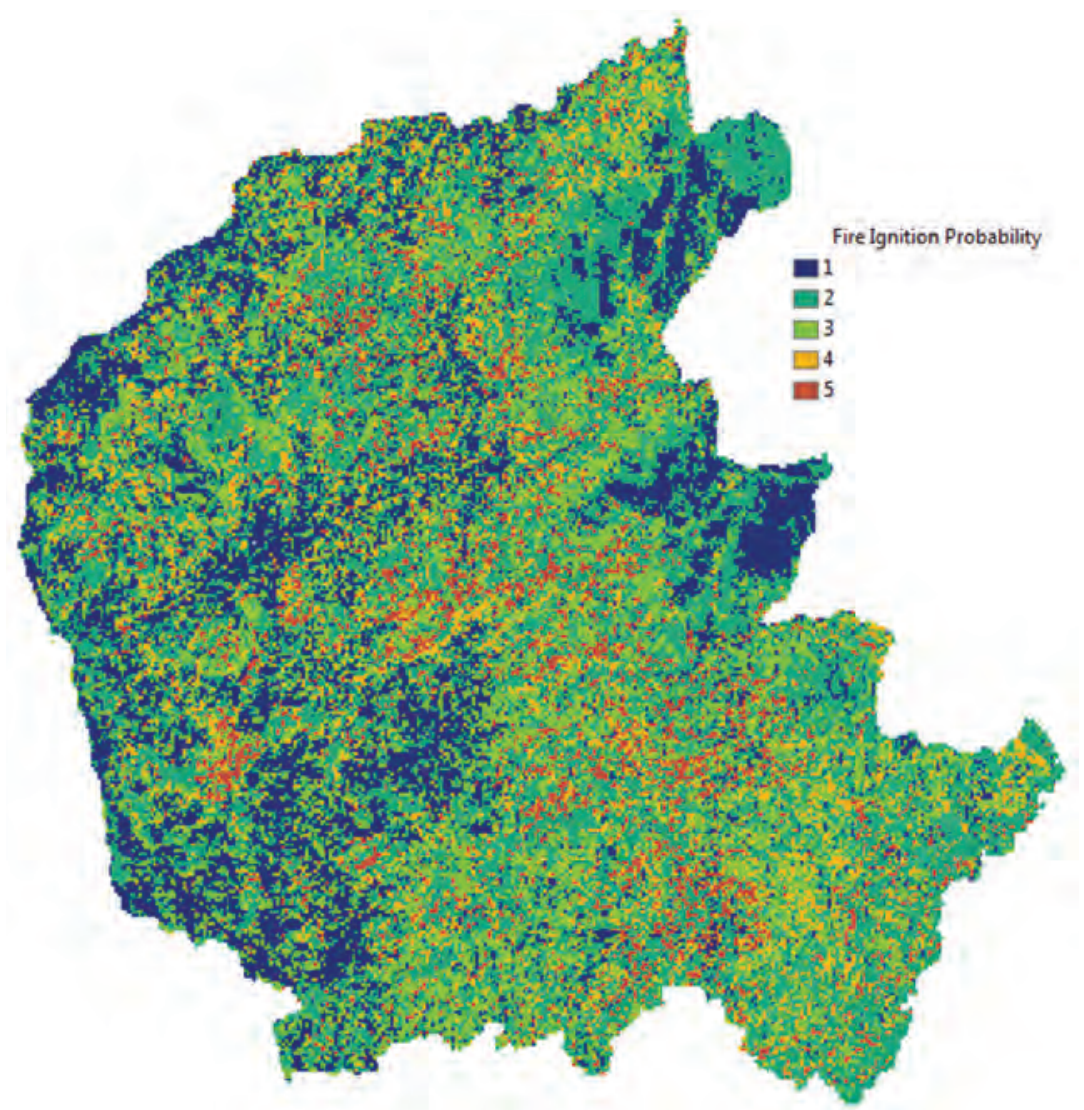

Fig. 4 - Mapa sazonal de probabilidade de ocorrência de incêndios na região NW de Portugal (Fonte: Olveira et al., 2014).

Fig. 4 - Seasonal probability map of fire occurrence in NW Portugal (Source Oliveira et al., 2014). 


\section{Mapa de vulnerabilidade}

O mapa de vulnerabilidade expressa, como já foi anteriormente referido, uma medida relativa do nível potencial de perda. A avaliação de vulnerabilidade resultou da combinação de 3 componentes (índices), que representam circunstâncias diversas (fig. 5): (i) Exposição (presença de elementos); (ii) Sensibilidade (propensão dos elementos expostos para sofrerem determinado tipo e magnitude de danos); (iii) Capacidade de antecipação e de resposta (medidas e atividades de prevenção ou de resposta que influenciam a exposição ou sensibilidade dos elementos).

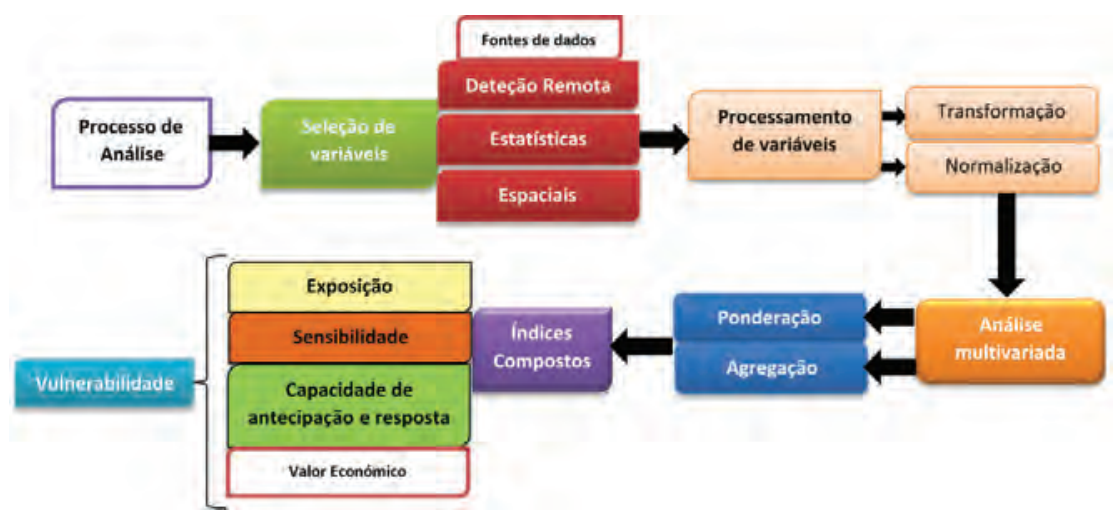

Fig. 5 - Esquema de processamento de variáveis e desenvolvimento dos índices compostos que integram a análise de vulnerabilidade (Fonte: Nunes et al., 2015).

Fig. 5 - Scheme of variable processing and development of composite indexes that comprise vulnerability analysis (Source: Nunes et al., 2015).

Três índices intermédios foram criados individualmente, representando a exposição (TABEla II), a sensibilidade e a capacidade de antecipação e de resposta. Estes índices são calculados a partir da análise de um conjunto de variáveis e normalizadas para a escala 0 -1, com 1 a representar o nível máximo da componente que se encontra na área de interesse (fig. 6).

Estes índices são, posteriormente, integrados num índice de vulnerabilidade através de um modelo aditivo; para cada pixel de 1 ha, há um valor entre 0 e 1 (escala contínua). Esta escala de valores é dividida em 5 classes $(0-0,2=1 ; 0,2-0,4=2$; $0,4-0,6=3 ; 0,6-0,8=4 ; 0,8-1=5)$. A classe 1 representa a vulnerabilidade mais baixa e a classe 5 o valor mais alto de vulnerabilidade na área avaliada. 
TABELA II - Exemplo de variáveis a integrar na componente exposição.

TABLE II - Example of variables to be included in the exposure component.

\begin{tabular}{|l|l|l|}
\hline \multicolumn{1}{|c|}{ Parâmetros } & \multicolumn{1}{c|}{ Dimensão } & \multicolumn{1}{c|}{ Variáveis } \\
\hline População total & Social & Densidade da população \\
\hline Uso/coberto do solo & Ambiental/social & Tipo de uso/coberto vegetal \\
\hline Edifícios & Social & Densidade de edifícios \\
\hline Infraestruturas & Social & Densidade de vias de comunicação (estradas) \\
\hline Áreas protegidas & Ambiental & \% de área classificada como protegida \\
\hline
\end{tabular}

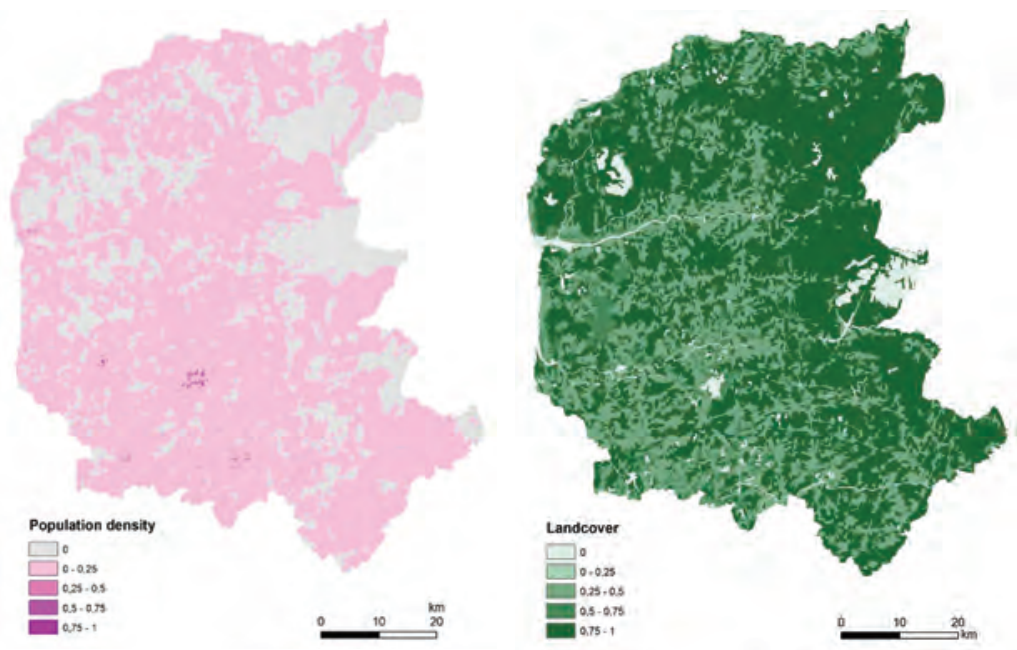

Fig. 6 - Expressão territorial da densidade da população e tipo de coberto vegetal no NW de Portugal (Fonte: Nunes et al., 2015).

Fig. 6 - Population density and vegetation cover in delimited area of NW Portugal (Source: Nunes et al., 2015).

\section{Mapa Sazonal de Risco}

O objetivo do mapa de risco visa identificar a suscetibilidade e a probabilidade de ocorrência, bem como o nível de danos causados pela eventual manifestação de incêndios. O mapa de risco resulta da combinação de dois produtos PREFER: o Mapa sazonal de probabilidade (representa a possibilidade de ocorrência de incêndios - hazard) e Mapa de vulnerabilidade (representa o potencial de perda) (fig. 7). 

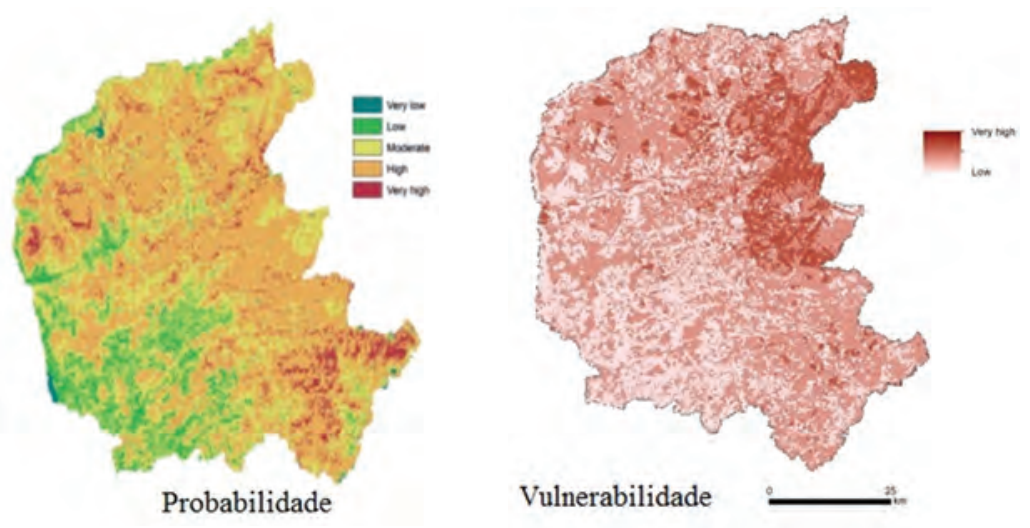

Fig. 7 - Mapa de probabilidade e de vulnerabilidade a incêndios florestais no NW de Portugal (Fonte: Oliveira et al., 2014).

Fig. 7 - Map showing probability of and vulnerability to forest fires in NW Portugal (Source: Oliveira et al., 2014).

Ambos os mapas são apresentados numa escala de 5 classes. A multiplicação do valor (1 a 5) das classes, de acordo com critérios pré-definidos, dá origem a uma escala de risco (fig. 8). A classe 1 representa o risco mais baixo, resultante da combinação de baixa probabilidade e baixa vulnerabilidade, e a classe 5 mostra o nível máximo de risco da área analisada.

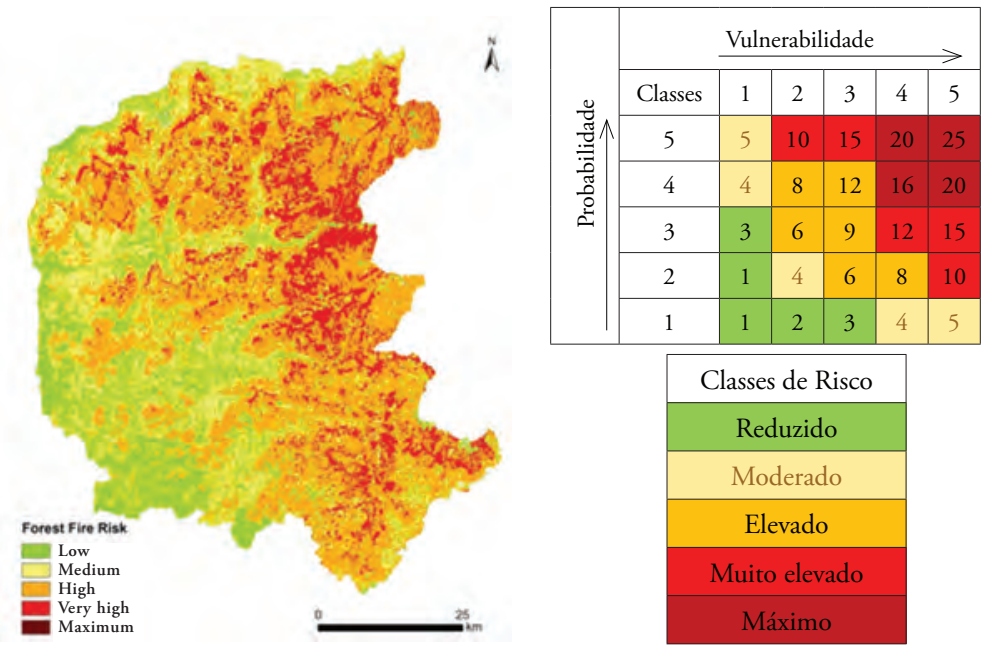

Fig. 8 - Risco de incêndio florestal no NW de Portugal (Fonte: Oliveira et al., 2014). Fig. 8 - Forest fire risk in NW Portugal (Source: Oliveira et al., 2014). 


\section{Perceção do Risco}

Compreender o espaço enquanto objeto geográfico, de cariz físico e social, integra uma complexa diversidade de entendimentos. Tal resulta, em parte, do processo percetivo individual e comunitário, que se relaciona com experiência vivenciais efetivas entre o(s) indivíduo(s) e o(s) território(s). Silva (2010) invoca os estudos de Heinrich (anos 80 do séc.XX) que destaca a importância do ambiente social, em termos de aceitação do risco, que, na nossa, perspetiva em muito é influenciada pela geografia da perceção, ou seja, o contexto de inserção da sociedade afetada. Mas quando se aborda a avaliação de risco, a dinâmica percetiva dos indivíduos nem sempre congrega opinióes consensuais relativamente à objetividade científica. Figueiredo et al. (2004) afirmam que existem um conjunto de fatores que interferem na conceção do perigo e o risco, nomeadamente a perceçáo sensorial, o grau de controlo sobre o fenómeno, a familiaridade com a fonte, o potencial catastrófico, o impacto sobre as gerações futuras, etc. Sobre esta questão, Fischer et al. (2002) chamam a atenção para o fato de, em alguns casos, "a obsessão pela objetividade e ou a negação da subjetividade impede uma avaliação realística" de situações de risco (ob. cit.: 1). Daí que estas autoras, sejam apologistas da integração de estudos de perceção na análise e avaliação dos Riscos. Tavares et al. (2011) destacam a importância da comunicação a várias escalas (individual, comunitária) para o entendimento e construçáo percetiva do risco.

Nesse sentido, também entendemos que considerar esta dinâmica é essencial no estudo dos Riscos, na medida em que parte da metodologia de análise e avaliação dos riscos passa pela perceção dos envolvidos sobre os fenómenos em causa, sobretudo quando se trabalha com questionários por inquérito ou questionários por entrevista.

\section{Reflexóes em torno da perceção espacial}

Uma das autoras que tem trabalhado sobre o tema da relação percetiva entre os indivíduos e os territórios é Rachel Pain (2001), a qual defende que o espaço reflete a atividade social: por exemplo, as áreas ghetizadas normalmente revelam as iniquidades sociais da população que a compóe, tendo em conta determinadas cara- 
terísticas referentes à classe social, raça, idade ou sexo desses indivíduos. Além disso, também considera que o espaço constrói a atividade social, uma vez que tem um papel preponderante na criação e manutenção das iniquidades sociais, numa lógica de continuidade da ideia anterior, ou seja, o reflexo da atividade social pode perpetuar a perceção - neste caso negativa - que se constrói relativamente a um lugar. $\mathrm{O}$ espaço também é um instrumento de resistência e celebração, funcionando como território simbólico evocativo de um determinado cronotopo. Veja-se o caso de locais onde se mantém um estilo de vida tradicional, ligado à terra e a determinadas tradiçóes (o caso dos Amish, nos Estados Unidos da América), ou o caso de lugares simbólicos associados a poder (por exemplo, o caso das embaixadas, consideradas até certo ponto como "Estados dentro do Estado", sujeitas a regras específicas no que diz respeito a casos de "asilo temporário").

Guy di Méo (1998) é um autor de referência na temática que aqui abordamos, chamando a atenção para a complexidade do conceito de "território", em relação com a componente percetiva, referindo que é composto por dois elementos. Por um lado o "espaço social", entendido como o lugar da biosfera onde se desenvolvem relações materiais (políticas, económicas, sociais, etc.) entre a sociedade e o espaço, e o espaço e a sociedade. Por outro lado, o "espaço vivido ou experienciado", com caráter existencialista e subjetivo, onde o indivíduo socializado, influenciado pela esfera social e pela perceção espacial, desenvolve relaçôes imateriais de identidade, de apreensão do legado simbólico, etc. Esta relação entre o espaço social e o espaço vivido é dominada por valores culturais que expressam a pertença a determinado grupo ou comunidade, conhecimento passa pela apreensão/compreensão percetiva das suas práticas, das suas representaçôes e dos seus imaginários espaciais.

Destas consideraçôes entende-se que a visão dos indivíduos sobre o território difere conforma o valor atribuído à dimensão espacial em causa. Esta variação pode interferir na forma como as comunidades encaram as situaçóes de risco, interferindo inclusive na forma como entendem as situaçôes de perigosidade. Mas não é só a comunidade civil que aqui se aborda. A dimensão percetiva, no que diz respeito a grupos decisores, nomeadamente a atores com poder de atuação político-estratégica, pode condicionar a forma de entendimento do risco, assim como de intervenção tanto a montante, como durante ou a jusante dos fenómenos de risco-perigo-crise. 
Regressemos, por isso, à visão de Guy di Méo (1998) sobre a construção dos territórios e a perceção espacial: este autor considera a existência de quatro aspetos a ter em conta na relação dos indivíduos com o território.

O primeiro são os "itinerários pessoais", que condicionam e são condicionados pela identidade coletiva e que definem a própria perceção do espaço. Estão relacionados com factos associados à individualidade, ao agregado ou à comunidade local. Por exemplo, numa estrada onde alguém teve um acidente e faleceu, é relativamente usual familiares marcarem o local com um símbolo específico (flores, cruz, etc.). Para quem não saiba do facto, será um símbolo anónimo (caso o veja), mas para quem conhece a história do local, terá desse espaço uma dinâmica percetiva muito mais intensa, do ponto de vista emocional, criando uma forte ligação com esse lugar.

O segundo é a "dimensáo política", que condiciona o acesso dos indivíduos aos territórios e tem como base a hierquização e simbologia atribuída aos espaços. Recorde-se o episódio dos jovens timorenses que nos anos 90 do séc.XX, aquando da intervenção da polícia indonésia na manifestação em que participavam, se refugiaram em diversas embaixadas em Díli, tendo ganho a nacionalidade dos respetivos países. Neste caso, o simbolismo político do espaço de uma embaixada, ganhou a dimensão de "estado dentro do estado", embora, do ponto de vista físico, se trate de um espaço de continuidade dos adjacentes. Do ponto de vista percetivo há, portanto, duas dinâmicas a considerar: a física, de continuidade geográfica, encarando-se todos estes micro-espaços na mesma unidade paisagística ambiental; a simbólica, de rutura geográfica, sugerindo que estes micro-espaços são redutos diferenciados da sociedade em que se inserem.

O terceiro diz respeito ao "campo simbólico", em que certos elementos patrimoniais contribuem para reforçar o sentimento de identidade coletiva, que se pode traduzir de formas visíveis, nomeadamente pela formalização de regras de utilização. Por exemplo, o uso do espaço de um cemitério é pautado por atitudes comedidas, sendo a perceção sobre este tipo de lugar ligada a aspetos pessoais muito próprios, de associação à espiritualidade ou à reflexão em torno do projeto humano, que pode condicionar o acesso ao mesmo, tanto num uso mais sistemático ou, pelo contrário, pela retração da ida a esse local (sentimentos de tristeza, medo, depressão, etc.). 
O quarto refere-se ao "capital histórico e temporal" que está na base da construção de territórios temáticos (por exemplo, o capital histórico e temporal que está associado a diversos monumentos ou espaços naturais, que lhe dáo a designação de património da humanidade ou reserva natural).

Este autor realiza uma síntese do território, como sendo o resultado da "materialidade geográfica", que integra os elementos da biosfera em conjunto com a ação humana; da "psique individual", ou seja, da ação humana resultante das interaçôes individuais e da perceção dos indivíduos sobre o espaço; das "representaçóes coletivas", ou seja, de açôes geradas pelas comunidades, que afetam o território do ponto de vista material e imaterial.

Tendo em conta esta ideia sumária, entende-se que Mendes (2015), na distinçâo das várias caraterísticas básicas do risco, indique a "complexidade" que, segundo o autor "tem a ver sobretudo com a dificuldade em se identifica ou quantificar conexöes numa multitude de fatores e de efeitos" (ob. cit.: 52). Esta complexidade também resulta da questão das "representaçôes" sobre o espaço, evocadas por Monteiro et al. (2015).

Neste sentido regressamos novamente a Guy di Méo (1998), o qual faz uma questão essencial: o entendimento percetivo daquilo que é o território resulta de um fenómeno psicológico ou representação social?

Invoca para isso estudos de Bordieu, dos anos 80 do séc.XX, o qual defende que a "territorialidade manifestada por cada um (relação entre o indivíduo e o território) é uma interiorização da exterioridade e uma exteriorização da interioridade". Significa que a construção do território deriva de fatores que emanam dos sujeitos, e de fatores que emanam do contexto social. A "medição" destes determinismos é explicada por quatro aspetos da dinâmica territorial.

Em primeiro lugar, a "parte psicológica dos indivíduos", donde deriva a importância da corrente da psicologia estruturalista, que procura perceber como é que se dá significado ao território, como se constroem símbolos e a própria identidade ligada ao espaço. Invoca os trabalhos de Lynch, que estuda a perceçâo de vários indivíduos que visitam cidades táo diversas como Boston, Jersey City ou Los Angeles, percebendo que há um fundo comum na estruturação percetiva que eles faziam sobre o espaço urbano. 
Em segundo lugar as "posiçôes sociais", onde se defende que certos territórios estáo confinados a indivíduos que ocupam determinados lugares na hierarquia social, sendo que os outros não lhes podem ter acesso (por exemplo, para a religião católica, o Tabernáculo/Sacrário só pode ser acedido por um padre ou por um ministro da celebração).

Em terceiro lugar, a "causalidade cultural", que destaca a importância dos "grandes sistemas ideológicos" como afetantes percetivos do espaço, ligados ao caso das crenças (religiosas ou filosóficas), do direito, das artes e das ciências, da língua, etc. que geram um determinado efeito no território (é o caso de Foz Côa que, por uma questão científica - descoberta das gravuras - deixou de ser encarado como um espaço económico - barragem - e passou a ser encarado com um espaço de elevado valor cultural). Também dá ênfase à "praxis social" - são os hábitos e as rotinas, os comportamentos tradicionais ou modernos da quotidianidade - , que atribui uma determinada lógica percetiva aos lugares de contato sistemático.

Daqui resulta, na quarta posição, "o efeito de lugar", derivante das rotinas do quotidiano, invocadas na "praxis social", dá corpo ao que o autor chama de "sociabilidade do ambiente". Esta sociabilidade promove a estruturaçấo dos territórios, uma vez que traduz os hábitos sistemáticos que são reproduzidos na esfera familiar, profissional, de amizades, associativa, etc.

Estas rotinas geográficas (de deslocação diária/sistemática) entre lugares criam no indivíduo esquemas mentais específicos, a que se associam estímulos sensoriais, os quais, ao longo do tempo, provocam comportamentos de orientaçâa quase automáticos, irrefletidos.

Pode-se então falar de uma construção paulatina e complexa, tanto à escala individual como à escala comunitária, de uma "territorialidade do quotidiano" que também se pode designar por "efeito de lugar", baseada no efeito percetivo, que irá influenciar, no geral, a construção da ideia do lugar. Lessard-Hébert et al. (2005), no que diz respeito à metodologia de investigação quantitativa e qualitativa refere-se à importância das "asserçóes de ordem empirica", as quais tendo uma forte componente percetiva, servem de base à indução analítica e até à construção e interpretação de quadros teóricos diversos. 
É com base nestas ideias que iremos refletir sobre a natureza do inquérito por questionário e do inquérito por entrevista na análise e avaliaçáo dos Riscos, pois é a partir destes instrumentos que ficam registadas e sistematizadas as impressóes percetivas dos indivíduos sobre esta temática.

$\mathrm{O}$ inquérito por questionário e o inquérito por entrevista como instrumentos metodológicos de análise e avaliaçáo do risco

\section{O inquérito por questionário}

Este instrumento é, segundo Mendes (2015), um instrumento de grande importância e relativa eficácia no estudo dos Riscos. O autor refere que "[...] 0 [inquérito por] questionário e o seu pré-teste permitem uma operacionalização dos conceitos de risco, de vulnerabilidade social e de perceção do risco, bem como a avaliação das práticas das pessoas, dos grupos e das comunidades na diminuição da sua exposição ao risco, das redes sociais ativadas em caso de ocorrência de acontecimentos extremos e do nivel de confiança nas instituiçôes relacionadas com a emergência e o socorro" (ob. cit.: 67).

Quivy et al. (2008) reforça esta ideia ao referir que o inquérito por questionário coloca um conjunto de questóes orientadas e fechadas, com o propósito de as tornar mais objetivas e simplificar a quantificação das respostas, pelo que todas as questôes são codificadas. Tal facilita o tratamento estatístico, tornando os resultados aparentemente mais pragmatizados do que em métodos e técnicas de consulta que permitem a resposta a questóes abertas.

Embora as respostas sejam tratadas do ponto de vista estatístico, tal ocorre apenas para facilitar o processo de análise, por exemplo através do tratamento dos dados em SPSS (Statistical Proceadures for Social Sciences), deixando na sua origem margem para os inquiridos responderem de acordo com a sua perceção. Neste sentido, Freixo (2009) concorda com a ideia, corroborando, para o contexto em causa que a metodologia quantitativa "constituiu um processo sistemático de recolha de dados [...] quantificáveis" (ob. cit.: 144). 
Segundo Pocinho (2012), a aplicação do inquérito por questionário pode ser por "administração indireta ou heteroadministraçãa", quando o investigador recolhe as informaçôes dadas pelo inquirido; por "administração direta ou autoadministraçâa", quando é o próprio inquirido que responde, ou seja, "preenche as questöes do formulário". Em termos académicos há uma discussão em torno da administração do questionário por inquérito havendo aqueles que defendem que o inquirido nunca deverá ler as questôes/possibilidades de resposta, para não ficar condicionado na sua opinião. Todavia há outra linha que defende o princípio da participaçáo ativa do sujeito, pelo que a leitura das questôes/possibilidade de resposta por parte do inquirido poderá ser benéfico, se o ajudar na reflexão e até mesmo no aprofundamento da opinião sobre o assunto em causa no questionário.

Bell (2008) refere-se ao tipo de questóes que podem constar de um questionário por inquérito, cuja natureza poderemos sistematizar da seguinte forma:

- Indicativa, que resulta numa informaçấo expressa por um número (por exemplo, idade) ou palavra (por exemplo, localidade de residência);

- Por categoria, que é uma forma similar à indicativa, contudo as respostas são pré-apresentadas em forma de intervalo ou em hipóteses de escolha;

- Hierarquizante, onde o inquirido é levado a referir a sua posiçáo com base num valor, normalmente apresentado em forma de escala;

- Grelha, está relacionada com a forma de apresentação do que se pretende saber, ou seja, pode haver a conjunçâo das formas anteriores, juntando-se várias questôes num quadro a ser preenchido.

Dependendo do que é questionado, a diversificaçáo das questóes deve adequar-se ao objeto em estudo, não havendo diretivas específicas quanto ao uso privilegiado de uma determinada tipologia.

Voltamos a Mendes (2015) que, com base na sua experiência em trabalhos de campo na área dos Riscos, chama a atenção para aspetos na construção do inquérito por questionário, nomeadamente:

- Uma clara definição da pergunta de partida do estudo, baseada num sólido quadro teórico, de onde derivarão as hipóteses de trabalho;

- A listagem exaustiva das variáveis de investigação associadas ao quadro teórico e às hipóteses de trabalho

- Especificação das questóes que irão ser utilizadas para medir cada variável; 
- Planeamento adequado de todas as seçôes do questionário;

- Testagem do questionário por inquérito num grupo-alvo e reformulaçáo do mesmo;

- Cuidada elaboração do "Manual de Inquérito" para os investigadores que irão aplicar o instrumento.

No que diz respeito à identificação do inquirido, Bell (2008) chama a atenção para a necessidade de se preservar o anonimato, no sentido de garantir a privacidade das respostas, assim como de deixar mais à vontade o inquirido e assim não haver constrangimento em revelar a suas opinióes.

Quivy et al. (2008) discute algumas reservas que são apresentadas no uso do inquérito por questionário. Em primeiro lugar, a questáo dos problemas de representatividade, pois a recolha da amostra pode, por vezes, gerar problemas de enviesamento, independentemente do método utilizado. Neste caso, achamos que dependendo das circunstâncias, a presença dos investigadores no campo de trabalho, assim como o uso de instrumentos complementares (por exemplo, o inquérito por entrevista), pode mitigar este ponto fraco. Outro aspeto prende-se com a veracidade das respostas. Esta situaçáo não é fácil de ultrapassar, pois é externa ao investigador, porém reiteramos o que foi defendido para a situaçáo anterior. Por fim, os autores chamam a atenção para a superficialidade das respostas, pois sendo de caráter fechado, não é dada margem para o inquirido expressar a sua posição de forma aberta. É por isso que se aconselha que no final do instrumento, possa haver um espaço para "observaçôes", onde o inquirido possa acrescentar outras informaçôes que considere pertinentes, e que foram valorizadas pelo inquirido, sem estarem contudo contempladas nas opçóes prévias de resposta. Neste sentido, Albarello et al (2005) destacam a importância do investigador como elemento facilitador do processo de descoberta, sem que induza necessariamente no inquirido elementos de conteúdo, ou seja, sem condicionar necessariamente as respostas.

\section{$\mathrm{O}$ inquérito por entrevista}

Destacamos para a análise e avaliação dos riscos, a validade do uso do inquérito por entrevista, tanto como instrumento principal, como complementar a outros métodos de trabalho. 
Segundo Rosa e Arnoldi (2006), os inquéritos por entrevista podem ser de vários tipos. No caso das entrevistas "estruturadas", pressupóe-se o estabelecimento de questóes formalmente elaboradas, com uma sequência lógica, linguagem sistematizada e de preferência fechada. Neste caso, exige-se que o entrevistado seja preciso e objetivo nas respostas. As autoras defendem que este tipo de entrevista deve ser aplicada a grupos de indivíduos onde se pretende recolher o mesmo tipo de informação (aplica-se o mesmo modelo de entrevista a todos).

Ainda referente a este tipo de entrevistas, podem ser "estruturadas e programadas" no caso de todas as perguntas serem passíveis de comparação, sendo que as respostas devem ser relativamente fechadas, para não darem margem a discussão; "estruturadas e não programadas", em que se admite alteraçóes na sequência e na natureza das questôes.

Outro tipo de questionário por entrevista identificado pelas autoras são as "semiestruturadas", em que as questóes deverão ser formuladas de forma a permitir que o sujeito discorra e verbalize os seus pensamentos, tendências e reflexôes sobre o tema. Neste caso as perguntas são mais profundas e subjetivas, levando a uma relaçáo de confiança entre o entrevistador e o entrevistado. Exige-se ao primeiro que componha um roteiro de tópicos selecionados, embora a formulaçáo e a sequência dependam do discurso dos sujeitos e da dinâmica da própria entrevista.

Por fim as autoras identificam as entrevistas "livres", em que não há uma lista de perguntas abertas para serem realizadas, sendo antes um relato oral, aproximado do método do "relato biográfico".

Albarello et al. (2005), assim como Rosa e Arnoldi (2006) explicitam intervençôes de conteúdos, entendidas como táticas para validar as respostas dos entrevistados, a saber:

- Reformulação sob a forma de clarificação ou resumo, reafirmação ou repetição dos conteúdos respondidos;

- Interpretação sobre o que foi dito e confirmação por parte do entrevistado;

- Confrontação com afirmaçóes ditas anteriormente, para verificar ou evitar a contradição; 
- Expressóes breves de encorajamento para o entrevistado continuar a falar;

- Pedido de informaçáo adicional;

- Manifestaçáo de incompreensão involuntária e pedido de esclarecimento;

- Técnica do espelho, que consiste na repetiçáo da última ideia do entrevistado, com o objetivo de enfatizar essa parte do discurso.

- Técnica do silêncio, deixando o entrevistado falar livremente, para que o entrevistador possa interpretar o rumo tomado na resposta;

- Tática da alteração do tema, em casos em que o entrevistado está com dificuldade em responder às questóes colocadas;

- Tática da pós-entrevista, em que há o terminus do processo em si, porém verifica-se a continuação da abordagem oral, num tom mais informal.

Sobre o tratamento dos dados obtidos pela entrevista, Albarello et al. (2005) refere o uso da grelha ou a transcrição direta das informaçóes com vertente analítica interpretativa. Também aconselhamos o uso de programas informáticos, com destaque para o NVivo, desenvolvido para o tratamento de dados em análises qualitativas, ajudando a estruturar informaçáo aparentemente sem pontos de ligaçáo óbvios, como é o caso das entrevistas, em que as respostas, embora focando os mesmos fenómenos, podem surgir sob formas de expressão oral e escrita muito diversificadas.

Ainda sobre a validação dos resultados dos inquéritos por questionário, Lessard-Hébert et al. (2005) afirmam que é aceitável que seja efetuada com base na interação entre o entrevistador e os entrevistados. Este processo pode implicar um certo tempo de permanência e envolvimento no território onde decorreu o fenómeno, o que nem sempre é fácil, por questões logísticas, mas também por questōes éticas: até que ponto é válido/possível/desejável que o investigador se "transforme" no "objeto investigado"?

Além disso, estes autores sugerem outra forma de validação, por exemplo a partir de contatos e inferências feitas com outros investigadores e técnicos envolvidos no processo e com bons contatos na comunidade civil. Por outro lado,, a documentaçáo de todos os procedimentos envolvidos no inquérito por questionário virá solidificar a validade científica deste instrumento de trabalho e dos dados resultantes. 


\section{Conclusão}

O processo de avaliaçáo de riscos deverá integrar uma abordagem multidisciplinar, uma vez que os riscos podem abranger uma ampla gama de causas e consequências. Depois da análise e avaliação do risco é fundamental que os resultados apresentados, sob a forma de mapa ou outra, sejam interpretados corretamente, quer pelas entidades políticas quer pelas ligadas à gestáo do território, e tomem consciência desse mesmo risco. O grau de conhecimento do risco depende da quantidade e qualidade das informaçóes disponíveis e da forma como as pessoas percepcionam o risco.

Com efeito, a perceção do risco varia segunda a sensibilidade de cada governo, comunidade ou pessoa, dependente das formas de comunicação e de envolvimento, as quais são influenciadas pela comunicação e educação sobre os riscos. De um modo geral, as pessoas são mais vulneráveis quando não estão táo conscientes dos processos e eventos naturais, antrópicos e mistos suscetíveis de colocar em risco as suas vidas e propriedades. Neste sentido, a obtenção de dados através de instrumentos de trabalho como o inquérito por questionário e o inquérito por entrevista, permite sistematizar e validar, numa abordagem científica, a relaçáo estabelecida entre as populaçôes e os fenómenos, no que diz respeito à noção de risco.

Assim, fomentar e melhorar a capacidade, a todos os níveis, para reunir e divulgar informações científicas e técnicas sobre o(s) risco(s) que afeta(m) uma determinada sociedade, no intuito de promover uma cultura de perceção do risco, através da Educação, fortalecerá a cooperação na prevenção, preparação, resposta, mitigação e reabilitação na sequência da plena manifestação do risco.

\section{Referências bibliográficas}

Albarello, L., Digneffe, F., Hiernaux, J. P., Maroy, C., Ruquoy, D., Saint-Georges, P. (2005). Práticas e métodos de investigação em Ciências Sociais. Lisboa: Gradiva.

Almeida, A. B. (2011). Risco e gestáo do risco: questóes filosóficas subjacentes ao modelo técnico conceptual. Territorium, n. 18, p. 23-31.

http://www.uc.pt/fluc/nicif/riscos/Documentacao/Territorium/T18_artg/Antonio_Betamio_de_Almeida.pdf

Barros, J. L. A. (2010). Riscos Naturais e Tecnológicos com expressáo no concelho de Lamego. Contributo para o Ordenamento e Gestão de Emergência Municipal (Diss. Mestrado). FCT, Universidade de Coimbra, 127p. 
Baumeister, R. F. (1993). Exposing the self-knowledge myth [Recensão a The self-knower: A hero under control, by R. A. Wicklund and M. Eckert]. Contemporary Psychology, 38, 466-467.

Bell, J. (2008). Como realizar um projeto de investigação. Lisboa: Gradiva.

Betâmio de Almeida, A. (2014). Gestão do risco e da incerteza. Conceitos e filosofia subjacente. In: Realidades e Desafios na Gestão dos Riscos. Diálogos entre Ciência e Utilizadores, Luciano Lourenço e Fantina Tedim (Cood.), NICIF - Núcleo de Investigaçāo Científica de Incêndios Florestais em cooperação com a Imprensa da Universidade de Coimbra; 19-29.

DOI: http://dx.doi.org/10.14195/978-972-8330-23-1_2

Birkmann, J. (2006). Measuring vulnerability to promote disaster-resilient societies: Conceptual frameworks and definitions, in: Measuring Vulnerability to Natural Hazards; Towards Disaster Resilient Societies. pp. 9-54.

Birkmann, J., Cardona, O.D., Carreño, M.L., Barbat, a. H., Pelling, M., Schneiderbauer, S., Kienberger, S., Keiler, M., Alexander, D., Zeil, P., Welle, T. (2013). Framing vulnerability, risk and societal responses: the MOVE framework. Nat. Hazards 67, 193-211.

Cantor, C.R. and Smith, C.L. (1999). Genomics: the science and technology behind the Human Genome Project $\left(2^{\text {nd }}\right.$ ed.). New York: John Wiley \& Sons.

CNPC - COMISSÃO NACIONAL DE PROTEÇÃO CIVIL (2014). Avaliação Nacional de Risco. http://www.prociv.pt/bk/RISCOSPREV/AVALIACAONACIONALRISCO/Documents/2016_ Avaliacao_Nacional_Riscos.pdf

Cunha, L. (2013). Vulnerabilidade: a face menos visível do estudo dos riscos naturais. Livro de Homenagem ao Professor Doutor Fernando Rebelo", Coord. e Org.: Luciano Fernandes Lourenço e Manuel Alberto Mateus, Departamento de Geografia. Faculdade de Letras. Universidade de Coimbra, p. 153-165. https://www.uc.pt/fluc/depgeotur/publicacoes/Livros/livro_homenagem_FRebelo/153_165

Cutter, S.L. (2011). A ciência da vulnerabilidade: Modelos, métodos e indicadores. Rev. Crit. Cienc. Sociais 93, 59-69.

Di Méo, G. (1998). Géographie Social et Territories. Paris: Nathan.

Eakin, H. and Bojórquez-Tapia, L. A. (2008). Insights into the composition of household vulnerability from multicriteria decision analysis. Global Environmental Change, 18(1), 112-127.

EIRD - ESTRATÉGIA INTERNACIONAL PARA LA REDUCCIÓN DE DESASTRES/NACIONES UNIDAS (2004), Vivir con el Riesgo: Informe mundial sobre iniciativas para la reducción de desastres. Informe mundial sobre iniciativas para la reducción de desastres. Elaborado por la ONU/EIRD Oficina Regional para las Américas (disponível em http://www.eird.org/vivircon-el-riesgo/index2.htm, consultado em 20 de Setembro de 2016).

Faugères, L. (1990). La dimension des faits et la théorie du risque. Le Risque et la Crise, European Coordination Centre for Research and Documentation in Social Sciences, Malta: Foundation for International Studies, 1990. p. 31- 60.

Figueiredo, E.; Valente, S.; Coelho, C.; Pinho, L. (2004). Conviver com o Risco - a importância da incorporação da perceção social nos mecanismos de gestáo dos riscos de cheia no concelho de Águeda. Atas do VII Congresso Luso-Brasileiro de Ciências Sociais, Coimbra: 1-12.

Fine, M. and Kurdek, L. A. (1993). Reflections on determining authorship credit and authorship order on faculty-student collaborations. American Psychologist, 48, 1141-1147. Acedido a 7 de junho de 1999, em http://www.apa.org/journals/amp/kurdek.html.

Fischer, D.; Guimarães, L. B. D. M. (2002). Perceção de risco e perigo: um estudo qualitativo. Recife: Atas do VII Congresso Ibero-Americano de Ergonomia, pp.1-6. 
Fonseca, S. (2004). Projecto Sinesbioar: Um olhar sociológico sobre a poluiçāo do ar (disponível em: http://ec.europa.eu/environment/life/project/Projects/index.cfm?fuseaction=home.show File\&rep=file\&fil=SINESBIOAR_ObserCom.pdf, consultado em 15 de Outubro de 2016)

Freixo, M. (2009). Metodologia científica. Fundamentos, métodos e técnicas. Lisboa: Instituto Piaget. Holton, Glyn A. (2004). “Defining Risk”. Financial Analysts Journal, Vol. 60, Number 6, CFA Institute, p. 19-26.

ISRD - INTERNATIONAL STRATEGY FOR DISASTER REDUCTION (2009). UNISDR Terminology on Disaster Risk Reduction. Geneva, Switzerland; United Nations.

Juliāo, R. P.; Nery, F.; Ribeiro, J. L.; Castelo Branco, M. e Zêzere, J. L. (2009). Guia metodológico para a produção de cartografia municipal de risco e para a criação de sistemas de informaçáo geográfica (sig) de base municipal. ANPC, Lisboa, $92 \mathrm{p}$.

Klir, G. J. (1995). Principles of uncertainly: What are they? Why do we need them?, Fuzzy Sets and Systems, 74: 15-311.

Lavorel, S., Flannigan, M.D., Lambin, E.F., Scholes, M.C. (2007). Vulnerability of land systems to fire: Interactions among humans, climate, the atmosphere, and ecosystems. Mitig. Adapt. Strateg. Glob. Chang. 12, 33-53.

Leal Martins, J. A.; Lourenço, L. (2009). Os riscos em Proteção Civil. Importância da análise e gestáo de riscos para a Prevenção, o Socorro e ... a Reabilitação. Territorium, Revista da Associação Portuguesa de Riscos, Prevenção e Segurança, Lousã, no 16, p. 191-217. http://www.uc.pt/fluc/nicif/riscos/Documentacao/Territorium/T16_artg/T16art19.pdf

Lessard-Hébert, M.; Goyette, G.; Boutin, G. (2005). Investigação qualitative. Fundamentos e práticas. Lisboa: Instituto Piaget, 2a edição.

Lourenço, L. (2015). Risco, perigo e crise: Pragmatismo e contextualizaçăo. In Riscos de desastres relacionados à água: aplicabilidade das bases conceituais das Ciências Humanas e Sociais para a análise de casos concretos, Siqueira, Antenora; Valencio, Norma; Siena, Mari; Malagodi, Marco Antonio (Ed.).. São Carlos: RiMa Editora, p. 3-43. http://www.uc.pt/fluc/nicif/ Publicacoes/Estudos_de_Colaboradores/PDF/Livros_e_Guias/2015_RiscosDesastres_LL_.pdf

Lourenço, L., Oliveira, S., Félix, F., Bento-Gonçalves, A., Nunes, A., Vieira (2014). O projeto PREFER: informação de apoio à prevençáo e à recuperação de áreas ardidas, com recurso à deteção remota. Territorium, 21: 196-199.

http://www.uc.pt/fluc/nicif/riscos/Documentacao/Territorium/T21_artg/T21_NNR04.pdf

Malczewski, J. (1999). GIS and Multicriteria Decision Analysis. New York: John Wiley and Sons.

Martins, V. N. B. (2010). Avaliação da vulnerabilidade socioecológica ao risco sísmico no concelho de Vila Franca do Campo (Açores). Contributo para a construção de uma comunidade resiliente (Diss. Mestrado). ISEGI - Universidade Nova de Lisboa, 144p.

Mendes, J. M. (2015). Sociologia do Risco. Uma breve introdução e algumas liçôes. Coimbra: Imprensa da Universidade de Coimbra.

Miguel, A. (2007). Manual de Higiene e Segurança doTrabalho. (10ª ed.). Porto: Porto Editora

Monteiro, A.; Cardozo, C.; Lopes, E. (2015). Sentidos Territoriais: a paisagem como mediação em novas abordagens metodológicas para os estudos integrados em riscos de desastres. In: Siqueira, A.; Valêncio, N.; Siena, M.; Malagoli, M. (Org.). Riscos de desastres relacionados à água. São Paulo: RiMa.

Nunes, A., Oliveira, S., Lourenço, L., Vieira, A., Bento-Gonçalves, A., Félix, F. (2015). Vulnerabilidade a incêndios na Europa Mediterrânea. Abordagem conceptual e a utilização de dados de satélite. In : J. G. dos Santos; C. Fonte, R. F. de Figueiredo; A. Cardoso, G. Gonçalves; J. P. Almeida, A. baptista (Eds), Atas das I Jornadas Lusófonas Ciências e Tecnologias de 
Informação Geográfica, Marcos e Marcas Lusófonas, Coimbra, 11 a 13 de Setembro de 2014, 330-344. DOI: http://dx.doi.org/10.14195/978-989-26-0983-6_18

Oliveira, S., Nunes, A., Lourenço, L., Vieira, A., Bento-Gonçalves, A., Félix, F. (2014). Information support for Prevention and Preparation Phase: Seasonal Vulnerability Map \& Seasonal Risk Map. PREFER- Space-based Information Support for Prevention and Recovery of forest Fires Emergency in the Mediterranean Area, $2^{\text {nd }}$ Progress Meeting, 5-6TH June 2014, Madrid, Spain.

Oliveira, S., Bento-Gonçalves, A., Nunes, A., Vieira, A., Félix, F., Lourenço, L. (2014). Prevenção de incêndios florestais e análise da vulnerabilidade com recurso a dados de satélite. O exemplo do projecto PREFER. Cadernos de Geografia, 33, Faculdade de Letras, Coimbra: 183:188. http://www.uc.pt/fluc/nicif/Publicacoes/Estudos_de_Colaboradores/PDF/editoriais/2014_ CadGeo_33_Nota.pdf

Pain, R., Gough, J., Mowl, G., Barke, M., MacFarlene, R., Fuller, D. (2001). Introducing Social Geographies. Nova Iorque: Arnold Publishers.

Pocinho, M. (2012). Metodologia de Investigação e comunicação do conhecimento científico. Lisboa: Lidel.

Quivy, R.; Campenhoudt, L. V. (2008). Manual de investigação em Ciências Sociais. Lisboa: Gradiva, $5^{\text {a }}$ ediçăo.

Rashed, T., e Weeks, J. (2003). Assessing Social Vulnerability to Earthquake Hazards through Spatial Multicriteria Analysis of Urban Areas. International Journal of Geographic Information Science, 17, 549-576.

Rebelo, F. (1995). Os conceitos de risco, perigo e crise e a sua aplicaçáo ao estudo dos grandes incêndios florestais. Biblos, n. 71, p. 511-527, 1995.

Rosa, M.; Arnoldi, M. (2006). A entrevista na pesquisa qualitativa. Belo Horizonte: Autêntica.

Rot, A. (2008). IT Risk Assessment: Quantitative and Qualitative Approach. Proceedings of the World Congress on Engineering and Computer Science 2008, WCECS 2008, October 22 - 24, San Francisco, USA.

Siegrist, M., Gutscher, H. (2005). Perception of risk: the influence of general trust, and general confidence. Journal of Risk Research 8 (2), 145-156.

Silva, E. (2010). Percę̧ão do risco e cultura de segurança. O caso aeroportuário (Dissertação de Mestrado em Dinâmicas Sociais, Riscos Naturais e Tecnológicos, na especialidade de Ciências do Risco). Faculdade de Economia da Universidade de Coimbra (policopiado).

Stoffle, Richard W., Michael W. Traugott, John V. Stone, Paula D. McIntyre, Florence V. Jensen and Carla C. Davidson (1991). Risk Perception Mapping: Using Ethnography to Define the Locally Affected Population for a Low-Level Radioactive Waste Storage Facility in Michigan. American Anthropologist 93(3):611-635.

Tavares, A. O., Mendes, J. M., Basto, E. (2011). Perceçấo dos riscos naturais e tecnológicos, confiança institucional e preparação para situaçōes de emergência: o caso de Portugal continental. Revista Critica de Ciências Sociais, 93: 167-193.

UNISDR - UNITED NATIONS OFFICE FOR DISASTER RISK REDUCTION (2004). Living with risk: a global review of disaster reduction initiatives. 429 p. 
(Página deixada propositadamente em branco) 


\section{MODELOS DE GESTÁO DOS RISCOS E AS POLÍTICAS PÚBLICAS \\ MODELS FOR RISK MANAGEMENT AND \\ PUBLIC POLICIES}

\section{Alexandre Oliveira Tavares \\ Departamento de Ciências da Terra e Centro de Estudos Sociais \\ Universidade de Coimbra \\ ORCID: 0000-0003-1621-6183 atavares@ci.uc.pt}

Sumário: Os modelos de gestão do risco incluem uma dimensão organizacional e uma dimensão conceptual, de onde emergem atividades, recursos, compromissos, planos ou instrumentos que determinam a capacidades de antecipar, responder e recuperar dos impactos prováveis, iminentes ou em curso. Apresentam-se três modelos distintos para a gestão do risco, como são o modelo sequencial, o modelo cíclico e o modelo multinível, que organizam o conhecimento, recorrem a procedimentos ou definem interlocutores distintos. Os modelos são marcados pelo contexto organizacional, apresentam diferentes graus de adesão para os interveniente e partes interessadas, ou promovem variáveis formas de decisão e comunicação.

Palavras-chave: Gestão do risco, modelo sequencial, modelo cíclico, modelo multinível, políticas públicas. 


\begin{abstract}
Risk management models include an organizational and a conceptual dimension. These generate activities, resources, commitments, plans and instruments that determine the capacity to anticipate, respond and recover from the probable, imminent or ongoing impacts. Three models for risk management are presented, namely, the sequential model, the cyclical model and the multilevel model, which organize knowledge, use procedures or define different interlocutors. The models are marked by organizational context, and show different degrees of uptake on the part of the participants and stakeholders and promote different forms of decision and communication.
\end{abstract}

Keywords: Risk management, sequential model, cyclical model, multilevel model, public policies.

\title{
Introdução
}

As ciências do risco ao evoluírem na conceptualização ganharam abrangência e assumiram a necessidade de uma avaliaçáo integrada entre os processos de perigo e as estratégias de gestáo, que cruzasse simultaneamente os elementos naturais, tecnológicos e sociais (Renn, 1998; Bankoff, 2012; Wisner et al., 2012). A relevância da gestão das crises é salientada quer pelo impacto nas políticas e nos atores (Tavares, 2013a; Thaler e Levin-Keitel, 2016), quer pelo condicionamento das organizaçôes (Boin et al., 2005; Alexander, 2016), bem como pela importância da decisão no planeamento territorial (Birkmann et al., 2010a; Wehn et al., 2015).

Os referenciais atuais demonstram, simultaneamente, condiçôes globais de menor admissibilidade social, económica e jurídica às perdas e incertezas relacionadas com os processos, o que determina a atenção sobre os modelos de gestấo do risco que os suportam (Eiser et al., 2012; Tavares, 2013b; Komendantova et al., 2014). Procura-se, como tal, que os modelos definam respostas proativas, preventivas e planeadas aos acontecimentos, tendo como enquadramento o desempenho das organizaçóes (Handmer e Dovers, 2007; Mendes e Tavares, 2009) ou a qualidade de vida das comunidades (Tavares, 2010; Wachinger et al., 2013). 
Segundo Aven e Renn (2010) a gestão do risco começa com a revisão de todas as informaçóes relevantes, de forma combinada, envolvendo a caracterização científica da avaliação do perigo, da perceção do risco, dos impactos económicos e a das respostas sociais para a fonte de risco. Observa-se uma incorporação crescente na gestão do risco de novos atores e de diferentes discursos como salientam, entre outros, Christapolos et al. (2001), Aven e Renn (2010) ou Cardona et al. (2010), o que constitui um desafio para o desenho dos modelos, para o seu entendimento e aplicação. Como refere de Almeida (2011) a gestão de riscos constitui uma gestáo de incertezas e de expectativas inerentes à condição humana, enquanto insaciável vontade de poder, mas também, uma tentativa de resposta organizada à finitude humana e ao sentimento de perda.

Ao nível das políticas públicas sobre o risco, assiste-se ao aparecimento cumulativo de instrumentos de políticas de planeamento territorial, a par da incorporação de competências técnicas baseadas na responsabilidade da administração, conforme salientam Schwab e Topping (2010) ou Tavares (2013a). Os intervenientes projetam nos instrumentos e critérios, bem como nas instituiçốes da proteção civil, emergência e socorro, a capacidade de gestáo dos riscos, enquadrando uma pluralidade de conhecimentos e valores, bem como exigem níveis de participação e de decisão, envolvendo diferentes atores (Aven e Renn, 2010).

Trata-se, assim, de gerar um conjunto de conhecimentos, capacidades e açóes para antecipar, responder e recuperar dos impactos, prováveis, iminentes ou em curso, resultantes de condiçóes de perigo, ou como referem Crozier (2006) ou Birkmann et al. (2013), de criar formas antecipatórias que permitam reduzir ou eliminar o impacto das catástrofes na sociedade e no ambiente, as quais podem ser subdivididas em medidas de mitigação estruturais, semi-estruturais e não-estruturais. Como referem Martins e Lourenço (2009) o mérito da análise e gestão do risco dependem essencialmente dos dados disponíveis e do rigor dos métodos utilizados.

Numa dimensão mais ampla a governação do risco pode ser entendida como a estrutura e os processos de tomada de decisão coletiva envolvendo os atores relevantes, a administraçáo, os grupos de interessados, as ONGs e os grupos sociais nos processos de tomada de decisão, num contexto geográfico ou funcional definido, como uma comunidade, região ou organização (Keohane e Nye, 2000; IRGC, 2005). 
Na dimensão das políticas públicas pode-se considerar que os processos de governação descrevem estruturas e processos para a tomada de decisão coletiva, envolvendo atores governamentais e não-governamentais, a multi-escala (Corfee-Morlot et al., 2011; Birkmann et al., 2013).

De acordo com Klinke e Renn (2012) a governação do risco implica, quer a estrutura institucional, quer o processo político, que orientam as atividades coletivas de um grupo, sociedade ou comunidade internacional para regular, reduzir ou mitigar o risco. A governação do risco procura, assim, adicionar aos processos de decisão a complexidade, a incerteza científica e a ambiguidade sociopolítica (Van Asselt e Renn, 2011; Renn e Klinke, 2013).

\section{Os modelos de gestáo do risco}

Os modelos de gestão e governação do risco refletem uma visão abrangente dos processos e das açôes de mitigação, assim como incluem a configuração institucional e os mecanismos de decisão (Pelling et al., 2008; Klinke e Renn, 2012). Ressalta, como objetivo para a gestão do risco, a implementação de um conjunto de ações que, simultaneamente, reduzam as vulnerabilidades e estimulem os pontos fortes e as capacidades das comunidades expostas (Cardona, 2011). A gestão do risco para Amaro (2005) constitui, para além de uma competência técnica, uma qualidade humana e, para além de um saber-fazer, um saber-estar.

De acordo com V. Hwacha (2005), uma visão estratégica sobre a gestão dos riscos deve ser suportada por valores de: (1) identificação de perigos e avaliação dos riscos, visando garantir que as medidas para reduzir o impacto das catástrofes prováveis são fundamentadas; (2) parcerias e responsabilidade partilhada entre a administração, os grupos profissionais, a academia, o setor privado e os voluntários, de forma a desenvolver um consenso sobre as questóes de mitigação de catástrofes e de utilização dos recursos; (3) liderança e coordenação, que envolva os vários níveis da administração, o setor privado, as organizaçóes não-governamentais e comunidades, garantindo uma abordagem integrada para a gestão da mitigação; (4) investigação, divulgação, informação e sistema de apoio à decisão, de forma que o 
conhecimento, acessível e coordenado, possibilite a melhor tomada de decisão sobre a redução das catástrofes; (5) sensibilização, formação e educaçáo, garantindo que os vários níveis de governação e os cidadáos reconhecem e entendem o risco e as medidas de reduçáo dos impactos. Uma visão mais operacional é proposta pela norma ISO (ISO 31000, 2009) que salienta que a gestão do risco permite, por exemplo, promover açóes proativas, aumentar a confiança dos stakeholders, estabelecer uma adequada base para a decisão e o planeamento, alocar os recursos ao tratamento dos riscos, aumentar a eficácia e eficiência operacional, minimizar as perdas, melhorar os processos de aprendizagem e a resiliência organizacional.

Verifica-se, nomeadamente na última década, a preocupaçáo crescente na participaçáo individual e coletiva nos processos decisórios sobre o risco, assim como na explicação, por parte dos reguladores do risco, de como direcionar medidas de mitigaçáo para os riscos mais graves, para os territórios mais expostos ou para os locais onde é necessário maior controle (Renn e Klinke, 2013; Santos e Tavares, 2015).

Como referem Aven e Renn (2010) os modelos de governaçáo do risco permitem conhecer as açôes ou medidas que podem apresentar limitaçôes, assim como identificar o nível de monitorizaçáo para avaliar o desempenho, a par do conhecimento dos custos e benefícios associados a cada opção.

É neste contexto que se apresentam os três modelos associados à gestáo ou governaçáo do risco, os quais utilizam ou organizam diferenciadamente os mecanismos de decisão, apresentam formas distintas de comunicaçáo, ou definem objetivos contrastados de monitorização ou revisão. Por simplificação de designação considera-se um modelo sequencial, muito associado ao controlo dos processos, um modelo cíclico vocacionado para o desenvolvimento organizacional e um modelo multinível que valoriza as interaçôes múltiplas.

\section{O modelo sequencial de gestáo do risco}

O modelo sequencial tem vindo a ser utilizado por diferentes organizaçóes para a gestão do risco (FEMA, 2004; EMA, 2004; ANPC, 2009, FSEPS, 2010), sendo igualmente o apresentado pela norma ISO 31000 (2009). Segundo esta norma a ges- 
tão do risco constitui um conjunto de atividades coordenadas para dirigir as organizaçóes em relação ao risco, as quais envolvem processos de construção, implementação, monitorização e revisão. A natureza preventiva associada envolve desde formas de prevenção e redução, a formas de mitigação racional. A organização norte-americana FEMA (2004) recorre ao modelo sequencial, o qual é suportado pela organização de recursos, a que se segue a avaliaçáo do risco, para fundamentar a sequente construção de um plano de mitigação, estratégico e focado na minimização dos impactos. Este modelo é ulteriormente composto por açôes de implementação e de monitorização do plano, com base em avaliaçóes periódicas e revisôes eventuais.

A organização conceptual deste modelo, de acordo com a norma ISO 31000 (2009), apresenta uma análise sequencial, de fases sucessivas, em que na definição de contexto se debatem os parâmetros internos e externos que devem ser tomados em consideração na gestão do risco, assim como se definem os objetivos e os critérios para a gestão dos riscos (fig. 1). Como contexto externo são considerados o ambiente social, cultural, político, legal, regulamentar, financeiro, económico e natural, a diferentes escalas, presente na área em análise, assim como os elementos exteriores com impacto nas organizaçôes, ou as perceçóes e valores das partes interessadas externas. Como contexto interno são considerados a cultura, processos e estratégia das organizaçóes relacionadas com o risco, podendo incluir o levantamento dos recursos materiais e humanos, a capacitação institucional, nomeadamente a relacionada com os sistemas de informação e comunicação e com os procedimentos e normas adotadas.

Procura-se com este levantamento inicial estabelecer os objetivos a desenvolver na análise do risco, as metodologias a utilizar, assim como, definir os critérios para o acesso aos dados sobre processos e catástrofes, quer tendo em consideração a visão dos stakeholders e o nível de aceitabilidade do risco.

Por sua vez, a avaliação do risco inclui diferentes ações que passam pela identificação do risco, a análise do risco e a avaliação/classificação do risco. Aquando da identificação do risco procura-se conhecer as fontes do risco, as áreas de impacto, o tipo de processos, suas causas e potenciais consequências, os elementos expostos e a vulnerabilidade destes. Com um conjunto de procedimentos diversificados e temporalmente extensos, procura-se identificar o conjunto de processos potencialmente 
perigosos, afetando, ou não, os contextos, interno ou externo, da organização. É frequente nesta fase que se realize a consideraçáo de cenários, ou de efeitos cumulativos ou em cascata, o que pode incluir novas metodologias e a integraçáo de outros domínios de conhecimento.

Com a análise do risco pretende-se considerar, para as diferentes fontes e tipos de risco, as consequências positivas ou negativas, e a probabilidade com que podem ocorrer. A partir da identificaçấo dos fatores que determinam as consequências ou a probabilidade dos processos e da avaliaçáo dos elementos de minimização ou controlo instalados, é possível definir níveis de risco que devem ser consistentes com os critérios de risco definidos previamente. A análise do risco pode recorrer a métodos determinísticos, probabilísticos ou estocásticos, dependentes do acesso e confiança de dados e da escala de análise (Guzzetti et al., 1999; Grêt-Regamey e Straub, 2006; van Westen et al., 2008; Zêzere et al. 2008).

Com a avaliação/classificação do risco pretende-se comparar os níveis de risco obtidos com os critérios definidos para os contextos interno e externo. É com base nesta avaliação/classificaçáo dos riscos que se devem ajustar os critérios de tolerabilidade às decisóes sequentes de mitigaçáo, por via estrutural ou não estrutural. A avaliaçáo do risco é suportada, por exemplo, por diversas matrizes de interação (HSE, 2001; OHS, 2004; AS/NZS4360, 2004; IDEHLG, 2006; OEM, 2008; ANPC, 2009).

$\mathrm{O}$ tratamento do risco representa o processo de seleção de medidas para modificar os riscos, mas também a decisão do nível residual do risco que é considerado tolerável, assim como a consideraçáo sobre a eficácia das medidas a implementar (Godschalk et al., 1999; Crozier, 2006; Meyer et al., 2013).

As açôes de comunicação e consulta incluem, em contínuo, a partilha de informação sobre os riscos e respetivas causas e consequências, sendo que procuram igualmente facilitar as fases de implementação do processo de gestão e de aceitação pelos interessados nas decisōes (Höppner et al., 2010; Kellens et al., 2013).

Com a monitorização e revisão dos procedimentos de gestáo pretende-se assegurar o controlo efetivo e eficiente do tratamento, melhorar o nível de conhecimento sobre os riscos e identificar os riscos emergentes, incorporando na gestão as modificaçóes ocorridas nos contextos, interno e externo, bem como as aprendizagens reais ou simuladas. 


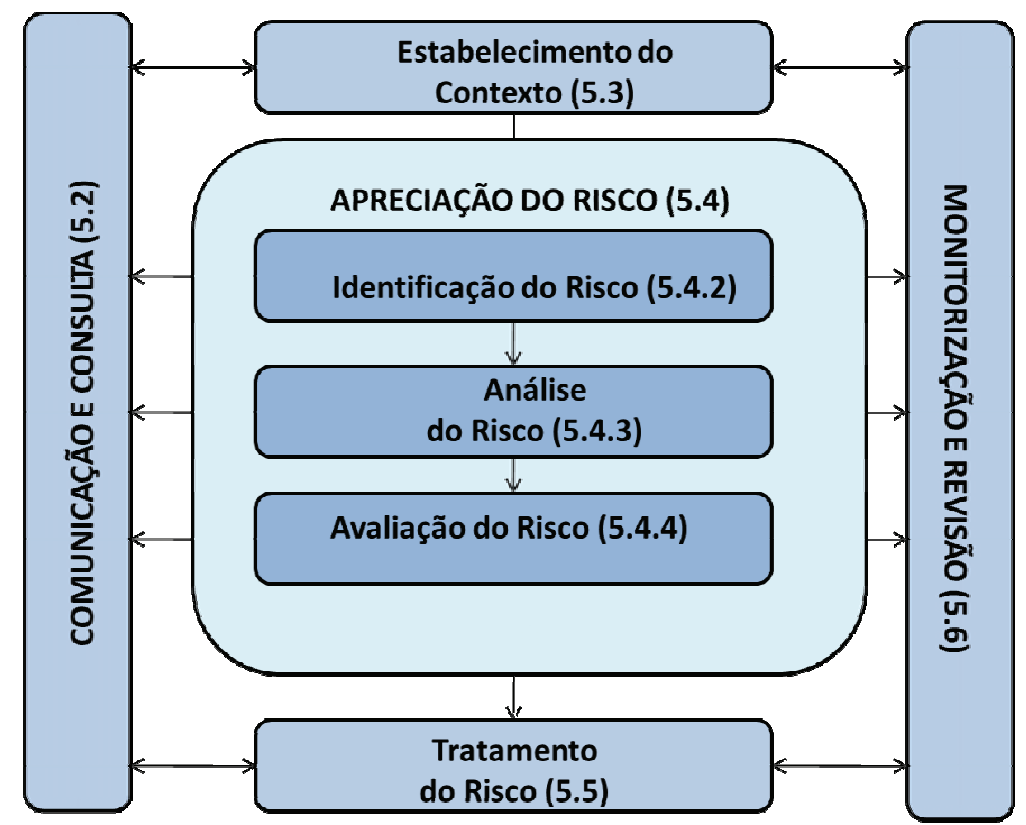

Fig. 1 - Modelo de gestão sequencial do risco, a partir da norma ISO 31000 (2009).

Fig. 1 - Sequential risk management model, based on ISO 31000 (2009).

Este modelo é baseado em quatro tarefas estruturantes: a avaliação dos recursos e da área de atuação, a identificação das condicionantes territoriais e organizacionais, a construção de respostas sequenciais, traduzindo a diminuição dos impactos ou dos obstáculos institucionais, e a implementação formal de ações.

A aplicação deste modelo por Ayala-Carcedo (2002), para a gestão dos riscos naturais, envolve genericamente três fases: o inventário dos fatores de risco, a análise do risco e a definição da redução ou das estratégias de mitigação do risco (fig. 2). O fluxograma ilustra a gestão do risco, a qual incorpora, para além das formas intrínsecas de avaliação do risco, os vetores extrínsecos que condicionam as estratégias de gestấo do risco. Estes vetores extrínsecos podem ser organizados em dois blocos, os que resultam de fatores societais, como a admissibilidade económica, social, legal e de prioridade pública, e os que remetem para fatores de tomada de decisão, como a seleção de medidas mitigadoras ou de operacionalização. 


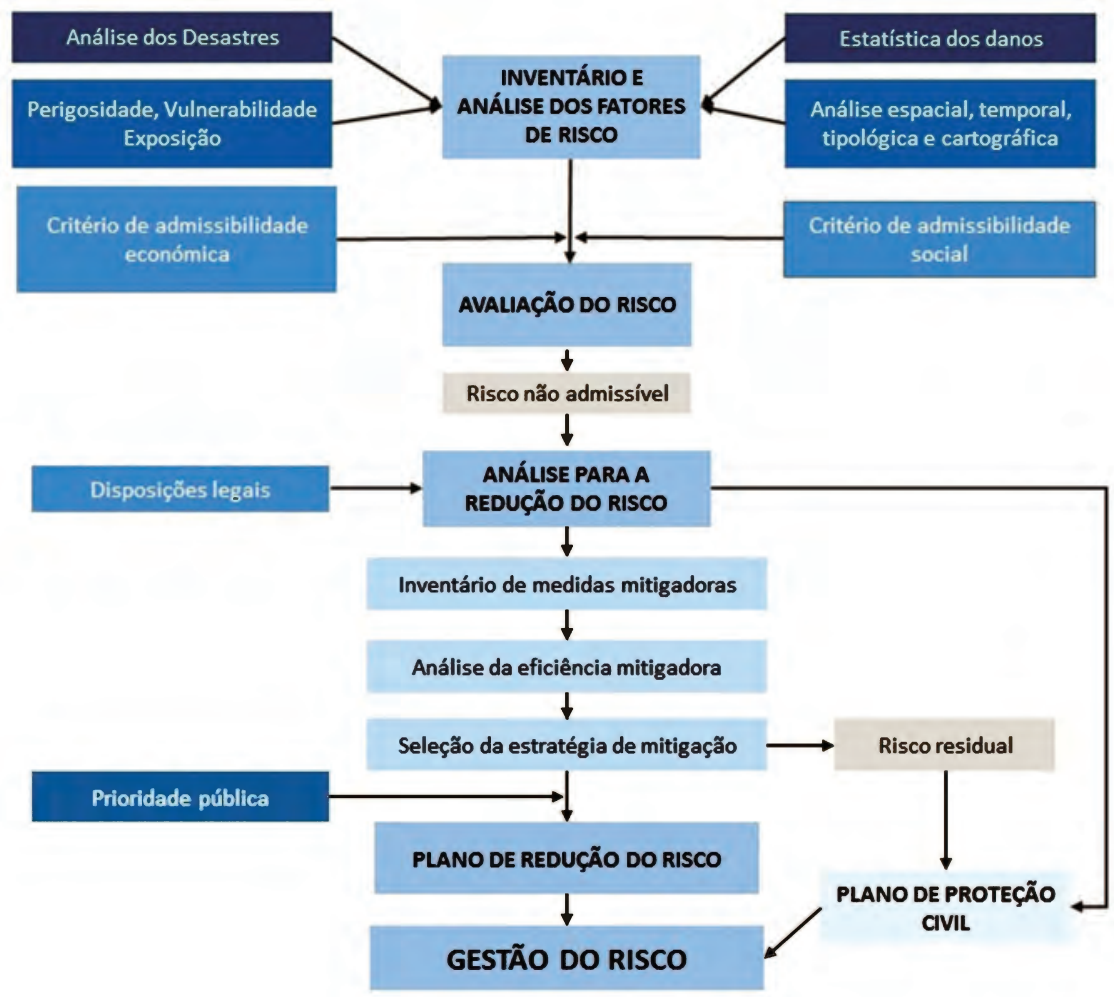

Fig. 2 - Modelo sequencial de gestáo dos riscos naturais, segundo Ayala-Carcedo (2002)

Fig. 2 - Sequential model for natural risk management, according to Ayala-Carcedo (2002).

O processo de análise inicia-se com a identificação e caracterização dos processos perigosos que, histórica e potencialmente, afetaram o território ou geraram impactos, para sequentemente se avaliar o risco mediante critérios e se proporem medidas de mitigação na dependência da redução dos fatores de impacto (Godschalk et al., 1999; FEMA, 2010).

Este modelo sequencial pode ser considerado como aquele que suporta respostas a problemas específicos, fundamentando a escolha de medidas de mitigação. É tipicamente utilizado pelas agências da administração (quer central, regional ou local) para respostas de redução do risco. Este modelo é utilizado pelos agentes 
operacionais para a resposta de emergência no contexto do acesso e utilizaçấo de recursos. Constitui, assim, um modelo de gestão do risco do agrado dos decisores em situaçôes de crise ou de emergência.

\section{O modelo cíclico de gestáo do risco}

Com a ampliação da noção de gestão para formas envolvendo as estruturas e os processos de tomada de decisão coletiva, envolvendo diferentes atores (Keohane e Nye, 2000; Aven e Renn, 2010), construiu-se um nível de interação entre as instituiçôes governamentais, as forças económicas e os atores da sociedade civil, correspondendo a um outro modelo de gestão do risco.

O modelo cíclico mais generalizado é o proposto pelo International Risk Governance Council (IRGC, 2005) e está organizado em quatro fases sequentes, onde a comunicaçâo é considerada fundamental em todas as fases de avaliação do processo. Este modelo sublinha o esforço contínuo de comunicaçáo do risco, não só na vertente de divulgação, mas também na interação entre os atores e na troca de informaçôes, o que sugere um conjunto de recursos disponíveis e uma estratégia de envolvimento das diferentes partes interessadas (Klinke e Renn, 2012), a qual deve ser abrangente e reconhecida pela comunidade. A necessidade de conciliar o conhecimento científico com instrumentos técnicos emerge com a inclusão de experiências e práticas a partir do envolvimento dos atores (Vandermoere, 2008; Mendes e Tavares, 2009), ou de perceçôes cognitivas e culturais (Siegrist et al., 2005; Kellens et al., 2011).

De acordo com a ciclicidade que caracteriza este modelo de gestáo do risco, as açôes estão baseadas em dois domínios: um domínio de aquisição de conhecimentos e um domínio de gestâo (fig. 3). O modelo compreende um quadro amplo que inclui não só a análise do risco, mas também a tomada de decisões com diversos atores, exigindo a coordenação e a conciliação entre objetivos, perspetivas e atividades. $\mathrm{O}$ modelo apresentou, quando da sua formulaçáo, duas grandes inovaçôes: o contexto social e a categorizaçáo dos conhecimentos relacionados com o risco. 
As açóes do ciclo de gestão do risco iniciam-se por duas etapas que contêm a avaliação do problema e a avaliação do risco, baseadas nos recursos, no levantamento e cartografia dos processos de risco. A etapa seguinte é a de caracterização e análise do risco, sendo baseada nas preocupaçóes e dados anteriores. A fase de decisão e gestão sensu stricto envolve as relaçôes entre os instrumentos institucionais e regulamentares no âmbito de proteção civil, bem como os relacionados com a população e o território (EMA, 2004). Esta visão cíclica e retroalimentada traduz uma aproximação holística sobre a gestão dos riscos e a tomada de decisão, apoiadas por estratégias de interação consistentes

Os objetivos da fase de pré-avaliação são elencar tanto a variedade de problemas que as partes interessadas associam a um determinado risco ou multirriscos, como os indicadores existentes, procedimentos e convençóes que influem na avaliação do risco. A perceção do risco pode ser diferente para os vários grupos de atores, sendo importante que na pré-avaliação se estabeleça um entendimento comum sobre o risco e sobre os impactos previsíveis. A fase de pré-avaliação corresponde ainda à deteção precoce e ao acompanhamento das evidências do processo perigoso, assim como ao levantamento dos meios institucionais de monitorização e de alerta precoce. Esta fase inclui, ainda, a pré-triagem dos sistemas operacionais acessíveis, bem como a seleção das diretivas, protocolos, convençôes e regras disponíveis para a avaliação e gestão do risco.

O objetivo da fase de avaliação do risco é o de proporcionar a base de conhecimento para a decisão societal sobre o que é considerado, ou não, risco e em caso afirmativo, sobre as eventuais medidas de prevenção, redução ou mitigação a implementar.

A primeira componente procura associar as fontes potenciais de dano, as características dos processos perigosos, com prováveis consequências, especificando a probabilidade de ocorrência dos processos. Dependendo da fonte do risco, da cultura organizacional e das especificidades da comunidade, existem diferentes formas para a estruturação da caracterização/análise do risco, que incluem a identificação e, se possível, a estimativa do risco, a avaliação de exposição e/ou da vulnerabilidade e a estimativa das consequências do risco. $\mathrm{O}$ último passo que corresponde à estimativa do risco agrega os resultados em função de graus de gravidade e da probabilidade de ocorrência. A dificuldade de estabelecer relaçóes de causa/efeito, a qualidade 
dos dados e dos modelos de conhecimento condiciona a avaliação do risco, dando lugar a três dimensóes que devem ser explicitadas - a complexidade, a incerteza, e ambiguidade (IRGC, 2005; Aven e Renn, 2010).

A segunda componente da avaliação corresponde ao levantamento do grau de conhecimento e da perceçáo das partes interessadas, bem como sobre as prováveis consequências sociais, implicaçôes económicas e respostas políticas. Corresponde a uma dimensão interdisciplinar em que as experiências prévias, as relaçóes de escala espacial e temporal, o nível de confiança nas instituiçôes, ou o nível de sensibilização determinam a avaliação do risco como salientam Tavares et al. (2011).

A fase de análise do risco tem como objetivo avaliar a aceitabilidade e/ou tolerabilidade de um risco, em que a um risco considerado aceitável são associadas limitadas consequências negativas, o que determina a não adoção de medidas de redução ou

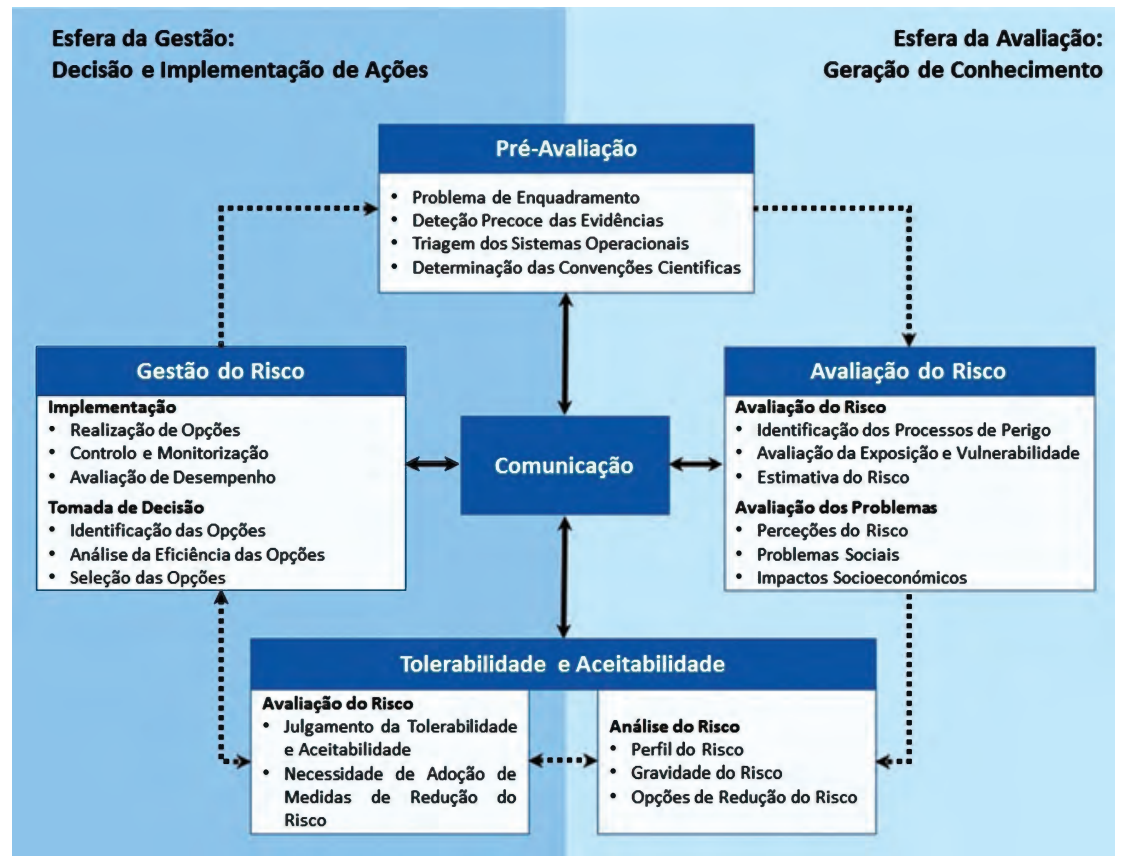

Fig. 3 - Modelo cíclico de gestão do risco, segundo o International Risk Governance Council (IRGC, 2005).

Fig. 3 - Cyclical model of risk management, according to the International Risk Governance Council (IRGC, 2005). 
mitigação. Este julgamento é constituído por várias componentes interligadas, que incluem as medidas consideradas para a redução e mitigação dos riscos, mas também a seleção da tecnologia disponível e necessária, bem como do potencial de substituição. Tomam-se ainda em consideração os fatores de compensação pela escolha de soluçóes, para além dos equilíbrios sociais e valorização dos custos e benefícios associados, num contexto das políticas e instrumentos de ordem pública (Woodruff, 2005; French et al., 2005). A capacidade de avaliar a dimensão societal do risco e comparar esta com a eficácia das várias medidas ou estratégias de mitigaçáo do risco (Leroi et al., 2005; Jonkman et al., 2011; Bedford, 2013) é um recurso utilizado para facilitar a decisão, sendo exemplo as curvas F-N (frequência-número de afetados).

A fase de gestáo $s$. s. do risco corresponde à implementaçáo das açôes e recursos necessários para prevenir, reduzir ou mitigar os riscos. Baseia-se numa sequência de etapas que fundamentam a tomada de decisão, que se inicia pela reavaliação do conhecimento adquirido na fase de avaliação do risco, permitindo a seleção de potenciais opçôes baseadas em critérios de eficácia e eficiência, de minimização dos efeitos colaterais e de sustentabilidade. Após esta avaliação é selecionada a opçáo a ser implementada, assim como são definidas as medidas de acompanhamento periódico e de avaliação de desempenho.

É a partir da consideração das quatro categorias de risco (Aven e Renn, 2010), baseadas nas condiçôes de rotina/linearidade, complexidade, incerteza e ambiguidade, que se definem os princípios específicos de segurança e, consequentemente, se projetam as medidas específicas para a gestáo do risco.

A fase remanescente do processo de gestão do risco é a comunicação, a que corresponde a função de permitir a ligação entre as partes interessadas, e simultaneamente, permitir entender a lógica dos resultados e das decisóes tomadas. Esta fase facilita a tomada de decisão, equilibrando os conhecimentos técnicos e científicos com os interesses pessoais, preocupaçóes, crenças e valores. A comunicação eficaz promove a confiança institucional, a cooperação pessoal e organizacional, o reconhecimento da informação e a tolerância sobre pontos de vista conflituantes (Aven e Renn, 2010; Wachinger et al., 2013).

A comunicação do risco permite, igualmente, a conciliação do conhecimento científico com os instrumentos técnicos, a inclusão das experiências e práticas locais 
nas medidas de gestão do risco, a articulação dos instrumentos de gestão do risco com os instrumentos de ordenamento do território (Tavares, 2010; Kellens et al., 2013).

A redefinição do modelo cíclico produzido por Renn e Klinke (2013) salienta a necessidade de incorporar na gestáo do risco a capacidade das instituiçóes, nomeadamente com o dimensionamento dos recursos institucionais e financeiros nos processos de decisão, bem como o conhecimento dos recursos técnicos e dos recursos humanos disponíveis. O papel da comunicação no envolvimento adequado das partes interessadas e do público (fig. 4), considera que só assim se assegura a integração da capacidade de adaptação e se promove a aceitação social das soluçôes de gestão e de governação do risco.

Esta abordagem associa ao modelo cíclico de gestão do risco do IRGC (2005) uma nova dimensão de natureza institucional e organizativa, a qual é decisiva quer na avaliação do risco e no julgamento das potenciais açóes, quer nos processos de decisão, do ponto de vista instrumental e de envolvimento das partes interessadas.

O modelo ć́clico de gestáo do risco é muito utilizado nos processos de planeamento, constituindo a estrutura que fundamenta as opçóes das organizaçôes e

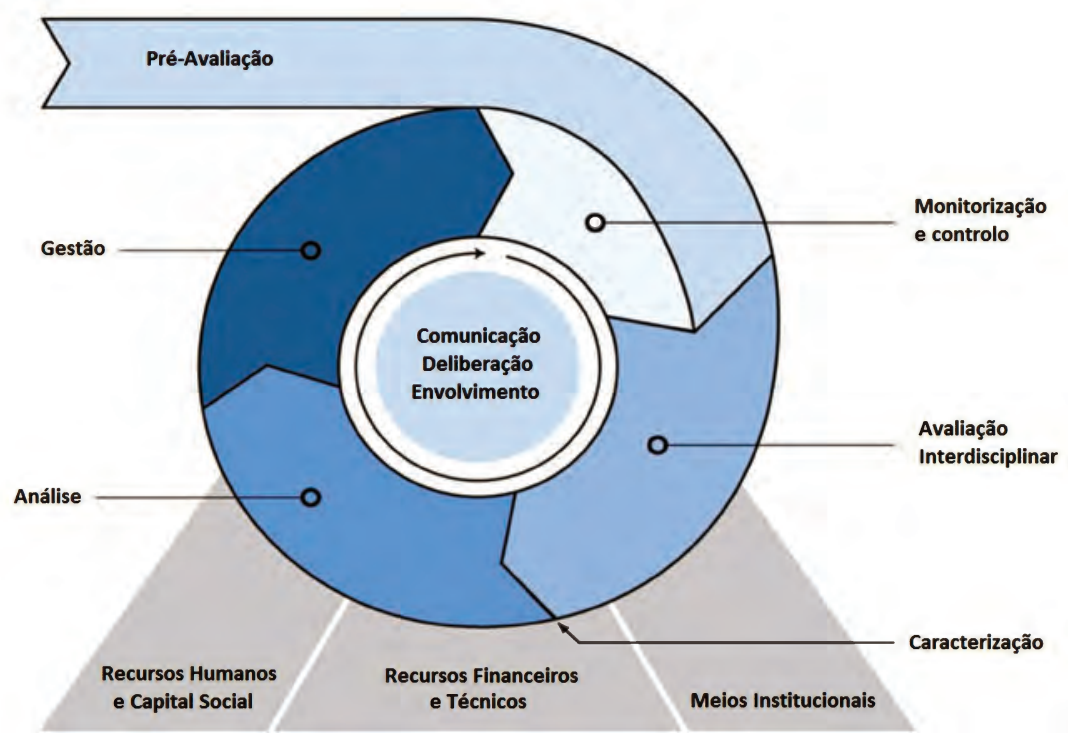

Fig. 4 - Modelo cíclico de gestão do risco, segundo Renn e Klinke (2013).

Fig. 4 - Cyclical model of risk management, according to Renn \& Klinke (2013). 
que suporta os processos de decisão. A criação de planos e de rotinas de interação e partilha de recursos é facilmente enquadrável por este modelo de gestão, tanto para medidas preventivas, de emergência como de recuperaçáo. $\mathrm{O}$ modelo cíclico apresenta o desenvolvimento em contínuo, consumindo muitos recursos na construção e validaçáo, assim como na revisão e monitorização.

\section{O Modelo multinível de gestáo do risco}

A gestão do risco, ao refletir tanto a estrutura institucional, os processos de decisáo que orientam as respostas coletivas de prevençáo, redução ou mitigação do risco, como o contexto geral dos processos e das configuraçóes estruturais de resposta (Pelling et al., 2008; Klinke e Renn, 2012), exige abordagens inclusivas.

Estas respostas baseiam-se no alargamento progressivo de açôes e atores na gestáo e governaçáo, sem que este facto represente uma hierarquização de procedimentos ou de níveis de conhecimento. Esta forma de abordagem permite, por exemplo, valorizar os aspetos naturais e sociais que são afetados pela decisão, identificar os indivíduos, grupos e organizaçôes potencialmente afetadas ou que tomam parte na decisão, assim como priorizar o envolvimento das partes interessadas nos processos de decisão (Reed et al., 2009). De acordo com Paton et al. (2001), a propósito do risco associado ao vulcanismo, os modelos de gestáo do risco e de construçáo de resiliência, baseiam-se nas inter-relaçôes entre três níveis de envolvimento progressivamente mais alargados, do individual ao coletivo e organizacional. De acordo com Meyer et al. (2009) a gestáo do risco de inundaçôes, dada a escala de tempo em que as decisōes operam ou o nível de incerteza associada aos modelos, requer diferentes níveis de resposta que devem estar presentes na tomada de decisão. Os autores assumem que este aspeto é vital para a abordagem dos vários processos perigosos e das múltiplas funçôes das bacias hidrográficas, bem como para a integração das caraterísticas sociais e organizacionais que promovem a capacidade de adaptação.

A abordagem multinível de gestão do risco permite, segundo Cash et al. (2006) ou Corfee-Morlot et al. (2011), reconhecer de forma flexível as prioridades das diferentes partes envolvidas, através do entendimento dos valores e perceçôes, assim 
como perceber os constrangimentos dos vários níveis de decisão da administração, e os contextos associados (domínio público ou privado, interesses setoriais ou não setoriais, agências governamentais ou não governamentais, escala local a supra nacional, comunidades ou agentes específicos).

Uma análise da qualidade das organizaçóes e do nível dos seus processos é determinante no processo de tomada de decisão, sendo a estabilidade organizacional um valor fundamental para a gestão do risco (Hiller, 2013). De acordo com Pahl-Wostl (2009) os modelos multinível de gestão, nomeadamente quando associados à gestão da água, justificam-se dado que os atores de um nível (por exemplo, o nível nacional) participam nos processos de decisão de outros níveis (por exemplo, o nível regional ou de bacia hidrográfica), podendo assim os atores ser ativos na produção das regras que os influenciam. Esta visão multinível pode ainda ser justificada dado que as instituições (formais e informais), produzem processos que influenciam outros níveis, traduzindo fluxos de autoridade/decisão top-down ou bottom-up, assim como o conhecimento produzido num nível influencia as decisóes tomadas noutros níveis de conhecimento (por exemplo, entre o conhecimento produzido nas instituiçóes setoriais ou na academia).

A necessidade de participação das partes interessadas na tomada de decisão partilhada, em que as entidades adotam um papel multifacetado (perito, responsável ou interessado em função dos temas discutidos) é fundamental para o estabelecimento de modelos coerentes e reconhecidos, como salienta Heintz et al. (2012), ao evocar um modelo multinível para a gestão das inundações.

O modelo multinível (fig. 5) reflete, segundo Corfee-Morlot et al. (2011), os atores que influenciam a decisão sobre o risco, os grupos ou formas de deliberação ou persuasão associados, assim como os conhecimentos e os recursos técnicos e científicos disponíveis na tomada de decisão. De acordo com os autores o modelo é caraterizado por diferentes níveis escalares de decisão, do local ao nacional, os quais pode ser extrapolados para níveis supranacionais a globais.

Os diferentes níveis de decisão podem ser organizados segundo uma área central, uma área interna e uma área externa. A área central inclui as instituiçôes com capacidade formal de decisão, capazes de influenciarem diretamente o processo de avaliação e a decisão sobre o risco. A área interna associa as organi- 


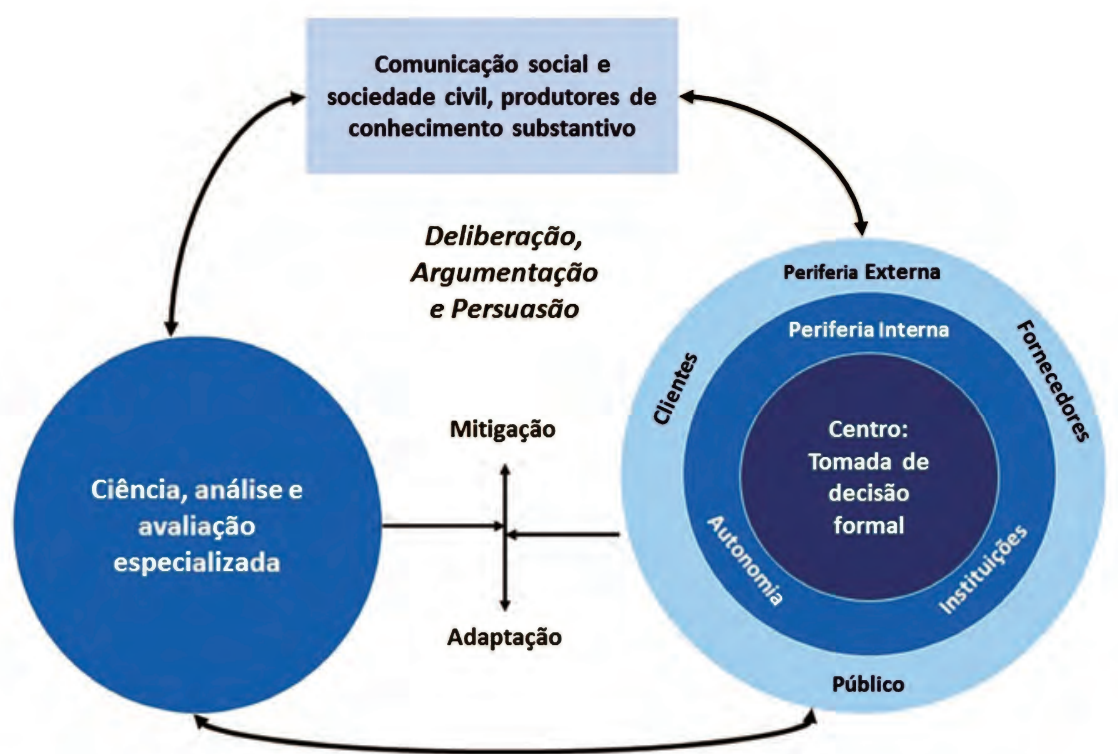

Fig. 5 - Modelo multinível de gestão do risco, segundo Corfee-Morlot et al. (2011).

Fig. 5 - Multi-level model of risk management, according to Corfee-Morlot et al. (2011).

zaçóes e instituiçóes capazes de influenciarem o nível de decisão, quer ao nível da priorização de medidas de adaptação quer na seleção das açôes de mitigação. A área externa pode ser considerada o nível periférico de decisão, corresponde à esfera pública, e engloba os cidadãos, as instituiçóes da sociedade civil, a comunicação social e outras partes interessadas. De acordo com este modelo permite-se ultrapassar muitas das limitações locais para a implementação das medidas de adaptação às alterações climáticas, através de processos deliberativos, mostrando que a governação das mudanças climáticas em todos os níveis de governo, e com todas as partes interessadas, é relevante para evitar lacunas entre a política dos planos de ação locais e as estruturas de política nacional (integração vertical) e para incentivar aprendizagens multi-escalares, entre serviços competentes ou instituiçôes da administração local e regional (dimensão horizontal) (Corfee-Morlot et al., 2009).

Uma representação deste modelo multinível, baseia-se na responsabilidade política, em que a decisão formal sobre as medidas de gestão do risco são su- 
portadas em primeiro lugar pela construção substantiva e seleção de medidas de mitigação ou adaptação, as quais são analisadas segundo as dimensōes técnico/ jurídicas e os mapas de interesses (fig. 6). Chegada a decisão formal, decorre a aplicação das medidas, as quais são monitorizadas na aplicação e na necessidade de reformulação da decisão, retomando-se a responsabilidade política do ato de gestáo. Expressa-se assim, a gestáo do risco, como forma crítica de interagir em redes complexas de julgamento e decisão sobre o risco, ou como a forma normativa para comunicar com as partes interessadas da sociedade sobre como lidar com os riscos van Asselt e Zelli (2014).

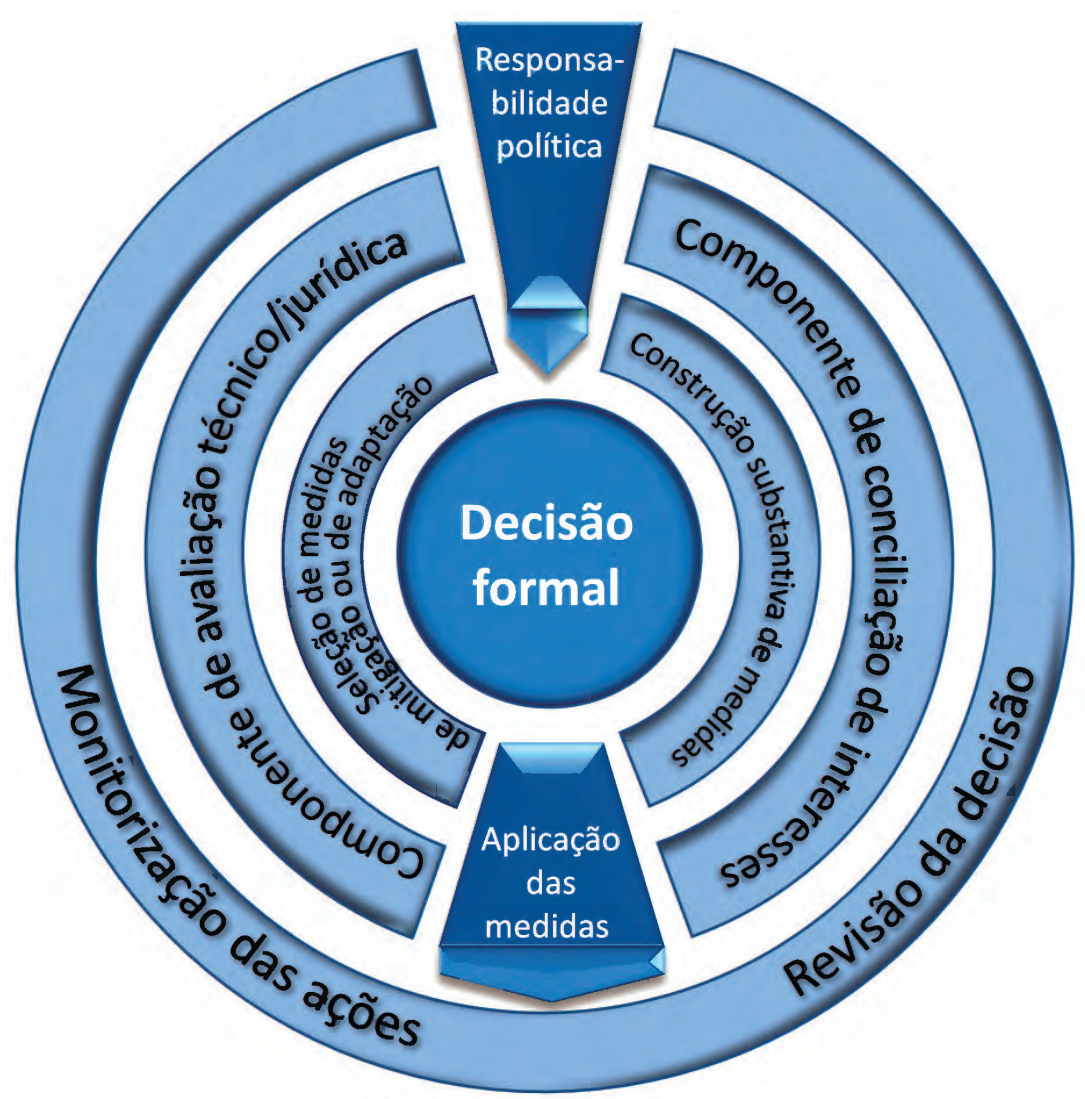

Fig. 6 - Modelo multinível de gestão do risco.

Fig. $\mathbf{6}$ - Multi-level model of risk management. 
Este modelo de gestâo reconhece a complexidade dos atores e a diversidade dos contributos para a gestão do risco, assumindo a importância da visão dos vários setores para a formulaçáo das açóes de mitigação ou adaptação. Assume a centralidade da decisão formal, a partir de estruturas hierarquizadas. Trata-se de um modelo que tem suportado as opçōes no âmbito das políticas de adaptação às alterações climáticas, tendo ganho importância enquanto modelo para situaçóes de partilha coletiva do risco para problemas caracterizados pela ambiguidade e incerteza.

\section{Conclusão}

A gestáo do risco pode ser considerada como a forma de implementar políticas de regulação pública para reduzir as consequências de eventos perigosos (Alesch $e t$ al., 2012), o que influencia quer a capacidade de suporte disponível na sociedade, comunidade ou organizaçóes para responder às solicitaçóes individuais e coletivas (UNISDR, 2009), quer a capacidade dos diferentes atores para lidarem com o risco (Höppner et al., 2010). Como referem Martins e Lourenço (2009) a gestáo do risco inclui para além da cultura, processos, estruturas e meios dirigidos para a prevenção e combate dos efeitos do risco, uma dimensão de comunicação que envolve a informaçáo e os avisos e alertas dirigidos à populaçáo.

As políticas públicas requerem, por sua vez, abordagens holísticas centradas nas interdependências e inter-relaçôes entre grupos (Klinke e Renn, 2006), pedindo diferentes níveis de análise e de envolvimento de atores, o que constitui, simultaneamente, a oportunidade para a gestáo escalar do risco, na aceção de Fekete e outros (2010), ou para a alocação de recursos, segundo Murphy e Gardoni (2007).

As relaçôes entre o contexto territorial do risco e os modelos organizados de gestáo constituem o suporte para os instrumentos de política pública previstos para a prevenção, redução ou mitigação dos riscos naturais em Portugal.

Os referenciais para Portugal das políticas de gestáo do risco estão fundamentalmente alicerçados em lógicas top down, e baseados em instrumentos estratégicos, regulamentares ou operacionais (Tavares, 2013b). O complexo quadro de instrumentos e normas existente pressupóe a articulação entre orientaçóes top down e as 
práticas ou instrumentos locais, municipais ou intermunicipais, o que, enquanto processo continuado de interação, não está isento de inconformidades, como salientam Tavares e Mendes (2010) ou Tavares (2010).

Por exemplo, na sua conceção e desenvolvimento, os Planos Municipais de Defesa da Floresta contra Incêndios e os Planos Municipais de Emergência e Proteção Civil assumem um modelo cíclico de organização e interação/comunicação com os agentes e a comunidade, o que não os isenta de frequentes conflitos pela ausência de modelos formais de decisão e de responsabilização política. Os mecanismos de avaliação e aprovação destes planos pressupóem a obrigatoriedade de conteúdos que vão para além da articulação interinstitucional e da coordenação de meios, o que limita o seu reconhecimento e aceitação local, e, simultaneamente, não valoriza o contexto intermunicipal, com a continuidade espacial de pressupostos e medidas.

A análise da transposição da Diretiva Comunitária sobre a Gestão de Inundaçóes, pelo Dec. Lei no 115/2010, mostra um conjunto de açóes que remetem para um modelo cíclico de gestão, visando reduzir as consequências prejudiciais. Contudo, na sua organização os planos de gestão associados às inundaçóes traduzem um modelo sequencial de gestão, centrados na dimensão administrativa, na redução das potenciais consequências prejudiciais das inundaçóes, e na admissibilidade de iniciativas não estruturais e/ou na redução da probabilidade de inundaçôes (Santos et al., 2014). Os mecanismos de participação e comunicação não se constituem como centralidade do processo de gestão, desvalorizando o conhecimento local, a importância dos impactos indiretos, ou os mecanismos de participação envolvendo os setores público e privado. Assim, análise e gestão das inundações não remetem para abordagens multinível, que permitam a contingência para os setores económicos e a proteção civil, visando assegurar a eficácia das operações de emergência, bem como assegurar a comunicação entre as partes interessadas.

O regime jurídico da Reserva Ecológica Nacional, Decreto-Lei n. ${ }^{o}$ 239/2012, enquanto salvaguarda da preservação dos valores naturais fundamentais, bem como da prevenção e mitigação de riscos para pessoas e bens, institui um conjunto de condicionamentos à ocupação, uso e transformação do solo, identificando os usos e as açóes compatíveis. Trata-se de um instrumento de decisão formal, baseado em pressupostos substantivos para os quais se estabelecem medidas para prevenir e re- 
duzir os efeitos da degradação da recarga de aquíferos, dos riscos de inundação marítima, de cheias, de erosáo hídrica do solo e de movimentos de massa nas vertentes, contribuindo para a adaptaçáo aos efeitos das alteraçóes climáticas e acautelando a sustentabilidade ambiental e a segurança de pessoas e bens. Trata-se, assim, de um instrumento multinível de gestáo do risco, envolvendo uma responsabilização política, que consagra no $\operatorname{Art}^{\circ} .60^{\circ}$ o direto à informação e participaçáo, ou no $\operatorname{Art}^{\circ}$. 27..$^{\circ}$ a invalidade dos atos e a responsabilidade civil. O regime jurídico da REN tem apresentado um nível de conflito elevado entre as diferentes entidades envolvidas na proposta, conferência e aprovaçáo das áreas delimitadas e da viabilização de usos, considerando-se que os processos de deliberação são pouco flexíveis ou incorporando uma limitada conciliação de interesses. Decorre, assim, um quadro sequencial estrito de aplicação em que as medidas de mitigação são consagradas pelas orientaçôes operativas, nomeadamente a delimitação das áreas de prevenção de riscos naturais.

Os Programas de Ordenamento da Orla Costeira constituem formas de intervenção que visam a prossecuçáo dos interesses públicos e estabelecem regimes de salvaguarda de recursos e valores naturais, através de medidas que instituem açóes permitidas, condicionadas ou interditas. Estes planos, agora programas, na sua estruturação utilizam um modelo cíclico de gestão permitindo enquadrar açôes de adaptaçáo que englobem a proteção costeira, a acomodação e o recuo planeado/ relocalização da ocupação. Estes instrumentos de gestão territorial, encontram-se regulamentados pelo Decreto-Lei n. ${ }^{\circ}$ 159/2012, que define o quadro de princípios a observar na gestão da orla costeira, permitindo caracterizar a morfodinâmica costeira, nomeadamente a suscetibilidade ao galgamento, a sensibilidade à erosão e o balanço sedimentar, assim como, identificar as áreas críticas determinadas pela degradaçáo e conflitos de uso, ou a necessidade de intervençôes de adaptaçáo às alteraçôes climáticas. Há semelhança com as Bases para a Estratégia da Gestão Integrada das Zonas Costeiras, define-se um modelo multinível e multissetorial para a gestão costeira, visando contenção de usos e atividades que possam ampliar a exposição ao risco atual e futuro, assim como de corresponsabilizaçáo e operacionalizaçáo que integre as componentes de intervençóes de defesa costeira com a gestáo dos espaços em risco. Contudo as açôes de intervenção ligadas à monitorização e partilha de 
conhecimento, bem como às intervenções estruturais e não estruturais de salvaguarda do equilíbrio biofísico e da segurança, decorrem de intervençôes de gestão sequencial, baseadas na eficácia das medidas de mitigação, centradas via de regra na proteção de pontos críticos. Emergem sobre a gestão da orla costeira conflitos que radicam na não clareza do modelo de gestão do risco, dado que na conceção é multinível, na implementação é cíclico e na operacionalização do risco é sequencial.

O Plano Especial de Emergência para o Risco Sísmico na Área Metropolitana de Lisboa e Concelhos Limítrofes é um instrumento cíclico de suporte ao sistema de gestão operacional em caso da ocorrência de um evento sísmico na região. Visa implementar a autoproteção baseada na mobilização cívica e em comportamentos previsíveis para os indivíduos e os grupos sociais. Este plano ao concentrar os seus objetivos na coordenação da resposta, disponibilização de meios indispensáveis à minimizaçáo dos efeitos adversos ou de promoção de estratégias de continuidade de funçôes da sociedade estabelece uma abordagem sequencial estrita, abandonando a análise e julgamento do risco, ou tomadas de decisão locais. Por oposição ao Estudo do Risco Sísmico e de Tsunamis do Algarve, em que o diagnóstico, análise da vulnerabilidade e cenarização dos impactos é determinante, para a regiấo de Lisboa o Plano Especial não valoriza as medidas de adaptaçấo e prevençáo, ou estabelece um referencial de comunicaçáo e sensibilização alargada. Dado o enquadramento sismotectónico de Portugal e as vulnerabilidades associadas, seria determinante um modelo de gestáo multinível, onde os requisitos formais da decisão fossem claros, mas simultaneamente objeto de formas de persuasão e deliberação coletiva, para a prevenção, resposta e recuperação.

A escolha e a utilidade de um modelo, e as etapas em que este se desenvolve, estâo dependente dos dados e dos processos de análise utilizados (Handmer e Dovers, 2007), devendo ser compreensíveis tanto para os decisores como para o público (Schwab, 2010). Estes determinantes estáo, frequentemente, pouco presentes na seleção e implementação dos modelos de gestão do risco no País. A seleção e implementação de modelos para a gestâo do risco exigem uma avaliação, quer dos processos, quer da configuração institucional (Klinke e Renn, 2012), factos pouco decisivos nos pressupostos das políticas públicas em Portugal sobre a gestão do risco.

A exigência de políticas públicas de gestão do risco efetivas e transparentes emergem como uma das prioridades de ação saídas do Quadro de Sendai para 
2015-2030 para a redução do risco de catástrofes, tendo como objetivo o fortalecimento da prevençáo, mitigação, preparação, resposta, recuperação e reabilitação, num contexto de planeamento em que intervêm os distintos setores de atividade.

Ao nível da Uniăo Europeia o "Action Plan on the Sendai Framework for Disaster Risk Reduction 2015-2030 - A disaster risk-informed approach for all EU policies" estabelece os vetores de definiçẫo das políticas públicas para a gestão do risco, através de formas como: "building risk knowledge in EU policies; an all-of-society approach in disaster risk management; promoting EU risk informed investments; supporting the development of a holistic disaster risk management approach", determinando, como tal, uma articulação entre a tomada de decisão e os processos de decisáo, dado que os processos de julgamento e decisão sobre o risco exigem escolhas e dimensóes sociais caracterizadas pela complexidade, incerteza ou ambiguidade (Van Asselt e Renn, 2014).

\section{Referências bibliográficas}

Alesch, D. J., Arendt, L. A., Petak, W. J. (2012). Natural Hazard Mitigation Policies: Implementation, Organizational Choice, and Contextual Dynamics. Springer, Dordrecht.

Alexander, D. (2016). How to write an emergency plan. Dunedin Academic Press.

Amaro, A. (2005). Consciência e cultura do risco nas organizações. Territorium, (12), 5-9. http://impactum-journals.uc.pt/territorium/article/view/3372

ANPC (2009). Guia para a Avaliação de Risco no Âmbito da Elaboração de Planos de Emergência de Proteçấo Civil. Caderno Técnico PROCIV 9, Autoridade Nacional de Proteção Civil.

AS/NZS (2005). Risk Management Guidelines. Companion to AS/ NZS 4360:2004. In: Hand Book 436:2004. Standards Australial Standards, New Zealand, Wellington.

Aven, T., Renn, O. (2010). Risk Management and Governance: Concepts, Guidelines and Applications. Risk, Governance and Society, V. 16, Springer-Verlag Berlin Heidelberg.

Ayala-Carcedo, F.J (2002). Introducción al análisis y gestión de riesgos. Riesgos naturales. Ed. Ayala-Carcedo y Cantos, Barcelona, Ariel Ciencia, 133-146.

Bankoff, G. (2012). Historical concepts of disaster and risk. The Routledge Handbook of Hazards and Disaster Risk Reduction. London: Routledge.

Bedford, T. (2013). Decision making for group risk reduction: dealing with epistemic uncertainty. Risk Analysis, 33(10), 1884-1898.

Birkmann, F., Betsill, M. M., Gupta, J., Kanie, N., Lebel, L., Liverman, D., Schroeder, H., Siebenhüner, B., Zondervan, R. (2010a). Earth system governance: a research framework. International Environmental Agreements: Politics, Law and Economics, 10(4), 277-298. 
Birkmann, J., Cardona, O. D., Carreńo, M. L., Barbat, A. H., Pelling, M., Schneiderbauer, S., Kienberger, S., Keller, M., Alexander, D., Zeil, P., Welle, T. (2013). Framing vulnerability, risk and societal responses: the MOVE framework. Natural hazards, 67(2), 193-211.

Boin, A., Hart, P., Stern, E., Sundelius, B. (2005). The Politics of Crisis Management: Public Leadership under Pressure. Cambridge University Press, Cambridge.

Cardona, O. (2011). Disaster Risk and Vulnerability: Concepts and Measurement of Human and Environmental Insecurity. In Coping with Global Environmental Change, Disasters and Security. Threats, Challenges, Vulnerabilities and Risks. Brauch et al. (Eds.), Springer-Verlag Berlin Heidelberg, 3, 107-121.

Cardona, O., Bertoni, J., Gibbs, T., Hermelin, M., Lavell, A. (2010). Understanding and Managing Risk Associated with Natural Hazards: An Integrated Scientific Approach in Latin America and the Caribbean. ICSU - LAC, Science for a Better Life: Developing Regional Scientific Programs in Priority Areas for Latin America and the Caribbean. Vol. 2, Rio de Janeiro and Mexico City.

Cash, D., Adger, N., Berkes, F., Garden, P., Lebel, L., Olsson, P., Pritchard, L., Young, O. (2006). Scale and Cross-Scale Dynamics: Governance and Information in a Multilevel World. Ecology and Society, Vol. 11(2), 8p.

Christapolos, I., Mitchell, J., Liljelun, A. (2001). Re-framing d risk: the changing context of disaster mitigation and preparedness. Disasters, Vol. 25, nº3, 185-198.

Corfee-Morlot, J., Cochran, I., Hallegatte, S., Teasdale, P. J. (2011). Multilevel risk governance and urban adaptation policy. Climatic change, 104(1), 169-197.

Corfee-Morlot, J., Kamal-Chaoui, L., Donovan, M. G., Cochran, I., Robert, A., Teasdale, P. (2009). Cities, Climate Change and Multilevel Governance. Environmental Working Papers, 14, OECD publishing.

Crozier, M. (2006). Management Frameworks for Landslide Hazard and Risk: issues and options. Landslide hazard and risk. Glade, Anderson \& Crozier Eds. Wiley, West Sussex, 331-350.

de Almeida, A. B. (2011). Risco e gestâo do risco. Questôes filosóficas subjacentes ao modelo técnico conceptual. Territorium, (18), 23-31.

http://impactum-journals.uc.pt/territorium/article/view/3096/2351

Eiser, J. R., Bostrom, A., Burton, I., Johnston, D. M., McClure, J., Paton, D., van der Pligh, J., White, M. P. (2012). Risk interpretation and action: A conceptual framework for responses to natural hazards. International Journal of Disaster Risk Reduction, 1, 5-16.

EMA (2004). Emergency Risk Management Applications Guide. Emergency Management Australia, Manual 5, Australian Emergency Series.

Fekete, A., Damm, M., Birkmann, J. (2010). Scales as a challenge for vulnerability assessment. Natural Hazards, Vol. 55, 729-747.

FEMA (2004). Multi-hazard mitigation planning. Guidance under the disaster mitigation Act of 2000. FEMA, Federal Emergency Management Agency, Washington, DC 20472.

FEMA (2010). Developing and Maintaining Emergency Operations Plans. Comprehensive Preparedness Guide (CPG) 101, Version 2.0, Federal Emergency Management Agency.

French, S., Bedford, T., Atherton, E. (2005). Supporting ALARP decision making by cost benefit analysis and multiattribute utility theory. Journal of Risk Research, 8(3), 207-223.

FSEPS (2010). A guide to risk assessment in major emergency management. Guidance document 1 . Fire Services and Emergency Planning Section, Irish Department of the Environment, Heritage \& Local Government, Dublin.

Godschalk, D., Beatley, T., Berke, P., Brower, D., Kaiser, E. J. (1999). Natural hazard mitigation: Recasting disaster policy and planning. Island Press. 
Grêt-Regamey, A., Straub, D. (2006). Spatially explicit avalanche risk assessment linking Bayesian networks to a GIS. Natural Hazards and Earth System Science, 6(6), 911-926.

Guzzetti, F., Carrara, A., Cardinali, M., Reichenbach, P. (1999). Landslide hazard evaluation: a review of current techniques and their application in a multi-scale study, Central Italy. Geomorphology, 31(1), 181-216.

Handmer, J., Dovers, S., (2007). The handbook of disaster and emergency policies and institutions. Earthscan, London.

Heintz, M. D., Hagemeier-Klose, M., Wagner, K. (2012). Towards a risk governance culture in flood policy-findings from the implementation of the Floods Directive in Germany. Water, 4(1), 135-156.

Hiller, P. (2013). Multi-level Governance in Environmental Risk Management. Oñati Sociolegal Series [online], 3 (2), 312-325.

Höppner, C., Bründl, M., Buchecker, M. (2010). Risk Communication and Natural Hazards. CapHazNet WP5 Report, Swiss Federal Research Institute WSL.

HSE (2001). Reducing Risks, Protecting People: HSE's Decision-making Process. Risk Assessment Policy Unit, Health and Safety Executive HSE Books, Her Majesty's Stationery Office, London.

Hwacha, V. (2005). Canada’s Experience in Developing a National Disaster Mitigation Strategy: A Deliberative Dialogue Approach. Mitigation and Adaptation Strategies for Global Change, 10(3), 507-523.

IDEHLG (2006). A Framework for Major Emergency Management - Working Draft. Guidance document 1: A Guide to Risk Assessment in Major Emergency Management. Irish Department of the Environment, Heritage \& Local Government.

IRGC (2005). Risk governance: Towards an integrative approach. White paper $n^{o} 1$. Renn \& Graham Annex. International Risk Governance Council, IRGC, Geneve.

ISDR (2009). Risk and poverty in a changing climate. Invest today for a safer tomorrow. 2009 Global Assessment Report on Disaster Risk Reduction, United Nations. Geneve.

ISO 31000 (2009). Guide 73. Risk Management - Vocabulary. Geneve.

Jonkman, S. N., Jongejan, R., Maaskant, B. (2011). The use of individual and societal risk criteria within the Dutch flood safety policy - Nationwide estimates of societal risk and policy applications. Risk Analysis, 31(2), 282-300.

Kellens, W., Zaalberg, R., Neutens, T., Vanneuville, W., De Maeyer, P. (2011). An analysis of the public perception of flood risk on the Belgian coast. Risk Analysis, 31(7), 1055-1068.

Kellens, W.; Terpstra, T. Maeyer, Ph. (2013). Perception and communication of flood risk: a systematic review of empirical research. Risk Analysis, Vol. 33, No. 1, 24-49.

Keohane, R., Nye Jr, J. (2000). Introduction 1, Governance in a globalizing world, Nye \& Donahue Eds. Washington, DC, USA: Brookings Institution, 1-43.

Klinke, A., Renn, O. (2006). Systemic risks as challenge for policy making in risk governance. In Forum qualitative sozialforschung/forum: qualitative Social Research. Vol. 7, No. 1.

Klinke, A., Renn, O. (2012). Adaptive and integrative governance on risk and uncertainty. Journal of Risk Research, 15(3), 273-292.

Komendantova, N., Mrzyglocki, R., Mignan, A., Khazai, B., Wenzel, F., Patt, A., Fleming, K. (2014). Multi-hazard and multi-risk decision-support tools as a part of participatory risk governance: feedback from civil protection stakeholders. International Journal of disaster risk reduction, 8, 50-67.

Leroi, E., Bonnard, C., Fell, R., McInnes, R. (2005). Risk assessment and management. Landslide risk management, 159-198. 
Martins, J., Lourenço, L. (2009). Os riscos em Protecção Civil. Importância da análise e gestão de riscos para a Prevenção, o Socorro e a Reabilitação. Territorium, 16, 191-217.

http://impactum-journals.uc.pt/territorium/article/view/3232/2480

Mendes, J. M., Tavares, A. (2009). Building resilience to natural hazards. Practices and policies on governance and mitigation in the Central Region of Portugal. Safety, Reability and Risk Analysis: Theory, Methods and Applications. Taylor \& Francis Group, London, 1577-1584.

Meyer, V., Becker, N., Markantonis, V., Schwarze, R., van den Bergh, J. C. J. M., Bouwer, L. M., Bubeck, P., Ciavola, P., Genovese, E., Green, C., Hallegatte, S., Kreibich, H., Lequeux, Q., Logar, I., Papyrakis, E., Pfurtscheller, C., Poussin, V., Przyluski, V., Thieken, A.H., Viavattene, C. (2013). Review article: Assessing the costs of natural hazards-state of the art and knowledge gaps. Natural Hazards and Earth System Science, 13(5), 1351-1373.

Meyer, V., Haase, D., Scheuer, S. (2009). Flood risk assessment in European river basins-Concept, methods, and challenges exemplified at the Mulde River. Integrated environmental assessment and management, 5(1), 17-26.

Murphy, C., Gardoni, P. (2007). Determining public policies and resources allocation priorities for mitigation natural hazards: a capabilities-based approach. Science and Engineering Ethics, Vol. 13, 487-504.

OEM (2008). Hazard Analysis Methodology. Oregon Emergency Management.

OHS (2004). Risk Management Handbook, HB 205-2004, Standards Australia International Ltd, Sydney, Australia.

Pahl-Wostl, C. (2009). A conceptual framework for analysing adaptive capacity and multi-level learning processes in resource governance regimes. Global Environmental Change, 19(3), 354-365.

Paton, D., Millar, M., Johnston, D. (2001). Community resilience to volcanic hazard consequences. Natural Hazards, 24, 157-169.

Pelling, M., High, C., Dearing, J., Smith, D. (2008). Shadow spaces for social learning: a relational understanding of adaptive capacity to climate change within organisations. Environment and Planning, 40(4), 867-884.

Reed, M. S., Graves, A., Dandy, N., Posthumus, H., Hubacek, K., Morris, J., Prell, C., Quinn, C, Stringer, L. C. (2009). Who's in and why? A typology of stakeholder analysis methods for natural resource management. Journal of environmental management, 90(5), 1933-1949.

Renn, O. (1998). Three decades of risk research: accomplishments and new challenges. Journal of Risk Research, 1(1), 49-71.

Renn, O., Klinke, A. (2013). A Framework of Adaptive Risk Governance for Urban Planning. Sustainability, 5(5), 2036-2059.

Santos, P. P., Tavares, A. O. (2015). Basin Flood Risk Management: A Territorial Data-Driven Approach to Support Decision-Making. Water, 7(2), pp. 480-502.

Santos, P. P., Reis, E., Tavares, A. O. (2014). Flood risk governance towards resilient communities: opportunities within the implementation of the Floods Directive in Portugal. Proceedings ANDROID Residential Doctoral School. Ed. Perera, Henriksen, Revez \& Shklovski, Salford Quays, UK, 140-150

Schwab, J. (2010). Hazard Mitigation: Integrating Best Practices into Planning. 9 Final recommendations. Schwab (Ed). American Planning Association, Planning Advisory Service, Report Number 560, 131-137.

Schwab, J., Topping, K. (2010). Hazard Mitigation: An Essential Role for Planners. In Schwab, J. (Ed.). Hazard Mitigation: Integrating Best Practices into Planning. American Planning Ass. and Federal Emergency Management Agency. Planning Advisory Service, Report 560, Chicago, 1-14. 
Siegrist, M., Keller, C., Kiers, H. A. (2005). A new look at the psychometric paradigm of perception of hazards. Risk Analysis, 25(1), 211-222.

Tavares, A. O. (2010). Riscos Naturais e Ordenamento do Território. Modelos, Práticas e Políticas Públicas a partir de uma reflexão para a Região Centro de Portugal. Prospectiva e Planeamento, 17, 33-55.

Tavares, A. O. (2013a). Referenciais e modelos de governação dos riscos, in Luciano Fernandes Lourenço e Manuel Alberto Mateus (Org.), Riscos naturais, antrópicos e mistos. Homenagem ao Professor Doutor Fernando Rebelo. Coimbra: Depart. Geografia. Faculdade de Letras, Univ Coimbra, 63-80.

Tavares, A. O. (2013b). Gestão do Risco: a importância da escala local. In Fernandes, J., Cunha, L.,Chamusca, P. (Org.) - Ist International Meeting Geography \& Politcs, Policies and Planning. FLUP/ CEGOT, Porto, 628-642.

Tavares, A. O., Mendes, J. M. (2010). Risk prevention, risk reduction and planning policies: misunderstangings and gaps in a local context. Risk, Models and Applications - Selected Papers. Kremers and Susini Eds. CODATA Germany, Lecture Notes in Information Sciences, Berlin, 73-88.

Tavares, A. O., Mendes, J. M., Basto, E. (2011). Perceção dos riscos naturais e tecnológicos, confiança institucional e preparaçáo para situaçóes de emergência: o caso de Portugal continental. Revista Crítica de Ciências Sociais, (93), 167-193.

Thaler, T., Levin-Keitel, M. (2016). Multi-level stakeholder engagement in flood risk management - A question of roles and power: Lessons from England. Environmental Science \& Policy, 55, 292-301.

UNISDR (2009). Global Assessment Report on Disaster Risk Reduction. United Nations Press, Geneve.

Van Asselt, H., Zelli, F. (2014). Connect the dots: managing the fragmentation of global climate governance. Environmental Economics and Policy Studies, 16(2), 137-155.

Van Asselt, M. B., Renn, O. (2011). Risk governance. Journal of Risk Research, 14(4), 431-449.

Van Westen, C. J., Castellanos, E., Kuriakose, S. L. (2008). Spatial data for landslide susceptibility, hazard, and vulnerability assessment: an overview. Engineering Geology, 102(3), 1, 12-131.

Vandermoere, F. (2008). Hazard perception, risk perception, and the need for decontamination by residents exposed to soil pollution: the role of sustainability and the limits of expert knowledge. Risk Analysis, 28(2), 387-398.

Wachinger,G., Renn, O., Begg, C., Kuhlicke, C. (2013). The Risk Perception Paradox-Implications for Governance and Communication of Natural Hazards. Risk Analysis, Vol. 33(6)., 1049-1065

Wehn, U., Rusca, M., Evers, J., Lanfranchi, V. (2015). Participation in flood risk management and the potential of citizen observatories: A governance analysis. Environmental Science \& Policy, 48, 225-236.

Wisner, B.; Gaillard, JC., Kelman, I (2012). Framing Disaster. Theories and stories, seeking to understand hazards, vulnerability and risk. The Routledge Handbook of Hazards and Disaster Risk Reduction. London: Routledge, 18-33

Woodruff, J. M. (2005). Consequence and likelihood in risk estimation: A matter of balance in UK health and safety risk assessment practice. Safety Science, 43(5), 345-353.

Zêzere, J. L., Garcia, R. A. C., Oliveira, S. C., Reis, E. (2008). Probabilistic landslide risk analysis considering direct costs in the area north of Lisbon (Portugal). Geomorphology, 94(3), 467-495. 
(Página deixada propositadamente em branco) 


\section{PREVENÇÃO, SOCORRO E REABILI'TAÇÃO, OS TRÊS PILARES DE SUSTENTAÇAO DE UMA PROTEÇÃO CIVIL MODERNA}


(Página deixada propositadamente em branco) 


\title{
A GESTÁO do RISCO, COMO MEDIdA DE PREVENÇÃo
} RISK MANAGEMENT AS A PREVENTION MEASURE

\author{
A. Bento-Gonçalves \\ Departamento de Geografia, CEGOT, Universidade do Minho \\ ORCID: 0000-0002-9646-156X bento@geografia.uminho.pt \\ A. Vieira \\ Departamento de Geografia, CEGOT, Universidade do Minho \\ ORCID: 0000-0001-6807-1153 vieira@geografia.uminho.pt \\ L. Martins \\ Departamento de Geografia, Universidade do Minho \\ batoca12@gmail.com \\ D. Pereira \\ Departamento de Geografia, Universidade do Minho \\ dianapereira.gp@gmail.com \\ J. Monteiro \\ Departamento de Geografia, Universidade do Minho \\ joao.miguel15@hotmail.com
}

Sumário: A prevenção (lato sensu) dos incêndios florestais passa obrigatoriamente pelo ordenamento do território, pelo ordenamento florestal, por uma aposta séria na educação, na sensibilização e na formaçáo da população, apostando ainda em estratégias regionais/locais de intervenção, direcionada para os diferentes grupos de cidadãos.

Palavras-chave: Risco, incêndios florestais; prevenção.

Abstract: Forest fire prevention (lato sensu) requires land management, forest management planning, serious investment in education and regional/ local intervention strategies, targeting different groups of citizenss.

Keywords: Risk, forest fires, prevention. 


\section{Introduçáo}

O Plano Nacional de Defesa da Floresta Contra Incêndios (PNDFCI) (APIF, 2005) refere que um dos espaços que a Política de Ordenamento do Território visa gerir e ordenar é necessariamente o "espaço florestal", uma vez que, "um valor bem gerido e estimado, estará com certeza menos exposto a tal fatalidade". Diríamos nós que, "um valor se bem gerido e estimado, estaria com certeza menos exposto a tal fatalidade", ou seja, seriam espaços mais "resilientes" e "sustentáveis".

Serve este pequeno parágrafo para realçar a importância que o ordenamento do território e a gestão do espaço florestal (aqui entendido como o "negativo" dos espaços urbanos e agrícolas) têm na prevenção dos incêndios florestais, sem obviamente esquecer o importante e crucial papel da educaçáo florestal.

Se a ação humana, quer por negligência, quer de forma intencional é fulcral para o deflagrar de incêndios, o desordenamento do território e a falta de gestáo do espaço florestal, a par do clima, do relevo e da eficácia do combate e da primeira intervenção, são algumas das variáveis fundamentais na explicação da dimensão que alguns incêndios atingem.

Neste âmbito, quando surgiu, o PNDFCI veio definir uma estratégia e um conjunto articulado de açôes com vista a fomentar a gestão ativa da floresta, que poderiam criar condições propícias para a redução progressiva do número de incêndios florestais, bem como da sua intensidade.

Para alcançar os objetivos, açóes e metas consagradas no PNDFCI, preconizavam-se intervençôes em 3 domínios prioritários: prevençâo estrutural, vigilância e combate.

- Assim, foram identificados 5 eixos estratégicos de atuação:

- Aumento da resiliência do território aos incêndios florestais;

- Redução da incidência dos incêndios;

- Melhoria da eficácia do ataque e da gestão dos incêndios;

- Recuperar e reabilitar os ecossistemas; e

- Adaptação de uma estrutura orgânica e funcional eficaz.

O PNDFCI acentuava a necessidade de uma açáo concreta e persistente na política de sensibilização, no aperfeiçoamento dos instrumentos de gestão do risco, 
bem como no desenvolvimento de sistemas de gestão e de ligação às estruturas de prevenção, deteção e combate, reforçando a capacidade operacional. O reforço do número de unidades da capacidade operacional dos sapadores florestais, o papel da GNR e a melhoria da capacidade de intervenção dos Bombeiros visaria garantir a reduçáo gradual do tempo de resposta da $1^{\text {a }}$ intervenção.

As mudanças estruturais propostas, que deveriam sentir-se progressivamente até 2012, com o incremento de uma nova política florestal (prevenção estrutural) e com novos métodos de organização ao nível da 1. a intervenção e combate, faziam antever a possibilidade de serem conseguidos os objetivos propostos de defesa efetiva da floresta contra incêndios. No entanto, em 2016, poucas são as diferenças existentes antes de depois do PNDFCI.

\section{Prevençáo de incêndios florestais}

Segundo o Plano Nacional de Defesa da Floresta Contra Incêndios (2005), entende-se por prevençáo de incêndios florestais o conjunto de atividades que têm como objetivo reduzir ou anular a possibilidade de se iniciar um incêndio através da tentativa de diminuir a sua capacidade de desenvolvimento e mitigar os efeitos indesejáveis que o incêndio pode originar.

A prevenção de incêndios florestais atua em duas vertentes principais: o controlo das igniçóes e o controlo da propagação. Assim, o Decreto-Lei n. ${ }^{\circ}$ 124/2006, de 28 de Junho, estabelece as medidas e açôes estruturais e operacionais relativas à prevenção e proteção das florestas contra incêndios, a desenvolver no âmbito do Sistema Nacional de Defesa da Floresta Contra Incêndios.

Os incêndios florestais têm a particularidade de serem um processo cujo impacte pode ser alterado pela ação do homem. Para além da prevenção estrutural e conjuntural, a ação antrópica é fundamental para travar a progressão do incêndio. Assim, o sistema assenta em três pilares fundamentais:

- Prevenção estrutural;

- Vigilância, deteção e fiscalização;

- Combate, rescaldo e vigilância pós-incêndio. 
Da seguinte forma e no âmbito do Sistema de Defesa da Floresta Contra Incêndios é atribuído:

- Ao Instituto da Conservação da Natureza e das Florestas as açóes de prevenção estrutural, nas vertentes de sensibilização, planeamento, organização do território florestal, silvicultura e infraestruturação;

- À Guarda Nacional Republicana, através do SEPNA e do GIPS, a coordenação das ações de prevenção relativas à vertente da vigilância, detenção e fiscalização;

- Aos Bombeiros a coordenação do combate, rescaldo e vigilância pós-incêndio.

A prevenção de incêndios é atualmente considerada uma atividade essencial para a solução do problema, e por isso se estranha que táo poucos recursos sejam canalizados para as atividades de prevençáo, o que permitiria evitá-los e preveni-los, em vez de se continuar a apostar, quase exclusivamente, no combate, que deveria ser o último recurso.

Uma prevençấo eficiente, complementada com uma verdadeira estratégia de educação florestal e assente num Ordenamento do Território pensado para o médio e longo prazo, possibilitaria uma reduçấo significativa do número de igniçóes e incêndios de menor intensidade, tornando por seu lado todo o dispositivo de combate muito mais eficaz.

Quando em 1999, em Conselho de Ministros foi aprovado o Plano de Desenvolvimento Sustentável da Floresta Portuguesa (PDSFP) no27/99 de 8 de Abril, Declaração de Retificação no 10-AA/99 de 30 de Abril, foram precisamente contempladas medidas de prevenção de curto, médio e longo prazo (QUADro I).

No entanto, passadas quase duas décadas sobre a aprovação do PDSFP, pouco mais se apostou do que no Combate, na Vigilância e na Deteção e, pontualmente, na Gestáo de Combustíveis, deixando completamente de fora a Educação e o Ordenamento do Território.

A operacionalização das várias medidas de prevenção de incêndios florestais encontra-se intimamente ligada às questóes do planeamento dos espaços florestais e da gestâo dos espaços florestais, como são exemplo disso os diversos planos existentes: 
QUADRO I - Medidas de Prevenção.

TABLE I - Prevention Measures.

\begin{tabular}{|c|c|c|}
\hline Curto Prazo & Médio Prazo & Longo Prazo \\
\hline Informação & Sensibilização & Educação \\
\hline Silvicultura Preventiva & Formação & \multirow{2}{*}{ Ordenamento do Território } \\
\hline Gestão de Combustíveis & Investigaçãáo & \\
\hline Vigilância & Ordenamento Florestal & \\
\cline { 1 - 2 } Deteção & \multicolumn{2}{|c|}{} \\
\hline Combate & \multicolumn{2}{|c|}{} \\
\cline { 1 - 2 } Fiscalização* &
\end{tabular}

*Código Penal Português no1, Art272/n² Art272/Art nº15º.

- PNDFCI-Plano e Sistema Nacional de Defesa da Floresta contra Incêndios;

- $\quad$ PROF-Planos Regionais de Ordenamento Florestal;

- PMDFCI-Planos Municipais de Defesa da Floresta contra Incêndios;

- PGF-Planos de Gestão Florestal;

- PDF-Plano de Defesa Florestal;

Apenas a título de exemplo, podemos sistematizar algumas das muitas medidas de prevenção que constam dos diferentes diplomas legais em vigor (QUADRo II).

No entanto, continua a existir uma profunda falta de recursos humanos nas instituiçóes responsáveis quer pela implementação de algumas destas medidas, quer nas incumbidas da sua fiscalização, para não se falar das incongruências jurídico-legais existente e que em muito dificultam a implementação de parte significativa das medidas preconizadas. 
QUADRO II - Exemplos de Medidas de Prevenção.

TABLE II - EExamples of Prevention Measures.

- Criar uma faixa de proteção à volta da casa. Por lei, o perímetro mínimo é de 50 metros, calculados a partir da parede exterior da habitação;

- Garantir que nos 10 metros à volta da casa não cresce vegetação mais inflamável, como silvas ou canas;

- O acesso à casa deve estar sempre limpo e desobstruído. Se for possível, crie também uma zona que permita aos carros fazerem a inversão de marcha

- Os telhados, as caleiras e os passadiços de madeira acumulam erva e folhas secas. Limpe essas áreas regularmente;

- Instale uma rede de retenção de fagulhas nas chaminés da casa. Em caso de incêndio, esteja atento às frestas das portas e das janelas por onde as fagulham possam entrar.

- Caso tenha plantaçóes, separe as culturas com barreiras corta-fogo (por exemplo, um caminho);

- Se precisar trabalhar com combustíveis, evite os dias muito quentes e as horas de maior calor

- Caso esteja a trabalhar com ferramentas moto-manuais ou corta-matos, evite que toquem em pedras e metais;

- Avise as autoridades se existir lixo acumulado próximo das habitações;

Fonte: Adaptado INCF e ANPC. Source: Adapted from ICNF abd ANPC.

Outro problema grave relacionado com a prevenção, é a falta de uma "adequada estratégia de intervenção, direcionada para os cidadãos que exercem atividades em espaços florestais, em particular quando estas são realizadas no denominado período crítico", apesar de, como referem Fernandes e Lourenço (2013), "desde a década de 90 que, em Portugal, se tem tentado melhorar a determinação das causas dos incêndios florestais, por se reconhecer que o seu conhecimento é um dos pilares da prevenção, pois permite recolher informação sobre as motivaçóes sociais inerentes à ignição e ao modo como estas foram evoluindo ao longo dos anos". 


\section{Gestâo do risco e os índices de risco de incêndio florestal}

O processo de gestão pró-ativa de riscos internacionalmente aceite é baseado em 5 passos distintos e sequenciais (fig. 1):

- A identificação consiste no levantamento dos principais riscos que afetam o processo, projeto ou plano. Este passo tem como resultados a sistematização e a definição de uma lista com os $\mathbf{n}$ riscos que assumem maior relevância.

- A análise visa converter os dados conhecidos sobre os riscos em informação de suporte à decisão. Durante esta fase, os riscos deverão ser definidos, estimados e quantificados.

- O planeamento consiste na conversão de informação sobre os riscos em decisóes e ações, sendo exemplo desta fase a categorização por prioridade de ações em caso de intervenção, bem como a identificação dos riscos residuais.

- O seguimento consiste na monitorização do estado do risco e das açóes levadas a cabo para o mitigar, em função das métricas e níveis pré-definidos.

- O controlo consiste na aferição das métricas e dos níveis de risco pré-definidos, incorporando as necessárias correçóes em todo o processo de gestão de riscos.

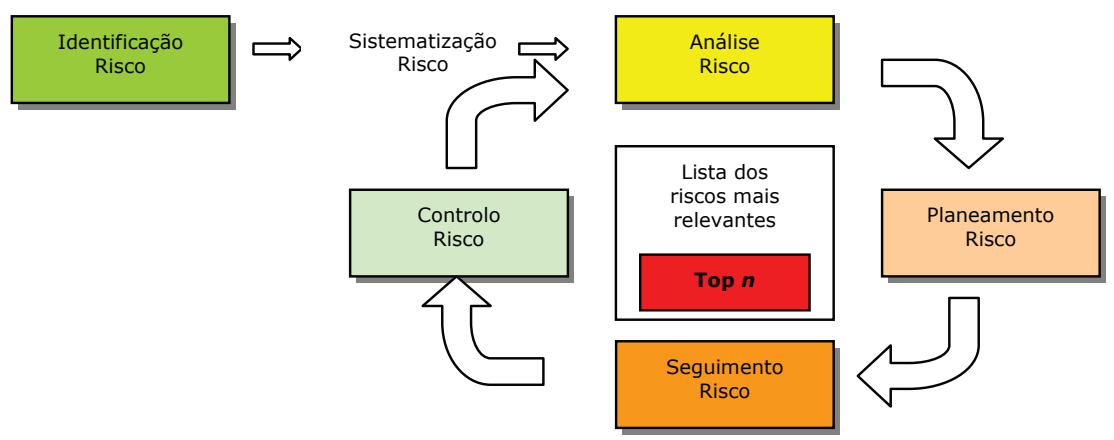

Fig. 1 - Caracterização do processo de gestão de risco proactiva (Fonte: APIF, 2005).

Fig. 1 - Characterization of proactive risk management process (Source: APIF, 2005). 
Quando se aborda a problemática dos incêndios florestais na perspetiva da gestâo de riscos, é necessário abordar o problema sob duas perspetivas, temporal e analiticamente distintas: o imediato e o médio/longo prazo.

Nesse sentido e no âmbito do Sistema Nacional de Proteção da Floresta contra Incêndios através do Decreto-Lei no 156/2004, de 30 de Junho, revogado pelo Decreto-Lei n. ${ }^{0} 124 / 2006$, de 28 de Junho, estabeleceu-se o risco diário de ocorrência de incêndio florestal, (contempla 5 níveis de risco: Reduzido; Moderado; Elevado; Muito Elevado; Máximo), que conjuga a informação meteorológica de base e previsôes, com o estado de secura dos combustíveis e o histórico das ocorrências, entre outros, revelando-se fundamental para a elaboração das medidas de prevenção.

No entanto, vários são os índices existentes. Relativamente ao imediato/curto prazo, é comum falar-se de índice de risco dinâmico ou diário, calculado a partir de dados tratados (temperatura, humidade relativa, estado do tempo, entre outros), fornecidos pelos "Institutos de Meteorologia" e outros afins. Relativamente ao médio/longo prazo, procura-se estimar o índice de risco estrutural, calculado, essencialmente, com base nas chamadas variáveis lentas (população, relevo, clima, edificado, vegetação, histórico das áreas ardidas, entre outras).

Seguindo a mesma análise, foi introduzida pela Comissão Europeia, através do Joint Research Centre, a classificação de índices de acordo com a sua escala temporal (Bento-Gonçalves, 2011), que a seguir se indica:

Estruturais ou de longo prazo - são derivados de fatores que não variam rapidamente, i.e., a topografia ou a ocupaçáo do solo;

Dinâmicos ou de curto prazo - baseiam-se em parâmetros que variam de forma quase contínua, i.e., as condições meteorológicas e o estado da vegetação;

Integrados ou Avançados - incluem variáveis estruturais e dinâmicas, devidamente ponderadas.

Em Portugal, o risco estrutural (fig. 2), desenvolvido pelo Departamento de Engenharia Florestal do Instituto Superior de Agronomia, entra em linha de conta com o histórico de correlação de área ardida com variáveis de ocupação do solo, orográficas, climatológicas e população e visa apoiar o ordenamento florestal e a silvicultura preventiva. 

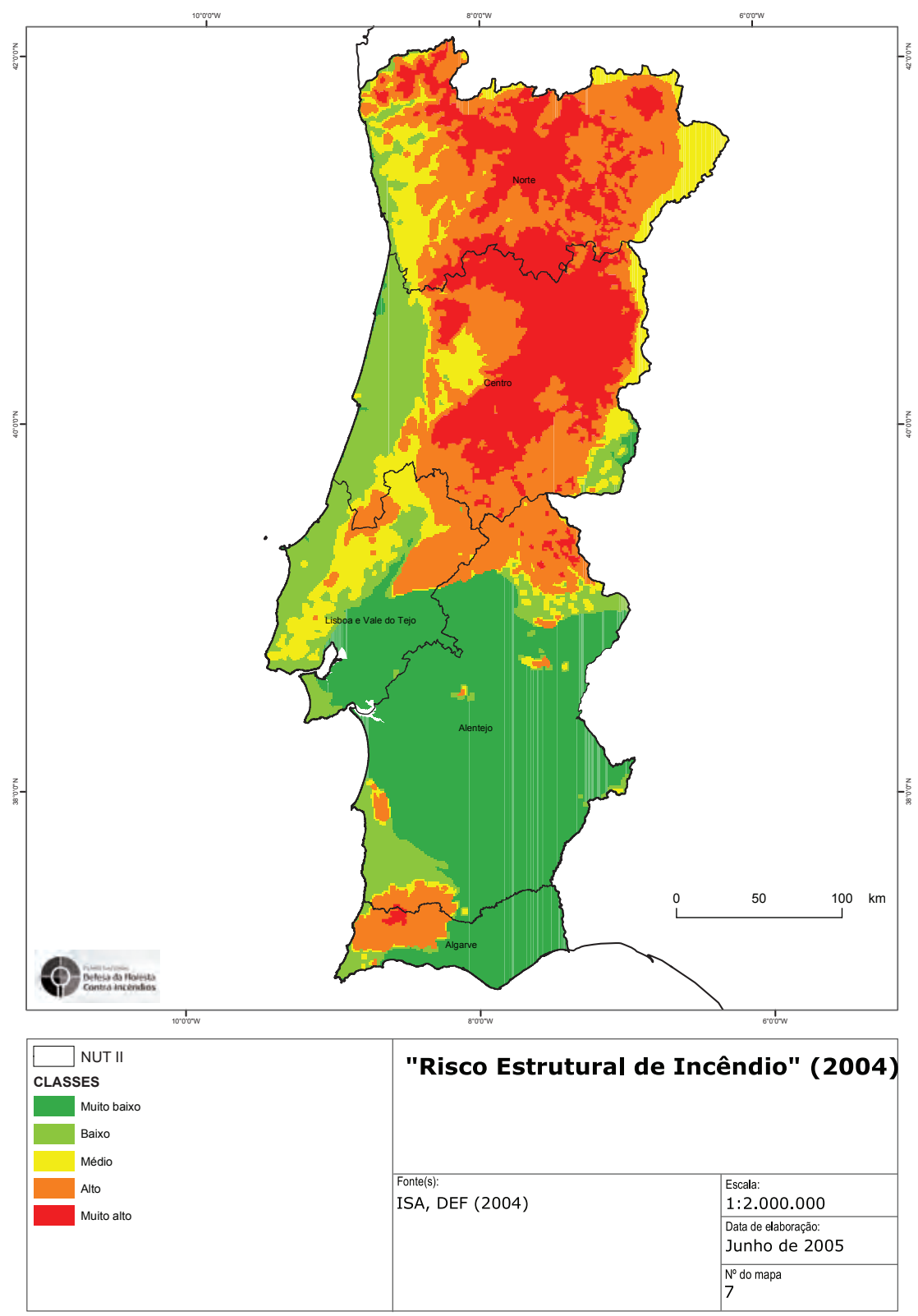

Fig. 2 - Risco estrutural de incêndio florestal (2004) em Portugal Continental (Fonte: APIF/ISA, 2005).

Fig. 2 - Forest fire structural risk (2004) in mainland Portugal

(Source: APIF / ISA, 2005). 
Esta cartografia de risco estrutural de incêndio florestal implica um período de atualização de cinco a dez anos e comporta cinco classes de risco: muito baixo, baixo, médio, alto e muito alto.

Trata-se da cartografia publicada na Portaria n. ${ }^{\circ}$ 1060/2004 no Diário da República de 21 de Agosto e permite a localizaçấo de áreas prioritárias para silvicultura de prevenção/controlo de combustíveis, de forma a conter a progressão de grandes incêndios.

O risco conjuntural (fig. 3) foi igualmente desenvolvido pelo Departamento de Engenharia Florestal do Instituto Superior de Agronomia ${ }^{1}$ e visava produzir uma carta que considerasse as alteraçôes ocorridas nos últimos anos, em termos da influência da área ardida na ocupação do solo.

Destina-se fundamentalmente a ser utilizada no estabelecimento de prioridades de prevenção, tanto no que diz respeito à defesa da floresta como à proteção civil, ou seja, planeamento estratégico de colocação de meios de combate, o que implica uma atualização anual.

Apresenta igualmente cinco classes de risco (muito baixo, baixo, médio, alto e muito alto), e na sua elaboração entram dois grandes grupos de variáveis: os de resposta lenta (histórico de correlação de área ardida, declive, número de dias em que a temperatura máxima é superior a $25^{\circ} \mathrm{C}$, número de dias em que a precipitação entre Maio e Setembro é superior a $1 \mathrm{~mm}$ e a densidade populacional) e os de resposta rápida: estado da vegetação - acumulação de biomassa e potencial produtivo.

Atualmente, em Portugal continental, foram produzidas, com base na metodologia CSP (Cover, Slope and Probability) desenvolvida por João Verde, cartas de perigosidade ${ }^{2}$ de incêndio florestal.

\footnotetext{
${ }^{1}$ Em colaboração com a (entấo) DGRF e financiada pela COTEC Portugal - Associaçấo Empresarial para a Inovação, no âmbito da Iniciativa sobre Incêndios Florestais.

${ }^{2}$ Neste contexto a perigosidade de incêndio florestal traduz o grau de possibilidade de afetação de um determinado local por via de um incêndio florestal.
} 


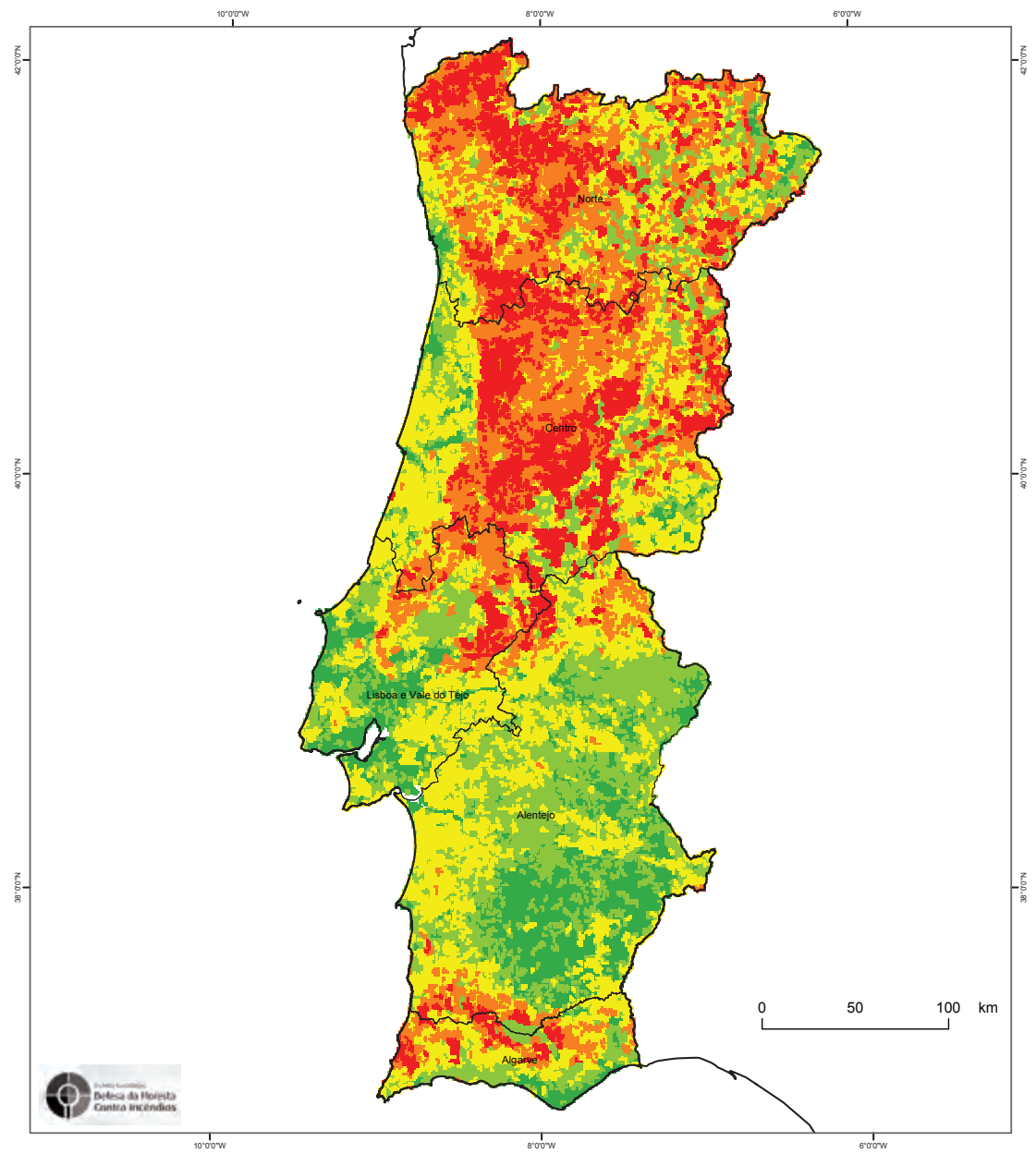

\begin{tabular}{|c|c|c|}
\hline \begin{tabular}{|l} 
NUT II \\
CLASSES \\
Muito Baixo
\end{tabular} & \multicolumn{2}{|c|}{$\begin{array}{l}\text { "Risco Conjuntural de Incêndio" } \\
\text { (2005) }\end{array}$} \\
\hline Médio & & \\
\hline $\begin{array}{l}\text { Atto } \\
\text { Muito Alto }\end{array}$ & \multirow{2}{*}{ 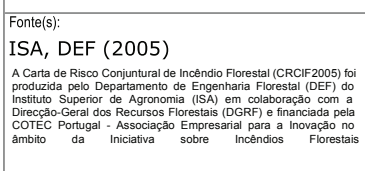 } & \begin{tabular}{|l|} 
Escala: \\
1:2.000.000 \\
Data de elaboracăa: \\
Junho de 2005
\end{tabular} \\
\hline & & $\begin{array}{l}\text { No do mapa } \\
8\end{array}$ \\
\hline
\end{tabular}

Fig. 3 - Risco conjuntural de incêndio florestal (2005) em Portugal Continental (Fonte: APIF/ISA, 2005).

Fig. 3 - Short-term risk of forest fires (2005) in Portugal mainland (Source: APIF / ISA, 2005). 


\section{Cartografia de risco de incêndio florestal}

Como referimos anteriormente, quando se atua ao nível da gestão do risco de incêndio florestal, no processo para a sua identificação e análise, tem-se generalizado o recurso a ferramentas cartográficas para a sua aferição e espacialização.

A utilização de técnicas cartográficas, empregues de forma generalizada para a representação do risco de incêndio florestal, viu-se reforçada pelo advento dos Sistemas de Informação Geográfica, capazes de integrar um elevado número de variáveis, de processar elevado volume de dados e de integrar modelos matemáticos mais ou menos complexos.

Ainda que sujeitos a algumas críticas fundamentadas pelo seu deficiente ou abusivo uso (Lourenço, 2008; Lourenço et al., 2011), estas técnicas permitiram uma gestáo mais eficaz do território, nomeadamente no que ao risco de incêndio florestal diz respeito.

$\mathrm{Na}$ sequência da plena manifestação do risco de incêndios florestais a partir da década de 70 do século XX (Lourenço et al., 2011), o estudo deste fenómeno, das suas causas e consequências e também da sua ocorrência espacial ganhou destaque, especialmente na Universidade de Coimbra, pela mão de Fernando Rebelo e, posteriormente por Luciano Lourenço.

Nos seus trabalhos da década de 80 e início da década de 90, desenvolve já diversa cartografia de áreas ardidas e risco de incêndios florestais (Lourenço, 1986; Lourenço, Bento-Gonçalves e Soares, 1988;), as primeiras ainda com recurso a técnicas manuais de construção cartográfica apoiadas em trabalho de campo (fig. 4).

O desenvolvimento de técnicas de obtenção de dados de forma remota (fotografia aérea e imagem de satélite) e sua progressiva integração em sistemas automatizados de produção cartográfica e, posteriormente, em Sistemas de Informação Geográfica, permitiram a disseminação da produção de cartografia de risco, que necessariamente passou a ser standardizada e uniformizada, bem como a determinação, por parte das entidades oficiais competentes (atualmente o Instituto da Conservação da Natureza e das Florestas), de normas para a sua execução e aplicação na defesa do território, a nível nacional e a nível municipal 
e sua integração em planos de ordenamento territorial. A legislaçáo relacionada com a defesa da floresta contra incêndios produzida desde inícios dos anos 80 do século XX (Decreto-Lei n.o 327/80, de 26 de Agosto; Decreto Regulamentar n. ${ }^{0} 55 / 81$, de 18 de Dezembro), para além de promover a organizaçáo da defesa contra incêndios florestais e definir as estratégias de intervenção, incorpora a determinação do risco de incêndio florestal e seu zonamento, nomeadamente através da produção de cartografia de risco.

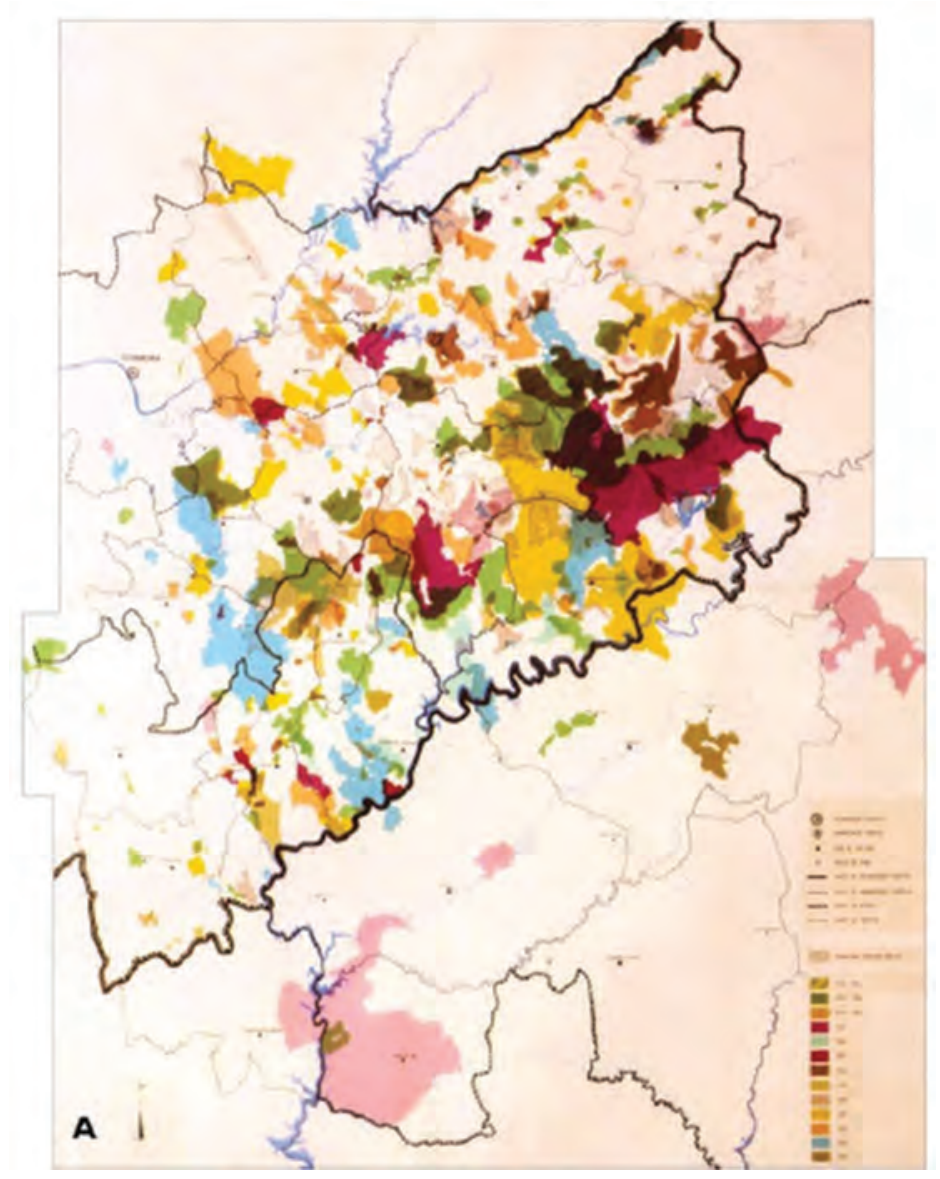

Fig. 4 - Cartografia das áreas queimadas na floresta das serras de xisto do Centro de Portugal (extraído de Lourenço, 2004).

Fig. 4 - Cartography of burned areas in the forests on the schist mountains of central Portugal (extracted from Lourenço, 2004). 
No entanto, apenas a partir da década de 90 se concretiza uma produção de cartografia de risco de incêndio regular, a partir de um projeto-piloto desenvolvido pelo CNIG, através do qual foram produzidas cartas de risco a nível concelhio, com base em metodologia de análise multi-critério proposta por Almeida et al. (1995).

A partir de 2004, sob a responsabilidade do Instituto Geográfico Português, e com base na mesma metodologia, ainda que com algumas modificações, começou a ser produzida a CRIF (Cartografia de Risco de Incêndio Florestal), inicialmente para o distrito de Viseu e posteriormente aplicada aos restantes distritos do território continental (a sua junção permite a representação de todo o território nacional continental).

A partir de 2011, a cartografia utilizada para as açôes de defesa da floresta contra incêndios florestais, para o território nacional, foi modificada, sendo a que se encontra em vigor.

Como referimos no ponto anterior, atualmente a cartografia produzida a nível nacional corresponde à carta de perigosidade de incêndio florestal e baseia-se na aplicação da metodologia proposta por Verde (2008), suportada pela metodologia CSP (fig. 5). As cartas foram geradas em formato raster, com ferramentas de álgebra de mapas e com recurso à seguinte informação-base:

- Carta de ocupação do solo de 2007 Nível 3 (COS2007).

- Carta de declives produzida a partir do Modelo Digital de Elevação (MDE) Pan-Europeu, baseado na fusão por média ponderada das mediçôes altimétricas SRTM e ASTER GDEM.

- Cartografia de áreas ardidas (para cada ano são usados os dados dos 20 anos anteriores).

Os valores de perigosidade obtidos foram sujeitos a uma reclassificaçáo com base no método dos quintis para a totalidade do território de Portugal Continental.

Estas cartas tem ediçấo desde 2012, com atualização anual.

Relativamente à cartografia de risco de incêndio florestal à escala local, tem vindo a ser desenvolvida no âmbito dos Planos Municipais de Defesa da Floresta Contra Incêndios (PMDFCI), definidos pelo Decreto-Lei no 124/2006, de 28 de Junho / Decreto-Lei n.o 17/2009, de 14 de Janeiro (e regulamentado 


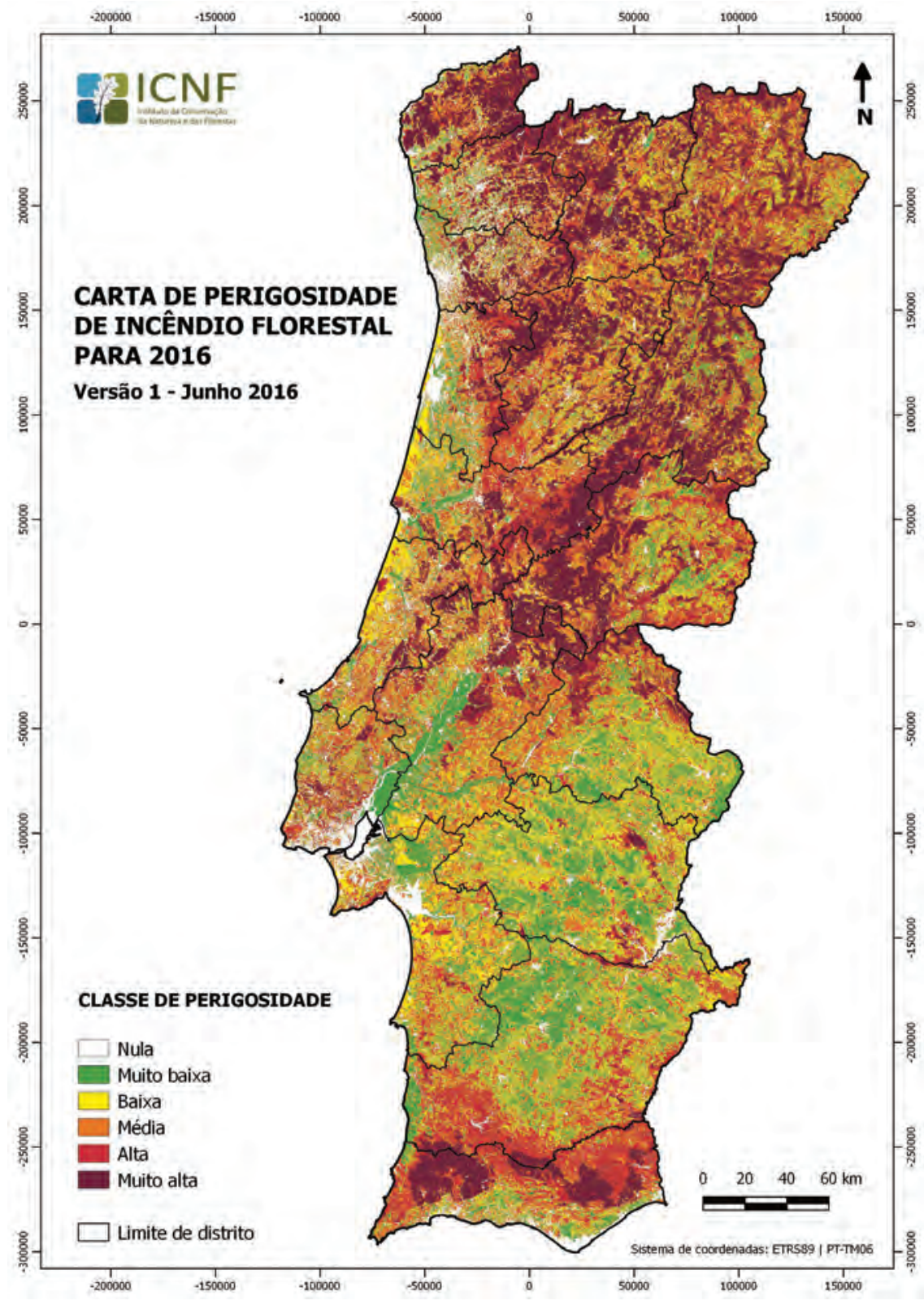

Fig. 5 - Carta de perigosidade de incêndio florestal para 2016 (ICNF). Fig. 5 - Forest fire danger map for 2016 (ICNF). 
pelo Despacho n. ${ }^{\circ} 4345 / 2012$ ), e é implementada de forma padronizada nos diversos municípios portugueses.

A determinação do risco de incêndio florestal é definida a partir de uma metodologia que se baseia no cálculo da perigosidade e do dano potencial, em funçâo dos quais se obtém o risco (fig. 6) (DUDF, 2012).

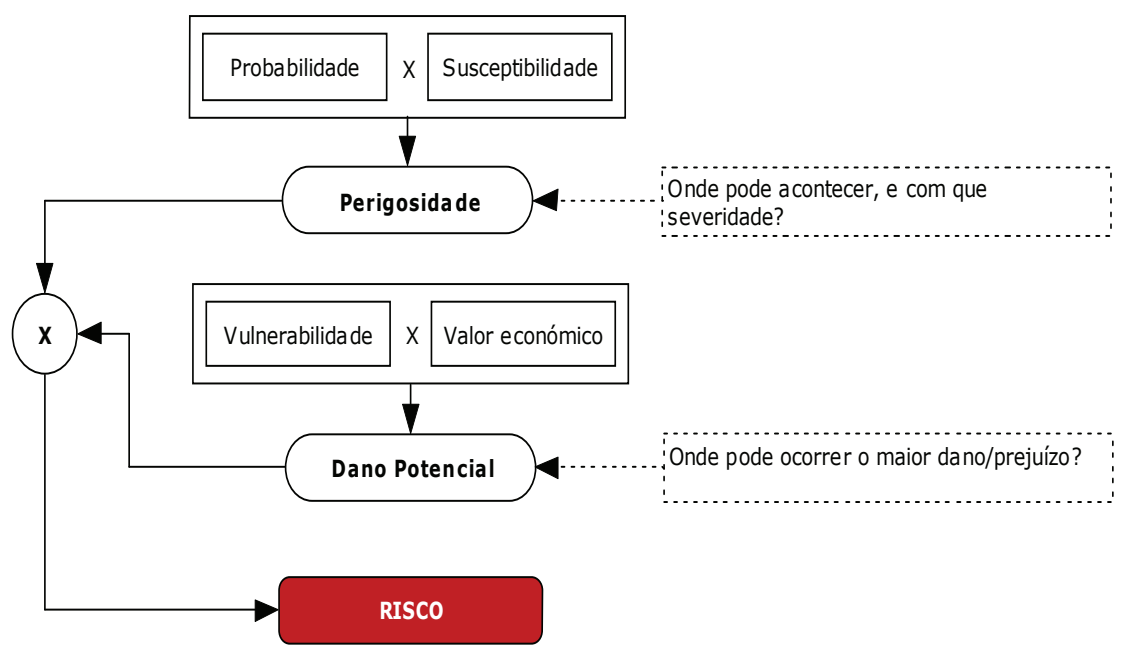

Fig. 6 - Componentes do modelo de risco (Verde e Zêzere, 2007).

Fig. 6 - Components of the risk model (Verde and Zêzere, 1007).

Neste modelo a componente relativa à perigosidade é calculada em função da probabilidade, que "traduz a verosimilhança de ocorrência de um fenómeno num determinado local em determinadas condiçôes" (DUDF, 2012, pág. 47), e da suscetibilidade, correspondente às "condiçôes que esse território apresenta para a ocorrência e potencial de um fenómeno danoso" (DUDF, 2012, pág. 47).

No que diz respeito ao dano potencial, resulta da vulnerabilidade, considerada como o "grau de perda a que um determinado elemento em risco está sujeito" (DUDF, 2012, pág. 47), e do valor económico, que determina o "valor de mercado em euros (ou na divisa aplicável ao local) dos elementos em risco" (DUDF, 2012, pág. 48). 


\section{Conclusão}

Portugal, como refere Stephen Pyne (2006), reúne todas as condiçóes para que se possa afirmar que possui um piro ambiente, pois, juntando às caraterísticas mediterrâneas, que conjugam a época quente com a época seca, tem uma feição Atlântica que lhe permite uma elevada produtividade vegetal.

A esta realidade acresce um relevo muito acidentado a norte do rio Tejo e no Algarve, com um desordenamento florestal estrutural (num contexto de um marcado desordenamento do território), onde predominam as monoculturas de eucalipto (Eucaliptus globulus) e de pinheiro bravo (Pinus pinaster) e uma profunda falta de educação florestal.

Com efeito, com a profunda desestruturação do mundo rural (envelhecimento e baixa densidade populacional nas áreas rurais, especialmente nas áreas de montanha) e as marcadas debilidades da "floresta" portuguesa, com um regime de propriedade assente em proprietários privados (muitas vezes absentistas) e propriedades de muito reduzida dimensão, o fogo deixou de ser uma ferramenta útil e passou a ser uma ameaça permanente.

É neste contexto muito favorável à ocorrência e desenvolvimento de incêndios que, quer por negligência, quer por dolo, Portugal apresenta uma das mais elevados taxas de igniçóes a nível mundial, pelo que urge tornar o nosso território mais resiliente aos incêndios e diminuir drasticamente o número anual de igniçôes.

Assim, pensando no curto e médio prazos, é necessário continuar a apostar na melhoria do combate (nomeadamente na melhoria dos equipamentos; na formação de todos os interveniente, com particular atenção ao comportamento do fogo, ...), da vigilância/dissuasáo (através do reforço do número de efetivos do SEPNA, ...) e da prevenção estrutural (por exemplo reforçar os sapadores florestais; ...).

Pensando no longo prazo, é imprescindível apostar seriamente na Prevenção (lato sensu), o que passa obrigatoriamente pelo ordenamento do território (apostar no desenvolvimento do interior e em particular das áreas de montanha; ...) e pelo ordenamento florestal (promover o cadastro florestal; incentivar as ZIF's; repensar a legislação que liberalizou a plantação de eucaliptos; desincentivar as 
extensas áreas de monoculturas; ...), na educação, na sensibilização e na formação da população, apostando ainda em estratégias regionais/locais de intervenção, direcionada para os diferentes grupos de cidadáos.

\section{Referências bibliográficas}

AGÊNCIA PARA A PREVENÇĀO DE INCÊNDIOS FLORESTAIS (APIF) E INSTITUTO SUPERIOR DE AGRONOMIA (ISA) (2005). Plano Nacional de Defesa da Floresta contra Incêndios, Estudo Técnico I, Diagnóstico, Visão e Objectivos Estratégicos, Lisboa.

Bento-Gonçalves, A. (2011). Geografia dos incêndios em espaços silvestres de montanha: o caso da Serra da Cabreira, Fundação Calouste Gulbenkian.

DIRECÇÃO DE UNIDADE DE DEFESA DA FLORESTA (2012). Plano municipal de defesa da floresta contra incêndios (PMDFCI). Guia técnico. MADRP, AFN, 90 p.

Fernandes, S. Lourenço, L. (2013). Um olhar sobre as causas e a prevenção de incêndios em Portugal, Núcleo de Investigação Científica de Incêndios Florestais (NICIF), da Universidade de Coimbra. http://www.barometro.com.pt/2013/07/04/um-olhar-sobre-as-causas-e-a-prevencao-de-incendios-em-portugal/

Lourenço, Luciano (1986). Consequências geográficas dos incêndios florestais nas serras de xisto do centro do país. Actas, IV Colóquio Ibérico de Geografia, Coimbra, pp. 943-957.

http://www.uc.pt/fluc/nicif/Publicacoes/Estudos_de_Colaboradores/PDF/Comunicacoes_ congressos/IVColoquio_iberico_de_Geografia_1986

Lourenço, Luciano (2004). Consequências geográficas dos incêndios florestais nas serras de xisto do Centro de Portugal. In Manifestaçôes do risco dendrocaustológico. Colectâneas Cindínicas IV, FLUC, 11-28. https://www.uc.pt/fluc/nicif/Publicacoes/Colectaneas_Cindinicas/Download/Colecao_IV/Artigo_I.pdf

Lourenço, Luciano (2008). 'Perigos' das 'cartas de riscos'. Comentários ao modelo proposto no guia técnico para elaboraçáo do PMDFCI. Territorium, 15, RISCOS, 122-126.

http://www.uc.pt/fluc/nicif/riscos/Documentacao/Territorium/T15_artg/T15NNR11.pdf

Lourenço, L., Bento-Gonçalves, A., Soares, H. (1988). Distribuição espacial dos incêndios florestais no Centro de Portugal, no período de 1983 a 1987. Contribuição para um mapa de risco de incêndios florestais. Comunicaçōes, Jornadas Científicas dobre Incêndios Florestais, Vol. II, Coimbra, p. 4.5. - 1 a 26.

http://www.uc.pt/fluc/nicif/Publicacoes/Estudos_de_Colaboradores/PDF/Comunicacoes_ congressos/Jornadas_Cientificas_sobre_IF_1988

Lourenço, L., Bernardino, S., Bento-Gonçalves, A., Vieira, A. (2011). Cartografia Dendrocaustológia. Do desenho manual à era digital. Atas do IV Simpósio Luso-Brasileiro de Cartografia Histórica, Porto, 20 p. http://eventos.letras.up.pt/ivslbch/comunicacoes/107.pdf

Pyne, Stephen (2006). Fogo no jardim: Compreensão do contexto dos incêndios em Portugal. Ed. J. Pereira, J. Pereira, F. Rego, J. Silva, T. Silva - Incêndios florestais em Portugal: caracterização, impactes e prevenção, ISA Press, Lisboa, p.115-131.

Verde, J. C. (2008). Avaliação da Perigosidade de Incêndio Florestal (Dissertação de mestrado em Geografia Física e Ordenamento do Território). Apresentada à Universidade de Lisboa.

Verde, J.; Zêzere, J.L. (2007). Avaliação da perigosidade de incêndio florestal. Actas do VI Congresso da Geografia Portuguesa, Pensar e Intervir no Território. Uma Geografia para o Desenvolvimento, Lisboa, CD-ROM, 17p. 


\title{
A gestáo da CATÁstrofe, COMO MEdida de RESPOSTA À CRISE
}

\author{
DISASTER MANAGEMENT AS A RESPONSE
}

TOCRISIS

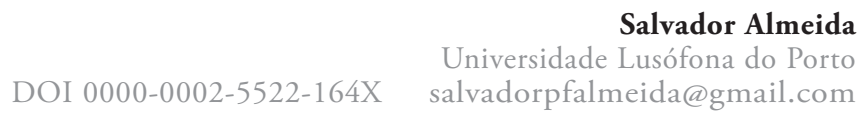

Sumário: Os impactos duma catástrofe são maciços e difusos, perduram no tempo, pelo que as açôes a desenvolver devem ser uma prioridade e ter quatro pontos fundamentais: preparação, resposta, reabilitaçáo e mitigaçáo, o que significa considerar a proteçâo civil como uma atividade de investimento e náo como uma atividade de despesa.

Palavras-chave: Catástrofe, reabilitação, recuperaçấo e mitigação.

Abstract: The impacts of a disaster are massive and diffuse; they are long-lasting, so taking action must be a priority and four fundamental points must be kept in mind, which are preparedness, response, rehabilitation and mitigation. This means seeing civil protection as an investment, not an expense.

Keywords: Disaster, rehabilitation, recovery and mitigation. 


\section{Introduçáo}

A lei de bases de proteção civil, Lei n. ${ }^{\circ} 80 / 2015$, no n. ${ }^{\circ} 1$ do seu art. ${ }^{\circ} 3 .^{\circ}$ define o "acidente grave" como sendo um acontecimento inusitado, com efeitos relativamente limitados no tempo e no espaço, susceptível de atingir as pessoas e outros seres vivos, os bens e o ambiente.

Por sua vez, no n. ${ }^{\circ} 2$ do art. ${ }^{\circ} 3$. $^{\circ}$ dessa mesma lei, define a "catástrofe" como sendo o acidente grave ou a série de acidentes graves, suscetíveis de provocarem elevados prejuízos materiais e, eventualmente, vítimas, afetando intensamente as condiçóes de vida e o tecido socioeconómico em áreas ou na totalidade do território nacional.

Se pretendermos agarrar os fenómenos catastróficos, compreender o seu desenvolvimento, explicar a sua formação e prever as suas consequências, verificamos que as ferramentas da linguagem são muito importantes e que estão mal definidas, como é constatado pela maioria dos especialistas (A. Dauphiné et al., 2013), já que um mesmo termo pode ter vários significados e é utilizado para descrever factos diferentes.

Quando de fala de "risco”, "perigo”, “crise”, "ocorrência”, “incidente”, "acidente grave", "catástrofe", "suscetibilidade", "probabilidade", "vulnerabilidade", "perigosidade", "resiliência", ou quando se propóe trata da "gestão da catástrofe", utiliza-se uma linguagem própria, designada como "linguagem do risco" e, por isso, não podemos deixar de mencionar alguns dos autores que se dedicaram a esta temática, designadamente: L. Faugères (1990 e 1991); G. Y. Kervern e P. Rubise (1991); F. Rebelo (1995, 1999, 2003, 2005 e 2010); E. L. Quarantelli (1998); L. Lourenço (2003 e 2015); F. Tedim e D. Paton, (2012); A. Dauphiné e D. Provitolo (2013); K. Smith (2013); e L. Lourenço e F. Tedim, (2014).

Após a catástrofe, é muito importante fazer a respetiva avaliação, uma vez que, geralmente, os relatórios pós catástrofe não mostram nem evidenciam o mecanismo que despoletou o "perigo", embora a avaliação dos mecanismos que provocaram a catástrofe tenha um valioso retorno de experiências, mas este trabalho de avaliação está cheio de armadilhas (A. Dauphiné et al., 2013). Geralmente são os estudos realizados após a catástrofe que conduzem à implementação de leis para Prevenção e Gestão do Risco, de que são exemplo: 
(i) O incêndio do Chiado, de 25 de agosto de 1988, que deu origem ao Regulamento Segurança Contra Incêndio em Edifícios de Habitação, publicado no Decreto-Lei n. ${ }^{\circ}$ 64/90, de 21 fevereiro e às Normas de Segurança em Estabelecimentos Comerciais, publicadas no Decreto-Lei n. ${ }^{\circ}$ 61/90, de 15 fevereiro

(ii) A tragédia da queda da ponte de Entre-os-Rios, a 4 de março de 2001, que originou vistorias a todas as pontes do País, medida de prevenção crucial para evitar outras tragédias;

(iii) Os trágicos incêndios florestais registados entre 17 e 24 de junho e de 14 a 16 de outubro de 2017, que levaram à aplicação da legislação sobre faixas de gestão de combustível à volta dos aglomerados populacionais e perímetros industriais e que nos levam a interrogar se será desta que aprendemos e vamos resolver as fragilidades evidenciadas?

Cabe-nos a nós ajudar a criar uma cultura de segurança, antes da plena manifestação do risco, investindo nas atividades de prevenção e de preparação para a catástrofe e, ao mesmo tempo, no planeamento das operaçóes de socorro bem como no treino, em treinar os intervenientes, pois só assim estaremos aptos a saber fazer e a salvar.

\section{A gestão da catástrofe}

A proteção civil é a atividade desenvolvida pelo Estado, regióes autónomas e autarquias locais, pelos cidadãos e por todas as entidades públicas e privadas com a finalidade de prevenir os riscos coletivos inerentes a situaçóes de acidente grave ou catástrofe, de atenuar os seus efeitos e proteger as pessoas e bens em perigo quando aquelas situaçóes aconteçam (n. ${ }^{\circ} 1$, art. ${ }^{\circ} 1 .^{\circ}$, Lei n. ${ }^{\circ}$ 80/2015, de 3 de agosto).

Diz o n. ${ }^{\circ} 2$, do art. $^{\circ} 1^{\circ}$ da referida Lei n. ${ }^{\circ} 80 / 2015$, que a atividade de proteção civil tem carácter permanente, multidisciplinar e plurissectorial, cabendo a todos os órgãos e departamentos da Administração Pública promover as condiçóes indispensáveis à sua execução, de forma descentralizada, sem prejuízo do apoio mútuo entre organismos e entidades do mesmo nível ou proveniente de níveis superiores. 
Os riscos e as catástrofes são fenómenos complexos, pelo que não podem ser compreendidos nem explicados sem serem estudados, no espaço e no tempo. Como refere A. Dauphiné et al. (2013) não podemos negligenciar o fator espacial. A resposta a dar é diferente se considerarmos uma pequena região, uma cidade ou um continente. Não existe uma escala de intensidades comum a todas as catástrofes. F. Rebelo (2010) disse que o que pesa mesmo para dar dimensão à catástrofe é a enorme vulnerabilidade das populaçóes.

Não pretendendo apresentar o estado da arte, importa sim, clarificar os conceitos, pois, para ser eficaz, a observação científica pressupóe a existência dum vocabulário preciso, composto de noçóes e de conceitos bem definidos (A. Dauphiné et al., 2013).

Os termos risco, perigo, acaso e dano potencial devem servir para definir o aspeto potencial da ciência do risco, enquanto que os termos acidente, catástrofe, crise, cataclismo, calamidade, drama, tragédia, urgência e emergência servem para descrever uma realidade, um fenómeno que verdadeiramente aconteceu (A. Dauphiné et al., 2013).

Assim, neste contexto, apresenta-se o enquadramento de alguns destes conceitos:

- Risco - probabilidade de ocorrência de acontecimento danoso. O risco permite caraterizar um evento identificado, mas não realizado (L. Faugères, 1990; F. Rebelo, 2003, 2005 e 2010; L. Lourenço, 2015).

O risco tem uma dimensão probabilística, mas a catástrofe não, pois quando acontece é já uma certeza. Por exemplo, a França tem risco de irradiação nuclear, mas até hoje não teve qualquer acidente nuclear importante (A. Dauphiné et al., 2013).

Os riscos podem ser de origem natural (inundação, erupção vulcânica, ciclone, avalanche, etc.), de origem antrópica, quer seja tecnológica (explosóes em fábricas químicas, naufrágio de petroleiros, etc.), quer social (guerras, terrorismo, etc.) e podem ser ainda mistos, isto é ter causa natural ou antrópica (erosão, epidemias, incêndios florestais, ...).

- Perigo - proximidade iminente de manifestaçáo do risco, de algo danoso que está prestes a acontecer, de se manifestar sob a forma de Crise, mas que pode acabar por não acontecer, ou seja, neste caso não representa perigo efetivo (F. Rebelo, 2003 e 2005; L. Lourenço, 2015). 
Como refere L. Lourenço (2015) estar em risco ou correr perigo são conceitos distintos. Há uma explosão e incêndio em simultâneo, significa que o risco se manifestou, logo corremos perigo, que irá estar presente até ao fim da manifestação, isto é, até ao incêndio estar extinto.

Se alguma coisa correr mal e criar problemas ao homem ou às suas realizaçóes, fala-se de risco (F. Rebelo, 2003). Risco tem a perda. O perigo reconhece-se por meio de sinais de alerta, a que se pode chamar de "perigosidade", isto é, têm a ver com a qualidade de ser perigoso, uma vez que o processo em si, nem sempre é perigoso, muitas vezes até é benéfico. A existência de sinais que nos indicam que a manifestação do risco está iminente, permitem reconhecer a existência de perigo, logo, essa existência passou a implicar perigo (L. Lourenço, 2015).

- Crise - situação anormal e grave, que corresponde à plena manifestação do risco fora do controlo do ser humano e em que não é possível controlar o perigo, ou seja, controlar o incêndio nascente, controlar a fuga da matéria perigosa, etc., pelo que há incapacidade de agir sobre os processos e incerteza absoluta sobre o desenvolvimento da crise e dos seus impactes (L. Lourenço, 2003.

Chernobyl e Fukushima são exemplo de catástrofes nucleares. A catástrofe de Chernobyl, acontecida a 26 de abril de 1986, causou um total estimado de cem mil mortos e o risco perdura muito tempo depois da catástrofe ter sido declarada (A. Dauphiné et al., 2013).

- Vulnerabilidade - outro conceito muito importante que, no entender das Naçóes Unidas (citadas por L. Lourenço, 2015), diz respeito às "características e circunstâncias de uma comunidade que a tornam suscetivel aos efeitos nocivos do processo".

Sabemos que o risco de incêndio urbano é muito elevado em determinadas populaçóes, menos preparadas e onde não existe a cultura da prevenção, logo mais vulneráveis, nomeadamente devido à falta de preparação para atuar quando são emitidos os avisos e os sinais de alertas. Assim não se atua, não se faz a evacuação das áreas em crise, pelo que haverá vitimas, para além dos prejuízos materiais, ou seja, esta comunidade terá uma elevada vulnerabilidade.

Atendendo a que a vulnerabilidade é multidimensional, será muito importante:

- Hierarquizar, com clareza, os conceitos de risco, perigo e crise, o que vai permitir a sequência apropriada para o trabalho dos diferentes Agentes de Proteção 
Civil e de todas as Entidades públicas e privadas com dever especial de cooperação, antes, durante e após a crise;

- Implementar uma "Cultura de processos, estruturas e meios" necessários tanto para a prevençáo, como para o combate efetivo dos efeitos adversos da manifestação de risco;

- Facilitar a comunicaçáo do risco, envolvendo: informaçáo, avisos e alertas que são necessários e é preciso fazer, para se chegar às pessoas, quer individual quer coletivamente.

\section{Ocorrências}

Em função da respetiva gravidade, é possível classificar as ocorrências segundo diferentes tipos e os acidentes graves estáo em primeiro lugar, na hierarquia das ocorrências capazes de gerar operaçóes que dizem respeito ao Sistema de Proteçáo Civil. Segundo E. L. Quarantelli (2005), uma ocorrência designa-se por catástrofe quando:

- Os impactos são maciços e difusos;

- Os responsáveis locais não podem realizar as suas missōes da maneira habitual;

- A ajuda vem essencialmente de regióes mais remotas, como por exemplo a ajuda internacional;

- As funçóes comunitárias mais quotidianas são fortemente interrompidas;

- Os "média" internacionais dão muita atençấo à catástrofe;

- Os funcionários e as agências governamentais de nível nacional são diretamente implicados na gestáo do evento.

A. Dauphiné et al. (2013) apresentam três escalas para classificar as catástrofes: (i) uma escala de catástrofe naturais, segundo a gravidade dos danos humanos e materiais (QUADRo I); (ii) uma escala de catástrofe tecnológicas, segundo a gravidade dos danos humanos e materiais (QUADro II) e (iii) uma escala global de catástrofes, em função de três perdas: humanas, financeiras e ecológicas (QuADro III). Várias propostas poderiam ser tidas em consideração para elaborar a classificação, mas os autores valorizaram essencialmente a vida humana. 
QUADRO I - Escala de catástrofes naturais.

TABLE I - Scale of natural disasters.

\begin{tabular}{|l|l|l|}
\hline \multicolumn{1}{|c|}{ Incidente } & \multicolumn{1}{c|}{$\mathbf{0}$ mortos } & \multicolumn{1}{c|}{$\mathbf{0 , 3} \mathbf{M} €$} \\
\hline Acidente & 1 morto e vários feridos & entre 0,3 e $3 \mathrm{M} €$ \\
\hline Acidente grave & 1 a 9 mortos & entre 3 e $30 \mathrm{M} €$ \\
\hline Acidente muito grave & 10 a 99 mortos & 30 e $300 \mathrm{M} €$ \\
\hline Catástrofe & 100 a 999 mortos & $300 \mathrm{M}$ a 3 Biliōes $€$ \\
\hline Super Catástrofe & 1000 mortos ou mais & $>3$ Biliōes $€$ \\
\hline
\end{tabular}

Fonte/Source: A. Dauphiné et al., 2013.

QUADRO II - Escala de catástrofes tecnológicas.

TABLE II - Scale of technological disasters.

\begin{tabular}{|l|l|l|}
\hline Incidente & 0 mortos & $<0,05 \mathrm{M} €$ \\
\hline Acidente & 1 morto & entre 0,05 e $0,1 \mathrm{M} €$ \\
\hline Acidente grave & 2 a 5 mortos & entre 0,1 e $0,5 \mathrm{M} €$ \\
\hline Acidente muito grave & 6 a 19 mortos & entre 0,5 e $2 \mathrm{M} €$ \\
\hline Catástrofe & 20 a 49 mortos & entre 2 e $10 \mathrm{M} €$ \\
\hline Super Catástrofe & 59 mortos ou mais & $>$ que $10 \mathrm{M} €$ \\
\hline
\end{tabular}

Fonte/Source: A. Dauphiné et al., 2013.

Para fundamentarem a escala apresentada, dão vários exemplos: Gripe espanhola, (1918-1919), classificada como Super catástrofe, com número de vítimas superior a um milhão de pessoas; Sismo no México (1985), classificado como um acidente muito grave; Ciclone Iniki Estados Unidos (1992), classificado como um acidente; Tempestade em França, dezembro 1999, classificada como Super catástrofe, com perda de biomassa maior que 1000000 toneladas; Sismo d'Izmit, na Turquia (1999), classificado como Catástrofe de grandes proporçóes; Furacão Katrina, Estados Unidos, (2005), classificado como Catástrofe. 
QUADRO III - Escala global de catástrofes.

TABLE III - Global scale of disasters.

\begin{tabular}{|c|c|c|c|c|}
\hline Perdas humanas & $\begin{array}{l}\text { Milhóes de } \\
\text { Euros }\end{array}$ & $\begin{array}{l}\text { Perdas Ecológicas } \\
\text { (ton/Biomassa) }\end{array}$ & Nível & Exemplos \\
\hline 0 a 9 & $\begin{array}{c}0-9 \\
10-99\end{array}$ & $\begin{array}{c}0-9 \\
10-99\end{array}$ & I & Acidente \\
\hline 10 a 99 & $\begin{array}{c}0-9 \\
10-99 \\
100-999 \\
1000-9999\end{array}$ & $\begin{array}{c}0-9 \\
10-99 \\
100-999 \\
1000-9999\end{array}$ & II & Desastre \\
\hline $\begin{array}{c}100 \text { a } 999 \\
\text { e } \\
1000 \text { a } 9999\end{array}$ & $\begin{array}{c}0-9 \\
10-99 \\
100-999 \\
1000-9999 \\
10000-99999 \\
>100000\end{array}$ & $\begin{array}{c}0-9 \\
10-99 \\
100-999 \\
1000-9999 \\
10000-99999 \\
100000-999999\end{array}$ & III & Catástrofe \\
\hline 10000 a 999999 & $\begin{array}{c}10-99 \\
100-999 \\
1000-9999 \\
10000-99999 \\
>100000\end{array}$ & $\begin{array}{c}10-99 \\
100-999 \\
1000-9999 \\
10000-99999 \\
100000-999999 \\
>1000000\end{array}$ & IV & $\begin{array}{l}\text { Catástrofe } \\
\text { grandes } \\
\text { proporçōes }\end{array}$ \\
\hline $\begin{array}{c}100000 \text { a } 999999 \\
\text { e } \\
>1000000\end{array}$ & $\begin{array}{c}1000-9999 \\
10000-99999 \\
>100000\end{array}$ & $\begin{array}{c}10-99 \\
100-999 \\
1000-9999 \\
100000-999999 \\
>1000000\end{array}$ & V & Super catástrofe \\
\hline
\end{tabular}

Fonte/Source: A. Dauphiné et al., 2013.

\section{Perspetivas de atuaçáo}

A Gestão da Catástrofe assenta essencialmente em três perspetivas de atuaçáo.

\section{A perspetiva operacional}

Esta perspetiva diz respeito às Entidades de execução e é nesta fase que se verifica a importância de se ter efetuado previamente uma análise de risco, envolvendo 
processos e vulnerabilidades, que estimasse o tipo e intensidade das manifestaçôes e que vão permitir mostrar se há ou não articulação política para uma boa operacionalizaçáo do sistema, transformando os planos em açóes concretas para ajudar as populaçôes, principalmente os mais pobres, através de auxilio económico e programas devidamente elaborados e credenciados para a recuperação das suas vidas.

Esta intervençáo diz respeito a profissionais e voluntários.

Exige prontidáo da resposta e socorro eficaz que é levado a efeito com o auxílio dos bombeiros, das forças de segurança, da emergência médica, bem como outros agentes e de outras equipas. Envolve a reabilitaçáo de emergência, que compreende: evacuação de populações, acolhimento, assistência social, realojamentos, bem como a posterior recuperaçáo dos bens e haveres destruídos que pode passar por várias fases e ser mais demorada, pois deverá implicar a reconstruçáo da área afetada, com vista à redução das anteriores vulnerabilidades, tornando-a assim mais resiliente a eventuais novas manifestaçóes dos processos.

\section{A perspetiva Comunicacional}

Um fator muito importante, uma prioridade de ação durante a emergência, é assegurar o estabelecimento de comunicaçôes entre os diversos intervenientes, por exemplo, entre o Diretor do Plano Municipal de Emergência, os elementos da Comissão Municipal de Proteção Civil (CMPC), o Comandante Operacional Municipal, o Posto de Comando e as outras forças de intervençáo.

Por sua vez, a comunicação das emergências e, em particular, a comunicação da declaração das Situações de Alerta, de Contingência ou de Calamidade (Lei n. ${ }^{\circ}$ 80/2015, de 3 de agosto), é um aspeto deveras importante, pois enquadra-se no reconhecimento e necessidade de adotar medidas adequadas e proporcionais ao enfrentamento de graus crescentes de perigo e, por conseguinte, de crises de maior ou menor gravidade.

Nestas situaçôes, face à republicação da Lei n. ${ }^{\circ}$ 27/2006, há obrigação especial de colaboração dos órgáos de comunicação social, designadamente quando é declarada a situação de: 
(i) Alerta, nos termos do: n. ${ }^{\circ} 2$ art. $^{\circ} 15 .{ }^{\circ}$;

(ii) Contingência, nos termos do n. ${ }^{\circ} 1$ do art. $^{\circ} 18 .^{\circ}$ e do n. ${ }^{\circ} 2$ do Art. ${ }^{\circ} 15 .^{\circ}$;

(iii) Calamidade, nos termos do n. ${ }^{\circ} 1$ do $^{2}$ rt. $22 .^{\circ}$ e do n. ${ }^{\circ} 2$ do $^{\circ}$ art. $^{\circ} 15 .^{\circ}$.

As competências para declarar cada uma destas situaçóes dependem do âmbito (inframunicipal, municipal, supramunicipal e nacional) e do tipo de cada situação (alerta, contingência ou calamidade) (QuAdro IV).

No que respeita à comunicação pública da crise, ela assenta na Lei n. ${ }^{\circ}$ 80/2015, de 3 de agosto, cujo art.o $7 .^{\circ}$ trata da informaçáo e formação dos cidadãos, referindo explicitamente:

1. Os cidadãos têm direito à informaçâo sobre os riscos a que estão sujeitos em certas áreas dos territórios e sobre as medidas adotadas e a adotar com vista a prevenir ou a minimizar os efeitos de acidente grave ou catástrofe;

2. A informação pública visa esclarecer as populaçóes sobre a natureza e os fins da Proteçâo Civil, consciencializá-las das responsabilidades que recaem sobre cada instituição ou individuo e sensibilizá-las em matéria de autoproteção;

Quadro IV - Competência Declaração Situação Alerta, Contingência e Calamidade (Fonte: CT-PROCIV, n. ${ }^{\circ}$ 23).

TABLE IV - Authority to Declare State of Alert, Emergency and Disaster (Source: CT-PROCIV, n. ${ }^{\circ}$ 23).

\begin{tabular}{|c|c|c|}
\hline DECLARAÇÃo & ÂMBITO & COMPETÊNCIA PARA DECLARAR \\
\hline \multirow{4}{*}{$\begin{array}{l}\text { SITUAÇÃO } \\
\text { DE ALERTA }\end{array}$} & Inframunicipal & \multirow{2}{*}{$\begin{array}{l}\text { Presidente da Câmara Municipal } \\
\text { Ministro da Administração Interna }\end{array}$} \\
\hline & Municipal & \\
\hline & Supramunicipal & $\begin{array}{l}\text { Comandante Operacional Distrital (ouve CM) } \\
\text { Ministro da Administração Interna }\end{array}$ \\
\hline & Nacional & Ministro da Administração Interna \\
\hline \multirow{4}{*}{$\begin{array}{l}\text { SITUAÇÃO } \\
\text { DE CONTINGÊNCIA }\end{array}$} & Inframunicipal & Ministro da Administração Interna \\
\hline & Municipal & Ministro da Administração Interna \\
\hline & Supramunicipal & $\begin{array}{l}\text { Presidente da ANPC (ouve, se possível, CM) } \\
\text { Ministro da Administração Interna }\end{array}$ \\
\hline & Nacional & Ministro da Administração Interna \\
\hline \multirow{4}{*}{$\begin{array}{l}\text { SITUAÇÃO } \\
\text { DE CALAMIDADE }\end{array}$} & Inframunicipal & \multirow{4}{*}{$\begin{array}{l}\text { Conselho de Ministros* (reveste forma de RCM) } \\
\text { Ou, em caso de urgência, } \\
\text { Ministro da Administração Interna } \\
\text { e Primeiro-Ministro, a preceder Resolução do } \\
\text { Conselho de Ministros (Despacho Conjunto) }\end{array}$} \\
\hline & Municipal & \\
\hline & Supramunicipal & \\
\hline & Nacional & \\
\hline
\end{tabular}

* Comissão Nacional de Protecção Civil assiste o Primeiro-Ministro e o Governo na declaração de situação de calamidade. 
3. Os programas de ensino, nos seus diversos graus, devem incluir na área de formaçấo civica, matérias de proteção civil e autoproteção, com a finalidade de difundir conhecimentos práticos e regras de comportamento a adotar no caso de acidente grave ou catástrofe.

É, pois, absolutamente urgente implementar o Referencial de Educação para o Risco (Saúde et al., 2015), aprovado a 28 de julho de 2015, pelo Secretário de Estado do Ensino Básico e Secundário (RERisco).

\section{A Perspetiva Integral}

Quando as comunidades forem afetadas por acidentes graves ou catástrofes e essas situaçôes estiverem abrangidas por declaração de situação de calamidade, poderão beneficiar dos seguintes apoios financeiros:

- Conta de emergência - assistência financiada para assegurar a reposiçáo da normalidade das condiçôes de vida nas áreas abrangidas pela declaração de situação de calamidade;

- Fundo de Emergência Municipal - concessão de auxílios financeiros às autarquias locais para a recuperação de equipamentos públicos da responsabilidade das mesmas, abrangidos por declaração de situação de calamidade;

- Fundo de Solidariedade da União Europeia - é um instrumento pensado para "catástrofes de grandes proporçôes", mas pode também ser usado em "catástrofes regionais extraordinárias".

Perante agressão efetiva ou iminente por forças estrangeiras, de grave ameaça ou perturbação da ordem constitucional democrática ou de calamidade pública é declarado o Estado de Sítio (art. ${ }^{\circ}$ 19. ${ }^{\circ} / 2$ da Constituição e art. ${ }^{\circ}$ 8. ${ }^{\circ} 1$ e 2 da Lei n. ${ }^{\circ}$ 44/86, de 30 setembro, alterada pela Lei Orgânica n. ${ }^{\circ}$ 1/2012, de 11 maio);

Quando os pressupostos da declaração de Estado de Sítio se revistam de menor gravidade, esta apenas pode determinar a suspensão de alguns direitos, liberdades e garantias que sejam suscetíveis de serem suspensas, sendo então declarado o Estado de Emergência (art. ${ }^{\circ}$ 19. $/ 3$ da Constituição e art. ${ }^{\circ}$ 9. $\% / 1$ e 2 da Lei n. ${ }^{\circ}$ 44/86, de 30 setembro, alterada pela Lei Orgânica n. ${ }^{\circ} 1 / 2012$, de 11 de maio). 


\section{Articulação com o Sistema de Segurança Interna:}

Os órgãos do Sistema de Segurança Interna são o Conselho Superior de Segurança Interna, o Secretário-Geral e o Gabinete Coordenador de Segurança (art. ${ }^{\circ}$ 11. ${ }^{\circ}$, Lei n. ${ }^{\circ}$ 53/2008, de 29/8, alterada pela Lei n. ${ }^{\circ}$ 59/2015, de 24/6).

Compete ao Secretário-Geral do Sistema de Segurança Interna garantir a articulação entre as Forças de Segurança e o Sistema Integrado de Operaçóes de Proteção e Socorro (SIOPS), (Lei n. ${ }^{\circ}$ 53/2008, de 29/8, alterada pela Lei n.o 59/2015, de 24/6).

As forças e os serviços do SIOPS são colocados na dependência operacional do Secretário-geral de Segurança Interna através dos seus Dirigentes máximos, quando cumulativamente, se verifiquem:

- Ataques terroristas, acidentes graves ou catástrofes;

- Situaçóes determinadas pelo Primeiro-ministro, após comunicação fundamentada pelo Presidente da República;

- Situaçóes que exijam a intervenção das Forças de Segurança e das forças do SIOPS.

\section{A preparação}

O risco deve ser gerido e, por conseguinte, não deverá ser aceite pacificamente. Devemos começar pelo que nós temos em casa, de equipamento e de preparaçáo que nos possa salvar, a cada um de nós e à comunidade. Será que temos uma mala de primeiros socorros? Teremos lanternas e pilhas? Temos água e bolachas? Temos um Plano de Atuação em caso de crise?

O trabalho feito antes da emergência é a base do sucesso ou insucesso quando acontece a crise. Para isso, temos que partir dum vocabulário preciso, composto de noçôes e conceitos bem definidos.

A função primordial da preparação é levar a efeito a Análise e Gestão do Risco, que abrange quatro fases interrelacionadas: análise do risco ou avaliação do risco, consciência do risco; percepção do perigo e, como consequência, a gestão do risco.

A análise e gestão do risco visa alcançar, entre outros, os seguintes objetivos: 
- O primeiro e, porventura, o mais importante, é que os "políticos" passem a considerar os dinheiros despendidos na gestáo do risco como investimentos e não como despesas;

- Um segundo, é que a gestáo do risco englobe as medidas necessárias para manter o risco dentro de limites aceitáveis;

- Um terceiro, se o risco se apresentar como não tolerável, será a necessidade de proceder ao seu controlo, através de planos de ação e medidas apropriadas;

- Um quarto, se o risco for considerado inaceitável, é o de implementar medidas de mitigação.

Estudam-se os dados existentes, fazem-se planos, treinam-se os intervenientes (operacionais e cidadáos) e define-se como objetivo essencial que os riscos conservem o seu carácter potencial e que não se transformem em catástrofes.

Com efeito, o chamado ciclo da catástrofe compreende três fases: antes, durante e depois da crise, as quais envolvem vários tipos de situaçóes, cada uma delas com procedimentos próprios (fig. 1), como referimos a seguir.

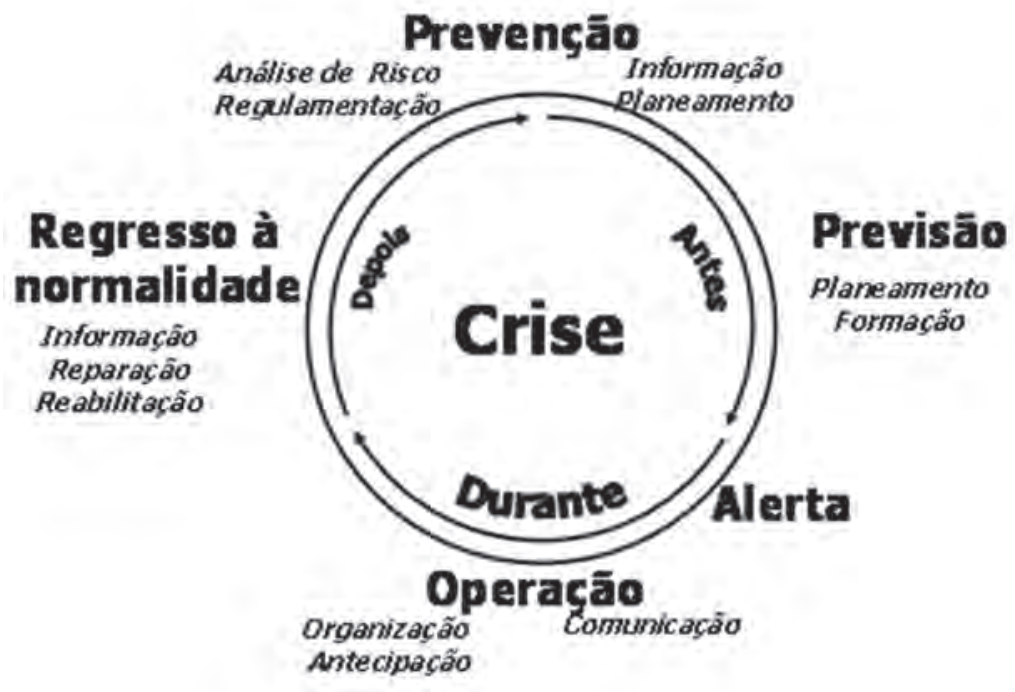

Fig. 1 - Diagrama exemplificando o antes, durante e depois da crise (Fonte: Adaptado de D. Alexander,2001).

Fig. 1 - Diagram illustrating before, during and after a crisis (Source: adapted from D. Alexander, 2001). 


\section{Prevençáo}

No que diz respeito à prevenção, apresentam-se alguns aspetos que são considerados na análise, prevenção, informação e planeamento do risco.

\section{Análise de Risco}

Um bom instrumento para identificação e avaliação dos riscos é a cartografia, através da qual se podem representar vários riscos, como sejam os de incêndio: em floresta e mato, em detritos, em edifícios urbanos, em infraestruturas, em indústrias, ou os de inundaçáo: rural e urbana (fig. 2).

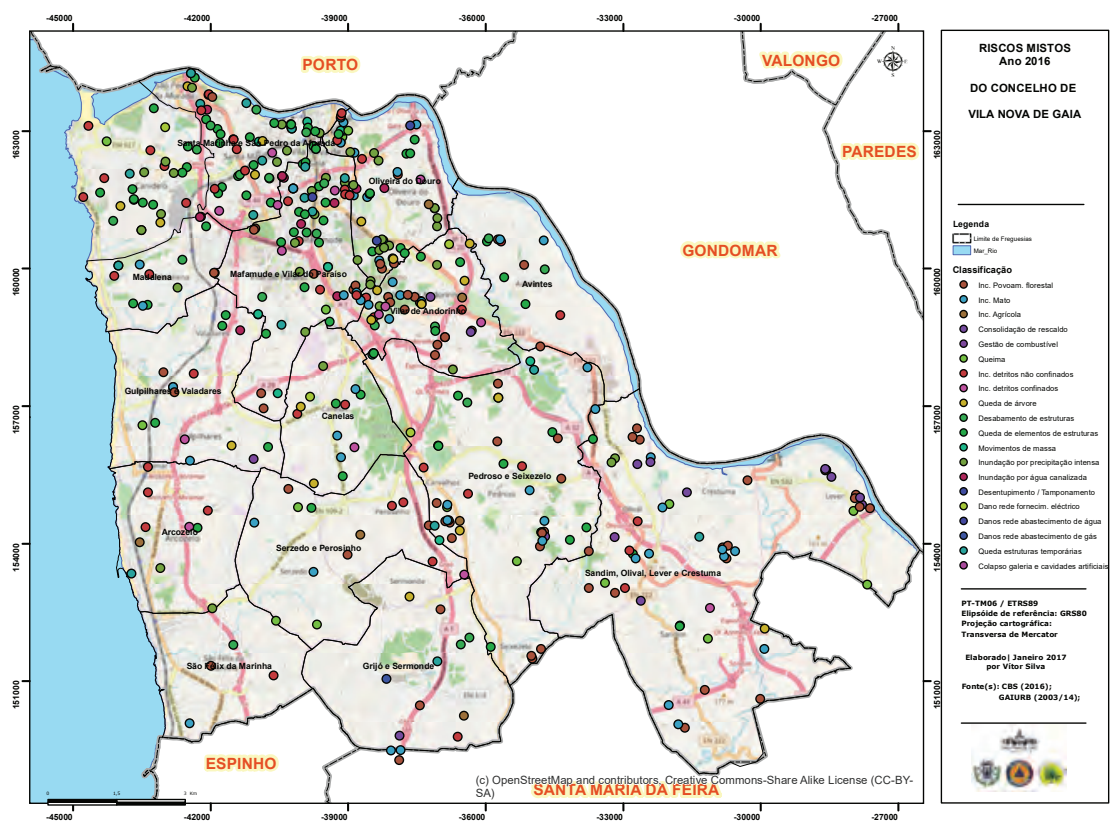

Fig. 2 - Georreferenciação dos Riscos Mistos em 2016 (Fonte: Bombeiros Sapadores de V.N. de Gaia).

Fig. 2 - Georeferencing of Mixed Risks in 2016 (Source: Fire Brigade of V. N. de Gaia). 
A análise do risco é importante para conhecer os riscos que corremos e comporta diferentes aspetos, de entre os quais devem ser tidos em consideração os fatores desencadeantes.

Tomando para exemplo o caso das inundaçóes, devemos analisar as condiçóes meteorológicas, especificando as caraterísticas da precipitação, ou seja, quantidade ( $\mathrm{mm}$ ou $\left.1 / \mathrm{m}^{2}\right)$, intensidade $(\mathrm{mm} / \mathrm{h})$, duração, concentração temporal, distribuição espacial na bacia hidrográfica, bem como eventuais intervençóes antrópicas e falhas técnicas (ruptura de condutas e coletores) e proceder ao inventário de locais mais suscetíveis, aspetos que é fundamental conhecer na hora de tomar decisóes.

\section{Regulamentação}

A ocorrência de acidentes graves e de grande dimensão, sobretudo de acidentes industriais associados à libertação de substâncias perigosas, como foi o caso do ocorrido em Seveso, na Itália, em 1976, obrigou à criação de mecanismos quer para prevenção, quer para controlo dos riscos associados a esse tipo de indústrias.

As grandes repercussóes e custos ecológicos e económicos deste tipo de acidentes, deu origem à aprovação de diversas Diretivas, salientando-se, a título de exemplo, as seguintes:

- Diretiva n. ${ }^{\circ}$ 82/501, de 24 de junho de 1982 (Diretiva SEVESO I - transposta pelo Decreto-Lei n. ${ }^{\circ} 224 / 87$, de 3 de junho);

- Diretiva n. 9 96/82/CE, de 9 de dezembro de 1996 (Diretiva SEVESO II - transposta pelo Decreto-Lei n. ${ }^{\circ}$ 164/2001, de 23 de maio, alterada pelo Diretiva n. ${ }^{\circ}$ 2003/505, de 16 de dezembro, transposta pelo Decreto-Lei n. ${ }^{\circ}$ 254/2007, de 12 de julho);

- Diretiva n. ' 2012/18/EU do Parlamento Europeu e do Conselho, de 4 de julho de 2012 (Diretiva SEVESO III transposta pelo Decreto-Lei n. ${ }^{\circ}$ 150/2015, de 5 de agosto).

\section{Informação}

A informação é, sem dúvida, um dos aspetos primordiais para divulgação dos aspetos relativos à prevenção. Dos muitos aspetos que poderiam ser considerados, 
referimos exemplos relativos aos riscos mais frequentes: incêndios florestais e inundações.

\section{Risco de incêndio florestal}

O Instituto de Conservação da Natureza e das Florestas define qual deve ser o comportamento dos cidadãos, das organizaçóes e dos agentes durante o período crítico no que concerne ao espaço florestal, fazendo essa divulgação (fig. 3).

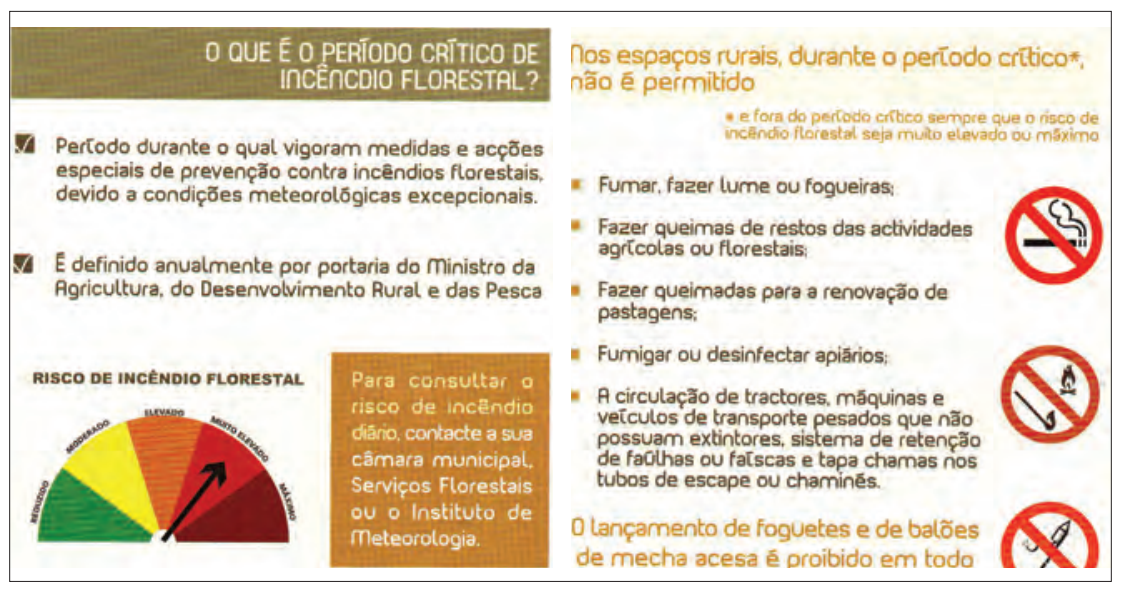

Fig. 3 - Painel de informação risco de incêndio florestal, com proibições/conselhos a ter no espaço rural (Fonte: Instituto de Conservaçáo da Natureza e Florestas (ICNF).

Fig. 3 - Forest fire risk information panel, prohibitions/precautions to take in the countryside (Source: Conservation Institute for Nature and Forest (ICNF).

A título de exemplo, divulga-se um folheto sobre gestão dos espaços florestais envolventes de habitaçôes (fig. 4) que foi produzido pela Câmara Municipal de Gaia e enviado pela Empresa Águas de Gaia, juntamente com o recibo da água do mês de fevereiro 2018.

O Folheto foi expedido para cerca de 100000 consumidores registados, o que significa chegou a cerca de 300000 habitantes do Município de Vila Nova de Gaia, constituindo uma medida importante de prevenção e proteção. 


\section{PROTEJA A SUA/NOSSA CASA}

Assegure o cuidado pela natureza e pela seguranca de todos

AVISO A LIMPEZA DE ESPAÇOS FLORESTAIS É OBRIGATÓRIA

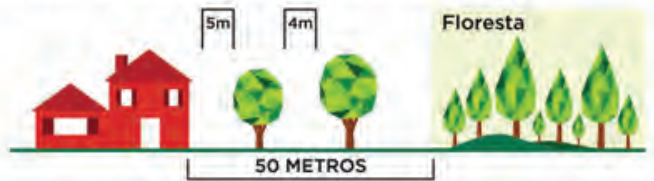

De acordo com o disposto no artigo 153\%, da Lei do Orcamento de Estado para 2018, informa-se:

Os proprietários, arrendatários, usufrutuários ou entidades que detenham terrenos confinantes a edificios inseridos em espacos nurais, devem proceder à limpeza dos terrenos. numa faixa năo inferior a 50 metros medida a partir da alvenaria exterior do edificio, até ao dia 15 de Março de 2018

(De acordo com os critérios definidos no $n^{\circ} 2$, do artigo 15", do DL $n^{2}$ 124/2006, de 28 de Junho, com as sucessivas alteraçes).

Em caso de incumprimento da disposto na $n^{\prime \prime} 2$, do artigo 15?, do DL $n^{\prime \prime} 124 / 2006$, de 28 de Jurtho, com as sucessivas alteraç̧̋es. a coima varia de $280 €$ a 10.0006 , para pessoa singular, e de $1.600 E$ a $120.000 €$, para pessoas coletivas.

\section{ATENÇÃO}

De acordo com as normas regulamentares em vigor no munieipio de Vila Nova de Gaia é proibida a existéncia de árvores, arbustos, sebes, silvados, baisas, lixos ou quaisquer residuos nos terrenos ou logradouros dos prédios nusticos ou urbanos quando consthuam perigo de incéndio, para o ambiente ou para a saćde pública

Esta proibiçăo é ainda extensiva à existència de arvores de crescimento espontàneo e náo protegidas por lei que pelas suas caracteristicas, dimensáo ou especie, possam constituir perigo de incéndio para o ambiente ou para a saúde püblica, designadamente eucaliptos, pinheiros bravos e as espécies consideradas daninhas.

E iguaimente proibido manter árvores, arbustos, silvados, sebes pendentes sobre a va pública, que estorvem a irvre e comoda passagem e impecam a limpeza urbana.

O incumprimento destas obrigaçōes constitui infraçăo punivel com coima e execuçào coerciva dos trabalihos a cargo do infrator.

Fig. 4 - Folheto enviado no recibo da água de fevereiro 2018 pela Empresa Municipal Águas de Gaia.

Fig. 4 - Leaflet sent with the the February 2018 water bill by Empresa Municipal Águas de Gaia (water utility).

\section{Risco de inundação}

O Centro de Previsão e Prevenção de Cheias (CPPC) do rio Douro funciona há quase 30 anos, efetuando análise e previsão da ocorrência de cheias, prevenindo as consequências das manifestaçóes do riscos de inundação, com o objetivo de reduzir os seus efeitos nas populações e garantir a segurança das pessoas e a proteção dos seus bens.

Funciona em coordenação com os Municípios da bacia hidrográfica e resultou de um protocolo conjunto de vários ministérios: Ministério da Defesa Nacional (MDN), Ministério da Administração Interna (MAI), Ministério do Planeamento Administração do Território (MPAT), Ministério da Indústria e Comércio (MIC) 
e Ministério das Obras Públicas Transportes e Comunicaçóes (MOPTC), de 20 de maio de 1986, publicado no Diário da República n. ${ }^{\circ}$ 126, II série, de 3 junho, posteriormente revogado por Despacho Conjunto de 21 fevereiro de 1995, do Ministério da Defesa Nacional, do Ministério da Administração Interna e do Ministério da Indústria e Energia, Ambiente e Recursos Naturais, publicado no Diário da República n.o 148, II série, de 29 de junho de 1995.

O Protocolo encontra-se de novo em revisão/alteração e, por isso, a avaliação e gestâo dos riscos de inundaçôes são enquadradas no Decreto-Lei n. ${ }^{\circ}$ 115/2010, de 22 de outubro (Diretiva 2007/60/CE, relativa aos mapas de risco de inundaçóes, que se encontra disponível através do site: http://sniamb.apambiente.pt/diretiva60CE2007).

As entidades que integram este Protocolo são as seguintes: Autoridade Nacional de Proteção Civil (ANPC), através dos CDOS de Bragança, Guarda, Vila Real, Viseu, Porto e Aveiro; Agência Portuguesa do Ambiente (APA); Instituto Português do Mar e da Atmosfera (IPMA); Eletricidade de Portugal (EDP-Produção); e Autoridade Marítima Nacional (AMN).

O sistema de vigilância da rede da bacia hidrográfica é composto por estaçóes meteorológicas e estaçôes hidrométricas que fornecem informaçôes em tempo real e que, na fase de vigilância, permitem informar a população e os agentes para serem tomadas as medidas adequadas às situaçôes de aviso, alerta (cheia possível), pré-emergência (cheia provável), emergência (cheia iminente ou em curso).

Todavia, nem sempre se consegue obter a informação proveniente das Estaçóes Meteorológicas e das Estaçôes Hidrométricas, o que pode derivar de várias situaçôes, designadamente de avarias nos equipamentos, o que pode criar situaçóes muito preocupantes pois o sistema de vigilância e alerta de recursos hídricos (SVARH) - programa rios - pode ficar seriamente comprometido.

Tal sucedeu na bacia hidrográfica do Rio Douro, quando mais de metade das estaçóes meteorológicas e estaçóes hidrométricas estiveram avariadas (fig. 5), não fornecendo dados e comprometendo, por isso, toda a gestáo da bacia hidrográfica do Rio Douro, nomeadamente as diversas fases da vigilância, em vigor de 1 de outubro a 31 de março, e que permitiriam tomar decisóes em tempo útil para salvaguarda das populaçôes e defesa dos seus bens. 


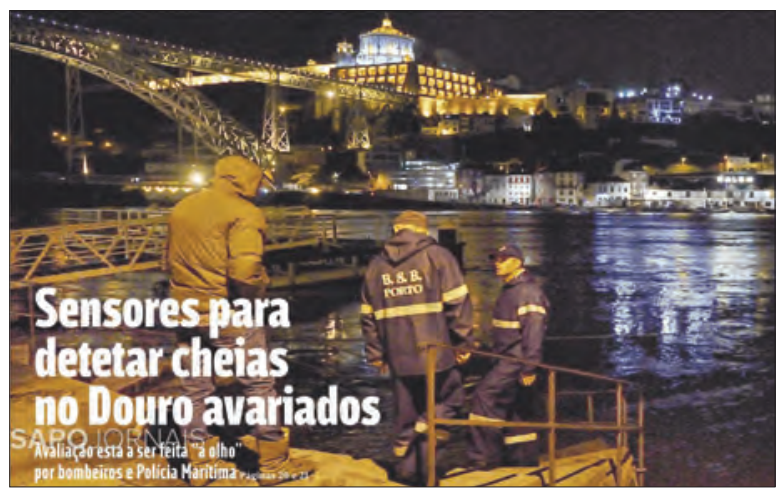

Fig. 5 - Notícia muito preocupante (Fonte: Jornal de Notícias de 13 de janeiro de 2016).

Fig. 5 - Very worrying news (Source: Journal de Notícias, 13 January, 2016).

Vários outros exemplos negativos poderiam ser dados e onde se verifica que a informação não chegou às populaçóes em tempo útil, afetando a sua vida e os seus bens.

Por vezes, a vigilância não funciona e não há alerta dos recursos hídricos, no que se refere à fase de observação meteorológica e, em particular, à pluviometria, nem ao comportamento das barragens, por forma a que, em termos de gestão da bacia hidrográfica e em tempo útil, se emita o aviso às populaçóes, da possibilidade de cheia e da consequente inundação, a fim de tomarem as medidas necessárias à sua salvaguarda e dos seus bens.

Isso parece ter sido o que sucedeu na inundação do rio Ceira (fig. 6). Aparentemente, não funcionou nem a Junta Freguesia, nem a Câmara Municipal, nem a ANPC, nem a EDP, salvando-se em toda esta situação, mais uma vez e quando a crise estava instalada, a ajuda que os bombeiros prestaram às populaçóes.

Todavia, quando se analisa a situação com mais algum detalhe (Cruz et al., 2016), percebe-se que nem sempre as condiçóes são favoráveis à emissão dos avisos em tempo oportuno, sobretudo quando se trata de pequenas bacias hidrográficas, de regime torrencial, em que o tempo de resposta é muito rápido e, por conseguinte, quando essas situaçóes são inopinadas e ocorrem durante a noite, com a população está a dormir, há pouco tempo para perceber o que aconteceu e emitir o aviso.

Em contrapartida, noutras situações a informação é preparada com antecedência, como é o caso da referente a certos locais da cidade do Porto, situados na marginal do Rio Douro, suscetíveis de serem afetados pela ondulação (fig. 7) e 


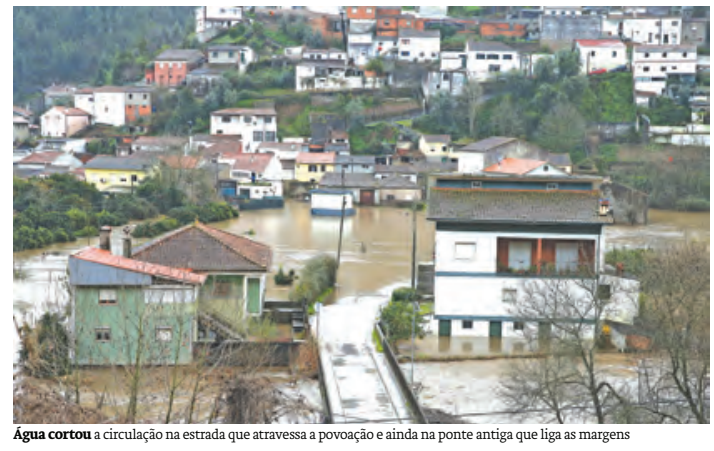

REPORTAGEM Doze casas inundadas e prejuízos por estimar. Câmara de Coimbra requer inquérito para apurar responsabilidades Por Carina Fonseca

\section{Cabouco acordou em sobressalto com a cheia}

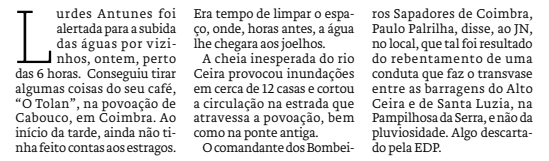

"O caudal escoado na zona que sofreu a rutura foi diminuto face ao caudal que passou pela barragem, pelo qu
este facto não deve ser aponeste facto não deve ser apon-
tado como causa das cheias tado como causa das cheia
em curso", informou a EDP. Em nota escrita, a empresa inicio da tarde, ainda não tido pela EDP.

de energia referiu ainda que

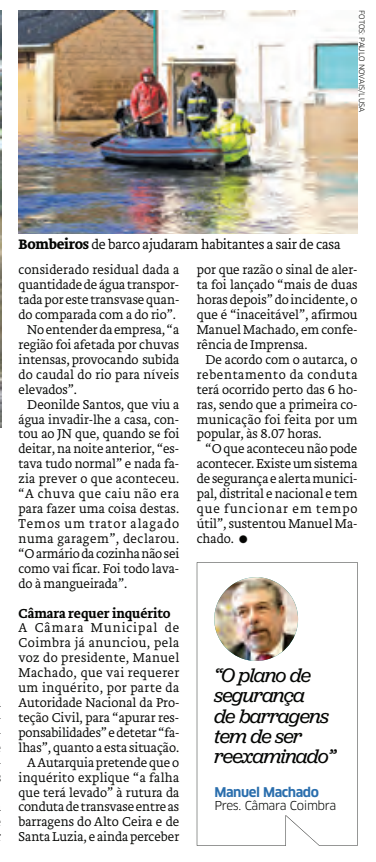

Fig. 6 - Cheia no Rio Ceira - Bacia Hidrográfica do Rio Mondego

Fonte: Jornal de Notícias (JN) de 1 fevereiro 2015).

Fig. 6 - FRiver Ceira in flood - Mondego River basin

(Source: Jornal de Noticias (JN)1 February 2015).

que constitui uma preciosa informação para o Serviço Municipal de Proteção Civil (SMPC), a fim de que, em tempo útil, ou seja, antes da emergência, possa tomar as medidas necessárias e suficientes para proteger as populaçóes e os seus bens.

Uma outra situação, em que apresenta os efeitos da ondulação marítima sobre um monumento religioso, a Capela do Senhor da Pedra situada na praia de Miramar, freguesia de Gulpilhares, Vila Nova de Gaia (fig. 8), o que também constitui uma preciosa informação para o Serviço Municipal de Proteção Civil (SMPC) de Vila Nova de Gaia para, em tempo útil (antes da emergência), tomar as medidas necessárias e suficientes para proteger as populações, nomeadamente os fiéis e turistas, que diariamente visitam este monumento religioso e, ainda, os seus bens. 


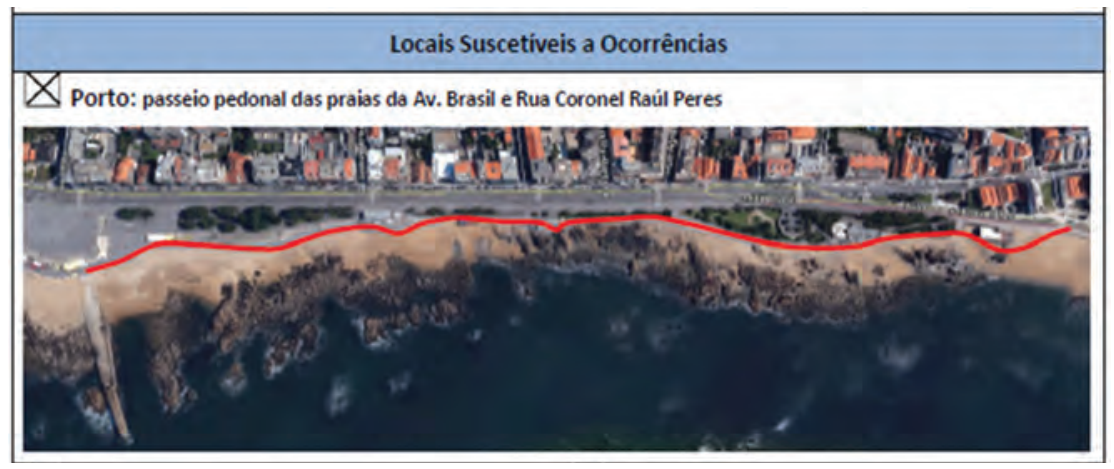

Fig. 7 - Local suscetível a ocorrência - Porto (Fonte: Capitania do porto do Douro).

Fig. 7 - Local susceptible to occur - Porto (Source: Douro Port Captaincy).

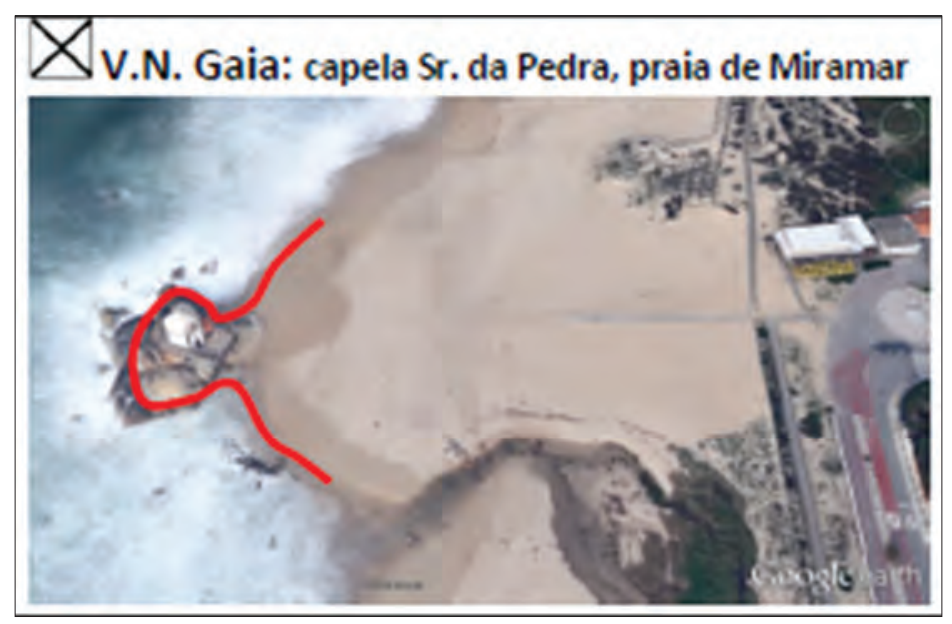

Fig. 8 - Local suscetível a ocorrência - Vila Nova de Gaia (Fonte: Capitania do porto do Douro).

Fig. 8 - Locality susceptible to occurrence - Vila Nova de Gaia (Source: Douro Port Captaincy).

\section{Planeamento}

O planeamento corresponde à última fase da Prevenção e, ao mesmo tempo, diz também respeito à primeira fase da Previsão, razão pela qual será abordado nestas duas fases embora com perspetivas diferentes. 
Por exemplo, a adoção de medidas preventivas, no sentido de tomar posiçôes e definir açóes concretas para eliminar as causas que dáo origem à manifestação de riscos, como é o caso das centrais térmicas que funcionam com biomassa florestal (fig. 9).

Como refere a notícia, a entrada em funcionamento da central de Fradelos, Famalicão, será, num futuro próximo, uma excelente medida preventiva não só para todo o distrito do Porto, "campeão" de ocorrências de incêndios florestais, mas também para o norte de Portugal, já que passará a receber e reutilizar os produtos sobrantes da gestão dos espaços rurais, transformando-os em energia e, por conseguinte, valorizando-os, constituindo um forte incentivo para a limpeza da floresta.

Infelizmente, de acordo com notícia do JN, de 4 março 2018, ainda náo entrou em funcionamento, encontrando-se em testes e prevendo-se a sua entrada em funcionamento no mês de abril 2018(?!), seguindo-se-lhe as centrais de Viseu e Fundão, com previsão de entrada em funcionamento em 2019 e, depois, as centrais de Figueira da Foz, Vila Velha do Ródão e Mangualde.

\section{Câmara de biomassa pronta a laborar no próximo ano}

FAMALICÃo A Câmara de Famalicão acredita que o risco de incêndios florestais deverá "reduzir acentuadamente" com a construção da central térmica a biomassa florestal que está a ser construída na freguesia de Fradelos. A nova infraestrutura começará a funcionar no início do próximo ano.

A central térmica vai consumir 18 toneladas de biomassa florestal, por hora, perfazendo um total de 432 toneladas diárias de resíduos florestais que vão produzir 14,75 megawatts de energia, por hora, que será debitada na rede pública.

A biomassa florestal é constituída pela parte biodegradável dos produtos gerados na floresta e pela

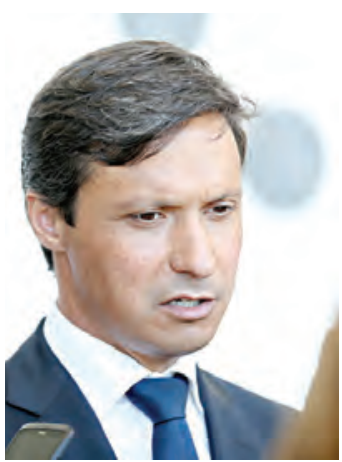

Paulo Cunha, presidente da Câmara matéria orgânica residual gerada nos processos das indústrias de transformação da madeira.

De resto, a empresa já começou a recolha da matéria-prima, e no final do ano a central entra numa fase de teste durante 60 dias.

A construção da central é um investimento de 30 milhões de euros e vai criar 28 postos de trabalho diretos.

Para o presidente da Câmara de Famalicão, Paulo Cunha, "além do importante impacto económico e social na região, o aproveitamento dos resíduos florestais contribuirá para uma maior limpeza das matas e para a redução do risco de incêndios florestais". ALEXANDra LoPES

Fig. 9 - Instalação de Câmara de Biomassa em Famalicáo

(Fonte: JN, 31 de agosto de 2016).

Fig. 9 - Biomass power plant installation in Famalicão (Source: JN, August 31, 2016). 
A entrada em funcionamento das Centrais de Biomassa será um contributo muito importante para receção dos resíduos florestais, criando receitas aos proprietários florestais, um forte contributo para diminuir a poluição das centrais de carvão e, simultaneamente, uma enorme esperança para o ambiente, pois faz-se o reaproveitamento dos resíduos florestais, ao mesmo tempo que se produz energia, sendo uma boa aposta no desenvolvimento das energias renováveis e de eficiência energética.

Outro tipo de medidas de planeamento estão mais voltadas para a cartografia e de que é exemplo a prática em uso no SMPC de V. N. de Gaia que, ao longo dos anos, tem georreferenciado as ocorrências, tal permite que, após os avisos do IPMA, seja possível tomar medidas preventivas, em tempo útil, tais como, por exemplo, a limpeza de sargetas, em pontos baixos e mais suscetíveis a inundaçôes, e o alerta precoce às populaçôes, para a possibilidade ou a iminência de inundaçóes.

Permite ainda a execução de cartografia de risco de inundaçóes, dando assim cumprimento ao Decreto-Lei n. ${ }^{\circ} 115 / 2010$, de 22 de outubro, ou a cartografia de risco de incêndio (fig.s 2, 10 e 11) ou de outros riscos (fig. 12).

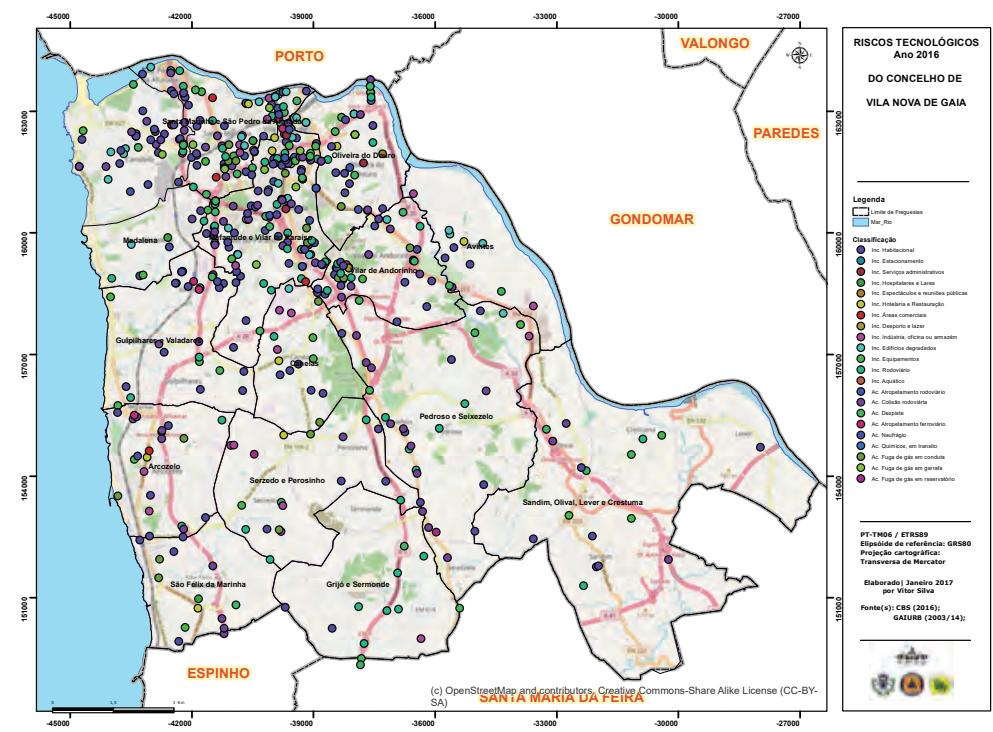

Fig. 10 - Georreferenciação dos Riscos Tecnológico em 2016 (Fonte: Bombeiros Sapadores V. N. Gaia).

Fig. 10 - Georeferencing of Technological Risks in 2016 (Source: Fire Brigade of V. N. de Gaia). 


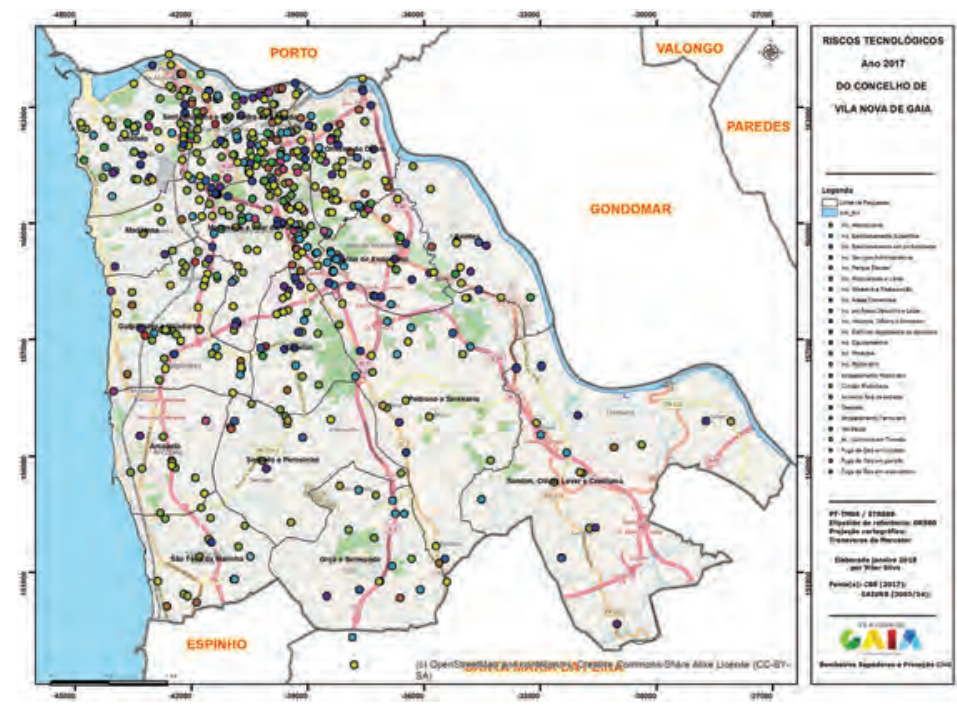

Fig. 11 - Georreferenciação dos Riscos Tecnológico (Fonte: Bombeiros Sapadores V. N. Gaia).

Fig. 11 - Georeferencing of Technological Risks (Source: Fire Brigade of V. N. de Gaia).

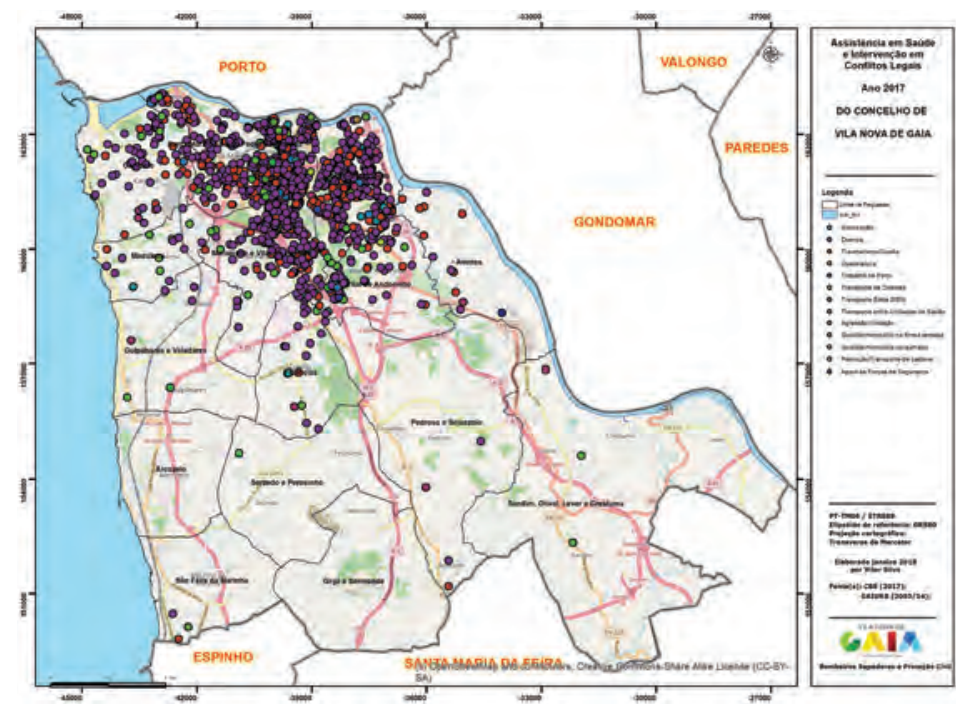

Fig. 12 - Georreferenciação assistência em saúde e intervenção em conflitos legais em 2017 (Fonte: Bombeiros Sapadores de V. N. de Gaia).

Fig. 12 - Georeferencing of health care and intervention in legal conflicts in 2017 (Source: Fire Brigade of V. N. de Gaia). 
Assim, as medidas de organização do território, de silvicultura e de infraestruturação constituem três aspetos cruciais no sistema de defesa da floresta contra incêndios, plasmados no Decreto-Lei n. ${ }^{\circ}$ 156/2004, de 30 de junho, revogado pelo Decreto-Lei n. ${ }^{\circ}$ 124/2006, de 28 de junho, alterado pelos Decretos-Lei n.os 15/2009 e 17/2009, de 14 de janeiro, 3. a alteração pelo Decreto-Lei n.o 114/2011, de 30 novembro, 4 . $^{\text {a }}$ alteração pelo Decreto-Lei n. ${ }^{\circ}$ 83/2014, de 23 de maio, e 5. ${ }^{a}$ alteração pela Lei n. ${ }^{\circ}$ 76/2017, de 17 de agosto.

$\mathrm{Na}$ defesa de pessoas e bens o art. ${ }^{\circ} 16 .^{\circ}$, n. $^{\circ}$ 2, obriga (desde 2004) à gestão duma faixa de 50 metros à volta das edificaçóes o que constitui uma medida preventiva muito eficaz (fig. 13). Infelizmente, durante muitos anos esta legislação foi ignorada por proprietários e pelas entidades públicas com responsabilidade de fiscalização e autuação, que têm a obrigação de fazer cumprir esta importante medida prevista na lei, mas a burocracia e o habitual "deixar andar" não permitiu cumprir este objetivo que, impedindo a propagação do incêndio, defenderia vidas e habitações, ao contrário do que sucedeu no fatídico verão de 2017.

Ora, na sequência desses incêndios, foram tomadas uma série de medidas de prevençáo, designadamente para proteção e salvaguarda do Parque Nacional da Peneda-Gerês, através da colocação de trabalhadores especializados em silvicultura

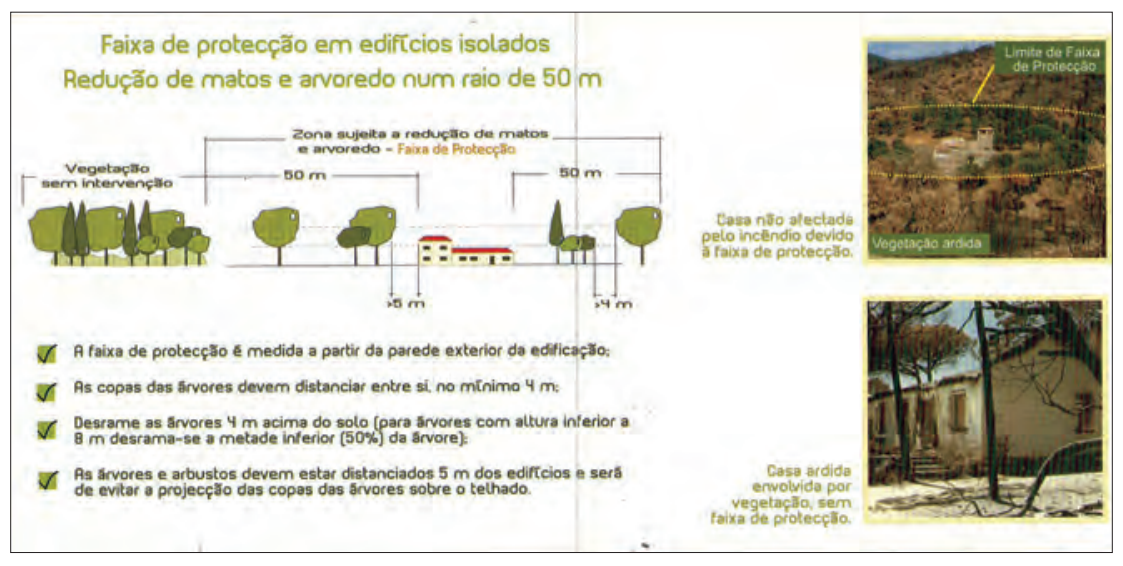

Fig. 13 - Faixa proteção edifícios isolados (Fonte: Instituto de Conservaçáo da Natureza e Florestas (ICNF).

Fig. 13 - Protective strip for isolated buildings (Source: Institute for Nature Conservation and Forestry (ICNF). 
preventiva, vigilância e auxílio aos bombeiros no combate (diz o Ministro: "Temos que ter mais gente no terreno e mais equipas de Sapadores Florestais"...). Trata-se de uma notícia muito importante (fig. 14) para tâo emblemático espaço público nacional, que é reserva ambiental da humanidade e garantia da biodiversidade.

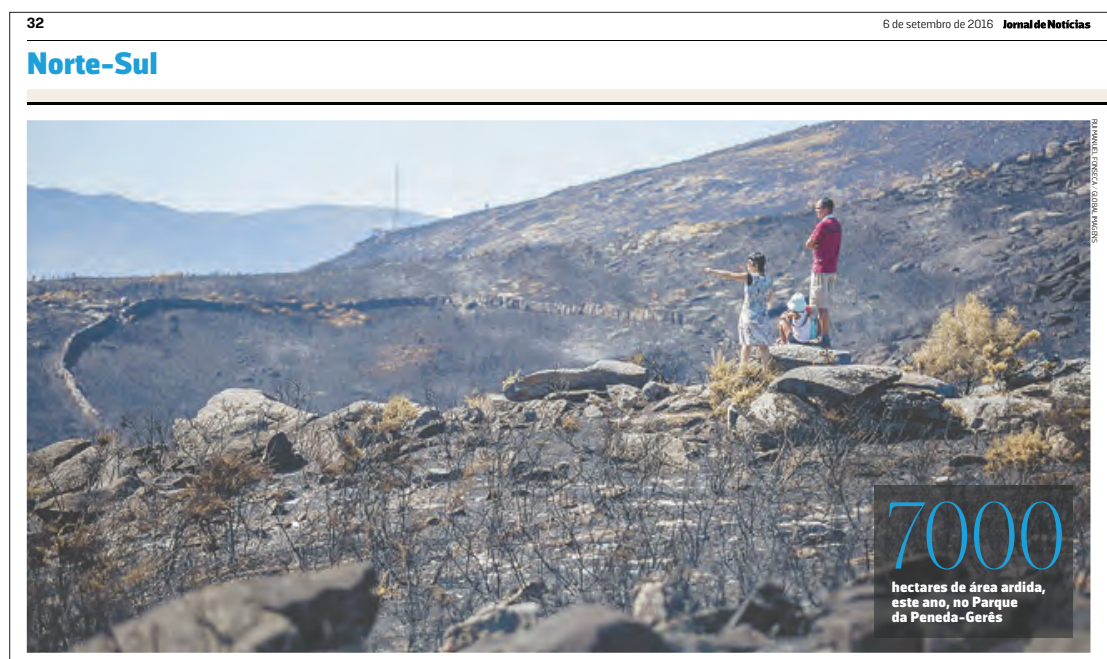

Ponte da Barca Ministro do Ambiente anuncia reforço de meia centena de sapadores florestais já no próximo ano

\section{3,4 milhões para travar fogos na Peneda-Gerês}
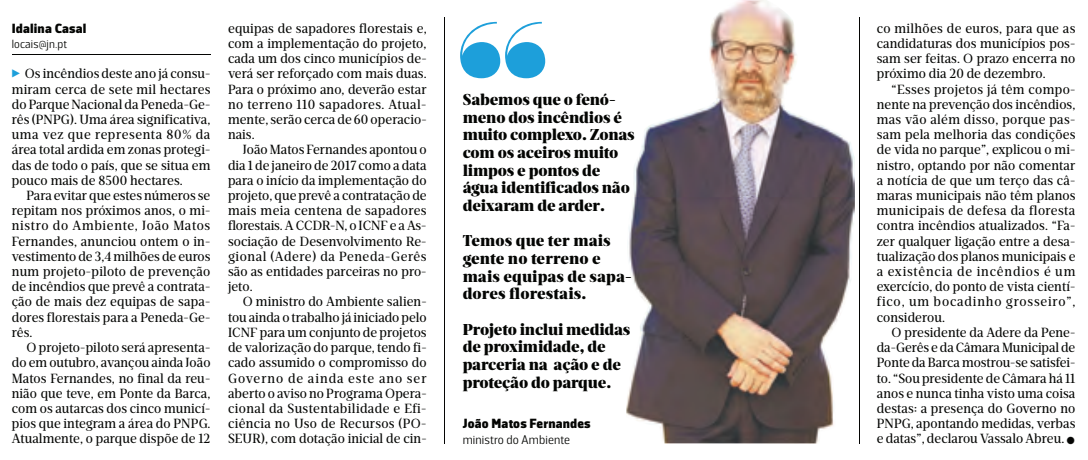

Fig. 14 - O Parque da Peneda - Gerês: Medidas preventivas

(Fonte: Jornal de Notícias, 6 de setembro de 2016).

Fig. 14 - Peneda - Geres Park: Preventive measures

(Source: Jornal de Noticias, September 6, 2016). 


\section{Previsão}

Como prever e prevenir a manifestaçáo de riscos maiores? A crise pode chegar, manifestar-se a qualquer momento. Os agentes locais de proteção civil estáo no terreno e seráo os responsáveis pela sua gestấo. Mas, para evitar que tal aconteça, a prioridade será prever riscos sem haver crises. Como fazer?

Como foi referido anteriormente, é necessário analisar os riscos e, em particular, as medidas de planeamento, algumas das quais já foram descritas a propósito da prevenção, mas que também dizem respeito à previsão, em particular no que concerne à preparação de Planos de Emergência, sejam Gerais, Especiais ou Prévios de Intervenção, razão pela qual se voltam a mencionar.

\section{Planeamento}

O planeamento é a base de toda a atividade da proteçâo civil. A base do trabalho para minimizar o risco ou mesmo evitar o perigo, deverá ser o planeamento de emergência (D. Alexander, 2005).

Todos temos que fazer algo para minimizar e evitar situações que ponham em causa o bem-estar e a segurança dos cidadáos. $\mathrm{O}$ art. ${ }^{\circ} 50{ }^{\circ}$ da Lei n. ${ }^{\circ}$ 80/2015, de 3 de agosto (alteração da Lei n. ${ }^{\circ}$ 27/2006, de 3 de julho - Lei de Bases de Proteçáo Civil), define claramente os vários tipos de planos conforme as finalidades. Assim, temos, por exemplo:

- Plano Municipal de Emergência de Proteção Civil (PMEPC);

- Plano Municipal de Defesa da Floresta Contra Incêndios (PMDFCI);

- Plano Operacional Municipal de Defesa da Floresta (POMDF);

- Plano Especial de Emergência de Proteção Civil (PEEPC), para um tipo de risco, uma área ou uma infraestrutura, de que são exemplo:

- PEERS-AML-CL para o risco sísmico na área metropolitana de Lisboa e concelhos limítrofes (ANPC, 2003);

- Plano Especial de Emergência de Risco Sísmico e de Tsunamis na região do Algarve, 2011, com a 1a revisão aprovada em 28 de janeiro de 2014 (ANPC, 2010). 
A Diretiva emanada pela Comissão Nacional de Proteção Civil - Resolução n. ${ }^{\circ}$ 30/2015, de 7 de maio, fixa os critérios e normas técnicas para a elaboração e operacionalização dos planos mencionados.

A título de exemplo apresenta-se o Plano Prévio Municipal para Intervenção em Acidentes Rodoviários no Município de Vila Nova de Gaia (fig. 15) amplamente discutido em várias reunióes com todas as entidades com superintendência técnica e operacional nesta matéria, aprovado em 1 de julho de 2007, com a definição da grelha de atuação em todo o Município.

Em outubro de 2010, a ANPC publicou a Diretiva Operacional n.o 3 (DON n. ${ }^{\circ}$ 3)/NRBQ - Dispositivo Integrado de Operaçôes Nuclear, Radiológico, Biológico e Químico.

\begin{tabular}{|c|c|c|c|c|c|c|c|c|c|c|}
\hline \multicolumn{11}{|c|}{$\begin{array}{l}\text { MUNICIPIO DE V. N. GAIA } \\
\text { Gaia CIdade D'oura } \\
\text { b) Grelha de Actuação da ZOE de Vila NOva de Gaia }\end{array}$} \\
\hline \multirow[b]{2}{*}{$\begin{array}{l}\text { Corpos de } \\
\text { Bombeiros }\end{array}$} & \multicolumn{10}{|c|}{ Alerta } \\
\hline & Azuil & \begin{tabular}{c}
\multicolumn{1}{|c|}{ An } \\
$\begin{array}{c}\text { Feridas }+ \\
\text { Encarcerados }\end{array}$
\end{tabular} & $\begin{array}{l}\text { marelo } \\
\text { Comin } \\
\text { Incesndio } \\
\end{array}$ & $\begin{array}{l}\text { Matérias } \\
\text { Perigosas }\end{array}$ & $\begin{array}{c}\text { Feridost } \\
\text { encarcerados }\end{array}$ & \begin{tabular}{|l|} 
Laranja \\
Com \\
Incéndio \\
\end{tabular} & $\begin{array}{l}\text { Mathías } \\
\text { Perigasas }\end{array}$ & \begin{tabular}{|c|c|}
\multicolumn{2}{|c|}{ Ve } \\
Fenidas \\
encarcerados
\end{tabular} & $\begin{array}{c}\text { Com } \\
\text { Incêndio } \\
\end{array}$ & $\begin{array}{l}\text { Matsír } \\
\text { Perigacas }\end{array}$ \\
\hline 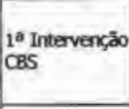 & $\operatorname{ABSC} \mid \begin{array}{l}1 \\
v \\
A\end{array}$ & \begin{tabular}{l|l} 
VSAE \\
VUCI \\
ABSC
\end{tabular} & $\begin{array}{l}\text { VSAE } \\
\text { VUCI } \\
\text { ABSC }\end{array}$ & $\begin{array}{l}\text { VSAE } \\
\text { VUCI } \\
\text { ABSC }\end{array}$ & $\begin{array}{l}\text { VSAE } \\
\text { VUCI } \\
\text { ABSC }\end{array}$ & \begin{tabular}{|l|} 
VSAE \\
vUCA \\
ABSC
\end{tabular} & \begin{tabular}{l|l} 
VSAE \\
VUCI \\
ABSC
\end{tabular} & $\begin{array}{l}\text { VSAE } \\
\text { VUCI } \\
2 \times \text { ABSC }\end{array}$ & $\begin{array}{l}\text { VSAE } \\
\text { VUCI } \\
2 \times A B S C\end{array}$ & $\begin{array}{l}\text { VSAE } \\
\text { VUCT } \\
\text { VITI } \\
\text { ABSC } \\
\end{array}$ \\
\hline $\begin{array}{l}1^{0} \text { Intervencão } \\
\text { CBV Local }\end{array}$ & ABSC & $\begin{array}{l}\text { VSAT } \\
2 \text { X ABSC }\end{array}$ & $\begin{array}{l}\text { VSAT } \\
\text { VUCI } \\
\text { ABSC }\end{array}$ & $\begin{array}{l}\text { VSAT } \\
\text { WUCI } \\
\text { ABSC }\end{array}$ & $\begin{array}{l}\text { VSAT } \\
2 \times A B S C\end{array}$ & $\begin{array}{l}\text { VSAT } \\
\text { VUCI } \\
\text { ABSC }\end{array}$ & $\begin{array}{l}\text { vSUT } \\
\text { vuCI } \\
\text { ABSC }\end{array}$ & $\begin{array}{l}\text { VSAT } \\
3 \text { X ABSC }\end{array}$ & $\begin{array}{l}\text { VSAT } \\
\text { VUCI } \\
2 \times \text { XABC }\end{array}$ & $\begin{array}{l}\text { VSAT } \\
\text { VUCI } \\
3 \times \text { ABSC }\end{array}$ \\
\hline $\begin{array}{l}1^{\circ} \text { Reforms } \\
\text { (a pedido do } \\
\text { aMOS) }\end{array}$ & & & $V_{\text {ABSC }}$ & $\begin{array}{l}\text { VSAT } \\
\text { VTIU } \\
\text { ABSC }\end{array}$ & $\begin{array}{l}\text { VSAT } \\
2 \times \text { ABSC }\end{array}$ & $\begin{array}{l}\text { VSAT } \\
\text { VITU } \\
2 \times \text { ABSC } \\
\end{array}$ & $\begin{array}{l}\text { VSAT } \\
\text { VTTU } \\
\text { ABSC }\end{array}$ & $\begin{array}{l}\text { VSAT } \\
2 \times A B S C\end{array}$ & $\begin{array}{l}\text { VSAT } \\
\text { VTIU } \\
3 \times \text { ABSC } \\
\end{array}$ & $\begin{array}{l}\text { VSAT } \\
\text { VTTU } \\
3 \times \text { ABSC. }\end{array}$ \\
\hline $\begin{array}{l}2{ }^{2} \text { Reforcos } \\
\text { (a pedido do } \\
\text { CMOS) }\end{array}$ & & & & & & $A B S C$ & $\left|\begin{array}{l}\text { VSAT } \\
2 \times V T U \\
2 \times \text { ABSC }\end{array}\right|$ & $\begin{array}{l}\text { VSAT } \\
2 \times A B S C\end{array}$ & $\begin{array}{l}\text { VSAT } \\
2 \times A B S C\end{array}$ & $\begin{array}{l}\text { VSAT } \\
2 \times \text { VTV } \\
3 \times \text { ABSC }\end{array}$ \\
\hline Outros melos & & & A PEDI & IDD DO CM & 1OS - Centro M & tunicipal de & Operagōes & 5 de Socorto & & \\
\hline \multicolumn{7}{|c|}{$\begin{array}{l}\text { VSAE- Veículo de Socorro e Assistência Especial } \\
\text { VUCI- Veículo Urbano de Combate a Incêndios } \\
\text { VSAT- Veículo de Socorro e Assistência Tático }\end{array}$} & \multicolumn{4}{|c|}{$\begin{array}{l}\text { VTTU- Veículo Tanque Urbano } \\
\text { ABSC- Ambulância de Socorro }\end{array}$} \\
\hline
\end{tabular}

Fig. 15 - Plano Prévio Municipal Intervenção em Acidentes Rodoviários no Município de V. N. de Gaia.

Fig. 15 - Preliminary Municipal Intervention Plan for Road Accidents in the Municipality of $V$. N. de Gaia. 
É um instrumento de planeamento, coordenação e comando operacional no quadro das açôes de resposta a situaçóes de emergência envolvendo agentes NRBQ e ainda como documento de referência para os planos e diretivas das outras entidades públicas ou privadas da área de proteção e socorro.

Ao nível dos Comandos Distritais de Operaçóes de Socorro (CDOS), nomeadamente no CDOS-Porto foi apresentado e aprovado o Plano de Operaçóes Distrital (PLANOP), que tem com "Missão" garantir a mobilização de meios e recursos humanos e técnicos, passíveis de, sob um comando único responder às situaçôes de proteçáo e socorro que envolvam riscos NRBQ, no espaço territorial do Distrito do Porto.

Prevê o PLANOP, num Anexo, duas fichas, uma designada "Ficha de Notificação Inicial", que se destina a recolher toda a informação relativa a situaçôes de suspeita ou confirmação de agentes NRBQ para enviar ao CDOS e uma segunda ficha designada "Ficha de Reconhecimento" - incidentes com suspeita ou envolvimento de Agentes NRBQ, que se destina a apoiar as Equipas de Avaliaçáo e Reconhecimento da Situação NRBQ (ERAS NRBQ).

A ANPC, através do Despacho n. ${ }^{\circ}$ 12160/2012, de 7 de setembro, definiu os modelos de Fichas para os relatórios com obrigatoriedade de execução relativos a acidentes com matérias perigosas (fig. 16).

O sistema ECURIE - European Community Urgent Radiological Information Exchange - é um programa da Direcção-Geral da Energia e dos Transportes da Comissão Europeia, que tem por objetivo assegurar a troca rápida de informaçáo em caso de eminência ou ocorrência de um acidente nuclear/emergência radiológica com reflexos sobre qualquer um dos países aderentes (países da Uniāo Europeia e a Suíça).

Em Portugal existem 2 pontos de contacto deste sistema:

- PT-1, Agência Portuguesa do Ambiente (APA) que tem por missão receber as notificaçóes de acidentes nucleares ou emergências ocorridas fora do território nacional;

- PT-2, Autoridade Nacional de Proteçâo Civil (ANPC), que tem a responsabilidade de notificar internacionalmente os acidentes nucleares ou emergências ocorridas em território nacional. A ANPC funciona como o ponto de contacto permanente. 


\title{
MINISTÉRIO DA ADMINISTRAÇÃO INTERNA
}

\author{
Autoridade Nacional de Proteção Civil \\ Despacho n. ${ }^{0} 12160 / 2012$
}

\section{Relatórios de acidentes no transporte rodoviário e ferroviário de mercadorias perigosas}

Ao abrigo do disposto na alínea $f$ ) do n. ${ }^{\circ} 8$ do artigo $13 .^{\circ}$ do Decreto-Lei n. ${ }^{\circ} 41-\mathrm{A} / 2010$, de 29 de abril, determino:

1 - Os modelos de relatórios de acidentes relativos ao transporte terrestre de mercadorias perigosas por estrada ou por caminho-de-ferro são definidos, respetivamente, nos anexos I e II ao presente despacho, que dele fazem parte integrante.

2 - Devem ser analisados e elaborados relatórios de acidente sobre os acontecimentos ocorridos com o meio de transporte em trânsito, estacionado ou nas operações de carga ou de descarga, acondicionamento ou estiva, em que se verifique alguma das seguintes situações:

a) Explosão;

b) Incêndio;

c) Perda de contenção da mercadoria ou queda de parte ou da totalidade da carga durante o transporte;

d) Necessidade de trasfega da mercadoria para outro reservatório, efetuada fora de um recinto apropriado;

e) Morte ou lesões provocadas pela mercadoria perigosa;

f) Intervenção no local de serviços de emergência públicos ou de elementos a cargo da empresa expedidora ou transportadora;

g) Outros acontecimentos com características que, do ponto de vista do conselheiro de segurança, apresentem interessa técnico específico para a prevenção de acidentes ou para a limitação das respetivas consequências.

3 - O presente despacho revoga o despacho n. ${ }^{\circ} 2338 / 2001$, publicado no Diário da República, 2. ${ }^{\text {a }}$ série, n. ${ }^{\circ} 29$, de 3 de fevereiro de 2001.

4 - O presente despacho produz efeitos no dia seguinte ao da sua publicação.

7 de setembro de 2012. - O Presidente, Arnaldo José Ribeiro da Cruz.

Fig. 16 - Despacho n. ${ }^{o}$ 12160/2012 - Relatórios de acidentes no transporte rodoviário e ferroviário de mercadorias perigosas).

Fig. 16 - Administrative Order n. ${ }^{\circ} 12160 / 2012$ - Accident reports on road and rail transport of dangerous goods). 


\section{Plano Especial de Emergência para o Risco Sísmico na Área Metropolitana de Lisboa (PEERS-AML) e concelhos limítrofes (CL).}

A Área Metropolitana de Lisboa (AML), bem como os concelhos limítrofes (CL), está associada a diversos registos de fenómenos sísmicos, sobressaindo o célebre terramoto de 1755 , considerado internacionalmente como a primeira catástrofe da era moderna.

O Plano Especial de Emergência para o Risco Sísmico na Área Metropolitana de Lisboa e Concelhos Limítrofes (PEERS-AML-CL) é um instrumento essencial de suporte ao Sistema de Proteçáo Civil para a gestáo operacional de um evento sísmico na regiáo em apreço.

Face à Lei de Bases de Proteçấo Civil (Lei n. ${ }^{\circ}$ 27/2006, alterada pela Lei n. ${ }^{\circ}$ 80/2015 de 3 de agosto), classifica-se este Plano como Especial quanto à finalidade e como Supradistrital no que diz respeito à sua abrangência geográfica.

Na elaboração do PEERSAMLCL foi considerada a sua articulação com o Plano Nacional de Ordenamento do Território (PNOT), com os Planos Distritais de Emergência, dos distritos de Lisboa, Santarém e Setúbal, e com os Planos Diretores Municipais (PDM) da AML e CL.

Esta articulação é crucial para estabelecer comportamentos, para correta utilização do solo, para adequada construção de infraestruturas, implementação de equipamentos sociais e para fiscalização do cumprimento das disposiçôes legais.

A Resolução n. ${ }^{\circ}$ 22/2009, define os Critérios para a ativaçấo do Plano, que será ativado por decisão da Comissão Nacional de Proteção Civil (CNPC) ao abrigo da alínea a) do n. ${ }^{\circ} 3$ do art. $^{\circ} 36 .{ }^{\circ}$ da Lei de Bases de Proteção Civil ou na sequência de emissão de Declaração, pelo Governo, da Situação de Calamidade, de acordo com a alínea b), do n. ${ }^{\circ} 2$, do art. ${ }^{\circ} 22 .^{\circ}$ da Lei de Bases de Proteção Civil.

Sem prejuízo destas competências o PEERS - AML- CL será ativado automaticamente desde que:

1 - Ocorra evento sísmico com epicentro na AMLCL com estimativa de magnitude de igual ou superior a 6,1 na Escala de Richter;

2 - Ocorra evento sísmico na AML-CL com estimativa de intensidade máxima, obtida a partir de medidas instrumentais, igual ou superior a VIII na Escala de Mercalli Modificada (independentemente da localização do epicentro). 
A questão que se deve colocar é a de saber se, para além do PEERSAMLCL, estaremos a fazer o necessário para preparar os cidadãos?

Os cientistas dizem que não. A convicção do autor também é a de que não estamos a trabalhar na Prevenção, uma vez que falta o trabalho diário de sensibilização à população, de preparação para ela saber o que fazer e para onde fugir, bem como de treino tanto do que deve, como do que não deve ser feito, pelo que é crucial fazer exercícios envolvendo as populaçóes, as Escolas, as Associaçóes e demais Instituições (fig. 17).

\section{ALUNOS DE LISBOA EXIGEM SIMULACROS DE SISMOS}

Três associações de estudantes denunciam falhas graves na prevenção

Três associações de estudantes de escolas de Lisboa entregaram, na última semana, uma petição com 500 assinaturas, na Assembleia Municipal de Lisboa (AML) a pedir a atualização dos planos de emergência das escolas básicas e secundárias do concelho. Os signatários alertam para o facto de não serem efetuados si- mulacros há pelo menos três anos na maioria dos estabelecimentos.

"A lei manda que sejam realizados anualmente, mas há casos, como a Padre António Vieira, onde não se faz um simulacro há sete anos", referiu ao JN Nuno Guerreiro, presidente da Associação de Estudantes daquela escola. Acrescentou que a petição

\section{Sete anos}

A Escola Secundária Padre António Vieira não recebe qualquer exercício de prevenção de catástrofe há sete anos, segundo os estudantes

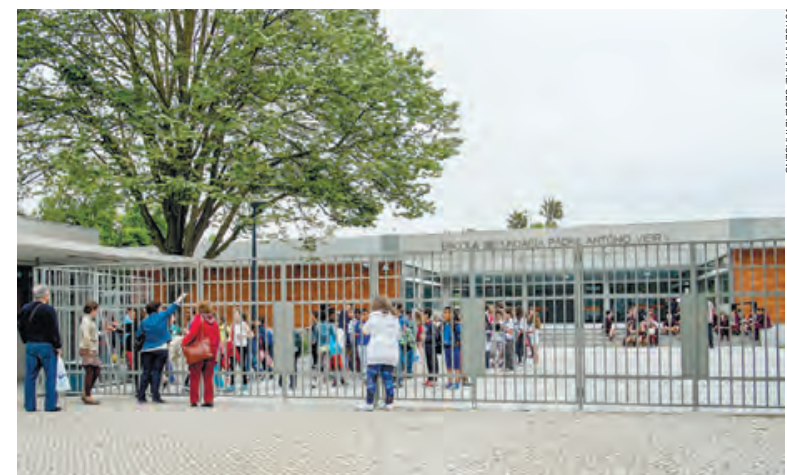

surge depois de ter falado com variadíssimos colegas e ter chegado à conclusão de que a situação é igual ou parecida. "Se a lei fosse cumprida, um aluno que começasse a fazer simulacros no 1. ${ }^{\circ}$ ano chegava ao $12 .^{\circ}$ com 11 participações nestas atividades e portanto preparado para saber como reagir em caso de uma emergência. Assim, isto não acontece", observa.

Nuno Guerreiro adianta ainda que os simulacros servem para identificar como aquelas que ocorrem na sua escola em que, diz, "duas saídas de emergência de um bloco estão bloqueadas".

A petição foi subscrita pelas associações de estudantes das escolas Padre António Vieira, Rainha D. Leonor e D. Pedro V, mas, segundo Nuno Guerreiro, conta com o apoio de outras.

O JN tentou uma reação do Ministério da Educação, mas não obteve resposta em tempo útil. Paulo LOURENço

Fig. 17 - Notícia salientando a importância da Prevenção

(Fonte: JN, 4 maio de 2018).

Fig. 17 - News highlighting the importance of prevention

(Source: JN, May 4, 2018) 


\section{Planeamento Logístico}

No âmbito da Proteção Civil nomeadamente na preparação da gestão da catástrofe, falar de logística significa planear e executar operaçôes que envolvem transporte, gestão e armazenamento de bens e gestão de ativos (agentes de proteção civil). As operaçóes de logística obedecem a uma hierarquização obrigatória, conforme a operação em causa.

A prioridade das prioridades será sempre o apoio à população afetada, nomeadamente assegurando a alimentação, distribuição de água potável, agasalhos, material sanitário, transporte para zonas seguras e acompanhamento médico.

Em qualquer cenário de crise, a logística é fundamental e absolutamente decisiva no sucesso ou insucesso de toda e qualquer operação de proteção civil, a qual requer um apoio contínuo.

Teremos assim, a par do conceito de área de operaçóes, a área de logística que não é mais do que a área de apoio.

\section{Área de apoio}

A escolha desta área é muito importante, pelo que deve ser realizada com muito rigor e deve atender aos seguintes fatores:

Localização - deve ser implantada o mais próximo possível da área de operaçóes, mas no exterior ou nos limites da área de operaçóes. O espaço deve ser amplo, para englobar todas as etapas da operação e de forma a que elas não colidam: receção, armazenamento e distribuição de produtos, bens e máquinas. Deve prever-se o local destinado à instalaçáo de contentores e de tendas, de preferência deve procurar escolher-se um espaço arborizado;

- Segurança (safety) - deve ser um local afastado de taludes, bem como de linhas de água.

O solo deverá ser o mais consistente possível e o terreno ser levemente inclinado;

- Segurança (security) - o local escolhido deve ser vedado ou caso náo seja possível, deve permitir a vigilância pelas forças de segurança;

- Acessibilidade - o espaço deve garantir um acesso franco à área de apoio, nomeadamente a veículos pesados; 
- Infraestruturas - a área deve ter as infraestruturas básicas: energia elétrica, abastecimento de água potável e saneamento de águas residuais domésticas.

- Subordinação - um dos princípios fundamentais da logística é a sua subordinaçáo à manobra operacional, isto é, a logística destina-se, obrigatoriamente, a apoiar e a manter em funcionamento as operações. Por isso, nas diretivas operacionais o capítulo da administração e logística é um ponto fundamental. Exemplifiquemos:

\section{Diretiva Operacional Nacional n. ${ }^{\circ} 1\left(\mathrm{DON}\right.$ n. ${ }^{\circ}$ ) - Dispositivo Integrado das Operaçôes de Proteção e Socorro (DIOPS) - janeiro 2010}

Esta Diretiva define claramente as bases de apoio logístico como sendo medidas logísticas constituídas à ordem da ANPC, para apoio e suporte direto ao desenvolvimento e sustentação das operaçóes de proteção e socorro (fig. 18):

\section{Administração}

(1) As despesas de pessoal e administrativas, decorrentes da implementação desta directiva, são suportadas pelas entidades contribuintes, e pela ANPC em conformidade com os programas de financiamento, directivas, circulares ou despachos orçamentais aplicáveis.

(2) A ANPC garante os recursos humanos, materiais e informacionais necessários ao funcionamento do Centro de Coordenação Operacional Nacional (CCON) e dos Centros de Coordenação Operacional Distrital (CCOD).

\section{Logística}

(1) O Corpo de Bombeiros da área da ocorrência providenciará, numa primeira fase, 0 apoio logístico indispensável à sustentação das operações de socorro.

(2) A alimentação do pessoal e o reabastecimento dos meios em água e combustível deverão ser assumidas como acções imprescindíveis daquele Corpo de Bombeiros.

(3) Logo que uma ocorrência evolua, o Comandante das Operações de Socorro desencadeará 0 processo de empenhamento do Serviço Municipal de Protecção Civil para apoio logístico mais diferenciado às forças de socorro, de forma a garantir a sustentação das operações, no mínimo por 12 horas.

Fig. 18 - Administração e Logística

(Fonte: ANPC - DON n. ${ }^{\circ}$ 1/DIOPS - Jan. 2010).

Fig. 18 - Administration and Logistics

(Source: ANPC - DON n. ${ }^{\circ}$ 1/DIOPS - Jan. 2010). 


\section{Diretiva Operacional Nacional n.o 3 - Dispositivo Integrado de Operaçóes: Nuclear, Radiológico, Biológico e Químico (NRBQ) - outubro 2010}

Esta Diretiva Operacional Nacional (DON) constitui-se como um instrumento de planeamento, organização, coordenação e comando operacional no quadro das ações de resposta a situações de emergência envolvendo agentes NRBQ e, ainda, como um documento de referência para os planos e diretivas das outras entidades públicas ou privadas da área da proteção e do socorro

Define claramente as bases de apoio logístico como sendo medidas logísticas constituídas à ordem da ANPC, para apoio e suporte direto ao desenvolvimento e sustentaçáo das operaçóes de proteção e socorro (fig. 19).

Partindo do princípio que todos os municípios portugueses (Serviços Municipais de Proteção Civil) conhecem esta Diretiva, questionamo-nos sobre quantos deles terão meios para atuar nas estradas municipais e nas estradas nacionais que atravessam os seus concelhos? $\mathrm{Ou}$, então, sobre quantos protocolos de colaboração existirão entre os Municípios e Instituto Estradas de Portugal, de forma a haver uma intervenção coordenada, rápida e segura?

\section{ADMINISTRAÇÃO E LOGÍSTICA}

a) No âmbito das operações de resposta a incidentes envolvendo agentes NRBQ, e desde que em cumprimento da missão legalmente atribuída, cada entidade assume os custos associados à mobilização dos respectivos meios e recursos.

b) 0 apoio logístico às operações, nomeadamente no que respeita à alimentação para os operacionais envolvidos e o abastecimento de combustíveis, e sempre que estas se estendam por mais de 12 horas, deverá ser assegurado pela Câmara Municipal da respectiva área.

c) Compete ainda às Câmaras Municipais, e no que respeita à respectiva área geográfica, articular com as entidades relevantes com vista a garantir uma adequada e atempada intervenção no âmbito da limpeza das vias eventualmente afectadas por operações envolvendo agentes NRBQ, nomeadamente no que respeita à remoção de resíduos e águas residuais, sempre em estreita observância pelas regras de segurança.

Fig. 19 - Administração e Logística (Fonte: ANPC - DON n. 3/NRBQ - outubro 2010)

Fig. 19 - Administration and Logistics (Source: ANPC - DON n. 3/NRBQ - October 2010). 


\section{Diretiva Operacional Nacional n. ${ }^{\circ} 4$ - Dispositivo Integrado de Resposta a Acidentes com Aeronaves (DIRACAERO)}

Esta Diretiva Operacional Nacional n. ${ }^{\circ}$ 4, conhecida como DIRACAERO (ANPC, 2013a), constitui-se como um instrumento de planeamento, organização, coordenaçáo e comando operacional e ainda como documento de referência para os planos e diretivas das outras entidades públicas ou privadas da área da proteçáo e do socorro de modo a constituir base doutrinária no quadro das açóes de resposta a situaçōes de emergência, envolvendo acidentes com aeronaves (fig. 20).

Quantos Municípios (Serviços Municipais de Proteção Civil) conhecerão esta Diretiva e as obrigaçóes nela plasmadas caso aconteça alguma ocorrência com aeronaves que envolvam operaçôes com Agentes Externos ao Município?

\section{ADMINISTRAÇÃO E LOGÍSTICA}

a) No âmbito das operações que decorrem da presente Diretiva, e desde que em cumprimento da missão legalmente atribuída, cada entidade assume os custos associados à mobilização dos respetivos meios e recursos.

b) 0 apoio logístico às operações, nomeadamente no que respeita à alimentação para os operacionais envolvidos e o abastecimento de combustíveis, e sempre que estas se estendam por mais de 6 horas, deverá ser assegurado pela (s) Câmara (s) Municipal (ais) da respectiva área.

c) Compete ainda às Câmaras Municipais, e no que respeita à respetiva área geográfica, articularse com as entidades relevantes com vista a garantir um adequado e atempado apoio logístico e de sustentação às operações em curso, nomeadamente no que respeita à remoção de resíduos e águas residuais, sempre em estreita observância pelas regras de segurança e garantindo a colaboração das entidades com competência específica para o efeito.

Fig. 20 - Administração e Logística

(Fonte: ANPC - DON n.o 4/DIRACAERO - maio 2013).

Fig. 20 - Administration and Logistics

(Source: ANPC - DON n. ${ }^{4}$ / DIRACAERO - May 2013).

Diretiva Operacional Nacional n. ${ }^{\circ}$ 2, sobre o Dispositivo Especial de Combate a Incêndios Rurais (DECIR) - Abril de 2018

Esta Diretiva Operacional (DON) é subsidiária da Diretiva Única de Prevenção e Combate (DUPC), aprovada pela RCM no 20 /2018, de 1 de Março e ainda 
subsidiária da da DON n. ${ }^{\circ} 1$ - Dispositivo Integrado das Operações de Proteçấo e Socorro (DIOPS) da ANPC e atualiza a DON n. ${ }^{\circ}$ 2/2017 da ANPC - DECIF, com base na legislaçáo em vigor e nos contributos dos Agentes e Entidades que a integram, constituindo-se como um instrumento de planeamento, organização, coordenaçáo e comando operacional.

Com esta DON, define-se a arquitetura da estrutura de direçáo, comando e controlo, a forma como é assegurada a coordenação institucional, a regulação, a articulação e otimização da atuação operacional das forças integrantes do SIOPS, dos organismos e instituiçóes envolvidas ou a envolver nas operaçôes de defesa da floresta contra incêndios, entendida esta na vertente da proteçấo e socorro, tendo em vista o cumprimento dos objetivos estratégicos definidos pelo Governo nesta matéria.

Define claramente a Administração e bases logísticas para apoio e suporte direto ao desenvolvimento e sustentação das operações de proteção e socorro.

Esta DON é para consulta permanente das entidades que concorrem para as açóes de proteção e socorro no âmbito dos incêndios florestais, e está disponibilizada publicamente no sítio da internet da ANPC (fig. 21).

Quantos presidentes de Câmara conhecerão a Diretiva e essencialmente as suas implicaçôes? Quantos SMPC a conhecem ou, melhor, quantos a não conhecem? Mais de 50\% dos Municípios de Portugal não têm SMPC organizado! Como tratarão os municípios da implementação desta Diretiva? O CDOS requisita uma máquina do Município de Mirandela, para atuar no Município de Freixo de Espada à Cinta, a máquina avaria-se e quem tem que pagar o arranjo, é quem cumprindo o princípio da cooperaçáo (art. ${ }^{\circ}$ 5$^{\circ}$ Lei n. ${ }^{\circ}$ 80/2015) emprestou a Máquina? (fig. 22).

Através do Despacho n. ${ }^{\circ}$ 14587/2010, de 21 de setembro, dando cumprimento às $\mathrm{DON}$ n. ${ }^{\circ} 1$ e n. ${ }^{\circ}$ 2, foram criadas Bases de Apoio Logístico (BAL) que são estruturas, constituídas à ordem da ANPC, para apoio e suporte direto ao desenvolvimento e sustentação das operações de proteção e socorro.

As Bases de Apoio Logístico propostas situam-se:

- Albergaria-a-Velha - Distrito de Aveiro;

- Paredes - Distrito do Porto;

- Santa Comba Dão - Distrito de Viseu;

- Mafra - Distrito de Lisboa; 


\section{a. Administração}

(1) 0 desempenho de funções pelos Bombeiros que constituem as equipas que integram o DECIR, afetos aos CB durante as fases de maior empenhamento operacional (Níveis III e IV), são

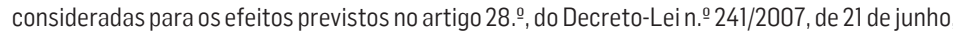
com as alterações introduzidas pelo Decreto-Lei n. ${ }^{0}$ 249/2012, de 21 de novembro, serviço em situação de emergência;

(2) As despesas de pessoal e administrativas, decorrentes da implementação desta diretiva, são suportadas pelas entidades contribuintes, em conformidade com os programas de financiamento e orçamentais aplicáveis;

(3) De acordo com Diretiva Financeira da ANPC, homologada pelo Secretário de Estado da Proteção Civil, as entidades detentoras dos CB serão ressarcidas das despesas decorrentes da atividade extraordinária de combate aos incêndios rurais e abonadas de subsídio diário a atribuir ao seu pessoal empenhado no DECIR, nomeadamente quando determinado o EAE do SIOPS, pelo CCON;

(4) Constituem despesas da ANPC as decorrentes da colaboração das FFAA.

\section{b. Logística}

(1) 0 CB da área onde decorre um incêndio providenciará o apoio logístico indispensável à sustentação das operações de combate aos meios terrestres das diversas entidades integrantes do DECIR, presentes no município ou nos municípios adjacentes;

(2) A alimentação do pessoal e o reabastecimento dos meios em água e combustível deverão ser assumidas como ações imprescindíveis do CB local;

(3) A ANPC procederá a um levantamento de todas as Associações Humanitárias de Bombeiros que não tenham condições de fornecer por seu intermédio ou por terceiros a alimentação ou 0 combustível destinado aos veículos operacionais dos Bombeiros, em ordem a permitir a ponderação quanto aos procedimentos adequados a promover pela ANPC para o fornecimento deste apoio logístico;

(4) Os veículos ativados para qualquer incêndio devem apresentar-se atestados;

(5) Logo que um incêndio evolua, implicando um reforço de meios para além dos presentes no município e nos municípios adjacentes, o COS desencadeará o processo de envolvimento do SMPC, para apoio logístico mais diferenciado às forças de socorro e entidades técnicas que colaboram com o COS na articulação do dispositivo, de forma a garantir a sustentação das operações de combate;

(6) A evolução do incêndio para outros estágios levará à ativação da CMPC e através desta, se necessário, a solicitação de apoio logístico ao escalão Distrital;

Fig. 21 - Administração e Logística

(Fonte: ANPC - DON n. ${ }^{\circ} 2$ / DECIR - Abril 2018).

Fig. 21 - Administration and Logistics

(Source: ANPC - DON n. 2 / DECIR - APRIL 2018). 


\section{Proteção Civil recusa pagar estrago à Câmara}

TORRE DE MONCORVO O Município de Torre de Moncorvo ficou sem 30 mil euros da reparação de uma máquina de rastos da Câmara, deslocada pela Autoridade Nacional de Proteção Civil (ANPC) para um incêndio no concelho de Freixo de Espada à Cinta.

A Câmara mantém um diferendo com a ANPC há cerca de um ano. A reparação custou $30 \mathrm{mil} \mathrm{eu}^{-}$ ros, pagos pelo município. "A máquina foi mandada pelo Comando Distrital de Operações e Socorro (CODIS) para acudir a um incêndio que existia no concelho de Freixo de Espada à Cinta, onde fez um trabalho que facilitou o combate e permitiu que casas não fossem queimadas. No decorrer do incên- dio, a máquina avariou", explicou o presidente da Câmara, Nuno Gonçalves.

"Como a máquina estava ao serviço da Proteção Civil, esperávamos que o custo fosse suportado por esta entidade, mas um parecer técnico, que eu acho que não tem bom senso, dizia que a Câmara é que devia suportar o custo e assim foi", acrescentou o autarca.

Nuno Gonçalves não se conforma com a decisão da Autoridade Nacional e expôs o caso ao secretário de Estado da Administração Interna, Jorge Gomes. O governante afirmou ao "Jornal de Notícias" que "vai tentar que a Câmara seja ressarcida".

GLÓRIA LOPES

Fig. 22 - Notícia JN, 21, março de 2016.

Fig. 22 - News item Jornal de Notícias, 21 March 2016.

- Castelo Branco - Distrito de Castelo Branco;

- Loulé - Distrito de Faro.

De acordo com o Despacho n. ${ }^{\circ}$ 14587/2010, as BAL devem ter a capacidade para assegurar alojamento, alimentaçáo, armazenamento de equipamentos, abastecimento e parqueamento de veículos dos meios de reforços.

Diz ainda o Despacho que a existência das BAL referidas não prejudica a existência de Bases de Apoio Logístico de caráter secundário (fig. 23), de funcionamento sazonal nos Distritos onde tal se justifique na sequência de proposta do Comandante Operacional Nacional (CONAC). 


\section{Bases de Apoio Logístico (BAL)}

(a) Ativação de até 19 (dezanove) BAL, principais e secundárias, como locais para apoio e suporte direto ao desenvolvimento e sustentação das operações de proteção e socorro;

(b) Ativação de BAL temporárias de cariz distrital para pré-posicionamento temporário de meios de reforço intradistritais, decorrente da análise, da avaliação da situação diária e da previsão do perigo de incêndio sob responsabilidade dos CODIS;

(c) Anexo 20 - Bases de Apoio Logístico.

\section{Centros de Meios Aéreos (CMA)}

(a) Ativação de 39 (trinta e nove) CMA de apoio e suporte às operações de proteção e socorro, providos pelos meios aéreos afetos ao DECIR;

(b) Anexo 18 - Rede Nacional de Heliportos Principais e Alternativos;

(c) Anexo 19-Rede Nacional de Pistas e Heliportos Principais e Alternativas;

(d) Anexo 23 - CMA alternativos para helicópteros de Ataque Ampliado (ATA);

(e) Anexo 24-CMA alternativos para aviões de ataque ampliado - aviões anfíbios;

(f) Anexo 25-CMA alternativos para meios de ataque ampliado - helicópteros.

Fig. 23 - Administração e Logística

(Fonte: ANPC - DON n. ${ }^{\circ} 2$ / DECIR - Abril 2018).

Fig. 23 - Administration and Logistics

(Source: ANPC - DON n. 2 / DECIR - April 2018).

Consultando a DON n. ${ }^{\circ}$ 2, anexo 20 Bases de Apoio Logístico (BAL), vemos a distribuição por distrito das BAL principais e secundárias (QUADroV).

É de referir que no cumprimento do Despacho n. ${ }^{\circ}$ 14587/2010, desde 12 agosto de 2013, a BAL de Castelo Branco, está operacional e localiza-se no mesmo espaço do novo aeródromo da cidade, partilhando as mesmas instalaçóes com o novo Centro de Meios Aéreos (CMA).

Saliente-se que a pista de aviação tem 1600 metros, a plataforma tem zonas de estacionamento e de aparcamento com parque de viaturas coberto e um armazém de apoio. Tem capacidade para acolher 120 elementos, tem uma cozinha industrial, lavandaria, salas de trabalho e convívio, para além de gabinetes de planeamento e sala de operaçôes. 
QUADRO V - BAL (Fonte: ANPC - DON n. ${ }^{\circ}$ 2/DECIF - março 2016).

TABLE V - BAL (Source: ANPC - DON n. ${ }^{\circ}$ 2/DECIF - March 2016).

\begin{tabular}{|c|c|c|c|c|}
\hline DISTRITO & LOCALIZAÇÃO & CATEGORIA & $\begin{array}{l}\text { CAPACIDADE DE } \\
\text { ALOJAMENTO }\end{array}$ & $\begin{array}{l}\text { CAPACIDADE DE } \\
\text { ALIMENTAÇÃO }\end{array}$ \\
\hline Aveiro & Albergaria-a-Velha & Principal & 100 & Sim \\
\hline Beja & Ourique & Secundária & 40 & --- \\
\hline Braga & Famalicenses & Secundária & 100 & (restaurante) \\
\hline Bragança & Macedo de Cavaleiros & Principal & 100 & Sim \\
\hline Castelo Branco & Castelo Branco & Principal & 129 & Sim \\
\hline Coimbra & Vila Nova de Poiares & Secundária & 64 & Sim \\
\hline Évora & Évora & Secundária & --- & --- \\
\hline Faro & Loulé & Principal & 80 & Sim \\
\hline Guarda & Guarda & Secundária & --- & --- \\
\hline Leiria & Pombal & Secundária & --- & -- \\
\hline \multirow{2}{*}{ Lisboa } & Mafra & Secundária & 60 & Sim \\
\hline & Sintra BA 1 & Principal & --- & --- \\
\hline Portalegre & Nisa & Secundária & 35 & (restaurante) \\
\hline Porto & Paredes & Principal & 150 & Sim \\
\hline Santarém & Ferreira do Zêzere & Secundária & 52 & Sim \\
\hline Setúbal & Setúbal & Secundária & --- & --- \\
\hline Viana do Castelo & Ponte de Lima & Principal & 100 & Sim \\
\hline Vila Real & Vila Real & Principal & 40 & Sim \\
\hline Viseu & Mangualde & Principal & 64 & Sim \\
\hline
\end{tabular}

Temos assim uma importante infraestrutura de apoio logístico no distrito de Castelo Branco, imprescindível para o sucesso das operaçôes de socorro na Região Centro, para além de apoiar outros operacionais que venham em reforço. Ainda é de referir que estas instalações terão em permanência uma Equipa da Força Especial de Bombeiros (FEB - Despacho n. ${ }^{o} 14546 / 2009$ de 29 de junho), 2 helicópteros de combate a incêndios na fase Charlie (Nível de Empenhamento Operacional Reforçado - Nível IV) e um Grupo de Reforço de Ataque Ampliado (GRUATA) de nível nacional, também da FEB e à ordem do CONAC (ANPC, 2013d).

Por último refira-se que foi construído o Polo Logístico Nacional de Proteção Civil em Almeirim (inaugurado em 18 abril de 2015). Será a Base permanente da 
FEB e terá uma Unidade de Reserva Logística, composta por 2 edifícios independentes, um dos quais albergará o Parque de Veículos Operacionais Nacionais para receber os veículos que compóe o Centro Tático de Comando, o Veículo Mortuário, o Veículo de Apoio Alimentar e o Veículo Frigorífico e o outro armazém albergará a Reserva Estratégica Nacional de Proteção Civil, o Armazém Logístico da FEB e os Equipamentos Operacionais da ANPC, exceto os equipamentos destinados a ajuda humanitária que continuarão armazenados na Base Aérea de Sintra.

Nesta unidade de reserva logística de Almeirim, ficará instalada a Brigada Logística da FEB com a responsabilidade Logística desta unidade (ANPC, 2013d e 2015a).

Ainda como fator fundamental na preparação da gestão da catástrofe é fundamental que os agentes de proteçáo civil estejam organizados. Exemplifiquemos o caso dos Corpos de Bombeiros.

O modelo de organização de base dos Corpos de Bombeiros compreende: a Estrutura de Comando, a Estrutura Operacional e o Núcleo de Apoio e Estado-maior (art. ${ }^{\circ}$ 2. $^{\text { do Despacho n. }}{ }^{\circ}$ 20915/2008, de 11 de agosto).

\section{Organização dos Agentes Locais de Proteção Civil}

A par das Comissōes Municipais de Proteção Civil, a criação de Unidades Locais de Proteçáo Civil, ao nível das Freguesias, que praticamente ainda não existem, mas que deverão ser num futuro próximo a verdadeira base descentralizada da proteção civil, a qual precisa de ter bons alicerces, para fortalecer o patamar municipal e contribuir decisivamente para a verdadeira gestão do risco, através do levantamento, previsão, avaliação e prevenção dos riscos coletivos e análise permanente das vulnerabilidades perante situaçôes de risco (fig. 24).

Na parte esquerda da notícia um investigador afirma:.... as populaçóes têm de estar organizadas, pois há o risco de não serem atempadamente socorridas..., na parte direita da figura a notícia, evidencia o trabalho da populaçáo da Aldeia de Casal de São Simão, em Figueiró dos Vinhos, com o objetivo de criar uma faixa de 100 metros de proteçáo à Aldeia, através da plantação de árvores autóctones, sobreiros e medronheiros, bem como da criação de uma rede de caminhos e algumas zonas 
ajardinadas, constituindo uma medida de prevenção muito acertada e já prevista na legislaçáo há 13 anos (n. ${ }^{\circ} 3$, do art. ${ }^{\circ} 16 .^{\circ}$ do Decreto-Lei n. ${ }^{\circ}$ 156/2004, de 30 de junho, revogado pelo Decreto-Lei n. ${ }^{\circ}$ 124/2006, de 21 de junho, alterado pela Lei n. ${ }^{\circ} 76 / 2017$ de 17 de agosto que manteve esta disposiçáo no art. ${ }^{\circ} 15 .{ }^{\circ}$ ).

\section{Fogos Populações cada vez mais em situaçōes sem socorro}

- O investigador Xavier Viegas considera que as populações têm de se capacitar que cada vez mais vão enfrentar situações em que não vão ser socorridas e defendeu que têm de se organizar. "As populações têm que se capacitar que, se calhar, cada vez mais, vão ter situações em que não vão ser socorridas. Os bombeiros não chegam lá, não chegam lá a tempo. Têm de estar organizadas", afirmou. O diretor do Centro de Estudos de Incêndios Florestais da Universidade de Coimbra, que falava numa conferência sobre a contribuição da ciência para o problema dos incêndios florestais, em Proença-a-Nova, sublinhou a necessidade de organização das populações para dizer que "ou fogem antes do fogo chegar e retiram as pessoas ou ficam". "A nossa experiência [investigadores] é que as casas em que há gente são casas que têm mais probabilidade de não arder", frisou.

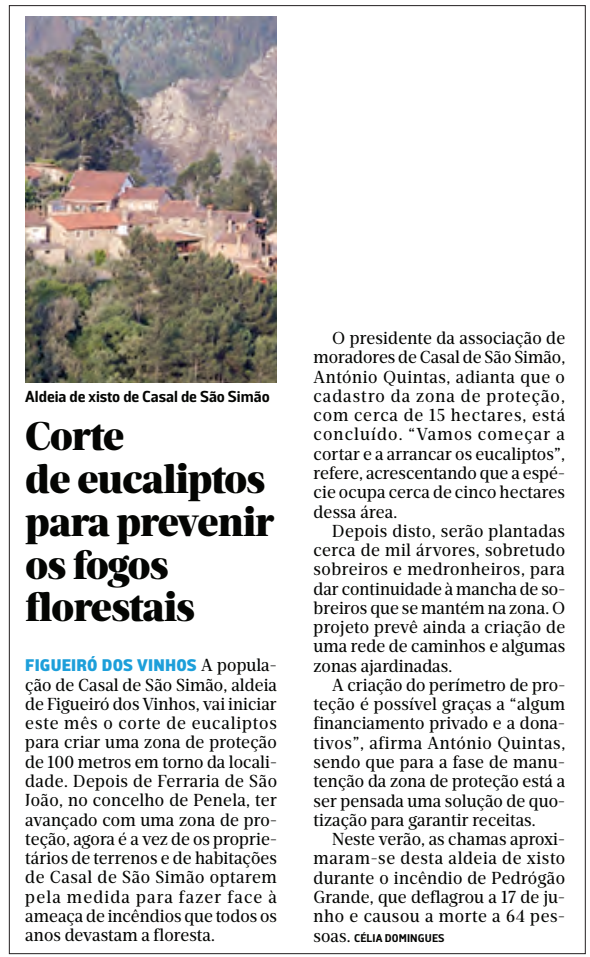

Fig. 24 - Populaçôes cada vez mais em situaçôes sem socorro e implementação de Medidas de Prevenção (Fonte: JN, 2 e 3 novembro 2017).

Fig. 24 - Populations increasingly in situations without help and implementation of preventive measures (Source: JN, 2 and 3 November 2017).

Um recente e bom exemplo, previsto na Lei de Bases de Proteção Civil, foi implementado pela Câmara de Vieira do Minho (fig. 25).

Considerando que a prevenção/vigilância é fundamental para detetar precocemente qualquer ignição e dar o alerta aos bombeiros e às forças de segurança, 30 cidadãos desempregados, receberam formação dos bombeiros e foram transforma- 
dos em vigilantes que, em articulação com as Juntas de Freguesia, vigiam e ajudam ao combate numa fase inicial.

É uma iniciativa muito importante, com um custo irrisório, que deveria ser estendida obrigatoriamente a todos os Municípios, mesmo os urbanos que possuam uma grande inter-relação com o rural.

Com efeito, a minha experiência ao longo dos últimos 21 anos (1995-2016) no Município de Vila Nova de Gaia, onde todos os anos sempre promovi iniciativa similar, mas nem sempre apoiada, tiveram sempre resultados extraordinários na redução do número de igniçóes e em área ardida tendo em conta que os desempregados e beneficiários do RSI não eram profissionais mas sim pessoas que receberam formação intensiva e prestaram serviço público inestimável, mas desprezado pelas autoridades, pois consideram este serviço uma despesa quando ele é verdadeiramente um investimento (fig. 25).

\section{Floresta vigiada por quem está no desemprego}

VIEIRA DO MINHO A partir de amanhã, o Município de Vieira do Minho vai ter em quase todas as 16 freguesias e uniões de freguesias do concelho cerca de 30 desempregados a tratar da vigilância, prevenção e auxílio no com bate aos incêndios florestais. Serão um complemento aos organismos da Proteção Civil que estarão no terreno na fase Charlie, a mais crítica em relação ao combate aos fogos.

"Dado o sucesso alcançado no último ano, decidimos repetir o projeto este verão", afirmou ao JN o presidente da Autarquia, António Cardoso. O responsável assegura que, em 2016, a área ardida no concelho foi inferior ao ano anterior, em cerca de $20 \%$ a $30 \%$. "Fomos afetados por fogos de concelhos vizinhos, como Fafe, senão acredito que teríamos uma redução que chegaria aos 50\%", afirmou o autarca, sublinhando que o cenário foi contrário ao resto do país, que se deparou com grandes incêndios no último ano.

Os elementos que compõem estas brigadas de prevenção de incêndios foram indicados pelas respetivas juntas e estão preparadas para, além da vigilância, ajudarem no combate numa primeira fase. "Tiveram uma formação ligeira com os bombeiros, que lhes ensinaram, por exemplo, a utilizar os kits de incêndio que estão disponiveis nas juntas", explicou António Cardoso.

Constituídas por dois elementos por cada freguesia, as brigadas estarão ao serviço todos os dias, até ao final do mês de setembro. O projeto, financiado integralmente pela Câmara em cerca de 15 mil euros, vem ocupar pessoas em situação de desemprego. sandra Freitas

\section{Vila Nova de Gaia \\ Beneficiários do RSI combatem incêndios}

Um grupo de 28 beneficiários do Rendimento Social de Inserção (RSI), de Vila Nova de Gaia, inicou hoje um plano de formação de vigilância florestal. O comandante dos bombeiros sapadores disse à Renascença que o projecto visa que os beneficiários "colaborem para diminuir o número de ocorrências".

De acordo com Salvador Almeida, existem "muitas ocorrências" de fogos florestais "no distrito do Porto e Gaia não foge a isso", apontando uma redução de 10-15\% como um resultado que fará deste investimento algo de "positivo".

O projecto resulta de uma parceria do Instituto de Emprego e da Câmara de Gaia. A intenção é colocar beneficiários do RSI a prestarem actividades socialmente úteis em entidades públicas.

Fig. 25 - Vigilância na floresta, Municípios Vieira do Minho

(Fonte: JN 30 Junho 2017) e V. N. de Gaia (Fonte: RR, 16 de Julho 2012).

Fig. 25 - Forest Monitoring in Vieira do Minho municipality

(Source: JN 30 June 2017) and V. N. de Gaia (Source: RR, 16 of July of 2012). 


\section{Formação}

Ações de sensibilização, informação e formação

As açóes de sensibilização, informação e formação permitem saber evitar riscos desnecessários, saber minimizar os riscos inevitáveis e saber correr riscos imprescindíveis (Recomendação n. ${ }^{\circ}$ 5/2011, de 20 outubro, do Conselho Nacional de Educação), de que foi exemplo uma ação levada a efeito pelo Serviço Municipal de Proteção Civil/Bombeiros Sapadores de Vila Nova de Gaia, durante um ano, todos os dias, em açóes de sensibilização, formação e informação nas escolas do Município (fig. 26).

Esta ação foi um êxito, mas deveria ser contínua, ano após ano, dia após dia, trabalhando verdadeiramente na Prevenção. Infelizmente por falta de recursos humanos e vontade política está parada, fazendo-se pontualmente o que é manifestamente insuficiente

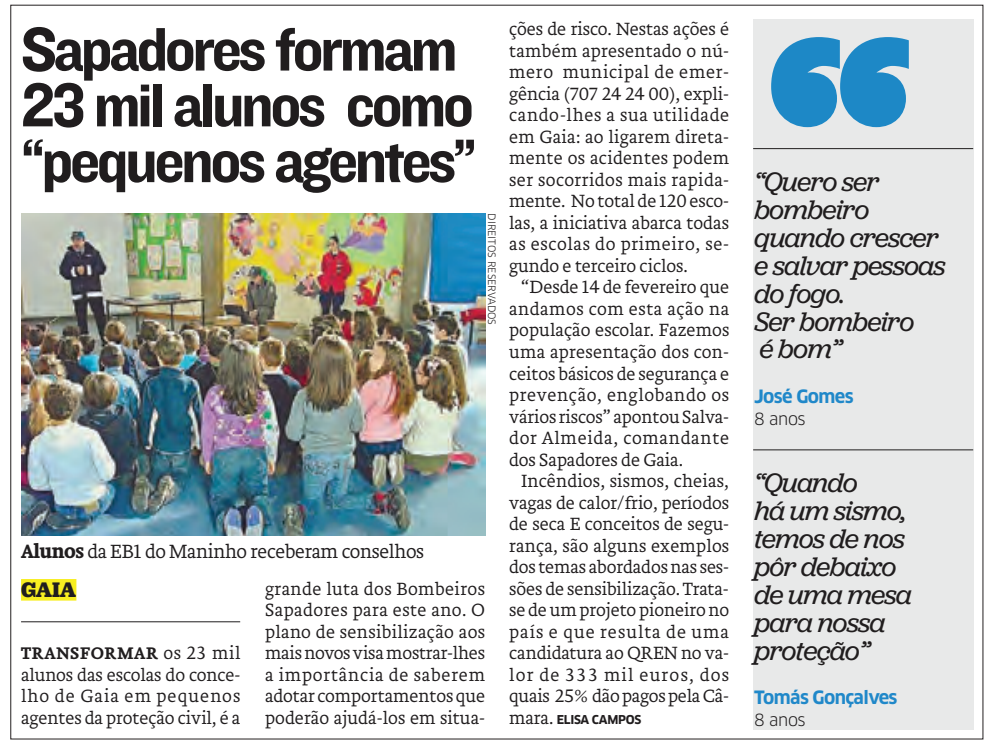

Fig. 26 - Notícia salientando a importância da Sensibilização/Educação

(Fonte: Jornal de Notícias, 8 abril de 2013).

Fig. 26 - News item stressing the importance of raising awareness/education

(Source: Jornal de Noticias, April 8 of 2013). 


\section{Execução de Manuais de Sensibilização;}

A educação para o risco é uma componente absolutamente crucial do desenvolvimento sustentável que se deseja para as nossas comunidades, pelo que saber como atuar perante um acidente grave ou uma catástrofe é determinante na salvaguarda da vida humana e dos seus bens.

O Guia de Autoproteção para os Cidadãos, em caso de Acidente Grave ou Catástrofe, é uma excelente iniciativa do Município de Alvaiázere que deveria ser replicada por todos os Municípios do País e distribuída aos seus munícipes (fig. 27).

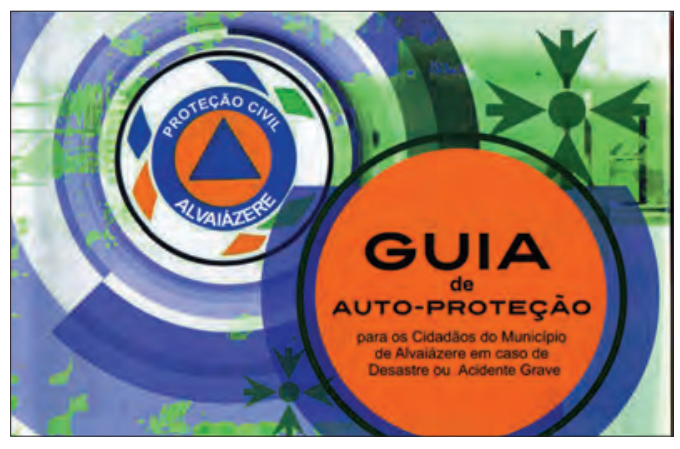

Fig. 27 - Guia de Autoproteção para os cidadãos de Alvaiázere (Fonte: Município de Alvaiázere, maio,2012).

Fig. 27 - Self-protection guidance for the residents of Alvaiazere (Source: City of Alvaiázere, May, 2012).

\section{Execução de exercícios e simulacros.}

Após as ações de sensibilização, formação e informação (saber), é muito importante saber fazer, logo impóe-se que as entidades e os agentes de proteção civil façam exercícios e simulacros.

\section{Simulacro na refinaria da Petrogal - 14 de abril de 2016}

A refinaria da Petrogal localizada no concelho de Matosinhos é uma indústria SEVESO de nível de perigosidade superior pelo que, para além de ter o seu Plano de Emergência Interno (PEI) elaborado de acordo com as orientaçóes fixadas pela Agência Portuguesa do Ambiente, IP (APA) e pela Autoridade Nacional de Prote- 
ção Civil (ANPC), de acordo com o art. ${ }^{\circ} 27 .{ }^{\circ}$ do Decreto-Lei n. ${ }^{\circ}$ 150/2015, de 5 de agosto, é obrigada a realizar exercícios de aplicação dos PEI no mínimo uma vez por ano.

A realização de um exercício em 14 de abril de 2016 (fig. 28), para dar cumprimento a esta obrigatoriedade, foi uma boa iniciativa, mas que na prática se revelou insuficiente, uma vez que, para além dos Agentes de Proteção Civil, não foram envolvidos outros serviços municipais, designadamente para colaborarem na evacuação das populaçóes.

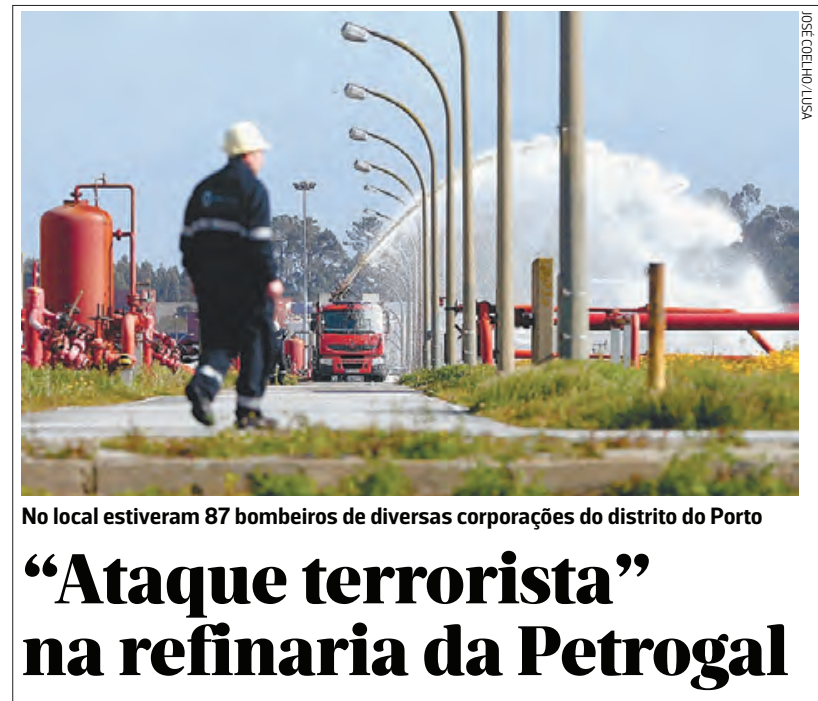

MATOSINHOS Eram 9.45 horas quando uma "bomba" explodiu, ontem, num dos reservatórios de petróleo bruto da refinaria de Leça da Palmeira, em Matosinhos, "ferindo" nove pessoas. De imediato, as estradas da área envolvente foram cortadas. Uma nuvem de fumo tóxico propagava-se por Maia, Valongo, Gondomar, Porto e Gaia. Bombeiros, Polícia e Proteção Civil uniram-se, ontem, num simulacro de atentado terrorista.

"A seguir à explosão da bomba, a refinaria acionou o seu plano interno de segurança”, explicou Lurdes
Queirós, vereadora da Proteção Civil de Matosinhos. Nestes casos, os mecanismos internos da Petrogal revelam-se insuficientes, pelo que é necessária a interação de todas as forças da Proteção Civil.

Um atentado naquela zona implicaria a evacuação de 1313 habitações. As pessoas retiradas de casa seriam mantidas num pavilhão designado para o efeito.

O exercício contou com sete elementos da GNR, 48 agentes da PSP, 87 bombeiros de várias corporações do distrito e oito operacionais da Cruz Vermelha. cLÁdiA MaIOTO

Fig. 28 - Notícia salientando a importância da Prevenção (Fonte: JN, 14 abril de 2016). Fig. 28 - News item stressing the importance of prevention (Source: JN, April 14, 2016). 
Seria um grande exemplo de cidadania o envolvimento da populaçấo, embora se saiba que ele acarreta riscos e custos, mas que importa ter realmente, para se viver uma situação que seja o mais real possível e que sirva de aprendizagem, sensibilização/formação do público-alvo e dos Agentes.

\section{Execução de exercícios e simulacros em Vila Nova de Gaia - Exemplos}

No terceiro quadrimestre de 2015 decorreu, em V. N. de Gaia, um conjunto de Exercícios e Simulacros que envolveram Escolas, Jardins-de-infância e Creches, Lares, Empresas públicas e privadas, Instituiçôes de Solidariedade Social e Saúde, os quais muito contribuíram para a prevenção, ao prepararem os utilizadores para a crise (fig.s 29 e 30).

Apresentam-se exemplos de vários exercícios e simulacros, levados a efeito durante este período:

17 de setembro - Simulacro de incêndio e evacuação, para testar o Plano de Segurança Interno das instalaçôes de Carlos Ferreira da Silva Filhos, Lda. - Antiga Casa Pompeu envolvendo todos os funcionários (fig. 29-1); 29 de setembro - Simulacro de incêndio e evacuação, para testar o Plano de Segurança Interno das instalaçôes do Centro de Reabilitação do Norte Dr. Ferreira Alves (fig. 29-2);

17 de novembro - Exercício de evacuação, para testar o Plano de Segurança Interno da Creche e do Jardim de Infância Doa Emília de Jesus Costa da Santa Casa da Misericórdia de Vila Nova de Gaia, envolvendo utentes e funcionários (fig. 29-14);

18 de novembro - Exercício de evacuação, para testar o Plano de Segurança Interno das instalaçôes da APPACDM - CAO Dr. Mário Dias - Canidelo, envolvendo todos os utentes e funcionários (fig. 29-15);

18 de novembro - Exercício de evacuação, para testar o Plano de Segurança Interno do J. I. de Laborim, envolvendo utentes e funcionários (fig. 30-1);

19 de novembro - Simulacro de incêndio e evacuação, para testar o Plano de Segurança Interno do Lar Residencial das Devesas da Santa Casa da 
Misericórdia de Vila Nova de Gaia, envolvendo utentes e funcionários (fig. 30-2);

25 de novembro - Simulacro de incêndio e evacuação, para testar o Plano de Segurança Interno do Lar Salvador Brandáo da Santa Casa da Misericórdia de Vila Nova de Gaia, envolvendo utentes e funcionários (fig. 30-3);

26 de novembro - Simulacro de incêndio e evacuação, para testar o Plano de Segurança Interno do Lar Familiar de Valadares, envolvendo utentes e funcionários (fig. 30-4);

27 de novembro - Simulacro de incêndio e evacuação, para testar o Plano de Segurança Interno do Hotel IBIS-Porto Gaia, envolvendo utentes e funcionários (fig. 30-5);

28 de novembro - Simulacro de incêndio e evacuação, para testar o Plano de Segurança Interno do Hotel Solverde Gaia, envolvendo utentes e funcionários (fig. 30-6);

4 de dezembro - Simulacro de incêndio e evacuação, para testar o Plano de Segurança Interno do Lar S. Nicolau - Mafamude, envolvendo utentes e funcionários (fig. 30-7);

7 de dezembro - Simulacro de incêndio e evacuação, para testar o Plano de Segurança Interno do Hotel IBIS BUDGET - Porto Gaia, envolvendo utentes e funcionários (fig. 30-8);

9 de dezembro - Simulacro de incêndio e evacuação, para testar o Plano de Segurança Interno das Instalaçôes Fabris e Administrativas da SUMA, envolvendo todos os funcionários (fig. 30-9);

11 de dezembro - Simulacro de incêndio e evacuação, para testar o Plano de Segurança Interno do Hotel NOVOTEL-Porto Gaia, envolvendo utentes e funcionários (fig. 30-10);

16 de dezembro - Simulacro de incêndio e evacuação, para testar o Plano de Segurança Interno do Hotel Mercúrio- Porto Gaia, envolvendo utentes e funcionários (fig. 30-11);

16 de dezembro - Simulacro de incêndio e evacuação, para testar o Plano de Segurança Interno do Centro Hospitalar V. N. Gaia/Espinho, envolvendo utentes e funcionários (fig. 30-12); 


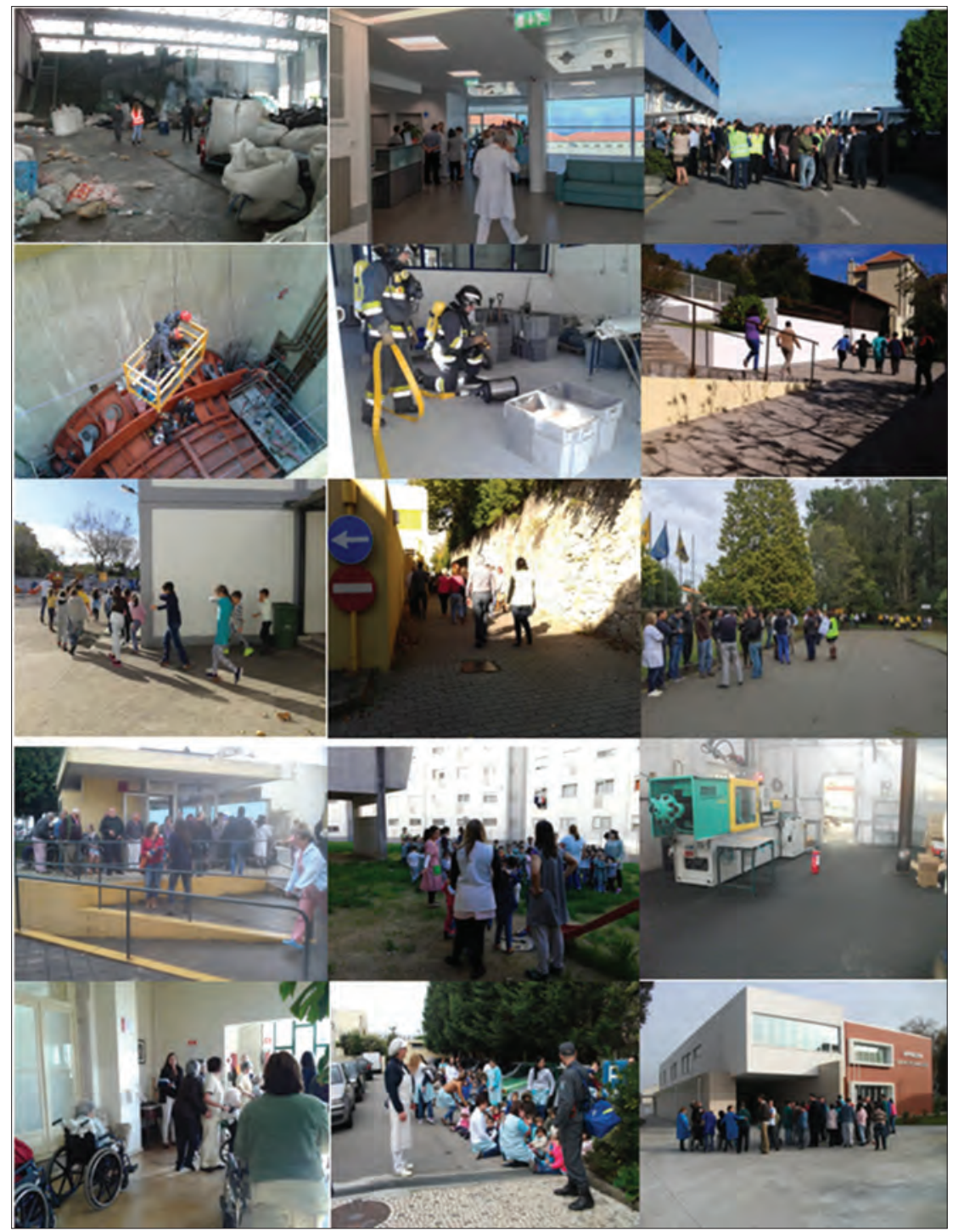

Fig. 29- Exercícios e Simulacros realizados no terceiro quadrimestre de 2015 - Vila Nova de Gaia (Fonte: Bombeiros Sapadores e Proteção Civil de Vila Nova de Gaia). Fig. 29 - Exercises and drills held in the last four months of 2015 - Vila Nova de Gaia (Source: Firefighters and Civil Protection of Vila Nova de Gaia). 


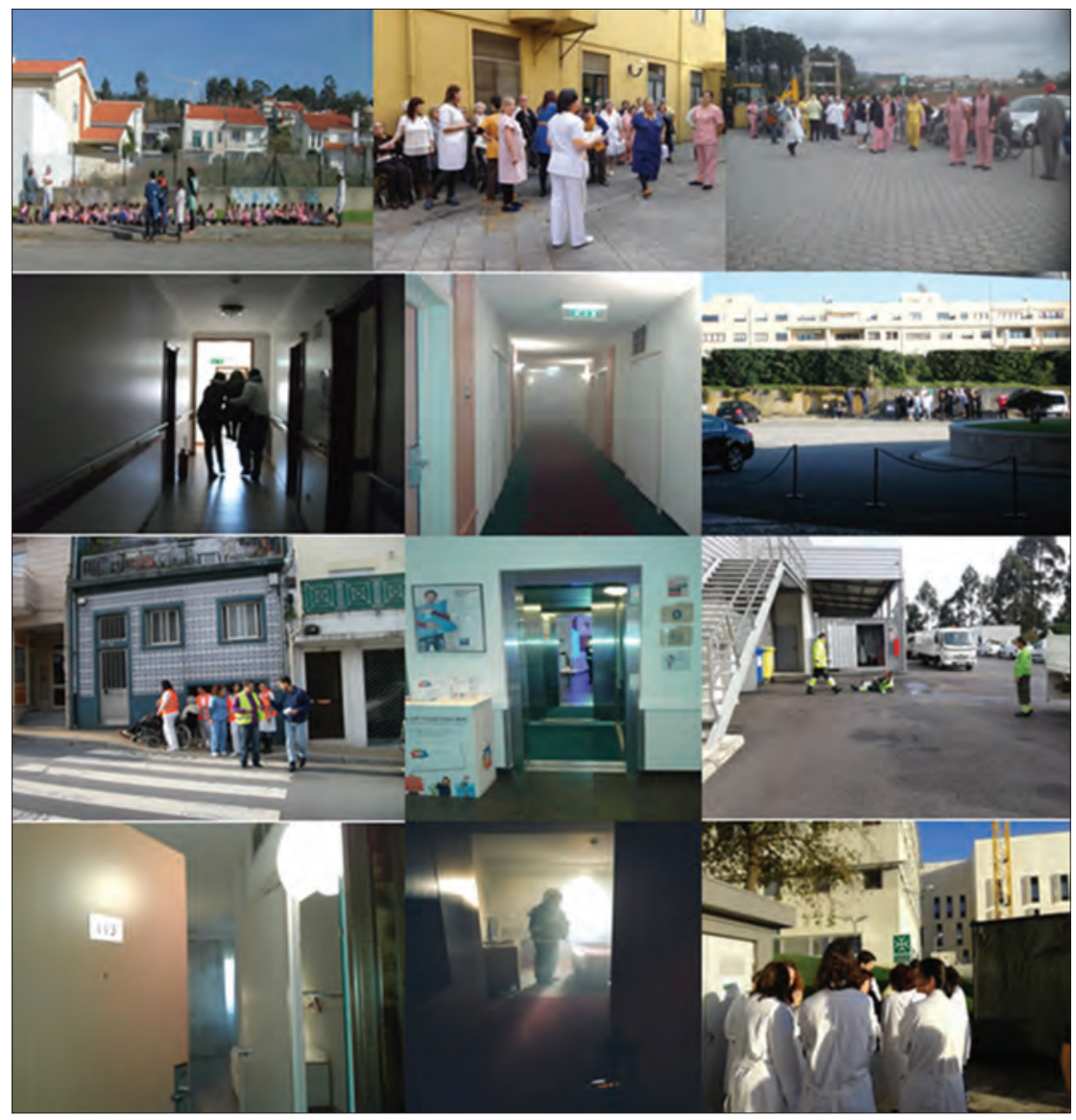

Fig. 30 - Exercícios e Simulacros realizados no terceiro quadrimestre de 2015 - Vila Nova de Gaia (Fonte: Bombeiros Sapadores e Proteção Civil de Vila Nova de Gaia). Fig. 30 - Exercises and drills held in the last four months of 2015 - Vila Nova de Gaia (Source: Firefighters and Civil Protection of Vila Nova de Gaia).

A situação necessária e suficiente para a realização deste trabalho deveria conduzir a que, todos os dias, uma equipa do SMPC/Bombeiros Sapadores de Vila Nova de Gaia e de todos os Municípios do País, tivesse como trabalho principal diário, a realização de exercícios e simulacros, pois só praticando/treinando é que é possível saber fazer: 


\section{Alerta}

O estado de alerta, destina-se aos operacionais e é antecedido por avisos à população.

\section{Avisos do IPMA}

O Instituo Português do Mar e da Atmosfera (IPMA), através das suas Estaçôes automáticas e de Radar, recolhe uma série de informaçôes que, comparando-as com os registos históricos e utilizando ferramentas de previsão, lhe permite lançar "Avisos" de que é exemplo uma notícia da Lusa, do dia 15 de junho de 2015:

"Cinco concelhos dos distritos de Faro e Beja apresentam esta quarta-feira risco 'Muito Elevado' de incêndio, segundo informação do Instituto Português do Mar e da Atmosfera (IPMA)".

De acordo com informação disponível na página do IPMA na Internet, estão em risco 'Muito Elevado' de incêndio os concelhos de Loulé, São Brás de Alportel, Tavira e Alcoutim (Faro) e Barrancos (Beja). O Instituto indica também que há vários concelhos dos distritos de Faro, Beja, Évora, Portalegre e Setúbal em risco 'Elevado' de incêndio.

Mais recentemente, o IPMA emitiu comunicados de:

"Aviso VERMELHO para Agitação Marítima no distrito do Porto entre 110300MAR18 e $111500 M A R 18.11 C D O S "$.

Após os comunicados do IPMA, que são AVISOS destinados a todos os cidadãos, a ANPC emite ALERTAS específicos para os Agentes de Proteção Civil:

“CTO 06/2018 - Condiçôes Meteorológicas Adversas - Precipitação, vento e agitação marítima, determina-se a elevação do Estado de Alerta Especial, do SIOPS para o DIOPS, para o nivel Laranja, para o Distrito do Porto de 101800MAR18 até 111500MAR18, com redução posterior do nivel do EAE para o determinado no CTO 05/2018. 1 CDOS Porto". 
Um exemplo de alerta para os agentes de Proteção Civil, por forma a serem tomadas as medidas previstas no Plano Municipal de Emergência de Vila Nova de Gaia (fig. 31), com vista à implementação do Plano Municipal de Prevenção e Atuação de Cheias no Douro.

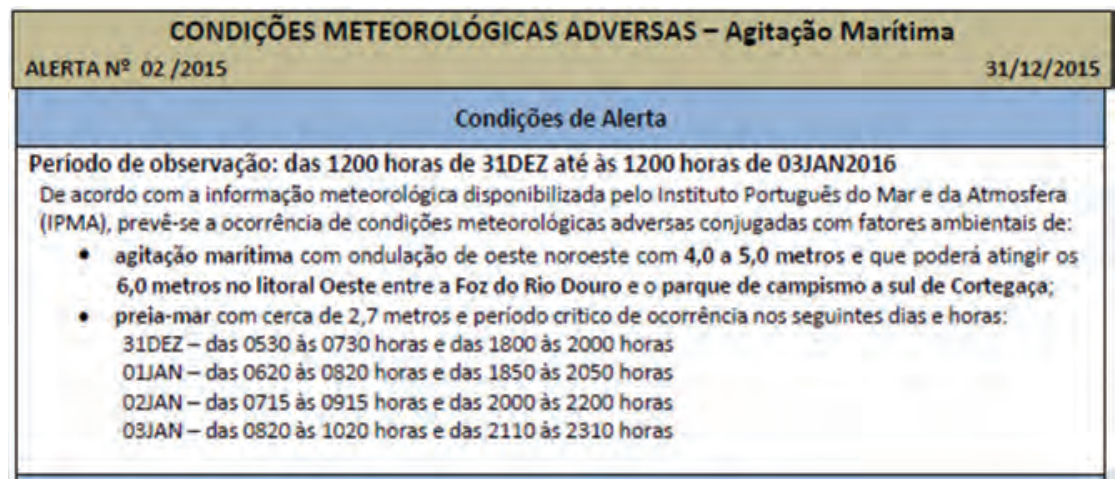

Fig. 31 - Condições Meteorológicas Adversas/Agitação Marítima (Fonte: Capitania do porto do Douro).

Fig. 31 - Adverse weather/heavy seas (Source: Douro Port Captaincy).

\section{Definição do Período Critico}

A definição do período crítico (ex.: Portaria n. ${ }^{\circ}$ 167/2016, de 15 de junho) pode ser entendido como um aviso de caráter genérico (fig. 32). uma vez que tem em conta o regime pluviométrico de Portugal Continental, os antecedentes históricos das ocorrências de incêndios florestais e, ainda, as condicionantes de prevenção e combate a incêndios florestais

\section{Operação}

Para que as operações decorram com sucesso é necessário organização, para a que é fundamental o planeamento, que permite preparar e disponibilizar meios humanos e materiais para o socorro com alguma antecipação e de que serve de exemplo o combate a incêndios florestais. 
Diário da República, $1 .{ }^{a}$ série-N. ${ }^{\circ} 113-15$ de junho de 2016

\section{AGRICULTURA, FLORESTAS E DESENVOLVIMENTO RURAL}

\section{Portaria n. ${ }^{\circ} 167 / 2016$}

de 15 de junho

O Sistema de Defesa da Floresta contra Incêndios, aprovado pelo Decreto-Lei n. ${ }^{\circ} 124 / 2006$, de 28 de junho, alterado pelos Decretos-Leis n. ${ }^{\text {os }} 15 / 2009$ e $17 / 2009$, de 14 de janeiro, $114 / 2011$, de 30 de novembro e $83 / 2014$, de 23 de maio, prevê um conjunto de medidas e ações de articulação institucional, de planeamento e de intervenção relativas à prevenção e proteção das florestas contra incêndios, nas vertentes da compatibilização de instrumentos de ordenamento, de sensibilização, planeamento, conservação e ordenamento do território florestal, silvicultura, infraestruturação, vigilância, deteção, combate, rescaldo, vigilância pós-incêndio e fiscalização, a levar a cabo pelas entidades públicas com competências na defesa da floresta contra incêndios e entidades privadas com intervenção no sector florestal.

Assumindo a prevenção estrutural um papel predominante, assente na atuação de forma concertada de planeamento e na procura de estratégias conjuntas, conferindo maior coerência regional e nacional à defesa da floresta contra incêndios, compete à Autoridade Florestal Nacional a sua organização e coordenação, que durante o período crítico se integra na estrutura operacional coordenada pela Autoridade Nacional de Proteção Civil.
Nesta medida, para a definição de período crítico no presente ano relevam, para além do regime pluviométrico de Portugal Continental, o histórico das ocorrências de incêndios florestais, e ainda as condicionantes associadas à organização dos dispositivos de prevenção e combate a incêndios florestais.

Assim:

Ao abrigo do disposto na alínea $s$ ) do n. ${ }^{\circ} 1$ do artigo $3 .^{\circ}$ do Decreto-Lei n. ${ }^{\circ} 124 / 2006$, de 28 de junho, alterado pelos Decretos-Leis n. ${ }^{\text {os }} 15 / 2009$ e 17/2009, de 14 de janeiro, $114 / 2011$, de 30 de novembro e 83/2014, de 23 de maio, manda o Governo, pelo Secretário de Estado das Florestas e Desenvolvimento Rural, o seguinte:

\section{Artigo 1. ${ }^{\circ}$ \\ Período Crítico}

No ano de 2016, o período crítico no âmbito do Sistema de Defesa da Floresta contra Incêndios, vigora de 1 de julho a 30 de setembro, e nele devem ser asseguradas medidas especiais de prevenção contra incêndios florestais.

\section{Artigo 2. ${ }^{\circ}$}

Entrada em vigor

A presente portaria entra em vigor no dia seguinte ao da sua publicação.

O Secretário de Estado das Florestas e do Desenvolvimento Rural, Amândio José de Oliveira Torres, em 6 de junho de 2016 .

Fig. 32 - Portaria n. ${ }^{\circ}$ 167/2016 Período Critico no Âmbito do Sistema de Defesa da Floresta Contra Incêndios (Fonte: DR).

Fig. 32 - Ordinance n. ${ }^{\circ}$ 167/2016 Critical Period within the Forest Fire Protection System (Source: Diário da RepúblicalOfficial Gazette).

\section{Antecipação}

A capacidade de antecipação, embora não consiga evitar a manifestação do risco, ajuda a minimizar as consequências dessa manifestação, pelo que não deve ser menosprezada. A título de exemplo, apresentamos duas situaçóes referentes aos riscos mais frequentes em Portugal.

\section{Risco de incêndio florestal}

Os incêndios florestais originam situaçóes complexas, muito potenciadas por condiçóes meteorológicas excecionais, de difícil ou de muito curta antecipação, podendo originar perdas de vidas humanas e bens. 
Assim é definido um Dispositivo Especial de Combate a Incêndios Rurais, sendo publicada a Diretiva Operacional.

Todavia, quando este dispositivo se revela incapaz de dar resposta eficaz, surgem os mais variados (e incompreensíveis) discursos (fig. 33) que permitem levantar algumas interrogaçóes. Como se deduz da Diretiva, o dispositivo já estaria em potência máxima em 2016, permitindo então concluir que em 2015 e 2016 ele tinha sido bom.

Por isso, se o dispositivo em 2017 era exatamente igual aos dois anos anteriores, porque é que não tinha financiamento suficiente?

Porventura, só em 2017 é que os operacionais enfrentaram a morte? Não receberam, todos eles, equipamentos de proteçấo individual? Não receberam, todos os bombeiros, o Guia de Bolso - Segurança no Combate a Incêndios Florestais (Ediçáo ANPC/CNOS, abril, 2014)?

Náo receberam, todos os bombeiros, o Auxiliar de Bolso - Sistema de Gestão de Operaçóes - SGO - Incêndios Florestais (ANPC/CNOS)? Não tiveram, todos eles, formação e treino?

Entáo porque é que foi em plena Fase Charlie que se pôs em causa o SDFCI? Não teria sido melhor ter resolvido esses problemas no final do período crítico do ano 2016?

Sabemos que vivemos numa sociedade de risco e que não é possível evitar muitos dos riscos (fig. 34) e que a melhor maneira de minimizar as suas consequências, quando ocorrem, é prevenindo, isto é, sabemos que o risco existe e, por conseguinte, deveremos fazer uma gestáo adequada, respeitando a história, a vulnerabilidade, os efeitos da ameaça máxima e a probabilidade de ocorrência (fig. 34)

Se há cidadãos que têm comportamentos negligentes e dolosos devem as Forças de Segurança e Justiça atuar impedindo os referidos comportamentos (fig. 35 B).

A par da intervençáo das forças de segurança e da justiça, é importante o investimento em equipamentos, nomeadamente a implementação da georreferenciaçáo, isto é, SirespGL, estendido a todas as corporaçóes do País (fig. 35 A). Relativamente a tão importante notícia, quantos equipamentos foram executados em 2017? Onde foram investidos os 3,6 milhôes de euros do Fundo de Coesão? Quantos Quartéis e veículos foram dotados com tão importante ferramenta? 


\section{Incêndios Ministra garante que dispositivo de combate a fogos está em "potência máxima"}

- A fase Charlie, a mais crítica em matéria de incêndios florestais, arrancou ontem, com a ministra da Administração Interna, que tutela os bombeiros, a garantir que o dispositivo de combate está no terreno em "potência máxima”. Constança Urbano de Sousa recordou, na sede da Autoridade Nacional de Proteção Civil (ANPC), que a existência de fogos depende sempre de "imponderáveis", como a meteorologia ou o comportamento humano. Por isso, a ministra apelou aos cidadãos que evitem "comportamentos de risco" durante o verão. Até 30 de setembro, o Dis positivo Especial de Combate a Incêndios Florestais (DECIF) prevê que 9.708 operacionais estejam no terreno, apoiados por 2.043 viaturas e 47 meios aéreos, entre os quais três dos seis Kamov do Estado.

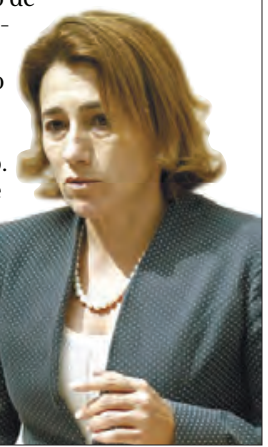

2 de julho de 2016

\section{Incêndios Bombeiros aprovam dispositivo}

O presidente da Liga dos Bombeiros Portugueses disse ontem estar "satisfeito" com o dispositivo de combate a incêndios para este ano, idêntico ao de 2015. Segundo Jaime Marta Soares, "o Dispositivo Especial de Combate a Incêndios Florestais de 2015 foi bom, o melhor de sempre em recursos humanos e em equipamentos".

18 de março de 2016

\section{Ministro confiante no dispositivo}

FOGOS

o MINISTRO da Administração Interna, Miguel Macedo, mostrou-se ontem confiante no dispositivo de combate de previsões apontarem que o próximo verão poderá se incêndios florestais, apesar "um dos piores de sempre". "Aquilo que nos temos de fazer é preparar o dispositivo

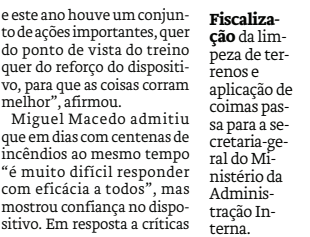

do presidente da Liga dos Bombeiros Portugueses, sobre a falta de prevenção, Mi"tem dito, e bem, que o conjunto do dispositivo que temos é bom e está preparado para cerca de 200 ignições/dia". "Nós tivemos o ano passado perto de $400 \mathrm{em}$ alguns dias, o que significa uma brutalidade do ponto de vista de ignições", frisou. guel Macedo referiu que ele

9 de junho de 2014

\section{Jaime Soares critica financiamento "ridiculo" a bombeiros}

INCÊNDIOS Ridículo. Foi este o adjetivo ontem usado pelo presidente da Liga dos Bombeiros Portugueses Jaime Marta Soares para classificar a verba com que o Estado financia em 2017 as 435 corporações de voluntários do país: 25,7 milhões de euros.

"Os bombeiros, como se viu em Pedrógão Grande, enfrentam a morte sem que o Governo lhes dê qualquer incentivo", afirmou, lembrando que um bombeiro morreu e quatro ficaram gravemente feridos ao tentarem desencarcerar um automobilista apanhado pelas chamas.

Quanto à tragédia de Pedrógão Grande (que vitimou 64 pessoas e deixou mais de 250 feridas), o presidente da Liga garantiu que os bombeiros não falharam, "fizeram muito bem o que tinham que fazer". E acrescentou: "Vamos exigir, até ao fim, que se saiba o que se passou em Pedrógão".

Segundo Jaime Marta Soares, a maioria das corporações atravessa uma situação financeira "gravíssima", ainda mais pelo facto de o Governo lhes dever 30 milhões de euros de serviços de transporte de doentes ainda não pago.

O responsável lembrou que há 30 mil bombeiros voluntários em Portugal, a que acrescem 15 mil na reserva e outros tantos no quadro de honra. "Somos responsáveis por $98 \%$ da atividade de proteção civil, por $96 \%$ dos efetivos de combate aos incêndios e 95 por cento das atividades do INEM", frisou.

O líder da Liga falava nos Bombeiros Voluntários de Terras de Bouro, que ontem celebraram os 32 anos da fundação, cerimónia onde o presidente da Direção, Manuel Tibo, homenageou o autarca local, Joaquim Cracel, e o comandante, José Dias. Luis MorelRA

10 de julho de 2017

Fig. 33 - Notícias controversas na Preparação

(Fonte: JN, 9 de junho de 2014, 2 julho e 18 março,2016 e 10 julho,2017).

Fig. 33 - Controversial news items on preparedness

(Source: JN, June 9, 2014, July 2 and March 18, 2016 and July 10, 2017). 

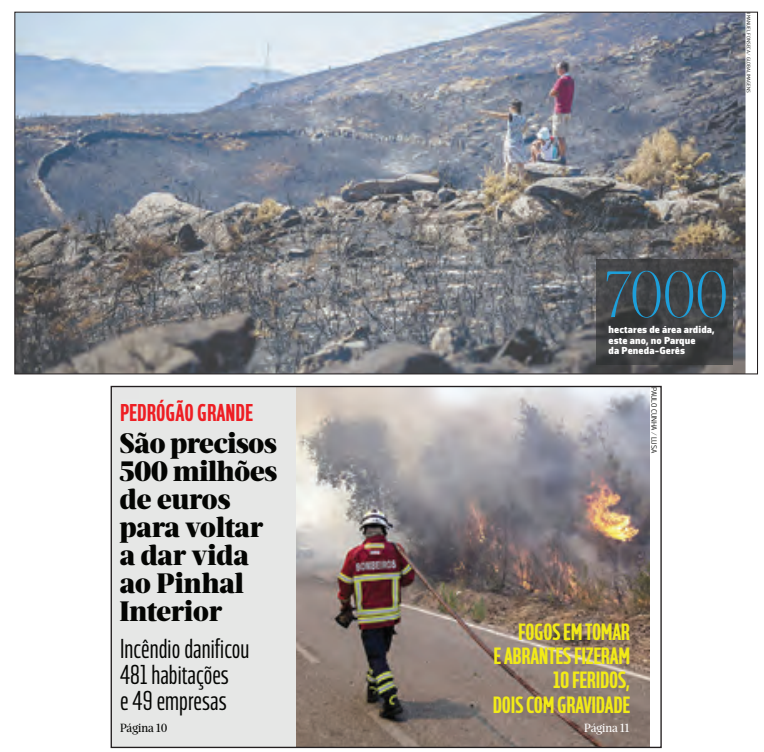

Fig. 34 - Notícia salientando a brutalidade dos incêndios florestais (Fonte: JN, 6 setembro de 2016 e 4 de julho 2017).

Fig. 34 - News items highlighting the brutality of forest fires (Source: JN, September 6, 2016 and Jully 4, 2017).

\section{4,2 milhões para prevenir incêndios}

PROTEÇÃO CIVIL O combate aos incêndios vai contar com um reforço de investimento na prevenção na ordem dos 4,2 milhões de euros. No que toca a meios técnicos, a tutela anunciou ontem o alargamento do sistema de referenciação a todos os quartéis do país.

Os dez projetos aprovados destinam-se a reduzir riscos de incêndio em terreno não privado (baldios e terrenos do Estado ou das autarquias locais), estando previsto, entre outros, a abertura de corredores de separação florestal. As dez candidaturas aprovadas correspondem a um montante do Fundo de Coesão de 3,6 milhões de euros, sendo que o investimento total é de 4,2 milhões.

O Instituto de Conservação da
Natureza e das Florestas, por exem plo, viu aprovada uma candidatura que envolve um montante global de 1,6 milhões de euros.

O secretário de Estado da Administração Interna, Jorge Gomes, anunciou que o sistema de georreferenciação para bombeiros, Siresp GL, vai ser estendido a todas as corporações do país já em 2017.

Esta nova ferramenta permite localizar as viaturas e os diferentes meios nos teatros de operação em tempo real e a monitorização das decisões operacionais. O Governante sublinhou que o projeto $\mathrm{Si}$ resp GL é “especialmente relevante" na garantia de melhores condições de segurança dos operacio nais envolvidos em missões de proteção e socorro.

Fig. 35 A - Notícia salientando a importância da Prevenção (Fonte: JN, 9 julho 2016). Fig. 35 A - News items stressing the importance of prevention (Source: JN, July 9, 2016). 


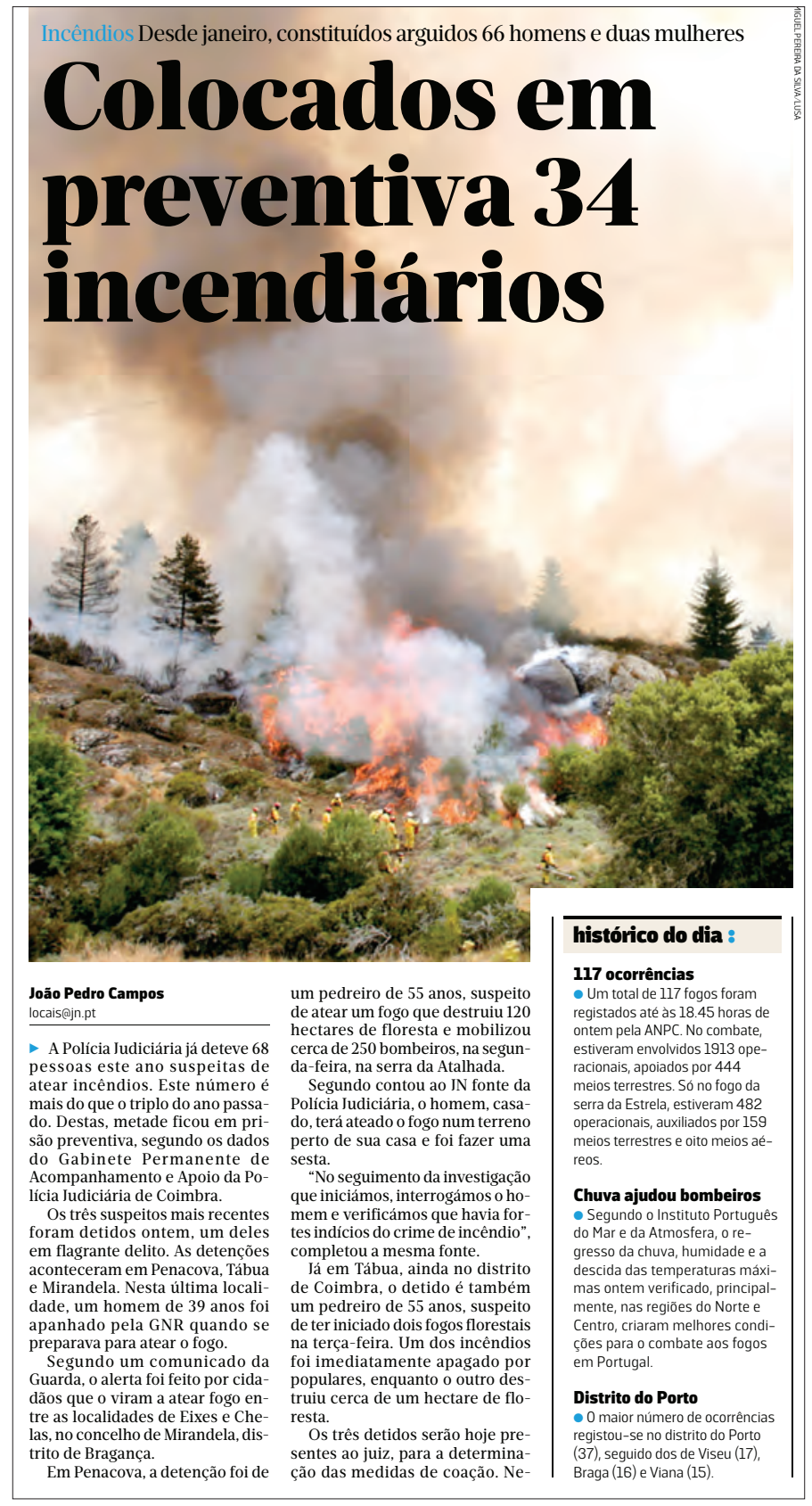

Fig. 35 B - Notícia salientando a importância da Prevenção (Fonte: JN, 13 agosto 2015). Fig. 35 B - News items stressing the importance of prevention (Source: JN, August 13, 2015). 
E porque o financiamento dos corpos de bombeiros, para apoio à construção/ renovação de quartéis e à aquisição de veículos e equipamentos, é um aspeto importante, refere-se que, recentemente, foi aprovado legislaçáo muito importante com essa finalidade.

Assim, a Lei n. ${ }^{o}$ 94/2015, de 13 agosto, aprovou um Financiamento permanente indexado a um orçamento de referência, a aprovar na Lei do Orçamento do Estado, embora continue aprovado um Financiamento Estrutural, através dos Programas de Apoio Infraestrutural, para investimento em infraestruturas de apoio aos corpos de bombeiros, bem como o Programa de Apoio aos Equipamentos.

Mas, voltando ao risco de incêndio florestal, o Instituto Português do Mar e Atmosfera (IPMA) em articulação com ICNF-IP, elabora o índice de risco temporal de incêndio estabelecendo o risco diário de ocorrência de incêndio florestal, conjugando a informação do risco meteorológico, o estado de secura dos combustíveis e o histórico das ocorrências, entre outros (n. ${ }^{\circ} 1$ e 2, art. $4^{\circ}$ DL n. ${ }^{\circ}$ 76/2017 de 17 de agosto, alteraçáo do DL n. ${ }^{\circ}$ 124/2006 de 28 de junho) que, se bem utilizado, pode ser um importante instrumento para tomar medidas de antecipaçáo adequadas aos vários tipos de risco.

Por outro lado, vigilância, deteçấo e fiscalizaçáo, sendo um dos pilares mais importantes do Sistema de Defesa da Floresta Contra Incêndios (SDFCI), se forem entendidas como medida de antecipação, podem constituir uma forma muito eficaz de contrariar a enorme quantidade de ocorrências e, talvez, até a mais capaz de contrariar o que é sentido por todos, nomeadamente pelo Comandante Operacional Nacional da ANPC, quando afirma que, "90\% dos incêndios florestais são de origem humana" ou pelo Presidente da Liga dos Bombeiros Portugueses quando diz " $85 \%$ dos incêndios florestais têm origem criminosa" (fig. 36).

Então, sendo assim, dá vontade de perguntar por que razão não se investe na vigilância?

De facto, existem Manuais desde 1991 (fig. 37). Também há recursos humanos com vontade de trabalhar, pelo que não se compreende a falta de vigilância.

Todos os anos era definido o "Período Crítico", ou seja, o período durante o qual vigoravam medidas e açóes especiais.

No ano 2017, foi definido pela Portaria n. ${ }^{\circ}$ 195/2017, de 22 de junho, do Ministério da Agricultura, Florestas e Desenvolvimento Rural (n. ${ }^{\circ}$, art. ${ }^{\circ} 3{ }^{\circ}$, De- 


\section{$85 \%$ de incêndios florestais têm mão criminosa}

JAIME MOTA SOARES, presidente da Liga dos Bombeiros Portugueses, afirmou à Lusa que $85 \%$ dos incêndios florestais têm mão criminosa e origem em interesses económicos. "As pessoas têm de deixar de se preocupar com a arraiamiúda e apanhar a graúda, que está na génese destas situações", denunciou. "Pirómanos ou alcoólicos são só um bode expiatório", disse, reconhecendo também que "a floresta está mal tratada".

\section{$690 \%$ dos incêndios são de origem humana"}

ALERTA O comandante da Autoridade Nacional de Proteção Civil (ANPC), José Manuel Moura, afirmou ontem que "90 \% dos incêndios são de origem humana, seja doloso ou por descuido". "Há todos os dias algumas dezenas, centenas de pessoas que, de forma negligente ou descuidada ou por dolo, colocam fogo na nossa floresta. E isto é um trabalho de todos", declarou José Manuel Moura, sublinhando que muitos fogos "são por descuido" no uso, por exemplo, de maquinaria agrícola.

Mas os dados da ANPC também indicam que perto de $40 \%$ dos incêndios têm início durante à noite. E a essa hora, admite José Manuel Moura, "não são de causa natural".

José Manuel Moura considerou também que, "para o combate, era muito importante que todos os que têm apetências para ações criminosas no âmbito dos incêndios florestais sejam detidos".

Na semana passada, a GNR indicou que, até 6 de agosto deste ano, já foram detidas 48 pessoas pelo crime de incêndio florestal, mais nove do que em igual período de 2014.

Fig. 36 - Notícia salientando a origem incêndios florestais

(Fonte: JN,1 abril 2012 e 12 agosto 2015).

Fig. 36 - News items highlighting the origin of forest fires

(Source: JN, April 1, 2012 and August 12, 2015).
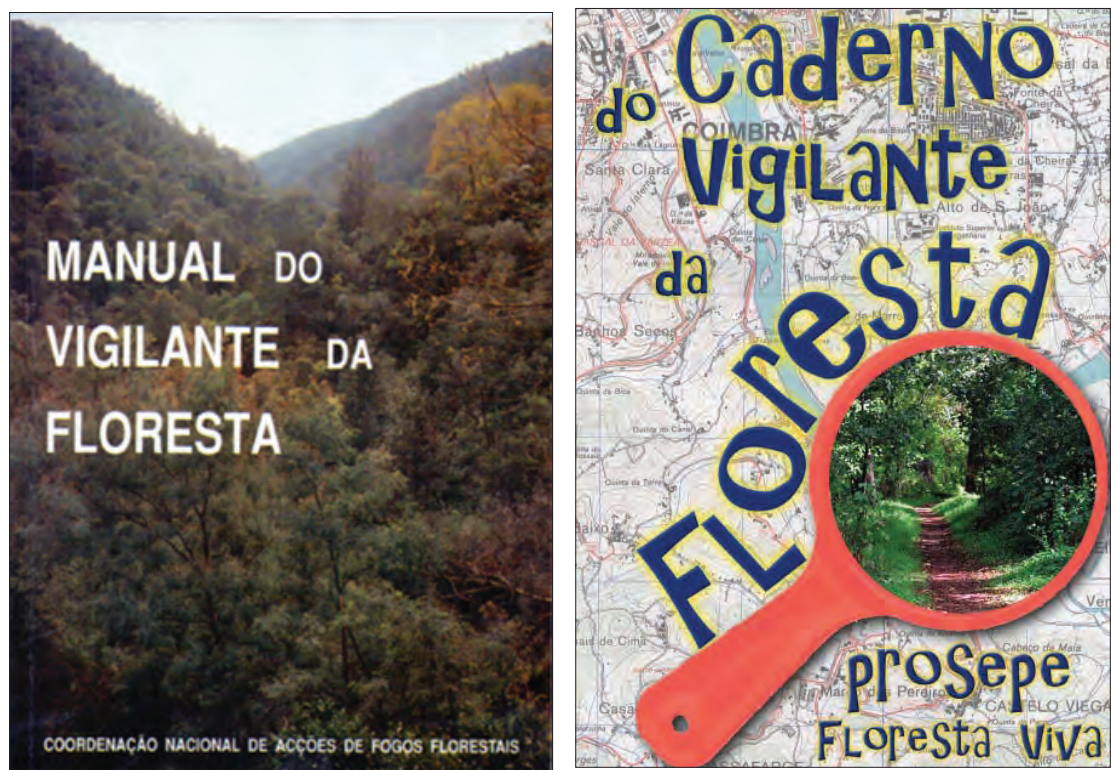

Fig. 37 - Manual do Vigilante da Floresta1 (1991) e o Caderno do Vigilante da Floresta (1998).

Fig. 37 - Forest Guard's Manual, 1991, and the Forest Vigilante book (1988). 
creto-Lei n. ${ }^{\circ}$ 124/2006, de 28 de junho, alterado pelos Decretos-Lei n. ${ }^{\circ}$ 15/2009 e n. ${ }^{\circ}$ 17/2009, de 14 de janeiro, Decreto-Lei n. ${ }^{\circ}$ 114/2011, de 30 de novembro, e Decreto-Lei n. ${ }^{\circ}$ 83/2014, de 23 de maio e Lei n. ${ }^{o}$ 76/2017 de 17 de agosto), para funcionar de 22 de junho a 30 de setembro (fig. 38). Para o ano 2018 ainda não foi definido, pelo menos até hoje dia 13 de Maio.

Para a definição do "Período Crítico" do ano de 2017 foi relevante o Regime Pluviométrico de Portugal Continental, o histórico das ocorrências de incêndios florestais e, ainda, as condicionantes associadas à organização dos dispositivos de prevenção e combate a incêndios florestais (Portaria n. ${ }^{\circ}$ 195//2017 de 22 de junho).

Sendo assim, as notícias de 1 e 10 de outubro de 2016, a alertarem para "Postos de Vigia dos fogos abandonados em período crítico" e "Postos de vigia das florestas fechados" (fig. 39 A e B) são incompreensíveis dado que o Período Critico tinha sido prolongado!

\section{Diário da República, 1. ${ }^{a}$ série - N. ${ }^{\circ} 119-22$ de junho de 2017}

\section{AGRICULTURA, FLORESTAS E DESENVOLVIMENTO RURAL}

\section{Portaria n. ${ }^{\circ} 195 / 2017$}

de 22 de junho

O Sistema de Defesa da Floresta contra Incêndios, aprovado pelo Decreto-Lei n. ${ }^{\circ} 124 / 2006$, de 28 de junho, alterado pelos Decretos-Leis n. ${ }^{\text {os }} 15 / 2009$ e 17/2009, ambos de 14 de janeiro, 114/2011, de 30 de novembro e 83/2014 de 23 de maio, prevê um conjunto de medidas e ações de articulação institucional, de planeamento e de intervenção relativas à prevenção e proteção das florestas contra incêndios, nas vertentes da compatibilização de instrumentos de ordenamento, de sensibilizacão, planeamento, conservação e ordenamento do territorio florestal, silvicultura, infraestruturação, vigilância, deteção, combate, rescaldo, vigilância pós-incêndio e fiscalização, a levar a cabo pelas entidades públicas com competências na defesa da floresta contra incêndios e entidades privadas com intervenção no sector florestal.

Assumindo a prevenção estrutural um papel predominante, assente na atuação de forma concertada de planeamento e na procura de estratégias conjuntas, conferindo maior coerência regional e nacional à defesa da floresta contra incêndios, compete à autoridade florestal nacional a sua organização e coordenação, que durante o período crítico se integra na estrutura operacional coordenada pela Autoridade Nacional de Proteção Civil.

Nesta medida, para a definição de período crítico relevam, entre outros, o histórico das ocorrências de incêndios florestais e, em especial, as condições meteorológicas existentes e expectáveis.
Assim, estando previstas condições meteorológicas adversas de temperatura, que determinam o aumento do nível de perigosidade para alerta vermelho e laranja no território continental, que incrementam o nível de risco de ocorrência de incêndios florestais, torna-se necessário antecipar o período crítico no âmbito do Sistema de Defesa da Floresta contra Incêndios durante o qual estão vedados certos comportamentos e procedimentos que configuram de per si um risco acrescido para a ocorrência de tais incêndios.

Assim:

Ao abrigo do disposto na alínea $s$ ) do $n .^{\circ} 1$ do artigo $3 .^{\circ}$ do Decreto-Lei n. ${ }^{\circ} 124 / 2006$, de 28 de junho, alterado pelos Decretos-Leis n ${ }^{\text {os }}$ 15/2009 e 17/2009, ambos de 14 de janeiro, 114/2011, de 30 de novembro e $83 / 2014$, de 23 de maio, e ao abrigo da subalínea viii) da alínea $b$ ) do $\mathrm{n}^{\circ} 5$ do Despacho n. ${ }^{\circ} 2243 / 2016$, de 12 de fevereiro, manda o Governo, pelo Secretário de Estado das Florestas e do Desenvolvimento Rural, o seguinte:

\section{Artigo $1 .^{\circ}$ \\ Período Crítico}

No ano de 2017, o período crítico no âmbito do Sistema de Defesa da Floresta contra Incêndios, vigora de 22 de junho a 30 de setembro, e nele devem ser asseguradas medidas especiais de prevenção contra incêndios florestais.

\section{Artigo $2 .^{\circ}$}

\section{Entrada em vigor}

A presente portaria entra em vigor no dia da sua publicação.

O Secretário de Estado das Florestas e do Desenvolvimento Rural, Amândio José de Oliveira Torres, em 21 de junho de 2017.

Fig. 38 - Portaria n. ${ }^{\circ}$ 195//2017 de 22 de junho que define o "Perído Crítico".

Fig. 38 - Ordinance n. ${ }^{\circ}$ 195/2017 of 22 June that defines the "Critical Period". 
Incêndios 924 vigilantes já não se apresentam hoje ao serviço, apesar de a GNR

ter dado parecer positivo à decisão do secretário de Estado das Florestas

\section{Postos de vigia dos fogos abandonados em período crítico}

\section{Rosa Ramos \\ rosa.ramos@jn.pt}

- A partir de hoje, os 231 postos de detecão de incêndios espalhados pelo país ficam sem vigilantes, ape-

sar de o período crítico dos fogos ter sido alargado até ao dia 15

A rede de postos - ativada a 15 de maio e reforçada entre 1 de julho e 30 de setembro - é gerida pela GNR, que contrata civis para fazer a vigilância. Mas os 924 funcionários já não se apresentam hoje ao serviço, uma vez que o Ministério da Administracão Interna (MAI) e a Autoridade Nacional de Proteção Civil (ANPC) decidiram não acompanhar a decisão do secretário de Estado das Florestas de prolongar o período crítico dos incêndios, com base nas previsões do Instituto Português do Mar e da Atmosfera (IPMA) que apontam para tempo seco, quente e ventoso nas próximas semanas.

Assim, com o fim da Fase Char lie dos fogos, que terminou ontem, e 0 arranque da Fase Delta, que começa hoje, o dispositivo de combate no terreno é reduzido para quase metade e os postos de vigia são abandonados, como previsto no Dispositivo Especial de Combate a Incêndios Florestais da ANPC aprovado no início do ano.

Ao que o IN apurou, o secretário de Estado das Florestas pediu pareceres ao Serviço de Proteção da Natureza e do Ambiente (SEPNA) da GNR, ao Instituto de Conservação da Natureza e Florestas (ICNF) e à ANPC antes de assinar o despacho que prolongou o período crítico. A GNR e o ICNF concordaram e só a ANPC se opôs. Porém, e apesar de validar o alargamento do período crítico, a Guarda não pode prolongar o funcionamento dos postos de vigia. “É uma decisão que carece de autorização da tutela", explica uma fonte da GNR

Os postos de vigia são ativados na Fase Bravo, a 15 de maio, com 159 pontos, a que se juntam outros 72 na Fase Charlie, a 1 de julho.

Arderam 153221 hectares

Até ao fim da Fase Charlie, e segun-

do dados da GNR, Portugal perdeu

\section{incêndios : balanço e meios de combate na Fase Delta}

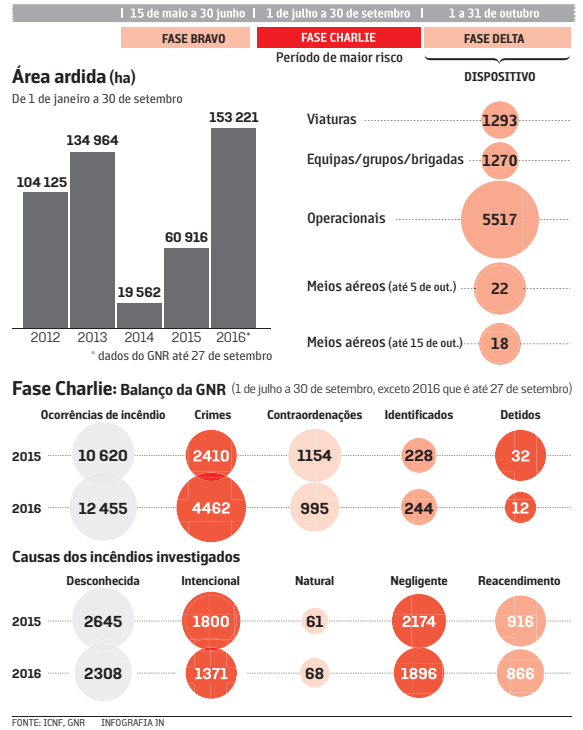

\section{Madeira Partidos pedem estudo sobre meios aéreos}

- 0 Parlamento aprovou por unanimidade, ontem, dois projetos de resolução do PS e do

PCP, em que se pede ao Governo que avance com o estudo da utilização de meios aéreos no combate a incêndios na Madeira. Se o texto comunista lembra que já não é primeira vez que se questiona a ausência de tais meios na ilha, já o dos socialistas pede testes "com a maior brevidade", para que 0 Governo Regional possa tomar uma decisão sobre a aquisição de meios aéreos.
153221 hectares de floresta. E, se gundo relatório mais recente do ICNF, $79 \%$ de tudo o que ardeu este ano foi em agosto, mês em que foram destruídos 115973 hectares. De acordo com o IPMA, citado no documento, na primeira quinzena de agosto registou-se uma temperatura média de 25,07 graus - mais 2,88 graus que 0 considerado nor . Ainda assim, 6 de setembro foi o di mais quente do ano, com uma tem peratura média de 29,2 graus em todo o país.

Ainda de acordo com o ICNE, este ano houve menos $21 \%$ de fogos, mas mais 16\% de área ardida do que a média dos últimos anos. Com o fim da Fase Charlie conclui-se, por outro lado, que 2016 tem a maior área ardida da última década.

Fig. 39 A- Notícia salientando falta de Prevenção (Fonte: JN,1de outubro, 2016).

Fig. 39 A - News items highlighting lack of prevention (Source: JN, October 1, 2016). 


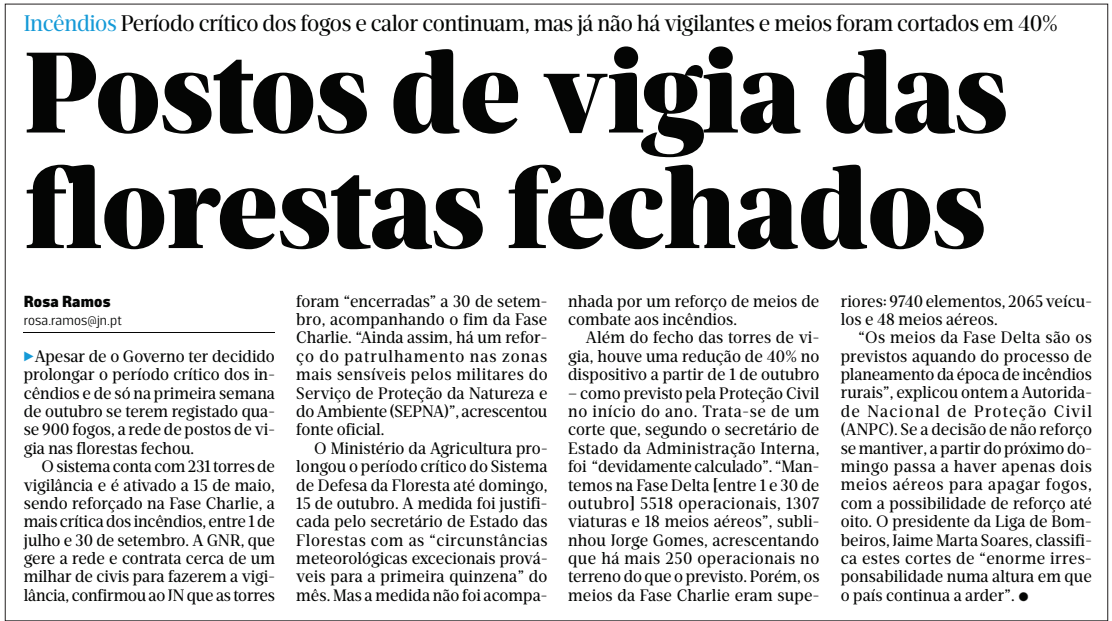

Fig. 39 B - Notícia salientando falta de Prevenção (Fonte: JN,10 outubro,2017).

Fig. 39 B-News items highlighting lack of prevention (Source: JN, October 10, 2017).

É um exemplo objetivo e sem margem de dúvidas da forma como as Autoridades Políticas entendem a Prevenção, na sua vertente mais genuína, a deteção de fogos, em suma, como encaram a defesa da floresta.

Mesmo depois dos grandes incêndios de junho, mesmo depois de tantas mortes, primou a falta de sensibilidade e responsabilidade, pois esqueceram completamente o que diz o art. $^{\circ} 2 .^{\circ}$ do Decreto-Lei n. ${ }^{\circ} 124 / 2006$, de 28 de junho, alterado pela Lei n. ${ }^{\circ} 76 / 2017$, de 17 de agosto. Como foi possível?

\section{Risco de inundação}

É absolutamente crucial que os Serviços Municipais de Proteção Civil (SMPC) e os Departamentos Municipais de Urbanismo, Obras, Infraestruturas e Ambiente, tenham em atenção o cumprimento do Decreto-Lei n. ${ }^{\circ}$ 115/2010, de 22 de outubro, que aprovou o quadro para avaliação e gestão dos riscos de inundação, com o objetivo de reduzir as suas consequências prejudiciais e indo igualmente ao encontro da preocupação relativa à mitigação dos efeitos das inundações: 
i) Deve-se estar atento e atender à morfologia local e à sua previsível evolução;

ii) Atender à eventualidade da ocorrência de fenómenos de ponta (chuvas intensas) e situaçóes prolongadas no tempo;

iii) Ter um programa de limpeza regular dos canais de escoamento e não só após episódios de grandes cheias;

iv) Redimensionar as sargetas e rever o seu desenho e implantação no terreno;

v) Ter programas de manutenção das obras de drenagem urbanas;

vi) Ter os equipamentos de medida operacionais e, pelo contrário, não ter uma total ausência de manutenção dos equipamentos (fig. 5).

\section{A resposta de emergência}

Perante uma emergência, seja um acidente grave ou uma catástrofe, o que há a fazer é responder com os meios humanos e materiais, aplicando o que se encontra descrito nos planos de atuação, tanto de prevenção como de emergência, delineados para os vários tipos de risco, com o objetivo de atenuar, o mais possível, os piores efeitos.

Face à crise, de acordo com o art. $^{\circ} 8 .^{\circ}$ da Lei n.o $80 / 15$, de 3 de agosto, deve ser declarada a situação que mais se lhe adequa, seja de alerta, de contingência, ou de calamidade.

A declaração da situação de alerta, de contingência e de calamidade pode reportar-se a qualquer parcela do território, adotando um âmbito inframunicipal, municipal, supramunicipal, regional ou nacional (n. ${ }^{\circ} 4 .^{\circ}$, art. ${ }^{\circ} 8^{\circ}$ do Decreto-Lei n. ${ }^{\circ} 80 / 2015$, de 3 de agosto.

Os poderes para declarar a situação de alerta, contingência, encontram-se circunscritos pelo âmbito territorial da competência dos respetivos órgãos, n. ${ }^{\circ} 5$, art. $^{\circ}$ 8. ${ }^{\circ}$ do Decreto-Lei n. ${ }^{o}$ 80/2015, de 3 de agosto (QuADro IV).

O Ministro da Administração Interna pode declarar a situação de alerta, de contingência para a totalidade do território nacional ou com o âmbito circunscrito a uma parcela do território nacional (n. ${ }^{\circ}$ 6, art. ${ }^{\circ} 8 .^{\circ}$, Lei n. ${ }^{\circ} 80 / 2015$, de 3 de agosto).

Face à ocorrência de acidente grave ou catástrofe podemos ter a Situação de Alerta quando há necessidade de adotar medidas preventivas e ou especiais de reação. 
A Situação de Contingência acontece quando há necessidade de adotar medidas preventivas e ou medidas especiais de reação não mobilizáveis no âmbito municipal. Por sua vez, é declarada Situação de Calamidade quando há necessidade de adotar medidas de caráter excecional destinadas a prevenir, reagir ou repor a normalidade das condiçóes de vida nas áreas atingidas pelos efeitos da plena manifestação do risco (art. ${ }^{\circ}$ 9. ${ }^{\circ}$, Lei n. ${ }^{\circ}$ 80/2015, de 3 de agosto

Em casos de exceção, tais como agressão efetiva ou iminente por forças estrangeiras, de grave ameaça ou perturbação da ordem constitucional ou de calamidade pública pode ser declarado o Estado de Sítio ou Estado de Emergência (art. ${ }^{\circ} 1 .^{\circ}$ da Lei Orgânica n. ${ }^{\circ} 1 / 2012$, de 11 de maio).

O Estado de Sítio é declarado quando se verifiquem ou estejam iminentes atos de força ou insurreição que ponham em causa a soberania, a independência, a integridade territorial ou a ordem constitucional democrática e não possam ser eliminados pelos meios normais previstos na constituição e na Lei $\left(n .{ }^{\circ} 1\right.$, art. ${ }^{\circ} 8 .^{\circ}$, Lei Orgânica n. ${ }^{\circ} 1 / 2012$, de 11 de maio).

O Estado de Emergência é declarado quando se verifiquem situaçóes de menor gravidade, nomeadamente quando se verifiquem ou ameacem verificar-se casos de calamidade pública (n. ${ }^{\circ}$ 1, art. ${ }^{\circ}$ 9. ${ }^{\circ}$, Lei Orgânica n.o 1/2012, de 11 de maio) (fig. 40).

Perante a crise, a principal prioridade é o socorro, que constitui Missão dos Bombeiros, salientando-se, de acordo com o art. ${ }^{\circ} 3 .^{\circ}$, Decreto-Lei n. ${ }^{\circ}$ 248/2012, de 21 de novembro, os seguintes aspetos:

- A prevenção e o combate aos incêndios;

- $\quad$ O socorro às populaçóes, em caso de incêndios, inundaçóes, desabamentos e, de um modo gera, em todos os acidentes;

- O socorro a náufragos e buscas subaquáticas;

- $\quad$ O socorro e transporte de acidentados e doentes, incluindo a urgência pré-hospitalar, no âmbito do Sistema Integrado de Emergência Médica (SIEM).

Na resposta de emergência é fundamental a implementação e cumprimento do Sistema Integrado de Proteção e Socorro (SIOPS), como um conjunto de normas e procedimentos que asseguram que todos os Agentes de Proteção Civil, atuam, no plano operacional, sob um Comando Único, sem prejuízo da respetiva dependência hierárquica e funcional (n. ${ }^{\circ} 1$ art. $^{\circ} 1 .^{\circ}$, Decreto-Lei n. ${ }^{\circ} 134 / 2006$, de 25 de julho, com a redação do Decreto-Lei n. ${ }^{\circ}$ 72/2013, de 31 de maio). 


\begin{tabular}{|c|c|c|c|c|}
\hline NO QUADRO DE & É DECLARADO & DE ÂMBITO & $\begin{array}{c}\text { PELA ENTIDADE } \\
\text { COMPETENTE }\end{array}$ & DETERMINANDO \\
\hline \multirow{2}{*}{$\begin{array}{l}\text { Ameaça efectiva } \\
\text { ou iminente por } \\
\text { forças estrangeiras, } \\
\text { de ameaça grave } \\
\text { ou perturbação } \\
\text { da ordem } \\
\text { constitucional } \\
\text { democrática } \\
\text { ou de calamidade } \\
\text { pública }\end{array}$} & $\begin{array}{l}\text { ESTADO } \\
\text { DE SÍTIO }\end{array}$ & $\begin{array}{c}\text { Parte } \\
\text { do território } \\
\text { Totalidade } \\
\text { do território }\end{array}$ & \multirow{2}{*}{$\begin{array}{l}\text { Presidente } \\
\text { da República } \\
\text { - Após audição } \\
\text { do Governo } \\
\text { - Com autorização } \\
\text { da AR }\end{array}$} & $\begin{array}{l}\text { Suspensão total ou } \\
\text { parcial do exercício } \\
\text { de direitos, } \\
\text { liberdades e garantias }\end{array}$ \\
\hline & $\begin{array}{c}\text { ESTADO } \\
\text { DE EMERGÊNCIA }\end{array}$ & $\begin{array}{c}\text { Parte } \\
\text { do território } \\
\text { Totalidade } \\
\text { do território }\end{array}$ & & $\begin{array}{l}\text { Suspensão parcial } \\
\text { do exercício de } \\
\text { direitos, liberdades } \\
\text { e garantias }\end{array}$ \\
\hline $\begin{array}{l}\text { Agressão efectiva } \\
\text { ou iminente que } \\
\text { ponha em causa } \\
\text { a independência } \\
\text { nacional, } \\
\text { a salvaguarda } \\
\text { do território, } \\
\text { a liberdade } \\
\text { e a segurança } \\
\text { das populações }\end{array}$ & $\begin{array}{c}\text { ESTADO } \\
\text { DE GUERRA }\end{array}$ & $\begin{array}{c}\text { Defesa } \\
\text { nacional }\end{array}$ & $\begin{array}{l}\text { Presidente } \\
\text { da República } \\
\text { - Sob proposta } \\
\text { do Governo } \\
\text { - Após audição } \\
\text { do Conselho } \\
\text { de Estado } \\
\text { - Com autorização } \\
\text { da AR }\end{array}$ & $\begin{array}{l}\text { Relações } \\
\text { Internacionais; } \\
\text { A nível interno: } \\
\text { declaração } \\
\text { de estado de sítio } \\
\text { ou de estado } \\
\text { de emergência }\end{array}$ \\
\hline
\end{tabular}

Fig. 40 - Estado Sítio, Emergência e Guerra-Competência para declarar (Fonte: Caderno Técnico PROCIV, n. ${ }^{\circ} 23$ ).

Fig. 40 - States of Siege, Emergency and War: Power to declare them (Source: PROCIV Technical Notebook, no. 23).

O SIOPS visa responder a situaçóes de iminência ou de ocorrência de acidente grave ou de catástrofe.

O art. ${ }^{\circ} 12 .^{\circ}$ de atrás referido Decreto-Lei define o Sistema Geral de Operaçóes (SGO), que se desenvolve de uma forma evolutiva e se configura nos níveis estratégico, tático e de manobra (art. ${ }^{\circ} 13 .^{\circ}$, Decreto-Lei n. ${ }^{\circ}$ 134/2006, de 25 de julho, com a redação do Decreto-Lei n. ${ }^{\circ}$ 72/2013, de 31 de maio).

No nível estratégico assegura-se a gestão da operação, define-se a estratégia apropriada, elabora-se o plano estratégico de ação (PEA), faz-se a previsão e planeamento dos resultados e fixam-se os objetivos para o nível tático.

No nível tático dirigem-se as operações tendo em consideração os objetivos definidos, sempre sob o comando do Comandante Operaçôes de Socorro (COS) e definem-se as orientaçóes para o nível de manobra. 
No nível de manobra, para atingir os objetivos, executam-se as tarefas, com apoio humano e meios técnicos (art. ${ }^{\circ}$ n. ${ }^{\circ} 13$, Decreto-Lei n. ${ }^{\circ}$ 134/2006, de 25 de julho, com a redaçáo do Decreto-Lei n. ${ }^{\circ} 72 / 2013$, de 31 de maio).

O art. ${ }^{\circ} 14 .^{\circ}$, Decreto-Lei n. ${ }^{\circ}$ 134/2006, de 25 de julho, com a redaçáo do Decreto-Lei n.o 72/2013, de 31 de maio, define o Posto de Comando Operacional (PCO), como órgão diretor das operaçóes de socorro no local da ocorrência para apoiar o COS.

O PCO é constituído pelas células de Planeamento, Operaçóes e Logística. As três células teráo responsáveis, nomeados pelo COS, designando-se Oficial de Planeamento, Oficial de Operaçōes e Oficial de Logística.

O COS é assessorado por três oficiais, um como Adjunto de Segurança, outro como Adjunto de Relaçóes Públicas e o outro como Adjunto de Ligaçáo com as Entidades.

Fazem parte do PCO os representantes dos Agentes de Proteção Civil presentes no teatro de operaçóes (TO) (art. ${ }^{\circ} 16 .^{\circ}$, Decreto-Lei n. ${ }^{\circ} 134 / 2006$, com a redaçáo Decreto-Lei n. ${ }^{\circ}$ 72/2013, de 31 de maio).

$\mathrm{O}$ art. $^{\circ} 23 .^{\circ}$ define o Estado de Alerta Especial (EAE), para as organizaçóes integrantes do SIOPS, o qual tem como objetivo intensificar as açóes preparatórias para as tarefas de supressão ou minoraçáo das ocorrências, colocando meios humanos e materiais de prevenção em relação ao período de tempo e à área geográfica em que se preveja especial incidência de condiçôes de risco ou de emergência (art. ${ }^{\circ}$ 23. ${ }^{\circ}$ Decreto-Lei n. ${ }^{\circ} 134 / 2006$, de 23 de julho, com a redação do Decreto-Lei n. ${ }^{\circ}$ 72/2013, de 31 de maio).

O EAE compreende os níveis: azul, amarelo, laranja e vermelho, progressivos conforme a gravidade da situaçáo e o grau de prontidão que este exige (n. ${ }^{\circ} 2$, art. ${ }^{\circ}$ 24, Decreto-Lei n. ${ }^{\circ}$ 134/2006, de 23 de julho, com a redação do Decreto-Lei n. ${ }^{\circ}$ 72/2013, de 31 de maio).

Entretanto a Comissão Nacional de Proteção Civil (CNPC) aprovou a Declaração n. ${ }^{\circ}$ 97/2007, de 16 de maio, que determina as regras de ativação do EAE para as organizaçóes integrantes do SIOPS. A competência para acionar o EAE pertence exclusivamente ao Centro de Coordenação Operacional Nacional (CCON) que é coordenado pelo Presidente da ANPC (n. ${ }^{\circ} 2$ art. $^{\circ} 25 .^{\circ}$, Decreto-Lei n. ${ }^{\circ}$ 134/2006, de 23 de julho, com a redaçáo do Decreto-Lei n. ${ }^{\circ}$ 72/2013, de 31 de maio.

Para ser mais fácil de entender aquilo que foi descrito, vejamos três exemplos: 


\section{Exemplo 1 - Incêndio em Fábrica de Tintas - SILACA, ocorrência n.o 24751/2013, em 28 de fevereiro (fig. 41).}

Face ao alerta foram de imediato para o local todos os meios disponíveis na C.B.S.Gaia e dos B.V.Carvalhos, cumprindo-se a grelha de atuaçầo.

Chegados ao local verificamos que a fábrica se encontrava tomada pelas chamas em alguns sectores de laboração. Face ao cenário solicitou-se à nossa Central tanques de água $(\mathrm{VTTU}(\mathrm{s})$ ) dos vários $\mathrm{CB}(\mathrm{s})$ do Município. Foi também solicitado ao Batalhão Sapadores Bombeiros Porto uma Autoescada pois a da C.B.S.Gaia está inoperacional.

De imediato foi delineada uma estratégia de ataque pelo que rapidamente se iniciou o combate ao incêndio com várias linhas de água de alto débito de $45 \mathrm{~mm}$ acompanhadas com outras linhas de água utilizando-se espumífero.

Passados alguns minutos chegou ao local o Sr. Comandante Operacional - Eng. Salvador

Almeida que assumiu de imediato o COS e estabeleceu o respetivo posto de comando.

Reuniu com três elementos do comando e atribuindo a cada um deles o seu sector de atuaçấo.

Sector Alfa, responsável, Adjunto dos B.V.Carvalhos.

Sector Bravo, responsável, Adjunto dos B.V.Coimbrôes António Vieira.

Sector Charlie, responsável, Chefe de 2a da C.B.S.Gaia Victor Soares.

Esteve no T.O. A partir das $14 \mathrm{~h} 00$ o Sr. Comandante dos B.V.Carvalhos.

O combate ao incêndio foi bastante demorado, de grande risco, pois havia várias explosôes e parte da cobertura ruiu o que muito dificultou o combate, pois não permitia um ataque direto.

No decorrer do combate quatro bombeiros (1 B.V.Carvalhos - Carlos Nunes, 1 B.V.Valadares - Luís Augusto Sousa Gomes, 1 B.V.Coimbróes - Manuel Silva e 1 C.B.S.Gaia - Sérgio Afonso), tiveram ferimentos sendo transportados ao CHVNG/Espinho. Após tratamento regressaram a casa com alta.

No que ao socorro pré hospitalar diz respeito, devemos referir que aquando da nossa chegada foi-nos transmitida a existência de duas vítimas que se encontravam em decúbito dorsal na via pública. Ao fazer a triagem verificamos que ambas estavam conscientes, orientadas e colaborantes: a primeira referia má disposição, enormes dores em toda a regiăo corporal causadas pelas graves queimaduras de $2^{\circ} \mathrm{e} 3^{\circ}$ grau.

Ao mesmo tempo que pedíamos ajuda diferenciada bem como meios adicionais ao CODU iniciamos o socorro naquela vítima queimada de acordo com o protocolo para estas situaçóes: atenção máxima à permeabilizaçáo da via aérea, remoção de todo o vestuário (exposição) aplicação de soro fisiológico e compressas esterilizadas nas áreas afetadas, $60 \%$ do corpo (sensivelmente) e controlo de temperatura. Imediatamente a seguir chegou a equipa médica (VMER) de Gaia (chefiada pelo Dr. Basil) que assumiu toda a responsabilidade deste serviço.

A ABSC da CBS transportou a vítima António Pedro Marques Domingues ao CHVNGaia/Espinho.

A ABSC dos B.V.Carvalhos transportou a vítima Ricardo Manuel Lopes Pinto ao CHVNGaia/Espinho.

No decorrer dos trabalhos mais dois trabalhadores sentiram indisposição e foram transportados ao CHVNG/Espinho pelos BV Avintes José Carlos Oliveira Dias e Alberto Manuel Rocha Viana.

A partir do Posto de Comando, durante os trabalhos foram transmitidos vários POSIT ao CDOS (posit dado ao posto de comando pelo sector Charlie às $11 \mathrm{~h} 39 \mathrm{~min}$, confirmou que os trabalhadores se encontravam todos no exterior; posit dado ao posto de comando pelo sector

Charlie às $11 \mathrm{~h} 47 \mathrm{~min}$, incêndio ativo; posit dado ao posto de comando pelo sector Charlie às $12 \mathrm{~h} 02 \mathrm{~min}$, cedência de estrutura de um pavilháo tendo atingido dois bombeiros, um dos B.V. de Coimbróes e um dos B.V. de Valadares - assistidos no local pela VMER e de seguida foram transportados a $\mathrm{CHVNG/Espinho;} \mathrm{posit} \mathrm{dado} \mathrm{ao} \mathrm{SALOC} \mathrm{durante} \mathrm{o} \mathrm{incêndio} \mathrm{pelo} \mathrm{Comandante} \mathrm{Operacional;} \mathrm{posit} \mathrm{dado} \mathrm{ao} \mathrm{posto} \mathrm{de}$ comando pelo sector Alfa, às $12 \mathrm{~h} 06 \mathrm{~min}$ - incêndio ativo; posit dado ao posto de comando pelo sector Bravo, às $12 \mathrm{~h} 07 \mathrm{~min}$ - substituição de aricas; posit dado ao posto de comando pelo sector Bravo, às $12 \mathrm{~h} 40 \mathrm{~min}$ - incêndio ativo; às $13 \mathrm{~h} 00$ foi dada ordem pelo posto de comando para efetuarem a rendiçáo de bombeiros para logística; às $14 \mathrm{~h} 21 \mathrm{~min}$, o sector Charlie foi assumido pelo $2^{\circ}$ Comandante dos B.V. dos Carvalhos; posit dado ao posto de comando pelo sector Alfa, Bravo e Charlie às $15 \mathrm{~h} 20 \mathrm{~min}$ - incêndio controlado; às $15 \mathrm{~h} 30 \mathrm{~min}$ o sector Charlie foi assumido pelo Chefe de 2a CBS Victor Soares; posto de comando recebeu informaçấo dos B.V. Valadares que o bombeiro teve alta do hospital às $13 \mathrm{~h} 45 \mathrm{~min}$ e o bombeiro de Coimbróes teve alta do hospital às $14 \mathrm{~h} 38 \mathrm{~min}$.

O posto de comando desmobilizou meios do T.O. Às 16h20min, ABSC 03, VTTU 03 e VLCI 03 CBS Gaia, VE 3002 do Batalhão Sapadores Bombeiros Porto, VTTU e VUCI dos B.V.Coimbróes; das 16h20min às 17h00, VTTU B.V.Avintes; às $17 \mathrm{~h} 15 \mathrm{~min}, \mathrm{VTTU} \mathrm{e}$ VUCI dos B.V.Valadares; às $17 \mathrm{~h} 50 \mathrm{~min}$ VTTU dos B.V. Crestuma e VTTU e VUCI dos B.V.Aguda.

Pelas $18 \mathrm{~h} 00 \mathrm{o}$ incêndio entrou em rescaldo que foi assegurado pela CBS Gaia e pelos B.V.Carvalhos.

$\mathrm{O}$ incêndio foi dado como extinto às $22 \mathrm{~h} 50 \mathrm{~min}$.

Fig. 41 - Relatório de ocorrência/atuação

(Fonte: Bombeiros Sapadores e Proteção Civil de Vila Nova de Gaia).

Fig. 41 - Report of occurrencelaction taken

(Source: Fire Brigade and Civil Protection of Vila Nova de Gaia). 
O resgate dos 33 mineiros foi uma "obra-prima da Engenharia" (Torres, 2010), uma vez que após a ocorrência do acidente, foi implementada uma tentativa de resgate, com recurso a meios humanos, através das chaminés de ventilação. Porém, a 7 de agosto, a equipa de salvamento náo conseguiu avançar por ter verificado o deslizamento de rochas, também na zona das chaminés.

Face a esta tentativa falhada com recurso a meios humanos, foi necessário, como alternativa, utilizar tecnologia de ponta para a localização dos mineiros no subsolo e para o posterior processo de resgate. Foi inegável o papel desempenhado pela engenharia nas duas etapas de salvamento dos 33 mineiros (fig. 42)

Na 1. a etapa, para localizar os mineiros, foi determinante a contribuição da topografia, geologia, prospeçáo, métodos de exploração subterrânea, planeamento e controle das operaçôes.

$\mathrm{Na} 2 .^{\text {a }}$ etapa, para escavar a chaminé de resgate e proceder ao salvamento, foi imprescindível a utilizaçáo de alta engenharia geológica e mineira, apoiada pela topografia, pela engenharia mecânica, hidráulica, informática, bem como o planeamento estratégico e a política.

Como conclusão, na hipótese de acontecer um caso similar em Portugal, pode afirmar-se que "existem condições técnicas para resolvê-lo" (Torres, 2010).

Ainda acrescenta que as três principais minas portuguesa subterrâneas (Mina da Panasqueira, Mina de Neves e Corvo e Mina de Aljustrel) operam com aplicação de boa tecnologia e uso de técnicas de sondagens, construção de poços de grande profundidade com "raise borer" (fig. 43) e sistemas de extração de mineral e do pessoal automatizado

Conclui, afirmando que "A lição de humanidade que o inédito acidente chileno deu, teria sido inimaginável sem a contribuição dos avanços da topografia, prospeção, geologia, métodos de exploração, equipamentos mineiros, entre outras intervençôes, aliado à decisão administrativa e política". "Num suposto acidente similar em Portugal, o procedimento de resgate seria semelhante, devido a existir conhecimento e experiência no dominio da tecnologia utilizada para o salvamento" (Torres, 2010). 


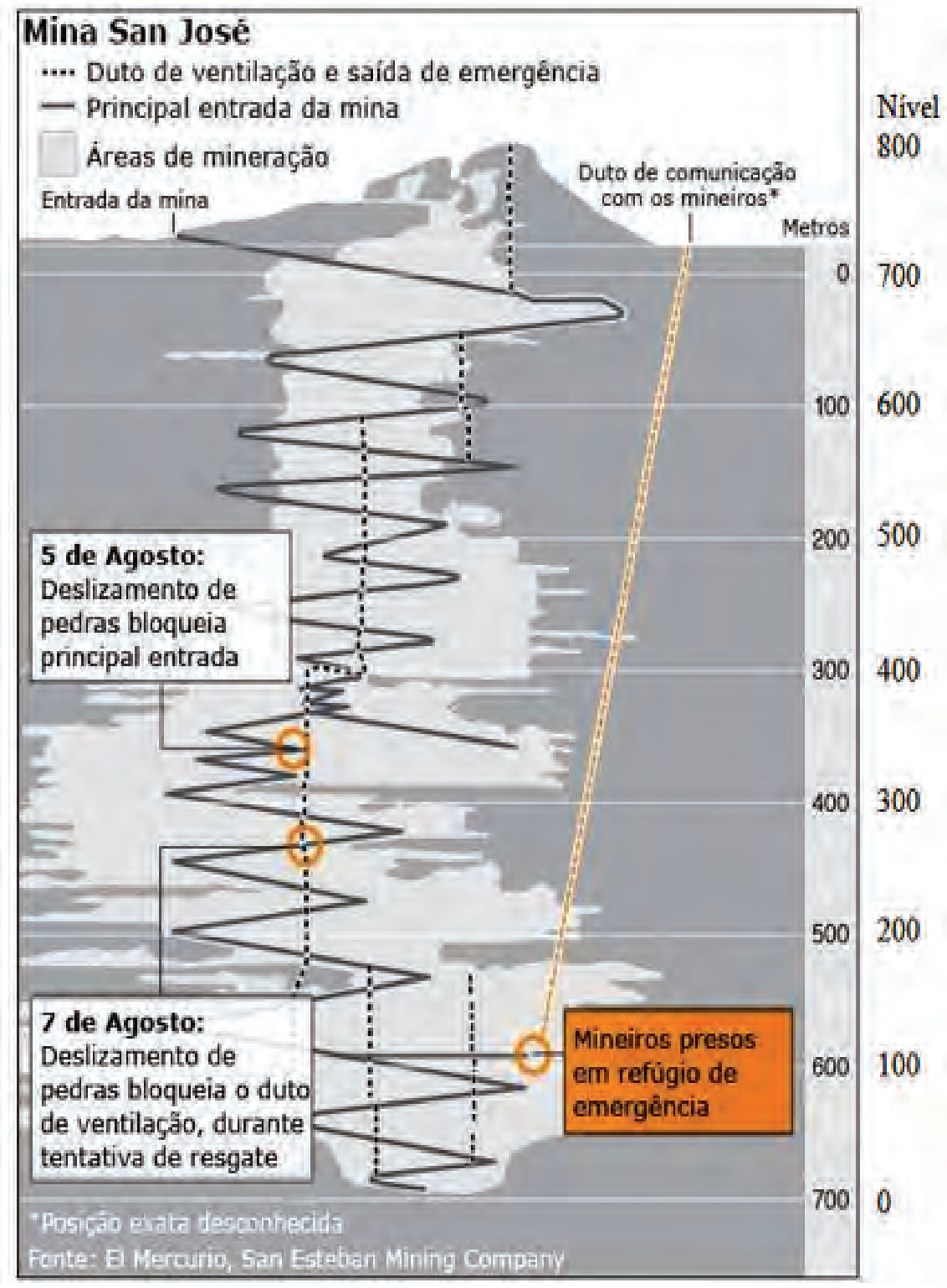

Fig. 42 - Acidente na mina de San José - Chile, no 5 de agosto de 2010 (Fonte: Revista Ingenium, n. ${ }^{\circ} 119,2010$ ).

Fig. 42 - Accident at the San José mine, Chile, on 5 August 2010 (Source: Ingenium Magazine, n. ${ }^{\circ} 119,2010$ ). 

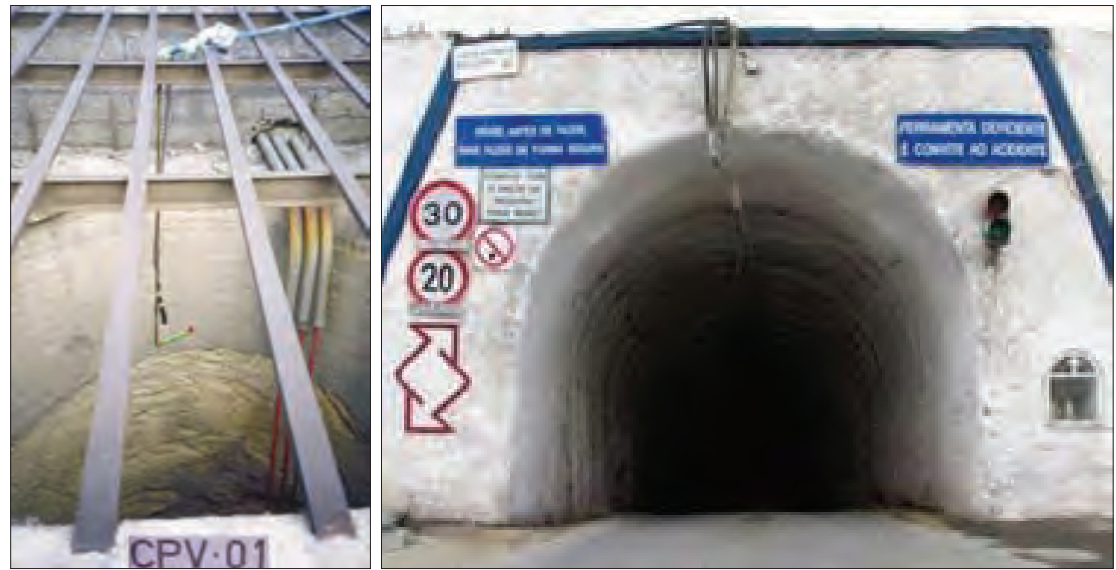

Fig. 43 - Poço CVP-01 (4) e rampa de Castro da Mina de Neves Corvo

(Fonte: Revista Ingenium, n. $\left.{ }^{\circ} 119,2010\right)$.

Fig. 43 - Well CVP-01 (4) and Castro ramp of Neves Corvo Mine

(Source: Ingenium Magazine, n. ${ }^{\circ} 119$, 2010).

\section{Exemplo 3 - Incêndio no Túnel do Marão}

A notícia de 13 de junho de 2017 (fig. 44), levanta uma série de dúvidas quanto à segurança dos milhares de cidadãos que circulam na $\mathrm{A} 4 \mathrm{e}$ mais concretamente no “Túnel do Marão”.

Perante um incêndio em veículos no túnel ou em qualquer infraestrutura, sabem os operacionais do socorro, isto é os bombeiros, que um minuto é tempo a mais, quanto mais serem os bombeiros acionados 15 a 20 minutos após deflagrar o incêndio (fig. 44).

Qual a razão de a chamada náo cair de imediato nos corpos de bombeiros que têm a responsabilidade do socorro, bem como no INEM e nas Forças de Segurança?

Qual a razão de ser um Centro de Controlo e Alerta a cerca de $300 \mathrm{Km}$, a avaliar e decidir o socorro? Porque não cai o alerta no Centro de Controlo e Alerta que está em Almada (?!) e ao mesmo tempo nas três entidades atrás referidas (Bombeiros, INEM e Forças de Segurança). 


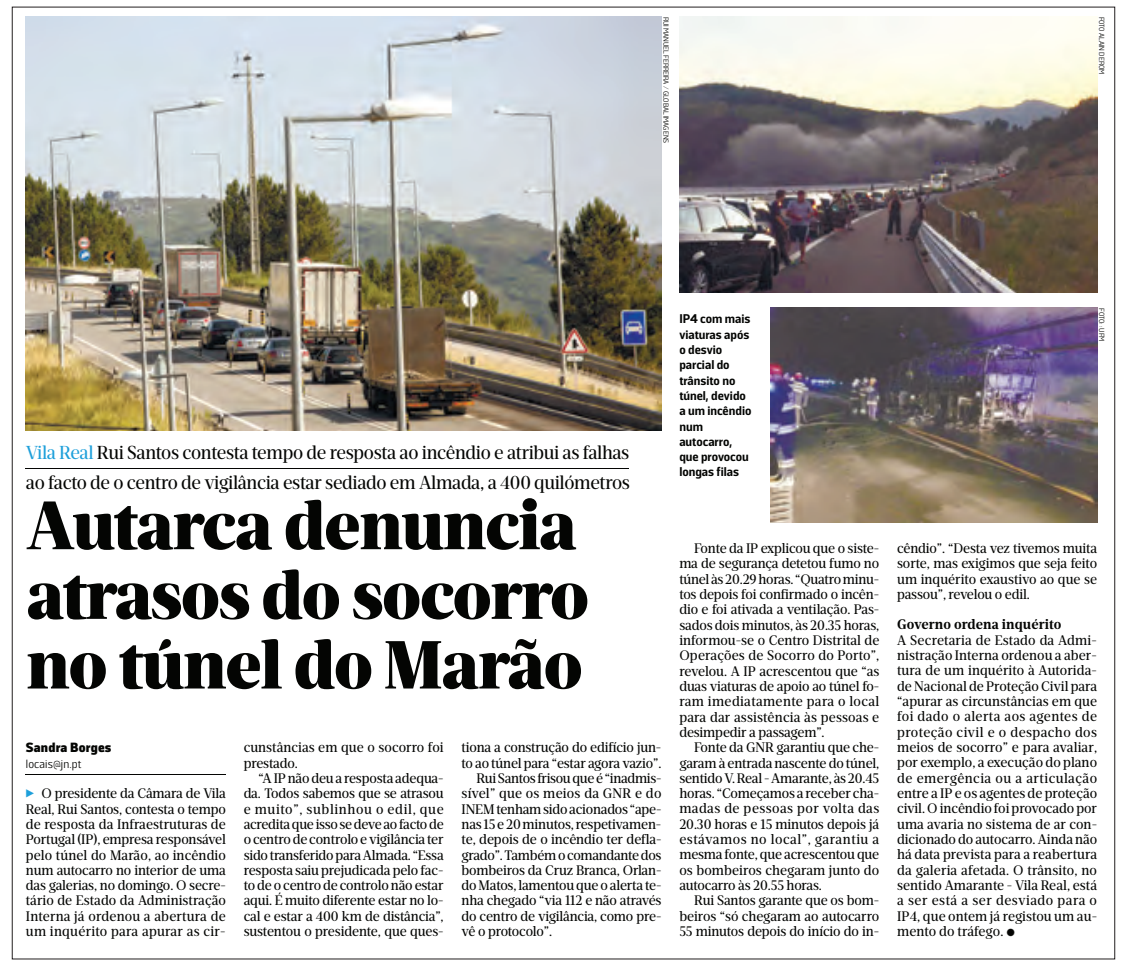

Fig. 44 - Incêndio no Túnel do Marão (Fonte: JN,13 de junho 2017).

Fig. 44 - Fire in the Marão Tunnel (Source: JN, June 13, 2017).

Seria uma decisão acertada que protegeria os cidadãos que circulam no túnel e os bombeiros que têm de intervir em situaçóes de grande perigo pondo a vida em risco, pois nessa altura não são os técnicos do Centro de Controlo e Alerta que vão para a ocorrência, que vão combater o incêndio, fazer o desencarceramento, resgatar soterrados se os houver!

Esta grande obra da Engenharia Portuguesa exige medidas de segurança adequadas, proporcionais e, acima de tudo, geridas com sensatez, prevalecendo um princípio de custo benefício, mas sempre como critério principal a prevenção e proteção da vida humana.

Verificou-se, mais uma vez, que a Segurança/Safety (Proteção Civil) foi descurada, pelo que vem agora o Despacho n. ${ }^{\text {o }}$ 1407-A/2018, de 5 de fevereiro, emanado dos Gabinetes 
dos Secretários de Estado da Proteção Civil e das Infraestruturas (fig. 45), dar prazo à ANPC e às Infraestruturas de Portugal (IP, S.A.) para, até 31 março, procederem a:

- Revisão do Plano de Emergência Interno, pela IP, S.A.;

- Elaboração dum Plano de Prevenção, pela IP, S.A.;

- Revisão do Plano Prévio de Intervenção pela ANPC;

- Realização dum simulacro para testar os planos e essencialmente a articulaçáo entre todas as entidades.

Entretanto a 26 de Abril, vinte e seis dias após o prazo estabelecido no despacho, os Senhores, Secretário de Estado das Infraestruturas e da Proteção Civil, assinaram um protocolo de cooperação com a Corporação de Bombeiros da Cruz Branca de Vila Real, que permitirá ter um veículo e três bombeiros, por turnos perfazendo cerca de 20 bombeiros.

Foram também apresentados os Planos de acordo com o Despacho no 1407 A/2018 de 5 de Fevereiro, faltando o simulacro (fig. 46).

Esperemos que os Planos e os exercícios demonstrem a justeza da pretensão dos bombeiros e proteção civil, para serem alertados ao mesmo tempo que o Centro de Controlo e Alerta de Almada, evitando-se perdas de tempo e desculpas a posteriori que, geralmente, nada resolvem.

\section{Catástrofes: a resposta europeia}

A Europa tem sido fustigada, ao longo dos anos, por várias catástrofes e a par da resposta dos sistemas nacionais e locais, tem sido a relação entre Estados que tem prevalecido na ajuda, através do princípio da subsidiariedade, princípio segundo o qual a EU só deve atuar quando a sua ação seja mais eficaz do que uma ação desenvolvida a nível nacional, regional ou local, exceto quando se trate de domínios da sua competência exclusiva.

Em 2001, no âmbito do Programa de Ação 2000-2004, instituíram-se diversos mecanismos para facilitar essa atuação, designadamente:

i) Criação de um Mecanismo Comunitário de Proteção Civil, que assenta no funcionamento de um Centro de Informação e Vigilância, o MIC (do Inglês, Monitoring and Information Center), acessível 24 horas e 
Diário da República, $2{ }^{a}$ série $-N .^{\circ} 28-8$ de fevereiro de 2018

\section{ADMINISTRAÇÃO INTERNA E PLANEAMENTO E DAS INFRAESTRUTURAS}

\section{Gabinetes dos Secretários de Estado da Proteção Civil e das Infraestruturas}

\section{Despacho n. ${ }^{\circ}$ 1407-A/2018}

1 - Considerando o relatório final elaborado no processo de inquérito n. ${ }^{\circ}$ 09/2017 da Autoridade Nacional de Proteção Civil (doravante ANPC), mandado instaurar pelo Secretário de Estado da Administração Interna a 12 de junho de 2017, para avaliação da resposta operacional à ocorrência de incêndio em veículo pesado de transporte coletivo de passageiros no Túnel do Marão, em 11 de junho de 2017, que recomenda a revisão do Plano Prévio de Intervenção (PPI) pela ANPC e do Plano de Emergência Interno (PEI) pela Infraestruturas de Portugal, S. A. (doravante IP, S. A.), bem como a realização de um simulacro de incêndio no interior do túnel para validar a conformidade das novas versões dos planos e de modo a salvaguardar a segurança de pessoas e bens, determina-se que:

2 - A ANPC e a Infraestruturas de Portugal S. A. promovam, com urgência, até 31 de março de 2018:

a) A revisão do Plano de Emergência Interno, pela IP, S. A., no âmbito da evacuação de pessoas em situação de emergência; da atuação das equipas de segurança da entidade gestora; da valorização das potencialidades do Posto de Controlo, localizado junto à saída do túnel, no sentido de Amarante,

b) A elaboração de um Plano de Prevenção, pela IP, S. A., que concretize os procedimentos de manutenção e conservação das instalações técnicas e dos equipamentos e sistemas de segurança, englobando ainda as medidas de autoproteção, o plano de formação, bem como os procedimentos de rotina no âmbito da segurança.

c) A revisão do Plano Prévio de Intervenção (PPI), pela ANPC, no sentido da otimização do despacho de meios em situação de emergência, de modo a assegurar uma resposta operacional oportuna e eficaz.

3 - Após a revisão e elaboração dos planos mencionados no ponto 2, deverá ser realizado um simulacro de incêndio no interior do Túnel do Marão, tendente a avaliar a articulação e a resposta à emergência por parte das entidades envolvidas, nomeadamente as equipas de segurança da entidade gestora e as equipas dos agentes de proteção civil. Este simulacro não prejudica a realização dos exercícios periódicos definidos no Plano de Emergência Interno.

5 de fevereiro de 2018. - O Secretário de Estado da Proteção Civil, José Artur Tavares Neves. - O Secretário de Estado das Infraestruturas, Guilherme Waldemar Goulão dos Reis d'Oliveira Martins.

311125214

Fig. 45 - Despacho n. ${ }^{\circ} 1407$ - A/2018 de 5 de fevereiro, ANPC e IP, S.A.

Fig. 45 - Administrative Order no. 1407 - A/2018 of 5 February, ANPC and IP, S.A. 


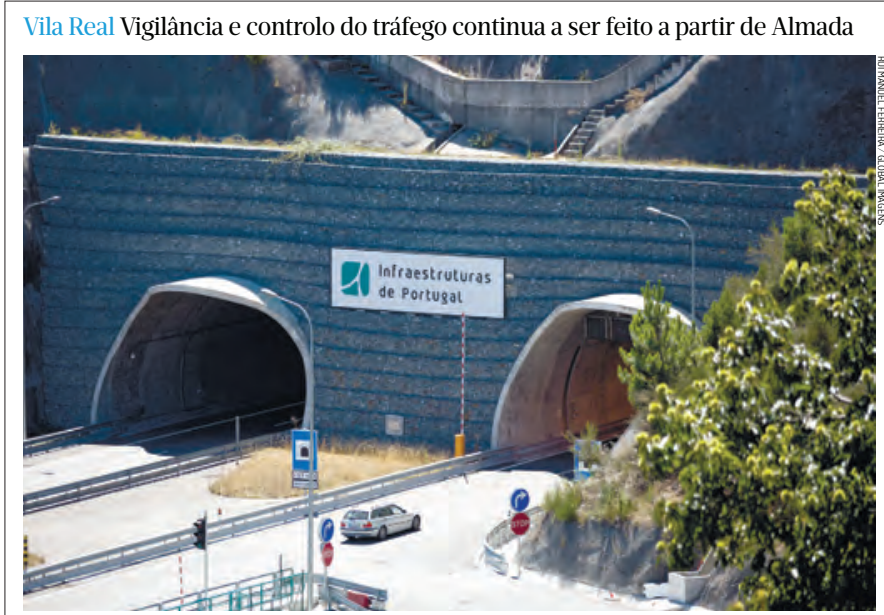

0s 5665 metros do túnel do Marão vão ter em permanência três bombeiros e uma viatura de combate a incêndios

\section{Túnel do Marão com bombeiros 24 horas por dia}

\section{Sandra Borges} locais@jn.pt

- O túnel do Marão, com 5,6 quilómetros, vai passar a ter em permanência uma equipa com três bombeiros e uma viatura de combate a incêndios, mas a vigilânci e o controlo do tráfego vão manter-se em Almada, no centro operacional da Infraestruturas de Portugal(IP), concessionária do túnel. No edifício do centro localizado junto à saída da galeria norte, no sentido Vila Real-Amarante, haverá apenas uma sala preparada para ser usada como posto de comando, em caso de emergência.

Amanhã os secretários de Estado das Infraestruturas e da Proteção Civil irão visitar aquela sala e assinar um protocolo com a corporação da Cruz Branca, de Vila Real, que permitirá ter cerca de $20 \mathrm{bom}$ beiros a assegurar o serviço, por turnos, no túnel do Marão. Ainda não é conhecida a data em que a equipa e a viatura passarão a estar em permanência no túnel, uma vez que ainda não foi feito o recrutamento dos operacionais, nem a aquisição do veículo.

Também amanhã, serão apresentados os novos planos de inter- venção, emergência e prevenção que foram reestruturados devido às falhas apontadas pelo inquérito ao autocarro que ardeu por completo no in rão, em junho de 2017, e será divulgada a data do simulacro de incêndio, que deverá realizar-se durante o mês de maio.

O presidente da Câmara de Vila Real, Rui Santos, está satisfeito. “E

\section{Portagens 15,8 milhöes de euros em dois anos}

A duas semanas de assinalar dois anos de funcionamento, o túnel do Marão já rendeu cerca de 15,8 milhões de euros em portagens. No primeiro trimestre deste ano, a receita fo de 2,2 milhöes de euros, um valor que representa um crescimento de cerca de $20 \%$ face ao verificado no período homólogo do ano passado. Em 2016, nos oito meses em que esteve aberto ao tráfego, o vaIor da receita com portagens foi de 4,9 milhões. Já no ano seguinte, o valor global ascendeu aos 8,7 milhões de euros. uma boa solução, melhor até do que aquela que alguma vez imaginávamos ou que alguma vez foi equacionada", sublinhou. Ainda antes do incêndionoautoc Santos reivindicou a reabertura do centro de comando do túnel, que fechou seis meses após a abertura da infraestrutura, e apelidou de "erro" a deslocalização da vigilância para Almada.

Já o deputado do PSD Luís Ramos descreve esta solução como "um sinal positivo", mas adianta que representa "apenas um remendo para não assumir que aquilo que foi prometido não vai acontecer", nomeadamente a reabertura total do centro de comando do túnel.

Trabalhadores têm dúvidas A comissão de trabalhadores da IP afirma que esta solução, que apelidou de "capricho", levanta dúvidas. "Se o futuro passa por ter bombeiros no túnel e se for a IP a suportar estes vencimentos, vamos questionar a empresa sobre as razões de não serem funcionários da empresa a estar no túnel", afirmou o porta-voz da comissão, Fernando Semblano, que admite que poderá "gerar-se uma sobreposição de funções". •

Fig. 46 - Túnel do Marão (Fonte: JN, 25 de abril 2018).

Fig. 46 - The Marão Tunnel (Source: JN, April, 2018). 
que permite uma ligação com todos os pontos de contacto dos vários Países, sendo em Portugal o ponto de contacto efetuado pela ANPC, através do seu Comando Nacional de Operaçóes de Socorro;

ii) Constituição e registo prévio de Peritos;

iii) Constituição de Módulos de Proteção Civil, que são equipamentos prontos para intervir em qualquer parte do espaço europeu;

iv) Realização de um Programa de Formação, complementado com um programa de troca de Peritos (fig. 47);

v) Criação de um Sistema de Informação Conjunta, o CESIS;

vi) Identificação PRÉVIA de Peritos e Monitorização de Equipas de Avaliação e de Coordenação no terreno.

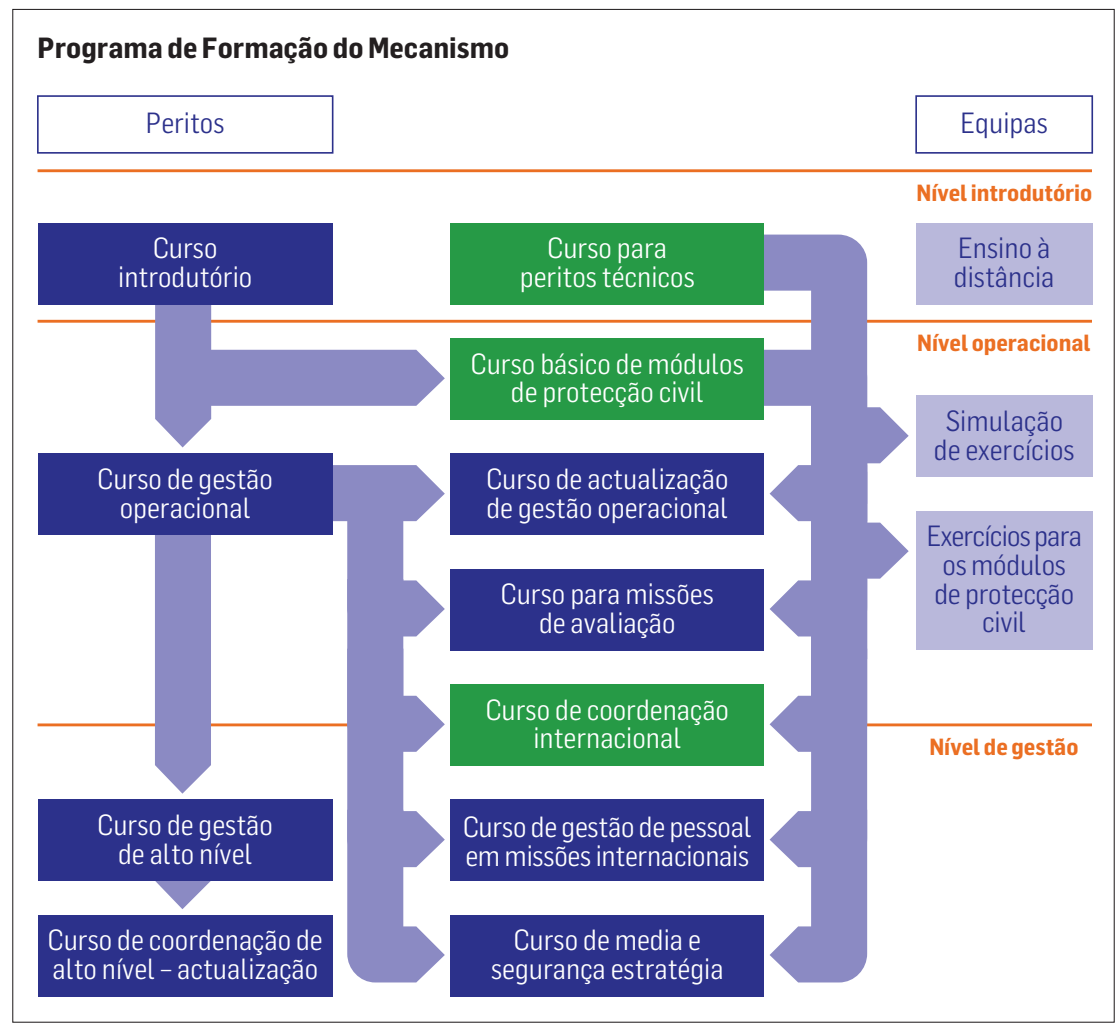

Fig. 47 - Organigrama do Programa de Formação de Peritos (Fonte: PROCIV, n. ${ }^{\circ}$ 10, ANPC). Fig. 47 - Organizational chart of the Programme for Training Experts (Source: PROCIV, n. ${ }^{\circ}$ 10, ANPC) 
A ativação do Mecanismo Europeu em território dos Estados Participantes realiza-se da seguinte forma: um Estado participante afetado por catástrofe que necessita de assistência ativará o Mecanismo Comunitário de Proteção Civil através de um pedido formal ao MIC, que fará a difusão aos demais Estados, para que estes se possam pronunciar.

Se o pedido for proveniente de um outro Estado, é a ANPC que em Portugal recebe o pedido, após o que dará conta à tutela e, posteriormente, será dada resposta ao MIC (fig. 48).

Entretanto, face às muitas catástrofes, aos custos a elas associados e muito especialmente ao número de vítimas, melhorou-se o sistema existente e criou-se um Centro de Resposta de Emergência, fusão do MIC, com novas capacidades, 24 sobre 24 horas, a monitorizar e gerir, em simultâneo, diversas ocorrências.

Este novo Centro, designado por Emergency Response Centre (ERC), foi inaugurado em 15 de maio de 2015, tendo ficado com a capacidade para dar resposta, planeada e coordenada, às necessidades de socorro e assistência, mobilizando os Peritos, as Equipas e os Equipamentos que sejam considerados necessários (ANPC, 2013a).

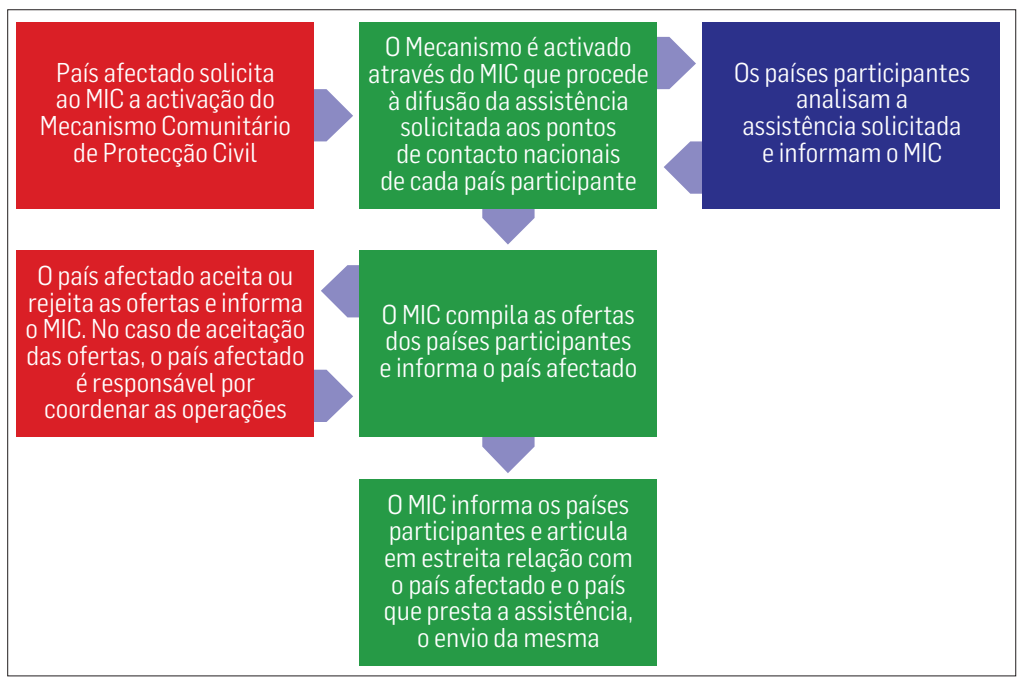

Fig. 48 - Organograma Ativação Mecanismo Proteção Civil em território dos Estados Participantes (Fonte: PROCIV, n. ${ }^{\circ}$ 10, ANPC).

Fig. 48 - Organizational Chart for the Civil Protection Activation Mechanism in the participating states (Source: PROCIV, n. ${ }^{\circ}$ 10, ANPC). 


\section{Plataforma Global para a Redução do Risco de Catástrofes (GPDRR)}

A Organização das Naçóes Unidas (ONU) aprovou em 2000, a Estratégia Internacional para a Redução de Catástrofes (International Strategy for Disaster Reduction-ISDR). Como consequência realizou-se em 2005, em KOBE-Japão a Conferência Mundial para a Prevenção de Catástrofes, sendo aprovada a Declaração de HYOGO e o seu Quadro de Ação 2005-2015.

As sessóes da Plataforma Global para a Redução do Risco de Catástrofes reuniram vários atores envolvidos na ISDR, nomeadamente os Governos, ONG(s), Instituiçôes Científicas, Privados, Académicos, etc. A representação Portuguesa esteve a cargo da ANPC. O Quadro de Ação de Hyogo recomendou a criaçáo de plataformas nacionais. A partir de 31 de maio de 2010 a Comissão Nacional de Proteção Civil (CNPC), constitui-se como Plataforma Nacional para a Redução do Risco de Catástrofes, tendo sido reconhecida pela UNISDR (Estratégia Internacional de Redução de Catástrofes das Naçóes Unidas) em abril de 2011 (PROCIV, n.o 64, julho 2013).

O grande desafio será conseguir envolver todos os sectores envolvidos no grande objetivo que é contribuir para a redução do risco. O patamar local (municipal e freguesia) precisa ser valorizado e está esquecido, ser chamado à tarefa principal da análise e gestão do risco (subvalorizada na Lei de Bases de Proteção Civil, para não dizer esquecida).Este grande objetivo só será conseguido apostando em recursos humanos bem preparados, motivados (muito urgente regulamentar a Lei n. ${ }^{\circ}$ 65/2007 de 12 de novembro).

Entretanto sucedendo à Declaração de Hyogo (2005-2015), realizou-se em Sendai, a 3. ${ }^{a}$ Conferência Mundial para a Redução de Catástrofes, da qual saiu O Quadro de Sendai para a Redução de Catástrofes, 2015-2030. Portugal esteve representado pelo Ministro da Administração Interna e pela ANPC.

Resultou da Plataforma de Sendai, o grande propósito de fazer das cidades espaços resilientes, tendo Portugal aderido à campanha "Making Cities Resilient - My City is Getting Ready” promovida pela UNISDR. O grande paradigma é passar do conceito de gestão de catástrofes para o conceito de gestão de risco de catástrofes. 
A fase da recuperação, reabilitaçấo e reconstrução tem um grande destaque, nomeadamente através do conceito "Build-back better" (re-construir melhor), o que se constitui como uma medida de preparação para as catástrofes.

A conferência identificou 13 princípios orientadores, 4 prioridades de ação e 7 metas globais quantitativas (fig. 49).

Portugal tem um enorme trabalho a fazer na abordagem e preparaçáo para prevenir riscos e reduzir os riscos de catástrofes existentes e previsíveis através duma abordagem multirrisco e multissectorial e aplicada a todos os riscos sejam de pequena ou grande escala e de grande e pequena probabilidade.

\begin{tabular}{|c|c|c|}
\hline Princípios orientadores & Prioridades de açáo & Metas globais \\
\hline $\begin{array}{l}\text { a) - Os Estados têm a principal responsabi- } \\
\text { lidade para prevenir e reduzir catástrofes, } \\
\text { inclusive através de mecanismos de co- } \\
\text { operaçáo. } \\
\text { b - A reduçáo de risco de catástrofes requer } \\
\text { responsabilidades partilhadas entre os } \\
\text { governos centrais e entidades relevantes } \\
\text { ao nível nacional. } \\
\text { c) - Os objectivos da gestáo do risco de } \\
\text { catástrofes devem as matérias de direitos } \\
\text { humanos. } \\
\text { d) - A reduçáo de risco de catástrofes requer } \\
\text { o envolvimento de toda a sociedade. } \\
\text { e) - A redução e gestáo de risco de ca- } \\
\text { tástrofes depende de mecanismos de } \\
\text { coordenaçáo entre sectores e com as } \\
\text { entidades relevantes, o que requer o } \\
\text { envolvimento total das instituiçôes do } \\
\text { Estado. } \\
\text { f) - As autoridades locais devem implemen- } \\
\text { tar as medidas de redução de catástrofes } \\
\text { sob coordenaçáo do governo central } \\
\text { g) - A reduçáo de risco de catástrofes requer } \\
\text { uma abordagem multirrisco. } \\
\text { h) - O desenvolvimento e implementaçáo } \\
\text { de políticas deve ter em conta a relaçáo } \\
\text { entre reduçáo de risco de catástrofes e } \\
\text { desenvolvimento entre os diversos se- } \\
\text { tores. } \\
\text { i - Os riscos de catástrofes assumem ca- } \\
\text { racterísticas ao nível local, que devem } \\
\text { ser tidas em conta na implementação } \\
\text { das medidas. } \\
\text { h) - Os países em desenvolvimento necessi- } \\
\text { tam de soluçóes à medida. }\end{array}$ & $\begin{array}{l}1 \text { - Perceção sobre risco de } \\
\text { catástrofes; } \\
2 \text { - Fortalecer a governança } \\
\text { na gestáo do risco de catás- } \\
\text { trofes; } \\
3 \text { - Investir na reduçáo do } \\
\text { risco de catástrofes em prol } \\
\text { da resiliência; } \\
4 \text { - Melhorar a preparaçáo } \\
\text { face a catástrofes para uma } \\
\text { resposta efectiva, e "re- } \\
\text { construir melhor" (Build } \\
\text { Back Better") na fase de } \\
\text { recuperação, reabilitaçáo e } \\
\text { reconstruçáo. }\end{array}$ & $\begin{array}{l}\text { a) - Reduzir substancialmente ao nível } \\
\text { global, até } 2030 \text {, a mortalidade provocada } \\
\text { por catástrofes, com o objectivo de redu- } \\
\text { zir o valor médio por } 100.000 \text { no período } \\
2020-2030 \text {, em comparaçáo com o período } \\
2005-2015 \text {. } \\
\text { b) - Reduzir substancialmente ao nível glo- } \\
\text { bal, até } 2030 \text {, o número de pessoas afectadas } \\
\text { por catástrofes, com o objectivo de reduzir o } \\
\text { valor global médio por } 100.000 \text { no período } \\
2020-2030 \text {, comparativamente com o perí- } \\
\text { odo } 2005 \text {-2015. } \\
\text { c) - Reduzir, até } 2030 \text {, as perdas económicas } \\
\text { directas causadas por catástrofes em relaçáo } \\
\text { ao Produto Interno Bruto mundial. } \\
\text { d) - Reduzir substancialmente, até } 2030 \text {, } \\
\text { os danos de catástrofes em infraestruturas } \\
\text { críticas e a inter- rupçáo de serviços básicos, } \\
\text { incluindo equipamentos de saúde e de edu- } \\
\text { caçáo, através do aumento da sua resiliência. } \\
\text { e) - Aumentar substancialmente, até } 2020 \text {, o } \\
\text { número de países com estratégias de reduçáo } \\
\text { de riscos de catástrofes ao nível nacional e } \\
\text { local. } \\
\text { f) - Reforçar substancialmente, até } 2030 \text {, a } \\
\text { coopera- çáo internacional com países em } \\
\text { desenvolvimento através de apoio adequa- } \\
\text { do e sustentável para complementar as suas } \\
\text { acçóes nacionais para implementaçáo deste } \\
\text { Quadro. } \\
\text { g) - Aumentar substancialmente, até } 2030 \text {, } \\
\text { a dispo- nibilidade de acesso à populaçáo a } \\
\text { sistemas de alerta precoce, multirrisco, e a } \\
\text { informaçáo sobre risco e avaliaçáo de risco. }\end{array}$ \\
\hline
\end{tabular}

Fig. 49 - Quadro de Ação de Sendai 2015-2030

(Fonte: PROCIV, n. ${ }^{\circ} 84$, maio/junho 2015).

Fig. 49 - Sendai Framework for Action 2015-2030

(Source: PROCIV, n. ${ }^{\circ}$ 84, MaylJune 2015). 


\section{A proteção de infraestruturas críticas}

Infraestrutura crítica (IC) "é a componente, sistema ou parte deste situado em território nacional que é essencial para a manutenção de funções vitais para a sociedade, a saúde, a segurança e o bem-estar económico ou social, e cuja perturbação ou destruição teria um impacto significativo, dada a impossibilidade de continuar a assegurar essas funçôes" (alínea a, art. 2º, DL n. ${ }^{\circ}$ 62/2011 de 9 de maio).

Infraestrutura crítica europeia (ICE) "é a infraestrutura crítica situada em território nacional cuja perturbação ou destruição teria um impacto significativo em, pelo menos, mais um estado membro da União Europeia sendo o impacto avaliado em função de critérios transversais, incluido os efeitos resultantes de dependências intersectoriais em relação a outros tipos de infraestruturas" (alínea b, art. 2, DL n. ${ }^{\circ}$ 62/2011).

Em Portugal, a proteção de infraestruturas críticas teve início em 2004, em simultâneo com as primeiras iniciativas levadas a efeito na União Europeia, através da Deliberação do Conselho de Ministros 51-DB/2004 de 18 de março.

Foi criado um grupo de trabalho coordenado pelo Conselho Nacional de Planeamento Civil de Emergência (CNPCE), envolvendo entidades públicas e privadas que desenvolveu um importante trabalho em 3 fases (PROCIV, n. 51 - junho de 2012):

- Identificação e classificação das infraestruturas nacionais;

- Análise e avaliação do risco e apresentação de medidas para a sua proteção;

- Implementação das medidas preconizadas e monitorização do risco.

Foram inventariadas e catalogadas cerca de 11600 infraestruturas importantes para o País e cerca de 2,5\% (290) foram classificadas como infraestruturas críticas onde predominam os setores de energia, transportes e comunicações (PROCIV, n. ${ }^{\circ}$ 51).

Entretanto a 9 de maio foi publicado o DL n. ${ }^{\circ}$ 62/2011, Transpondo a Diretiva n. ${ }^{\circ}$ 2008/114/CE do Conselho de 8 de dezembro ganhando assim suporte legal em Portugal, que estabelece os procedimentos de identificação de proteção das infraestruturas essenciais para a saúde, a segurança e o bem-estar económico e social da sociedade nos setores de:

- Energia:

- Infraestruturas e instalaçóes de produção de transporte de eletricidade;

- Infraestruturas de produção, refinação, tratamento, armazenagem e transporte de petróleo por oleodutos; 
- Infraestruturas de produção, refinação, tratamento, armazenagem e transporte de gás por gasodutos e terminais para gás natural em estado líquido (GNL).

- Transportes:

- Rodoviários;

- Ferroviários;

- Aéreos;

- Por vias navegáveis interiores;

- Marítimos incluindo de curta distância e portos.

O procedimento de identificação das infraestruturas críticas europeias (ICE) competia ao Conselho Nacional de Planeamento Civil de Emergência (CNPCE), conforme o n. ${ }^{\circ} 1$, art. ${ }^{\circ} 4 .^{\circ}$ do Decreto-Lei n. ${ }^{\circ}$ 62/2011, mas com a extinção do CNPCE (alínea a), n. ${ }^{\circ} 1$ art. $^{\circ} 12 .^{\circ}$ do Decreto-Lei n. ${ }^{\circ} 73 / 2012$, de 26 de março, que alterou o Decreto-Lei n. ${ }^{\circ}$ 75/2007, de 29 de março, que foi revogado pelo Decreto-Lei n. ${ }^{\circ} 73 / 2013$, de 31 de maio, exceto o art. ${ }^{\circ} 22 .^{\circ}$ e que foi alterado pelo Decreto-Lei n. ${ }^{\circ}$ 163/2014, de 31 de outubro), todas as competências foram absorvidas pela Autoridade Nacional de Proteçáo Civil (ANPC), que se encontra a trabalhar em estreita parceria com o Gabinete do Secretário Geral do Sistema de Segurança Interna (art. ${ }^{\circ} 11 .^{\circ}$, Lei n. ${ }^{\circ}$ 53/2008, de 29 de agosto, alterada pela Lei n. ${ }^{\circ}$ 59/2015, de 24 de junho), com as forças e serviços de segurança e com as entidades representantes dos sectores da energia e dos transportes (ANPC, 2012a).

A par desta identificação, está em curso a identificação dos Planos de Segurança dos operadores já existentes e a definição de um modelo orientador para a elaboraçáo e implementaçáo dos Planos em falta (ANPC, 2012a).

Um bom exemplo é todo o trabalho que está ser levado a efeito em Sines, pois numa área de $30 \mathrm{~km} 2$, localizam-se $8 \%$ das infraestruturas críticas, bem como o único porto de águas profundas e numerosas indústrias com grande relevância económica (ANPC, 2015).

A ANPC está ainda em contacto com o Centro Nacional de Proteção de infraestruturas Críticas de Espanha e entidades relevantes com o fim de estudarem eventuais Infraestruturas Críticas Europeias (ICE) localizadas no nosso país e que podem afetar a Espanha (ANPC, 2012a). 
É de referir ainda que a ANPC participa nos Grupos de Trabalho da Comissão Europeia, sendo o ponto de contacto, onde se discute a implementação do Programa Europeu para a Proteção das Infraestruturas Críticas (n. ${ }^{\circ} 1$ do art. ${ }^{\circ} 15 .^{\circ}$ do Decreto-Lei n. ${ }^{\circ}$ 62/2011).

O Secretário-geral do Sistema de Segurança Interna é o ponto de contacto para a Proteçâo das Infraestruturas Críticas Europeias (PICE) no Plano de Segurança das ICE, cabendo ao operador designar o seu agente de ligaçáo de segurança (n. ${ }^{\circ}$ 2, art. $^{\circ} 15 .^{\circ}$, Decreto-Lei n. ${ }^{\circ}$ 62/2011).

Compete ao Secretário-geral do Sistema de Segurança Interno, em articulaçáo com as forças e serviços de segurança competentes, proceder a uma avaliação das ameaças em relação aos subsectores das Infraestruturas Críticas (IC) um ano após a sua designaçáo como ICE (n. ${ }^{\circ} 1$ art. $^{\circ} 12 .^{\circ}$, Decreto-Lei n. ${ }^{\circ}$ 62/2011).

Entre 11 e 12 de maio de 2016, realizou-se um Exercício Europeu - VITEX2016, na cidade de Amersfoot (Holanda) para testar o cenário de uma grave falha de abastecimento de energia elétrica e ver a cooperaçáo entre as entidades envolvidas, públicas e privadas, tanto a nível nacional como europeu. Foi um exercício sem forças no terreno. O VITEX 2016, envolveu equipas de 24 países, num total de 125 profissionais. Portugal esteve representado pela ANPC, pelo Gabinete do Secretário Geral do Sistema de Segurança Interna, pela Direçáo Geral da Energia e Geologia, REN e EDP Distribuição (ANPC, 2016b).

\section{As operaçóes de busca e salvamento}

As operaçôes de busca e salvamento (Artur Gomes et al), são normalmente operaçōes difíceis e complexas, que exigem elevado conhecimento e muito treino dos operacionais e, muitas vezes, um elevado grau de comprometimento com o objetivo principal que é salvar, preservando a vida humana, mas pondo em risco a própria.

As situaçôes são muito diversas salientando-se as intervençôes em incêndios urbanos e industriais e em espaços confinados onde as operaçôes de busca e salvamen- 
to são de primordial importância e exigem o domínio de técnicas que se não forem do conhecimento dos bombeiros conduzirão ao insucesso e à existência de vítimas. As "manobras de salvamento" exigem um conjunto de operaçóes, com utilização de equipamentos e cumprimento de Diretivas sem as quais não é possível atuar, tais como:

- O reconhecimento, ou seja, a primeira fase da marcha geral das operaçôes, crucial para o sucesso das mesmas e para o salvamento das vítimas e das pessoas em perigo. É uma fase decisiva na definição de táticas e dos procedimentos a usar;

- As manobras de busca, fazem-se usualmente em duas fases:

i) a busca primária que é uma procura rápida de vítimas sem que estejam montados equipamentos para as operaçóes de salvamento, acontece muitas vezes na sequência de informaçóes à chegada de equipas ao local e muitas vezes é executada sob condiçóes muito adversas, muito fumo, muito calor, mas mesmo assim deve ser efetuada pois tem uma importância fundamental no salvamento de vítimas, devendo ser o mais minuciosa possível;

ii) a busca secundária deve ser ainda mais minuciosa, executa-se depois de as equipas de socorro atuarem e resolveram as ocorrências e deve garantir que não ficaram vítimas por localizar.

- As montagens de vários tipos de escadas, garantindo o acesso a locais inacessíveis;

- A orientação e condução para saída dos ocupantes dos edifícios multifamiliares, comerciais, instalação industriais e espaços confinados para local seguro;

- As operaçóes de ventilação tática, essenciais para remoção de gases e fumos para o exterior permitindo entrada de ar fresco para as vítimas e aumentando as condiçóes de segurança dos bombeiros e outros socorristas para além de melhorar a visibilidade permitindo localizar as vítimas. É uma manobra fundamental para o sucesso da busca e salvamento de vítimas;

- O estabelecimento de meios de ataque, como por exemplo, linhas de mangueira para extinguir os incêndios e permitir ao mesmo tempo o salvamento, a maioria das vezes executado em simultâneo;

- A utilização de escoramentos, essenciais para situaçóes de emergência onde o colapso parcial ou total das estruturas está iminente e assim criar as condiçóes mínimas de segurança para proceder à criação de acessos, desobstrução de caminhos e, assim, ser possível procurar retirar as vítimas; 
- A utilização de técnicas de desencarceramento, para extrair vítimas encarceradas, retirando-as nas mesmas condiçōes ou em condiçōes mais estáveis do que se encontravam no início das operaçôes de socorro;

A Diretiva Operacional Nacional n. ${ }^{\circ}$ 1/ANPC/2007, "Estado de Alerta para as Organizaçôes Integrantes do Sistema Integrado de Operaçôes de Proteção e Socorro (SIOPS)", Declaração (extrato) n. ${ }^{\circ}$ 97/2007, de 16 de maio, estabelece as regras para a ativação do Estado de Alerta Especial (EAE) para o Sistema Integrado de Operaçôes de Socorro (SIOPS), (Decreto-Lei n. ${ }^{\circ}$ 134/2006, de 25 de julho, alterado pelo Decreto-Lei n. ${ }^{\circ} 72 / 2013$, de 31 de maio) e aplica-se a todas as organizaçóes integrantes do SIOPS.

O SIOPS, no âmbito da monitorizaçấo e gestão do risco, inclui o Estado Normal (EN) e o Estado de Alerta Especial (EAE).

Ao Estado Normal (EN) corresponde o Nível Verde - compreende a monitorização e o dispositivo de rotina.

Ao Estado de Alerta Especial (EAE) correspondem os níveis Azul, Amarelo, Laranja e Vermelho, níveis progressivos conforme a gravidade da situação e o grau de prontidão exigível.

A matriz de risco para ativação do EAE para o SIOPS resulta do grau de gravidade e do grau de probabilidade associados ao risco.

O grau de gravidade resulta da intensidade das consequências negativas das ocorrências, tendo vários graus (Residual, Reduzida, Moderada, Acentuada e Critica), (Tabela n. ${ }^{\circ}$, Declaração (extrato) n. $97 / 2007$, de 16 de maio).

O grau de probabilidade resulta da probabilidade/frequência de consequências negativas das ocorrências, tendo vários graus (Confirmada, Elevada, Média-Alta, Média, Média-baixa e Baixa (Tabela n. ${ }^{\circ}$ 2, Declaraçáo (extrato) n.o 97/2007, de 16 de maio).

A Matriz de risco é a relaçáo entre a gravidade das consequências negativas e a probabilidade de ocorrências, (Tabela n. ${ }^{\circ}$ 3, Declaraçăo (extrato) n.o 97/2007, de 16 de maio).

Tendo em conta o grau de risco obtém-se a Matriz dos níveis do EAE para o SIOPS versus grau de risco (QUADRo VI).

Com base nos Níveis do EAE é definido o grau de prontidão e de mobilização de meios e recursos e sem prejuízo do definido em cada plano e ou diretivas da ANPC para cada situaçáo em concreto, incluindo os meios e recursos de $1^{\mathrm{a}}$ intervenção/ataque inicial (QUADRo VII). 
QUADRO VI - Adaptação da tabela n. ${ }^{\circ} 5$ da Declaração n. ${ }^{\circ}$ 97/2007 de 16 de maio (Fonte: Declaraçáo n. ${ }^{\circ}$ 97/2007 de 16 maio).

TABLE VI - Table no. 4 from Declaration no. 97/2007 of 16 May

(Source: Declaration n. ${ }^{\circ}$ 97/2007 of 16 May).

\begin{tabular}{|c|c|}
\hline \multicolumn{2}{|c|}{ Matriz dos níveis do EAE para o SIOPS versus grau de risco } \\
\hline Nivel & Grau de Risco \\
\hline Vermelho & Extremo \\
\hline Laranja & Elevado \\
\hline Amarelo & Moderado, gravidade moderada e probabilidade média-alta \\
\hline Azul & Moderado \\
\hline
\end{tabular}

QUADRO VII - Tabela n. 5 da Declaração n.o 97/2007 de 16 de maio

(Fonte: Declaração n. ${ }^{\circ}$ 97/2007 de 16 maio).

TABLE VII - Table no. 5 from Declaration no. 97/2007 of 16 May

(Source: Declaration n. ${ }^{\circ}$ 97/2007 of 16 May).

\begin{tabular}{|c|c|c|}
\hline \multicolumn{2}{|c|}{ Grau de prontidáo e de mobilizaçáo } \\
\hline Nível & Grau de prontidáo & Grau de mobilizaçáo (percentagem) \\
\hline Vermelho & Até 12 horas & 100 \\
\hline Laranja & Até 6 horas & 50 \\
\hline Amarelo & Até duas horas & 25 \\
\hline Azul & Imediato & 10 \\
\hline Verde & Rotina & Arto $^{\circ} 19-A$,DL248/2012 de 21/11 (*) \\
\hline
\end{tabular}

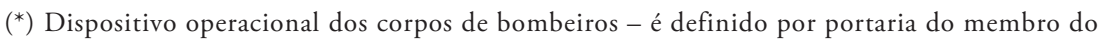
Governo responsável pela área da proteção civil o dispositivo operacional dos corpos de bombeiros, para efeitos de coordenaçáo, comando e controlo, em articulação com a ANPC e as câmaras municipais das áreas de atuação envolvidas.

O ponto n. ${ }^{\circ} 6$ da Declaração n. ${ }^{\circ}$ 97/2007, de 16 de maio, define a responsabilidade da ativação/cancelamento do EAE para o SIOPS. Saliente-se que esta responsabilidade compete ao Centro de Coordenação Operacional Nacional (CCON), podendo excecionalmente ser declarado pelo Coordenador do CCON, mas a posteriori a decisão deve ser confirmada pelo CCON. 
O Presidente da ANPC pode alterar o nível do Estado de Alerta Especial (EAE).

O Comandante Operacional Nacional pode, em circunstâncias excecionais de reconhecida urgência e gravidade alterar o nível do EAE para o SIOPS, devendo a posteriori ser ratificado pelo Presidente da ANPC.

Compete ao Comando Nacional Operacional de Operaçóes de Socorro da ANPC a transmissão das ordens de declaração/cancelamento/alteração

\section{A Ajuda Humanitária no contexto do Sistema Português de Proteção Civil}

Perante uma crise, ter uma resposta de ajuda, de solidariedade, é absolutamente crucial para atenuar o sofrimento e as carências de agasalhos, água, alimentos e medicamentos que só existem com a ajuda externa.

Assim, a Resoluçáo do Conselho Ministros n.o 196/2005, de 22 dezembro, aprovou o documento de cooperação denominado "Uma visão estratégica para a cooperação portuguesa”.

Entretanto, foi aprovada a Resolução do Conselho de Ministros n. ${ }^{\circ}$ 65/2015, de 27 agosto, que definiu a estratégia operacional de Ajuda Humanitária e de Emergência tendo como base o Conceito Estratégico da Cooperação Portuguesa 2014-2020, aprovada pela Resolução do Conselho de Ministros n. ${ }^{\circ} 17 / 2014$ de 7 março, que determina:

"A ação humanitária e de emergência têm com objetivo proteger a integridade física e moral das pessoas que se encontram em situaçóes de catástrofe natural ou calamidade pública, aliviando as carências concretas delas resultantes, numa ótica de curto prazo.

A intervençâo da cooperação portuguesa nesta área é guiada pelos princípios de humanidade, imparcialidade, neutralidade e independência, consagrados no Conselho Europeu em Matéria de Ajuda Humanitária, e cujos esforços são realizados no sentido de promover e respeitar o Direito Humanitário Internacional, o Direito dos Refugiados e os direitos humanos, no respeito pelos Principios e Boas Práticas do Doador Humanitário (GHD - Good Humanitarian Donorship), subscritos por Portugal em 2006. 
Nesta matéria, Portugal adotará uma abordagem integrada, em particular na cooperação com os Estados frágeis, nos termos previstos no Novo Acordo para o Envolvimento Internacional em Estados Frágeis e afetados por conflitos.

Decorrente da estratégia neste dominio, será criado um mecanismo operacional de coordenação entre as entidades com competência ou intervenção nesta área, partindo de um plano operacional que contemple o enquadramento $e$ mecanismos de articulação interinstitucional, sobretudo numa ótica de parceria com as organizaçôes da sociedade civil, com destaque para as $O N G$, dada a sua presença no terreno, flexibilidade e grau de especialização.

Este esforço de coerência, coordenação e complementaridade de esforços ao nivel nacional, nomeadamente com a Autoridade Nacional de Proteção Civil e o Instituto Nacional de Emergência Médica, constitui um elemento importante para uma atuação eficaz, que se refletirá ao nivel do trabalho com os países parceiros, designadamente na integração de temáticas relacionadas com a ajuda humanitária, tais como a redução do risco de catástrofes e a resiliência" (Resolução do Conselho de Ministros n. ${ }^{\circ}$ 17/2014, de 7 de março).

\section{Conclusão}

Apesar do grande progresso em prever e os esforços da prevenção, as catástrofes acontecem. Os responsáveis políticos têm sempre como objetivo salvar as vidas humanas, mas têm um conhecimento incompleto do perigo, não só porque têm formaçôes variadas, mas também porque conhecem mal o território.

Quando a catástrofe acontece, a rapidez com que se atua é primordial, no sentido de reduzir a intensidade do (s) processo (s) e de atenuar as vulnerabilidades das populaçốes atingidas. Um bom exemplo, foi o "acidente" na Mina de San José, no Chile, que provocou a retenção de 33 mineiros no subsolo. Teve uma operaçáo de salvamento muito bem-sucedida, o que nos leva a afirmar que o engenho e a arte do homem conhecem poucos limites (Torres, 2010).

A complexidade dos riscos e das catástrofes é ainda mal apreendida. A desorganização dos espaços e dos territórios é ao mesmo tempo uma causa e uma consequência das catástrofes (A. Dauphiné et al., 2013). 
A pergunta que se faz sempre é: Como levar a efeito a Prevenção e Gestão do Risco? Há quem considere que Prevenção significa apenas as açôes de contenção dos efeitos negativos das catástrofes e há outros agentes que consideram açôes específicas para eliminar realmente a causa.

No nosso País sobressaem as políticas destinadas a limitar os efeitos negativos das catástrofes e, mesmo assim elas são muito diminutas, variando de município para município e sofrendo de problemas estruturais que impedem que a Prevenção seja eficaz (fig. 50), pois esquecemos que não habitamos um Mundo sem risco, não ouvimos a Natureza que permanentemente nos dá sinais, esquecemos as pessoas, que são um recurso e não um problema, apesar de a vida humana estar em permanente conflito com a natureza.

\section{"Falta coragem para ordenar a floresta"}

SANDE SILVA Enquanto o legislador não tiver a coragem de aplicar à floresta portuguesa o conceito do condomínio, para uma gestão conjunta do território, os incêndios vão continuar a ser um problema, acredita Joaquim Sande Silva, professor da Escola Superior Agrária de Coimbra e um dos 12 peritos que integram a Comissão Técnica Independente de análise aos incêndios de junho, cuja primeira reunião terá lugar amanhã na Assembleia da República.

"Não havendo essa coragem é impossivel convencer os proprietários a voluntariamente aderirem a uma ideia de bem público e de ordenarmos em conjunto a floresta, isso nunca vai acontecer", afirmou, juntando que é "ingénuo" acreditar que um regime de adesão voluntária permitirá reunir sob gestão coletiva os 10 milhões

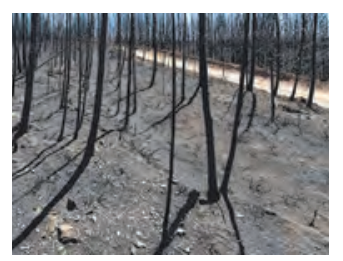

Primeira reunião da comisão técnica marcada para amanhã de prédios rústicos existentes no país".

O conceito de "condomínio florestal" - que esteve na génese da criação das Zonas de Intervenção Florestal (ZIF), em que o proprietário cede o direito de gestão a uma entidade gestora - não está vertido na lei, nem na versão hoje em vigor nem no quadro legal em debate no Parlamento. "Enquanto não se conseguir resolver este problema da gestão do minifúndio e do poder que os proprietários continuam a ter sobre as milhares de pequenas parcelas de terreno que depois dão origem a estes incêndios, não se resolve problema nenhum de ordenamento e não mudamos o cenário que temos até agora", advogou.

Décadas de negligência de cadastro e de abandono do mundo rural resultaram na situação atual, em que os proprietários “ou já nem sabem que a terra é deles ou, se sabem, limitam-se a pôr os eucaliptos e ir lá dez anos depois e tirar o que está, ou então desmoralizam completamente, porque sabem que daí a algum tempo vem um incêndio e arde tudo", disse.

Nem as ZIF ajudam. Hoje gerem perto de um milhão de hectares, mas o seu impacto no ordenamento florestal, "na maior parte dos casos, é zero, é nulo", devido a cons trangimentos de natureza financeira e legal, asseverou.
Fig. 50 - Falta coragem para ordenar a floresta (Fonte: JN 17-07-2017).

Fig. 50 - Courage lacking

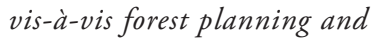
organization (Source: JN 1707-20). 
Então, o que fazer no estado normal, no antes da emergência? Como vivemos numa sociedade de risco, o primeiro objetivo da gestão de uma crise é diminuir o impacto da mesma, impedindo a perda de vidas humanas e de outros seres vivos, bem como de bens materiais e, ainda, a destruição do ambiente. O segundo grande objetivo será o tratamento dos feridos e enterramento dos mortos, seguido da reposição da qualidade do meio e da recuperação dos bens afetados, isto é, da reposição da normalidade.

Apresento dois bons exemplos, de atitudes simples, mas que farão toda a diferença se forem multiplicados escola a escola, associação a associação, cidadão a cidadão (fig. 51), pois apesar dos grandes incêndios de junho e outubro de 2017, com tantos cidadãos mortos, as queimas sem controlo, a negligência e mau uso do fogo continuam, tendo originado tantos incêndios florestais em fevereiro de 2018! (fig. 52).

Incorporar a avaliação do risco nos Planos de Emergência, terá de ser um desígnio nacional, traduzindo-a em mapas de risco, que vão permitir aos agentes operacionais elaborar planos prévios de intervenção, absolutamente fundamentais, considerando os diferentes níveis de atuação: municipal, intermunicipal e nacional. A Administração Central e Local têm a responsabilidade da gestáo da crise. O conhecimento empírico tem que ser compreendido e considerado e a tecnologia tem de ser uma ferramenta prática.

A orientação fundamental parte da Lei de Bases de Proteção Civil (Lei n.o 80/2015, republicação da Lei n. ${ }^{\circ}$ 27/2006) e, para além dos princípios consagrados na Constituição e na Lei, os Planos de Emergência orientam-se por princípios especiais, a saber $\left(\right.$ art. $\left.^{\circ} 5 .^{\circ}\right)$ :

- Princípio da Prioridade, Princípio da Prevenção, Princípio da Precaução, Princípio da Subsidiariedade, Princípio da Cooperação, Princípio da Unidade de Comando e Princípio da Informação.

É sabido que uma crise implica muitas vezes a perda de vidas humanas, a afetação do ambiente e enormes perdas de bens materiais, para além que pode arrastar-se por muitos meses até estar tudo normalizado, pelo que a Proteçáo Civil é hoje uma preocupação com lugar de destaque.

Impóe-se neste paradigma de uma "sociedade de risco" criar novas competências pessoais que incentivem uma cidadania mais ativa, participada e 
informada que deve ser adquirida desde o início do percurso escolar, mas trabalhada diariamente em toda a nossa atividade e não só quando há "problemas"

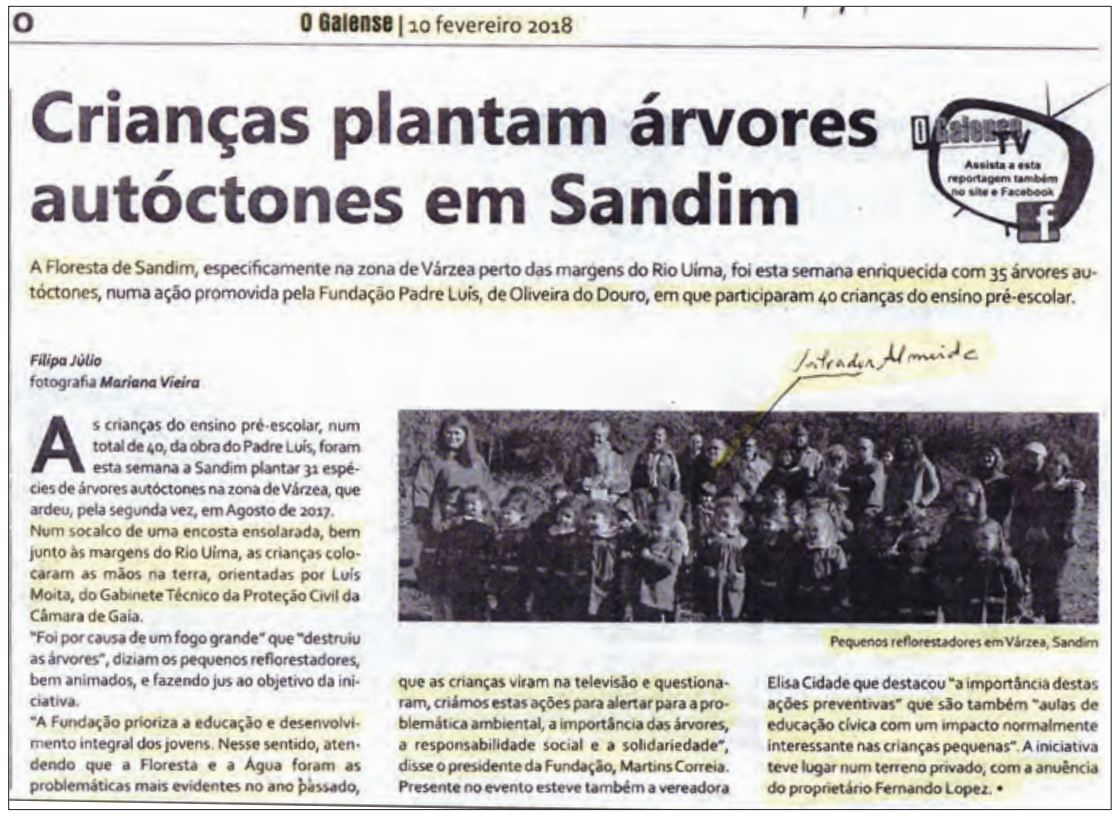

\section{Florestas Milhares de árvores plantadas}

Mais de 14 mil árvores foram plantadas ontem em ações de reflorestação de zonas ardidas em várias regiões do país. Realizaram-se em Braga, Seia, Fundão e Arganil. A partir de amanhã, a Câmara de Gouveia promove uma iniciativa que envolve funcionários da autarquia, bombeiros, alunos e população em geral .

\section{Sismos Engenheiros pedem revisão da lei}

O bastonário da Ordem dos Engenheiros (OE), Carlos Mineiro Aires, criticou ontem o atraso na revisão da lei sobre segurança sísmica nos edifícios e apelou ao Governo para que aja "o mais urgentemente possível”. Alertando que é preciso implementar normas e legislação mais condicentes com a realidade do país.

Fig. 51 - Notícias relatando iniciativas de prevenção e proteção

(Fonte: O Gaiense 10-02-2018 e JN 8 e 25-02-2018).

Fig. 51- News items reporting on prevention and protection initiatives

(Source: The Gaiense 10-02-2018 and JN 8 e 25-02-2018). 


\section{Centro Chamas atingem região}

- Vários concelhos do distrito de Leiria, como Pedrógão Grande e Figueiró dos Vinhos, foram ontem atingidos pelas chamas. A região, palco da tragédia do verão passado com incêndios, teve uma segunda-feira difícil, segundo dados da Autoridade Nacional de Proteção Civil. As chamas terão tido origem em queimadas. À hora do fecho desta edição, continuavam ativos 12 incêndios.

Fig. 52 - Notícia estranha e preocupante (Fonte: JN 27-02-2018).

Fig. 52 - Bizarre and worrying news (Source: JN 27-02-2018).

Será que todos os responsáveis políticos e técnicos vão responder ou simplesmente ignorar?

Como a resposta vai certamente demorar, não podemos nem devemos esquecer que, a Proteção Civil é uma tarefa de todos e para todos e não devemos esperar que os outros façam o que compete a cada um de nós.

\section{Referências bibliográficas}

Alexander, D. (2001). Principles of Emergency Planning and Management. Oxford University Press on Demand. Alexander, D. (2005). Towards the development of a standard in emergency planning. Disaster,Prevention and Management. Vol. 14 n. ${ }^{\circ}$ 2, p. 158-175.

ANPC - AUTORIDADE NACIONAL DE PROTEÇĀO CIVIL (2003). Plano Especial de Emergência de Proteção Civil para o Risco Sísmico na Área Metropolitana de Lisboa e Conselhos Limitrofes (PEERS-AMLCL), Carnaxide, ANPC.

ANPC - AUTORIDADE NACIONAL DE PROTEÇĀO CIVIL (2009). Caderno Técnico PROCIV, n. 10 Organizaçōes, Sistemas e Instrumentos Internacionais de Proteção Civil, Carnaxide, ANPC..

ANPC - AUTORIDADE NACIONAL DE PROTEÇĀO CIVIL (2010). Estudo Risco Sísmico e de Tsunamis do Algarve, Carnaxide, ANPC.

ANPC - AUTORIDADE NACIONAL DE PROTEÇÃO CIVIL (2010). Diretiva Operacional Nacional $n .^{o}$ 1-DIOPS, Carnaxide, ANPC. 
ANPC - AUTORIDAde NACIONAL DE PROTEÇĀO CIVIL (2010). Diretiva Operacional Nacional n.o 3-NRBQ, Carnaxide, ANPC.

ANPC - AUTORIDADE NACIONAL DE PROTEÇÃO CIVIL (2011). Boletim PROCIV, n. ${ }^{\circ} 39$ - Educar e Preparar para os riscos e catástrofes, Carnaxide, ANPC.

ANPC - AUTORIDADE NACIONAL DE PROTEÇÃO CIVIL (2012). Caderno Técnico PROCIV, n.o 23-Manual de Apoio à Decisão Politica: Situação de Alerta, de Contingência e de Calamidade, Carnaxide, ANPC;

ANPC - AUTORIDAdE NACIONAL DE PROTEÇÃO CIVIL (2012a). Boletim PROCIV, n. ${ }^{\circ} 51$, Carnaxide, ANPC.

ANPC - AUTORIDADE NACIONAL DE PROTEÇĀO CIVIL (2013a). Boletim PROCIV, n. ${ }^{\circ}$ 63, Psicologia de Catástrofe na Gestão de Emergências, Carnaxide, ANPC.

ANPC - AUTORIDADE NACIONAL DE PROTEÇĀO CIVIL (2013b). Boletim PROCIV, n.o 64, Plataforma Global para a Redução de Catástrofes, Carnaxide, ANPC.

ANPC - AUTORIDADE NACIONAL DE PROTEÇÃO CIVIL (2013c). Boletim PROCIV, n. ${ }^{\circ} 65$, A Atividade Seguradora em Acidentes Graves e Catástrofes, Carnaxide, ANPC.

ANPC - AUTORIDADE NACIONAL DE PROTEÇÃO CIVIL (2013d). Boletim PROCIV, n. ${ }^{\circ}$ 66, Instalação de uma Equipa de Força Especial de Bombeiros na BAL de Castelo Branco, Carnaxide, ANPC.

ANPC - AUTORIDADE NACIONAL DE PROTEÇÃO CIVIL (2013e). Diretiva Operacional Nacional n. ${ }^{\circ}$ 4 - DIRACAERO, Carnaxide, ANPC, maio 2013.

ANPC - AUTORIDADE NACIONAL DE PROTEÇÃO CIVIL (2015a). Boletim PROCIV, n.o 84, Quadro de Ação Sendai, 2015-2030, Carnaxide, ANPC.

ANPC - AUTORIDADE NACIONAL DE PROTEÇĀO CIVIL (2015b). Boletim PROCIV, n. ${ }^{\circ}$ 87, Carnaxide, ANPC. ANPC - AUTORIDADE NACIONAL DE PROTEÇÃO CIVIL (2016a). Diretiva Operacional Nacional n. ${ }^{\circ}$ 2-DECIF, Carnaxide, ANPC.

ANPC - AUTORIDADE NACIONAL DE PROTEÇĀO CIVIL(2016b). Boletim PROCIV, n. ${ }^{\circ}$ 91, Carnaxide, ANPC. ANPC - AUTORIDAde NACIONAL DE PROTEÇĀO CIVIL (2017). Diretiva Operacional Nacional n.o 2-DECIF, Carnaxide, ANPC.

ANPC - AUTORIDADE NACIONAL DE PROTEÇĀO CIVIL (2018). Diretiva Operacional Nacional n. ${ }^{\circ}$ 2-DECIR Carnaxide, ANPC.

Cruz, C. e Lourenço, L. (2016). A inundaçáo do dia 31 de janeiro de 2015 na bacia inferior do Rio Ceira: contributo para o conhecimento dos riscos e importância da informação para a gestão da emergência. Territorium, (23), 171-190

Cruz, C. da, et al. (2001). Comunicaçôes. Seminário Os Bombeiros e o Socorro em Situaçôes de Catástrofe, CNEMA, Santarém, Escola Nacional de Bombeiros, 56 p.

Dauphiné, A., Provitolo, D. (2013). Risques et catástrofes. Observer,Spatialiser, Comprendre, Gérer, 2a edição. Paris, Armand Colin, p. 412.

Declaração (extrato) n. ${ }^{\circ} 97$ / 2007, de 16 de maio, INCM, E.P., Aprovou a Diretiva operacional relativa ao Estado de Alerta Especial para as organizaçōes integrantes do Sistema Integrado de Operaçóes de Proteçấo e Socorro (SIOPS). 
Decreto-Lei n. ${ }^{\circ}$ 61/90, de 15 fevereiro - Normas de Segurança em Estabelecimentos Comerciais;

Decreto-Lei n. ${ }^{\circ}$ 64/90, de 21 fevereiro - Regulamento Segurança Contra Incêndio em Edifícios de Habitação;

Decreto-Lei n.o 225/2009, de 14 de setembro, Aprovou o Fundo de Emergência Municipal.

Decreto-Lei n. ${ }^{\circ} 84 / 2010$, de 14 de julho, Aprovou as normas de funcionamento do Secretariado Permanente do Gabinete Coordenador de Segurança e da respetiva Sala de Situação.

Decreto-Lei n. ${ }^{\circ}$ 115/2010, de 22 de outubro, aprova a avaliaçâao e gestâo dos riscos de inundaçôes.

Decreto-Lei n. ${ }^{\circ}$ 62/2011, de 9 de maio,, Aprovou os procedimentos de identificação e de proteção das infraestruturas críticas.

Decreto-Lei n. ${ }^{\circ} 248$ /2012, de 21 de novembro, republicação DL n. ${ }^{\circ}$ 247/2007 de 27 junho,, aprovou o Regime Jurídico dos Corpos de Bombeiros.

Decreto-Lei n. ${ }^{\circ} 249$ /2012, de 21 de novembro, republicação DL n. ${ }^{\circ}$ 241/2007 de 21 de Junho que aprovou o Regime Jurídico dos Bombeiros Portugueses.

Decreto-Lei n. ${ }^{\circ} 72 / 2013$, de 31 de maio, altera o DL n. ${ }^{\circ} 134 / 2006$ de 25 de julho, alterado pelo D. L. $n^{\circ}$ 114/2011 de 30/11, aprovou o Sistema Integrado de Operaçóes de Proteçáo e Socorro (SIOPS).

Decreto-Lei no 163/2014 de 31/10, alterou o D.L. n.o 73/2013, de 31/5, que revogou o D.L. $\mathrm{n}^{\circ}$ 75/2007 de 29/3, alterado pelo D.L. no 73/2012 de 26/3, aprova a Lei Orgânica da Autoridade Nacional Proteção Civil.

Decreto-Lei no 150/2015 de 5 de Agosto., alterou o D.L n.o 254/2007, de 12/7,que revogou D.L. 164/2001 de 23/5 - Estabelece o Regime de Prevençáo de Acidentes Graves envolvendo substâncias perigosas e de Limitação das suas consequências para a saúde humana e para o Ambiente.

Deliberaçẫo do Conselho de Ministros n. ${ }^{\circ} 51$ - DB/2004, de 18 de março,Aprovou a criação de um grupo de trabalho coordenado pelo Conselho Nacional de Planeamento Civil de Emergência (CNPCE) para estudar a proteção das infraestruturas críticas.

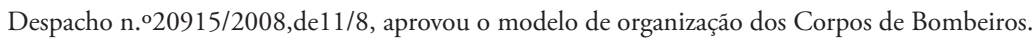

Despacho n. ${ }^{\circ}$ 14546/2009 de 29 de junho, aprova a constituição e organizaçáo da Força Especial de Bombeiros (FEB).

Despacho n. ${ }^{\circ}$ 14587/2010, de 21 de setembro, aprovou a criação das Bases de Apoio Logístico (BAL).

Despacho n. ${ }^{\circ} 3551 / 2015$, de 9 de abril, aprovou a regulamentação e define o desenvolvimento do Sistema de Gestâo de Operaçốes (SGO).

Faugères, L. (1990). La Dimension des faits et la Théorie du Risque. Le Risque et la Crise, European Coordination Centre for Research and Documentation in Social Sciences, Malta: Foundation for International Studies, p. 31-60.

Faugères, L. (1991). La Géo-Cindynique, Géo-Science du Risque.Bull. Assoc. Géogr. Francais, Paris, 3, p. 179-193;

Gomes, Artur et al. (2002). Busca e Salvamento. Volume XI. Escola Nacional de Bombeiros, (2002), Sintra.

Kervern, G. Y., Rubise, P. (1991). L `Árchipel du danger. Introduction aux Cindyniques, Económica, Paris, $444 \mathrm{p}$. 
Lei n. ${ }^{0}$ 65/2007, de 12 de novembro, INCM, E.P., Aprovou a o sistema de Proteçẫo Civil a nível Municipal.

Lei Orgânica n. ${ }^{\circ}$ 1/2012 de 11 de março, altera a Lei n. ${ }^{\circ}$ 44/86 de 30 de setembro - Regime do Estado de Sítio e Estado de Emergência.

Lei n.o 59 /2015, de 24 de junho, alteraçăo da Lei n. ${ }^{\circ}$ 53/2008 de 29 de agosto - Aprova a Lei de Segurança Interna.

Lei n. ${ }^{\circ}$ 80/2015, de 3 de agosto, alteração da Lei n. ${ }^{\circ} 27 / 2006$ de 3 de julho, Lei de Bases de Proteção Civil.

Lei n. ${ }^{\circ}$ 76/2017 de 17 de agosto, procede à $5^{\text {a }}$ alteração do DL n. ${ }^{\circ}$ 124/2006 de 28 de junho, que revogou o D.L. n. ${ }^{\circ}$ 156/2004 - Sistema Nacional de Defesa da Floresta Contra Incêndios,

Lourenço, L. (2003). Análise de riscos e gestão de crises. O exemplo dos incêndios florestais. Territorium,10, p.89-100. Disponívelem: http://www.uc.pt/fluc/nicif/riscos/Documentacao/Territorium/T10_ artg/T10_artg06.pdf

Lourenço, L. (2015). Risco, perigo e crise: pragmatismo e contextualização. Seminário Internacional de Riscos e Desastres Relacionados à Água: aplicabilidade de bases conceituais das Ciências humanas e Sociais para a análise de casos concretos. Disponível em: http://www.uc.pt/fluc/nicif/Publicacoes/ Estudos_de_Colaboradores/PDF/Livros_e_Guias/2015_RiscosDesastres_LL_.pdf

Lourenço, L. e Tedim, F. (2014). Realidades e Desafios na Gestão dos Riscos. Diálogo entre Ciência e Utilizadores. Coimbra: NICIF/FLUC. Disponível em: https://digitalis.uc.pt/pt-pt/livro/realidades_e_desafios_na_gest\%C3\%A3o_dos_riscos_di\%C3\%A1logo_entre_ci\%C3\%AAncia_e_utilizadores

Portaria n. ${ }^{\circ}$ 167/2016, de 15 de junho - definiçāo do período Critico no âmbito do SDFCI;

Portaria n. ${ }^{0}$ 195/2017, de 22 de junho - definição do período Critico no âmbito do SDFCI;

Quarantelli, E. L. (1998). What is a disaster? Perspectives on the question. Routledge, Londres, $312 \mathrm{p}$.

Quarantelli, E. L. (2005). A Social Science Research Agenda for the Disaster of the 21 $1^{\text {st }}$ Century, in Perry R. W., Quaranteelli E.(eds), What is a Disaster? New answers to Old questions, Philadelphia, Xlibris Books.

Rebelo, F. (1995). Os conceitos do risco, perigo e crise e a sua aplicação ao estudo dos grandes incêndios florestais. Biblos, Coimbra, 71, p. 511-527.

Rebelo, F. (1999). A teoria do risco analisada sob uma perspectiva geográfica. Cadernos de Geografia, Coimbra, 18, p. 3-13. Disponível em: http://www.uc.pt/fluc/depgeo/Cadernos_Geografia/Números_publicados/CadGeo18/artigo01

Rebelo, F. (2003). Riscos Naturais e Ação Antrópica. Estudos e Reflexōes, 2a edição revista e aumenta- da. Coimbra, Imprensa da Universidade, 286 p. (1ª ediçấo, 2001). Disponível em: https://digi-talis.uc.pt/pt-pt/ livro/riscos_naturais_e_ac\%C3\%A7\%C3\%A3o_antr\%C3\%B3pica_estudos_e_reflex\%C3\%B5es

Rebelo, F. (2005). Uma Experiência Europeia em Riscos Naturais. Coimbra, Minerva Coimbra. Rebelo, F. (2010). Geografia Física e Riscos Naturais. Coimbra, Imprensa da Universidade, 215 p.

Recomendação n. ${ }^{0}$ 5/2011 de 20 de outubro, INCM, E.P., Ministério da Educação e Ciência.

Resolução do Conselho de Ministros n. ${ }^{\circ}$ 6/2003 de 20 de janeiro, INCM, E.P.

Resolução do Conselho de Ministros n. ${ }^{\circ}$ 196/2005 de 22 de dezembro, INCM, E.P., Aprova a Ajuda Humanitária. 
Resoluçáo do Conselho de Ministros n. ${ }^{\circ}$ 17/2014, de 7 de março, INCM, E.P., aprovou o Conceito Estratégico da Cooperação Portuguesa 2014-2020.

Resolução da Assembleia da República n. ${ }^{\circ}$ 51/2014 de 12 junho 2014, DR, $1^{\text {a }}$ série, n. ${ }^{\circ} 112$, Recomenda ao Governo a adoção de medidas com vista a assegurar maior eficácia no âmbito da prevenção e combate aos fogos florestais.

Resoluçấo do Conselho de Ministros n. ${ }^{\circ}$ 65/2015 de 27 de agosto, INCM, E.P., aprovou as Normas da Ajuda Humanitária.

Saúde, A., Costa, E., Fernandes, J. J., Esteves, M. J., Amaral, M. L., Almeida, P. e André, T. L. (2015). Referencial de Educação para o Risco - Educação Pré-Escolar, Ensino Básico (1. ${ }^{\circ}, 2^{\circ}$ e $3 .^{\circ}$ ciclos) e Ensino Secundário. Ministério da Educação e Ciência, Lisboa, 114 p.

Smith, K. (2013). Environmental Hazards. Assessing risk and reducing disaster, London and New York. Routledge, 478 p. (6a ediçăo).

Tedim, F. e Paton, D. (2012). A Dimensão Social dos Incêndios Florestais, Para Uma Gestão Integrada e Sustentável, Fundação Ciência Tecnologia, 191 p. (1a edição).

Torres, V. N. (2010). Resgate dos 33 Mineiros do Chile. Obra-prima da Engenharia, Ingenium, n.o 119 , p. 4-6. 
(Página deixada propositadamente em branco) 


\title{
INTERVENÇÃO MÉDICO SANITÁRIA URGENTE
} EM SITUAÇÓES DE CATÁSTROFE.

\author{
ANALISE E CONCEPTUALIZAÇÁO
}

EMERGENCY MEDICAL-SANITARY INTERVENTION

IN DISASTER SITUATIONS. ANALYSIS AND CONCEPT

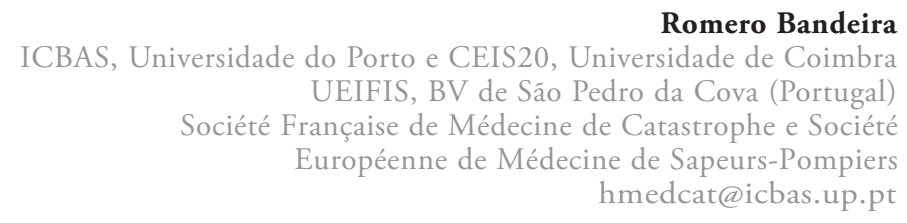

Sumário: A noção de Medicina de Catástrofe surge-nos como uma prioridade numa emanaçáo dos tempos que correm. A este tipo de intervençáo médica pluridisciplinar e polivalente junta-se uma preocupação constante que vem a ser a existência duma desadequaçáo entre o número de vítimas e a capacidade de socorro; concomitantemente há uma fase inicial com um período de improvisação puro. Estas circunstâncias fazem com que a Medicina de Catástrofe se paute por métodos e processos específicos e diferentes da Medicina de Urgência habitual. Assim, como Urgência Coletiva: estas situaçôes existem mas, podem ser consideradas como um prelúdio à prática da Medicina de Catástrofe ou um simples prolongamento da Medicina de Urgência no quotidiano? (Noto, 2010a, Fouilla, 2011 e Fontanille, 2011). Como Resposta Polimorfa: tem por substrato, muitas vezes, a inadequaçáo dos meios disponíveis versus as necessidades imediatas, a qual, quando existe, se pretende que seja parcial e transitória (Noto, 2010a). 
O caos gerado em situação de catástrofe, face ao contexto de exceção que vem a ser o caos que impregna uma situaçáo de catástrofe, não permita esquecer que ao lado da Medicina de Urgência temos toda uma vertente da medicina do quotidiano.

Devemos precisar o que ela não é. Não é uma Medicina que cuida de órgáos ou funçôes (ex. Pneumologia), náo é uma atividade de separação anatómica (ex. Cirurgia), não é uma Medicina de agressão química ou física (ex. Cancerologia), não é uma Medicina de Diagnóstico (ex. Radiologia), não é uma Medicina do espírito (ex. Psiquiatria). É praticada desde quando? Inicialmente foi organizada nas açốes de massa em cuidados de Urgência extra-hospitalares, mas, a exemplo da Medicina de Guerra, de que é herdeira, teve de equacionar os procedimentos logísticos inabituais na prática médica corrente mesmo no que concerne às situaçôes de urgência polivalentes.

Palavras-chave: Catástrofe, implicados, interventores, medicina, socorros, urgência.

Abstract: The notion of disaster medicine has emerged as a priority in a manifestation of the times we live in. This type of multidisciplinary and multi-purpose medical intervention goes hand-in-hand with a constant concern that there is a mismatch between the number of victims and the relief capability; at the same time, there is an initial stage with a period of pure improvisation. These circumstances mean that disaster medicine based on specific methods and processes is different from usual emergency medicine. Thus, as a collective emergency: these situations exist but can they be seen as a prelude to the practice of disaster medicine or are they simply an extension of everyday emergency medicine? (Noto, 2010a, Fouilla, 2011 and Fontanille, 2011). As a multiform response: it is often based on inadequate available means versus the immediate needs, which, if it exists, is intended to be partial and transitory (Noto, 2010a). 
The chaos generated in a disaster, whose exceptional context becomes one of chaos that permeates the whole disaster situation, does not ignore the fact that as well as emergency medicine we have the entire range of everyday medicine.

We must be clear about what it is not. It is not a form of medicine that takes care of organs or functions (e.g. pneumology), it is not an activity of anatomic separation (e.g. surgery), is not a medicine of physical or chemical aggression (e.g. oncology), it is not a diagnostic medicine (e.g. radiology), is not a medicine of the mind (e.g. psychiatry).

For how long has it been practised? It was first organized in the mass actions undertaken in extra-hospital emergency care, but, like military medicine from which it has descended, it has had to address logistical procedures that are unusual in current medical practice, even in the case of multi-faceted emergency situations.

Keywords: Disaster, implicated, intervenors, medicine, relief, emergency.

\section{Introduçáo}

Num Mundo em convulsão permanente a Medicina procura minorar sofrimentos e tanto quanto possível dar-lhes um termo. Só que, apesar de o Homem de hoje ter o seu espírito impregnado de dúvidas e temores tal como o Homem Grego ou Renascentista, os avanços científicos e tecnológicos propiciaram à Humanidade recursos, mas ao mesmo tempo de sistemas, os quais, ou por que fogem do controle humano, ou por que nos propiciam potencialidades, num ápice, podem transformar uma situaçáo de equilíbrio e de bem-estar numa situaçáo de catástrofe (Bandeira, 2008).

Arreigou-se, pois, a ideia de abordar estes problemas nos domínios científicos com particular ênfase para a Medicina, criando-lhe um novo campo de ação que é a Medicina de Catástrofe. 
Trata-se de uma nova especialidade ou de uma competência se assim lhe quisermos chamar. Propriamente será uma ação pluridisciplinar em que os conhecimentos do foro médico se interpenetram com outros de índole profundamente diferente, quer sejam de carácter Meteorológico ou Espeleológico.

A intervenção em Medicina de Catástrofe não é claramente definida em termos do que é a ação médica e daquilo que o não é. Para a ajuda, proteção e tratamento das vítimas se torna irrelevante colocá-las em condiçôes de receber tratamento clínico se não houver possibilidades de o fazer; o inverso é rigorosamente verdadeiro, ou seja, caso existam os meios médico-sanitários para cuidar dessas vítimas e não exista quem seja capaz de as colocar em posição de socorro para seguidamente colaborar integrando-se no dispositivo das equipas medicalizadas.

Tem sido profunda a evolução dos conceitos e avanços científicos e tecnológicos. Cada vez mais nos afastamos do tempo em que a Ética Médica ficou padronizada no seu Juramento Hipocrático sem dúvida alguma, traduzindo uma excecional evoluçáo do pensamento médico, mas que náo pode ser definitivamente encarada como sendo a última palavra neste domínio com carácter de perenidade absoluta.

Presentemente a noção de Ética ou seja, a ciência da ordem, que o homem introduz nos seus atos voluntários ou morais, tem particular relevância na Medicina.

Surge-nos assim em toda a sua dimensão a Iatroética, termo que prefiro ao de Ética Médica, não só porque neste os elementos da sua formação são um de raiz grega e outro de raiz latina, mas também porque dadas as raízes helénicas da Medicina Ocidental, assume aquele uma maior clareza e propriedade de expressão.

Epidemias (peste, cólera, gripe, sida, etc.), Acidentes (rodoviários, ferroviários, marítimos, aéreos), Vulcôes, Terramotos, Inundaçôes, os Conflitos Bélicos, são alguns dos exemplos de situaçóes de emergência que preocuparam e preocupam o Homem, influindo na sobrevivência da Espécie ao longo dos séculos até à atualidade, obrigando assim, ao aparecimento progressivo de terapêuticas médico-cirúrgicas, apoiadas em modelos tecnológicos cada vez mais evoluídos com a subsequente especialidade comportamental no âmbito da Medicina de Catástrofe (Abreu, 1996 e Antunes, 2007).

A noção de Medicina de Catástrofe surge-nos como uma prioridade numa emanação dos tempos que correm. 
A este tipo de intervenção médica pluridisciplinar e polivalente junta-se uma preocupação constante que vem a ser a existência duma desadequação entre o número de vítimas e a capacidade de socorro; concomitantemente há uma fase inicial com um período de improvisação puro. Estas circunstâncias fazem com que a Medicina de Catástrofe se paute por métodos e processos específicos e diferentes da Medicina de Urgência habitual. Assim,

Como Urgência Coletiva: estas situaçôes existem mas, podem ser consideradas como um prelúdio à prática da Medicina de Catástrofe ou um simples prolongamento da Medicina de Urgência no quotidiano? (Noto, 2010a, Fouilla, 2011 e Fontanille, 2011).

Como Resposta Polimorfa: tem por substrato, muitas vezes a inadequação de meios disponíveis versus as necessidades imediatas, a qual quando existe pretende-se que seja parcial e transitória (Noto, 2010a).

O Médico Urgentista: há uma ligação profunda entre a Medicina de urgência extra-hospitalar e a medicina de Catástrofe, uma vez que foram os especialistas nesta área (inicialmente Anestesistas- reanimadores e Cirurgióes) que iniciaram este tipo novo de conceito de exercício da Medicina, apoiando-se na estrutura organizativa da Medicina de Guerra (Noto, 1992).

A parca experiência prática nos domínios dos ataques NRBQ e das intoxicaçóes coletivas: as circunstâncias de intervenção são hoje profundamente diferentes do passado quer no domínio dos acidentes tecnológicos, quer nos acidentes naturais.

O caos gerado em situação de catástrofe: face ao contexto de exceção que vem a ser o caos que impregna uma situaçáo de catástrofe, não podemos esquecer que ao lado da Medicina de Urgência temos toda uma vertente da medicina do quotidiano.

Devemos precisar o que ela não é: náo é uma Medicina que cuida de órgãos ou funçôes (ex. Pneumologia), não é uma atividade de separação anatómica (ex. Cirurgia), não é uma Medicina de agressão química ou física (ex. Cancerologia), não é uma Medicina de Diagnóstico (ex. Radiologia), não é uma Medicina do espírito (ex. Psiquiatria).

É praticada desde quando? Inicialmente foi organizada nas açôes de massa em cuidados de Urgência extra-hospitalares, mas, teve a exemplo da Medicina de Guerra, de que é herdeira, de equacionar os procedimentos logísticos inabituais na prática médica corrente mesmo no que concerne às situaçôes de urgência polivalentes. 
Subjacente a este método de ensino-aprendizagem deve ficar evidenciada a postura sui generis - que em termos de filosofia médica nos informa - de três personalidades: Ortega e Gasset com a sua "yo soy yo y mi circunstancia y si no la salvo a ellla no me salvo a yo", Letamendi quando escreveu "Del medico que no sabe más que Medicina, ten por cierto que ni Medicina sabe" e que foi a postura emblemática de Abel Salazar. Finalmente, o nosso Dr. Pedro Victorino Ribeiro (1910) que na sua táo excecional como desconhecida Tese apresentada à Escola Médico-Cirúrgica do Porto escreveu "proclamar as sumas vantagens da organizaçâo dos socorros médicos nos sinistros" bem como a vulgarização dos socorros de urgência".

\section{Breve Evolução Histórica}

As situaçôes que são passíveis de engendrar uma catástrofe, limitada ou não, são múltiplas. Albertch Dürer (1471-1528) prefigurou de forma magistral, no seu célebre quadro "Os Cavaleiros do Apocalipse" cujo termo "catastrophe" vem referido na Prosodia de Benedicto Pereyra (1750) com o significado de "Destruição, mudança das cousas, fim, ou morte".

\section{Epidemias}

Em 21 de Janeiro de 1568, de acordo com Barbosa Machado, citado por Maximiano Lemos, morre por contágio, vítima de peste, um médico albicastrense notável, Amato Lusitano (1511 - 1568), na longínqua Tessalónica (Lemos 1907). Sem pretender de forma alguma "chauvinisar" a questáo, ele foi um dos médicos portugueses mais notáveis, um vulto da nossa Escola Iatroética Quinhentista; pelo tipo de vida que trilhou, pode muito bem ser considerado como um precursor dos atuais "Médicos sem Fronteiras".

Há doenças epidémicas designadas por "pestes", que se deveriam chamar antes "pestilências" de forma a não as confundir com a verdadeira peste (Grmek, 1983), que atingiram de tal forma a humanidade mas cujas melhores descriçóes foram feitas não por médicos mas por historiadores. 
Quando em 1569 Portugal é devassado pela chamada peste grande - a peste de 1603 o povo cognominou-a de pequena - D. Sebastiáo cumpre escrupulosamente as instruçóes do Leal Conselheiro, e, apavorado escapa-se para Sintra e posteriormente para Alcobaça, entregando o governo de Lisboa nas máos de um "gabinete de crise" constituído pelos Vereadores, pelo Governador da Casa do Cível, pelo Capitão-Mor e pelo Vedor da Fazenda Real.

\section{Guerra}

Entendida desde tempos imemoriais como um dos Cavaleiros de Apocalipse, a Guerra, antes, como hoje, continua a marcar a Humanidade com o seu ferrete, que poderá ir até ao holocausto nuclear.

Do ponto de vista tático, Walsh (1963) refere que a Rainha Isabel, a Católica em Abril de 1485 estabeleceu um hospital militar na regiáo de Antequera, admirado pelo Exército, que consistia em 6 grandes tendas com camas e medicamentos e outros utensílios hospitalares, guarnecido com médicos e que ficou conhecido por Hospital da Rainha.

Com o elevado número de vítimas provenientes de conflitos bélicos tornou-se mandatório o desenvolvimento da Medicina Militar designadamente nas Idades Moderna e Contemporânea.

As Campanhas Napoleónicas são disso um exemplo claro. Sobressaindo como introdutor de novos métodos científicos e técnicas que revolucionaram a época em que foram estabelecidas, e que ainda hoje nos influenciam, avulta o Barão Jean Dominique Larrey, que se tornou um paradigma no relacionamento médico-doente e que na qualidade de Médico-Chefe dos exércitos de Napoleão, este, tivesse escrito no seu testamento: "Lego ao Cirurgiäo em Chefe, Larrey, cem mil francos. É o homem mais virtuoso que jamais conheci”.

Criou, pois, as célebres ambulâncias volantes ligeiras, as quais passaram a oferecer um transporte mais rápido e eficaz, possibilitando que os soldados recebessem pouco depois de feridos, por vezes mesmo debaixo de fogo os socorros devidos.

Esta situaçẫo não era inédita, embora houvesse há muito quem se interessasse profundamente pelas feridos de guerra, designadamente em França onde as "Filles de la 
Charite" tal como se encarregavam de grande parte dos estabelecimentos hospitalares civis também o faziam para os militares. Foram oficialmente integradas nos hospitais militares através do Regulamento do Serviço de Saúde Francês de 31 de Agosto de 1865 embora, seguindo o exemplo do seu patrono S. Vicente de Paulo em 1658, acompanhavam desde há muito o Exército nos campos de batalha (Guillermand, 1988).

A sua ação tornou-se exuberante na Guerra da Crimeia, quando num total de 175 elementos, a partir de Agosto de 1854 seguiram de Marselha com destino aos hospitais e ambulâncias do exército do Oriente, juntando-se às 150 presentes, já, na Turquia.

Por essa razáo William Russel correspondente inglês na Guerra da Crimeia, publicou no Times em 13 de Outubro de 1854 um artigo enaltecendo a acçáo do Serviço de Saúde e evidenciou as açôes das "Filles de la Charité" a seguir à batalha de Alma podendo extratar-se o seguinte:

"Here the French are greatly our superiors. Their medical arrangements are extremely good, their surgeons more numerous, and they are also the helps of the "Sisters of Charity", who have accompanied the expedition in incredible numbers. These devoted women are excellent nurses, and perform for the sick and wounded all the offices which could be rendered in the most complete hospitals" (Times, 13 de outubro de 1854).

Este artigo despoletou a consciência e orgulho proverbiais Britânicos, fazendo com que um contingente de 38 enfermeiras chefiadas por Florence Nightingale desembarcasse em Scutari, frente a Constantinopla em 4 de Novembro de 1854. Aqui, neste hospital a presença de feridos ou doentes russos foi um dado marcante; preludiou a internacionalizaçáo dos cuidados de saúde, em que a Guerra da Crimeia apresentou os primeiros exemplos em larga escala. Há no entanto a acrescentar que, já desde Ambroise Paré, era norma cuidar igualmente dos feridos inimigos. Porém, o que se passava na frente russa assemelhava-se ao que decorria em campo Francês e Inglês, dado que após a tomada de Sebastepol o Inspetor Médico Lucien Baudens pode constatar, surpreso, o lugar que aí ocupavam as enfermeiras, muitas delas oriundas da aristocracia russa.

Um outro conflito, a Guerra da Itália que iria opor Franceses e Sardos aos Austríacos alguns anos depois, traduzir-se-ia por um menor tempo de operaçôes mas 
por uma gravidade acrescida, tendo atingido o zénite no campo de batalha de Solferino. Para se ter uma ideia das perdas, o Exército Francês teve 3409 mortos ou desaparecidos e 9407 feridos, o Sardo 1949 mortos ou desaparecidos e 3405 feridos, o Austríaco teve perdas na casa dos 20000 homens (Guillermand, 1988). Foi este cenário de guerra que gerou a ideia da Cruz Vermelha.

A situação bélica limite, ou seja, a guerra nuclear, será abordada, embora sinopticamente, em 5 - Iatroética face à Urgência Coletiva, neste trabalho.

\section{Inundações}

No dia 27 de Novembro de 1967, os meios de comunicaçáo social, designadamente a imprensa, noticiavam que "Lisboa e arredores sob o manto da tragédia" (Jornal de Notícias e editorial de $1^{a}$ página). O número de mortes cifrou-se em mais de 400 (Sousa, 1994), tendo ficado uma aldeia no Ribatejo completamente arrasada.

Destaca-se o facto de várias pessoas comunicarem a gravidade da situaçáo à entáo Emissora Nacional, no sentido de lançar um alerta, tendo-lhes sido retorquido que não podiam interromper a emissão nem correr o risco de alarmar o País. Neste caso falhou estrepitosamente um plano de socorro, que se caracterizou entre outras pela fase de alerta, como já se disse.

\section{Desastre da Ponte das Barcas}

Durante a II Invasão Francesa, quando as tropas do Marechal Soult tomaram a Cidade, a ponte foi vista pela população como o único salvatério para a fuga, que se converteu na catástrofe, que passou à História como o Desastre da Ponte das Barcas.

"Compadecidos os proprios Francezes de taó lastimozo desastre providenciaraó nesse momento sobre o que convinha fazer para acudir, áquelles que forcejavaó por salvar se, mas receiando depois a aproximaçaô das tropas Inglezas por meio d' expulsaó fizeraô voar a mesma ponte, consumindo o fogo todos os seus restos" (Reis, 1984). 


\section{Terramotos}

A 23 de Agosto de 79 ao começo da tarde, sobre Herculano e Pompeia, o Vesúvio começou a sua obra de destruição.

Para além das ruínas, há o relato coevo da catástrofe, que talvez possa ser considerado como o primeiro relatório científico acerca de um fenómeno desta ordem, que vem a ser a carta - a 16 a do Livro VI - que Plínio, o Moço dirigiu a Tácito, sobre seu tio, o célebre Plínio, o Velho, investigador e militar.

Analisando o texto citado, constata-se que Plínio para além da missão científica que incumbiu a si próprio, juntou-lhe uma outra, de carácter humanitário, com vista ao socorro e salvamento dos habitantes, e que lhe veio a causar a morte.

Portugal, muito especialmente o sul do País, tem pago um pesado tributo aos tremores de terra. De 377 a. C. a 1755 cerca de 350 abalos sísmicos atingiram Portugal Continental e Insular.

Quando a 1 de Novembro de 1755 cerca das 9 h e $30 \mathrm{~m}$ se abate sobre Lisboa uma catástrofe major e complexa, as estruturas sanitárias da época responderam da forma possível.

Tratou-se de um Terramoto acompanhado de um Maremoto e de um Incêndio de proporçóes gigantescas que vitimaram milhares de pessoas.

Outras regióes do País não ficaram indemnes, designadamente o Algarve.

Teriam sido destruídos na capital cerca de 10000 edifícios e o número de mortos avançados estaria compreendido entre 6 e 90 mil, aceitando Saraiva (1993) o número de 12 mil, de acordo com os cálculos mais autorizados e plausíveis.

Com base no trabalho de Gunn (1992) em que os ratios de morbilidade/mortalidade observados em quatro terramotos major, designadamente na Nicarágua 1972, Paquistão 1974, Guatemala 1976 e Itália 1980, em que a proporção foi de 3.3 feridos para 1 morto, estaríamos perante cerca de 40000 feridos.

Embora assumindo a direção dos Socorros, o Marquês fez expedir ordens locais e para todo o País, tendo organizado aquilo que hoje designaríamos como um Gabinete de Protecção Civil. Porém, duas personalidades tiveram um desempenho impar, que urge destacar, o Monteiro-Mor, D. Fernando José de Mello e o Duque Regedor, D. Pedro Henrique de Bragança, $1^{\circ}$ Duque de Lafóes. Analisando os documentos constantes das Memórias das Principais Providências que se deram no 
Terramoto, que Padeceo a Corte de Lisboa no ano 1755, por Amadeu Patrício de Lisboa 1758 e Esparsos. pp 238-242 por José Maria António Nogueira, Imp. Un. Coimbra, 1934, constata-se que quem exerceu a verdadeira função de Director das Operaçôes de Socorro, como hoje a designaríamos, foi o Monteiro-Mor do Reino coadjuvado pelo Duque Regedor (Bandeira e Gandra, 2015).

Em termos de síntese, podemos dizer que uma análise retrospetiva dos grandes sismos dos últimos dez anos deveria fornecer dados imprescindíveis acerca da estratégia mais oportuna em funçáo do tipo de habitat e dos dados demográficos locais (La gestión del riesgo de desastres hoy, 2008; Noto 2010a), na medida em que a investigação em Medicina de Catástrofe tem que ter uma componente histórica profunda, talvez mesmo a mais importante, com a finalidade de se elaborarem medidas de carácter preditivo e preventivo.

\section{Definição de Termos. Conceitos}

Torna-se absolutamente necessário que sejam definidos com clareza os termos que se empregam atinentes à resolução duma situação de catástrofe. Hoje existe todo um vocabulário em termos médicos estratégicos e táticos que todos os intervenientes no terreno devem conhecer, sob pena do socorro não se tornar eficaz.

Para se conhecer a amplitude do conceito de catástrofe torna-se necessário uma ação bipolarizada, ou seja, por um lado a análise histórica e por outro a direta e reflexiva sobre a realidade (Leiva et al., 1992). Neste tipo de análise há, assim, a considerar, de acordo com estes autores, quatro componentes: obtenção de dados objetivos (componente técnico) compreensão de que as vítimas sofrem psicossomaticamente (componente epistemológico), capacidade de resposta da sociedade (componente sociológico) e por último os problemas da intervenção médica (componente ético).

O desenvolvimento científico e tecnológico avoluma o espectro do conhecimento acerca da catástrofe; o seu conceito tem, profundamente marcada a vertente antropocêntrica, dada a sua interaçáo sobre o homem, pois, caso contrário uma catástrofe classificada como natural, náo passaria dum acontecimento meteorológico ou geológico (Gunn, 1992). 
A noção de socorros medicalizados é impulsionada por Cot, médico-chefe dos Sapadores Bombeiros de Paris, concretiza-se de 1924 a 1930 nesta cidade, fulcrada no seguinte:

"Dans le domaine de ces urgences accidentelles graves, 5 principes fondamentaux sont alors édictés:

- c'est le médicin (ou plutôt l'equipe médicale) qui se déplace au chevet du patient et non le patient qui est déplacé de première intention vers l'hôpital;

- des premiers soins sur place doivent être ainsi réalisés rapidement dans le seul but de stabiliser la situation pathologique;

- Le transfert vers centre hospitalier ne sera autorisé qu'aprés stabilisation des grandes fonctions vitales;

- ces soins sont essentiellement symptomatiques et reposent sur l'emploi de techniques ayant fait la preuve de leur efficacité en milieu hospitalier;

- le transport ne devra être fait que dans un véhicule ambulance spécialement aménagé à cet effet, sous surveillance médicale et en poursuivant les soins initiaux".

Associada à urgência individual, aparece-nos a urgência coletiva que vem a ser a coexistência dum grande número de vítimas, o que obriga essencialmente a partir de 1978 a criar uma organização específica para ela.

Assim, à antiga regra de «todos por um» na urgência individual, sobrepóe-se a de «um por todos» uma vez que os cuidados náo podem ser prestados simultaneamente, mas progressivamente (Noto, 1992). Tropologicamente, poderíamos enunciar assim «o princípio dos Três Mosqueteiros», tendo em conta que a resposta a produzir deve considerar o maior número de vítimas (Plotkowski, 1994).

Em conferência feita no $3^{\circ}$ Congresso Nacional da Sociedade Francesa de Medicina de Catástrofe, Rousseau (1990) referiu que:

"Ao colocar em paralelo a ajuda médica urgente com a Medicina de Catástrofe é evocar o que aproxima e diferencia estas duas formas de medicina mas é também examinar os meios que permitem passar de uma à outra e capitalizar os dados adquiridos de uma em benefício da outra". 
A designação "acidente catastrófico de efeito limitado" (ACEL) foi criado por Hohl (1984) a propósito do acidente na fábrica de malte no Porto de Metz, que se traduziu por 12 mortos e 5 feridos.

Este termo torna-se útil em todas as situaçôes nas quais o acidente, com a sua área de influência é limitado no tempo (algumas horas), no espaço (confinado ao local em que se desencadeou, ou às suas proximidades) e desprovido em princípio de riscos evolutivos. Ainda de acordo com Weber et al. (1993) é facto posto em evidência que o ACEL não prefigura o conceito clássico de catástrofe quanto aos meios imediatos de a gerir.

Não existe, pois, definição quanto ao número exato de vítimas; porém, este não deve, relativamente aos outros termos de definição ultrapassar a centena. Em sentido lato o ACEL faz algumas dezenas de vítimas, feridos, queimados, traumatizados por efeito de sopro (blast), intoxicados ou simplesmente implicados na situação.

Quanto aos meios envolvidos no socorro, eles são os pré-existentes, limitados mas suficientes, rondando em termos quantitativos 80 homens e uma vintena de viaturas.

Para finalizar queremos dizer que em nossa opiniáo, o conceito de urgência, não deixa dúvidas; quanto porém, à palavra emergência, associada a imperativos de ordem médica fomos claros ao corroborarmos a opiniāo de Corominas (1987), que foi professor de Filologia Românica na Universidade de Chicago o qual escreveu no seu dicionário:

\footnotetext{
"EMERGENCIA en el sentido de "alarma", "caso urgente" (de emergencia "de socorro") es reciente, inútil y grosero anglicismo. Inmersión, deriv. del lat. immergere "meter en el agua".
}

concordante com a posição anteriormente já desenvolvida por esse mesmo autor (Corominas, 1954)

"EMERGÊNCIA (S. XVII, Aut.; está ganando terreno el grosero anglicismo consistente en darle el sentido de "alarma", "caso urgente", "caso de necesidad")". 


\section{Lei de Bases da Protecção Civil}

Continua desajustada em relação à atualidade. Em Portugal, a Lei de Bases de Protecção Civil, Lei n. ${ }^{\circ}$ 27/2006 de 3 de Julho, define no seu art. $^{\text {o }} 3^{\text {o: }}$ : Acidente Grave e Catástrofe e no art. ${ }^{\circ}$ : Alerta, Contingência e Calamidade, conforme a seguir se transcreve:

"Artigo 3.o

Definiçōes de acidente grave e de catástrofe

1 - Acidente grave é um acontecimento inusitado com efeitos relativamente limitados no tempo e no espaço, susceptivel de atingir as pessoas e outros seres vivos, os bens ou o ambiente.

2 - Catástrofe é o acidente grave ou a série de acidentes graves susceptiveis de provocarem elevados prejuizos materiais e, eventualmente, vítimas, afectando intensamente as condiçōes de vida e o tecido sócio-económico em áreas ou na totalidade do território nacional.

Artigo 8. ${ }^{\circ}$

Alerta, contingência e calamidade

1 - Sem prejuizo do carácter permanente da actividade de protecção civil, os órgãos competentes podem, consoante a natureza dos acontecimentos a prevenir ou a enfrentar e a gravidade e extensão dos seus efeitos actuais ou potenciais:

a) Declarar a situação de alerta;

b) Declarar a situação de contingência;

c) Declarar a situação de calamidade".

Não está referenciada a palavra desastre. Quanto ao termo calamidade este já foi anteriormente tratado e a definição de acidente grave é algo confusa uma vez que integra o conceito de sinistro e de cataclismo.

Poderá ser consultada toda a Legislação nesta matéria, acedendo a: http://www. prociv.pt/LEGISLACAO/Pages/LegislacaoEstruturante.aspx.

Medicina de urgência e de campo, medicina de adaptação e de doutrina, com grandes conhecimentos colhidos da medicina militar; medicina de massas e global, é, assim, a Medicina de Catástrofe. 
Após terem sido expostos os conceitos anteriores são igualmente conhecidos, embora explanados diversamente de acordo com os vários autores, os estádios de uma catástrofe ou de um ACEL.

No tempo poderão ser definidos do seguinte modo de acordo com a TABELA I:

TABELA I - A dimensão temporal duma situação de Catástrofe (modificada com base em Raphael, 1986 e Adler, 1988).

TABLE I - Disaster time scale (modified from Raphael, 1986 and Adler, 1988).

\begin{tabular}{|c|c|c|c|c|c|c|c|}
\hline \multirow{2}{*}{$\begin{array}{c}\text { Condiçóes } \\
\text { Pré-Desastre }\end{array}$} & 1 & 2 & 3 & 4 & 5 & 6 & 7 \\
\cline { 2 - 7 } & Aviso & Ameaça & Impacto & Inventário & Socorro & $\begin{array}{c}\text { Remédio } \\
\text { ou } \\
\text { Recurso }\end{array}$ & $\begin{array}{c}\text { Recuperaçáo } \\
\text { ou } \\
\text { Recobro }\end{array}$ \\
\hline Fases & \multicolumn{2}{|c|}{ Pré-Impacto } & \multicolumn{3}{|c|}{ Impacto } & \multicolumn{2}{|c|}{ Post-Impacto } \\
\hline
\end{tabular}

As fases quanto à duração dos dias variam e se na maioria dos casos a fase aguda se equaciona por um ou dois dias, pode no entanto ser prolongada por semanas ou meses. Assim, nos desastres industriais a fase de contaminação pode ser desdobrada numa de consolidação ( 2 a 3 semanas) e uma de reabilitação muito mais longa.

Poder-se-á postular com Raphael (1986) que a resposta a um desastre assume um diagrama ação-reação deste tipo (fig. 1):

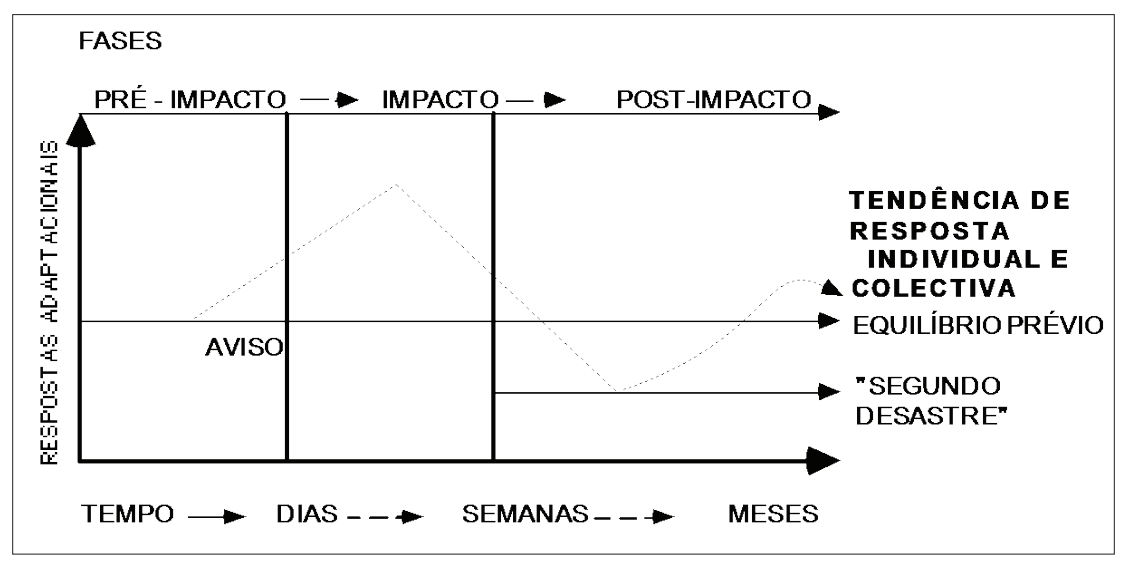

Fig. 1 - Fases de resposta à Catástrofe (Raphael, 1986).

Fig. 1 - Stages of Response to Disaster(Raphael, 1986). 
Situaçóes profundamente stressantes na fase de post-impacto podem traduzir-se como um segundo desastre.

Uma fase de desilusão que surge quando o desastre começa a ser esquecido e relegado para um segundo plano, quando o suporte organizacional começa a ficar circunscrito, a realidade das perdas, os constrangimentos burocráticos e as alteraçôes forjadas pelos desastres e que não podem ser tergiversadas mas têm que ser resolvidas.

Há outros fatores que contribuem para a utopia post-desastre como sejam a euforia de ter sobrevivido à morte e à destruição, a recusa de perda, a queda de barreiras sociais e o reforço mútuo da quota parte na experiência.

Quanto ao arranjo espacial da situaçáo de catástrofe a partir do seu epicentro para a periferia ela pode ser discriminada em zona de choque, zona intermediária e zona exterior à catástrofe.

No momento presente, em termos operacionais, de âmbito Médico-Sanitário as Catástrofes podem ser caracterizadas basicamente em:

- ACEL até 100 vítimas;

- ACEM até 1000 vítimas;

- Catástrofe até 3000 vítimas;

- Megacatástrofe n.o superior a 3000 vítimas.

Consideramos esta uma classificaçáo básica; no entanto tenhamos em vista o acontecido com simplesmente 13 vitimas, na Tailândia, e as profundas implicaçôes a nível Mundial. A existência de um número de implicados absolutamente impensável, face ao stress e à angústia emergentes, perante o número de pessoas envolvidas, torna-se mandatório que face aquele número de implicados, classifiquemos este acontecimento catastrófico pelo menos como ACEM.

Se não existem vítimas as situações de exceção poderão ser simples acidentes geológicos, meteorológicos, sociais, etc. 


\section{Evidências versus Especificidades. Conceptualização Atual.}

Apresentam-se alguns exemplos de situaçôes que ajudam a ilustrar como se chegou à atual conceptualização.

Porto - A Tese do Dr. Pedro Victorino Ribeiro (1910)

A tese mencionada em epígrafe é um autêntico marco miliário na urgência pré-hospitalar.

Apresentada como Dissertação Inaugural à Escola Médico- Cirúrgica do Porto em 1910, pelo Dr. Joaquim Pedro Victorino Ribeiro, intitulada "Socorros de Urgência (Breves Notas)” a doutrina nela expendida é duma atualidade marcante (Kol- d'Alvarenga, 1945).

O I capítulo intitula-se "Necessidade e vantagens do serviço de prompto socorro. Sua organização em diversos paizes”.

No fim deste escreveu:

"Taes são, singelamente esboçados, os serviços de prompto soccorro nos variados paizes que lhes têm dedicado o interesse que merecem. Muito seria para estimar que alguma coisa n'este sentido fosse tentada em Portugal, não esquecendo tambem a divulgação dos cuidados de urgencia que é d'uma provadissima utilidade".

\section{Portugueses na Guerra 1914 - 1918}

Quanto à I Guerra Mundial, estudamos um relatório publicado em 7 de Abril de 1916 que foi apresentado pelo Chefe do Serviço de Saúde do 2o grupo de Companhias de Saúde do Exército. Este relatório intitulado "Um capítulo de Técnica Sanitária Militar" foi baseado em elementos obtidos num exercício que teve lugar nos arredores da cidade de Coimbra no período de 1 a 7 de Outubro de 1915. 
Através daquele aquilata-se da conceção tática e logística do Serviço de Saúde do Exército Português, precisamente antes dele ser testado como interventor na I Guerra Mundial.

Três conclusōes podem ser extraídas da análise do relatório:

- A Técnica Sanitária Militar Portuguesa em 1915 estava atualizada;

- O objetivo era "O princípio humanitário de que o Socorro deve ir ao ferido". Podemos ir buscar aquela técnica, princípios e métodos fundamentais, extrapolando-os com êxito para a Medicina de Catástrofe atual.

\section{Medicina Humanitária. Medicina de Urgência. Socorrismo}

A organização da Urgência Médica Civil, inspira-se nos cuidados da frente militar (Emmanuelli e Emmanuelli, 1996) e após a II Guerra Mundial, em caso de Urgência Civil opta-se pela Formação de Socorristas. O impacto da Medicina de Urgência americana sobre a Medicina francesa não se faz sentir senáo nos anos 1950, mas em 1956 a epidemia de poliomielite obriga a que o Hospital saia extra muros (Grosclaude, 1991; Goulon, 2004) e o Professor Cara prepara um dispositivo de transporte medicalizado secundário, o qual, juntamente com o Prof. Larengue, contribuíram decisivamente, num forte contexto de ceticismo institucional, para o estabelecimento dos SAMU (Service d'Aide Medicale Urgente) em França. Por seu lado, a caridade e o Humanitarismo perdem-se na bruma dos tempos; porém, em Junho de 1859, na Itália do Norte, nasce sob a égide de Henry Dunant, conforme já aludimos a Cruz Vermelha que corporizou a ideia de humanitarismo que ainda subjaz na atualidade, hoje sob a capa de variadíssimos intervenientes designadamente as ONG, MSF, EPRUS (Reserva Sanitária) etc. Intervêm estas instituições em conflitos civis, militares ou mistos os quais se avolumam cada vez mais.

\section{Interventores (Classificação de Heymans e Wiersma)}

Nas aulas ministradas no Curso de Medicina de Catástrofe do ICBAS/HGSA o Prof. Custódio Rodrigues expendeu que: 
"A nosso ver, as exigências do perfil psicológico do interventor não deverão confinar-se à ausência de perturbaçôes psiquiátricas que possam interferir com as capacidades de julgamento e decisão. "integridade do comportamento emotivo ou caracterial", para além da confusão inadmissivel de "emoção" com "carácter", é manifestamente insuficiente, pois um individuo que seja afectivamente normal, mas de temperamento emotivo elou de ressonância das representaçóes secundário (classificação dos temperamentos de Heymans e Wiersma) não será, por certo, um interventor eficaz na zona de impacto. No primeiro caso - ser emotivo - faltará lucidez imediata para avaliar a situação; no segundo caso - ser secundário - surgirá lenta uma acção que se deseja o mais rápida possivel; no terceiro caso - ser emotivo e secundário - a emotividade paralisará mesmo por vários minutos uma acção que urge executar".

Quanto à outra das três variáveis que Heymans e Wiersma juntaram à emotividade e à ressonância das representaçôes - a atividade - será de escolher preferencialmente para a zona de impacto os indivíduos ativos.

Não serão, contudo, de excluir liminarmente da equipa de socorros indivíduos com os traços de personalidade atrás mencionados, dado em zonas recuadas de apoio eles poderem executar com eficácia os atos decorrentes das suas competências técnicas. Mas devem ser especificamente classificados como interventores de retaguarda.

Entende-se pois igualmente, com base em trabalhos já publicados por aquele autor (Custódio-Rodrigues et al., 1989) que na escolha de pessoal interventor - médicos ou não - o primeiro parâmetro a analisar e que deverá ser eliminatório, será o do perfil psicológico.

\section{Primointerventores}

Atualmente os primointervenientes em situação de catástrofe são os médicos urgentistas civis e militares, obviamente os que possuem as respetivas competências (Adler, 1988; Poirson-Sicre, 2000; Noto, 2010a). 


\section{Implicados}

Conceito desenvolvido pelo General Noto em que se pode entender o implicado como qualquer indivíduo que não seja vítima somática no local do acidente mas cujo comportamento necessita de um acompanhamento adaptado, extensivo aos indivíduos que não estavam presentes no local. Assim sendo, existe um "traumatismo psíquico" que necessita de "socorros psicológicos" e obviamente duma correta gestão do stress (Sanches e Amor, 2002).

\section{Definição estratégica de Medicina da Frente, no Terreno}

Alguns tratados clássicos, designadamente o de Huguenard, o da Universidade de Cambridge, o Pré-hospital Medicine e o Disaster Planning consignam vários capítulos não só aos aspetos clínicos de intervenção em multivítimas, mas também em aspetos estratégicos e táticos que têm por finalidade ajudar a resolver as situaçóes que envolvem multivítimas. Porém, há que ter em linha de conta que a profusáo de acontecimentos, matizados por especificidades sem conta obrigam ao estudo de textos oriundos dos mais diversos países em que a experiência no terreno (autêntico laboratório) mas pode nunca ser negligenciada sob pena de se utilizarem métodos e processos que nunca conduzirão de uma forma eficaz ao tratamento.

A medicalização dos socorros, a organização das evacuações e as técnicas de reanimação pré-hospitalar devem ser implementadas o mais cedo possível no terreno. Tratam-se sempre de procedimentos que têm a ver com multivítimas e com a condição das mesmas, em ambiente aberto ou fechado. (Noto, 2010a)

Esta Medicina Avançada não pode ser confundida com medicalização dos socorros nas intervençóes quotidianas. Assim sendo e sempre que possível a vítima deve ser tratada com garantia de segurança, higiene, aprovisionamento sanitário e sobretudo em quietude operacional e ao abrigo de olhares.

Por maioria de razão, em situações com multivítimas os cuidados devem ser prestados, por analogia com a Medicina de Guerra (Debenedetti, 1961), numa estrutura de cuidados mesmo improvisada, ou, por outro lado tratar no terreno, mesmo face a uma 
situação caótica e sem sabermos sequer para onde a vítima virá a ser evacuada? Salvo o caso de vítimas encarceradas ou soterradas que obrigatoriamente beneficiarão com uma medicação "in situ" as outras, deverão ser transportadas para estruturas de acolhimento.

\section{Direcção de Socorros}

Quando os dispositivos no terreno assumem uma amplitude complexa em meios humanos e materiais há que constituir um trinómio de Comando que englobe as autoridades policiais, os Bombeiros e outros meios de proteção civil, bem como um Médico Coordenador do conjunto da estrutura médico-sanitária deslocada (Baskett e Weller, 1988).

Os socorros podem ser equacionados em dois tipos, quer quanto à situação, quer quanto à açáo. Os socorros locais tipo loco-regionais que interviráo num primeiro tempo (minutos a horas), serão dirigidos às vítimas que numa situação de catástrofe, serão fácil e objetivamente localizadas, talvez mesmo a sua grande maioria e cuja rapidez no atendimento não está correlacionada com a gravidade ou benignidade das lesóes.

Os socorros que chegam muitas horas ou vários dias depois, caso dos socorros internacionais, dever-se-ão ocupar na busca de outro tipo de vítimas, designadamente aquelas que se encontram em locais de difícil acessibilidade, ou complementando as açóes desenvolvidas pelas equipas sanitárias de socorro que se encontravam empenhadas no terreno até à sua chegada (Organización Panamericana de la Salud, 1999; Noto, 2010a).

Particularmente, quando há crianças envolvidas, não se contentar em delegar noutros as suas funçóes; saber organizar as condiçóes de acolhimento, de alojamento, alimentação e de cuidados tanto para os feridos como para os sãos e salvos, sobretudo para aquelas crianças que não possuem estruturas familiares de apoio.

Saber estabelecer ligaçóes permanentes com as autoridades sobretudo nos casos em que as crianças ficaram sós e desamparadas.

Devem pois ser tomadas medidas no sentido que o pessoal se socorro tenha recebido formação adequada nas áreas acima mencionadas. 
Convém deixar aqui expresso o recente conceito de Director Médico de Crise, que se encontra plasmado no atual Plano Branco Hospitalar, da Assistência Pública dos Hospitais de Paris, revisto em dezembro de 2017, e que se caracteriza pelo facto de que a personalidade escolhida para o desempenho dessas funçóes, deverá ser reconhecido pelos seus pares e fazendo prova de "leadership". Ele é, assim, o correspondente único para comunicar com a Direcção Médica dos Cuidados Pré-hospitalares.

\section{Organizaçôes Governamentais}

No socorro público, na maioria dos países aos quais o nosso se junta o socorro no terreno é levado a cabo pelas Instituiçóes que normalmente o fazem mesmo no caso de uma situação que envolva um número ilimitado de vítimas, salvo se o próprio dispositivo de socorro ficar profundamente abalado pelas circunstâncias em si, que o passam a inibir de prestar um socorro eficaz.

No nosso País, as autoridades policiais (PSP, GNR, PJ) possuem, neste âmbito, as suas competências próprias, de acordo com a legislação em vigor.

\section{Defesa Civil, Militar e Económico - Financeira}

Em função do que acima foi exposto, facilmente se aquilata que o conceito de defesa da População cambiou extraordinariamente através dos tempos.

No imaginário da população, sempre preponderou a noção de que a defesa era fundamentalmente de carácter militar.

Se o caminhar dos tempos assim o provou, também essa situação evolutiva obrigou ao desenvolvimento do conceito de Defesa Civil (DCT, 1956). Esta, sem a qual a Defesa Militar acabaria por sair grandemente depauperada uma vez que aquela se encarregou de colmatar largos segmentos da Defesa encarada em termos globais, designadamente, a atuação direta junto da População Civil (CICR, 2008).

Porém, há que não esquecer a Defesa Económico - Financeira, que hoje assume contornos cada vez mais marcados, e sem a qual - devidamente estruturada e operativa - as outras duas vertentes não têm qualquer viabilidade no Mundo atual. 
A nível do socorro médico sanitário quer em atividades de média ou de grande envergadura, a inexistência de capacidade económico-financeira para suporte dessas missóes torná-las-á inviáveis.

\section{Área de Saúde}

A área de Saúde envolve vários intervenientes e diversos procedimentos, de entre os quais se mencionam os seguintes:

\section{Planos para situaçóes de emergência}

Conhecidos na Europa por várias designaçóes dizem respeito aos Hospitais e ao socorro no terreno sendo naturalmente designadas, por exemplo, em França, por Brancos e Vermelhos, Gerais e Específicos. Em Portugal denominam-se por Planos de Emergência Externa e por Diretivas Operacionais Nacionais da Autoridade Nacional de Protecção Civil, também estas gerais e específicas pese embora o facto de em Portugal, felizmente, na prática não terem sido testadas, exceção feita aos Incêndios Florestais e salvo um ou outro caso em Instalações Industriais mas que não se têm traduzido na prática em situaçôes de gravidade, como foi o caso da situação de alerta vermelho para o Concelho de Matosinhos no dia 12 de Abril de 2012.

\section{Bombeiros}

Os Bombeiros em Portugal, encontram-se sediados em quartéis numa malha que cobre todo o território Nacional, os quais são autênticos centros de socorros polivalentes na medida em que é neles que fisicamente se encontram localizados os postos de emergência médica e os postos de reserva do INEM, os quais na grandíssi- 
ma maioria dos casos são guarnecidos por pessoal sanitário pertencente ou oriundos dos aludidos corpos de Bombeiros.

Quanto ao Serviço de Socorros a Náufragos. Assim sendo, os quartéis de Bombeiros são incontornavelmente os Centros de socorros mais próximos da população e os quais mesmo numa situação pós desastre melhor podem, quer em termos logísticos, quer em termos operacionais dar resposta às solicitaçóes que lhes são dirigidas.

Além do mais, as suas centrais de Comunicaçóes, em rede, podem cobrir todo o território Nacional.

Encontram-se agrupados em zonas operacionais, reportadas aos Comandos Distritais, um por Distrito, os quais, por sua vez reportam ao Comando Nacional de Operaçóes de Socorro.

\section{Instituto Nacional de Emergência Médica (INEM)}

A sua ação baseia-se na constituiçãao de trinómios (Médicos, Enfermeiros e Auxiliares sanitários), apoiados por material próprio, os quais têm por missão intervir no terreno quer autonomamente quer integrados num dispositivo polivalente. Procura, em Portugal, ser semelhante ao SAMU francês.

\section{Sectorização do Teatro de Operaçóes}

Sem a adequada sectorização do Teatro de Operaçóes, não é possível um socorro eficaz. Se eventualmente a ocorrência se desencadear só num local é óbvio que a concentração de meios humanos e materiais pode ser gerida mais facilmente; porém, se esta se desencadear simultaneamente em vários locais, a sectorização terá igualmente sempre que ser feita. A gestáo dos meios recenseados e alocados deverá ser efetivada de molde a que exista uma real eficácia no tratamento das vítimas por forma a neutralizar assimetrias marcadas sempre indesejáveis neste tipo de situaçóes. 


\section{Posto Médico Avançado (PMA)}

Hoje mais propriamente designado Posto Sanitário Móvel; trata-se de uma estrutura que pratica e conceptualmente e tem vindo a sofrer modificaçóes ao longo do tempo, já que hoje podemos concebê-lo de uma forma virtual, ou seja, de poder apresentar uma plasticidade e heterogeneidade tais, não confinadas a estruturas padronizadas, mas sim adaptadas às disponibilidades de espaço e tempo, sem nunca perder a sua especificidade de "amortecedor de choque" das estruturas sanitárias mais pesadas: CME (Centro Médico de Evacuação), ou mesmo HR (Hospital de Retaguarda).

Trata-se de uma estrutura chave e fundamental da organização do socorro no terreno, designadamente ao nível da medicalização extra-hospitalar (Hertgen e Fuilla, 2012) e que sem o seu funcionamento otimizado conduzirá indubitavelmente ao fracasso, ou pelo menos a uma deficiência profunda das estruturas no terreno, já que para além de todas as missóes que lhe estão cometidas tende a ser "o periscópio sanitário" das açóes de socorro.

\section{Centro Médico de Evacuação (CME)}

O Centro Médico de Evacuação situado mais afastado do local ou locais da ocorrência exercerá funções de "entidade reguladora" de todo o processo sanitário de socorro, permitindo que não só as evacuaçôes sejam devidamente reguladas, mas também que as vítimas da situação de catástrofe possam ter um tratamento (Hertgen e Fuilla, 2012) e atenção complementares do trabalho desenvolvido a nível do PMA/ PSM e que por sua vez não sejam levadas a "encharcar" os HR, permitindo que estes, mesmo os mais diferenciados possam desempenhar cabalmente a sua missão.

\section{Hospital de Retaguarda (HR)}

Como a sua designação indica, trata-se de um Hospital geral ou diferenciado, mas “ de fim de linha”. Assim sendo, espera-se que este consiga prodigalizar às víti- 
mas duma situação de catástrofe os cuidados diferenciados que aqueles que para ele são evacuados necessitam. (Amminatti et al., 1996)

Assim sendo, estes hospitais devem possuir planos gerais e específicos para situaçóes de catástrofe, os quais devem enquadrar a tipologia de desastres que podem ocorrer na área onde aquele hospital se insere e devem contemplar as alteraçóes arquitetónicas que o mesmo deve sofrer como adaptação à otimização de meios.

\section{Triagem}

Este é um conceito fundamental que tem vindo a emergir com toda a acuidade, uma vez que sem a caracterização das vítimas na situação de urgência não se torna possível realizar um socorro eficaz. Assim sendo, torna-se necessário equacionar e hierarquizar as prioridades, num contexto excecional de multivítimas e saber exatamente quais as atitudes terapêuticas adequadas e que prioridade de evacuaçáo apresentam. Se para uma triagem tipo cirúrgico a evidência é incontornável, para outros tipos de agressão este conceito pode ser muito menos explícito e como exemplos, podemos equacionar: os queimados, os politraumatizados (feridos, queimados e atingidos por "blast"), intoxicação por inalação face à diversidade dos quadros clínicos ligados aos vários tipos de tóxicos industriais. Igualmente, qual a postura a assumir face aos quadros clínicos infeciosos no caso de uma pandemia (Soler et al., 2008).

Nestes casos, como abordar a hipótese de uma triagem telefónica, numa situação de desorganização pandémica, se previamente não tiver sido feita uma formação capaz dos Operadores de Central?

Há pois que fazer um enquadramento tendo em vista os quadros clínicos, que face a uma pandemia ou epidemia, as vitimas nos podem apresentar do foro respiratório, digestivo, neurológico, circulatório, etc.

$\mathrm{Na}$ categorização das Urgências, poderemos utilizar a terminologia francesa em Absolutas e Relativas, a qual entendemos ser a mais adequada, ou a terminologia anglo- saxónica, por exemplo tipo Manchester (Marques, 2009) ou Start. 


\section{Evacuaçóes Sanitárias (EVASAN)}

As Evacuaçóes sanitárias têm que ser devidamente reguladas náo podendo em circunstância alguma a vítima ser evacuada ao acaso sem se saber com exatidão para que estrutura de retaguarda e sem ter sido previamente observada e medicalizada, ou seja, deverá existir prioridade nos gestos terapêuticos. (Noto, 2010a)

\section{Comunicaçôes}

As comunicaçôes constituem ontem como hoje um verdadeiro nó górdio no processo de socorro às vítimas (Ogrizek e Guillery, 1997).

Desde a simples comunicação verbal, a todo o atual e evoluído tipo de comunicação não filar apresenta-se sempre o problema da sintonia. Se em ACEL a situação é passível de ser contornada, numa Megacatástrofe as barreiras linguísticas com que se deparam os interventores e as vítimas, associadas aos problemas de frequência rádio das comunicaçóes, faz com que por vezes existam barreiras intransponíveis que comprometem todo e qualquer tipo de operaçóes de socorro. (Garshnek e Burkle, 2002)

As estruturas locais podem ser vantajosamente tornadas operacionais com rapidez, desde que a sua implementação geográfica seja conhecida da população local, bem como o pessoal que nela trabalha poderá servir como reserva de compreensão perante as vítimas face às barreiras linguísticas. (Tudela, 1994; Noto, 2010a).

\section{Reservas}

Em termos de socorro sanitário deve existir uma boa estruturação das Reservas. Não só as reservas (Pessoal sanitário e Material) nacionais mas também devem estar devidamente organizadas Reservas Internacionais de molde a que em situação de catástrofe o País em causa possa mais facilmente receber o auxílio externo e por outro lado ter a capacidade de em tempo útil dar resposta a pedidos de carácter internacional em situação de fase aguda. 


\section{Cooperação Civil - Militar}

A interoperabilidade entre os meios de socorro sanitário civil e o do Serviço de Saúde das Forças Armadas permite uma intervenção em rede que pode permitir intervenções pesadas ou específicas (Fontanille, 2011).

Lamentavelmente entre nós, e tomando como exemplo o Incêndio de Pedrogão-Grande, o Agrupamento Sanitário do Exército não chegou a intervir com o seu excelente Hospital de Campanha, o que poderia ter sido uma notável mais valia para o socorro às Vítimas in loco e entre outras missóes obviamente potenciar as evacuações terrestres e aéro-médicas.

A propósito dos fogos florestais e Medicina de Catástrofe queremos aqui relevar o trabalho publicado no Manuel de Médecine de Catastrophe (Bandeira et al., 2017).

\section{Sistema Evolutivo}

Uma vez colocado no terreno o dispositivo de socorro sanitário, temos que ter sempre presente que o mesmo é evolutivo, ou seja, deve estar preparado para que com o agravamento da situaçáo ele possa ser reforçado e com uma melhoria da situação ele possa ser desmobilizado proporcionalmente.

Quer em termos de pessoal (Médicos, Enfermeiros, Auxiliares sanitários, etc.) quer em termos de meios materiais (equipamentos, fármacos, etc.) a perspetiva estática e não evolutiva da situação, quer no sentido negativo, quer no sentido positivo, pode acarretar no primeiro caso agravamento de saúde das vítimas, e no segundo, uma desmotivação pessoal para futuras intervençóes.

Assim sendo, há que ter sempre presente que cada situação é específica e que talvez os interventores nela presentes poderão mesmo nunca mais vir a ter que intervir numa situação semelhante (Tavares, 2010). 


\section{Exemplos Estrangeiros}

A título exemplificativo, referenciamos alguns sistemas em uso de acordo com a respetiva metodologia geopolítico-social, baseada na experiência, posta em prática de acordo com os seguintes Países ou Regióes.

\section{Galiza / Platerga}

Do Plan Territorial de Emergencias de Galicia (Platerga) extratamos o seguinte texto: "Ante las diversas situaciones de emergencia que pueden surgir en la Comunidad Autónoma de Galicia y los diversos recursos humanos materiales necesarios para hacer frente a las distintas tipologías de riesgos que pueden darse en nuestro territorio, se hace necesario el establecimiento de una organización, planificación, coordinación y dirección de todos los agentes involucrados en la emergencia.

Para conseguir esto, desde la Dirección Xeral de Protección Civil se elabora y redacta el PLATERGA, que es un documento técnico que tiene como fin actuar como marco orgánico-funcional para la planificación de las actuaciones, gestión de las emergencias y mecanismo de coordinación entre las distintas Administraciones públicas implicadas y de éstas con los particulares, del mismo modo establece las instrucciones a llevar a cabo para permitir la movilización mde los recursos humanos y materiales necesarios para la protección de personas y bienes".

Trata-se de um documento muito importante para o socorro na Região Autónoma da Galiza o qual foi publicado em Janeiro de 2009.

\section{Modelo França (SAMU) / Germânico - Stay and Play}

Os atuais Destacamentos de Apoio Médico em França, dividem-se em duas grandes categorias: polivalentes com base no trinómio, ou hospitalares, devidamente adequados à função, tendo sempre em linha de conta a disponibilidade, com cerca de 20 ou 30 elementos, integrando Médicos, Enfermeiros, Farmacêuticos, Auxiliares Sanitários e de Farmácia (Fouilla, 2011). 
Modelo Anglosaxónico - Inglaterra e Estados Unidos/ Disaster Medicine - Scoop and Run (Robertson, 1991; Ward e Willis, 1997)

De acordo com Ward e Willis (1997) o treino de Paramédicos foi largamente iniciado e começou como resultado do influxo na América do Norte do regresso dos Paramédicos Militares do Vietnam. No Reino Unido, observadores da experiência Americana, constataram que a mesma poderia ser valiosa na prestaçáo de cuidados pré-hospitalares, com base nos simples primeiros socorros aplicados segundo o velho modelo do atendimento efetuado pelas ambulâncias.

A alternativa ao trabalho das intervençôes paramédicas no Reino Unido foi o desenvolvimento da Bristish Association of Immediate Care Scheme (BASICS) baseado nos clínicos gerais que responderiam á solicitação dos serviços de Ambulâncias.

Igualmente Robertson (1991) chama a atenção para este tipo de intervenção em vários Países de língua Inglesa e também em Israel que se baseia fundamentalmente na observação, cuidado e transporte do doente a um Centro Hospitalar de referência.

\section{Organizaçóes Sanitárias Não Governamentais}

Hoje em dia existem Organizaçôes Não Governamentais (ONG) que desempenham um papel fulcral no socorro, na medida em que são apolíticas, em princípio. Os seus membros gozam de uma autonomia e mobilidade que lhes permitem agilizar o socorro podendo levar às vítimas sem terem que se ver envolvidos em peia as do foro burocrático que em boa parte das vezes só servem para atrasar e complicar aquelas.

\section{Exercícios}

Os exercícios que são levados a cabo criteriosamente podem fazer com que todo aquele que presta cuidados sanitários com suas limitaçôes e capacidades e mutatis mutandis as daqueles com quem ombreia no socorro, venham a otimizar proficuamente as suas intervençôes num plano real de teatro de operaçóes. 
Os exercícios são importantes para a consciencialização e treino dos interventores e da própria população. Porém, não se deve pedir a um exercício, por muito bem programado que seja, mais do que aquilo que ele pode fornecer; ou melhor, não deve ser esquecido que um exercício testa meios humanos e materiais, mas não se tratam vítimas, porque elas não existem realmente, salvo uma ou outra ocorrência que surja no desenvolvimento daquele. Além disso, o abastecimento dos fluidos vitais, como água e eletricidade não está comprometido, a cadeia alimentar não foi cortada, as comunicaçóes encontram-se indemnes, enfim a rede de saneamento não foi atingida. Cria-se sempre um determinado enquadramento que todos os intervenientes sabem ser irreal e assim o stress nunca se apodera dos participantes.

Assim sendo, não se sabe nunca com exatidão onde se inicia ou acaba a convençẫo-tipo do exercício, com comportamentos heterogéneos em que uns fazem e outros dizem que já está feito tornando assim o resultado final geralmente bom (Besserre, 1994).

Em comunidades que habitem zonas de alto risco, banalizar os exercícios tornando-os muito frequentes, pode vir a criar a falsa ideia de que a realidade nunca ocorre, que é sempre mais um exercício e nesta ordem de ideias o público passa a minimizar os perigos reais.

Em boa verdade, o exercício real é aquele que emana duma situação verídica, a qual se radica em factos que motivaram o desencadear de todo um plano de socorro, com meios humanos e materiais de certo vulto no terreno, mas que no terminus da ocorrência se verificou a inexistência de vítimas, e em que os danos materiais foram estimados como irrelevantes.

\section{A Iatroética face à Urgência Colectiva}

A Ética não é somente um código mas o trabalho de crítica a esse mesmo código; é a reflexão fundamental sobre o que existe no humano, confrontado com a questáo do seu próprio agir e consequentemente a elucidação do homem enquanto responsável por aquilo que ele próprio e os seus semelhantes poderão executar.

Nuno Grande definiu exemplarmente a Ética, como: 
"termo grego cujo significado se aproxima da moral, é, hoje, mais usado como código de comportamentos e das atitudes, como se tratasse da aplicação dos valores morais, em função de parâmetros culturais...

Considero cultura a resultante dos saberes, hábitos e costumes que definem a identidade de um grupo populacional, de um povo ou de um conjunto de povos".

E quanto nós, portugueses, "somos, de facto, um grande heterozigoto, onde se reconhecem factores das culturas judaico-cristä, romana e céltica".

A transposição conceptual para o âmbito especifico da Medicina em que ao médico é cometida uma função sui generis, que Miguel Torga (1993) tão bem soube caracterizar, quando escreveu "ufania de pertencer à nossa gloriosa família hipocrática, e voto de que o futuro continue a pertencer-nos, pelo saber, pelo devotamento, pela compaixão e pelo amor. Que continuemos a ser amanhã o que somos hoje e fomos sempre: dentro do hábito branco da bata, os monges professos e laicos de uma Ordem civil e sagrada.”

Os problemas de carácter ético na Medicina não são passíveis de generalizações obsoletas e padronizadas. Têm obrigatoriamente que ser observadas num plano específico, e cada situação analisada sobre si.

Estão neste caso as situaçóes derivadas do atendimento médico a doentes urgentes, aquando duma emergência.

\section{A Iatroética na Medicina de Catástrofe}

Por sua vez, a Medicina de Catástrofe engloba todos os problemas e dilemas éticos acima referidos, juntamente com os de um grande volume de vítimas que se apresentam aos médicos num espaço de tempo reduzido e toda esta problemática ética passa a carecer assim, de estudo, profunda análise e reflexão.

O comportamento ético dos médicos ao longo da História da Medicina, especificamente nas situaçóes de catástrofe, nem sempre se têm pautado por normas que possam ser apontadas como modelos de conduta.

Quando, porém, se analisa o comportamento ético dum médico ou dum grupo de médicos, numa determinada época histórica, há que o fazer procurando interpre- 
tar e integrar esse comportamento no ambiente científico, sócio-cultural e religioso dessa mesma época e procurar não ter a tentação de analisar factos, já passados há vários séculos, à luz de conceitos atuais. Qual virá a ser opiniáo da Humanidade, em meados do $3^{\circ}$ Milénio, sobre a nossa atuação enquanto médicos e serviços de saúde, perante os doentes HIV seropositivos na última década do $2^{\circ}$ Milénio? Porventura não se repetirá, uma vez mais, a História?

Em 1382 foi publicada em Veneza uma lei proibindo a fuga dos médicos e a figura do "médico da peste" foi institucionalizada, passando estes a terem direito a habitação, a salário e a cidadania.

Outra situação muito grave é a do Risco Nuclear. O envolvimento dos médicos e pessoal de enfermagem na resoluçáo dum acidente deste tipo, carece duma postura ética que deve ser pautada pelo conhecimento científico da situação, tão claro quanto possível dado que a improvisação pode acarretar consequências extremamente negativas.

O médico nesta situação deve assumir uma postura ética correta, na medida em que é, moral e tecnicamente, um elemento de referência comunitário; o campo de informação racional será alterado por rumores e desinformaçáo, "na medida em que ninguém sabe nada, quer saber, mas não acredita no que se diz (Martel et al., 1994)".

A guerra nuclear será a situação limite. Os "hibakusha", nome pelo qual são conhecidos os sobreviventes das bombas atómicas, com a infinitude de sofrimento que arrastam consigo, são um exemplo vivo do holocausto nuclear. Em caso de conflito os médicos sobreviventes assumiriam, em princípio, um comportamento rígido e seletivo dos feridos, associado a uma incapacidade do Serviço de Saúde para atuar.

Pôr-se-ia ainda a seguinte pergunta: quais as equipas sanitárias sobreviventes, que voluntariamente entrariam nas zonas contaminadas expondo-se a posteriori a uma morte certa (Josephs e Sims, 1988; Percival, 1988; Zealley, 1988).

Não temos tido, a exemplo de muitas outras Naçóes, a cultura para prevenir ou gerir uma situação de catástrofe; em termos éticos os médicos mais expeditos nesta área afirmam que se deve salvar o que tem mais possibilidade de sobreviver.

A medicina de catástrofe usa as técnicas da medicina de urgência e apela ao mesmo método de trabalho. Mas do ponto de vista ético, há uma situaçấo conflitual e 
difícil por vezes de admitir, visto que em lugar da obstinação em salvar um caso sobre si, há que proceder a uma triagem criteriosa; em função dos meios disponíveis e do número de vítimas, permitir-se salvar no tempo mais curto com o mínimo de meios, os que apresentam condiçóes clínicas para tal (Huguenard e Desfemmes, 1989).

Em síntese, alguns aspetos éticos da Medicina de Catástrofe, podem consignar-se como se refere (para revisão conceptual ver: Noto e al t.,1987; Baskett, 1988; Silverstain e Jessie-Hackes, 1988; Louville e Thevenet, 1990; Manni, 1990; Nicolay, 1992):

- Impossibilidade da denegação da descrição. Informação criteriosa dos sinistrados e do público em geral, não podendo os médicos comprometer o direito do paciente à sua intimidade;

- Deve preparar-se pessoal e meios para a assistência às catástrofes em concomitância com a existência de planos prévios atempada e eficientemente;

- Dada a complexidade de que se reveste a Medicina de Catástrofe, pressupóe uma planificação aproximada da ideal e exige uma disciplina intelectual rigorosa por parte dos interventores;

- Em situação de guerra ou de paz os imperativos éticos que se impóem ao médico são basicamente os mesmos, por que subjacente a um militar ou a um civil está sempre um Ser Humano;

- Um médico deve abster-se de atuar em situaçôes clínicas que ultrapassam as suas capacidades e competência. Porém, em momentos de urgência real e quando necessário, colocar-se numa posição defensiva, passa imperativamente a atuar com défice ético grave;

- $\quad$ amor-próprio e a autoestima profissional devem ser ultrapassados pela responsabilidade perante os pacientes que solicitam coletivamente os seus cuidados;

- Só devem ser evacuados os doentes com possibilidades de sobrevivência;

- A pluralidade dos meios de intervenção pode levar a uma dispersão da noção de responsabilidade. Assim, esta deve estar devidamente codificada;

- A análise objetiva dos factos em ordem à resolução de todos os problemas exige a competência global de todos os interventores, não se devendo privilegiar quem chegou primeiro "anterioridade de presença", mas sim os mais eficientes "anterioridade de competência"; 
- A medicina de urgência coletiva implica homogeneidade nas atitudes terapêuticas. Deve ser, pois, normativa para ser eficaz e fiável;

- As vítimas não têm livre escolha;

- Os médicos têm uma capacidade de escolha limitada de meios e de estratégia de cuidados. Nesta ordem de ideias à equipa deve exigir-se uma disciplina intelectual rigorosa.

A Iatroética em situaçóes de catástrofe tem obrigatoriamente que se radicar em critérios clínicos rigorosos versus a capacidade de resposta terapêutica em função do número de pessoas sinistradas. Não pode ser encarada num plano pontual, mas global. Há, porém, que salvaguardar com prioridade, vítimas que real e efetivamente se salientem, como por exemplo, progenitores dignos de uma prole menor. A posição assumida pelo médico, será: para além da análise de cada caso clínico sobre si, encarar a totalidade das vítimas, como se de uma só vítima se tratasse, e, se tiver que "amputar", parte, fazê-lo para procurar salvar o todo.

Aquilo que Albert Schweitzer chamou "a reverência perante a vida", tem uma grande expressão nos locais de acidente com inúmeros feridos. O nosso papel como médicos deverá ser o de maximizar o potencial de vida, com a limitação possível do sofrimento, mesmo quando a morte é inevitável (Königová, 1993).

$\mathrm{O}$ projeto de Carta Ética Europeia e Mediterrânica sobre a resiliência às Catástrofes, de 24 de Março de 2010, do Conselho da Europa, é um documento que obrigatoriamente deve ser conhecido por todos aqueles que se dedicam à Medicina de Catástrofe.

Os seus 27 artigos "na falta dum instrumento jurídico adequado que precise, à escala Universal ou Regional os direitos e os deveres do Homem em caso de catástrofe", constituem recomendaçóes incontornáveis acerca dos deveres e direitos para todos aqueles que têm que lidar com situaçóes de catástrofe. Igualmente deve ser aqui evidenciado o documento Principes éthiques pour la réduction des risques de catastrophe et la résilience des personnes, do Conselho da Europa, de 28 de Setembro de 2010 em S. Petersburg.

A Medicina de Catástrofe, a Medicina de Urgência, a Medicina Humanitária devem fazer-nos refletir, acerca da passagem do individual ao coletivo, do quotidiano ao excecional, da situação normal à situação de crise, com as vertentes da Medicina de Urgência e da Medicina Humanitária. 


\section{Medicina Preditiva versus Situação de Catástrofe - Objectivos}

Com base na análise da evolução concetual da Medicina de Catástrofe, que se traduz por uma cada vez maior capacidade de intervenção a nível Local, Regional, Nacional e Internacional vários itens têm surgido dos quais extratamos alguns, como exemplo, que não podem ser olvidados e que cada vez mais, fruto da panóplia de intervençôes diferenciadas, merecem ser devidamente abordados, analisados e permanentemente estudados e atualizados.

\section{Planos Preditivos}

Segundo Jacques Ruffiè (1993) a Predição consiste em conjecturar acontecimentos que se poderão produzir no futuro. A predição permanece no domínio do possível ou do provável, mas não do certo. Se determinados elementos se reúnem, podem provocar determinadas consequências. Mas tudo isto permanece conjetural.

A predição é probabilista. Esta tipologia preditiva é apanágio da Medicina de Catástrofe, devendo os Planos Prévios de Intervenção serem devidamente enquadrados neste conceito aquando da sua elaboração.

Um plano prévio deve conter na sua estrutura todas as hipóteses possíveis de atuação face a uma situação de multivítimas devidamente enquadrado no espaço e no tempo.

\section{Medicina de Saúde Pública}

A sua intervenção através de ações de formação e de informação junto das populaçóes mais do que sobre a saúde individual de cada um, devem ser prolongadas no espaço e no tempo; deve apoiar-se em dados epidemiológicos objetivos, sem descurar as reais capacidades económico-financeiras do país face a situaçôes de exceção criadas pelas catástrofes (Adler, 1988; Atienza, 2006).Sabemos de antemão que os problemas de saúde pública assumem muito rapidamente características de 
prioridade após a fase inicial de urgência: água potável, alimentação, higiene geral e especial, vacinaçáo, alojamento e climatizaçáo do mesmo sobretudo em regiôes inóspitas, logística, sanitária, etc (Gonçalves Ferreira, 1990).

De acordo com Noto et al. (1994) e em síntese devemos considerar os:

a) Princípios de Higiene e salubridade em período normal:

- Circuitos de água potável;

- Circuitos de aprovisionamento fabricação e armazenagem de alimentação (Vegetal, animal);

- Circuitos de águas sujas e de dejetos;

- Aparição eventual de doenças infeciosas;

- Condiçóes de vida dos animais domésticos e familiares:

- Vacinações obrigatórias.

b) Princípios de Higiene e salubridade em Situação de Catástrofe:

- Existência de reservatórios de água potável;

- Recolha de dejetos: sólidos, líquidos, lixos domésticos;

- Recolha de cadáveres eventuais - humanos e animais:

- Controle da proliferação dos insetos e parasitas mas também dos animais errantes, domésticos ou familiares:

- Controle da higiene alimentar:

- Manutenção em condições do habitat;

- Neutralização parcial ou total das estruturas sanitárias obrigando a medidas de prevenção deteçáo e tratamento de doenças transmissíveis.

Em trabalho recente Noto (2018) estuda vários cenários face aos cadáveres, que se impóe pelo menos equacionar sinteticamente, perante a perceção da morte em situação operacional:

Cenário no 1 - A morte anunciada para pessoas em fim de vida:

Cenário no 2 - A descoberta de um corpo sem vida:

- A morte médica;

- A morte acidental;

- A morte violenta por suicídio;

- A morte violenta por homicídio; 
Cenário no 3 - Mortes coletivas:

- Neste ultimo cenário enquadram-se as vitimas coletivas que, emanam de situaçóes de catástrofe.

\section{Instituto de Vigilância Sanitária}

Quando existem situaçóes de agressão representadas por um risco infecioso coletivo há necessidade de previamente ter sido organizada uma instituição cujo objetivo seja o da vigilância sanitária, permitindo monitorizar de uma forma eficaz as situaçóes de risco pandémico, com as consequentes açóes de estratégia sanitária e de ação tática no terreno.

\section{Telemedicina em Medicina de Catástrofe}

Enquadrada no plano das novas tecnologias em Medicina de Catástrofe, a Telemedicina poderá configurar-se como a antítese do velho postulado da sobriedade que rege a prática de Medicina de Catástrofe.

Porém, não podemos esquecer, como refere Noto (2010a) que na batalha contra o tempo, a rapidez e a segurança são primordiais, num diagnóstico de gravidade lesional e funcional.

A Telemedicina encontra-se regulamentada em Portugal na prática diária; porém, devem ser equacionadas as práticas excecionais que podem ajudar a resolver duma forma eficaz situaçóes clínicas de urgência absoluta, quer digam respeito a casos individuais ou coletivos (Baptista, 2010).

Assim sendo, através da Telemedicina podem obter-se desde simples conselhos ou meras orientaçôes quanto à conduta a ter face a um doente agudo até á decisão final sobre casos clínicos que necessitam duma avaliação imediata com a adequada intervenção terapêutica (Barbará e Martin, 2008).

Para além da comunicação verbal passamos a poder contar com imagens e consequentemente com registo de exames realizados no local. 
Considerando que numa situação de exceção, tudo pode ser equacionado, desde a dispersão das vítimas a socorrer até ao número por vezes incrivelmente baixo dos interventores na área da saúde face ao elevado número de vítimas poder-se-á assim apoiar a ação de pessoal auxiliar sanitário, sempre enquadrados pelas equipas médicas que são sempre nestes casos pouco numerosas. Nesta ordem de ideias, poderão os aludidos interventores generalistas no socorro sanitário ser devidamente enquadrados por especialistas que se encontram à retaguarda.

Todavia, estas açóes não se podem improvisar (Raucoules-Aime et al., 2012); torna-se mandatório que os aludidos especialistas tenham um conhecimento dos métodos e técnicas que se utilizam no terreno e que por sua vez todo o pessoal da área da saúde tenha sido devidamente formado nos Centros da Telemedicina de molde a poderem ser rentabilizados todos os equipamentos e dispositivos no terreno, não pedindo mais do que aquilo que eles podem dar, nem subestimando as suas reais possibilidades.

\section{Formação da Populaçáo}

A prática da Medicina de Catástrofe caracteriza-se pela ação de "um por todos" na medida em que um profissional da saúde terá que se subdividir para atender por vezes um elevado número de vítimas.

Paradoxalmente, a prática tem-nos vindo a ensinar que um dos grandes auxiliares de quem presta cuidados são as próprias vítimas; $\mathrm{O}$ conceito de implicado na conceituada opiniáo de Noto (2010b) leva-nos a concluir que a populaçáo deve estar devidamente formada, sobretudo aquela que vive em zonas de risco, para poder com facilidade enquadrar todo o esquema global de socorro.

Para isso, as autoridades deverão ter planos bem claros em termos gerais e especiais que permitam à população em geral responder "ao minuto" face a uma situação de catástrofe.

O desequilíbrio latente, que sempre existe, entre os meios disponíveis e aqueles que são necessários deve obrigar-nos a refletir acerca da batalha contra o tempo que é o pano de fundo do cenário de catástrofe, aliado à necessidade de medidas diagnósticas e terapêuticas de qualidade que devem ser levadas a cabo com a colaboração de todos. 
Hoje em dia, face á evolução científica e tecnológica, no âmbito da saúde muito do material sofreu uma miniaturizaçáo em peso e volume com autonomia de funcionamento que permite uma eficácia náo atingida no passado. (Vaquero et al s/d; Noto, 2010a)

Porém, se desde os primeiros passos na escola, a população não for devidamente educada para ir obtendo conhecimentos progressivamente mais aprofundados acerca do seu comportamento face a situaçóes de catástrofe tudo aquilo que as equipas de saúde, mesmo as dotadas de competência e arsenal técnico invulgares, ser-lhe-á coartada a possibilidade de obterem resultados otimizados caso não haja por base uma formaçấo capaz, de toda a População, particularmente nas zonas de alto risco.

\section{Conclusốes}

A Medicina de Catástrofe nunca pode ser considerada como o "jazz" da Medicina; surdem situaçôes permanentemente evolutivas, polifacetadas e que obrigam a adequaçôes e especificidades marcadas, que não se pautam, amiudadamente, por uma padronização nas tarefas das Operaçōes de Socorro. Quanto a nós não se podem pois inferir ou deduzir, quanto a nós, conclusóes definitivas. Ao revés, dever-se-ão fazer sempre e iniludivelmente reflexóes que nos permitam estudar, com profundidade e isençáo, os autênticos marcos miliários do passado que vêm a ser situaçôes históricas já vividas. Assim tendo em linha de conta os erros praticados e as açôes notáveis levadas a cabo, possamos vir a estabelecer Normas e procedimentos que se venham a apresentar como verdadeiras pedras angulares no socorro a pessoas e bens, em épocas futuras. As seguintes treze reflexóes pretendem disso ser exemplo.

\section{Informação em situaçáo de catástrofe}

Devemos considerar a vertente dos media nacionais e a dos internacionais, que é consideravelmente diferente. Os nacionais que procuram saber da real expectativa 
das famílias, traduzindo a solidariedade para com eles, os internacionais comummente mais interessados em explorar os aspetos emocionais (Noto, 2010a).

Tenhamos em vista a excecional, programada e estruturada contenção de informação por parte das autoridades Tailandesas no período de 18 dias (23 de Junho a 10 de Julho de 2018) aquando do socorro na gruta de Tham Luang Khun Nam Nang Non e que se traduziu num exemplo explícito para prossecução dos objetivos em vista.

\section{Multiplicidade de interventores}

A panóplia de interventores no terreno que vai desde as autoridades políticas, coordenadoras da situação ao pessoal de socorro e salvamento, a relevar: Médicos, Enfermeiros, Farmacêuticos, que deve possuir um ecógrafo portátil e um mini laboratório e Veterinários passando inclusive pelos Psicólogos, Equipas médico-legais e Peritos em áreas específicas.

Obviamente que esta situação obriga a uma coordenação "musculada" sob pena de que todos estes interventores vejam a sua ação profundamente limitada, com todas as consequências que daí advêm, induzindo uma frustração no desempenho das suas tarefas, que pode afetar a missão e desmotivar o interventor para futuras missões.

\section{Medicina de Catástrofe e Prevenção}

E se numa primeira fase podemos padronizar de catástrofe a intervenção, sem esquecer especialidades designadamente Anestesistas e Ortopedistas, numa segunda fase complementar podemos necessitar de Pediatras, Ginecologistas, Obstetras, Psiquiatras, Legistas, incluindo Médicos de Saúde Pública e Veterinários.

Destacamentos de Apoio Médico Polivalentes, com base no trinómio Hospitalares, devidamente adequados à função, tendo sempre em linha de conta a disponibilidade, integrando cerca de 20 ou 30 elementos - Médicos, Enfermeiros, Farmacêuticos, Auxiliares Sanitários e de Farmácia (Fuilla, 2011). 


\section{Estruturas novas ou enxertadas/ Convivência das duas estruturas}

As estruturas médico sanitárias locais complementam-se com as estruturas aeromóveis de reforço, mas torna-se necessário um compasso de espera que é incontornável.

No caso de uma catástrofe de grandes dimensóes, as estruturas de socorro que chegam em reforço podem ficar inoperacionais durante longo período de tempo.

A gestão complementar permitirá melhorar a resposta à solicitaçôes múltiplas e heteróclitas e facilitará a gestão transversal de serviços; na articulaçấo com as autoridades torna-se necessária a presença em permanência de um elemento de ligação.

Obrigatoriamente tem que se entrar em linha de conta com as barreiras linguísticas, quer em relação aos interventores, quer em relação às vítimas e vice-versa.

Em múltiplas ocasiōes face a uma megacatástrofe, terá que se improvisar, tendo mesmo que se utilizar um marcador na pele da vítima ou em adesivos que acabarão por substituir as fichas de evacuação. (Fontanille, 2011).

O próprio pessoal local poder-se-á empenhar mais a fundo se tiver conseguido estabilizar os seus próprios problemas pessoais, laborais e familiares.

As regras higiénico-sanitárias devem ser mantidas em pleno.

As estruturas exteriores são habitualmente dotadas de autonomia, o que leva a que a sua operacionalidade venha a ser superior à estrutura fixa local.

No terreno, obviamente que face à fase dos socorros (ajuda ou estabilização) determinadas especialidades médicas serão de privilegiar e conforme refere Fontanille (2011) a fim de não "embolizar" os cuidados, as noçôes de triagem de urgência vital ou funcional devem ser supervisionadas pelo pessoal da frente.

As estruturas logísticas são fundamentais devendo sempre ter-se em linha de conta não só as restrições legais, como o transporte de $\mathrm{O} 2$ e de carburantes, mas também produtos sanguíneos e vacinas na ausência de rede de frio.

Há ainda que ter em linha de conta os lotes polivalentes e os lotes específicos (médicos, Cirúrgicos, Pediátricos, etc) tendo sempre presente o seu reaprovisionamento (Fouilla, 2011). 
O constrangimento das telecomunicações leva a que muitas vezes só sejam possíveis comunicações via satélite.

\section{Crianças e Catástrofe. Vulnerabilidades}

Há que reconhecer a vulnerabilidade das crianças face a uma situação de catástrofe. Segundo Felmet et al. (2009) e Noto (2010a), há que ter em linha de conta a sua vulnerabilidade somática e psíquica.

No primeiro tipo podem-se equacionar as sequelas de traumatismos, designadamente motores, patologia do foro infecto-contagioso, bem como desnutrição.

A vulnerabilidade psíquica por exemplo das crianças órfãs mesmo indemnes de patologia somática, mas também com ela associada.

Todos igualmente sabemos que há crianças que em situações de terramoto, são muitas vezes encontradas vivas sob os escombros, facto que porventura se fica a dever ao seu porte e resistência física.

\section{Antes e após o terramoto do Haiti}

O Terramoto do Haiti (12 de janeiro de 2010) é um autêntico marco miliário. Em termos de catástrofe, face ao número de vítimas, à extensão do caos, praticamente houve a metodologia do "scoop and run", face à observação clínica que procurou eliminar um risco vital, associado a um tratamento antálgico, uma imobilização por vezes minimalista.

Em termos médicos, os Cirurgióes e os Ortopedistas viram- se confrontados face ao elevado número de vítimas com membros esmagados ou comprimidos durante larguíssimo tempo, tendo que executar amputação que face ao Síndrome da "fáscia" conduziram num elevado número deles a desarticulaçóes com as sequelas clínicas que esta intervenção cirúrgica envolve.

Este tipo de intervenção, mesmo executada numa escala considerada anormal motivou o atingimento psicológico de alguns Ortopedistas que nunca tinham equacionado, face à sua experiência pessoal, levar a cabo um número tão elevado de desarticulaçóes. 


\section{Antes e após o soterramento no Chile}

A situação de soterramento ocorrida no Chile , a 5 de Agosto de 2010 assumiu um tipo de configuração fora do vulgar, obviamente não inédita, na medida em que aprisionou a 625 metros de profundidade 33 mineiros.

As situaçóes de soterramento, como descreve Noto (2010b) envolvem os problemas de sobrevivência imediata, mas também durante todo o tempo que demoram as situaçóes de socorro.

Associadas aos problemas técnicos de toda a operação, existem os problemas de comunicação; com os soterrados existem os relacionados com as famílias, os media, as autoridades e o público em geral, que no caso vertente foi mundial.

Nos 70 dias que durou o soterramento e apesar de ter sido possível fazer chegar uma sonda rudimentar ao fim de 17 dias, este acidente que em termos de números de vítimas e de patologia apresentada pode configurar um ACEL, o que é facto é que face ao número de implicados que envolvem, configuram um tipo de catástrofe de muito maiores dimensões.

\section{Antes e após Fukushima (Japão)}

Japão, sismo, Tsunami, Acidente Nuclear, 11 de Março de 2011. De acordo com a comunicação de MT Neuilly em Nantes, o Sismo verificou-se às 6.46h local, Magnitude 8.9 (Richter), frente a Sandai.

Incêndio nos complexos industriais petrolíferos. Destruição ao nível da Central Nuclear de Fukushima a $20 \mathrm{~km}$ de Sandai, devidas ao Tsunami e não propriamente ao sismo.

A vaga arrasa a costa, chegando a atingir 23 metros de altura.

Sandai, Kesennuma, Hakodate, Minamisanriku, Shaitara, Rikuzentakata, cidades em parte desaparecidas.

$\mathrm{Na}$ Central Nuclear de Fukushima, a explosão de um circuito de arrefecimento e aquecimento de vários reatores e a tentativa de arrefecimento dos reatores levou a uma situação de desestabilização que numa fase inicial se saldou póe meio milhão 
de pessoas deslocadas, 6500 mortos, 10000 desaparecidos até 18 de Março de 2011, a perda de familiares e bens, frio, fome, medo do nuclear, rumores e desinformação (Amundsan et al., 2009).

\section{Antes de depois dos Atentados de Paris de 13 de Novembro de 2015}

O impacto sócio-político, nacional e internacional levou a que nenhum facto ficasse indemne e sujeito a um tipo de escalpelização que culminou no aparecimento recente de uma publicação intitulada Agressions collectives par armes de guerre, condutas a ter para os profissionais de saúde, editada no âmbito das situaçóes sanitárias excecionais, e publicada sob a égide do Governo Francês, em Junho de 2018.

Independentemente de toda a complexidade na prestação de socorro ás vitimas uma situação profundamente emergente foi a segurança das equipes de socorro, elas também facilmente alvo dos agentes terroristas que operam nestas situaçôes.

\section{Antes e depois do ocorrido na Gruta Tham Luang Khun Nam Nang Non}

A situação ocorrida na Tailândia entre 23 Junho e 10 de Julho do ano em curso que se consubstanciou no salvamento de 4 vitimas a 8 de Julho, 4 a 9 de Julho e 5 a 10 de Julho, veio provar á saciedade que por muito empenhamento que tenhamos no socorro, em cenários multivítimas e em condiçōes inóspitas pode surdir uma situação para a qual não estamos preparados, mas que obriga por parte dos interventores no terreno e mormente por quem assume a tarefa da Direcçáo dos Socorros a ter capacidade de analise, de síntese, de raciocínio frio e cientifico-tecnologicamente muito evoluído para além de uma invulgar capacidade de trabalho de equipa, associada a uma humildade que deve sempre estar patente sem ser subserviente. No caso vertente náo existia até ao momento em qualquer parte do Mundo experiência prática na resolução de uma situação análoga.

A Tailândia, como sabemos veio pôr-nos a todos, à prova, na categoria dos Implicados. 


\section{Os interventores em Medicina de Catástrofe}

São os melhores embaixadores junto das Autoridades no sentido da sensibilização para uma política de previsão e prevenção face a todo o tipo de ameaças, com açóes objetivas de modo a perenizar no espaço e no tempo a sua credibilidade (Noto, 2010a)

\section{Os riscos e as crises}

Os riscos, as crises, a gestão das mesmas, tem levado ao longo dos anos a que o estudo de fatores polivalentes que venham a desencadear uma crise multifacetada. Aqueles, acarretam problemas de índole sanitária, extraordinariamente gravosos especialmente no que diz respeito aos escalóes etários mais vulneráveis (crianças e velhos).

Assim pressupóe-se que quem exerce Medicina de Catástrofe deva possuir um saber integrado transversal a todas as intervenções que se desencadeiam no terreno, mormente se for com decisóes na gestão da crise.

\section{A Formação atual é suficiente?}

Dada a complexidade das tarefas a desempenhar, a formação é nitidamente insuficiente.

Em primeiro lugar porque os riscos crescem exponencialmente. Em segundo lugar porque os meios de que dispomos para fazer face a todos os tipos de situação, têm sofrido uma evolução tecnológica tal, que obrigam a treinamento contínuo.

Em terceiro lugar, no âmbito estrito da Medicina de Catástrofe há novos métodos clínicos de intervenção na evacuação, no acompanhamento de doentes, enfim "a ponte" estabelecida entre o local e o Hospital de Retaguarda.

$\mathrm{E}$, finalmente, por que ao longo de uma vida, o conhecimento adquirido no terreno nunca é exaustivo. Qualquer interventor, em situação de grande catástrofe, salvo raríssimas exceçôes, nunca intervém num número elevado de vezes, Graças a Deus. 
Nota

O Autor esclarece que este Trabalho se baseou na Lição subordinada ao título "Medicina de Catástrofe - sua emergência e especificidade como Medicina de Excepção", elaborada para a realização de Provas de Agregação em Ciências Médicas, no âmbito do Ciclo de Estudos em Medicina de Catástrofe, do Instituto de Ciências Biomédicas de Abel Salazar da Universidade do Porto, em 4 de Abril de 2014, nos termos do Decreto-Lei n.o 239/2007 de 19 de Junho.

\section{Agradecimento}

O Autor agradece ao Exmo. Sr. Mário Ferreira, 20 Comandante dos BVS Pedro da Cova, pela colaboraçáo prestada na elaboraçáo do manuscrito.

\section{Bibliografia}

Abreu, P. (1996). Comunicação e Medicina, Ed Virtualidade, Coimbra.

Adler, J. (1988). Assessment of Disasters in the Developing World. In: Baskett P, Weller R (eds) Medicine for Disasters. Wright, London, pp 132-144.

AMminati, C., Nemitz, B., Nicolle, D., Jallu, J. L. (1996). L'Hôpital face à un afflux de victime. In: Huguenard P (Ed) Traité des Catastrophes, Elsevier, Paris, pp 89-96.

Amundson, D., Bracco, D., Parrish, J. S. (2009). Critical Care Management of Radiological Exposures. In: Geiling J (Ed) Fundamental Disaster Management, $3^{\text {th }}$ Ed. Society of Critical Care Medicine, USA Cap.6: 1-18.

Antunes, F. (2007). Da gripe espanhola à pandemia da gripe das aves, Rev. Fac. Med. Lisboa, Série III; 12 (5) 299-300.

Atienza, R, (2006). Puesta al dia y práctica en catastrophes sanitárias, Ed. Formacion Alcalá, Alcalá La Real (Jaen).

Bandeira, R. (2008). Medicina de Catástrofe. Da Exemplificação Histórica à Iatroética. Dissertação de Doutoramento. ICBAS/UP.

Bandeira, R., Gandra, S. (2015). Reflexão acerca da Gestão das Operações de Socorro no Terramoto de 1755. In: Lourenço L e Santos A (eds) Terramoto de Lisboa de 1755 O que aprendemos 260 anos depois, Imp. Un. Coimbra, pp 35-62.

Bandeira, R., Ponce-Leão, R., Gandra, S. (2017). Feux de Forêt et Médecine de catastrophe. In: Julien H (ed) Manuel de Médecine de Catastrophe, Ed. Lavoisier, Paris, pp 369-382.

Baptista, F. (2010). Telemedicina em Catástrofe (Dissertação de Mestrado em Medicina de Catástrofe), ICBAS-UP. 
Barbará, H. A., Martin, J. T. (2008). La Telemedecine Militaire Española, Urgencia, Emergencia y Catástrofes, Vol 8, nº $1: 39-42$.

Baskett, P. (1988). Training for Disaster Medicine. In: Baskett e Weller R (ed). Medicine for Disasters. Wright, London, pp 152-159.

Baskett, P., Weller, R. (1988). Medicine for Disasters, Butterworth \& Co., Great Britain.

Besserre, R. (1994). Dramatique accident de la route à Cadaujac. Urgence Pratique 9: 82 - 83.

CICR (2008.) Premiers Secours dans le context d'un conflit armé ou d'autres situations de violence, Genève.

Corominas, J. (1954). Diccionario Crítico Etimologico de la Lengua Castellana. Editorial Gredos, Madrid, 4 vols.

Custódio-Rodrigues (1989). Programaçôes Afectivas Inatas. In: Custódio-Rodrigues, Teixeira J, Gomes F (eds) Elementos Básicos de Psicologia Cientifica, vol IV, Afectividade. Contraponto, Porto, pp $81-105$.

Debenedetti, R. (1961). La Médecine Militaire, Presses Universitaires de France, Paris.

Emmanuelli, X., Emmanuelli, J. (1996). Au Secours de la vie - La médecine d'urgence, Ed Gallimard, Paris.

Felmet, K., Braner, D., Carl, L. (2009). Caring for Critically Ill Children. In Geiling J (Ed) Fundamental Disaster Management, $3^{\text {th }}$ Ed. Society of Critical Care Medicine, USA Cap.6: 1-18.

Fontanille, E. (2011). Réhabilitation de l'offre hospitalière à la suite d'une catastrophe majeure. Les leçons apportées par le séisme d'Haiti. Urgences SFMC. Cap. 92: 1-13.

Fuilla, (2011). Séisme d' Haiti. Stratégie d'assistance médicale. Urgences, SFMC, cap 56 : 1-11.

Garshnek, V. E., Burkle, F. M. (2002). Disaster Medicine Communication and Information Technology Tools for Disaster Response and Medical Assistance. In: Hogan D, Burstein J (Eds) Disaster Medecine. Lippincott Williams and Wilkins, Philadelphia, pp 143-153.

Gonçalves-Ferreira, F. (1990) História da saúde e dos serviços de saúde em Portugal, Fundaçăo Calouste Gulbenkian, Lisboa.

Goulon, M. (2004). La Réanimation, Ed Maloine, Paris.

Grosclaude, M. (1991). Vers une Histoire de la Réanimation, Glyphe y Biotem Éditions, Paris.

Guillermand, J. (1988). Histoire des Infrimières, vol I. Ed. France Selecion, Paris.

Gunn, S. A. (1992). Le Medecin et les Catastrophes. Revue de L'Amelisap 13: 20-23.

Hertgen, P. E., Fuilla, C. (2012) Analgesia, Sedação e Anestesia Pré-Hospitalar - Princípios e Protocolos. Trad. 2a Ed. Francesa. Bandeira R, Lopes M, Moura D (eds) U. Porto Editorial, Porto.

Hohl, B. (1984). Un Accident Catastrophique à Effet Limité l'Accident de la Malterie du Port de Metz. Thèse Mèd. Nancy.

Huguenard, P., Desfemmes, C. (1989). Enseignement en France de la Medicine de Catastrophe: Trop ou Trop Peu? Urgences 8: 15-18.

Josephs, D., Sims, P. (1988). Preventing the «Final Epidemic». The Practitioner 232: 266-269.

Kol- D’alvarenga (1945). Dr. Pedro Victorino, Sep. de Portvcale Vol. XVII, nº 101-102(Set- Dez de 1944) Ed de MARANUS, Porto.

Könningova, R. (1993). Ethical Problem in Mass Disasters. Ann. Medit. Burns Club 6: 190-192.

Lemos, M. (1907). Amato Lusitano, A sua vida e a sua obra. Tavares Martins, Porto.

Louville, Y., Thevenet, M. (1990). Secours en Situation d'Exception. Flammarion Medicine-Sciences, Paris.

Marques (2009). Triagem de Prioridades - Triagem de Manchester (Dissertação de Mestrado em Medicina de Catástrofe), ICBAS-UP. 
Martel, G., Vrousos, C., Kolodié, H., Pons, H., Menthonnex, P. (1994). Le Nucleaire et L'Information du Medicin Generaliste. Urgence Pratique 9 (Supl): 63-64.

Miguel-Torga (1993). Diário XVI. Ed. Autor, Coimbra.

Nicolay, S. (1992). Aspectos Éticos de la Medicina de Catástrofes. In: Leiva A, Campos C, Lorenzo H (eds). Manual de Assistencia Sanitaria en las Catastrofes. Ed. Libro del Año, Madrid, pp 63-67.

Noto. R., Huguernard. P., Larcan, A. (1987). Medicine de Catastrophe. Masson, Paris.

Noto, R. (1992). Des Urgences Individuelles aux Urgences Collectives: Naissance de la Médicine de Catastrophe. La Revue do Praticien, 180: 1281-1286.

Noto, R. (2010a). Medecine de Catastrophe, quel devenir, la Lettre de la SFMC no 63, Anexe I : 32-40

Noto, R. (2010b). Medecine de Catastrophe, quel devenir, la Lettre de la SFMC no 63, Anexe II : 41-42

Noto, R. (2018), Dossier : la rencontre avec la mort, la Lettre de la SFMC no 101: 26-32.

Ogrizek, M., Guillery, J-M (1997). La Communication de crise, Presses Universitaires de France, Paris.

ORGANIZACIÓN PANAMERICANA DE LA SALUD (1999). Asistencia humanitaria en caso de desastres Guia para proveer ayuda eficaz, Oficina Regional de la OMS, Washington.

Percival., I. (1988). Nuclear Winter. The Practitioner 232: 140-141.

Plotowski, L. M. (1994). Da Urgência Individual à Urgência Colectiva: A Importância da Medicina de Desastres e Catástrofes. Rev. Bras. de Emergência Pré-Hospitalar e Medicina de Desastres 1: 14-15.

Poirson-Sicre, S. (2000). La médecine d'urgence préhospitalière, Glyphe \& Biotem éditions, Paris.

Raucoules-Aime, M., Monthean, M., Bone, M., Alaux-Dhenin, V., Barberis, J., Paolini, B., Josseran, F. (2012). De la prise en charge préhospitalière des Urgences à l'aide médicale et médicosociale aux populations rurales par télémedicine, Urgence Pratique, 111 :23-27.

Raphael, B. (1986). When Disaster Strikes. Hutchkinson, London.

Robertson, B. (1991). Immediate care World- Wide. In: Graves I e Peter K (Eds) Pré-Hospital Medicine, Arnold, London, pp 9-14.

Rousseau, M. (1990). Aide Médicale Urgente et Medicine de Catastrophe. Urgences 9: 379-382.

Ruffié, J. (1993). Naissance de la Medecine Predictive. Ed. Odile Jacob, Paris.

Sanches, J., Amor, J. (2002). Intervencion Psicológica en las Catastrophes, Ed. Sintesis, Madrid.

Silverstein, M., Jessie-Hackes (1988). Disaster Planning in Developing Countries. In: Baskett P e Weller R (Ed). Medicine for Disasters. Wright, London, pp 116-131.

Soler, A., Correr, M., Guadarrama, L. (2008). Manual de triage prehospitalario, Elsevier Espanha, Barcelona Sousa, F. (1994). As Inundaçōes de 25 de Novembro de 1967. Bombeiros de Portugal, 119: pp 20-21.

Tavares, C. (2010). Catástrofe em aviação civil. Revisão dos princípios de medicina de catástrofe aplicados ao acidente com o voo Martinair MP495 no aeroporto de Faro em 1992 (Dissertação de Mestrado em Medicina de Catástrofe), ICBAS-UP.

Tudela, C. (1994). La información en las catástrofes, Editorial Mapfre, Madrid.

Vaquero, J. (SD). Samur Proteccion Civil - Manual de Procedimentos, $3^{\text {a }}$ Ed, Madrid.

Walsh, W. T. (1963). Isabel La Cruzada, $4^{\mathrm{a}}$ ed. Espasa-Calpe S A, Madrid.

Ward, M., Willis, M. (1997). Pre hospital care and the ambulance service. In: Skimer D, Swain A, Peyton R, Robertson (Eds) Cambridge Textbook of Accident and Emergency Medecine, University Press, Cambridge pp 284-288.

Zealley, M. (1988). The Medical Ethics of Nuclear War. The Practitioner 232: 618-621. 
(Página deixada propositadamente em branco) 


\section{O SISTEMA DE PROTEÇÃO E SOCORRO EM PORTUGAL - EVOLUÇÃO E DESENVOLVIMENTO - \\ THE PROTECTION AND RESCUE SYSTEM IN PORTUGAL - EVOLUTION AND DEVELOPMENT -}

\section{António Amaro}

Sumário: A Proteção Civil é hoje uma das temáticas mais prementes e prioritárias nos debates da atualidade nacional e internacional em diferentes escalas.

Todavia, enquanto conceito é uma criação recente. Efetivamente, entre nós, o socorro das populações ancorou-se desde muito cedo nos Corpos de Bombeiros criados e suportados pelas respetivas comunidades locais, através de Associações Humanitárias.

Entretanto, a reforma legislativa e estrutural operada a partir de julho/2006 reforçou a autoridade do Estado no setor e enquadrou as atribuiçóes, competências e responsabilidades dos diversos agentes de proteção civil.

Por outro lado, conceptualizou um sistema demasiado focalizado na resposta, operacionalmente centralizado, desvalorizando o patamar de intervenção municipal.

Palavras-chave: Proteção Civil, socorro, bombeiros. 
Abstract: Civil Protection is now one of the most urgent priority issues in discussions of national and international reality on different scales. However, as a concept it is a recent creation. In fact, in Portugal, the help provided to local communities has been based on the fire brigades from very early on, as these were created and supported by their local communities through humanitarian associations.

Meanwhile, the legislative and structural reform implemented from July 2006 reinforced the state authority in the sector and organized the duties, powers and responsibilities of the various civil protection agents. However, it conceptualized a system overly focused on response, operationally centralized, and that undervalued the municipal intervention level.

Keywords: Civil Protection, rescue, firefighters.

\section{Introduçáo}

No âmbito da segurança e proteção civil, a análise de riscos, o socorro e a gestão das crises têm assumido importância crescente, sobretudo a partir do final do último quartel do século passado, com o objetivo de dar uma resposta imediata e eficaz aos desastres sejam acidentes graves ou catástrofes, que, entretanto, passaram a ocorrer com maior frequência, ou talvez melhor, passaram a ser objeto de muito maior divulgação mediática.

De facto, as sociedades modernas, nomeadamente as mais desenvolvidas, debatem-se hoje com problemas que, não sendo novos, assumem, por vezes, uma dimensão redobrada, porque os riscos cresceram com o acelerado desenvolvimento tecnológico e com a expansão dum urbanismo desenfreado. Paralelamente os cidadãos, mais evoluídos, mais informados e daí naturalmente mais sensíveis, estão também psicologicamente menos preparados para os aceitar.

Os sinais de que os riscos de acidentes graves de trabalho e catástrofes estão cada vez mais presentes no contexto contemporâneo de globalização, emana, diariamente de um sem número de expressóes socio-ambientais e socioculturais 
pulverizados pelo planeta, exigindo dos sistemas de segurança e proteção civil, melhor preparaçáo, resposta e recuperaçáo, em ordem à salvaguarda das pessoas e do meio ambiente.

Como veremos a proteçấo civil, enquanto sistema de apoio às populaçóes é uma criação recente, enquanto o socorro emanado da sociedade civil organizada em Associaçóes Humanitárias tem raízes históricas muito mais antigas.

Este capítulo tem como grande objetivo analisar por um lado, a evolução histórica do socorro em Portugal até aos nossos dias, com especial enfoque na reforma legislativa e estrutural realizada a partir de julho de 2006 com publicação da Lei de Bases da Proteção Civil, do Sistema Integrado de Proteção e Socorro (SIOPS) e a criação da Autoridade Nacional de Proteção Civil (ANPC). Por outro lado, interrogar o sistema, quer ao nível dos diversos agentes e respetivas atribuiçóes, competências e responsabilidades, quer ao nível das incongruências institucionais e operacionais designadamente quanto à desvalorização do patamar mais próximo das ocorrências que é o patamar municipal, pondo em causa um dos princípios básicos da Proteção Civil, o princípio da subsidiariedade.

\title{
A Organização do Socorro em Portugal - Evolução e Desenvolvimento
}

\author{
Nascimento e desenvolvimento nos séculos XV, XVI, XVII e XVIII Medidas \\ de prevenção e iniciativas das Câmaras de Lisboa e Porto
}

$\mathrm{Na}$ Idade Média era comum as cidades surgirem apertadas entre muralhas como era o caso de Lisboa, com as muralhas Fernandinas, onde nem sempre era seguro e higiénico viver e onde espreitavam grandes calamidades nomeadamente incêndios e epidemias. Foi neste contexto que o rei D. João I, por carta régia de 25 de Agosto de 1395, e para proteger Lisboa determinou a constituição de um grupo de pessoas destinadas a vigiar e a combater os incêndios nos seguintes termos. 
"[...] que por quanto pr vezes se levanta fogo em essa cidade, considerando sobrelo alguu boó Remedio: Acordastes q era bem q os pregoeiros dessa cidade pr freguesias e cada hua noute, depois do signo da colhença, andem pr a dita cidade apregoando q cada huu guarde e ponha guarda ao fogo em suas casas. E $q$ ds nó queira, q todos os carpenteiros e calafates venham aaquel lugar, cada huu có seu machado, pr auere de atalhar o dito fogo: E q out ssi todas as molheres $q$ ao dito fogo acodiram, tragam cada huã seu cântaro ou pote $p^{a}$ carretar auga pa apagra o dito fogo". (Matos, 1995: $21-22$ ).

Durante os séculos XV e XVI não se conhecem outras medidas, senão esta, de organização e funcionamento dos serviços de extinção de incêndios em Lisboa. No entanto, em 14 de Julho de 1513, no reinado de D. Manuel I, a Câmara do Porto estabeleceu um contrato com alguns fiscais encarregados de verificarem se o "lume" era apagado à noite na cidade, ou seja, foi estabelecido o primeiro sistema de vigilância noturna fora da cidade de Lisboa e de que se tem conhecimento (Matos, 1995:29).

No reinado de Filipe II, várias medidas preventivas contra o risco de incêndio foram tomadas pela Câmara Municipal de Lisboa, nomeadamente respeitantes ao lançamento de foguetes na cidade e ao uso e comércio de pólvora, estabelecendo-se que este produto não podia ser vendido em mercearias. Além destas medidas, a Câmara de Lisboa determinou que os fornos de cal e as casas de pólvora fossem transferidos para fora da cidade, o que foi alvo de grandes polémicas (Santos, 1995:14).

Em 1612, no seguimento das medidas adotadas em 1513 e já no reinado de Filipe III, a Câmara do Porto decidiu colocar um certo número de machados à disposição de carpinteiros com a obrigação destes acorrerem aos incêndios na cidade.

Também a partir desta data a Câmara de Lisboa passou a pagar um salário (pela primeira vez) a dez carpinteiros, nomeados pelo respetivo mestre da Ribeira das Naus, dez pedreiros nomeados pelo mestre-de-obras da cidade e dez trabalhadores para andarem com escadas e baldes de água, tendo como obri- 
gação apagar os incêndios da cidade, que, nesta altura, eram maioritariamente originados por explosóes no fabrico e venda de pólvora (Caldeira, 2006:17).

Em 1678, no reinado de D. Pedro II e por determinação real de 28 de Março, foram criados os primeiros "quartéis" (um no Bairro Alto, outro em Alfama e outro num bairro intermédio a estes). Tais "quartéis" configuravam fisicamente armazéns onde seria guardado material destinado ao combate aos incêndios, nomeadamente escadas, baldes de couro ou madeira, machados, picaretas, alavancas e arpéus (as primeiras mangueiras) tendo, por determinação real de 24/10/1681, sido deliberada a aquisição de material na Holanda, exigência que a Câmara de Lisboa teve dificuldade em satisfazer. Começava, assim, a pensar-se no aperfeiçoamento do "serviço" de incêndios da cidade (Matos, 1995:30).

Em 1683, no reinado de D. Pedro II, foi publicado o primeiro regulamento destinado ao pessoal que, por obrigaçáo, deve acorrer aos incêndios, em Lisboa, cabendo aos "juízes do crime" fazer uma lista de todos os pedreiros, carpinteiros, calceteiros, serradores e outros trabalhadores que deveriam apresentar-se à Câmara de Lisboa para serem selecionados com vista ao combate dos incêndios e cada um dos ofícios deveria nomear 2 oficiais mais idóneos para servirem de "cabos". Ainda no reinado de D. Pedro II, em 1700, algumas medidas de prevenção foram tomadas, nomeadamente quanto à proibição do uso de fogos de pólvora, principal causa de incêndios da cidade de Lisboa. Em resumo, ao longo do século XVII, os instrumentos de combate aos incêndios variavam entre machados, enxadas, picaretas, alviôes, varas de madeira com bicheiros e escadas dobradiças manejadas por trabalhadores dos mais variados ofícios: calceteiros, carpinteiros, pedreiros, sob as ordens dos respetivos mestres.

Em 1734, no reinado de D. João V, procedeu-se à compra das primeiras 4 bombas-tanques com suporte para baldes, em Inglaterra, sendo também, neste reinado, que, devido a dificuldades financeiras, a Câmara de Lisboa chegou a dever cinco anos de salários ao pessoal destacado para combater incêndios.

Daqui à desorganização do serviço de incêndios foi um passo, o que infelizmente aconteceu várias vezes. Foi também nesta altura que apareceu pela primeira vez o termo bombeiro, aplicado aos trabalhadores das bombas dos serviços de incêndios (Santos, 1995:16). 
Em Janeiro de 1766, ainda no reinado de D. José, Domingos da Costa foi nomeado mestre dos calafates, com vista a organizar e dirigir o serviço de incêndios de Lisboa, obrigando-se todos os capatazes a comparecer nas açóes de combate a incêndios. É considerado o primeiro comandante remunerado dos bombeiros municipais e capitão das bombas, cuja ação não foi muito relevante tendo sido demitido e substituído por Mateus António da Costa, conforme Portaria do Senado da Câmara de 21/07/1786, que posteriormente, por portaria de 01/01/1794, foi nomeado Inspetor de Incêndios, com jurisdição sobre os capatazes, cabos e aguadeiros (Matos, 1995:35-36).

"E é em Lisboa que o capitão das bombas, Mateus António da Costa, se dedica a conceber uma bomba, que se construirá segundo vários modelos, nos anos de 1782, 1792, 1796 e 1802. É a designada bomba picota, pois o mecanismo hidráulico que fazia com que a água jorrasse com uma certa pressão era acionada através de uma haste de êmbolo. A picota atravessava longitudinalmente a caixa-de-ar deste sistema aspirante-premente. Todo este conjunto assentava num carro com quatro rodas de reduzidas dimensóes” (Almeida, 1994b: 34, cit. por Barreiros, 2001:136).

Em 31 de Maio do mesmo ano, a câmara decidiu designar um vereador para o sector de incêndios, publicando-se a 13 de Agosto um regulamento que veio a ser completado, após algum tempo, com mais medidas sobre a organização do serviço de incêndios.

Em 1788, foi criado o corpo de bombeiros municipais de Viana do Castelo e por provisão de 8 de Junho de 1799, D. João VI acedeu a "que a Câmara da cidade de Braga, forme huma companhia de 100 homens, à semelhança de Porto e Lamego, inclusos os competentes Officiais, para o laboratório da dita machina, e que promptos acudão aos incêndios que na cidade houver" (Santos, 1995:18).

Também por determinação régia, de 17 de Setembro de 1799, a Câmara de Guimarães foi incumbida de formar uma Companhia de Bombeiros, composta por 60 homens e duas bombas, importadas de Inglaterra pelo juiz de fora, Manuel Falcão, que foram pagas com o somatório dos donativos 
que angariou (Santos, 1995: 18). A criaçáo destes corpos de bombeiros é um sinal evidente de que a estruturaçáo dos serviços de incêndios, de modo organizado, vai ultrapassar no final do século XVIII, as duas maiores cidades do território português - Lisboa e Porto - em grande evidência na primeira fase da Idade Contemporânea.

Importa salientar que é no último quartel do século XVIII, (Santos, 1995:18), que surgem os primeiros serviços de incêndios privativos, instalados em repartições públicas, de Lisboa, e em palácios reais da capital e dos arredores.

Século XIX - Relevo para a açáo dos Municípios, nascimento e desenvolvimento do associativismo

Pode afirmar-se que, no seguimento da expansáo iniciada no final do século anterior, este século vai ser de autêntica explosão na implantaçáo de corpos de bombeiros no País, porque, a par de uma atuaçáo mais dinâmica do poder local, que promoveu a criação de alguns CBs, se assistiu, ao longo dos séculos XIX e XX, à criação de inúmeras associaçôes de beneficência ou humanitárias, por iniciativa das populaçóes que constituíam as comunidades locais, no sentido da defesa das próprias pessoas e bens (Matos, 1995:40).

Aliás, no espírito da época, a prevenção de incêndios era uma grande preocupação dos responsáveis dos municípios. De acordo com o decreto no 23 de 16 de Maio de 1832, de Mouzinho da Silveira, competia ao provedor do concelho (a que corresponde na atualidade o cargo de presidente da câmara municipal) no cumprimento das obrigaçôes de superintendência da polícia, "o dever de evitar os incêndios, fazendo visitas às chaminés e fornos, condenando as que se achem em estado perigoso e impondo multas e proibindo os fogos-de-artifício em lugares perigosos e disparar armas de fogo e similhantes" (Matos, 1995: 43).

Em 17 de Julho de 1834, a Câmara reorganiza os serviços de incêndio e delibera criar a primeira companhia de bombeiros de Lisboa, a que o povo chamou de Companhia de Caldo e Nabo, (mais tarde Corpo de Salvação Pública 
e transformada em Batalháo em 1937) dividindo a cidade em três distritos para efeitos de socorro e combate a incêndios. Em 1852 o serviço de incêndios de Lisboa foi novamente reorganizado e foi publicado o "Regulamento para os Empregados da Repartição dos Incêndios” (Matos, 1995:44).

Em 1853, a Câmara estabeleceu que todos os empregados da repartição de incêndios que se aleijassem no "serviço de fogos" seriam contemplados pela mesma, para efeitos de apoios sociais.

Antes, em 1839, foi criada a Companhia de Incêndios de Vila Nova de Gaia. Dezassete anos depois, em 1856, Viseu abre a sua Companhia de Bombeiros, composta por quarenta e sete elementos. Dois anos mais tarde, 1858, a "bomba" de Braga deu lugar a uma Companhia de Incêndios, e em 1860, foi o Município de Abrantes que criou a sua própria companhia.

Em 1864, Vila Real cria a Companhia de Socorro contra Incêndios, seguindo-lhe a Figueira da Foz. É ainda neste ano que o Corpo de Bombeiros de Lisboa adquire uma bomba a vapor, de tração braçal e hipomóvel, importada de Inglaterra, com desempenho superior às bombas de caldeira existentes.

Em 26 de Junho de 1867, sucedendo ao código administrativo de 1842, foi aprovada a primeira "Lei de Administraçáo Civil" que dividiu o Reino de Portugal em distritos, concelhos e paróquias civis.

Pelo n. ${ }^{\circ} 13$ do art. ${ }^{\circ} 87$ competia às câmaras municipais tomar resoluçóes sobre polícia de segurança e limpeza pública, serviço sanitário, socorros para a extinçáo dos incêndios e contra inundaçóes e demolição de edifícios arruinados ou que ameaçam ruína, nos termos da legislaçâo em vigor (Matos, 1995:49).

No no. 18, do mesmo artigo, "competia a distribuição de socorros dentro das forças do respetivo orçamento, quando se dê alguma calamidade pública" (Matos, 1995: 49).

Pela resoluçáo n. ${ }^{\circ}$ 577, de 21/07/1870 foi aprovado novo código administrativo, dizendo-se no artigo $121^{\circ}$ que a Câmara delibera nos termos das leis e dos regulamentos, nomeadamente: "sobre polícia de segurança e de limpeza pública, serviço sanitário, socorros para extinção de incêndios e contra inundaçōes e demolição de edifícios arruinados, ou que ameaçam ruina, nos termos da legislação em vigor" (Matos, 1995: 50). 
Por força de lei competia ao Administrador do concelho "providenciar nos casos de incêndio, inundaçôes, naufrágios e simelhantes e promover a distribuição de socorro no caso de calamidades públicas".

Sucedeu-se o código administrativo de 1878 , que, no artigo $103^{\circ}$, n. ${ }^{\circ} 2$, aludia à competência da Câmara para "[...] conceder pensöes aos bombeiros, que se impossibilitarem de trabalhar por desastre sofrido no serviço dos incêndios, devendo cessar a pensão, quando cesse a impossibilidade".

Em suma, os diversos códigos administrativos de 1836, 1842, 1870, 1878, 1886, 1895/96 e 1900, que podem ser, até certa medida, "consideradas sucessivas edições atualizadas do mesmo diploma", colocaram sempre a tónica da responsabilidade da Câmara e do seu "provedor/administrador/presidente" na organizaçáo dos serviços de extinção de incêndios, prevenção e socorro das populaçôes em situaçôes de calamidade (Quadro I).

QUADRO I - Disposiçôes dos Códigos Administrativos no Âmbito da Organização dos Serviços de Bombeiros - de 1836 a 1906.

TABLE I - Provisions of the Administrative Codes within the Fire Service Organization from 1836 to 1906.

\begin{tabular}{|c|c|c|c|c|c|}
\hline $\begin{array}{l}\text { Data do } \\
\text { Diploma }\end{array}$ & $\begin{array}{c}\text { Organizaçáo } \\
\text { do Serviço de } \\
\text { Incêndio ou } \\
\text { Socorros para Ext. } \\
\text { Incêndio }\end{array}$ & $\begin{array}{c}\text { Concessáo de } \\
\text { Pensóes a } \\
\text { Bombeiros } \\
\text { (N.o e Art.o })^{\circ}\end{array}$ & $\begin{array}{l}\text { Elaboraçáo de } \\
\text { Posturas para Limpeza } \\
\text { de Chaminés } \\
\left(\text { N.॰o Art. }{ }^{\circ}\right)\end{array}$ & $\begin{array}{l}\text { Despesas com } \\
\text { o Serviços de } \\
\text { Incêndios } \\
\left.\text { (N. e Art. }{ }^{\circ}\right)\end{array}$ & $\begin{array}{l}\text { Actuaçáo dos } \\
\text { Administradores } \\
\text { do Concelho } \\
\left.\text { (N. e Art. }{ }^{\circ}\right)\end{array}$ \\
\hline $12-07-1836$ & -...-. & -------- & - & -....... & art. $^{\circ} 63$ \\
\hline $18-03-1842$ & -..--..-- & & N. ${ }^{\circ} 3 /$ art. $^{\circ} 120$ & Ver art. $^{\circ} 120^{\circ}$ & N.o $15 /$ art.o $^{\circ} 249$ \\
\hline 20-06-1867 & $\begin{array}{l}\text { N. }{ }^{\circ} 13 / \text { art. }^{\circ} 83 \\
\text { (socorros) }\end{array}$ & & $\begin{array}{c}\text { Refere-se "posturas" } \\
\text { em geral }\end{array}$ & N. ${ }^{\circ} 10 /$ art. $^{\circ} 158$ & $\begin{array}{l}\text { Promover a dist. } \\
\text { de socorros }\end{array}$ \\
\hline $21-07-1870$ & N.o $22 /$ art. $^{\circ} 121$ & -_----o-- & $\begin{array}{c}\text { Refere-se "posturas" } \\
\text { em geral }\end{array}$ & N.o $13 /$ art. $^{\circ} 150$ & N. ${ }^{\circ} 15 /$ art. $^{\circ} 279$ \\
\hline 1878 & N.o $23 /$ art. $^{\circ} 103$ & N.o $20 /$ art. $^{\circ} 103$ & N. ${ }^{\circ} 4 /$ art. $^{\circ} 104$ & N.o 13 art. $^{\circ} 127$ & N. ${ }^{\circ} 15$ art. $^{\circ} 203$ \\
\hline $17-07-1886$ & N.o $19 /$ art. $^{\circ} 117$ & N. ${ }^{\circ} 22 /$ art. $^{\circ} 118$ & N. ${ }^{\circ} 4 /$ art. $^{\circ} 120$ & N.o $10 /$ art. $^{\circ} 141$ & N. ${ }^{\circ} 15 /$ art. $^{\circ} 242$ \\
\hline 04-05-1896 & N. ${ }^{\circ} 8$ /art.o 50 & N. ${ }^{\circ} 26 /$ art.o $^{\circ} 51$ & N. ${ }^{\circ}$ /art. ${ }^{\circ} 52$ & N.o 14 /art. ${ }^{\circ} 81$ & N. ${ }^{\circ} 17 /$ art. $^{\circ} 278$ \\
\hline 21-06-1900 & N. ${ }^{\circ} 8 /$ art. $^{\circ} 109$ & N.o 26/art.o 109 & N. ${ }^{\circ} 5$ /art. ${ }^{\circ} 111$ & N.o $14 /$ art. $^{\circ} 131$ & N.o $17 /$ art. $^{\circ} 318$ \\
\hline
\end{tabular}

Fonte: adaptado de Matos, 1995:60. Source: adapted from Matos, 1995:60. 
Além disso, cabia-lhe, como se disse, a concessão de pensôes aos bombeiros acidentados. Ora, com tais responsabilidades legais, que razôes explicam a existência de táo poucos corpos de bombeiros municipais ao nível do País, ontem e hoje?

A falta de recursos dos Municípios, num Estado centralizado, explicará tal fenómeno?

Que razóes levaram alguns Municípios (ao todo 22) que detinham corpos de bombeiros, a "prescindirem" dos mesmos, como sucedeu por exemplo, em Lamego e Guimarães, logo que foram criadas as Associaçôes Humanitárias locais?

Importa salientar que até à publicação dos Códigos 1936/1940 vigoraram as disposiçóes dos Códigos de 1878 e 1896, em que:

- A entidade que aprovava os estatutos e regulamentos das Associaçóes Humanitárias era o Governador Civil;

- A aprovação dos regulamentos e dos quadros dos corpos de bombeiros municipais competia à entidade tutelar.

\section{Expansão do Associativismo nos Bombeiros}

Foi Guilherme Cassoul que, na tarde de 17 de Outubro de 1869, sugeriu, num grupo de amigos (individualidades da cidade), a criaçáo de uma companhia de bombeiros voluntários. Este acontecimento deu-se na farmácia dos irmãos Azevedo, em Lisboa, na sequência de várias discussóes sobre o deficiente estado em que se encontrava o serviço de incêndio na cidade (Caldeira, 2006:19).

No dia seguinte, em reunião presidida pelo barão de Mendonça, presidente da Câmara Municipal de Lisboa, foi deliberado criar uma "companhia de voluntários bombeiros", que ficou adstrita ao Corpo de Bombeiros Municipais. Acordou-se ainda que ficavam desde logo inscritos 26 cidadãos (Caldeira, 2006:19).

Depois da criação em 1880 da "companhia voluntária de bombeiros" transformada na Associação dos Bombeiros Voluntários de Lisboa, até ao final do século XIX, foram fundadas 82 associaçôes de bombeiros voluntários e corpos de bombeiros municipais, sucedendo a algumas associaçôes entretanto extintas (Santos, 1995: 22). 
O movimento associativo nascente deu lugar ao aparecimento de grupos de homens e mulheres que abraçaram a causa dos bombeiros portugueses e que, integrando os corpos gerentes, deram e continuarão a emprestar o seu prestimoso contributo, administrando as associaçóes de bombeiros. São os vulgarmente chamados "bombeiros sem farda".

E se, nesta primeira fase da sua atividade, as associaçôes de bombeiros tinham como grande objetivo a extinção de incêndios, depressa se aperceberam que podiam alargar a sua ação a duas importantes áreas de socorro: a urgência extra-hospitalar e os socorros a náufragos.

$\mathrm{Na}$ área da urgência, começaram a ser organizadas as "ambulâncias", que tinham como objetivo "o serviço médico e cirúrgico, em ocasióes de sinistro e suas consequências" e dispunham de macas de padiola e de macas rodadas e de pessoal próprio, isto é, o "pessoal da ambulância", normalmente dirigido pelo "facultativo" (Santos, 1995: 23).

A ação dos bombeiros nos socorros a náufragos teve o seu início em 1870 . Antes mesmo da criação do Real Instituto de Socorros a Náufragos, em Abril de 1982, "os bombeiros de Portugal espalhados pelo pais em várias associaçóes humanitárias e vocacionados para socorrer o próximo em caso de cataclismo, cedo se aperceberam da sua utilidade para salvar náufragos de navios encalhados e perdidos na costa [...] com cabos de vaivém passados aos navios encalhados" (Fialho, 1995:61).

Ainda hoje existe uma estreita ligação entre os bombeiros e o Instituto de Socorros a Náufragos (ISN), cooperando muitos corpos de bombeiros com esta Instituição, através de socorros a partir da terra disponibilizando o Instituto equipamentos necessários e ministrando a formação especializada aos bombeiros destacados nos serviços de socorros a náufragos.

Na sequência de códigos anteriores, o código administrativo de $1878 \mathrm{deu}$ às câmaras a responsabilidade de "organizar serviços ordinários ou extraordinários para extinção dos incêndios [...]". Competia-lhes ainda fazer posturas "para limpeza das chaminés e fornos, e o serviço para a extinção de incêndios e contra inundaçóes" (Santos, 1995: 24).

Entretanto, no cumprimento das obrigaçôes legais que lhes atribuíram os diferentes códigos administrativos, as câmaras municipais continuaram a 
adquirir material para a extinção de incêndios, não obstante se constatar o facto de muitas vezes o socorro não funcionar com prontidão e eficácia, já que o material disponível não era utilizado corretamente, mormente por falta de instruções e competências. Nesta linha, "algumas câmaras municipais e muitas comunidades locais tomaram a iniciativa de organizarem corpos de bombeiros devidamente enquadrados e comandados" (Santos, 1995: 24).

A formação dos bombeiros era ministrada nos "quartéis" constando basicamente de exercícios práticos com bombas e com escadas. "Tratava-se, com certeza, de conhecimentos empíricos, obtidos ou transmitidos pela via da experiência, se preferirmos, através da formação em contexto de trabalho, porventura com técnicas e métodos pouco pedagógicos, aos olhos de hoje, mas, quiçá, tão eficazes quanto os atuais" (Lourenço, 2002:26).

Em 1876 foi entâo criada uma Escola de Bombeiros, dependente do Corpo de Bombeiros Municipais de Lisboa, na rua da Inveja, tendo-se iniciado por essa altura a realização de manobras, exercícios de salvamento e simulacros pelo País (fot. 1 e 2).

Um extrato da Ordem de Serviços do inspetor de incêndios de 15 de Janeiro de 1876, entre outros, determina que na Escola de Bombeiros se cumpra o seguinte:

Art. ${ }^{\circ} 10^{\circ}$ - A instrução é obrigatória para que todos os homens que compóem o corpo de bombeiros, e em cumprimento do art. ${ }^{\circ} 131$ do Regulamento ninguém poderá passar à classe imediatamente superior, nem mesmo ter preferência por qualquer serviço dentro da sua própria classe, senão em virtude das habilitaçôes que tiver alcançado pela sua aplicação. Para este efeito, nenhum "patrão" ou "aspirante" será nomeado para lugar imediatamente superior sem prévio exame das disciplinas que se ensinaram na Escola. "Cento e trinta e dois anos depois, o espirito desta ordem de serviço continua perfeitamente atual. Seria bom que fosse aplicado a todos os bombeiros, sobretudo aos elementos de comando" (Lourenço, 2001: 26).

Em 1882 o corpo ativo de bombeiros de Lisboa passou a chamar-se "Corpo de Bombeiros Municipais”, constituído por 163 homens, coadjuvados por um "corpo auxiliar" de 530 sotas, condutores e moços, "além de todos os homens que se acharam matriculados como aguadeiros na cidade de Lisboa" (Santos, 1995:25-26). 


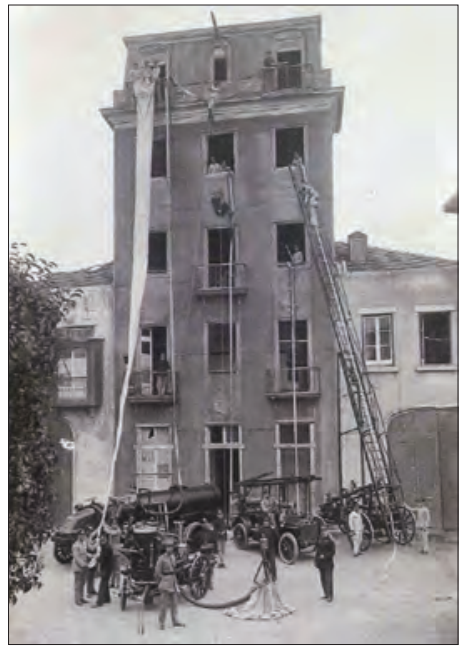

Fot. 1 - Manobras em esqueleto (BP, Vol. I, 1995:368).

Photo 1 - Skeleton Maneuvers

(BP, Vol. I, 1995:368).

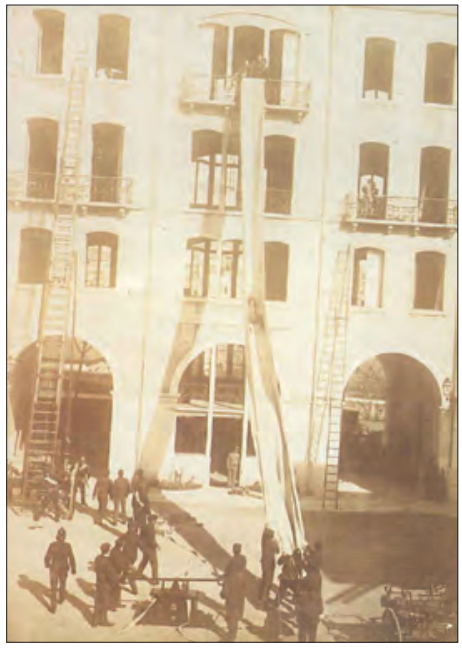

Fot. 2 - Exercícios de salvamento (BP, Vol. I, 1995:397).

Photo 2 - Lifesaving exercises (BP, Vol. I, 1995:397).

Em finais do século em análise estão registadas as primeiras manifestações desportivas, a publicação do primeiro poema em dedicatória dos bombeiros, a participação em concursos internacionais, o início da prestação de serviços de saúde para os sócios das associaçóes, o aparecimento das primeiras bandas de música, bibliotecas e o aparecimento dos primeiros capeláes dos bombeiros portugueses (Caldeira, 2006: 20).

\section{Os Bombeiros no Século XX}

O início do século XX representa um momento glorioso na história dos bombeiros. Foi a 18 de Agosto de 1900 que um grupo de bombeiros do Corpo de Salvação Pública do Porto, sob o comando de Guilherme Fernandes, conquistou em Vincennes, nos arredores de Paris, o concurso internacional de bombeiros, mostrando as suas perícias técnicas no combate a incêndios. Foi aliás, neste contexto, que terá nascido o lema "Vida por Vida” (Santos, 1995:27). 
Entretanto o novo código administrativo, aprovado em 21 de Junho de 1900, volta a cometer (como os anteriores, desde 1834) às câmaras municipais a responsabilidade de deliberar sobre prevençáo e organizaçáo de incêndios e de fazer posturas e regulamentos "para limpeza das chaminés e fornos", competindo ao administrador do concelho "providenciar para proteção e segurança das pessoas e cousas nos casos de incêndio, inundaçôes, naufrágios, calamidade pública e semelhantes, promovendo a prestação e distribuiçáa de socorros" (Santos, 1995: 27).

Em 1901, o serviço de incêndios do município de Lisboa passou a fazer parte do Estado, "ficando sob imediata superintendência do respetivo governador civil, continuando a ser encargo obrigatório do mesmo município a respetiva dotação" (Santos, 1995:27) .

Nos primeiros dez anos do século XX fundaram-se 21 associaçóes e, entre 1910 e 1929, foram criadas 95 associações de bombeiros voluntários, dois corpos de bombeiros municipais e um corpo de bombeiros privativo (Santos, 1995:27). Esta forte explosão "criadora de corpos de bombeiros, sobretudo voluntários, decorria naturalmente da força da população integrada nas comunidades locais e com base nos Concelhos, por náo existência de estruturas de socorro ou por deficiente funcionamento das estruturas existentes, por bairrismos ou influência de figuras carismáticas ou até por dissidências com as estruturas já existentes" (Laranjeira, CPE-2007:1). A entidade licenciadora era o Governador Civil que aprovava os estatutos das respetivas Associaçóes Humanitárias, donde emanavam os Corpos de Bombeiros, e a quem estas apresentavam os respetivos relatórios de atividades e contas, situação que, com o decurso do tempo, deixou de ser cumprida por grande parte das associaçóes.

Entretanto, depois das tentativas falhadas para a criação de uma estrutura federativa dos bombeiros portugueses, respetivamente em 1889, 1904 e 1929, as associaçóes e corpos de bombeiros, reunidos em congresso no Estoril em 1931, decidiram fundar uma Confederação Nacional denominada Liga dos Bombeiros Portugueses (LBP) com o grande objetivo de "defender e promover quanto importa aos interesses dos serviços de incêndios e socorro em calamidades públicas" (Santos, 1995:30). 
Com a criação da Liga, a ocorrência de acidentes em serviço originou uma preocupaçáo social para com os bombeiros e as suas famílias, criando-se uma Caixa de Previdência e Socorros aos Órfăos e Viúvas de Bombeiros, em funcionamento durante alguns anos, sucedendo-lhe o Fundo de Proteção Social do Bombeiro, ainda hoje existente, no âmbito da Fénix Social dos Bombeiros. Além desta vertente social, a Liga publica desde 1943 o Boletim da Liga dos Bombeiros Portugueses que em 1978 passou a denominar-se o Fogo e a Técnica, a que sucedeu, desde 1982, o atual jornal mensal Bombeiros de Portugal.

O Dia do Bombeiro era comemorado no dia 18 de Agosto e a primeira comemoraçáo foi no ano de 1923. Mais tarde, no congresso de 1986, a data foi alterada para o último Domingo do mês de Maio com a designação de "Dia Nacional do Bombeiro".

Os anos trinta do século XX foram ainda marcados por grandes acontecimentos para os bombeiros. Um dos mais importantes foi a substituição do material de tração humana e hipomóvel por viaturas mecânicas (Barreiros, 2001:139).

Sendo certo que a organização dos bombeiros, ao nível associativo se revigorou e adquiriu maior prestígio e direitos próprios sob a égide e orientação da LBP, liderada por uma plêiade de figuras de elevado nível da organização operacional, eram muito significativas as dificuldades com que se debatiam os corpos de bombeiros, seja devido à sua autonomia e dispersáo, seja devido à ausência de um órgão nacional aglutinador e coordenador.

Não obstante os esforços da Liga, não existia uma matriz comum, quer no que se refere à organização interna das Associações e dos seus corpos de bombeiros, quer na organização voltada para o exterior, relevando os aspetos disciplinares, a constituição do corpo de bombeiros, a nomeação dos elementos do comando, a instruçáo, o fardamento, entre outros, sendo evidente a necessidade de uma certa uniformizaçáo e a existência de uma entidade que represente convenientemente os bombeiros.

Neste contexto é legítimo referir que, "no periodo em apreço, é inexistente um quadro verdadeiramente estruturante, bem evidenciado pela diversidade de conceitos e práticas verificados na organização dos bombeiros, ainda que neste 
periodo tenham sido introduzidas inovaçôes dignas de registo, reconhecendo-se a necessidade de ser convenientemente institucionalizada a criação de entidades voltadas essencialmente para o socorro" (Matos, 1995: 78).

Ainda assim, em 1937, a LBP lançou um Plano de Uniformes para todos os corpos de bombeiros intentando contribuir também para regular a organização e funcionamento dos mesmos. Ora, volvidos 71 anos, ainda náo está conseguido este desiderato, comprovando-se, assim, a "singularidade autonómica" de cada um dos corpos de bombeiros ditos voluntários.

O Estado, pelo seu lado, evidenciava a sua vulnerabilidade no domínio da organização nacional dos serviços de incêndios (e outros serviços de socorro), e somente a partir do Código Administrativo de 1936 assumiria a publicação da primeira regulamentação de carácter global dos corpos e associaçóes de bombeiros. Foi então, o País dividido em duas zonas: Norte e Sul, com as respetivas Inspeçôes de Incêndios, dirigidas pelos comandantes dos Batalhôes do Porto e de Lisboa, que detinham poderes de "inspeção técnica em tudo o que respeita à aquisição, conservação e utilização de material e à instrução do pessoal' (art. ${ }^{\circ} 159$ do Código Administrativo, de 1936).

Pela primeira vez, a Administração Central do Estado Português, mantendo a independência das associaçóes, assume a tutela administrativa de todos os corpos de bombeiros: Sapadores, Municipais, Voluntários e Privativos.

Dez anos volvidos, merece especial menção a tentativa de uma maior organização nacional dos Serviços de Incêndios, através da publicaçáo do Decreto-Lei n. ${ }^{\circ}$ 35857, de 11 de Setembro de 1946, que criava o Conselho Nacional do Serviço de Incêndios, ao qual competia, entre outras incumbências, "fomentar a criação de corpos de bombeiros nas localidades onde se tornam necessários e indicar aos corpos existentes os serviços que mais convenha estabelecer" (Santos, 1995: 32).

Em suma, o Decreto - Lei n. ${ }^{\circ}$ 35857, de 11 de Setembro de 1946, regrou o que já estava instituído nas associaçôes e corpos de bombeiros. Foram definidas normas de organizaçáo dos corpos de bombeiros em que cada um deles deveria ter total ou parcialmente os seguintes serviços: serviço de incêndios, serviço de saúde, serviço de socorros a náufragos. Estes seriam constituídos internamente por comando e quadros ativo, auxiliar e honorário. 
Este diploma determinou também a classificação do material e as denominaçôes das unidades (divisão, secção, pelotão, companhia e batalhão), definiu normas sobre categorias, quadros, recrutamento, situaçóes no quadro, licenças, disciplina, instrução e prestaçấo de serviço. Inclui ainda o primeiro plano de uniformes de iniciativa governamental, determinando os tipos de uniformes e a sua composiçáo, os distintivos dos postos e especialidades do pessoal dos corpos de bombeiros, definiu o papel da mulher na estrutura dos bombeiros, ao nível dos serviços de enfermagem, condução de viaturas, cantinas, secretária e outras semelhantes e abriu a possibilidade de, nas localidades afastadas das sedes dos corpos de bombeiros, serem organizadas brigadas ou secçôes destacadas, como hoje são designadas (Santos, 1995:32-33). Datam também dos anos 40 os primeiros quartéis construídos de raiz com instalaçóes mais adequadas à missáo dos bombeiros e, em muitos casos, tendo também em vista objetivos de solidariedade social e de índole sociocultural com forte implantação na vida das respetivas comunidades locais (Branco, 1995:331-336).

Decorridos cinco anos sobre a publicação deste primeiro regulamento geral dos corpos de bombeiros, o governo embora reconhecendo o "notável êxito alcançado" e correspondendo a sugestôes dos próprios corpos de bombeiros, aprovou pelo Decreto-Lei n. ${ }^{\circ}$ 38439, de 27 de Setembro de 1951, novo regulamento geral, alterando apenas alguns preceitos estabelecidos de encontro ao contexto da época e aspiraçôes dos próprios bombeiros.

A nova lei atribuiu aos Inspetores de Zona (Norte e Sul) as competências de "aprovar os modelos de material e dar parecer sobre os tipos de viaturas e restante material de incêndios de que deviam ser dotados os corpos de bombeiros, tendo em atenção as características dos serviços a que se destinavam" (art. ${ }^{\circ}{ }^{\circ}$ do Dec. Lei no 38439).

Intentava-se desta forma "uniformizar a diversidade verificada até então na organização dos corpos de bombeiros municipais, voluntários e privativos". Por outro lado, no domínio da organização de conjuntura o referido Decreto-Lei n. ${ }^{\circ} 38439$, estabelecia na parte final, Capítulo V - Da prestação de serviços - algumas normas de uso interno, para cada corpo de bombeiros e princípios de comando, em caso de atuação conjunta de unidades idênticas ou de diferentes tipos . 
A década de 60 é ainda marcada pela realização, em Lisboa, do II Congresso Mundial do Fogo, promovido pelo Comité Técnico Internacional do Fogo (C.T.I.F.) e em 1963, são conhecidas as primeiras instruçóes conhecidas do Governo manifestando preocupaçôes aos Governos Civis, Câmaras e Direçôes das Associaçóes, sobre o número e a extensáo dos incêndios florestais "que causavam avultados prejuizos à economia nacional", mas que, nesta fase, não eram ainda responsabilidade dos Corpos de Bombeiros (Gomes, 2002:111).

Aliás o Decreto-Lei n. ${ }^{\circ}$ 38439, de 27 de Setembro de 1951, verdadeiro Regulamento Geral dos Corpos de Bombeiros "é omisso no que se refere a situaçôes graves (consideradas de calamidade pública) como sejam: incêndios em vastas zonas florestais, inundaçôes de grande vastidão nos meios populacionais, terramotos, ciclones, etc. Se é certo que a solução de tais emergências compete à Defesa Civil do Território, não é menos certo que em tais circunstâncias são as corporaçóes de bombeiros os principais agentes de socorro, como aconteceu em 1967 nas grandes inundaçôes ocorridas na área de Lisboa" (Laranjeira, 2002:63).

Por outro lado, quando tais emergências tinham lugar, sobretudo em áreas muito grandes ou em zonas dispersas, é evidente que os corpos de Bombeiros não podiam ter uma atuação oportuna e eficiente "enquanto não for criado, em cada Distrito, um Comando que tenha a seu cargo: o estudo dos meios necessários para as debelar; o planeamento da atuação das Corporaçôes; a requisiçẫo direta e imediata dos elementos atuantes e de reforço e a direção dos trabalhos de socorro e salvamento" (Laranjeira, 2002:63).

Num quadro de "intenso fervilhar de novas ideias", no Congresso da LBP, em Aveiro, realizado em 1970, ganha força a, já antiga, aspiração dos bombeiros para a criação de um serviço nacional, como entidade única de coordenação e apoio às atividades dos corpos de bombeiros, entidade que só viria a ser criada nove anos depois.

Em 1978, depois de trinta e dois anos de vigência do regulamento de 1951, foi reconhecido de "interesse público nacional e face às enormes carências em matéria de recursos humanos, de equipamentos e de meios financeiros" reestruturar o Conselho Nacional de Serviços de Incêndios, criando-se o Conselho 
Coordenador do Serviço de Bombeiros, o qual estava incumbido de apoiar o Governo na definição da política a desenvolver no sector, promover a realização de estudos sobre o ordenamento territorial dos meios de combate a incêndios e de açôes gerais de planeamento, coordenaçáo e implementação de medidas para uma utilização racional dos esforços e de equipamentos de combate a incêndios. Quanto às inspeçóes, o diploma previa a existência de serviços de apoio próprio a cargo de pessoal a destacar dos Batalhóes (Lisboa e Porto), onde funcionavam as sedes daquelas instituiçóes (Santos:1995:35).

Um ano mais tarde, a Lei n. ${ }^{\circ}$ 10/79 cria o Serviço Nacional de Bombeiros, competindo-lhe orientar e coordenar as atividades e serviços de socorro exercidos pelos corpos de bombeiros e assegurar a sua articulação, em caso de emergência, com o Serviço Nacional de Proteção Civil, criado em 1975, após a extinçáo em 1974, da Defesa Civil do Território (Santos, 1995:34-35).

Em 1980 é publicado o Decreto-Lei n. ${ }^{\circ}$ 418/80, de 29 de Setembro (um mês mais tarde publica-se a Lei Orgânica da Proteção Civil, Decreto-Lei no $510 / 80$, de 25 de Outubro), que implementou uma nova e autonomizada estrutura do Serviço Nacional de Bombeiros, com competências de orientar, coordenar e fiscalizar as atividades e serviços exercidos pelos corpos de bombeiros, assegurando a sua formação. Este diploma criou ainda cinco inspeçōes regionais de bombeiros que asseguram a nível regional a inspeção e coordenação do Serviço Nacional de Bombeiros. Além, destas atribuiçôes, cabia ao SNB, "promover a instalação gradual de uma escola nacional de bombeiros e assegurar a realização de açôes de formação e de aperfeiçoamento profissional, com vista à melhoria continua de conhecimentos técnicos do pessoal dos corpos de bombeiros" (Santos, 1995:36).

Por outro lado, o Decreto Regulamentar n. ${ }^{\circ}$ 55/81 veio cometer aos corpos de bombeiros, pela primeira vez, a responsabilidade do combate aos incêndios florestais, o que provocou uma profunda modificação na organização e atividade daqueles corpos, posto que os meios humanos e materiais dos CB's não tinham formação nem adequação às respetivas missões de combate na floresta. Além disso, salvo raras exceçôes subsistia um certo isolamento operacional intercorpos de bombeiros, logo inexistência de qualquer estrutura orgânica globalizante 
no âmbito operacional e ausência de quaisquer normas e procedimentos de natureza operacional conjunta (Santos, 1995: 214-215).

Mas para além destas dificuldades e disfunçóes com que o SNB e as suas Inspeçôes Regionais e Superior se depararam, acrescia ainda "a inexistência de normas e procedimentos de telecomunicações e de qualquer tipo de formação e treino de comandos, e bem assim desconhecimento por parte dos corpos de bombeiros da temática concernente ao transporte de mercadorias perigosas e, também, das técnicas e práticas tendentes ao estabelecimento de planos prévios de intervenção" (Santos, 1995:215).

Em conclusão, no decurso do século XX, mais propriamente entre 19001980, foram fundadas 298 Associações Humanitárias de Bombeiros Voluntários, 9 corpos de bombeiros Municipais e 10 corpos de bombeiros privativos. A fundação e distribuição geográfica dos Corpos de Bombeiros, obedeceu, salvo raras exceçóes, à iniciativa de alguns elementos das diversas comunidades locais, na grande maioria, ou à intervençáo de uma outra Câmara Municipal, em alguns casos, ou ainda, em muitos casos, por pressão de responsáveis superiores dos bombeiros nos concelhos onde não havia corpos de bombeiros (Moura, CPE- 2007:2).

Sendo certo que, até Dezembro de 1981, a responsabilidade dos incêndios florestais náo competia aos Corpos de Bombeiros, em termos operacionais e não obstante algumas exceções, comportavam-se "por tradição e em termos de atuação" como autênticas "ilhas", (variando de cidade para cidade e de vila para vila). "Quando em açâa conjunta, imperava a improvisaçáo e a indefiniçāo de comando" (Santos, 1995: 217).

Em suma, nascendo no seio de Associaçóes de Direito Privado, em contexto de parca intervençáo do Estado, sobretudo até aos anos oitenta, os Corpos de Bombeiros - sem prejuízo do reconhecido altruísmo e abnegaçáo da maioria dos bombeiros voluntários e dos dirigentes - foram espelhando ao longo do século XX, um desenvolvimento desigual, muito baseado no "espírito de courela”, ao nível organizacional, e de projeção externa e de forte improvisação, ao nível operacional, face às disparidades de instruçáo/formaçáo e de meios e equipamentos de intervenção existentes. Tais disparidades eram também verificáveis ao nível dos quartéis. 


\section{Organização do Sistema de Socorro até 2002}

Os anos que se sucederam até ao início dos anos oitenta caracterizaram-se por um intenso e participado debate entre o poder político e as entidades representativas da sociedade, mormente a LBP, quanto ao modelo estrutural e organizativo das atividades de socorro e emergência em Portugal.

Dos diplomas já citados, nomeadamente o código Administrativo de 1940, o Decreto-Lei no 38439, de 27 de Setembro de 1951, o Decreto-Lei no 418/80, de 29 de Setembro, alterado pelo Decreto Regulamentar no 277/94, de 3 de Novembro, o Decreto-Lei no 407/93, de 14 de Dezembro, só para referir alguns, verifica-se que a organização de bombeiros, além dos serviços de incêndios, presta serviços na área de saúde, em especial na prestaçáo de primeiros socorros, no transporte de doentes para unidades hospitalares, na área de socorros a náufragos, além da sua atuação como força de socorro na proteçấo civil.

Com a publicação do Decreto-Lei n. ${ }^{\circ} 510 / 80$, de 25 de Outubro, que aprovou a Lei Orgânica do SNPC, é consagrado no ordenamento jurídico nacional um conceito amplo da função proteção civil, estabelecendo que esta "compreende o conjunto de medidas destinadas a proteger o cidadão como pessoa humana e a população no seu conjunto, de tudo o que represente perigo para a saúde, recursos, bens culturais e materiais, limitando os riscos e minimizando os prejuizos quando ocorram sinistros, catástrofes ou calamidades, incluindo os imputáveis à guerra". Quanto ao SNB, a respetiva Lei Orgânica, aprovada pelo Decreto-Lei n. ${ }^{\circ}$ 418/80, de 29 de Setembro, conforme atrás referido, consagrou a sua missão específica definindo-o como um organismo com as atribuiçôes genéricas de "orientaçáo, coordenação e fiscalização das atividades e serviços exercidos pelos corpos de bombeiros" que na sua maioria eram (e continuam a ser) mantidos por Associaçôes de Bombeiros Voluntários, criadas pela sociedade civil organizada e independentes do Estado.

Relativamente à componente do socorro extra-hospitalar, na sequência da Resolução do Conselho de Ministros n. ${ }^{\circ}$ 84/80, de 11 de Março, é dado início a um trabalho de análise e aprofundamento do Serviço Nacional de Ambulâncias, criado pelo Decreto-Lei n. ${ }^{\circ}$ 511/71, de 22 de Novembro, tendo em vista criar 
um novo organismo que materializasse o conceito de Sistema Integrado de Emergência Médica, entretanto identificado como adequado para a elevação da qualidade do socorro prestado às populaçóes. É neste quadro que, através do Decreto-Lei n. ${ }^{o}$ 234/81, de 3 de Agosto, é criado o Instituto Nacional de Emergência Médica (INEM).

Em Dezembro do ano seguinte, o já referido Decreto Regulamentar n. ${ }^{\circ}$ 55/81 clarificou as competências das diferentes entidades quanto aos incêndios florestais, até aí dependentes dos serviços florestais do Ministério da Agricultura, ou seja, segundo Lourenço (2006 b):62):

- Os Serviços Florestais do Estado passaram a ficar responsáveis apenas pela prevenção e deteção;

- Os Corpos de Bombeiros passaram a responder pelo combate e rescaldo;

- Os Municípios assumiram a responsabilidade da proteção civil municipal e da dinamização das Comissóes Municipais Especializadas em Fogos Florestais.

Decorridos sete anos da aprovação da Lei Orgânica do SNB, foi publicada a Lei n. $21 /$ 87, de 20 de Junho, que aprovou o Estatuto Social do Bombeiro e sendo alterada anos depois pela Lei n. ${ }^{\circ}$ 23/95, de 18 de Agosto. A Liga dos Bombeiros Portugueses criou, com base nesse diploma de 1987, o já referido Fundo de Proteção Social do Bombeiro.

O regime jurídico dos corpos de bombeiros foi estabelecido no DecretoLei n. ${ }^{\circ}$ 407/93, de 14 de Dezembro, e foi também criado um novo Conselho Nacional dos Bombeiros Portugueses, órgão de cariz consultivo, presidido pelo Ministro da Administração Interna.

Entre 1980 e 1995 foram criadas 54 associaçóes de bombeiros voluntários e 8 corpos de bombeiros privativos (Santos, 1995: 36).

Mas a década de 90 foi marcada, no plano legislativo, pela aprovação da Lei n. ${ }^{\circ}$ 113/91, de 29 de Agosto (Lei de Bases da Proteção Civil), definindo esta como uma "atividade desenvolvida pelo Estado e pelos cidadãos".

A publicação desta lei marca um momento de viragem na função proteção civil no nosso País, uma vez que retira o SNPC do âmbito da legislação reguladora da Defesa Nacional e confere-lhe um conceito doutrinário autónomo e específico. 
Esta evolução legislativa e conceptual foi consolidada pela Resolução da Assembleia da República n. ${ }^{\circ} 10 / 92$, de 1 de Abril, que integrou, na ordem jurídica nacional, os Protocolos Adicionais I e II das Convençóes de Genebra, de 12 de Agosto de 1949, concluídos em Genebra em 12 de Dezembro de 1977, que, nos primeiros protocolos referidos, consagra um conceito amplo de proteção civil (Caldeira, 2003: 17).

$\mathrm{O}$ artigo 6. ${ }^{\circ}$ da Lei 113/91 considera a Proteção Civil "permanente, multidisciplinar e plurissectorial, cabendo a todos os órgáos e departamentos do Estado promover a sua execução de forma descentralizada" (delegaçóes distritais). No artigo $8 .^{\circ}$ (informação e formação dos cidadãos) diz-se que "os programas de ensino, nos seus diversos graus, incluirão, na área de formação cívica, matérias de Proteção Civil e auto proteçâo" e no artigo 18. (Agentes de Proteçấo Civil), consideram-se "SNB, Forças de Segurança, Forças Armadas, Sistema de Autoridade Maritima e Aeronáutica, Instituto Nacional de Emergência Médica. Especial dever de cooperação: Serviços e Associações de Bombeiros". Relativamente aos agentes de proteção civil, o legislador tipificou as suas funçôes, classificando-as como de "alerta, intervenção, apoio e socorro, de acordo com as suas atribuiçóes próprias" e atuando "sob a direção dos comandos ou chefias próprios".

Quanto às operações de proteção civil, este diploma estruturante do Sistema, prevê a ativação de centros operacionais de proteção civil de nível nacional, regional, distrital ou municipal, de harmonia com programas e planos de emergência previamente elaborados.

Mas esta década ficou igualmente marcada pela revisão de diversos diplomas reguladores do Sistema. Neste período foram revistas as Leis Orgânicas do SNPC, SNB e INEM, antevendo a necessidade de se proceder a uma análise integrada e de conjunto do sistema e subsistemas de socorro no nosso País (Caldeira, 2003:17).

Em 1992 foi reconhecida a "necessidade de promover a reestruturaçâo do quadro em que é exercida a atividade pelos bombeiros, pela importância primordial e pelos valores e tradição de que são depositários" (Santos, 1995: 37). Foi aprovado o novo estatuto de bombeiro profissional, pelo Decreto n.o 293/92, de 30 de Dezembro, alterado, por retificação, pela Lei n. ${ }^{\circ} 52 / 93$, de 14 de Julho. 
Particularmente importante é o Decreto-Lei n. ${ }^{\circ}$ 203/93, de 3 de Junho (Lei Orgânica do SNPC), que estabelece a organização, as atribuiçóes, as competências, o funcionamento, o estatuto e as estruturas inspetivas dos serviços que integram o Sistema Nacional de Proteção Civil, bem como a orgânica e competências do Serviço Nacional de Proteçẫo Civil. No seu art. ${ }^{\circ} 5 .^{\circ}$ pode ler-se que os Municípios dispôem de Serviços Municipais de Proteção Civil, devendo aqueles que à data de publicaçáo do diploma os náo tenham criado promover a sua criaçáo. Eis a primeira referência expressa de motivaçáo para a organização do subsistema municipal de proteção civil, que alerta para o cumprimento do DL n. ${ }^{\circ}$ 100/84, de 29 de Março - o qual define o regime de atribuiçóes das autarquias locais e as competências dos respetivos órgáos, com as alteraçóes introduzidas pela Lei n. ${ }^{\circ}$ 18/91, de 12 de Junho - que comete ao Presidente da Câmara Municipal a direção, em estreita articulação com o SNPC, do Serviço Municipal de Proteção Civil: "tendo em vista o cumprimento dos planos e programas estabelecidos e a coordenação das atividades a desenvolver no dominio da proteção civil, designadamente em operaçôes de socorro e assistência, com especial relevo em situaçôes de catástrofe e calamidade pública" (alínea i, do n. ${ }^{\circ} 1$, do art. $^{\circ}$ n. $\left.{ }^{\circ} 53\right)$.

Ora, como sabemos, decorridos 15 anos, existem Câmaras Municipais em que Serviço Municipal de Proteção Civil, ainda não se encontra organizado, não obstante o disposto na Lei 27/2006, de 3 de Julho (Lei de Bases da Proteção Civil) e em especial na Lei no 65/2007 de 12 de Novembro que define o enquadramento institucional e operacional da proteção civil no âmbito municipal e estabelece a organizaçáo dos serviços municipais de proteçáo civil e determina as competências do comandante operacional municipal.

Por outro lado, na sequência da iniciativa legal que criou o novo Estatuto Social do Bombeiro, seguiu-se o estabelecimento do novo regime jurídico dos corpos de bombeiros, pelo Decreto Regulamentar n. ${ }^{\circ}$ 62/94, de 2 de Novembro, que constitui "nova peça do quadro legislativo, definidor da atividade desenvolvida pelos bombeiros" (Santos, 1995:37).

Ainda em 1994, sobressai uma alteraçáo à Lei Orgânica do SNB, com vista à sua participação "numa associação de direção privada, sem fins lucrativos, 
entretanto fundada, destinada à formação técnica dos bombeiros, ou seja, a Escola Nacional de Bombeiros, que ainda hoje, não passa de um Centro de Formação Profissional cujas formaçōes ministradas apenas têm validade no contexto próprio do setor dos bombeiros".

\section{Fusáo do SNB, SNPC e CNEFF - Antes, durante e depois}

Em 1997, o Governo em funções, sob a orientação do Secretário de Estado da Administração Interna, iniciou um processo de "nova" abordagem do sistema de proteção civil, impulsionado pela ocorrência das inundaçóes no Alentejo e Algarve, de que resultaram graves consequências e puseram em causa, com ampla cobertura mediática, a forma de atuação e de coordenação dos serviços e agentes envolvidos nas operaçóes de socorro e assistência às populaçôes afetadas (Caldeira, 2003:17-18).

Neste mesmo ano, foi transposta para o ordenamento jurídico nacional a decisão do Conselho de Ministros da Comunidade Europeia de 29 de Julho de 1991 que criou o número de telefone 112 para toda a comunidade e que foi instituído como número nacional de emergência, através do Decreto-Lei n. ${ }^{\circ}$ 73/97 de 3 de Abril, confiando-se ao Ministério da Administração Interna " $a$ reformulação e gestão das centrais de emergência".

O Governo de então, a partir de um diagnóstico de vulnerabilidades, tomou a decisão programática de fundir três serviços do Ministério da Administração Interna (SNPC, SNB e CNEFF) ligados à proteçâo das populações, num único serviço tendo por objetivo, com tal medida, "garantir uma coordenação operacional eficaz e eficiente, em caso de acidente grave, catástrofe e calamidade". Esta intenção, assinala Caldeira (2003:18), deu origem a um anteprojeto de lei que chegou a ser explicitado, nas suas linhas gerais, aos parceiros associativos do Ministério da Administração Interna (MAI), Liga dos Bombeiros Portugueses e Associação Nacional dos Bombeiros Profissionais.

Esta iniciativa da reforma do sistema falhou, assevera Caldeira (2003:18), em consequência da falta de consenso quanto à matriz organizacional e funcional, em 
especial porque os responsáveis políticos que entáo lideravam o processo esqueceram aspetos essenciais que os "arquitetos legislativos" do Sistema de Socorro sempre tiveram presente, aquando da sua elaboraçáo conceptual, no período decorrente entre o final da década de 70 e o início da década de 80, a saber:

- As Associaçôes de Bombeiros Voluntários são entidades privadas e os corpos de bombeiros sapadores e municipais são unidades orgânicas dos respetivos municípios;

- A génese dos corpos de bombeiros confere-lhes uma dimensão essencialmente local, estando muito ligados às autarquias;

- A Administração Central não dispóe de corpos de bombeiros, nem de estruturas operacionais de reserva ou complemento.

E, finalmente, que o sistema de proteção civil em Portugal está sustentado no princípio da subsidiariedade (Caldeira, 2003: 18).

Em 1999, o objetivo "Reforma do Sistema" voltou à agenda do poder político e dos parceiros envolvidos e, no ano seguinte, surge desenvolvido pela mão do Secretário de Estado, Professor Carlos Zorrinho, responsável pela Proteção Civil, o conceito de Sistema Nacional de Proteção e Socorro, consubstanciado em dois pilares institucionais (SNPC e SNB) e três parceiros associativos Associação Nacional de Municípios Portugueses (ANMP), Liga dos Bombeiros Portugueses (LBP) e Associação Nacional dos Bombeiros Profissionais (ANBP). Pela sua importância, vejamos, em liminar síntese, as principais linhas de ação estratégicas definidas pelo então responsável político do sector, Professor Carlos Zorrinho:

a) "Reforço do voluntariado, com mecanismos complementares adequados - tratava-se de valorizar a matriz voluntária do Sistema Nacional de Proteçâa e Socorro, mas garantindo, gradativamente, a criação de grupos de intervenção permanente nos corpos de bombeiros, para efeitos de prontidão no socorro.

b) Definição de metodologias participadas e rigorosas de afetação de recursos", ou seja, distribuir, com racionalidade (sem bairrismos) os recursos disponíveis, concertados com os vários parceiros do sector.

c) "Implantação duma rede de emergência e circulação rápida de informação e desenvolvimento de uma cultura de rede e complementaridade de meios 
- com vista à implantação de uma rede integrada de comunicaçóes de emergência que interligará todas as associaçóes e agentes do sistema.

d) Atribuição à competência de proteção e socorro dum carácter qualificante" - ou seja, considerando a exigência da função bombeiro, é imperiosa a formação permanente e especializada, aludindo-se ao redesenhar do papel da ENB - Escola Nacional de Bombeiros, no sentido de priorizar a certificação das qualificações, à função de formadores e à formação descentralizada dos agentes do sistema.

Infelizmente, a este nível, a implementação do carácter qualificante veio a traduzir-se, na prática, pela substituição à frente da ENB, de um académico e pedagogo da Universidade de Coimbra, por uma personalidade que é reconhecida pelas suas competências de cariz político, no âmbito da confederação dos bombeiros portugueses.

f) "Estruturação de mecanismos intergovernamentais e interinstitucionais de resposta rápida a situaçôes de acidente grave, catástrofe e calamidade - A lei de bases da proteçáo civil traça os mecanismos de coordenação a acionar em situaçóes classificadas. "Tratava-se, no fundo, de criar um Manual de Conduta em situaçóes de acidente grave, catástrofe ou calamidade" (Caldeira, 2003: 19).

Em boa verdade, as linhas de ação estratégicas definidas não se traduziram em projetos concretos dignos de nota, considerando a resistência à mudança muito característico das Associaçóes e respetivos corpos de bombeiros, sem prejuízo de aqui e ali se assistir ao incremento de estruturas permanentes nos CB's, com dimensão financeira para tal.

Regia então o sistema, ao nível dos bombeiros o pacote legislativo iniciado com a nova "Lei Orgânica do Serviço Nacional de Bombeiros - Decreto-Lei n. ${ }^{\circ}$ 293/2000, de 17 de Setembro”. Nesse mesmo Diário da República de 17 de Setembro de 2000, para além do Decreto-Lei n. ${ }^{\circ}$ 293/2000 foram publicados os seguintes normativos: Regime Jurídico dos Corpos de Bombeiros; DecretoLei n. ${ }^{\circ}$ 294/2000,Regulamento Geral dos Corpos de Bombeiros; Decreto-Lei n. ${ }^{\circ}$ 295/2000, Centros de Coordenação de Socorros (CCS) a nível nacional e distrital, Decreto-Lei n. ${ }^{\circ}$ 296/2000 e Estatuto Social do Bombeiro, Decreto-Lei 
n. ${ }^{\circ}$ 297/2000. De relevar ainda a Portaria n. ${ }^{\circ}$ 449/2001, de 5 de Maio, que cria o "Sistema de Socorro e Luta contra Incêndios (SSLI)". Não obstante, esta profusa legislação subsistiram as dificuldades de articulação e coordenação entre os vários serviços e sectores envolvidos nas operaçôes de proteçấo e socorro, agravadas quanto maior era o número de agentes do sistema envolvidos, atenta a cultura diferenciada da sua natureza e matriz organizacional.

Por outro lado, dá-se conta, da reduzida exigência de habilitaçóes literárias no recrutamento a todos os níveis, Inspetores, Quadro de Comando e Bombeiros em geral, não se seguindo princípios em desenvolvimento noutros países europeus, como a França ou a Inglaterra. Neste aspeto é sintomático que, até no Estatuto Social do Bombeiro (Decreto-Lei n.o 297/2000), no que respeita a "Isenção de propinas e taxas de inscriçâo", apenas se menciona o ensino secundário (Art. ${ }^{\circ}$ 170) (Pena, 2005:266).

Apesar de tudo, em Janeiro de 2002, o balanço do projeto reformista concebido pelo Professor Carlos Zorrinho apresentava um rumo, uma estratégia e a séria vontade dos parceiros do Sistema se envolverem ativamente na construção conjunta de uma efetiva Reforma das estruturas de socorro em Portugal (Caldeira, 2003: 20).

"A Proteção e Socorro em Portugal recorre a uma confluência de contributos, que vão desde o papel basilar das Associaçôes Voluntárias de Bombeiros e das Corporaçóes Municipais ou Privadas, até ao papel regulador do Serviço Nacional de Bombeiros e do Serviço Nacional de Proteção Civil e à parceria indispensável das Autarquias Locais.

Procurando concretizar esta visáo fundada na sinergia e na complementaridade funcional, em parceria com os principais agentes do sector, foi possivel desenvolver e iniciar a aplicação do conceito de Sistema Nacional de Proteção e Socorro, traduzido num modelo organizacional coordenado pelo Secretário de Estado com a tutela e estruturado em dois pilares institucionais (Serviço Nacional de Proteção Civil e Serviço Nacional de Bombeiros) e três parceiros associativos (Associação Nacional de Municípios Portugueses, Liga de Bombeiros de Portugal e Associação Nacional de Bombeiros Profissionais). Este modelo está a ser progressivamente reproduzido à escala 
Distrital com a instalação de Centros Coordenadores de Socorros onde se aplica o conceito de Sistema Distrital de Proteção e Socorro, sob coordenação dos Governadores Civis e à escala Municipal com a aplicação do conceito de Sistema Municipal de Proteção e Socorro sob Coordenação do Presidente da Autarquia". (Zorrinho, 2002:8-9).

É evidente que, ao tempo, não obstante a bondade das propostas do Professor Zorrinho, nem as autarquias, nem a estrutura dirigente e operacional dos bombeiros, pouco qualificada, mas mantida quase intacta, estavam dispostas a eventuais mudanças que apontavam no sentido da criaçáo de Equipas Permanentes nos CB's, tendo-se mantido a "espinha dorsal" do socorro, baseada no modelo de voluntariado existente, náo obstante as insuficiências de disponibilidade, formação e segurança, dos bombeiros "ditos voluntários".

Por outro lado, a legislaçáo não conseguiu resolver os problemas de articulação e coordenação entre as entidades intervenientes no socorro, em especial a cultura de comando único.

Em Abril de 2002, inicia-se um novo ciclo político resultante das eleiçóes legislativas e, com ele, uma nova abordagem à problemática da reforma da Proteção Civil e dos Bombeiros, na sequência da publicação do Decreto-Lei n.o 49/2003 de 25 de Março.

\section{Criação do Serviço Nacional de Bombeiros e Proteção Civil (SNBPC)}

- Decreto-Lei no 49/2003, de 25 de Março

Este diploma, publicado no Diário da República, série I, n. ${ }^{\circ}$ 71, de 25 de Março de 2003, criou o SNBPC, em substituição dos entáo existentes, Serviço Nacional de Bombeiros (SNB), Serviço Nacional de Proteção Civil (SNPC) e Comissão Nacional Especializada de Fogos Florestais (CNEFF).

De acordo com a nova legislação, cabe ao SNBPC "prevenir os riscos inerentes a situaçóes de acidente, catástrofe ou calamidade, bem como resolver os efeitos decorrentes de tais situaçōes, protegendo e socorrendo pessoas e bens", mas também 
"orientar, coordenar e fiscalizar as atividades exercidas pelos corpos de bombeiros e todas as atividades de proteção civil e socorro". ( $\mathrm{n}^{\circ} 1 \mathrm{do}$ art. ${ }^{\circ} 3 .^{\circ}$ do Decreto-Lei n. ${ }^{\text {49/2003). }}$

Entre outras, o SNBPC tem a responsabilidade de "exercer a ação inspetiva sobre os corpos de bombeiros e as estruturas de proteção civil", homologar a criação de novos corpos de bombeiros voluntários e privativos e suas secçóes e "emitir parecer sobre projetos de natureza legislativa que visem questöes de socorro e proteçäo civil' (alínea e) do art.o 3.0 do Decreto-Lei 49/2003).

Dita ainda, o citado Decreto-Lei n. ${ }^{\circ}$ 49/2003 que o SNBPC passará a "emitir parecer obrigatório sobre os pedidos de isenção de impostos ou taxas relativos a importação de material ou equipamentos para os corpos de bombeiros, bem como sobre o reconhecimento de beneficios fiscais ao abrigo da lei do mecenato" (alínea m) do no 3 do art. $\left.{ }^{\circ} 3 .^{\circ}\right)$.

Em matéria de formação, este serviço deverá "assegurar a realização das açōes de formação e de aperfeiçoamento operacional com vista à melhoria contínua de conhecimentos técnicos do pessoal dos corpos de bombeiros".

O SNBPC é dirigido por um presidente - apoiado por três vice-presidentes, a quem cabe, entre outras tarefas, "orientar e dirigir a participação do SNBPC na atividade da Escola Nacional de Bombeiros, no âmbito da formação técnica do pessoal dos corpos de bombeiros e dos agentes de proteçáo civil". (alínea d) do no2 art. ${ }^{\circ}$ 6. ${ }^{\circ}$ ). É também ao presidente que cabe "elaborar o plano anual de apoio às associaçôes e corpos de bombeiros". (alínea g) do $\mathrm{n}^{\circ} 2$ do art. $^{\circ} 6^{\circ}$ ).

O novo serviço passa a ser dividido em serviços centrais e distritais. No primeiro caso subdividiu-se em o Centro Nacional de Operaçóes de Socorro, Núcleo de Proteção da Floresta, Direção de Serviços de Recursos Humanos e Financeiros, Direção de Serviços Técnicos e Direção de Serviços de Prevenção e Proteção. No que toca aos distritos, o diploma refere a criaçáo de Centros Distritais de Operaçôes de Socorro (dirigidos por coordenadores distritais).

Entre os serviços de apoio, o SNBPC contou com um Gabinete de Inspeção e uma novidade, o Gabinete de Apoio ao Voluntariado. 
Em matéria de orgânica deste serviço, passou a existir a Divisão de Saúde, à qual competia "promover e desenvolver as açôes necessárias à instalação e funcionamento de um sistema destinado à vigilância sanitária do pessoal dos corpos de bombeiros desde a sua admissão no quadro".

Fazia ainda parte do SNBPC a Divisão de Segurança contra Incêndios, cuja missão era "propor medidas legislativas, efetuar estudos, emitir pareceres, definir critérios de análise e elaborar planos de inspeçōes no âmbito da segurança contra incêndios". De qualquer forma, o diploma remete para regulamentação futura as matérias de segurança contra incêndios.

Ainda no que toca à Escola Nacional de Bombeiros, diz o referido Decreto-Lei que constituem encargos do SNBPC "as despesas decorrentes do funcionamento dos seus órgãos e serviços, bem como as despesas resultantes da sua participação na ENB" (alínea a) do art. ${ }^{\circ} 39$ ). O diploma refere que o SNBPC participa na ENB como associado, em moldes definidos por despacho conjunto dos ministérios das Finanças e da Administração Interna. De resto, o documento refere que "os planos, os programas e o desenvolvimento das atividades formativas são estabelecidos pelos associados em conformidade com as necessidades e os recursos disponiveis".

No que toca aos apoios às associaçóes e corpos de bombeiros, mantêm-se as condiçóes anteriormente existentes no Serviço Nacional de Bombeiros. Atualmente com a extinçấo do SNB e do SNBPC, o apoio financeiro e logístico à atividade associativa é regulado pelo art. ${ }^{\circ} 31$ da Lei no 32/2007 de 13 de Agosto, que aprovou o novo regime jurídico das associaçôes humanitárias de bombeiros, aplicável às Regiôes Autónomas, "sem prejuizo da sua adaptação às competências dos órgãos de governo próprios" (art.o 49).

Observemos, de seguida, as reaçóes de entáo, vindas de diversos quadrantes, na sequência da publicação deste diploma.

"Guerra na Proteção Civil. Os bombeiros criticam a sua integração no serviço e avisam que o combate aos fogos está atrasado.

O recém-criado Serviço Nacional de Bombeiros e Proteção Civil (SNBPC) ainda mal nasceu e já está a ser contestado pelas principais 
organizaçôes de bombeiros. [...]. Todos acusam o Governo de "falta de debate". [...]. Duarte Caldeira diz que todo "o processo decorreu de forma muito atribulada" e que "só com marcação cerrada" teve acesso ao projeto de diploma. [...] O Presidente da Associação Nacional dos Bombeiros Profissionais (ANBP) - que integra sapadores municipais das maiores cidades do pais, servindo mais de dois terços da população - é ainda mais feroz nas suas críticas: "É inconcebivel que toda esta reforma se tenha feito sem ouvir os profissionais", destaca Fernando Curto. "Fomos completamente ignorados em todo o processo dai recearmos que tudo não passe de uma reforma no papel", reitera este dirigente [...]" (Expresso, 2003/02/15, p. 14 - Valentina Marcelino).

"Reestruturação do Serviço Nacional de Bombeiros deixa corporações sem dinheiro. Fusão alvo de críticas.

[...] A reestruturação dos meios de socorro portugueses, com a fusão do Serviço Nacional de Bombeiros e da Proteção Civil, é vista com ceticismo por algumas corporaçôes de bombeiros. A ausência do Instituto Nacional de Emergência Médica (INEM) do novo organismo e a incapacidade de dar resposta aos principais problemas dos bombeiros são as criticas mais repetidas. Salvador da Luz, da Federação de Bombeiros do Distrito de Lisboa, defende que esta é apenas uma "arrumação técnica das cúpulas", que não resolve as deficiências existentes. [...]". (Público, 2003/03/29 - Mariana Oliveira - cit. por Pena, 2005: 278).

As reaçóes sucediam-se, além dos inspetores distritais, só três bombeiros compareceram fardados à tomada de posse de Leal Martins, como Presidente do SNBPC. (Pena, 2005: 279).

"Bombeiros ausentes na posse de Presidente. Polémica marca entrada em funçóes do responsável do novo serviço. 
[...] Aliás, de bombeiros fardados apenas estiveram presentes 14 inspetores do ex-Serviço Nacional de Bombeiros já que, apurou o Correio da Manhä, nem para uma pretendida guarda de honra houve disponibilidade dos bombeiros voluntários. [...] A respeito de ser um responsável oriundo de fora do meio dos bombeiros e socorro, Leal Martins referiu que embora a ligação às instituiçôes seja fundamental, a existência de "conhecimentos minimos" e a "capacidade de aprendizagem com a instituição em tempo útil" determinaram a sua aceitação no lugar. [...]" (Correio da Manhá, 2003/04/03, p: 10 - Falcão Machado).

Em resumo, a entrada em vigor do diploma 49/2003, de 25 de Março, mereceu o seguinte comentário do Primeiro-Ministro de então, Dr. Durão Barroso, que no discurso de tomada de posse frisou que "a entrada em vigor do diploma orgânico que criou o novo Serviço Nacional de Bombeiros e Proteção Civil é um importante passo numa das mais exigentes e difíceis reformas que o Programa do XV Governo preconiza na área da Administração Interna. Brevemente teremos o Serviço a operar em conformidade com o novo modelo orgânico, assim que tomem posse os coordenadores distritais cuja nomeação obedecerá a critérios rigorosos de competência e idoneidade, como é o meu desejo expressamente reiterado [...]” (Semanário, 2003/04/04, p. 22).

Particularmente relevante era a opinião, ao tempo, do Presidente da Liga: “[...] O Decreto-Lei n.o $49 / 2003$ de 25 de Março constitui o produto final de uma visáo inconsistente, incompleta e conceptualmente pobre, em especial no que concerne às articulaçóes operacionais entre os vários niveis em que se estrutura o Sistema definido pela Lei de Bases da Proteção Civil. Só a título de exemplo, importa sublinhar que o nivel municipal é completamente esquecido no diploma, isto é, a base em que se sustenta toda a doutrina da Proteção Civil' (Caldeira, 2003: 21).

O sentimento dominante na época era de grande desconfiança perante o novel serviço, no quadro do ambiente criado pelos catastróficos incêndios de 2003.

"Bombeiros estão a passar dificuldades como nunca sentiram [...] A LBP reivindicou junto do Ministro da Administração Interna uma 
nova lei orgânica que não se circunscreve ao SNBPC, um serviço que foi criado por um erro politico. A Liga quer também uma central integrada de coordenação entre as várias estruturas de socorro e quer estruturas permanentes de bombeiros que atuam nas populaçóes entre as $8 \mathrm{~h}$ e as 20 h, um periodo crítico durante o qual há dificuldade de garantir o socorro em algumas zonas do território" (Bombeiros de Portugal, s/autor, n. ${ }^{\circ}$ 216/2004:24).

Por outro lado, merece relevo o "equívoco semântico" da designação do novo serviço, dando-se a entender que os Bombeiros é que continham a Proteção Civil e não o contrário, ou seja, os bombeiros estavam contidos na Proteção Civil como seu "braço armado" na filosofia da Lei de Bases. Este erro semântico, aliado a toda a "dramatizaçáo" que se seguiu aos fogos florestais do Verão de 2003, não permitiram um mínimo de serenidade à presidência do serviço pelo Engenheiro Maquinista Naval Leal Martins, substituído “com mágoa” pelo Major General Paiva Monteiro, em 9 de Setembro de 2003, no rescaldo da pior época de incêndios de sempre. No balanço de quatro meses de trabalho, nega a presença de "lobbies" no serviço, mas defende que é necessário clarificar e fiscalizar o sistema. "Preocupa-me a formação deficiente dos responsáveis pelas associaçôes humanitárias de bombeiros que dirigem as associaçóes. [...]. Outra das finalidades é dotar a ENB da vertente de proteção civil e isso demora o seu tempo. Não há ainda cultura de proteção civil e, porventura, formadores adequados" (Pena, 2005: 282).

Relativamente à sua posição sobre a profissionalização dos bombeiros, o General Paiva Monteiro refere em entrevista à Revista Alto Risco de Junho 2004, o seguinte:

"A minha permanência à frente do serviço permite-me dizer que o voluntariado é importante na prevenção e socorro, por isso, devemos incentivá-lo. A estrutura do voluntariado tem de ser apoiada por um núcleo permanente de bombeiros que deve ir a cursos, visto o voluntário não ter disponibilidade para frequentar essas açōes de formação. 
Temos auscultado diversas entidades, designadamente câmaras municipais, quanto à forma de atuação na captação de voluntários, não só para a área dos bombeiros, mas também da proteção civil, que é uma área para a qual, em situação de catástrofe, é importante ter bolsas de voluntariado. É importante que o serviço tenha uma referência com voluntários para determinadas áreas" (Monteiro, 2004:9-10).

QUADRO II - Diplomas confinantes com a problemática da Proteção Civil e Bombeiros.

TABLE II - Laws touching on the issue of Civil Protection and Firefighters

Decreto-Lein. ${ }^{\circ}$ 80/2004 de 10 deAbrilNa sequencia da aprovaçấo da Resoluçāo do Conselho de Ministros no. 178/2003, de 17 de novembro, que institui a reforma de setor florestal.

Decreto Regulamentar no 5/2004, de 21 de abril

\section{Decreto-Lei no 94/2004, de 22 de abril}

Portaria no 1524/2004 - Licenciatura em Proteçáo Civil -Do Ministério da Ciência, Inovação e Ensino Superior, publicada no Diário da República, $1^{\mathrm{a}}$ Série B, no 305 , de 31 de dezembro.
Criou a Direcção-Geral dos Recursos Florestais DGRF),sucessora nas atribuições da Direcção-Geral das Florestas e das direçóes regionais de agricultura, competindo-lhe, na qualidade de autoridade florestal nacional " promover o desenvolvimento sustentável dos recursos florestais $e$ dos espaços associados $e$, ainda, dos recursos cinegéticos $e$ aquicolas das águas interiores, através do conhecimento da sua evolução e fruição, garantindo a sua protecção, conservação e gestão e promovendo os equilibrios intersectoriais, a responsabilização dos diferentes agentes e uma adequada organizaçāo dos espaços florestais". (no 2 do art .2 do Decreto-Lei no 80/2004, de 10 de abril).

Criou a Agência para a Prevençấo de Incêndios Florestais. Trata-se de um serviço central (Direção Geral) de coordenação do Ministério da Agricultura, Desenvolvimento Rural e Pescas, " com a missáo de concertar estratégias, compatibilizar e orientar açôes concretas de prevenção e proteção da floresta contra incendios".

Alterou o Decreto-Lei no 179/99, de 21 de maio, que criou equipas de sapadores florestaise regulamenta asua atividade. Quatro anos de vigência do anterior diploma "evidenciaram deficiências e fragilidades que urge corrigir com a melhoria do desempenho das equipas existentes e do alargamento da respetiva constituição a outras entidades ". Esta é a intenção do legislador que assim altera alguns aspectos relacionados com a criação das equipas de sapadores florestais.

Aprovou o plano de estudos do curso bietápico de licenciatura em Proteção Civil, ministrado pela Escola Superior de Tecnologia do Mar de Peniche do Instituto Politécnico de Leiria, "cujo programa curricular foi articulado com o SNBPC". (Bombeiros de Portugal s/ autor, no 216, p.8). 
Seguiram-se períodos de grande instabilidade organizacional no SNBPC, com a sucessiva nomeação e demissão de responsáveis a que não era alheia a instabilidade política no quadro do XVI Governo Constitucional e uma enorme desorientaçâo no sector. Da legislação produzida, até à tomada de posse do XVII Governo Constitucional, em 12 de Março de 2005, merecem ainda destaque, para a problemática da Proteçáo Civil e Bombeiros, na nossa perspetiva, os seguintes diplomas:

Após a criação da primeira licenciatura em Proteção Civil, em 2004, pelo Estado, ainda em modelo bietápico, seguiram-se mais duas licenciaturas criadas, também, em estabelecimentos do ensino superior público, respetivamente na Escola Superior de Tecnologia e Gestão de Beja e na Escola Superior Agrária de Castelo Branco. Mais recentemente, foram criadas, em estabelecimentos superiores privados, mais duas licenciaturas em Proteção Civil, respetivamente no Instituto Superior de Educação e Ciências e no Instituto Superior de Línguas e Administração, ambas em Lisboa e uma licenciatura que, embora com outra designação - Segurança Comunitária - também se situa na área da Proteção Civil e é ministrada no Instituto Superior de Ciências da Informação e da Administração (ISCIA), em Aveiro.

Sem prejuízo da importância e necessidade de formação superior nesta área, "existem problemas transversais às várias instituiçôes que lecionam estas licenciaturas. Uma dessas situaçôes é a incapacidade da adequação das áreas de componente geral, tais como as físicas, químicas, matemáticas, entre outras, dos conteúdos à real atuação e intervenção da atividade de proteção civil. Embora exista uma abordagem a estas problemáticas não é nada concreto $e$ específico, acabando por criar uma certa lacuna que exige uma aprendizagem posterior e mesmo quase autodidata, para a qual nem todos os alunos estão despertos" (Carmo, 2008:24).

Por outro lado, não sendo fácil encontrar docentes com elevadas qualificaçôes académicas em proteção civil (por se tratar de uma área científica recente), o recurso sistemático aos técnicos e profissionais do sector (independentemente das competências detidas), tende a dar 
a esta formação um cunho, ainda, marcadamente, técnico-profissional. Finalmente, o problema atual é que os licenciados em Proteçáo Civil não estão a conseguir integrar-se socio profissionalmente, seja no Estado Central seja nos Serviços Municipais de Proteçáo Civil que entretanto não abrem vagas para o efeito, não obstante o caracter imperativo da organização de serviços Municipais de Proteção Civil, nos termos da Lei no 65/2007 de 12 de novembro.

Novo Ordenamento Jurídico, Funcional e Operacional, "dito estruturante", do Sistema de Proteçáo e Socorro (2005 - 2008)

Nova Lei de Bases da Proteçáo Civil - Lei 26/2007 de 3 de julho, alterada pela Lei Orgânica no 1/2011 de 30 de novembro e pela Lei $n^{\circ}$ 80/2015 de 3 de agosto.

Antes de mais importa dar relevo ao contexto sócio-político que deu origem ao aparecimento do novo ordenamento político materializado na nova Lei de Bases da Proteçáo Civil. Efetivamente no Capítulo da Segurança Interna do Programa do XVII Governo Constitucional, que entrou em funçóes em 12 de Março de 2005, pode ler-se:

"A prevenção e a minimização das consequências de catástrofes - naturais ou provocadas - como os grandes incêndios florestais ocorridos no Verão de 2003 ou, à escala internacional, o ataque terrorista às torres de Nova Iorque em 11 de Setembro de 2001 e o maremoto asiático de Dezembro de 2004, requerem a elaboração ou atualização de planos de emergência relativos a incêndios, cheias e abalos sísmicos. A planificação é essencial para evitar uma politica puramente reativa. A simulação de situaçōes de perigo, por seu lado, é indispensável para criar uma capacidade de resposta efetiva nas comunidades. 
A sensibilização de crianças e adolescentes para estes problemas, através de preleçóes e exercícios realizados nas escolas, afigura-se muito relevante. Para dar um cunho sistemático a tais açôes, será valorizado o Dia Nacional da Proteção Civil. Para coordenar estas atividades, é imperioso reabilitar a Proteçấo Civil, cometendo-lhe a missão de elaborar um Plano Nacional de Deteção, Aviso e Alerta de Catástrofes.

Os corpos de bombeiros, por seu turno, carecem de um aumento do nivel de profissionalização, de uma revisão do sistema de financiamento (que deve tornar-se mais transparente) e da aprovação de um plano de reequipamento. Por outro lado, torna-se necessário rever a legislação em vigor, de forma a introduzir ou atualizar as regras de construção antissísmica e zelar pela sua efetiva aplicação.

Ao nivel do sistema de proteção civil, é necessário reavaliar os termos da articulação entre a Proteção Civil e os Bombeiros, de forma a assegurar o reforço da coordenaçáo e da operacionalidade. Por outra parte, devem ser criados Serviços Distritais de Proteção Civil, vocacionados para a análise de riscos, o planeamento operacional e a informação das populaçôes. Para que os corpos de bombeiros voluntários e municipais possam desempenhar com proficiência a sua missão de prestação de primeiro socorro, proceder-se-á à progressiva profissionalização, no decurso desta legislatura, da respetiva estrutura de comando e serão criadas, em parceria com os municípios, equipas profissionalizadas de primeira intervenção. Será ainda consagrado o princípio da inter-operacionalidade dos meios, permitindo aos corpos de bombeiros a utilização, em cada caso, dos equipamentos situados mais perto da sua área de intervençāo.

A prevenção de incêndios florestais, pela sua vital importância para o Pais, até como fator de desenvolvimento rural, envolve hoje responsabilidades transversais a todo o Governo, às autarquias e aos cidadãos. Serão reforçados os mecanismos de prevenção de fogos florestais, potenciando-se a intervenção da Agência para a Prevenção de Incêndios Florestais (APIF) e melhorando-se a capacidade operacional de alguns instrumentos, de que são exemplo as equipas de sapadores florestais". 
O diagnóstico da situação estava, em boa medida bem feito, entretanto, contra todas as expectativas relativamente à política de prevenção de incêndios florestais, o governo ao contrário do anunciado no seu programa, pelo Decreto-Lei 69/2006, de 23 de Março, extinguiu a Agência para a Prevençâo de Incêndios Florestais (APIF), entidade criada pelo Decreto Regulamentar n. ${ }^{\circ} 5 / 2004$, que constituiu uma verdadeira "lufada de ar fresco" no mar de "interesses" e "modismos" da política de gestão florestal vigente. A extinção da APIF, organizaçáo que era gerida pelo Professor Luciano Lourenço, figura incontornável do estudo técnico-científico da problemática da prevenção dos incêndios florestais, mereceu em 24/10/05, um requerimento entregue na Assembleia da República pelo deputado do partido ecologista "os Verdes", José Luís Ferreira, sustentando que "a APIF apesar de ter sido criada há pouco mais de um ano, tem um papel fundamental na compatibilização das intervençôes a nivel central e local no âmbito da prevenção e proteção da floresta contra incêndios. A triste realidade dos incêndios em Portugal comprova a inegável importância da APIF, no sentido de assegurar os necessários mecanismos de prevenção de incêndios. Todas as estratégias implementadas com o objetivo de pôr um ponto final definitivo neste drama sazonal são poucas", frisa o parlamentar no seu requerimento (Diário de Noticias, 24/10/05). Ficava assim provado, na perspetiva deste parlamentar, que a cultura da prevenção, tardia em impor-se como um dos pilares fundamentais da problemática da política de organização e gestão florestal.

Vejamos, de seguida, a legislação "dita estruturante" ou "revolução tranquila" dos Sistema de Proteção e Socorro que se inicia com a Nova Lei de Bases de Proteçấo Civil - Lei 27/2006, de 3 de Julho, alterada pela Lei Orgânica no 1/2011 de 30 de novembro (1º alteração) e pela Lei 80/2015 de 3 de agosto.

Esta nova Lei promoveu uma profunda alteração no sistema. Desde logo, porque provocou uma clarificação das estruturas política (competências do Ministro da Administração Interna, Governadores Civis e Presidentes de Câmara) e operacional, definindo-se a forma de participação e articulaçáo dos agentes de proteção civil e as obrigaçóes de colaboração de entidades agregadas. Por outro lado determinou quem declara as situaçóes de, alerta, contingência e calamidade 
e em que circunstâncias (art. ${ }^{\circ} 9^{\circ}$ ). Definiu os conceitos de acidente grave e de catástrofe $\left(\right.$ art. $\left.^{\circ} 3^{\circ}\right)$. Todavia, no seu extenso articulado, não se encontra claramente expresso o conceito de análise de risco, como metodologia de trabalho a "institucionalizar" o que consideramos uma séria limitação à dinâmica de gestâo de riscos em proteçấo civil. Relativamente à $1^{\circ}$ alteração da Lei de Bases pela Lei orgânica 1/2011, o seu enfoque recai sobretudo na clarificação das competências do comando operacional distrital não só na declaração do estado de alerta mas também na comissão distrital de Proteção Civil e ainda a capacidade de delegaçáo do Presidente da ANPC nos comandantes distritais quanto ao desencadear das açôes de Proteçâo Civil de prevenção, socorro, assistência e reabilitaçáo. Particularmente relevante é a $2^{\text {a }}$ alteraçáo à Lei de Bases através da Lei 80/2015 de 3 de agosto, importante pela necessidade de clarificar a responsabilidade pública ao nível distrital do sistema, na sequência da extinção dos governadores Civis. Neste sentido, o no 1 do art. ${ }^{o} 34$ refere que: "[...] compete ao membro do governo responsável pela Proteção Civil, no âmbito distrital, desencadear na iminência ou ocorrência de acidente grave ou catástrofe, as açôes de Proteção Civil de prevenção, socorro, assistência e reabilitação adequadas a cada caso, com a coadjuvação de Comandante Operacional Distrital e a colaboração dos agentes de Proteção Civil competentes, nos termos legais". E no no 2 do mesmo artigo considera-se: "O membro do Governo responsável pela área da Proteção Civil pode designar a entidade em que se delega competência para o exercício, a nivel distrital, das atribuiçōes da matéria de Proteção Civil".

Não se percebe a que entidade o legislador se refere, na qual o membro da Governo delega as suas competências a nível distrital.

No artigo $38^{\circ}$, prevê-se a existência em cada distrito de uma comissão distrital de Proteção Civil. No domínio da composição o diploma dispóe que integram esta Comissão "Três Presidentes de câmaras municipais, designados pela Associação Nacional dos Municípios Portugueses, sendo designados, entre eles, um que preside".

De qualquer modo, esta $2^{a}$ alteração à Lei de Bases não só continua a desvalorizar o nível municipal mantendo o refém do nível distrital que não é mais do que o desdobramento do nível nacional, como ignorou o preceituado da Lei 75/2013 de 12 de setembro na valorizaçâo das autarquias locais e entida- 
des intermunicipais ao nível da Proteção Civil. Neste sentido, é indispensável reequacionar a organização territorial e administrativa, dando efetiva consequência ao principio da subsidiariedade. Ora, perante uma qualquer situação de emergência a estrutura de resposta mais adequada para intervir em primeiro lugar é o municipal, tendo em conta, não só o conhecimento que tem da realidade local, a capacidade de análise imediata da situação e a proximidade dos meios de socorro.

Por isso, cada município devia estar dotado de um conjunto mínimo de estruturas, meios e recursos apropriados aos riscos em presença no território municipal, atribuindo-se aos Serviços Municipais de Proteção Civil, não só identificar e analisar os riscos mas também manter a adequada preparação na resposta à manifestação dos riscos.

Por outro lado, a Lei 80/2015 substitui, na composiçẫo da comissão municipal de Proteçâo Civil, o comandante operacional municipal pelo coordenador municipal de Proteção Civil, tornando imperativo a revisão e regulamentaçáo da Lei no 65/2007 de 12 de novembro. A revisão da referida Lei poderá constitui uma oportunidade para, no quadro da Lei de Bases, reforçar os poderes dos municípios, clarificar os efetivos poderes do Coordenador Municipal de Proteção Civil, e delinear e estruturação dos respetivos serviços municipais, em especial quanto á dotação dos mesmos com quadros técnicos qualificados para desempenho integrado das suas competências.

Em síntese, a nosso ver este diploma foi muito importante quanto:

a) À clarificação e simplificação dos atos de declaração da situação de alerta, contingência e calamidade (artigo 17, 21, 26 e 27 da Lei)

b) À obrigação de todas as entidades, com competências na área do risco, comunicarem à ANPC "as informaçôes provenientes dos sistemas de que são detentoras".

c) Ao reconhecimento legal das pessoas coletivas sem fins lucrativos, de voluntariado de Proteção Civil, como entidades com deveres de cooperação, nos termos a definir por portaria específica do membro do Governo responsável pela área da Proteçáo Civil (artigo 46º A) e clarifica os critérios dos Planos de Emergência. 
Sistema Integrado de Operaçóes e Socorro (SIOPS) - Decreto-Lei 134/2006, de 25 de Julho, publicado, no DR, 1. a Série, n. ${ }^{\circ} 142$, de 25 de Julho, alterado pelo Decreto-lei no 114/2011, de 30 de novembro e pelo Decreto-Lei no $72 / 2013$, de 31 de maio.

As ações de socorro integradas numa operação de proteção civil podem envolver agentes e serviços que advêm de diferentes organismos do Estado, das regióes autónomas, das autarquias locais e das organizaçóes não-governamentais, entre outros.

Foi neste quadro que se definiu o SIOPS, criado pelo Decreto-Lei n. ${ }^{\circ} 134 / 2006$, de 25 de Julho, "como um conjunto de estruturas, normas e procedimentos de natureza permanente e conjuntural que assegurem que todos os agentes de proteçáo civil atuam, no plano operacional, articuladamente sob um comando único, sem prejuizo da respetiva dependência hierárquica e funcional".

Este sistema "visa responder a situaçôes de urgência ou de ocorrência de acidente grave ou catástrofe" (n. ${ }^{\circ} 2$ do art. ${ }^{\circ} 1^{\circ}$ ), situações em que o sistema nacional de proteção civil deve ser ativado, constituindo um instrumento global e centralizado de coordenação e comando de operaçóes de socorro, ainda que a sua execução seja competência de diversas entidades não integradas na ANPC, mas que, operacionalmente, enquadram o SIOPS.

O princípio de comando único assenta nas duas dimensóes do sistema respetivamente Coordenação institucional e Comando operacional. A compreensão global do sistema, implica ainda o conhecimento da direção, coordenação e execução da política de proteção civil, com a inclusão lógica do Centro Municipal de Organização do Socorro (CMOS) na dependência do Coordenador Municipal de Proteção Civil.

Nesta perspetiva, para conseguir uma eficaz coordenação institucional, o SIOPS prevê a constituição de centros de coordenação operacional (CCO), que integram representantes das entidades, cuja intervenção se justifica em função de cada ocorrência em concreto.

Atualmente, os centros de coordenação são: 
- De âmbito nacional - Centro de Coordenação Operacional Nacional (CCON).

- De âmbito distrital - Centro de Coordenação Operacional Distrital (CCOD).

- De âmbito municipal - Centro de Coordenação Operacional Municipal (CCOM). Por outro lado, nos termos da $2^{a}$ alteração do SIOPS pelo Decreto-Lei no 72/2013, o modelo da organização da ANPC evoluiu operacionalmente da lógica distrital para uma organização apoiada numa lógica de agrupamento distrital, consagrando-se cinco novos agrupamentos de distritos reactivamente Norte, Centro Norte, Centro Sul, Sul e Algarve. Para uma visão global do sistema de coordenação sistemática e operacional (fig. 1).

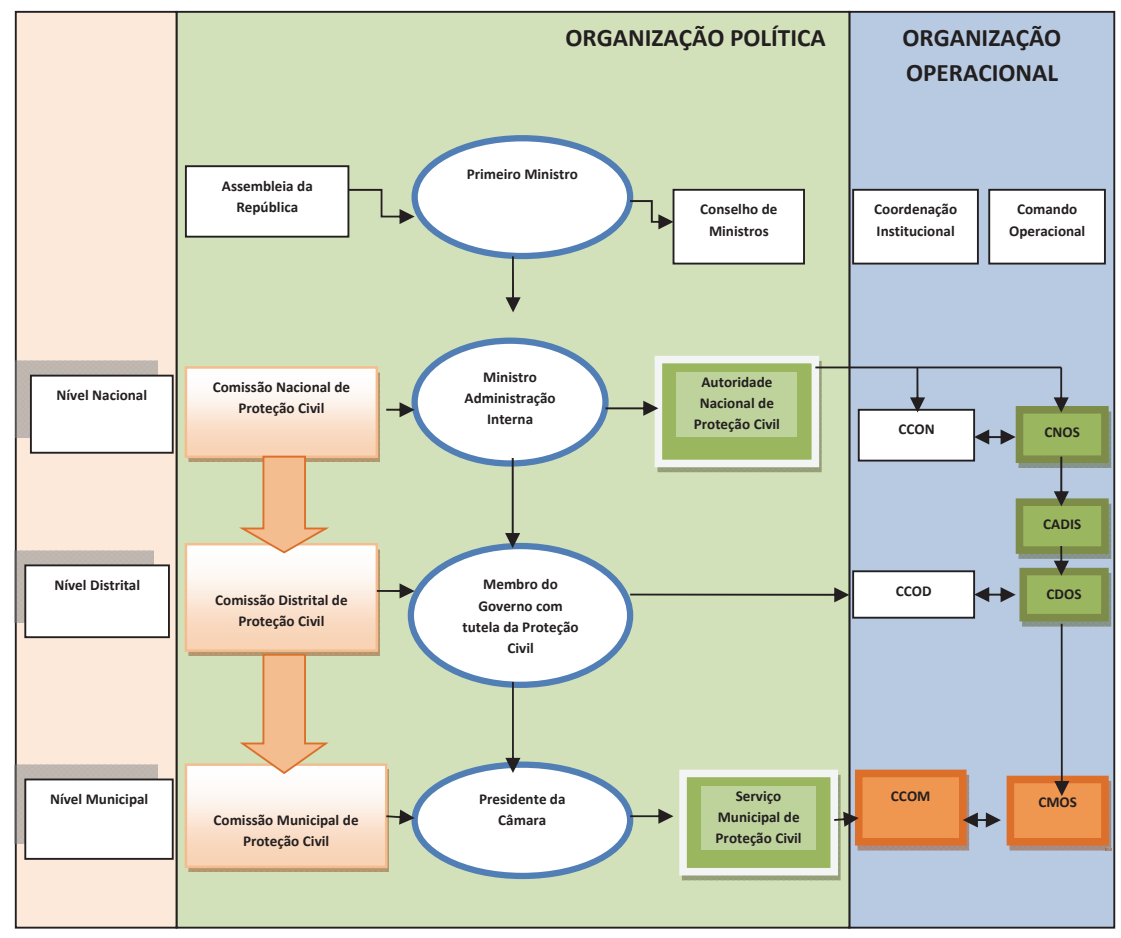

Fig. 1 - Organização política e operacional da Proteção Civil.

Fig. 1 - Political and operational organization of Civil Protection. 
No regulamento de funcionamento dos CCON e CCOD, aprovado pela Comissão Nacional de Proteção Civil (CNPC), estão previstas as formas de mobilização e de articulação entre as entidades integrantes, as relaçôes operacionais com o Comando Nacional de Operaçôes de Socorro (CNOS) e com os Comandos Distritais de Operaçóes e Socorro (CDOS), bem como a recolha e articulação da informação necessária à componente operacional.

Os CCO, Nacional e Distrital, asseguram, nos termos do no 2 dos artigos 3..$^{\circ}$ e $4 .^{\circ}$ do Decreto de Lei no 72/2013 (20 alteração do SIOPS), que todas as entidades e instituiçóes aí referidas, se articulam entre si, garantindo os meios considerados adequados à gestáo da ocorrência em cada caso concreto

Estas estruturas têm as seguintes atribuiçôes genéricas:

- Assegurar a coordenação dos recursos e do apoio logístico das operaçóes de socorro, emergência e assistência;

- Proceder à recolha de informação estratégica, relevante para as missóes de proteção e socorro e proceder à sua gestão;

- Recolher e divulgar informaçóes de carácter estratégico essencial à componente de comando operacional tático;

- Informar permanentemente a autoridade política respetiva, de todos os factos relevantes que possam gerar problemas ou estrangulamentos no âmbito da resposta operacional;

- Garantir a gestáo e acompanhar todas as ocorrências, assegurando uma resposta adequada, no âmbito do SIOPS.

Ao nível da gestão de operações, todas as instituições representadas nos centros de coordenaçáo operacional dispóem de estruturas de intervenção com direçâo e comando próprios, competindo, no entanto, à ANPC assegurar o Comando Operacional Integrado de todos os corpos de bombeiros, de acordo com o previsto no seu regime jurídico.

Nos termos do artigo 6. ${ }^{\circ}$ do SIOPS, o comando das operaçóes de socorro desempenhado pela ANPC é assegurado pelo CNOS que dispóe de um Comando Operacional Nacional, de um 2. ${ }^{\circ}$ Comandante Operacional Nacional e dos dois adjuntos de operaçôes e informaçôes e a célula de logística. Dispôe ainda 
de células de planeamento de operaçóes logística, gestâo de meios aéreos e de comunicaçóes, replicando-se esta estrutura para o nível distrital e municipal, com adaptaçóes determinadas no SIOPS.

Ao nível da gestáo de operaçóes propriamente dito, no Capítulo IV do diploma de criação do SIOPS (art. ${ }^{0} 12$ a 25) está estabelecido um sistema de gestão de operaçōes (SGO) onde se define a organização dos teatros de operaçōes (TO), dos postos de comando, clarificando-se competências e a doutrina operacional.

Ao nível da definiçấo, o SGO é um esquema de organização operacional que se desenvolve de forma modular, de acordo com a importância e o tipo de ocorrência.

Sempre que uma força de socorro de uma qualquer das entidades que integra o SIOPS seja acionada para uma ocorrência, o chefe da primeira força a chegar ao local assume o comando da operação e garante a construção de um sistema evolutivo de comando e controlo da operaçáo. Este comandante das operaçốes de socorro deve tomar a decisão de desenvolvimento da organizaçáo sempre que os meios disponíveis no ataque inicial e respetivos esforços se mostrem insuficientes.

Nos termos do artigo $13 .^{\circ}$ do SIOPS, o SGO configura-se nos níveis estratégicos, tático e de manobra.

No nível estratégico, n. ${ }^{\circ} 2$ do art. ${ }^{\circ} 13$ do SIOPS, assegura-se a gestão da operação, que inclui:

- "A determinação da estratégia apropriada;

- O estabelecimento dos objetivos gerais da operaçáo;

- A definição de prioridades;

- A elaboração e atualização do plano estratégico de ação;

- A receção e colocação de meios de reforço;

- A previsáa e planeamento de resultados;

- A fixação de objetivos a nível tático".

No local da ocorrência, o órgão diretor das operaçôes é o posto de comando operacional (PCO) e destina-se a apoiar o responsável das operaçóes na preparação das decisóes e na articulação dos meios no teatro de operaçóes.

O PCO, nos termos do art. ${ }^{\circ} 15$ do SIOPS, tem como missóes genéricas: 
- "A recolha e o tratamento operacional das informaçóes;

- A preparação das açōes a desenvolver;

- A formulação e a transmissão de ordens, diretrizes e pedidos;

- O controlo da execuçáo das ordens;

- A manutenção das capacidades operacionais dos meios empregues;

- A gestão dos meios de reserva”.

O Posto de Comando Operacional é constituído, nos termos do n. ${ }^{\circ} 1$ do art. ${ }^{\circ}$ 16, "pelas células de planeamento, combate e logística, cada uma com seu responsável e coordenadas pelo Comandante das Operaçôes de Socorro" (COS). Assessorando o COS existem ainda três oficiais, um como adjunto para a segurança, outro para as relaçóes públicas e outro para a ligação com outras entidades, ativando os recursos disponíveis e na adoção e coordenação de outras medidas que venham a ser oportunamente julgadas necessárias.

A gravidade da situaçáo e o grau de prontidão que esta exige dá origem a um diferente nível de alerta especial, graduado progressivamente entre os níveis azul, amarelo, laranja e vermelho.

As regras de ativação do estado de alerta especial são determinadas por diretiva operacional, devidamente aprovada pela comissão nacional de proteção civil (CNPC), nos termos do art.o 37 da LBPC, e a sua determinação é da competência exclusiva do CCON.

É ao CCON que compete a informação aos centros de coordenação operacional distritais (CCOD) sobre a ativação do estado de alerta especial, determinando as áreas abrangidas, tipo de situaçáo, gravidade, nível de prontidáo exigido e período de tempo em que se preveja especial incidência do fenómeno.

O dispositivo de resposta operacional é constituído por equipas de intervençáo permanente destinadas à intervenção prioritária em missóes de socorro e são dimensionadas de acordo com as competências e disponibilidades de cada um dos agentes de proteçấo civil (APC).

Para fazer face a determinadas ocorrências ou conjunto de ocorrências previsíveis ou verificadas, como seja o caso dos incêndios florestais, existem dois dispositivos, respetivamente, o dispositivo de Prevenção, Deteção, Vigilância e Fiscalização e o dispositivo especial de combate a incêndios florestais (DECIF). Este atua a dois níveis: ataque inicial e ataque ampliado. 
No primeiro caso, o ataque inicial configura uma primeira intervenção organizada e integrada, de resposta imediata a fogos nascentes, envolvendo equipas terrestres e meios aéreos com equipas helitransportada até o incêndio ser considerado resolvido (circunscrito) pelo comandante de operaçôes (COS), o que deverá suceder nos primeiros 90 minutos.

$\mathrm{O}$ ataque ampliado, inicia-se sempre que, chegado aos 90 minutos de incêndio, o mesmo não seja dado por circunscrito pelo COS, entrando em ação meios de reforço e outros agentes.

Ainda no domínio dos incêndios florestais as Forças Operacionais Conjuntas (FOCON) que constituem o socorro, organizam-se nos termos da diretiva operacional no 1/2008/ANPC, consoante as seguintes fases:

- Fase ALFA - (1 de Janeiro a 14 de Maio)

- Fase BRAVO - (15 de Maio a 30 de Junho)

- Fase CHARLIE - (1 de Julho a 30 de Setembro)

- Fase DELTA - (1 de Outubro a 15 de Outubro)

- Fase ECHO - (16 de Outubro a 31 de Dezembro)

Em síntese, vale a pena assinalar, mais uma vez, que a ligação entre os diferentes intervenientes do sistema de proteçấo e socorro obriga, necessariamente, a uma perfeita coordenação e entrosamento que garanta uma ação eficaz e uma rentabilidade adequada aos meios disponíveis, seja no domínio dos incêndios florestais, seja noutros domínios de riscos naturais e antrópicos.

Todavia, as experiências de anos anteriores e mormente dos anos críticos 2003 e 2005 mostraram quão difícil é de ser conseguida esta coordenação, sobretudo antes da instalaçấo de um posto de comando operacional conjunto (com forças de culturas organizacionais diferentes) que ainda não está instalado aquando da primeira intervenção, no período em que a coordenação referida é, a todos os títulos, essencial.

No entanto é justo salientar alguma melhoria ao nível organizacional global e designadamente, quanto ao sistema de comunicaçôes, de vigilância e deteção muito embora a violência dos incêndios de 2016 aí estejam para provar que pouco mudou neste domínio. 
Autoridade Nacional de Proteçấo Civil (ANPC) - Decreto-Lei n. ${ }^{0}$ 75/2007 de 29 de Março alterado pelo Decreto-Lei 73/2012 de 26 de março e pelo Decreto-Lei $\mathrm{n}^{\circ}$ 73/2013 de 31 de maio.

\section{Breve evoluçáo histórica do conceito de proteçáo civil.}

Sem prejuízo do que atrás já foi referido, importa salientar que, nos dias de hoje, a área de intervenção da Proteção Civil tem uma amplitude que vai muito para além daquela que esteve na sua génese, a Defesa Civil do Território (DCT) criada pelo Decreto-Lei no 31956 de 2 de abril de 1942, que tinha como objetivo principal assegurar o regular funcionamento, em tempo de guerra ou de grave emergência das atividades do país, ficando a cargo da Legião Portuguesa.

Nasce assim a defesa civil do território enquanto conceito e sistema, que surge de forma mais sólida em 1949, na Convenção de Genebra, como sistema de coordenação de açôes e respostas locais, nos termos do no 4 do artigo $66^{\circ}$ da Convenção de Genebra de 12 de agosto de 1949. Também nesta mesma convenção foi apresentada o distintivo internacional de defesa civil que consiste num triângulo equilátero azul em fundo cor de laranja utilizado para a proteção dos organismos de proteção civil que visavam a proteçấo das vítimas dos conflitos armados internacionais, suas instalaçôes, pessoal e material ou para a proteção dos abrigos civis e que ainda se mantém em vigor nos nossos dias como símbolo internacional da Proteçâo Civil. Encontra-se aliás definido no Protocolo Adicional às Convençôes de Genebra, de 12 de Agosto de 1949, relativo à Proteção das Vítimas dos Conflitos Armados Internacionais, de 8 de Junho de 1977, ratificado pelo Decreto do Presidente da República n. ${ }^{\circ}$ 10/92, de 1 de Abril. O n. 7 do mesmo artigo é definido que este símbolo pode ser utilizado em tempo de paz para identificar serviços e organizações de proteçâo civil. (fig.2)

Na sequência do 25 de abril de 1974, a Legião Portuguesa é extinta e com ela também a DCT sendo que é possível, assevera Caldeira (2003:16) que a sua "herdeira" devido às missôes desempenhadas foi o Serviço Nacional de 
Proteção Civil (SNPC), criado através do Decreto-Lei n. ${ }^{\circ} 78 / 75$ de 22 de fevereiro. Neste sentido, deixou de ser empregue o termo "defesa civil" e passa a ser utilizado o termo "proteção civil", com uma orientaçáo mais clara para a proteção contra acidentes e catástrofes naturais, fruto da diminuição do perigo militar sobre o território português.

Em 1991 é publicada a primeira Lei de Bases da Proteçáo Civil, Lei n. ${ }^{\circ}$ 113/91 de 29 de agosto, que sistematiza e estrutura a proteção civil. Depois, em 2003, é criado o Serviço Nacional de Bombeiros e Proteção Civil (SNBPC), Decreto-Lei n. 49/2003, de 25 de março, que substitui o SNPC e integra outros dois serviços que entretanto tinham sido criados com uma natureza semelhante, o Serviço Nacional de Bombeiros (SNB) e a Comissão Especializada em Fogos Florestais (CEFF), que tinham como missão, respetivamente, coordenar os corpos de bombeiros e o combate aos incêndios nas florestas. Por fim, em 2006, o SNBPC é reestruturado passando a designar-se Autoridade Nacional de Proteção Civil (ANPC), Decreto-Lei n. ${ }^{\circ}$ 203/2006 de 27 de outubro (fig.3).

\section{Novo modelo organizacional da ANPC}

É na sequência das alteraçôes "estruturais" atrás referenciadas, consubstanciadas na LBPC e no SIOPS, que surge a necessidade de alterar a estrutura do SNBPC, criando-se a Autoridade Nacional de Proteção Civil (ANPC). Esta nova entidade culmina um processo institucional evolutivo iniciado nos anos 80 .

A nova organização passou a contar desde logo com três novas Direções Nacionais de nível superior: uma Direção Nacional de Recursos de Proteção Civil, uma Direção Nacional de Planeamento de Emergência e uma Direçấo Nacional de Bombeiros, "[...] pretendendo-se cada vez mais prestigiar o papel dos bombeiros que passaram a ter uma dirȩão nacional que vai assumir daqui para a frente tudo o que tiver a ver com eles" (Cruz, 2007:32).

Ao nível legislativo, não pode deixar de reconhecer-se que este diploma respeita, "latu sensu", a especificidade dos bombeiros no quadro da proteção civil e trouxe alguma inovação ao nível institucional e operacional do 
Fig. 2 - Símbolo internacional da Proteção Civil.

Fig. 2 - International symbol of Civil Protection.

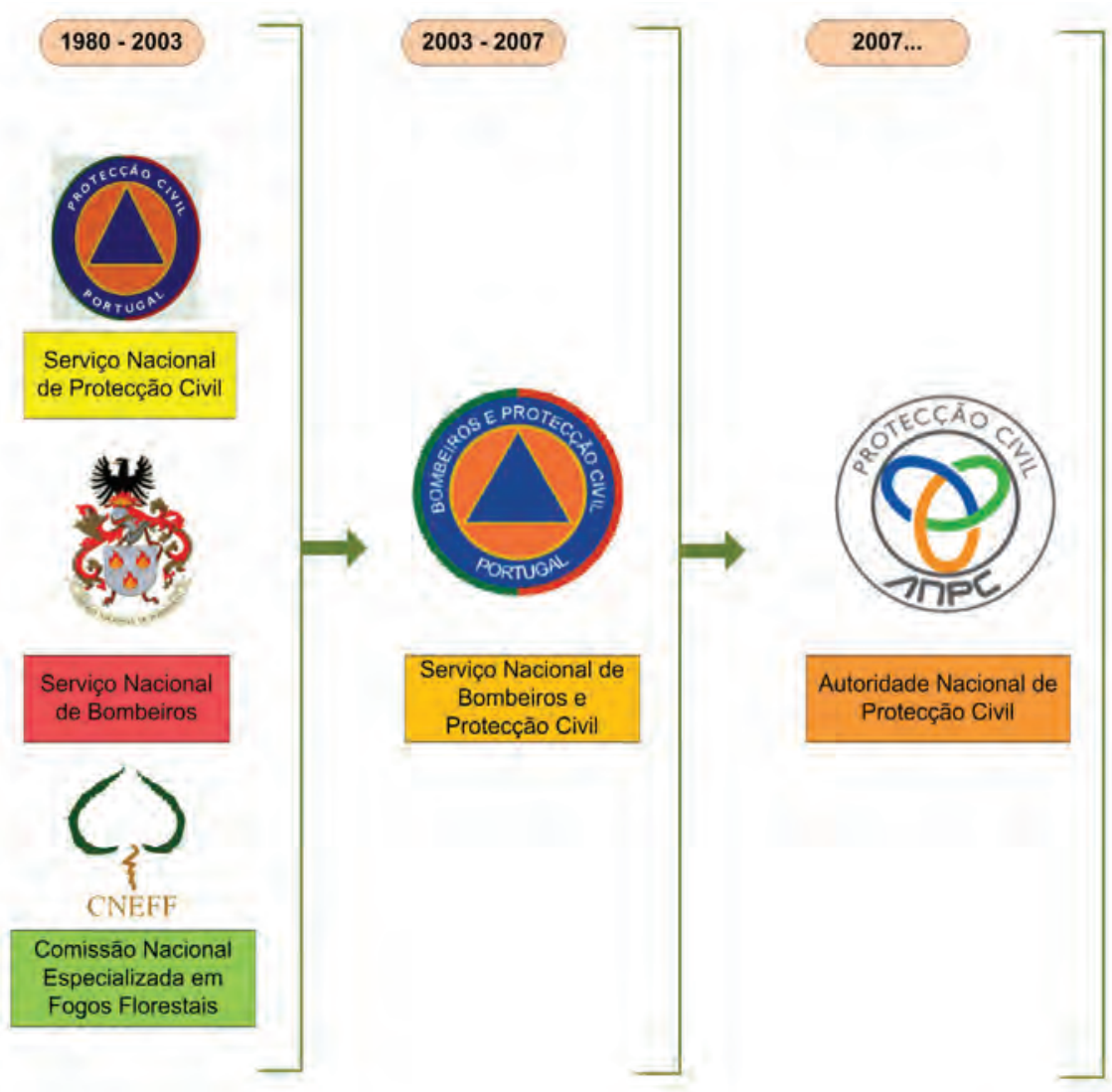

Fig. 3 - Evolução institucional da organização do socorro.

Fig. 3 - Institutional development of the organization of rescue services. 
sistema, cabendo-lhe planear, coordenar e executar a política de proteção civil, "designadamente na prevenção e reação a acidentes graves e catástrofes, de proteção e socorro das populaçóes e de superintendência da atividade dos bombeiros" (n. ${ }^{\circ} 1$ art. $^{\circ} 2 .^{\circ}$ ).

Mas é na $2^{a}$ alteração da ANPC pelo Decreto de Lei 73/2013 que se introduzem alteraçôes significativas ao modelo de organizaçáo interna da Autoridade, desde logo na criação de cinco Direçóes nacionais (ao invés das três anteriores) a citar:

- A Direção nacional do planeamento de emergência (que absorveu as atribuiçôes anteriormente cometidas ao Conselho Nacional de Planeamento Civil de Emergências).

- A Direção nacional de Bombeiros;

- A Direção nacional de recursos de proteção civil;

- A Direção nacional de meios aéreos (decorrente da extinção da Empresa de meios Aéreos, S.A (EMA) pelo Decreto-Lei no 57/2013.

- A Direção nacional de auditoria e fiscalização;

- Com vista a assegurar o comando operacional das operaçóes de socorro e onde o comando operacional integrado, a organizaçáo interna da ANPC compreende ainda:

- O comando nacional de operaçóes de socorro;

- Os agrupamentos distritais de operaçôes de socorro (decorrentes do modelo de passagem da lógica distrital para um modelo de lógica supra distrital);

- Os comandos distritais de operaçóes de socorro.

\section{Agentes de Proteçáo Civil. Atribuiçóes, Competências e Responsabilidades}

Nos termos do n. ${ }^{\circ} 2$ do art. ${ }^{\circ} 1 .^{\circ}$ da Lei n. ${ }^{\circ} 27 / 2006$, de 3 de Julho, "A atividade de proteção civil tem carácter permanente, multidisciplinar e plurissectorial, cabendo a todos os órgãos e departamentos da Administração Pública promover as condiçōes 
indispensáveis à sua execução, de forma descentralizada, sem prejuizo do apoio mútuo entre organismos e entidades do mesmo nivel ou proveniente de niveis superiores" .

Neste quadro, a necessidade de diversos agentes de proteção civil e socorro intervirem, complementando a sua intervenção e conjugando os seus esforços para a eficácia da operaçáo, obriga a que haja uma perfeita coordenaçáo de toda a ação de socorro num determinado teatro de operaçóes (TO).

Assim, abordaremos de seguida as estruturas e agentes do sistema de proteção civil com responsabilidades e competências no socorro, cabendo à Autoridade Nacional de Proteção Civil (ANPC) "um papel fundamental no âmbito do planeamento, coordenaçáa e execução da política de proteção civil" (Decreto-Lei n.o 75/2007 de 29 de Março).

Em situaçóes normais, consoante o tipo de acidente/emergência que lhes deu origem, as açóes de socorro podem dividir-se em cinco grandes grupos:

- Combate a incêndios;

- Urgência pré-hospitalar;

- Desencarceramento;

- Salvamento em grande ângulo;

- Socorro a náufragos e buscas subaquáticas.

A competência para o desempenho de cada uma destas missóes é atribuída especificamente, em função das respetivas características, designadamente:

- Combate a incêndios

- Corpos de Bombeiros;

- Grupo de Intervenção de Proteção e Socorro (GIPS) da Guarda Nacional Republicana (GNR) - neste caso, apenas, para o combate a incêndios florestais e em matérias perigosas.

- Urgência pré-hospitalar

- Instituto Nacional de Emergência Médica (INEM);

- Corpos de Bombeiros;

- Cruz Vermelha Portuguesa (CVP)

- Desencarceramento

- Corpos de Bombeiros 
- Salvamento em grande Ângulo

- Corpos de Bombeiros

- Socorro a Náufragos e buscas subaquáticas

- Autorida de Marítima

- Corpos de Bombeiros (apenas em operaçóes da terra para o mar, com cabos de vai-vem).

Ora a sobreposição de muitas destas competências obriga a uma coordenação eficaz e ao respeito pelas determinaçóes contidas no Sistema Integrado de Operaçôes de Proteção e Socorro (SIOPS), ou seja, nos termos do n. ${ }^{\circ} 3$ do

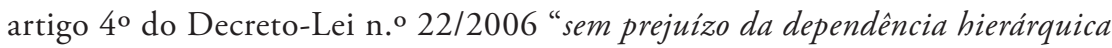
e funcional no quadro da GNR, o GIPS articula-se operacionalmente no comando único do sistema integrado de operaçôes e socorro".

Contudo, é sabido que nem sempre esta coordenação se faz da melhor forma, considerando que as instituiçóes em presença, Corpos de Bombeiros, GNR, INEM, CVP e Autoridade Marítima, possuem natureza, culturas institucionais, experiência, disciplina e estatutos diversos.

A Lei de Bases da Proteção Civil (LBPC), define, no seu artigo 46. ${ }^{\circ}$, como Agentes da Proteção Civil (APC) e de acordo com as suas atribuiçóes próprias:

- Corpos de Bombeiros;

- Forças de Segurança;

- Forças Armadas;

- Autoridades marítimas e aeronáutica;

- Instituto Nacional de Emergência Médica (INEM) e demais serviços de saúde;

- Sapadores florestais.

É ainda estabelecido no n. ${ }^{\circ} 2$ do citado artigo $46 .^{\circ}$ que a Cruz Vermelha Portuguesa (CVP) exerce, em cooperaçáo com os demais agentes e de harmonia com o seu estatuto próprio, funçóes de protecção civil nos domínios de:

- Intervenção;

- Apoio;

- Socorro;

- Assistência sanitaria e social. 
Para além dos agentes atrás referidos, como tendo competências específicas nas missões de socorro em situação de emergência, "impende especial dever de cooperação com os agentes de proteção civil sobre as seguintes entidades:

a) Associaçôes Humanitárias de Bombeiros Voluntários;

b) Serviços de Segurança;

c) Instituto Nacional de Medicina Legal;

d) Instituições de Segurança Social;

e) Instituiçóes com fins de socorro e de solidariedade;

f) Organismos responsveis pelas florestas, conservaçâo da natureza, indústria e energia, transportes, ,comunicaçöes, recursos hidricos e ambiente;

g) Serviços de segurança e socorro privativos das empresas publicas e privadas, dos portos e aeroportos" (Lei n. ${ }^{\circ}$ 27/2006, art. ${ }^{\circ} 46$ ).

De seguida seráo analisadas as competências nas missóes de socorro de cada um dos APC, com especial destaque para os CB's, deixando de fora desta análise os sapadores florestais, criados no âmbito do Decreto-Lei n. ${ }^{0}$ 38/2006 de 20 de Fevereiro, sem responsabilidades específicas no socorro das populaçóes. "Os sapadores florestais, independentemente da sua titularidade, intervêm na vigilância e na deteçâo, sob a coordenação da GNR, e nas açóes de ataque inicial a incêndios florestais, sob a coordenação do CDOS respetivo; a sua intervenção desencadear-se-á na dependência operacional do COS, [...] participando também em açôes de rescaldo e de vigilância ativa pós-rescaldo, desde que requisitados pelo COS”. (Diretiva Operacional n. ${ }^{\circ}$ 1/2008/ANPC, p. 26).

Em suma, estamos perante mais uma das situaçôes de difícil cooperação na intervenção, considerando que os agentes têm uma coordenação tripartida entre entidades com cultura, valores e práticas institucionais diferentes.

\section{Corpos de Bombeiros}

De harmonia com o novo regime jurídico, aplicável à constituição, organizaçáo, funcionamento e extinçáo dos corpos de bombeiros no território continental, aprovado pelo Decreto-Lei n. ${ }^{\circ}$ 247/2007, de 27 de 
Junho, "um corpo de bombeiros é uma unidade operacional, oficialmente homologada e tecnicamente organizada, preparada e equipada para o cabal exercicio das missóes".

A diversidade das missóes dos CB's, sejam eles profissionais ou voluntários, está descrita no artigo n. ${ }^{\circ}$ 3, do citado Decreto-Lei, como sendo:

a) Prevenção e o combate a incêndios;

b) Socorro às populações, em caso de incêndios, inundações, desabamentos e, de um modo geral, em todos os acidentes;

c) Socorro a náufragos e buscas subaquáticas;

d) Socorro e transporte de acidentados e doentes, incluindo a urgência pré-hospitalar, no âmbito do sistema integrado de emergência médica; e) Emissão, nos termos da lei, de pareceres técnicos em matéria de prevenção e segurança contra riscos de incêndio e outros sinistros;

f) Participação em outras atividades de proteção civil, no âmbito do exercício das funçôes específicas que lhe forem cometidas;

g) Exercício de atividades de formação e sensibilização, com especial incidência para a prevenção do risco de incêndio e acidentes junto das populaçóes;

h) Participação em outras açôes e o exercício de outras atividades, para as quais estejam tecnicamente preparados e se enquadrem nos seus fins específicos e nos fins das respetivas entidades detentoras;

i) Prestação de outros serviços previstos nos regulamentos internos e demais legislação aplicável.

Mais se assinala que o exercício "da atividade definida nas alineas a), b), c) $e$ e) do número anterior é exclusivo dos corpos de bombeiros e demais agentes de proteçâo civil". (n² do art. ${ }^{\circ} 3^{\circ}$ ).

Nos termos do artigo $5 .^{\circ}$, alíneas a) e b) do já citado Decreto-Lei n. ${ }^{\circ} 247$, "cada corpo de bombeiros tem a sua área de atuação definida pela ANPC, ouvido o Conselho Nacional de Bombeiros, de acordo com os seguintes princípios:

a) A área de atuação de cada corpo de bombeiros é correspondente à do município onde se insere, se for o único existente; 
b) Se existirem vários corpos de bombeiros voluntários no mesmo município, as diferentes áreas de atuação correspondem a uma parcela geográfica que coincide, obrigatoriamente, com uma ou mais freguesias contiguas.

Todavia, havendo no mesmo municipio um corpo de bombeiros profissional ou misto e um ou mais corpos de bombeiros voluntários, a responsabilidade de atuação prioritária e comando cabe ao corpo de bombeiros profissional ou, quando este não exista, ao corpo de bombeiros misto, sem prejuizo de eventual primeira intervenção de algum dos outros $C B$ 's da respetiva área de atuação, em benefício da rapidez e prontidão de socorro.

Em rigor, no n. 3 do artigo $4 .^{\circ}$ do Novo Regime Jurídico dos Corpos de Bombeiros alterado pela Lei no 48/2009 de 4 de agosto e pelo Decreto-Lei no 249/2012 de 21 de novembro, assinala-se que "a criação e extinção dos corpos de bombeiros devem resultar de uma ponderação técnica dos riscos, dos tempos de atuação na área a proteger e das condiçóes humanas, técnicas e operacionais disponiveis nos corpos de bombeiros existentes e sua articulação na correspondente área municipal'.

Por outro lado, conjugando o teor do n. 5 e 6 do citado artigo $4 .^{\circ}$, conclui-se que o parecer do Município "relativo à criação dos corpos de bombeiros, quando negativo, é vinculativo", o que nos reconduz à ideia chave de que é na análise, cientificamente comprovada, do risco municipal que deve fundamentar-se a criação, extinção ou adequação dos corpos de bombeiros.

Em suma, parece-nos óbvio que uma análise séria de âmbito nacional, centrada na avaliação técnico-científica dos riscos municipais, irá certamente modificar a atual distribuição dos recursos humanos e materiais afetos ao dispositivo de socorro. Contudo, porque tal análise/avaliação iria incomodar decisores políticos, locais e nacionais, destas matérias, vai-se adiando a verdadeira reforma.

Embora não sejam objeto de análise neste trabalho, vale a pena assinalar que os Corpos de Bombeiros privativos pertencem a uma pessoa coletiva privada que, por razóes da sua atividade ou património, tem necessidade de criar em manter um corpo profissional de bombeiros para auto proteção. A sua área de atuação restringe-se aos limites da propriedade da entidade detentora, podendo atuar fora dela por requisiçáo do Presidente da Câmara do respetivo município ou da ANPC. 
Esta $2^{\text {a }}$ alteração ao regime Jurídico dos deveres, direitos e regalias dos bombeiros portugueses, a que atrás aludimos, veio clarificar por um lado as obrigaçôes do "estatuto social do bombeiro" mas, por outro, introduzir algumas alteraçóes pertinentes para melhorar a dinâmica dos corpos de bombeiros como sejam:

- Permitir a possibilidade de um bombeiro do quadro de reserva de um Corpo de Bombeiros poder transferir-se para o corpo ativo de outro Corpo de Bombeiros;

- A criação da carreira de bombeiro especialista vocacionada para áreas funcionais específicas;

- A introduçấo da carta de missão para o comandante no inicio de cada comissão de cinco anos, o que constitui uma mais valia considerando a curta validade da função de comandante.

- Implementação de um sistema de acompanhamento de saúde dos bombeiros, a cargo da Liga dos Bombeiros Portugueses.

Finalmente, importa referenciar vária legislaçáo relativa aos oficiais bombeiros como seja:

O Despacho no 9915/2008 que define as tipologias das funçôes dos oficiais; o Decreto-Lei 249/2012 que regulamenta o bombeiro especialista, o Despacho no 363/2012 que regulamenta as carreiras de oficial de bombeiro e de comandante voluntário e o Despacho 4205-B/2014 que volta a regulamentar num só normativo as carreiras de bombeiro voluntário, especialista e oficial bombeiro.

Todo este legislativo é pertinente e importante, muito embora o setor dos bombeiros continua a caracterizar-se por um forte heterogeneidade, quer ao nivel da gestão das Associaçôes Humanitárias que suportam os CBs, quer ao nivel operacional, co fragilidades ao nivel da formação e da saúde operacional. No entanto, a base do socorro em Portugal, sob os auspicios da ANPC, continua a assentar nos 412 CBs de matriz Associativa, 26 CBs Municipais e 6 CBs sapadores respetivamente em Lisboa, Porto, Braga, Coimbra, Setúbal e Vila Nova de Gaia, sem prejuizo da especificidade dos CBs sapadores de isboa e Porto na sua ligação com a ANPC. 
Estrutura de comando dos Corpos de Bombeiros: diferenciaçáo entre Profissionais e Voluntários

Nos termos da alínea c) do artigo 7.0 do Decreto-Lei 247/2007 "os corpos de bombeiros profissionais detêm uma estrutura que pode compreender a existência de regimentos, batalhöes, companhias ou seç̧ôes, ou pelo menos de uma destas unidades".

Diferentemente, dos corpos de bombeiros mistos e voluntários, como adiante veremos, os elementos que compóem estes corpos de bombeiros profissionais integram apenas dois tipos de quadro: o quadro de comando e o quadro activo, que também existem nos CB's Voluntários. Nos CB's organizados em regimentos e batalhôes existe ainda a seguinte estrutura organizativa interna:

- O comando;

- A secção técnica;

- A companhia de instrução;

- As companhias operacionais;

- Os serviços logísticos.

Nos corpos de bombeiros voluntários ou mistos a estrutura de comando é composta por:

- Comandante;

- $2^{\circ}$ Comandante;

- Adjuntos de Comando.

Por outro lado, a estrutura operacional do corpo de bombeiros voluntários, compreende, nos termos do artigo 4. ${ }^{\circ}$ do Despacho no 20915/2008, de 11 de Agosto, as seguintes unidades (fig. 4):

- Companhia;

- Seç̧ão;

- Brigada;

- Equipa.

Por outro lado, os bombeiros profissionais integrados em CB's sapadores (seis no País), são enquadrados no quadro do respetivo município, na qualidade de corpo especial da função pública. Já os restantes CB’s municipais (atualmente 
26) são enquadrados no quadro do respetivo município na qualidade de bombeiros funcionários municipais.

Quanto ao provimento das estruturas de comando nos corpos de bombeiros profissionais da administraçáo local, o provimento do comandante, nos termos do n. 2 do artigo 7. ${ }^{\circ}$ do Decreto-Lei n. ${ }^{\circ}$ 106/2002, de 13 de Abril, "é feito por concurso de entre indivíduos licenciados com experiência de, pelo menos, quatro anos na área da proteção e do socorro e no exercício da função de comando ou de chefia", ou por escolha e nomeação do respetivo Presidente da Câmara, em regime de comissão de serviço, por cinco anos, renovável, sem prejuízo do disposto no n. ${ }^{\circ} 3$ do artigo 7.o do citado Decreto-Lei 106/2002.

O método de seleçáo para os comandos e adjuntos técnicos das companhias segue os padrôes normais do regime geral de recrutamento e seleçáo de pessoal para os quadros da administraçáo local, nos termos, do n. ${ }^{\circ} 4$ do artigo $7 .^{\circ}$ do já referenciado Decreto-Lei 106/2002.

Quanto ao provimento da Estrutura de Comando nos Corpos de Bombeiros Voluntários ou Mistos não pertencentes ao Município, o comandante é nomeado pela entidade detentora do $\mathrm{CB}$, de entre indivíduos com idades compreendidas entre os 25 e os 60 anos e "preferencialmente de entre os oficiais bombeiros ou, na sua falta ou por razóes devidamente fundamentadas, de entre bombeiros da categoria mais elevada, habilitados com o $12 .^{\circ}$ ano ou equivalente, pelo menos, $e$ cinco anos de atividade nos quadros do CB" (alínea a) do art. ${ }^{\circ} 32$ do Decreto-Lei no 241/2007, de 21 de Junho). A nomeação é feita por cinco anos, renovável, até ao limite máximo de 65 anos de idade (n. 2 art. ${ }^{\circ} 32$ ).

A Lei permite ainda que sejam nomeados indivíduos de reconhecido mérito no desempenho de anteriores funçôes de liderança ou comando. "Contudo, a nomeação destes outros elementos não pertencentes à carreira de oficial bombeiro deve ser precedida de avaliação destinada a aferir as capacidades físicas e psicotécnicas dos candidatos, bem como a aprovação em curso de formaçâa, nos termos de regulamento a aprovar pela ANPC" (n. 3 do art. ${ }^{\circ}$ 32). O 2. ${ }^{\circ}$ Comandante e os Adjuntos de Comando são também nomeados pela Direção da Associação, sob proposta do comandante, observando-se idênticos critérios de recrutamento. 
Nos corpos de bombeiros voluntários o novo regime jurídico (Decreto-Lei n. ${ }^{\circ} 247 / 2007$ ) alterado pelo Decreto-Lei ${ }^{\circ}$ 243/2012, assinala no seu artigo $9 .^{\circ}$ que os elementos que compóem os corpos de bombeiros voluntários ou mistos integram os seguintes quadros de pessoal:

a) Quadro de Comando - onde se inserem os elementos com poder e autoridade para comandar o respetivo corpo nas missóes que lhes estão conferidas.

b) Quadro ativo - onde se inserem os bombeiros aptos para a execução de missôes, normalmente integrados em equipas operacionais.

c) Quadro de reserva - onde se inserem os bombeiros que atingiram o limite de idade para permanecer na respetiva categoria (60 e 65 anos, respetivamente, para o quadro ativo e quadro de comando) ou que, "não podendo permanecer nos restantes quadros por motivos profissionais ou pessoais, o requeiram e obtenham aprovação do comandante do CB".

d) Quadro de honra - onde se inserem os elementos que durante longo período de tempo serviram com zelo, dedicação, disponibilidade e abnegação, sem qualquer punição disciplinar, o seu corpo de bombeiros ou que adquiriam doença ou incapacidade ocorridas em serviço.

Por ultimo i8mporta referenciar que, nos termos do atual regime juridico, consoante o número de elementos integrantes dos corpos de bombeiros voluntários ou mistos, define as seguintes tipologias:

Tipo 4 - até 60 elementos;

Tipo 3 - até 90 elementos;

Tipo 2 - até 120 elementos;

Tipo 1 - superior a 120 elementos.

O Comandante dirige o corpo de bombeiros "e é o primeiro responsável pelo desempenho do corpo e dos seus elementos, no cumprimento das missóes que the são cometidas" (n. ${ }^{\circ} 2$ do art. $^{\circ} 12$ do Decreto-Lei 247/007), sendo coadjuvado pelo 2. ${ }^{\circ}$ Comandante que o substitui nos seus impedimentos e pelos adjuntos de comando, cujo número varia em função da tipologia do respetivo corpo de bombeiros.

Finalmente, importa assinalar que os elementos da Força Especial de Bombeiros (FEB) estrutura diretamente dependente da ANPC são recrutados 
nos BCs mistos e Voluntários sendo que o que distingue os Canarinhos dos restantes Bombeiros Voluntários é a disponibilidade permanente, a qualidade da formação e a remuneração.

\section{Forças de Segurança (PSP e GNR)}

Nos termos do teor preambular do SIOPS, citado pelo Decreto-lei n. ${ }^{\circ}$ 134/2006, de 25 de Julho, “todos os agentes de proteção civil atuam no plano operacional, articulamente sob um comando único, sem prejuizo da respetiva dependência hierárquica e funcional'. Assim, quer a GNR, quer a PSP, enquanto agentes de proteção civil, cumprem todas as missóes que legalmente lhe são atribuídas, de acordo com diretivas operacionais próprias, sendo a sua colaboração requerida pela ANPC " $\mathrm{d}$ e acordo com os planos de envolvimento aprovados ou quando a gravidade da situação assim o exija, mas sempre enquadrada pelos respetivos Comandos e legislação específica" (ANPC, 2008: 22).

Por outro lado, durante os períodos críticos, a GNR e a PSP (neste caso, a pedido da autoridade competente e na sua área de competência territorial) exercem missóes de condicionamento de acesso, circulação e permanência de pessoas e bens no interior de zonas críticas, bem como missóes de fiscalização sobre o uso de fogo, queima de sobrantes, realização de fogueiras e a utilização de foguetes ou outros artefactos pirotécnicos.

Finalmente, a pedido do CODIS ou do COS (Comandante das Operaçóes de Socorro) exercem missóes de:

- "Isolamento de áreas em zonas e periodos críticos;

- Abertura de corredores de emergência para as forças de socorro;

- Escolta e segurança de meios dos bombeiros no TO (teatro de operaçóes) ou em deslocamento para operaçóes;

- Apoio à evacuação de populaçôes em perigo" (Diretiva Operacional, 2008:23).

À GNR compete ainda a coordenação de açôes de prevenção, vigilância, deteção e fiscalização da floresta, disponibilizando informação permanente de apoio à decisão, ao CNOS e CDOS, através do seu oficial de ligação colocado naquelas estruturas. 
Importa salientar que, o papel da GNR no âmbito da Proteçấo Civil resulta largamente da sua Lei Orgânica, aprovada pelo Decreto- Lei no 63/2007 de 6 de novembro, que lhe atribui as seguintes competências nos termos das alíneas i) e g) dos nos. 2 e 3 do $\operatorname{art}^{\circ} \cdot 3^{\circ}$.

\begin{abstract}
"Proteger, socorrer e auxiliar os cidadãos e defender e preservar os bens que se encontrem em situaçóes de perigo, por causas provenientes da ação humana ou da natureza", e ainda, "Executar açôes de prevenção e de intervenção de primeira linha, em todo o território nacional, em situaçōes de emergência de proteção e socorro, designadamente nas ocorrências de incêndios florestais ou de matérias perigosas, catástrofes e acidentes graves".
\end{abstract}

Também o Regulamento Geral do Serviço da GNR (RGSGNR), aprovado pelo Despacho n. ${ }^{\circ} 10393 / 2010$ de 5 de maio, vem clarificar a missão atribuída à GNR, ao afirmar que as "tarefas [...] de proteção e socorro inserem-se na obrigatoriedade de prestaçāo de auxilio às pessoas em perigo, quer se encontrem isoladas, quer no caso de catástrofes naturais ou outras situaçóes que tal exijam, com especial incidência nas situaçôes de crise e que deve ser cumprida na generalidade por todas as Unidades Territoriais sob a coordenação técnica da Direção do Serviço de Proteção da Natureza e do Ambiente (SEPNA) [...] e em especial pelo Grupo de Intervenção, Proteção e Socorro (GIPS) da Unidade de Intervenção", nos termos do Decreto-lei n. ${ }^{\circ}$ 22/2006 de fevereiro de 2006.

É também na sequência da criação do GIPS que é consolidado o Serviço de Proteçấo da Natureza e do Ambiente e extinto o Corpo Nacional da Guarda Florestal (CNGF), da Direcção-Geral dos Recursos Florestais (DGRF) e como consequência o pessoal da carreira florestal foi transferido para a GNR, passando a integrar a estrutura do SEPNA. No mesmo diploma é atribuído ao SEPNA/GNR a competência para "[...] assegurar a coordenação ao nivel nacional da atividade de prevenção, vigilância e deteção [...]", bem como a "investigação das causas dos incêndios florestais, por manutenção das competências de autoridade florestal atribuida ao pessoal da carreira florestal". Neste quadro, este diploma é regulado por Portaria, que concretiza os termos 
em que se processa "[...] a prevenção, vigilância e deteção e investigação das causas de incêndios florestais [...], atribuindo em concreto esta competência à GNR/SEPNA, [...]". Cabe ainda, à GNR/SEPNA assegurar a alimentaçáo do Sistema de Gestão e Informação de Incêndios Florestais (SGIF), através da "garantia da atualização permanente da base de dados, nomeadamente no que respeita às localizaçôes, à cartografia das áreas ardidas, à sua quantificação e descrição e à investigação das respetivas causas, das quais dará conta em relatório anual a submeter à autoridade florestal nacional'.

Ainda, no mesmo contexto, é criado através do Decreto de lei n. ${ }^{\circ}$ 124/2006 de 28 de junho, republicado pelo DL n. ${ }^{\circ}$ 17/2009 de 14 de janeiro, o Sistema Nacional de Defesa da Floresta Contra Incêndios (SNDFCI), que assenta em três pilares (fig. 4):

1. Prevenção estrutural sob responsabilidade Autoridade Florestal Nacional (AFN);

2. Vigilância, deteção e fiscalização sob responsabilidade GNR;

3. Combate, rescaldo e vigilância pós-incêndio sob responsabilidade ANPC.

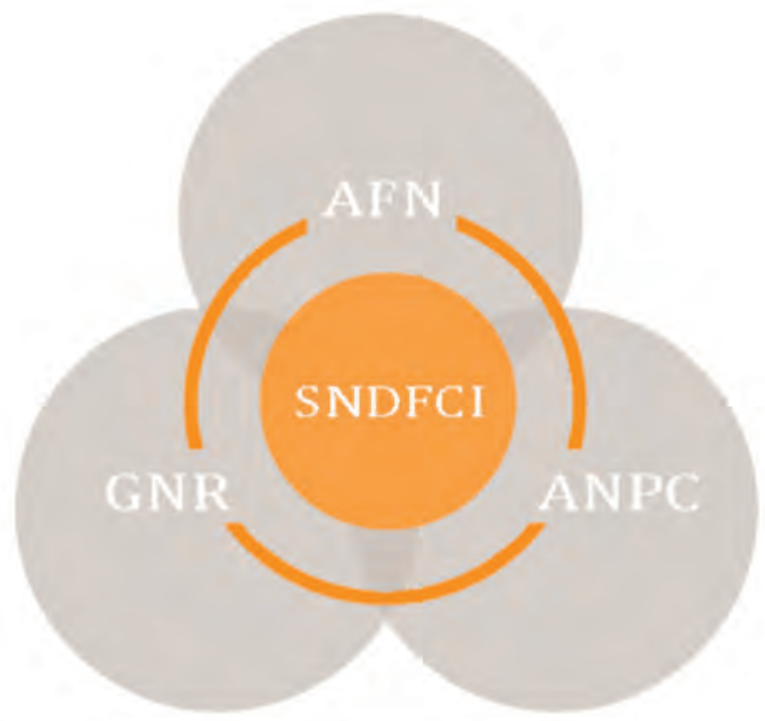

Fig. 4 - Entidades que intervêm nos pilares do SNDFCI (Fonte: (AFN, 2012).

Fig. 4 - Entities involved in the pillars of the SNDFCI (Source: (AFN, 2012). 
Finalmente o facto dos militares do GIPS terem uma dupla função, podendo assumir-se como órgão de polícia criminal, mas também detendo competência na proteção e socorro das populaçóes, a GNR constituiu-se como o único agente de Proteçấo Civil que intervém nos dois pilares da segurança "security" e "safety".

\section{As Forças Armadas, Autoridade Marítima e Aeronáutica}

As Forças Armadas (FA) colaboram com a proteção civil, nos termos dos artigos $52 .^{\circ}$ a $58 .^{\circ}$ da LBPC. Neste quadro jurídico, compete ao Presidentes de Câmaras Municipais solicitar ao Presidente da ANPC a participaçáo das FA em missóes de proteção civil nas respetivas áreas operacionais. Também, nos termos da $1^{\circ}$ alteração à Lei de Bases, Lei 1/2011, compete aos Comandantes Operacionais distritais solicitar ao Presidente de ANPC a participaçáo das Forças Armadas em funçóes de Proteçáo Civil nas respetivas áreas operacionais, sendo que, em casos de manifesta urgência, o podem fazer diretamente aos comandantes das unidades implantadas na área, informando disso mesmo o comandante operacional nacional.

Estas necessidades, após parecer do Comandante Operacional Nacional quanto ao tipo e dimensão da ajuda e definição de prioridades, são apresentadas ao Estado Maior General das Forças Armadas (EMGFA), ainda que a coordenação das açôes e meios das FA, ao nível do CNOS, seja feita através do seu oficial de ligação colocado em regime de permanência naquela estrutura. Em caso de manifesta urgência, a autorização de atuaçáo compete aos comandantes das unidades implantadas na área afetada para os efeitos solicitados.

Nos termos da Diretiva Operacional (1/2008) da ANPC e de acordo com os planos próprios e disponibilidade de recursos, as FA colaboram em ações de proteção civil com:

a) "Meios humanos e materiais para atividades de patrulhamento, vigilância e deteção, sob a coordenação da GNR, ataque inicial, rescaldo e vigilância ativa pós-incêndio;

b) Máquinas de Rasto para combate indireto a incêndios, defesa de aglomerados populacionais e apoio ao rescaldo; 
c) Apoio logístico às forças de combate em TO, nomeadamente infraestruturas, alimentação, água e combustivel;

d) Apoio à evacuação de populaçóes em perigo;

e) Disponibilização de infraestruturas para operação de meios aéreos, nacionais ou estrangeiros, apoio logistico e reabastecimento de aeronaves ao serviço da ANPC, quando exequivel e previamente coordenado;

f) Disponibilização de dois helicópteros Alouette III para a coordenação de operaçóes aéreas e transporte de pessoal;

g) Apoio à vigilância e deteção de incêndios quando da realização de missóes regulares das Forças Armadas.

h) Disponibilização de um Oficial de ligação ao CNOS e aos CDOS" (ANPC, 2008:23-24).

De forma a intervirem em determinadas operaçôes de apoio e socorro às populaçóes, estão definidos, os seguintes planos de operações:

- Plano de operações Lira: apoio do Exército na prevenção, deteção e eventual combate aos incêndios florestais e no abastecimento de água às populaçóes carenciadas;

- Plano de operaçóes Tejo: colaboração da Marinha nas zonas afetadas pelas cheias do rio Tejo;

- Plano de operaçóes Aluvião: apoio do Exército à estrutura de proteção civil em caso de eventuais situaçóes de cheias (Lopes, CPE-2007:2).

Nos termos do n. ${ }^{\circ} 1$ do art. ${ }^{\circ}$ 59, da Lei de Bases de Proteção Civil, "em situação de guerra e em estado de sitio ou estado de emergência, as atividades de proteção civil e o funcionamento do sistema instituido pela lei, subordinam-se ao disposto na Lei de Defesa Nacional e na Lei sobre o Regime do Estado de Sítio e do Estado de Emergência”.

Já quanto ao papel das Autoridades Marítima e Aeronáutica, no essencial, a colaboração da Autoridade Marítima no âmbito da Proteção Civil, "será requerida através do Centro de Coordenação de Busca e Salvamento Marítimo e dos seus órgáos locais (Capitanias dos Portos) na coordenação e georeferenciação das açôes de "scooping" dos aerotanques anfíbios para reabastecimento, em espaços jurisdicionais da Autoridade Maritima, de forma a garantir que estas decorram com segurança" (Diretiva Operacional, 2008: 24). 
Quanto às formas de colaboração da Autoridade Aeronáutica, a mesma cinge-se à cooperação contínua com a ANPC na avaliação, apoio técnico e controlo de manutenção das aeronaves do dispositivo da proteçáo civil, bem como no levantamento e determinação operacional dos pontos de "scooping" associados às aeronaves anfíbias e helicópteros.

Ambas as autoridades, disponibilizam, a pedido e sempre que a situação o justifique, um delegado para integrar cada um dos Centros da Coordenação Operacional Distrital ou participar em briefings do CDOS respetivo, no caso da Autoridade Marítima e no Centro de Coordenação Operacional Nacional e nos briefings do CNOS (Centro Nacional de Operaçóes de Socorro) no caso da Autoridade Aeronáutica.

\section{Instituto Nacional de Emergência Médica - Competências no Socorro Pré-Hospitalar}

Nos termos do Decreto-Lei n. ${ }^{\circ}$ 220/2007, de 29 de Maio, o Instituto Nacional de Emergência Médica (INEM) é o agente de proteçâo civil a quem cabe a função de coordenação do Sistema Integrado de Emergência Médica (SIEM), no quadro do qual se inclui toda a atividade de urgência/emergência, nomeadamente nos termos do $n .{ }^{\circ} 2$ do art. ${ }^{\circ} 3 .^{\circ}$ do Decreto-Lei n. ${ }^{\circ}$ 220/2007, o sistema de:

- "Socorro pré-hospitalar, nas suas vertentes, medicado e náo medicado;

- Transporte, receção hospitalar e a adequada referenciação do doente urgentelemergente;

- Referenciação e transporte de urgêncialemergência;

- Receçáo hospitalar e tratamento urgentelemergente;

- Formação em emergência médica;

- Planeamento civil e prevenção;

- Rede de telecomunicaçôes de emergência médica".

Para além de outras missóes relacionadas com o Sistema Integrado de Emergência Médica, incumbem ainda ao INEM, no âmbito do socorro a prestar 
à população, nos termos do n. ${ }^{\circ} 3$ do art. ${ }^{\circ} 3 .^{\circ}$ do diploma atrás referenciado, as seguintes missóes:

- "Assegurar o atendimento, triagem, aconselhamento das chamadas que lhes sejam encaminhadas pelo número de emergência 112 e acionamento dos meios de socorro apropriados no âmbito da emergência médica;

- Assegurar a prestação de socorro pré-hospitalar e proceder ao transporte para as unidades de saúde adequadas;

- Promover a receção e o tratamento hospitalar adequado do urgentelemergente;

- Promover a criaçáo e correta utilização de carregadores integrados de urgêncialemergência (“vias verdes”);

- Promover a integração coordenada dos serviços de urgêncialemergência no SIEM;

- Promover a correta referenciação do doente urgentelemergente;

- Promover a adequaçáo do transporte inter-hospitalar do doente urgentelemergente;

- Promover a formação e qualificação do pessoal indispensável às ações de emergência médica;

- Assegurar a elaboração dos planos de emergêncialcatástrofe em colaboração com as administraçóes regionais de saúde e com a Autoridade Nacional de Proteção Civil (ANPC);

- Orientar a atuação coordenada dos agentes de saúde nas situaçóes de catástrofe ou calamidade, integrando a organização definida em planos de emergêncialcatástrofe".

A legislação em vigor refere, ainda, que o transporte de doentes em situação de emergência está reservado ao INEM e às entidades por ele reconhecidas ou com as quais celebre acordos com essa finalidade, nomeadamente:

- Corpos de bombeiros (CB's);

- Polícia de Segurança Pública (PSP);

- Cruz Vermelha Portuguesa (CVP).

O INEM é um instituto público dotado de personalidade jurídica e financeira e património próprio, com sede em Lisboa e delegaçóes regionais, no Porto, Coimbra, Lisboa e Faro, exercendo a sua atividade a nível de todo o território continental. 
Nos termos dos seus Estatutos aprovados pela Portaria no 647/2007, de 30 de Maio, as delegaçóes regionais asseguram a gestão, na respetiva área geográfica, dos processos relativos à frota, rede de telecomunicaçôes e centro de formaçáo, bem como do funcionamento do CODU (Centro de Orientaçáo de Doentes Urgentes), que é responsável pela triagem telefónica, aconselhamento médico e acionamento de meios. Prevê-se para breve a georreferenciação dos meios de socorro, a qual permitirá a escolha de meio em função da distância/tempo e não da área de influência. $\mathrm{O}$ avanço nas novas tecnologias permitirá também, em futuro próximo, o acompanhamento de meios no local das ocorrências por telemedicina (Lopes, CPE-2007:2).

Por outro lado, compete ao INEM coordenar todas as atividades de saúde em ambiente pré-hospitalar, a triagem e evacuaçóes primárias e secundárias, a referenciação e transporte para as unidades de saúde adequadas, bem como a montagem de postos médicos avançados. Cabe também ao INEM a triagem e o apoio a prestar às vítimas no local da ocorrência, com vista à sua estabilizaçáo emocional e posterior referenciaçáo para as entidades adequadas. No âmbito dos incêndios florestais articula, no seu âmbito próprio, com o CNOS, a nível nacional, com o CDOS, a nível distrital e com o COS, no local da ocorrência, e disponibiliza ainda um elemento da ligação ao CNOS e ao CDOS, respetivamente.

\section{Competências do INEM e Bombeiros e respetivos Meios de Intervençáo}

No âmbito do socorro pré-hospitalar, a história do INEM é, a partir de dada altura, indissociável da dos bombeiros, sendo esta mais antiga e culturalmente mais rica, porque, como vimos atrás a história dos corpos de bombeiros é a história de cada uma das comunidades onde nasceram, onde se desenvolveram e progrediram, em muitos casos há mais de um século e daí, também, as razôes da sua heterogeneidade.

Eduardo Agostinho (1995:44-60) parece situar o aparecimento do Serviço de Saúde e das primeiras ambulâncias de socorro por altura da fundação, em Lisboa, da 1.a Associação de Bombeiros Voluntários, em 1868. Tal serviço, surgido 
então de forma espontânea e empírica, "confinava-se basicamente a auto-macas, servidas por guarniçôes que procuravam cumprir cabalmente o seu dever através de vicissitudes múltiplas. No entanto, há que relevar que muitos corpos de bombeiros possuiam um número elevado de médicos, enfermeiros e farmacêuticos, a que se associavam os maqueiros que eram recrutados entre aqueles que, pelos mais variados motivos, estavam associados para o serviço de saúde" (Bandeira et al., 2007:100).

Efetivamente, no quadro da evolução histórica do sistema de urgência pré-hospitalar importa referenciar que, antes de 1970, as ambulâncias limitavam-se ao transporte das vítimas/doentes para o hospital mais próximo, não só porque, em regra, não estavam equipadas com materiais de assistência, mas também porque não estava oficialmente consagrada formaçáo específica para os respetivos tripulantes. Esta situaçáo começa a ser ultrapassada pelo Decreto-Lei no 511/71, de 22 de Novembro, que cria o Serviço Nacional de Ambulâncias e a figura do tripulante de ambulância, já com alguma formaçáo, sobretudo ao nível das técnicas de imobilizaçáo. No entanto, aos tripulantes de ambulância não estava cometida ainda a responsabilidade de prestar cuidados durante o transporte.

Entretanto, face ao aumento das necessidades de socorro, a resoluçáo do Conselho de Ministros n. ${ }^{\circ}$ 84/80, de 11 de Março, procede à análise e avaliação do Serviço Nacional de Ambulâncias, com vista à criação de um novo organismo que dê forma ao conceito integrado de Emergência Médica.

Assim, pelo Decreto-Lei n. ${ }^{\circ}$ 234/81, de 3 de Agosto, foi criado o Instituto Nacional de Emergência Médica (INEM), materializando-se, desta forma, o conceito de Sistema Integrado de Emergência Médica (SIEM). Surgiu, pela primeira vez, a figura do Tripulante de Ambulância de Emergência Médica TAE (especifico do INEM), com formação para a prestação de cuidados no local de ocorrência, bem como durante o transporte. Seguidamente, o Decreto-Lei n. ${ }^{\circ}$ 38/92, de 28 de Março, regulou a atividade do transporte de doentes efetuada por via terrestre. Um ano mais tarde, através da Portaria n. ${ }^{\circ}$ 439/93, o Estado especificou os tipos de ambulância, os cursos de formação, currículos e cargas horárias dos tripulantes de ambulância de socorro e dos cursos básicos de socorrismo.

$\mathrm{Na}$ sequência da criação dos Técnicos de Ambulância de Emergência (TAE) do INEM, nasciam, assim, no âmbito dos corpos de bombeiros, os TAS 
(Tripulante de Ambulância de Socorro) e os TAT (Tripulante de Ambulância de Transporte), com formaçáo ministrada no INEM, no primeiro caso, e nos corpos de bombeiros, INEM e Cruz Vermelha, no segundo caso. Por sua vez, a ENB iniciou em 1997, a formação de tripulantes de ambulância de socorro, com a realização do primeiro curso de TAS.

Com a possibilidade da abertura do transporte de doentes ao sector privado, através da Portaria n. ${ }^{\circ}$ 1147/2001, o Estado explicitou a concessão do Alvará (Licenciamento), o tipo de ambulâncias e respetivas características técnicas, o enquadramento e respetiva formação dos tripulantes.

Decorrido um ano, a Portaria n. ${ }^{\circ}$ 1301/2002, alterou as disposições do regulamento anterior, quanto às características e equipamentos da célula sanitária e clarificou o processo de licenciamento e vistorias.

Finalmente, a Portaria n. ${ }^{\circ}$ 402/2007, de 10 de Abril, alterou e atualizou normas do regulamento aprovado pelas Portarias n. ${ }^{\circ}$ s 11247/2001 e 1301A/2002, sobretudo ao nível do equipamento de imobilizaçáo, cardiovascular e de telecomunicaçôes. Por outro lado, reduziu a equipa de tripulantes, de três para dois elementos, fragilizando, de algum modo, a eficácia do socorro. De qualquer modo, face à exiguidade de recursos humanos do INEM, para fazer face às necessidades do socorro no todo nacional, "os bombeiros são aqueles que na prática têm vindo a garantir a existência de uma rede de ambulâncias. No entanto não se pode afirmar que existe homogeneidade na prestação deste socorro uma vez que este está apoiado na sua boa vontade e na capacidade financeira das respetivas associaçôes. Verdade é que junto ao litoral e aos grandes centros urbanos o socorro prestado pelos corpos de bombeiros é na sua maioria de qualidade, estando praticamente apoiado em equipas profissionalizadas. No entanto no interior do País este é praticamente inexistente, facto motivado quer pela incapacidade financeira das associaçōes ou mesmo pelo desinteresse de alguns dos seus dirigentes que usam as associaçóes como empresas de transporte de doentes desvalorizando a sua principal missão que o socorro" (Batista, 2008:4).

Atualmente, o INEM tem uma estrutura dependente do Ministério da Saúde, nos termos da Lei no 48/90, de 24 de agosto, alterada pela Lei no 27/2012, de 8 de novembro, que aprovou a Lei de Bases e Saúde onde "a emergência médica 
pré- Hospitalar tem tido um papel de emergência na supervisáo das desigualdades de acesso da população aos cuidados de saúde cumprindo a obrigação constitucional de universalidade do acesso à proteção de cuidados de saúde". (Preâmbulo do Decreto de Lei no 19/2016 de 15 de abril). Assim, ao INEM enquanto entidade nacional coordenadora do Sistema Integrado de Emergência Médica, compete garantir às vitimas de doença súbita ou de acidente, a proteção adequada de socorro, assegurada pelos meios de emergência médica, acionados pelo Centro de Orientação de doente Urgentes (CODU).

Para garantir o acesso da população à emergência pré-hospitalar o INEM dispóe de uma rede nacional de ambulâncias de socorro, distribuídas por mais de duas centenas de postos de emergência médica (PEM), sedeados, (mediante protocolos) em corpos de bombeiros, sendo estes responsáveis pela guarniçáo da ambulância, mas cuja intervenção se encontra subordinada, como já foi assinalado, à coordenação dos Centros de Orientação de Doentes Urgentes (CODU). Dispóe ainda, nas áreas urbanas de Lisboa, Porto, Coimbra, Setúbal e Faro de ambulâncias com suporte imediato de vida (SIV), tripuladas por funcionários do INEM, num dispositivo próprio que assegura cerca de 30\% do total de emergências registadas no continente. A tripulação tem um enfermeiro e um técnico de ambulância de emergência.

Ainda em Lisboa, Coimbra e Porto, o INEM dispóe de ambulâncias especificamente destinadas a recém-nascidos e tripuladas por um médico com a especialidade em neonatologia. Estas ambulâncias deslocam-se a qualquer ponto do continente, permitindo a evacuação de recém-nascidos de alto risco para as unidades hospitalares adequadas. Em Lisboa e Porto, o INEM dispõe também de motos tripuladas por um tripulante de ambulância de socorro (TAS), com formação específica em desfribilhador automático externo, permitindo uma rápida chegada desta valência em períodos de trânsito muito intenso.

Ao longo do País e sedeadas nos hospitais que possuem urgência médico-cirúrgica ou urgência polivalente, encontram-se quatro dezenas de viaturas médicas de emergência e reanimação. Estas viaturas são tripuladas por um médico e um enfermeiro com formação específica em emergência médica, permitindo técnicos altamente especializados no local da ocorrência. 
Finalmente, complementando os meios de atuação, o INEM dispóe ainda de cinco helicópteros de evacuação aeromédica, estacionados em Tires, Matosinhos, Ourique, Macedo de Cavaleiros e Aguiar da Beira, no quadro da grande controvérsia ocorrida aquando do encerramento dos Serviços de Atendimento Permanente (SAP) e de alguns Centros de Saúde ao longo do País.

Para António Marques, elemento do Colégio de Competência de Emergência Médica da Ordem dos Médicos, "os helitransportes não vão resolver os problemas do Pais. Os helicópteros fazem sentido desde que haja investimento nas outras peças do puzzle e a base está nas ambulâncias do sistema. Os helicópteros e as VMER melhoram a resposta, mas o objetivo único é ter uma atuação rápida e o que está mais perto das populaçôes são as ambulâncias de socorros sedeadas, nos CB's' (Expresso, de 25/10/2008, $1^{\circ}$ caderno, p.10 - Vera Lúcia Arreigoso).

O INEM dispóe ainda através do respetivo protocolo de cerca de duas centenas de postos de Reserva INEM (RES), dispóe também de um hospital de campanha, com capacidade para 60 camas, bloco cirúrgico e meios complementares de diagnóstico, destinado a situaçôes de catástrofes em que fiquem condicionadas as capacidades de resposta hospitalares na área mais afetada. Igualmente, para situaçôes de exceção, dispõe de quatro veículos com capacidade de transporte de um posto médico avançado e equipamento logístico de comunicação e apoio. Existe também capacidade técnica e material para intervir em incidentes NRBQ (nucleares, radiológicos, biológicos e químicos), "competindo ao INEM a descontaminação das hipotéticas vítimas que possam vir a existir". (Lopes, CPE-2007:4).

Em rigor, temos duas instituições que "pisam" o mesmo terreno complementarizando-se, com os bombeiros maioritariamente enquadrados em Associações privadas, embora de utilidade pública, cada uma refletindo o meio sociocultural onde se insere, e o INEM, instituição de direito público "com fama de entidade rica", surgindo, aqui e ali, polémicas, por questôes de funcionalidade e coordenação, designadamente protagonismo dos agentes, fatores de desconfiança em relação ao outro, receios de submissão e, ao invés, desejo de preponderância, entre outros. 
Todavia, a lógica política dominante parece inclinar-se para uma maior profissionalizaçáo do socorro pré-hospitalar, parecendo inevitável que os corpos de bombeiros em matéria do socorro hospitalar possam vir a ser "relegados" para um papel cada vez mais complementar do INEM. Vai nesta perspetiva de profissionalização futura a opinião do então vogal do INEM (e hoje Diretor Nacional de Bombeiros da ANDC), Engenheiro Pedro Lopes ao referir que, "contrariamente ao que era meu desejo, tenho que admitir que, no futuro, os bombeiros tendem a ser apenas um complemento nas açôes de emergência médica pré-hospitalar, apoiando a missão do INEM ou substituindo-o nos locais do interior do País, onde o número de serviços não justificar o investimento em meios humanos elou materiais que o INEM necessitaria de fazer" (Lopes, CPE-2007:1).

Atualmente dos 278 concelhos de Portugal Continental, cerca de três dezenas de concelhos, de acordo com os dados do INEM, não têm ainda CB's com protocolo PEM ou RES, estando o socorro pré-hospitalar integralmente a cargo de ambulâncias dos respetivos CB's voluntários.

Para o INEM, assinala Lopes (CPE-2007) "o que importa é se o SIEM (Sistema Integrado de Emergência Médica) tem ou não alguma ambulância no concelho em análise, quer seja dos bombeiros (PEM) ou do INEM (SBV-Suporte Básico de Vida idêntica às dos PEM) ou SIV (Suporte Imediato de Vida), em que a tripulação é constituida por um TAS (Tripulante de Ambulancia de Socorro) no caso dos CBs e de TAE (Técnico de Ambulancia de Emergência), ao nivel do INEM, que, neste caso, além do curso TAS, possui o curso em DAE (Desfibrilhação Automática Externa) e em condução de emergência".

Mais uma vez, estamos perante uma situaçáo de incongruência, em que, para funções idênticas, existem estatutos, formação e designaçôes diferentes. Espera-se por isso que o recém publicado Decreto de Lei no 19/2016 de 15 de abril, que procede à revisão da carreira de técnico da ambulância de emergência e cria o regime especial de técnico de emergência pré-hospitalar possa vir a trazer novo alento ao sistema integrado de Emergência Médica e designadamente à Emergência pré-hospitalar, a bem da supressão das desigualdades de acesso da população aos cuidados de saúde às vitimas de doença súbita ou de acidente. Por outro lado, a nova carreira coloca maior exigência no perfil de 
competências técnicas constituindo boa noticia para o socorro pré-hospitalar que náo poderá deixar de continuar a contar com o apoio das $\mathrm{CBs}$ que, por sua vez, terão que melhorar as competências dos técnicos de emergência (TAT e TAS), garantindo-lhes a adequada formaçáo para acesso a esta nova carreira.

No entanto, caso venha a verificar-se a assumpção plena, pelo INEM, do socorro pré-hospitalar (situação que não parece pacifica e a breve prazo), conduzirá os bombeiros (tal como sucede na generalidade dos países) a focalizar-se no desencarceramento e no combate a incêndios - o cerne da sua missáo - e ficando disponíveis para complementarem a ação dos profissionais do INEM.

Esta é a situação mais comum em toda a Europa, EUA e América Latina, em que as ambulâncias se encontram sediadas nos hospitais, podendo até pertencer a entidades privadas, assumindo os bombeiros um papel complementar.

Noutros casos, como, por exemplo, no Chile, os bombeiros (todos voluntários) apenas têm atribuiçôes na área dos incêndios urbanos e no salvamento e desencarceramento, com Companhias especializadas, apenas numa destas missóes, como é o caso da cidade de Santiago do Chile, com mais de seis milhóes de habitantes, com socorro garantido por 22 companhias de bombeiros voluntários.

Em resumo, hoje em dia, a maior parte das operaçôes de socorro são partilhadas por vários agentes de proteção civil, para além dos bombeiros, em regra, os primeiros a intervir. É o caso, por exemplo, dos incêndios urbanos e industriais, em que além da presença dos bombeiros, estará também a PSP, Polícia Municipal ou GNR e, eventualmente, técnicos do INEM. Já nos acidentes rodoviários, além dos bombeiros, estará o INEM e a Brigada de Transito da GNR.

Nos exemplos referidos, o comando das operações de socorro é dos bombeiros "dado o carácter residual dos outros agentes" (Gomes, CPE-2007:21).

Se, pelo contrário a operaçáo de socorro for de grandes dimensóes, obrigando ao envolvimento mais substancial dos vários agentes de proteçáo civil (cada um com o seu comando próprio), "a atividade de cada uma dessas forças terá de ser coordenada com as manobras dos bombeiros, no âmbito do Sistema Integrado de Operaçôes de Proteção e Socorro (SIOPS).

Ora, a realidade é outra, pois a prática demonstra haver problemas com a interpretação do conceito de comando único, que requer um esforço enorme e uma 
abertura de espirito total por parte dos responsáveis pelas diferentes entidades e organizaçôes, incluindo dos corpos de bombeiros" (Gomes, CPE-2007:21).

Esta problemática de se saber quem conduz e coordena as diferentes forças de intervenção da proteção civil (desde os CB's, GNR, PSP, Forças armadas e outros APC) em operações de socorro de grandes dimensões, não está, ainda, culturalmente, superada pela doutrina do SIOPS, não obstante o avanço inquestionável que este instrumento jurídico trouxe à coordenação institucional e operacional das operaçôes de proteção e socorro. Por outro lado, também não está bem clarificado quando estamos perante uma operação de Proteção ou de socorro, ora, segundo o Comandante Artur Gomes, "as soluçôes encontradas noutros paises são bem diversas. Em França, é sempre o oficial de bombeiros quem comanda. No Reino Unido é sempre o oficial da polícia quem comanda". Obviamente que, em França, o oficial de bombeiros não diz à polícia como esta deve exercer a sua funçáo. Tăo pouco no Reino Unido a polícia diz aos bombeiros como fazer.

Conforme assinalou Artur Gomes (2007), a anterior soluçáo portuguesa (posto de comando conjunto, previsto na Portaria 449/2001) tinha sido adaptada dos EUA, pois o norte-americano "Incident Command System" que é utilizado por todas as forças de intervençâa americanas, prevê a existência dos chamados postos de comando multi-jurisdicionais, quer para as ocorrências que abranjam mais do que uma divisäo administrativa, quer para operaçôes multi-agente".

Concluindo, no quadro conjugado do SIOPS e da Lei de Bases da Proteçáo Civil e das respetivas alteraçôes atrás referenciadas, as dimensôes de coordenaçâo institucional e de comando operacional da proteção civil, de níveis nacional, supra-distrital e distrital, contrariamente ao nível municipal, parecem estar consolidadas, dos pontos de vista doutrinal e estratégico da proteção civil.

Também não deixa de constituir elo mais fraco do sistema, o facto dos bombeiros, os principais agentes de proteção civil e socorro terem base voluntária, contrariamente aos outros agentes de proteção civil, profissionalizados (PSP, GNR, Forças Armadas, INEM e Sapadores Florestais).

Nesta linha, assevera António Malheiro (2007) "não consigo perceber que, no século XXI, a mesma população que usufrui da maior variedade de polícias para todos os fins e feitios (totalmente suportadas pelo Estado), que usufrui da proteção das Forças 
Armadas (que inclusive, exercem atividade noutros paises), depende para sua própria proteção quanto a incêndios, emergências médicas e proteção dos seus bens, de um sistema fundamentalmente baseado no voluntariado e amadorismo" (Malheiro, 2007:48).

Sabemos que o País necessita de uma boa Rede Nacional de Ambulâncias que garanta uma efetiva resposta às populaçôes. Este é, indubitavelmente, o salto qualitativo que urge dar, agora que foi criada a carreira de Técnico de Emergência Pré Hospitalar.

Nestas e noutras matérias da organização do socorro e da proteção civil em geral, o caminho a percorrer é ainda longo, quando a própria Lei de Bases e as duas últimas alteraçôes, praticamente ignora conceitos fundamentais com sejam, por exemplo, Prevenção, Análise de Riscos, Gestáo de Riscos e Reabilitação ou seja, a tríade de uma proteção civil do século XXI: Prevenção-SocorroReabilitação. (fig.5)

O sistema continua a não ter um centro de saber e a ligação ao mundo Universitário e muito ténue Também continua a ser claro que o socorro continua muito dependente dos Corpos de Bombeiros, inseridos em Associaçôes Humanitárias de Bombeiros, instituiçóes com grande heterogeneidade ao nível da organização, funcionamento, qualificação, liderança e qualidade de intervenção ao nível do País.

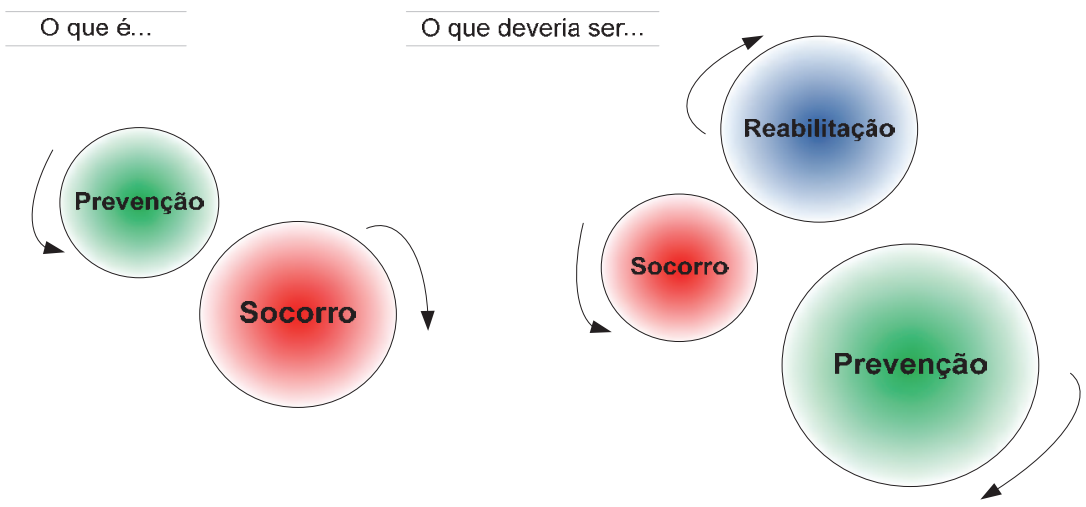

Fig. 5 - Gestäo da Proteção Civil.

Fig. 5 - Civil Protection Management. 
Por ultimo, os incêndios catastróficos deste agosto/2016 permitem elucidar que o trabalho desenvolvido pela ANPC e pelos frágeis serviços Municipais de Proteção Civil ( que as alteraçóes à Lei de Bases continuam a subalternizar ignorando o disposto nas Leis 65/2007 de 12 de novembro e Lei 75/2013 de 12 de setembro) é ainda insuficiente não só quanto ao Aviso e Alerta, mas também ao nível da preparação das populaçôes para lidarem com estes flagelos.

\section{Conclusão}

Conforme observamos, muito embora a protecção civil enquanto conceito seja uma criação recente, o socorro das populaçóes esteve a cargo, desde muito cedo, dos Corpos de Bombeiros ancorados juridicamente nas Associaçóes Humanitárias e sustentados pelas respectivas comunidades locais.

No entanto, o modelo de Sistema da Proteçáo Civil em vigor no nosso país, constitui a resultante de um processo conturbado, desenvolvido desde o início deste século.

No período de 2000 e 2011, o país teve cinco governos diferentes, outros tantos ministros da Administração Interna e respectivos secretários de Estado. Neste período, foram extintos o Serviço Nacional de Bombeiros (SNB) e o Serviço de nacional de Protecçáo Civil (SNPC), bem como o Serviço Nacional de Bombeiros e Proteçáo Civil (SNBPC) que lhes sucedeu, tendo este sido também extinto e criada a Autoridade Nacional de Protecção Civil (ANPC).

Ao longo do período, entre 2000 e 2005, o sector da Protecção Civil e dos Bombeiros foi palco de varias experiências que, apesar das boas intençóes manifestadas por alguns governantes - contrastando com a incompetência e o desnorte de outros-não tiveram sucesso.

Com a pose do XVII Governo Constitucional, foi definida e executada uma estratégia de sistema e elaborado o correspondente quadro legislativo de suporte que, ainda hoje se mantem em vigor.

Neste sentido, a Lei de Bases da Proteção Civil consagrada pela Lei n.o 27/2006 de 3 de julho; o Sistema Integrado de Operaçôes de Proteção e Socorro 
instituído pelo decreto de Lei n.o 134/2006 de 25 de julho; o enquadramento institucional e operacional da Protecção Civil no âmbito municipal definido pela lei n. ${ }^{\circ}$ 658/20207 de 12 de novembro; a Lei Orgânica da Autoridade Nacional de Proteçấo Civil consagrada pelo decreto de Lei n. ${ }^{\circ}$ 75/2007 de 29 de março e o Regime Juridico das Associaçóes Humanitárias de Bombeiros definido pela Lei n. ${ }^{\circ}$ 32/2007 de 13 de agosto trouxeram maior coerência ao sistema.

Os agentes de Protecçáo Civil passaram a dispor de um quadro de referência para a sua atuação no sistema, mais estável, porque institucionalmente mais centralizado e coordenado.

A maior profissionalização do agente Corpos de Bombeiros e a integração do GIPS da GNR e da Força Especial de Bombeiros (FEB) teve efeitos globalmente positivos, porque indutores da melhoria do desempenho da estrutura operacional do sistema.

Contudo, o sistema criado apresenta pontos fracos a citar:

- Inexistência de análise e tipificação de risco, enquanto variável estruturante do modelo de afectaçáo de recursos nomeadamente financeiros;

- O sistema não possui um centro de investigação e produção de doutrina;

- O nível municipal está deficitário de técnicos especializados, facto que obsta à plena operacionalização dos respectivos serviços.

Por outro lado, quer a criação de Equipas de Intervenção Permanente (EIP) em regime profissionalizado, na totalidade dos corpos de bombeiros voluntários do país (com a composição definida pela tipificação de cada CB) quer a evolução da Escola Nacional de Bombeiros como verdadeira Escola de Protecção Civil ajudaria bastante à melhoria do sistema em vigor. 


\section{Referencias bibliográficas}

\section{A - Livros, artigos e outros trabalhos científicos}

Agostinho, Eduardo, (1995). Desenvolvimento do Serviço de Saúde nos Bombeiros Portugueses, in Bombeiros Portugueses, seis séculos de História, Eds. SNB/LBP, vol. I, pp. 43-60.

Amaro, António (2012). O Socorro em Portugal, Lisboa, Ed. Instituto de Direito Público.

ANPC - AUTORIDADE NACIONAL DE PROTECÇÃO CIVIL (2008). Glossário de Proteç̧ão Civil, 2008, http://www.proteccaocivil.pt/glossario/pages/default.asp

Bandeira, Romero; Reis, Ana Mafalda; Leão; Rui Ponce; Gandra, sara; Gandra, Romero (2007). O Serviço de Saúde nos Bombeiros. A sua importância, da univitima à medicina de catástrofe, Revista Territorium, no 14, Coimbra, pp. $99-110$.

http://www.uc.pt/fluc/nicif/riscos/Documentacao/Territorium/T14_artg/T14art11.pdf

Batista, Nelson, (2008). O socorro pré-hospitalar, (inédito) 8 p.

Barreiros, Rita, (2001). A Evoluçấo Histórica do Equipamento dos Bombeiros, Actas do II Encontro Nacional sobre a História dos Bombeiros Portugueses, Ed. da AHBV de Coimbra, pp. 131-152.

Bombeiros Portugueses (1995), Vol. I e II, Ed. SNB/LBP.

Branco, Lopes, (1995). Quartéis de Bombeiros, in Bombeiros Portugueses, seis séculos de História, 1395-1995, vol. I, pp. 331-336.

Caldeira, Duarte, Nuno, (2003). Reforma do Socorro em Portugal, Revista ENB, no 25 de Jan./ Março/2003 pp. 15-21.

Caldeira, Pedro Zany e BRIGITE, Vicente, (2006). Análise e Controlo de Riscos Profissionais nos Bombeiros Voluntários Portugueses, Brochura de Informação Técnica no 24, Editada pelo Instituto de Segurança e Higiene no Trabalho (ISHT) hoje ACT (Autoridade para as Condiçóes no Trabalho).

Fialho, Gabriel, (1995). Apontamentos Históricos sobre a Participaçấo dos Bombeiros nos Socorros a Náufragos, in Bombeiros Portugueses, seis séculos de História, 1395-1995, Ed. SNB/LBP, vol. I, pp. 61-74.

Gomes, Artur (2015). Municipalizar o Socorro, CEIP - Informa, no 13, p.2

Gomes, Júlio de Sousa, (2002). Figuras Ilustres dos Bombeiros. O exemplo impar do Coronel Cansado, Actas do II Encontro Nacional sobre a História dos Bombeiros Portugueses, Ed. AHBV, Coimbra, pp. 103-129.

Laranjeira, José, António, (2002). Contributo para a Organização Associativa nos Bombeiros. Os Bombeiros do Distrito de Aveiro na Criação da $1^{\text {a }}$ Federação, Actas do II Encontro Nacional sobre a História dos Bombeiros Portugueses, Edição da. Associação Humanitária dos Bombeiros Voluntários de Coimbra.

Lourenço, Luciano (2001a). ENB - Um investimento pedagógico que carece de rendibilização prática, ENB, Revista Técnica e Formativa da Escola Nacional de Bombeiros, Sintra, n. ${ }^{\circ} 20$, p. 21-36. https://www.uc.pt/fluc/nicif/Publicacoes/Estudos_de_Colaboradores/PDF/editoriais/2001_ENB_20-01.pdf

Lourenço, Luciano, (2002). Formação dos Bombeiros Portugueses, Actas do II, Encontro Nacional sobre a História dos Bombeiros Portugueses, Ed. AHBV de Coimbra. http://www.uc.pt/fluc/ nicif/Publicacoes/Estudos_de_Colaboradores/PDF/Comunicacoes_congressos/IIEncontro_ Nacional_Historia_dos_Bombeiros_Portugueses_2002 
Lourenço, Luciano (2006b). Incêndios Florestais. Algumas Reflexôes sobre Prevenção e Mitos do Combate, Territorium, 13, Riscos - Associação Portuguesa de Riscos, Prevenção e Segurança, Coimbra, p. 59-70

http://www.uc.pt/fluc/nicif/riscos/Documentacao/Territorium/T13_artg/T13art06.pdf

Matos, António, Maria, (1995). O Panorama da Evolução da Organização dos Bombeiros Portugueses nos 500 anos da sua Existência, documento policopiado,153p. (inédito).

Monteiro, Alcides (2004). Associativismo e Novos Laços Sociais, Quarteto, Coimbra.

Pena, António de Oliveira (2005). A comunicação como forma para realizar a incerteza em situaçöes complexas de decisāo. Processos decisórios envolventes da integração dos corpos de bombeiros no sistema de protecção civil português. Dissertação de Doutoramento em Ciências da Comunicação na UNL. (Inédito).

Santos, Hermínio, F. (1995). Bombeiros Portugueses - Síntese de 600 anos de Acção, Bombeiros de Portugal, Ed. SNB/LBP, vol. I, pp. 13-42.

\section{B - Jornais e artigos de revistas de divulgaçáo específica}

Carmo, Eunice (2008). A minha protecção civil, Revistas Segurança em Protecção Civil, n. ${ }^{\circ}$ 1, pp. 23-24.

Cruz, Ribeiro, Arnaldo José (2007). A missão é proteger as pessoas e o património, Revista Alto Risco, no 26, 2a Série,Lisboa, pp. 32 - 39.

Malheiro, A. Silva (2008). Emergência Pré-Hospitalar, Revista Segurança, no 182, Lisboa, pp.49-50

Veloso, Manuel, (2002). O Sistema Nacional de Protecção Civil, in Revista Portuguesa de Proteç̧ão e Socorro, no 1, Jan./2002, Lisboa, pp. 10-12.

Zorrinho, Carlos, (20002). Reforma Tranquila, Revista Portuguesa de Proteç̧ão Civil, no 1 Jan./2002, Ed. SNPC, pp 8-9.

\section{C - Comunicaçóes pessoais escritas}

Gomes, Artur, (2007). Comunicação Pessoal Escrita, recebida em 18-06-2007, 22p

Laranjeira, José, (2007). Comunicação Pessoal Escrita, recebida em 3-12-2007. 13p

Lopes, Pedro, (2007). Comunicação Pessoal Escrita, recebida em 11-01-2008,15p.

Moura, A. Guedes (2007). Comunicação Pessoal Escrita, recebida em 12-12-2007,12p 


\title{
A RECUPERAÇÁO EMOCIONAL E O APOIO PSICOLÓGICO A SOBREVIVENTES \\ EMOTIONAL RECOVERY AND PSYCHOLOGICAL SUPPORT FOR SURVIVORS'
}

\author{
Cristina Queirós \\ Faculdade de Psicologia e de Ciências da Educação, Universidade do Porto \\ ORCID:0000-0002-8045-5317_cqueiros@fpce.up.pt \\ Fernando Passos \\ Divisão de Psicologia da Direção Nacional da PSP, Lisboa \\ fmpassos@psp.pt
}

Sumário: Descreve-se o impacto emocional e o distúrbio de stress pós-traumático experienciado por sobreviventes de acontecimento trágicos, com particular realce para os sintomas psicológicos. Em seguida apresentam-se diferentes modelos de primeiros socorros psicológicos/ emocionais e de intervençóes no trauma psicológico no sentido de recuperar o bem-estar emocional.

Palavras-chave: Impacto emocional, trauma, apoio psicológico.

Abstract: The emotional impact and post-traumatic stress disorder suffered by survivors of tragic events are described, with particular emphasis on psychological symptoms. We then present different models of first psychological/emotional assistance, and of interventions in psychological trauma that aims to promote the restoration of emotional well-being.

Keywords: Emotional impact, trauma, psychological support. 


\section{Introduçáo}

O século XXI tem sido marcado por inúmeros acontecimentos trágicos de causas naturais (ex: terramotos, cheias, incêndios) ou humanas (ex: acidentes aéreos ou rodoviários, choques de comboios, atentados terroristas), que, na tipologia de classificação dos riscos em função da sua génese (Lourenço, 2015a), se incluem, respetivamente, nas categorias de riscos naturais e riscos antrópicos.

Do ponto de vista das consequências para o ser humano que sobrevive a estes acontecimentos, ou, nele se encontra envolvido enquanto profissional de socorro (ex: bombeiros, profissionais do INEM, médicos, enfermeiros, psicólogos, profissionais da Proteção Civil, elementos de forças de segurança, etc.) o impacto emocional está sempre presente, seja de forma imediata, seja de forma crónica e duradoira no tempo, conforme a vulnerabilidade do indivíduo.

No âmbito da teoria do risco há uma hierarquia dos conceitos de risco, perigo e crise (Lourenço, 2015a, p.4), com a "existência de um limiar que marca a transição do risco para a crise, entendendo-se esta como uma manifestação do risco que, até então, estava latente", estando o perigo "associado à manifestação do risco e, por conseguinte, ele é indissociável do início da crise", sendo "comparado a uma linha amarela, que não deverá ser transposta, pois corresponde a sinais que alertam para a manifestação do risco, ou seja, significa que o perigo estará iminente. Com efeito, se essa linha for transposta, deixará de ser amarela e passará a vermelha, pois já diz respeito à manifestação do risco. Tal significará que o risco se está a manifestar e por conseguinte, como consequência, que se corre perigo efetivo. O perigo estará assim presente durante todo o desenvolvimento da crise [...], apesar de os efeitos da crise desencadeada pela manifestação do processo inicial poderem permanecer depois, por muito mais tempo, e, nestes casos, poderem evoluir para outros tipos de perigo". Contudo, persiste confusão entre risco e perigo, e a sua utilização nem sempre é concetualmente igual nas ciências sociais e naturais (Souza e Lourenço, 2015). Acresce ainda a referência ao conceito de vulnerabilidade, que Souza e Lourenço (2015, p.36) associam a suscetibilidade, resistência e resiliência, bem como a terminologia utilizada na Lei de Bases de Proteçáo Civil (Lei no 80/2015, p.5316) que não contempla a designação de incidente crítico da mesma forma que a Psicologia, que o define como 
um acontecimento negativo incomum na vida de uma pessoa, rompendo o seu equilíbrio psicológico, alterando o seu funcionamento habitual e afetando os seus mecanismos de adaptação normais (Everly \& Mitchell, 1999; Mitchell, 2006; Khan et al., 2017). Para não confundir, substituiremos a designação de incidente crítico à luz da Psicologia, pela de situação stressante ou evento potencialmente traumático

A transposição destes conceitos para a Psicologia remete-nos para o facto de a resposta emocional de sobreviventes ou profissionais envolvidos em acontecimentos trágicos comportar em si o risco de desenvolver psicopatologia (ex: distúrbio de stress pós-traumático), constituindo esta psicopatologia uma situação de perigo para o bem-estar do indivíduo pois pode desencadear no momento do acontecimento uma situaçáo de crise psicológica que carece de intervenção imediata (ex: stress agudo), área atualmente designada como intervenção em crise e que recorre aos chamados primeiros socorros emocionais ou psicológicos. Note-se que recentemente foi divulgado um documento (IFRDRCS, 2017) no que qual se sugere que a terminologia substitua a designaçáo de vítima por sobrevivente ou pessoa afetada, e de traumatizado por pessoa que vivenciou um acontecimento stressante,. Esta mudança tem como objetivo náo estigmatizar e, sobretudo, facilitar a recuperação e empoderar a pessoa, considerando-a como um sobrevivente ativo e não uma vítima passiva.

Este risco de adoecer psicológico depende, entre outros, da vulnerabilidade do indivíduo (enquanto fragilidade), mas também da sua capacidade de enfrentar o acontecimento (resistência) e de ser capaz de recuperar de forma positiva e melhorar as suas competências emocionais ou outras (resiliência). Quando o acontecimento trágico assume proporçôes que o definem como uma catástrofe, a gestáo desta deve incluir a resposta à crise psicológica de cada sobrevivente/ profissional, na medida em que a crise "requer uma ação urgente" (Lourenço, 2015a, p.15), tentando-se desta forma minimizar os potenciais danos psicológicos e promover a recuperação emocional através do apoio psicológico.

Para demonstrar o contributo da Psicologia na gestão da catástrofe, caracteriza-se seguidamente o stress pós-traumático e descrevem-se modelos de primeiros socorros psicológicos, terminando com a apresentação de formas de intervençáo ou tratamento do trauma no sentido de recuperar o equilíbrio e bem-estar psicológicos. 


\section{Stress pós-traumático}

Durante o vivenciar de acontecimentos trágicos enquanto situaçôes que estão "além do limite das experiências com que a vida confronta qualquer cidadão comum" (Pereira \& Monteiro-Ferreira, 2003, p.15), há uma situaçáo de stress agudo com um impacto emocional forte que pode levar a uma fixação no acontecimento, cuja recordação constitui uma "tirania do passado" (Van der Kolk et al., 1996, in Pereira \& Monteiro-Ferreira, 2003, p.16) pois o acontecimento já passou mas a sua recordação não se esbate com o passar do tempo e perturba a vivência diária. Quando tal acontece, ocorre o trauma, designado internacionalmente como PTSD ou Post-traumatic Stress Disorder, e em português como distúrbio de stress pós-traumático (Vaz Serra, 2003) ou como perturbação pós-stress traumático (Pereira \& Monteiro-Ferreira, 2003).

O trauma pode ser comparado a uma ferida emocional provocada por um agente externo que provoca desequilíbrio na pessoa e a deixa em sofrimento, afetando ainda a sua capacidade de adaptaçáo e de enfrentar a situação pela intensidade e imprevisibilidade com que ocorre, e gerando desorganização psicológica que impede uma adequada compreensão e uma correta atribuição de significado à situaçáo (Pereira \& Monteiro-Ferreira, 2003).

Segundo o Manual de Diagnóstico e Estatístico de Transtornos Mentais DSM-V (APA, 2013, 2014) os transtornos relacionados com trauma e stressores (classificação 309.81, F43.10) enumeram explicitamente como critério de diagnóstico a exposição da pessoa a um evento traumático ou stressante (como, por exemplo, ameaça de morte, lesáo grave ou violência sexual), vivenciado diretamente ou testemunhado noutras pessoas, bem como o facto de a pessoa poder tomar conhecimento de uma situaçáo grave que ocorreu com um familiar ou amigo próximo de forma violenta ou acidental, ou ter exposição repetida ou extrema a detalhes aversivos do evento traumático (ex: socorristas que recolhem partes de corpos humanos, polícias repetidamente expostos a situaçóes de abuso infantil, violência, etc.).

Qualquer uma destas situaçôes tem como consequência no sobrevivente/ observador um elevado grau de stress e disfuncionamento na interaçáo social, 
na capacidade de trabalho ou noutras áreas importantes do funcionamento, sem ter como causa outra condição médica nem consumo de substâncias.

Na última classificação do DSM-V (APA, 2014, p.271) é dada atenção aos sintomas comportamentais que acompanham o stress pós-traumático. Estes sintomas devem persistir mais de um mês após o evento (embora possa ocorrer uma manifestação tardia, após 6 meses do evento), pois a sua existência até um mês é considerada uma reação normal a uma situação de stress agudo. São agrupados em quatro categorias para definição do stress pós-traumático:

- Pensamentos intrusivos - reexperienciar do acontecimento de forma inesperada e involuntária, seja através de memórias frequentes, pesadelos ou reaçóes dissociativas/flashbacks em que a pessoa pensa estar de novo no evento (numa situação grave de dissociação contínua, a pessoa pode perder a noção da realidade como se estivesse a observar-se a ela própria). Existe angústia, sofrimento psicológico e reaçóes físicas intensas ou prolongadas perante estímulos internos ou externos semelhantes a algo do evento traumático. A mente está ocupada a processar constantemente o evento traumático e tem dificuldade em processar a informação do meio ambiente "devido ao medo permanente de que sejam ativados os mecanismos de alarme que tanto lhes custam a controlar", podendo existir alteraçôes na perceção, verbalização e até na personalidade da pessoa (Pereira \& Monteiro-Ferreira, 2003, p.59);

- Evitamento - esforço para evitar recordações, pensamentos ou sentimentos angustiantes sobre o evento ou associados a este, podendo mesmo ocorrer a recusa de contacto com pessoas, locais, conversas, atividades, objetos ou situaçôes passíveis de despertar recordaçôes do evento. Pode ocorrer embotamento e anestesia afetivas (incapacidade de sentir), fazendo a pessoa sentir-se diferente dos outros, "estranha [...], morta para mundo" (Krystal, 1978, in Pereira \& Monteiro-Ferreira, 2003, p.58);

- Pensamentos e humor negativos - alteração após o evento expressa na incapacidade de recordar aspetos importantes do evento (geralmente devido a amnésia dissociativa, e não a outros fatores como traumatismo 
craniano ou consumo de substâncias), crenças ou expectativas negativas persistentes e exageradas a respeito de si mesmo, dos outros e do mundo (ex: "o mundo é perigoso, todo o meu sistema nervoso está arruinado para sempre”, APA, 2014, p.271 ), cognições distorcidas persistentes sobre a causa ou consequências do evento traumático e nas quais a pessoa se culpa a si mesma ou aos outros, estado emocional negativo persistente (ex. medo, raiva, culpa, vergonha), diminuiçãa do interesse ou da participação em atividades significativas, sentimentos de distanciamento e alienação em relação aos outros, e incapacidade persistente de sentir emoçóes positivas;

- Hiperativação - reaçóes fisiológicas intensas associadas ao mecanismo instintivo de luta/fuga, momentos de irritação, raiva ou agressividade contra pessoas/objetos, comportamento imprudente ou autodestrutivo, hipervigilância, resposta de sobressalto exagerada, problemas de concentração e perturbação do sono (sono agitado ou dificuldade em iniciar/manter o sono). Existe uma incapacidade de modular o grau de alerta, estando este sempre no nível máximo, o que faz com que o mundo seja sentido como "hostil e perigoso" (Pereira \& MonteiroFerreira, 2003, p.58).

Numa situação que ameaça a sobrevivência ocorre a ativação de uma resposta instintiva de sobrevivência, designada por "luta ou fuga" (que faz primeiro agir e só depois processar cognitivamente o que se sente, pois se fosse o inverso haveria o risco de se ficar paralisados de terror, segundo autores como Pereira \& Monteiro-Ferreira, 2003 ou Palha, 2016), já que as emoçóes “infiltram-se em cada momento das nossas vidas [...] e de vez em quando podem deixar-nos magoados ou podem consumir-nos" (Frazzeto, 2014, p.12). É precisamente o que acontece com o estado emocional dos sobreviventes ou pessoas expostas a um evento stressante e potencialmente traumático, podendo, para prevenir a ocorrência do stress pós-traumático, ser prestado apoio psicológico que facilite a recuperação emocional. Este apoio psicológico é designado como intervenção em crise ou primeiros socorros psicológicos ou emocionais. 


\section{Primeiros socorros psicológicos ou emocionais}

A ideia de primeiros socorros psicológicos ou emocionais nasce na Austrália no contexto da Psiquiatria militar durante a II Guerra Mundial, alargando-se depois a situaçôes de desastre/catástrofe nas quais era necessário atuar de imediato para estabilizar emocionalmente os sobreviventes (Editorial Brief, 1969).

Posteriormente, quando na década de oitenta o DSM-III definiu a desordem de stress pós-traumático como um problema de saúde mental, surgiu a ideia de prevençáo do trauma através de intervençóes precoces e imediatas no momento do evento stressante (Dieltjens et al., 2014). Atualmente a World Health Organization (WHO, 2011, p.3) designa esta intervenção como psychological first aid (PFA) no sentido de ajuda humanizada, apoio e suporte, a pessoas que vivenciam uma situação desencadeadora de stress extremo, mas respeitando a sua dignidade, cultura e capacidades, e incluindo nesta ajuda o apoio psicológico e social (também designado como apoio psicossocial) defendendo que esta ajuda/ intervençáo pode ser utilizada pelas mais variadas pessoas e nas mais variadas situaçôes (ex: catástrofe, acidente, comunicação de más notícias), consistindo em saber como abordar as pessoas expostas ao evento e com elas comunicar sem as prejudicar nem correr riscos de segurança para sobrevivente nem interventor.

Esta intervenção tem vindo a ser recomendada por grupos internacionais (ex: IASC - Inter-Agency Standing Committee, 2007; Sphere Project, 2011) e reflete a tendência atual de utilizar modelos de atuaçáo psicológica em eventos stressantes e potencialmente traumáticos (Shultz \& Forbes, 2013; Wynn, 2015). Consiste em: providenciar ajuda e apoio de forma não invasiva nem sentida como imposta pelo sobrevivente; identificar as necessidades e preocupaçóes desta no momento; providenciar a satisfação de necessidades básicas (ex: alimentação, conforto físico, abrigo, informação sobre o evento stressante ou sobre o estado de pessoas conhecidas ou familiares envolvidos); possibilitar a escuta sem pressionar a pessoa a falar; confortar, acalmar e securizar a pessoa; ajudar a obter informação, serviços e apoio social; e, por fim, proteger de danos futuros.

Pode ser executada por não profissionais pois não é uma consulta profissional nem envolve um psychological debriefing, sendo este definido (Everly, 2006; 
Kenardy, 2000) no sentido de discutir os detalhes do evento que desencadearam o stress agudo, o que sentiu ou pensa sobre este, e atribuir significado que depois permita integrar este evento no percurso de vida do sobrevivente.

Os primeiros socorros psicológicos parecem facilitar a recuperaçáo posterior, pois tentam que o sobrevivente se sinta seguro, ligado a outras pessoas, calmo e com esperança, tenha acesso a apoio social, emocional e psicológico posterior, e que seja capaz de usar as suas capacidades para se auto-ajudar como pessoa e à sua comunidade que pode também ter sido afetada pelo evento stressante. Contudo, alguns sobreviventes, pela sua vulnerabilidade (ex: crianças, idosos, pessoas com incapacidades) ou pelas características do evento (ex: condiçôes pós-desastre más ou perdas graves de bens materiais, situaçóes de abuso sexual, grupos perseguidos em conflitos armados) poderáo necessitar de ajuda extra e de acompanhamento psicossocial posterior.

Com as frequentes tragédias humanitárias e múltiplas catástrofes, têm sido desenvolvidos guias de boas práticas e protocolos de atuaçâo bem definidos para aplicação em contextos não especializados de saúde, para interventores no terreno e para a promoção da melhoria da saúde mental durante crises humanitárias em populaçóes afetadas por conflitos armados ou refugiados, existindo diferentes modelos teóricos e de atuação (Everly, 2006; IASC, 2010; IFRDRCS, 2017; Mitchell, 2006; Seynaeve, 2001; WHO, 2010, 2011, 2012, 2013, 2015).

De um modo geral, os primeiros socorros psicológicos têm como objetivo realizar uma intervenção muito próxima ao evento traumático e que reduza o stress agudo a este associado, facilite um coping (capacidade de enfrentar) adaptativo e adequado, bem como uma boa transição para a normalidade no futuro (Allen et al., 2010). Assentam em cinco princípios (Allen et al., 2010, p.510; Hobfoll et al., 2007): promover a segurança; acalmar; estimular a autoeficácia ou eficácia do grupo/comunidade; estabelecer contactos e redes de suporte; e dar esperança.

Alguns estudos tentaram já avaliar a utilidade desta prática e a World Health Organization (WHO, 2011) sugere-a mesmo como mais útil do que o psychological debriefing. Num estudo com profissionais de socorro Allen e colaboradores (2010) concluíram sobre a importância de responder a necessi- 
dades imediatas como segurança, conforto e estabelecer contactos como mais importantes para os sobreviventes no momento do evento stressante, do que ensinar estratégias de coping adequado, valorizadas após a situação como forma de dar significado a esta.

Também Bae e colaboradores (2009) consideram que para além do conforto físico dos sobreviventes no momento de um desastre/catástrofe com perda de bens, é igualmente importante considerar as necessidades psicológicas, pois agindo no momento podem-se prevenir problemas de saúde mental no futuro.

Numa visão holística, o primeiro Psychological Support Center da Coreia do Sul para sobreviventes de desastres (Bae et al., 2009, p.352) propóe esta prática integrada em todo um planeamento que deve contemplar: (i) providenciar no evento stressante, e posteriormente, apoio emocional contínuo a sobreviventes e suas famílias, civis e profissionais de socorro; (ii) criar e manter redes de apoio a partir de recursos da comunidade, sejam instituiçôes, empresas, universidades, que possam contribuir com materiais, trabalho e conhecimentos; (iii) providenciar treino e educação para apoio em desastres a profissionais e voluntários; (iv) desenvolver programas de treino e educaçáo para os desastres; efetuar estudos sobre a vulnerabilidade de cada região em termos de prevalência dos desastres e consequentes perdas, mortalidade e problemas adicionais; $(v)$ providenciar conhecimentos e materiais para a educação para desastres e incorporar o apoio emocional no curriculum; e por fim, (vi) providenciar a realização de debriefin$g_{s} /$ defusings para trauma emocional, partilha de experiências e gestão do stress (recorde-se que o debriefing psicológico consiste em ajudar o sobrevivente a dar significado ao acontecimento após este, enquanto o defusing consiste em dar apoio emocional imediato e ajudar a pessoa a verbalizar as suas emoçóes no acontecimento, segundo Everly, 2006). Note-se que em Portugal, apesar da publicação em 2015 do "Referencial de Educação para o Risco", a educação para os riscos e desastre ainda se encontra num estado inicial e com "conceitos menos corretos" (Lourenço, 2015b, p.306).

Figueroa e colaboradores (2010) efetuaram uma revisão sistemática, propondo que a resposta psicológica precoce seja organizada em cinco níveis: (i) difusão (dar informação, fazer psicoeducação e diminuir a incerteza); (ii) apoio 
social (prestar os primeiros socorros psicológicos de forma a permitir triagem de quem está em risco de patologia e promover a resiliência); (iii) cuidados médicos gerais (estabilizar os sintomas intensos como ansiedade); (iv) cuidados psiquiátricos gerais (tratar sobreviventes em estado de stress agudo ou stress pós-traumático); e ( $v$ ) cuidados psiquiátricos especializados (tratar sobreviventes que não melhoraram com os nível de intervenção anterior). Consideram que apenas os sobreviventes com diagnóstico bem estabelecido devem receber psicoterapia ou medicação, devendo os restantes receber primeiros socorros psicológicos.

Mais recentemente, Dieltjens e colaboradores (2014) realçaram que a utilizaçấo dos primeiros socorros psicológicos é a primeira forma de cuidar dos sobreviventes, para além do apoio médico e de sobrevivência, podendo prevenir consequências graves de saúde mental no futuro e promover a resiliência no sentido de capacidade de resistência e de enfrentamento adequado da adversidade, promovendo assim a recuperação, seja de indivíduos, famílias ou comunidades, e acreditando que cada sobrevivente possui em si mesmo uma capacidade de recuperaçáo, que, quando devidamente orientada e apoiada, facilita o regresso à normalidade. Efetuaram uma revisão da literatura sobre os modelos e suas práticas, identificando cinco modelos (Hobfoll et al., 2007, modelo dos cinco princípios já anteriormente descrito; Bisson et al., 2007, modelo TENTS; Kelly et al., 2010, modelo australiano; Te Brake et al., 2009, modelo holandês; e, por fim, Vymetal et al., 2011, modelo EUTOPA), concluindo contudo sobre a falta de estudos de avaliaçáo das melhores práticas.

É ainda de referir aquele que parece ser o modelo mais divulgado, Critical Incident Stress Management (Everly, 2006; Mitchell, 2003, 2004, 2006, 2009), que se apresenta como um programa de intervenção "compreensivo, integrado sistémico e multi-componente" (Mitchell, 2009, p.1), composto por várias técnicas de intervenção em crise que pretendem, enquanto primeiros socorros psicológicos ou emocionais: mitigar o impacto de eventos traumáticos; facilitar o processo de recuperação de sobreviventes que apresentam reações consideradas habituais ao evento traumático em questão; reestabelecer as capacidades de adaptação; e identificar sobreviventes que necessitem de acompanhamento posterior e intervenção psicológica especializada. 
As técnicas devem ser utilizadas em conjunto e de acordo com um protocolo bem estabelecido, destinando-se a sobreviventes e a profissionais (neste caso designa-se como peer support ou apoio de pares), seja em termos individuais ou em grupo, sendo bastante utilizado a nível mundial no contexto militar, de socorro e policial, apesar de ter componentes mais direcionadas para o contexto americano (detalhes sobre este modelo podem ser consultados no site da fundação americana em https://www.icisf.org/).

De um modo geral, o programa CISM (Everly \& Mitchell, 1999; Mitchell, 2009) inclui componentes como: planeamento pré-evento stressante, educação e treino; avaliação da crise; planeamento estratégico; intervenção individual na crise; intervenção em grande grupo (desmobilização e crisis management briefing, geralmente destinados a grupos de profissionais interventores no evento traumático); intervenção em pequeno grupo (defusing e critical incident stress debriefing) destinado a grupos que vivenciaram o mesmo evento traumático, (sejam sobreviventes ou profissionais); intervenção pastoral; apoio a famílias; educação pós-desastre; serviços de acompanhamento pós-desastre, etc.

A intervenção para pequenos grupos expostos à mesma situação stressante inclui, no modelo Critical Incident Stress Debriefing (CISD) sete fases (Mitchell, 2005): introdução (estimular a participação e definir as regras do grupo); factos (descrever resumidamente o que aconteceu); pensamentos (descrever resumidamente o que pensou, permitindo fazer a transição do domínio cognitivo para o afetivo da fase seguinte); reaçóes (descrever resumidamente o que sentiu como mais doloroso); sintomas (que sintomas teve e como este evento influenciou a vida de cada um, permitindo regressar ao domínio cognitivo); educação (explicação sobre gestão do stress e sintomas, tentando uma normalização da experiência traumática); e, por fim, reentrada (síntese do que aconteceu na sessão e informaçóes adicionais, nomeadamente sobre onde e como obter acompanhamento psicológico posterior).

Para a intervenção individual foi desenvolvido o modelo SAFER-R (Everly, 2001), que começa com a fase da estabilização (introdução, identificação de necessidades básicas dos sobreviventes e mitigação das fontes de stress agudo), em seguida tem o reconhecimento (conhecer o evento e as reaçóes), 
a facilitação (promover a compreensão e normalizaçáo), depois encoraja a adaptaçáo (de forma adequada e eficaz) e por fim faz a recuperaçáo ou referenciação (restabelecimento, ou reencaminhar para acompanhamento psicológico posterior). Recentemente, Everly e Lating (2017) sistematizaram os diferentes modelos e suas formas de atuação na sua obra "The Johns Hopkins guide to psychological first aid", nomeadamente o seu modelo de cinco fases RAPID-PFA, testado e validado teórica e empiricamente. Mais recentemente ainda, Bartone e colaboradores (2018) identificaram as melhores práticas de apoio de pares para sobreviventes enlutados através de entrevistas a pessoas envolvidas no apoio de pares em contexto militar, das forças de segurança e de entidades que intervêm na comunidade em situaçôes de emergência. Dos temas referidos concluíram que os programas de peer support devem: ser facilmente acessíveis a quem deles necessita; confidenciais; proporcionar um ambiente seguro; treinar, selecionar e recorrer a pessoas com experiências semelhantes às dos sobreviventes; estabelecer parcerias com profissionais de saúde mental (ex: psicólogos, psiquiatras); e monitorizar e cuidar das pessoas / pares (peers) que fornecem este suporte para estas náo terem o risco de reviver as suas experiências traumáticas. Assiste-se, então, a um recente e crescente interesse pelo tema do apoio emocional a sobreviventes, bem como a uma preocupaçáo em avaliar ou usar programas já avaliados como úteis, resultado das constantes ocorrências de desastres naturais, acidentes multívitimas, atentados, etc.

Apesar de alguma controvérsia sobre a eficácia do psychological debriefing (Everly \& Mitchell, 2000; WHO, 2011), o programa tem vindo a ser testado (Boscarino et al., 2005; Harris et al., 2002; Vogt et al., 2004), sendo utilizado na aviação, tal como acontece em Portugal (EATM, 2004) tendo decorrido em 2015 já o $12^{\circ}$ Encontro Anual da Equipa CISM da NAV (detalhes no site https://www.nav.pt/cism).

Mesmo constituindo os primeiros socorros psicológicos uma intervenção imediata aquando do evento potencialmente traumático ou situaçáo stressante, tentando prevenir o stress pós-traumático, este pode ocorrer, existindo várias formas de intervençấo, tratamento ou recuperaçấo. 


\section{Intervençáo, tratamento e recuperaçáo do trauma}

Apesar de existirem dados variados relativos à percentagem de ocorrência do trauma, conforme o estudo e o tipo de evento traumático, Maia e Fernandes (2003, pp.41-43), citando vários outros estudos publicados desde a década de noventa, estimavam em sobreviventes de: terramoto no México 30\%; terramoto na Arménia 74\%; inundação por barragem 59\%, e 14 anos depois 25\%; acidentes rodoviários graves 12\%; vítimas de violação 57 a 94\%; veteranos de guerra 25 a $30 \%$ ou $70 \%$ aquando de guerra no Vietname, com $49 \%$ a apresentarem distúrbio de stress pós-traumático crónico; prisioneiros se guerra 50 a 70\%; sobreviventes de ataques terroristas 20 a 40\%; bombeiros expostos a desastres naturais $16 \%$.

Estudos mais recentes encontraram 53\% em familiares de vítimas de desastre aéreo (Johannesson et al., 2006); 51\% para sobreviventes de desastres, 48\% para sobreviventes de acidentes ou incêndios, 32\% para familiares de vítimas de acidente/desastre/violência, 53\% para vítimas e $33 \%$ para testemunhas de crime sexual ou com violência física, e 52\% para familiares enlutados por mortos em acidente/desastre/violência (Kilpatrick et al., 2013); 7\% em adolescentes sobreviventes de um tornado nos EUA (Adams et al., 2014); 68 a 73\% em combatentes no Iraque ou Afeganistão (Green et al., 2015); 31\% em sobreviventes dos atentados de 11 de Setembro EUA (North et al., 2015); 13 a 22\% em profissionais de socorro (Wilson, 2015); 61 a 81\% em adolescentes vítimas de violência sexual ou física ou perdas traumáticas (Sachser \& Goldbeck, 2016); 23\% em adolescentes expostos a violência na comunidade, violência entre pares ou cyberbullying (Ranney et al., 2016); 4\% em bombeiros envolvidos em incêndios, embora 30\% apresentassem já sintomas traumáticos (Khan et al., 2017), ou até mesmo entre 34\% a 46\% em profissionais de socorro (Mao et al., 2018). É ainda de referir a existência de inúmeros estudos sobre o impacto traumático dos atentados de 11 de Setembro nos Estados Unidos e que, mais de uma década depois continuam a estudar a saúde física e psicológica de sobreviventes e profissionais de socorro (Crupi \& 
Brondolo, 2017). Em 2017, uma vasta equipa de investigadores de 24 países liderada por Kessler, recolheu dados dos inquéritos de Saúde Mental da Organização Mundial de Saúde, num total de 68.894 inquiridos, concluindo que $70 \%$ tinham vivenciado situações traumáticas, com média de 3 por pessoa, destacando-se a violência interpessoal (77\%), violência por parte de companheiro/cônjuge (43\%), violação (13\%), crimes sexuais (15\%) e morte de alguém próximo (12\%). Os autores alertam para uma distribuição desigual da percentagem de trauma a nível mundial, e, sobretudo, para o fato de que embora os sintomas de trauma possam desaparecer alguns meses após o evento, a sua duraçáo é consideravelmente mais longa do que o que tem sido reconhecido ( 25 a $40 \%$ recuperam num ano mas uma percentagem elevada apresenta sintomas entre 6 a 13 anos).

Note-se que estas percentagens são indicações globais, pois é importante considerar o momento da recolha de dados (próximo do evento ou alguns meses ou anos depois) e o instrumento de diagnóstico utilizado. Brancu e colaboradores (2016) analisaram a mudança dos critérios de trauma do DSM-IV para o DSM-V, referindo percentagens globais entre quase $13 \%$ e $16 \%$, conforme o rigor dos estudos e os critérios de medição, alertando para a necessidade de uma correta avaliação que identifique precocemente cada pessoa exposta ao evento stressante e a encaminhe para tratamento.

É notório que existe uma percentagem relevante de pessoas expostas a situaçôes stressantes que desenvolvem o distúrbio de stress pós-traumático, necessitando de tratamento (Thordardottir et al., 2018), sendo, sendo as formas de tratamento mais utilizadas: abordagens cognitivo-comportamentais (Foa \& Meadows, 1997; Gouveia \& Sacadura, 2003); intervenção familiar (Pereira, 2003); redução de eventos traumáticos e imersão imaginada (Valentine, 2003); terapia farmacológica (Monteiro-Ferreira, 2003); hipnoterapia e abordagens psicodinâmicas (Foa \& Meadows, 1997); eye movement desensitization and reprocessing (EMDR), terapia narrativa e terapia por exposição (Cusack et al., 2016); e terapias baseadas na internet (Kuster, Niemeyer \& Knaevelsrud, 2016), integrando a mais recente tendência da e-health, combinando terapia cognitivo-comportamental com técnicas de 
relaxamento, treino de competências sociais, treino interactivo para ultrapassar vieses cognitivos, visualizaçáo de vídeos, auto-relato escrito de teor emocional, alertas por mensagem, contacto por videoconferência, chat ou email com terapeutas.

Apesar de ter como prioridade os sobreviventes no contexto militar, o National Center for PTSD, do U.S. Departement of Veterans Affairs, em conjunto com U.S. Department of Defense's National Center for Telehealth and Technology, criaram a aplicação online e para telemóvel PTSD-Coach, referindo no seu site, que esta tinha sido descarregue 100.000 vezes em 74 países (ou segundo Kuhn et al., 2014a, 130.000 em 78 países) podendo ser utilizada por pessoas com trauma e seus familiares (detalhes no site http://www.ptsd.va.gov/public/ materials/apps/PTSDCoach.asp). Estudos de avaliação preliminar revelaram a satisfação dos utilizadores (Kuhn et al., 2014a) e a disponibilidade de terapeutas (Kuhn et al., 2014b) na utilização desta aplicação, existindo já uma versão em francês para o Canadá.

Em todas as formas de tratamento do trauma pretende-se que a pessoa recupere a sua capacidade de autonomia e de viver, integrando o evento stressante como uma situação do passado e como algo que permitiu aumentar a sua capacidade de resiliência.

\section{Conclusão}

Segundo o United Nations Office for Disaster Risk Reduction (UNISDR, 2016), em 2015 foram reportados 356 desastres, com 22.773 mortos e 98,6 milhôes de pessoas afetadas. Apesar da redução relativamente à média para o período 2005-2014, os acidentes aéreos, rodoviários ou de comboio, bem como os atentados terroristas (ex: Barcelona 2017) ou incêndios florestais (ex: Portugal e Galiza 2017), confrontam-nos com uma nova de realidade de riscos antrópicos (Lourenço, 2015a). Como tal, faz sentido a criação de um plano de gestão dos desastres e riscos associados, como a proposta do Global Facility for Dissater Reduction and Recovery (GFDRR, 2015) direcionada para 2016/2018. 
Além disso, é de particular importância o bem-estar e saúde psicológica dos profissionais de socorro e elementos das forças policiais, pois estáo expostos frequentemente a eventos traumáticos (13 a 22\% podem desenvolver trauma segundo Wilson, 2015), necessitam de modelos de atuação específicos (Regehr, 2001; Regehr, Goldberg \& Hughes, 2002) e sem eles a gestão da catástrofe perde qualidade. Este grupo tem sido alvo de interesse crescente em termos de saúde ocupacional (Angelo, 2016; Jackson et al., 2003), pois o seu desempenho afeta diretamente as pessoas expostas ao evento stressante.

Atualmente, através das novas tecnologias de comunicação rápida (ex: web, sms, twitter) a simples notícia de uma tragédia constitui uma propagação de emoçóes negativas devido à sucessão de comentários de internautas, contribuindo para um estado emocional negativo alargado (Miura et al., 2016) que importa prevenir pois a todos afeta na comunidade. Apesar das terapias baseadas no $e$-health possibilitarem o acesso a tratamento a mais pessoas por não implicarem todas as sessōes face a face, são necessários estudos que comparem a eficácia e benefícios de cada forma de tratamento (Cusack et al., 2016), dada a variedade de eventos traumáticos, de sobreviventes, e a complexidade do stress pós-traumático (Gerger, Munder \& Barth, 2014).

Os trágicos incêndios florestais de Junho e Outubro 2017 e o recente incêndio numa associação cultural-recreativa de Tondela em Janeiro 2018, com o grande número de mortos e feridos, alertaram para a necessidade urgente de disponibilizar apoio psicológico aos sobreviventes, aos familiares enlutados e aos profissionais de socorro envolvidos. Além disso, o número crescente de notícias de situaçóes de violência extrema na via pública, bem como de homicídio/suicídio em contexto de violência doméstica, aumenta exponencialmente a probabilidade de cada um de nós observar ou vivenciar estas situaçóes, com todo o seu potencial impacto traumático. Urge, pois (sem pretender desvalorizar as práticas que cada entidade do nosso país tem vindo a utilizar), a construção de um modelo de intervenção na crise e de primeiros socorros psicológicos/ emocionais que possibilite uma aplicaçáo prática de acordo com as características e meios do contexto português. 


\section{Referências bibliográficas}

Adams, Z.W., Sumner, J.A., Danielson, C.K., McCauley, J.L., Resnick, H.S., Grös, K., Paul, L., Welsh, K. \& Ruggiero, K. J. (2014). Prevalence and predictors of PTSD and depression among adolescent victims of the spring 2011 tornado outbreak. Journal of Child Psychology and Psychiatry, 55(9), 1047-1055.

Allen, B., Brymer, M., Steinberg, A., Vernbergm E., Jacobs, A., Speir, A. \& Pynoos, R. (2010). Perceptions of Psychological First Aid Among Providers Responding to Hurricanes Gustav and Ike. Journal of Traumatic Stress, 23(4), 509-513.

Angelo, R.P. (2016). Psicologia da Saúde Ocupacional em organizaçóes de emergência. In M.J. Chambel (Ed.). Psicologia da Saúde Ocupacional (pp.113-134). Lisboa: Pactor.

APA, AMERICAN PSYCHIATRIC ASSOCIATION (2013). Posttraumatic Stress Disorder. Acedido Abril 2016, em http://www.dsm5.org/Pages/Default.aspx.

APA, AMERICAN PSYCHIATRIC ASSOCIATION (2014). Manual de Diagnóstico e Estatístico de Transtornos Mentais DSM-5. Porto Alegre: Artmed.

Bae, J., Kim, K., Panuncio, R., Choi, N. \& Im, S. (2009). Inauguration of the first Psychological Support Center for Disaster Victims in Korea. Nursing and Health Sciences, 11, 351-356.

Bartone, P. T., Bartone, J. V., Gileno, Z., \& Violanti, J. M. (2018). An exploration into best practices in peer support for bereaved survivors. Death Studies, (online first).

DOI:http://dx.doi.org/10.1080/07481187.2017.1414087

Bisson, J.I., Tavakoly, B., Witteveen, A.B., Ajdukovic, D., Jehel, L., Johansen, V.J., Nordanger, D., Orengo, F., Punamaki, R.L., Schnyder, U., Sezgin, A.U., Wittmann, L. \& Olff, M. (2010) TENTS guidelines: development of post-disaster psychosocial care guidelines through a Delphi process. British Journal of Psychiatry, 196(1), 69-74.

Boscarino, J.A., Adams, R.E. \& Figley, C.R. (2005). A Prospective Cohort Study of the Effectiveness of Employer-Sponsored Crisis Interventions after a Major Disaster. International Journal of Emergency Mental Health, 7(1), 31-44.

Brancu, M., Mann-Wrobel, M-, Beckham, J., Wagner, R., Elliott, A., Robbins, A., Wong, M., Berchuck, A. \& Runnals, J. (2016). Subthreshold Posttraumatic Stress Disorder: A MetaAnalytic Review of DSM-IV Prevalence and a Proposed DSM-5 Approach to Measurement. Psychological Trauma: Theory, Research, Practice, and Policy, 8(2), 222-232.

Cusack, K., Jonas, D. E., Forneris, C.A., Wines, C., Sonis, J., Middleton, J.C., Feltner, C., Brownley, K., Olmsted, K., Greenblatt, A., Weil, A. \& Gaynes, B.N. (2016). Psychological treatments for adults with posttraumatic stress disorder: A systematic review and meta-analysis. Clinical Psychology Review, 43, 128-141.

Crupi, R., \& Brondolo, E. (2017). Posttraumatic stress disorder post 9/11: A review of the evidence and implications for public health policy. TPM - Testing, Psychometrics, Methodology In Applied Psychology, 24(3), 363-378. DOI: http://dx.doi.org/10.4473/TPM24.3.4

Dieltjens, T., Moonens, I., Praet, K., Buck, E. \& Vandekerckhove, P. (2014). A Systematic Literature Search on Psychological First Aid: Lack of Evidence to Develop Guidelines. PLoS ONE 9(12), e114714. DOI: http://dx.doi.org/10.1371/journal.pone. 0114714

EATM, EUROPEAN AIR TRAFFIC MANAGEMENT (2004). Skyguide CISM Case Studies. Brussels: EUROCONTROL.

EDITORIAL BRIEF (1969). First-aid Psychiatry. Australian and New Zealand Journal of Psychiatry, 3(3), 115 [re-publish 2009 DOI: http://dx.doi.org/10.3109/00048676909159272. 
Everly, C. (2001). The SAFER-R model of crisis intervention with individuals. Acedido Abril 2016 em http://media1.razorplanet.com/share/510579-5514/siteDocs/SAFER-R_Model_Document.pdf.

Everly, G. (2006). Assisting individuals in crisis. Maryland: International Critical Incident Stress Foundation.

Everly, G.., \& Lating, J. M. (2017). The Johns Hopkins guide to psychological first aid. Baltimore, MD, US: Johns Hopkins University Press.

Everly, C. \& Mitchell, J. (1999). A Primer on Critical Incident Stress Management (CISM). Acedido Abril 2016 em www.scboces.org/cms/lib03/.../122/cismprimer.pdf.

Everly, C. \& Mitchell, J. (2000). The debriefing "controversy" and crisis intervention: a review of lexical and substantive issues. Journal of Emergency Mental Health, 24(4), 211-225.

Figueroa, R., Marion, H. \& Gonzalez, M. (2010). Apoyo psicológico en desastres: Propuesta de un modelo de atención basado en revisiones sistemáticas y metaanálisis. Revista Médica de Chile, 138, 143-151.

Foa, E.B. \& Meadows, E.A. (1997). Psychosocial treatment for posttraumatic stress disorder: a critical review. Annual Review of Psychology, 48, 449-480.

Frazzeto, G. (2014). Como sentimos: o que a neurociência nos pode ou näo pode dizer sobre as nossas emoçōes. Lisboa: Bertrand.

Gerger, H., Munder, T. \& Barth, J. (2014), Specific and Nonspecific Psychological Interventions for PTSD Symptoms: A Meta-Analysis With Problem Complexity as a Moderator. Journal of Clinical Psychology, 70, 601-615.

GFDRR, GLOBAL FACILITY FOR DISASTER REDUCTION AND RECOVERY (2015). Managing Disaster Risks for a Resilient Future: A Work Plan for the Global Facility for Disaster Reduction and Recovery 2016-2018. Washington, DC: World Bank.

Gouveia, J.P. \& Sacadura, C.A. (2003). Terapia cognitivo-comportamental na perturbação pósstress traumático. In M.G. Pereira \& J. Monteiro-Ferreira (Eds.). Stress traumático: aspectos teóricos e intervenção (pp.163-185). Lisboa: Climepsi.

Green, J.D., Bovin, M.J., Erb, S.E., Lachowicz, M., Gorman, K.R., Rosen, R.C., Keane, T. \& Marx, B.P. (2015). The Effect of Enemy Combat Tactics on PTSD Prevalence Rates: A Comparison of Operation Iraqi Freedom Deployment Phases in a Sample of Male and Female Veterans. Psychological Trauma: Theory, Research, Practice, And Policy, (online), 1-8, DOI: http://dx.doi.org/10.1037/tra0000086.

Harris, M.B., Baloglu, M., and Stacks, J.R. (2002). Mental Health of Trauma exposed firefighters and Critical Incident Stress Debriefing. Journal of Loss and Trauma, 7, 223-238.

Hobfoll, S. E., Watson, P., Bell, C. C., Bryant, R. A., Brymer, M. J., Friedman, M. J., ... \& Maguen, S. (2007). Five essential elements of immediate and midterm mass trauma intervention: Empirical evidence. Psychiatry: Interpersonal and Biological Processes, 70, 283-315.

IASC INTER-AGENCY STANDING COMMITTEE (2007). IASC Guidelines on Mental Health and Psychosocial Support in Emergency Settings. Geneva: IASC.

IASC INTER-AGENCY STANDING COMMITTEE (2010). Mental Health and Psychosocial Support in Humanitarian Emergencies: What Should Humanitarian Health Actors Know? Geneva: IASC.

IFRCRCS - INTERNATIONAL FOUNDATION OF RED CROSS AND RED CRESCENT SOCIETIES (2017). Talking and Writing about Psychosocial Support. Acedido Novembro 2017 in http://pscentre.org/talking-writing-psychosocial-support/.

Jackson, B., Baker, j., Ridgely, M.S., Bartis, J. \& Linn, H. (2003). Protecting emergency responders, volume 3: safety management in disaster and terrorism response. Cincinnati, $\mathrm{OH}$ : National Institute for Occupational Safety and Health. 
Johannesson, K.B., Stefanini, S., Lundin, T. \& Anchisi, R. (2006). Impact of bereavement among relatives in Italy and Sweden after the Linate airplane disaster. International Journal Of Disaster Medicine, 4(3), 110-117.

Kelly, C.M., Jorm, A.F. \& Kitchener, B.A. (2010) Development of mental health first aid guidelines on how a member of the public can support a person affected by a traumatic event: a Delphi study. BMC Psychiatry, 10(49), 1-15.

Kenardy, J. (2000). The current status of psychological debriefing: It may do more harm than good. BMJ. 321(7268), 1032-1033.

Kessler, R. C., Aguilar-Gaxiola, S., Alonso, J., Benjet, C., Bromet, E. J., Cardoso, G., ... On behalf of the WHO World Mental Health Survey Collaborators, K. C. (2017). Trauma and PTSD in the WHO World Mental Health Surveys. European Journal of Psychotraumatology, 8(sup5), 1353383. DOI: http://dx.doi.org/10.1080/20008198.2017.1353383.

Khan, K., Charters, J., Graham, T. L., Nasriani, H. R., Ndlovu, S., \& Mai, J. (2017). A Case Study of the Effects of Posttraumatic Stress Disorder on Operational Fire Service Personnel Within the Lancashire Fire and Rescue Service. Safety and Health at Work (online first), DOI: http://dx.doi.org/10.1016/j.shaw.2017.11.002.

Kilpatrick, D.G., Resnick, H.S., Milanak, M.E., Miller, M.W., Keyes, K.M. \& Friedman, M.J. (2013). National Estimates of Exposure to Traumatic Events and PTSD Prevalence Using DSM-IV and DSM-5 Criteria. Journal Of Traumatic Stress, 26(5), 537-547.

Kuhn, E., Greene, C., Hoffman, J., Nguyen, T., Wald, L., Schmidt, J., Famsey, K. \& Ruzek, J. (2014a). Preliminary Evaluation of PTSD Coach, a Smartphone App for Post-Traumatic Stress Symptoms - Military Medicine, 179, 12-18.

Kuhn, E., Eftekhari, A., Hoffman, J., Crowley, J., Ramsey, K., Reger, G. \& Ruzek, J. (2014b). Clinician Perceptions of Using a Smartphone App with Prolonged Exposure Therapy. Administration and Policy in Mental Health and Mental Health Services Research, 41, 800-807.

Kuster, A., Niemeyer, H. \& Knaevelsrud, C. (2016). Internet-based interventions for posttraumatic stress: A meta-analysis of randomized controlled trials. Clinical Psychology Review, 43, 1-16.

Lei n.o 80/2015 (2015). Segunda alteração à Lei n.o 27/2006, que aprova a Lei de Bases da Proteçáo Civil. Diário da República nº149, 3 agosto 2015, 5311-5326.

Lourenço, L. (2015a). Risco, perigo e crise: pragmatismo e contextualização. In A. Siqueira, N. Valencio, M. Siena \& M.A. Malagoli (Eds.). Riscos de desastres relacionados à água: aplicabilidade de bases concetuais das Ciências Humanas e Sociais para a análise de casos concretos (pp.3-43). Santa Paula - São Carlos, S. Paulo: Rima. http://www.uc.pt/fluc/nicif/Publicacoes/Estudos_ de_Colaboradores/PDF/Livros_e_Guias/2015_RiscosDesastres_LL_.pdf.

Lourenço, L. (2015b). Referencial de Educação para o risco, uma recente publicação do Ministério da Educaçăo e Ciência. Territorium, 22, 305-311

http://www.uc.pt/fluc/nicif/riscos/Documentacao/Territorium/T22_Artg/T22_NNR07.pdf.

Maia, A.C. \& Fernandes, E. (2003). Epidemiologia da perturbação pós-stress traumático (PTSD) e avaliação da resposta ao trauma. In M.G. Pereira \& J. Monteiro-Ferreira (Eds.). Stress traumático: aspectos teóricos e intervenção (pp.35-54). Lisboa: Climepsi.

Mao, X., Fung, O. M., Hu, X., \& Loke, A. Y. (2018). Review article: Psychological impacts of disaster on rescue workers: A review of the literature. International Journal of Disaster Risk Reduction, 27, 602-617. DOI: http://dx.doi.org/110.1016/j.ijdrr.2017.10.020.

Mitchell, J. (2003). Major Misconceptions in Crisis Intervention. International Journal of Emergency Mental Health, 5(4), 185-197. 
Mitchell, J. (2004). Characteristics of Successful Early Intervention Programs. International Journal of Emergency Mental Health, 6(4) 175-184.

Mitchell, J. (2005). Critical Incident Stress Debriefing (CISD). Acedido Abril 2016 em: http://www.info-trauma.org/en/e-library no7.

Mitchell, J. (2006). Critical incident stress management (CISM): group crisis intervention. Maryland: International Critical Incident Stress Foundation.

Mitchell, J. (2009). Critical Incident Stress Management. Acedido Abril 2016 em http://www.info-trauma.org/en/e-library.

Miura, A., Toriumi, F., Komori, M., Matsumura, N., \& Hiraishi, K. (2016). Relationship between emotion and diffusion of disaster information on social media: Case study on 2011 Tohoku earthquake. Transactions of the Japanese Society for Artificial Intelligence, 31(1) [online 10.1527/tjsai.NFC-EC1].

Monteiro-Ferreira, J. (2003). Terapia farmacológica da PTSD. In M.G. Pereira \& J. Monteiro-Ferreira (Eds.). Stress traumático: aspectos teóricos e intervenção (pp.221-249). Lisboa: Climepsi.

North, C., Pollio, D., Hong, B., Pandya, A., Smith, R. \& Pfefferbaum, B. (2015). The postdisaster prevalence of major depression relative to PTSD in survivors of the 9/11 attacks on the world trade center selected from affected workplaces. Comprehensive Psychiatry, 60, 119-125.

Palha, M. (2016). Uma caixa de primeiros socorros das emoçōes. Barcarena: Presença.

Pereira, M.G. (2003). Intervençấo familiar. In M.G. Pereira \& J. Monteiro-Ferreira (Eds.). Stress traumático: aspectos teóricos e intervençâo (pp.187-205). Lisboa: Climepsi.

Pereira, M.G. \& Monteiro-Ferreira, J. (2003). Stress traumático: aspectos teóricos e intervenção. Lisboa: Climepsi.

Ranney, M.L., Patena, J.V., Nugent, N., Spirito, A., Boyer, E., Zatzick, D. \& Cunningham, R. (2016). PTSD, cyberbullying and peer violence: prevalence and correlates among adolescent emergency department patients. General Hospital Psychiatry, 39, 32-38.

Regehr, C. (2001). Crisis debriefing groups for emergency responders: reviewing the evidence. Brief Treatment and Crisis Intervention, 1(2), 87-100.

Regehr, C., Goldberg, G. \& Hughes, J. (2002). Exposure to Human Tragedy, Empathy, and Trauma in Ambulance Paramedics. American Journal of Orthopsychiatry, 72(4), 505-513.

Sachser, C. \& Goldbeck, L. (2016). Consequences of the Diagnostic Criteria Proposed for the ICD-11 on the Prevalence of PTSD in Children and Adolescents. Journal of Traumatic Stress, 29(2), 120-123.

Seynaeve, G.J.R. (2001). Psycho-Social Support in situations of mass emergency. A European Policy Paper concerning different aspects of psychological support and social accompaniment for people involved in major accidents and disasters. Brussels: Ministry of Public Health.

Shultz, J. M., \& Forbes, D. (2013). Psychological First Aid. Disaster Health, 2(1), 3-12. DOI: http://dx.doi.org/10.4161/dish.26006.

Souza, K. \& Lourenço, L. (2015). A evoluçáo do conceito de risco à luz das ciências naturais e sociais. Territorium, 22, 31-44. DOI: http://dx.doi.org/10.14195/1647-7723_22_1.

SPHERE PROJECT (2011). Humanitarian Charter and Minimum Standards in Disaster Response. Geneva: The Sphere Project, IASC, Inter-Agency Standing Committee.

Te Brake, H., Duckers, M., De Vries, M., Van Duin, D., Rooze, M. \& Spreeuwenberg, C. (2009). Early psychosocial interventions after disasters, terrorism, and other shocking events: Guideline development. Nursing \& Health Sciences, 11, 336-343. 
Thordardottir, E. B., Gudmundsdottir, B., Petursdottir, G., Valdimarsdottir, U. A., \& Hauksdottir, A. (2018). Psychosocial support after natural disasters in Iceland-implementation and utilization. International Journal of Disaster Risk Reduction, 27, 642-648.

DOI: http://dx.doi.org/10.1016/j.ijdrr.2017.11.006.

UNISDR, UNITED NATIONS OFFICE FOR DISASTER RISK REDUCTION (2016). 2015 disasters in numbers. Geneva: United Nations Office for Disaster Risk Reduction.

Valentine, P. (2003). Redução de incidentes traumáticos. In M.G. Pereira \& J. Monteiro-Ferreira (Eds.). Stress traumático: aspectos teóricos e intervençâa (pp.207-220). Lisboa: Climepsi.

Vaz Serra, A (2003). O distúrbio de stress pós-traumático. Coimbra: Gráfica de Coimbra.

Vogt, J., Leonhardt, J., Koper, B. \&Pennig, S. (2004). Economic Evaluation of CISM - A Pilot Study. International Journal of Emergency Mental Health, 6(4), 185-196.

Vymetal, S., Deistler, A., Bering, R., Schedlich, C., Rooze, M., Orengo, F., Zurek, G. \& Krtickova, M. (2011) European Commission project: European Guideline for Target Group-Oriented Psychosocial Aftercare-Implementation. Prehospital Disaster Medicine, 26(3), 234-236.

Wilson, L.C. 2015. A systematic review of probable posttraumatic stress disorder in first responders following man-made mass violence. Psychiatry Research, 229(1-2), 21-26.

WHO, WORLD HEALTH ORGANIZATION (2010). mhGAP Intervention Guide for Mental Health, Neurological and Substance Use Disorders in Non-specialized Health Settings. Geneva: WHO Mental Health Gap Action Programme.

WHO, WORLD HEALTH ORGANIZATION (2011). Psychological first aid: Guide for field workers. Geneva: World Health Organization.

WHO, WORLD HEALTH ORGANIZATION (2012). Assessing mental health and psychosocial needs and resources Toolkit for humanitarian settings. Geneva: World Health Organization.

WHO, WORLD HEALTH ORGANIZATION (2013). Building Back Better: Sustainable Mental Health Care after Emergencies. Geneva: World Health Organization.

WHO, WORLD HEALTH ORGANIZATION (2015). Clinical Management of Mental, Neurological and Substance Use Conditions in Humanitarian Emergencies: mhGAP Humanitarian Intervention Guide (mhGAP-HIG). Geneva: World Health Organization.

Wynn, S. (2015). Natural Disasters: Planning for Psychological First Aid. Journal Of Christian Nursing : A Quarterly Publication Of Nurses Christian Fellowship, 34(1), 24-28. 
(Página deixada propositadamente em branco) 


\title{
A gestáo da pós-CATÁstrofe, COMO MEdida de PROTEÇÁO E DE MITIGAÇÁO DA CRISE, BEM COMO DE AUMENTO DA RESILIÊNCIA
}

POST-DISASTER MANAGEMENT AS A MEANS OF

PROTECTING AND MITIGATING A CRISIS, AS WELL AS INCREASING RESILIENCE

Salvador Almeida

Universidade Lusófona do Porto ORCID: 0000-0002-5522-164X_salvadorpfalmeida@gmail.com

Sumário: As situaçôes de catástrofe constituem acontecimentos raros e inopinados que só podemos fazer face de uma forma eficaz se nos prepararmos para essa possibilidade, pois ao contrário dos riscos que se situam no mundo do provável, as catástrofes são bem reais. Os pilares da gestão das crises são: atenuação dos efeitos da catástrofe, resposta de urgência e reabilitação.

Palavras-chave: Crise, gestão e reabilitação.

\begin{abstract}
Disaster situations are rare and unforeseen events that can only be effectively dealt with if we prepare for such a possibility, because, unlike the risks in the world of the probable, disasters are very real - The pillars of crisis management are mitigation of the effects of a disaster, emergency response and rehabilitation.
\end{abstract}

Keywords: Crisis, management and rehabilitation. 


\section{Introduçáo}

A situação pós catástrofe é muito difícil e normalmente por mais bem organizada que esteja a Proteçáo Civil nos vários patamares a resposta raramente é satisfatória. Tudo deve começar ao nível municipal conforme estipula a alínea d) n. ${ }^{\circ} 1$ art. 2. ${ }^{\circ}$ da Lei n. ${ }^{\circ}$ 65/2007 de 12 novembro, que diz "apoiar a reposição da normalidade da vida das pessoas nas áreas do município afetadas por acidente grave ou catástrofe".

Obriga esta alínea, que o Serviço Municipal de Proteção Civil esteja organizado, tenha o Plano Municipal de Emergência de Proteção Civil aprovado e, acima de tudo, testado.

No "antes", deve procurar-se a atenuação dos efeitos. É a prevenção do risco, na mitigação da vulnerabilidade e na preparaçáo para a resposta, isto é:

- Avaliação do risco;

- Reduçáo da vulnerabilidade;

- Prontidão na resposta, à crise, fazendo exercícios/simulacros e treino/formação. No "durante", é a resposta à urgência. Temos a crise. Os meios de combate são acionados. Esta resposta deverá passar por:

- Existência de Planos Prévios de Intervenção (são Planos de Emergência);

- Gestão e Coordenação de recursos;

- Aviso às populaçóes e mobilização de meios e recursos;

- Gestáo dos meios, tendo em atenção a fundamental prontidão na resposta;

- Atividades de busca e salvamento;

- Prestaçáo do socorro, face às vítimas encontradas, sejam, mortes, com problemas físicos (feridos, mutilados), desalojados, desaparecidos;

- Apoio Psicológico, quer às populações, quer aos combatentes;

- Implementar o Plano de Comunicação, que permitirá a transmissão da informação a todos os intervenientes na ocorrência.

No "após" a plena manifestação do risco, situação que corresponde às fases de reabilitação e de recuperação, procede-se à reconstrução da área afetada, com vista a torná-la mais resiliente no futuro, designadamente através das seguintes açôes:

- Tratar dos feridos, enterrar os mortos, prestar apoio social às famílias das vítimas e iniciar a reconstrução dos bens e haveres destruídos; 
- Procurar reduzir a vulnerabilidade e implementar programas de desenvolvimento;

- Usar as Linhas de Créditos Especiais (Decreto-Lei n. ${ }^{\circ} 38-B / 2001$, de 8 de fevereiro, com a redação Decreto-Lei n. ${ }^{\circ}$ 130/2008, de 21 julho).

- Utilizar a Conta de Emergência (Decreto-Lei n. ${ }^{\circ}$ 112/2008, de 1 de junho);

- Ativar o Fundo de Emergência Municipal (Decreto-Lei n.o 225/2009, de 14 de setembro);

- E, se for caso disso, o Fundo de Solidariedade da União Europeia (Regulamento n. ${ }^{\circ}$ 2012/2002 de 11 de novembro).

Por sua vez, pode ser desencadeado o Auxílio Internacional, que se faz segundo dois modelos diferentes:

- Cooperaçáo bilateral

Neste caso existem cinco instrumentos de assistência mútua, aprovados entre Portugal e os seguintes países:

- Espanha (desde 1992) - Decreto-Lei n. ${ }^{o}$ 49/1992, de 18 /12, DRI-A n. ${ }^{\circ}$ 291, de 18 de dezembro de 1992, Acordo com a Direção Geral de Proteção Civil e Emergência;

- Marrocos (desde 1992);

- França (desde 1995);

- Cabo Verde (desde 1998);

- Rússia (desde 1999).

- Cooperação multilateral

Em termos de cooperação multilateral há três instrumentos que podem ser utilizados:

- Mecanismo de Proteção Civil da União Europeia desde 2002, através do Emergency Response Coordination Centre (ERCC);

- Gabinete para Coordenação dos Assuntos Humanitários (OCHA) da Organização das Nações Unidas (ONU) desde 2004;

- Centro de Coordenação Euro-Atlântica para a resposta a Catástrofes, Organizaçáo do Tratado do Atlântico Norte (OTAN/NATO) desde 2005.

Em 2000 as Naçóes Unidas lançaram uma estratégia internacional para a redução de desastres.

Em 2005 esta estratégia foi concretizada na Plataforma de Ação Hyogo em que as prioridades da ação eram criar uma Cultura de Segurança e Resiliência 
focando a inclusão da redução do risco de desastre nos currículos escolares, na educação formal e não formal.

Desde 2010 que está a ser desenvolvida em Portugal uma Plataforma Nacional neste domínio, o que é muito positivo, mas pouco se sabe sobre o desenvolvimento. Quais sáo as instituiçōes envolvidas? Decorridos que são mais de 7 anos, quais são os resultados? Foi realmente considerado como prioridade a inclusão nos currículos escolares a educação para o risco? O que fazer para construir uma "cultura de prevenção e segurança?" $\mathrm{Na}$ opiniáo do autor, a construçâo deste grande desígnio passa pelas 3 fases seguintes:

- Antes da emergência, ou seja, antes da plena manifestação do risco, situação que corresponde ao que podemos designar por "estado normal";

- Durante a emergência, isto é, durante e imediatamente após a plena manifestação do rico, ou seja, durante o tempo em que decorre a fase de emergência e que corresponde ao estado de alerta especial, que inclui a reabilitaçáo de emergência;

- Após a emergência, ou seja, depois de terminar a intervençáo de emergência mas em que continuam as operaçôes de recuperação, com vista à reconstrução da área afetada, de modo a torná-la mais resiliente, intervençáo que se pode prolongar por vários anos.

Ora, para a construção de uma cultura de prevenção e segurança, o contributo dos "media" é fundamental.

$\mathrm{Na}$ alínea c), n. ${ }^{\circ} 2$ - art. $^{\circ} 2 .^{\circ}$, da Lei n. ${ }^{\circ}$ 65/2007, de 12 Novembro, diz que a Proteção Civil se exerce em vários domínios, nomeadamente: Informação e formação das populaçóes, visando a sua sensibilização em matéria de autoproteção e a colaboração com as autoridades.

A este nível, como sinónimo de organização, é ainda muito importante que a Comissão Municipal de Proteção Civil (CMPC), enquanto órgão fiscalizador da política de proteção civil, faça cumprir as suas atribuiçôes que, aliás, estấo muito bem definidos nas alíneas a), b), c), d) e e) do n. 3 da Lei n. ${ }^{\circ}$ 65/2007, que se transcrevem pela sua grande importância:

- Acionar a elaboração do plano municipal de emergência, remetê-lo para aprovaçáo pela Comissão Nacional de Proteção Civil e acompanhar a sua execução;

- Acompanhar as políticas diretamente ligadas ao sistema de proteção civil que sejam desenvolvidas por agentes públicos; 
- Determinar o acionamento dos planos, quando tal se justifique;

- Garantir que as entidades e instituiçôes que integram a CMPC acionam, ao nivel municipal, no âmbito da sua estrutura orgânica e das suas atribuiçôes, os meios necessários ao desenvolvimento das açôes de proteção civil;

- Difundir comunicados e avisos às populaçôes, às entidades e instituiçôes, inchuindo os órgãos de comunicação social.

Dependendo do grau de Catástrofe, o patamar municipal será insuficiente e há necessidade de, para além dos princípios consagrados na Constituição e na Lei, aplicar princípios fundamentais especiais aplicáveis às atividades de proteção civil (art. ${ }^{\circ}$ 5. ${ }^{\circ}$, Lei n. ${ }^{\circ} 80 / 2015$, de 3 de agosto), salientando-se o princípio da subsidiariedade, que determina que o subsistema de proteção civil de nível superior deve intervir, no caso de o patamar inferior não conseguir alcançar os resultados desejados.

A ocorrência da Catástrofe implica obrigatoriamente o dever de ser declarada a "Situação de Contingência", sendo reconhecida a necessidade de adotar medidas preventivas e medidas especiais de reação não mobilizáveis no âmbito municipal (n. ${ }^{\circ}$ 2, art. ${ }^{\circ}{ }^{\circ}$, Lei n. ${ }^{\circ}$ 80/2015), e, se for reconhecida a necessidade de adotar medidas de carácter excecional, destinadas a prevenir, reagir ou repor a normalidade das condiçôes de vida nas áreas atingidas pelos seus efeitos, será declarada "Situação de Calamidade" (n. ${ }^{\circ} 3$ art. $^{\circ}$ 9. ${ }^{\circ}$, Lei n. ${ }^{\circ}$ 80/2015, de 3 de agosto).

A competência para declarar a Situação de Contingência cabe à entidade responsável pela área da proteção civil no seu âmbito territorial de competência, precedida da audição, sempre que possível dos presidentes das câmaras dos municípios abrangidos (art. ${ }^{\circ} 16 .^{\circ}$, da Lei n. $.^{\circ} 80 / 2015$, de 3 de agosto).

$\mathrm{O}$ ato e âmbito que declara a situação de contingência reveste a forma de despacho e deve mencionar expressamente (art. ${ }^{\circ} 17 .^{\circ}$, da Lei n. ${ }^{\circ}$ 80/2015, de 3 de agosto):

- A natureza do acontecimento que originou a situação declarada;

- O âmbito temporal e territorial;

- O estabelecimento de diretivas especificas relativas à atividade operacional dos agentes de proteção civil e das entidades e instituiçōes envolvidas nas operaçóes de proteção e socorro;

- Os procedimentos de inventariação dos danos e prejuizos provocados;

- Os critérios de concessão de apoios materiais. 
Por sua vez, a competência para declarar a "Situação de Calamidade" é da competência do Governo e reveste a forma de Resolução do Conselho de Ministros (art. ${ }^{\circ} 19 .^{\circ}$, Lei n. ${ }^{\circ} 80 / 2015$, de 3 de agosto). O ato e âmbito que declara a situaçáo de calamidade deve mencionar expressamente (art. $21 .^{\circ}$, da Lei $n .^{\circ}$ 80/2015, de 3 de agosto):

- A natureza do acontecimento que originou a situaçáo declarada;

- O âmbito temporal e territorial;

- O estabelecimento de diretivas relativas à atividade operacional dos agentes de proteção civil e das entidades e instituiçôes envolvidas nas operaçōes de proteção e socorro;

- Os procedimentos de inventariaçáo dos danos e prejuizos provocados;

- Os critérios de concessáo de apoios materiais e financeiros: A declaração da situação de calamidade pode ainda estabelecer:

- A mobilizaçáa civil de pessoas, por períodos de tempo determinados;

- A fixação, por razóes de segurança dos próprios ou das operaçóes, de limites ou condicionamentos à circulação ou permanência de pessoas, outros seres vivos ou veículos;

- A fixação de cercas sanitárias e de segurança;

- A racionalização da utilização dos serviços públicos de transportes, comunicaçóes e abastecimento de água e energia, bem como do consumo de bens de primeira necessidade. A gravidade da situação pode exigir um reconhecimento antecipado, através de Despacho do Primeiro-ministro e do Ministro da Administraçáo Interna, adotando todas as medidas previstas no art. ${ }^{\circ} 21 .^{\circ}$, exceto as alíneas a) e $d$ ) do n. ${ }^{\circ} 2$.

Ainda determina a obrigatoriedade do acionamento das estruturas de coordenação política e institucional territorial competente e a ativação automática dos planos de emergência de proteçẫo civil do respectivo nível territorial (n. ${ }^{\circ} 2$ e 3 , do art. ${ }^{\circ}$ $17 .^{\circ}$, e n ${ }^{\text {os }} 3$ e 4 , do art. ${ }^{\circ} 21 .^{\circ}$, da Lei n. $.^{\circ} 80 / 2015$, de 3 de agosto).

A gestão da catástrofe exige assegurar o comando operacional das operaçóes de socorro e ainda o comando integrado de todos os agentes de proteçấo civil no respeito pela sua autonomia própria de cada entidade, pelo que compete à Autoridade Nacional de Proteção Civil (ANPC) planear, coordenar e executar a política de proteção civil, designadamente na prevenção e reação a acidentes graves e catástrofes e assegurar a articulação dos serviços públicos ou privados que devem desempenhar missōes relacionadas com o planeamento civil de emergência, a fim de que, em 
situação de acidente grave, catástrofe, crise ou guerra, se garanta a continuidade da ação governativa, a proteção das populaçóes e a salvaguarda do património nacional (n. os 1 e 2 , do art. ${ }^{\circ} 2 .^{\circ}$, do Decreto-Lei n. ${ }^{\circ}$ 163/2014, de 31 outubro).

Refira-se ainda que em situaçóes extraordinárias, determinadas pelo Primeiro-ministro após comunicação ao Presidente da República, de ataques terroristas ou de acidentes graves ou catástrofes que requeiram a intervenção conjunta e combinada de diferentes forças e serviços de segurança e, eventualmente do Sistema Integrado de Operaçóes de Proteção e Socorro (SIOPS), previsto no Decreto-Lei n. ${ }^{\circ}$ 72/2013, de 31 maio, e no Despacho ANPC n. ${ }^{\circ}$ 3551/2015, de 9 de abril, estes são colocados na dependência operacional do Secretário-geral do Sistema de Segurança Interna, através dos seus dirigentes máximos (n. ${ }^{\circ} 1$, art. ${ }^{\circ} 19 .^{\circ}$, Lei n. ${ }^{\circ}$ 59/2015, de 24 junho).

\section{A reabilitação de emergência}

Após a plena manifestação do risco, através da catástrofe, o principal objetivo do socorro é, em primeiro lugar, tratar dos feridos e, depois, com toda a dignidade, tratar de enterrar os mortos.

De seguida, é preciso avaliar os prejuízos, procurar saber as causas que deram origem à catástrofe, para se poderem implementar medidas de prevenção, usando o conhecimento e a experiência para indemnizar as vítimas e reconstruir a área afetada.

O patamar municipal perante a ocorrência de acidente grave ou catástrofe e em situação de calamidade, definida no art. ${ }^{\circ} 19 .^{\circ}$ da Lei n. ${ }^{\circ} 80 / 2015$ e tendo que desenvolver com urgência açóes de socorro e assistência, pode socorrer-se de apoios, designadamente dos previstos nos:

- Decreto-Lei n. ${ }^{\text {o } 38-B / 2001}$, de 8 de fevereiro, com a redação que lhe foi dada pelo Decreto-Lei n. ${ }^{\circ}$ 130/2008, de 21 de julho, que criou linhas de crédito bonificado como forma de apoio aos agentes económicos atingidos pelas intempéries, em protocolo obrigatório com o Instituto de Apoio às Pequenas e Médias Empresas e ao Investimento (IAPMEI).

Este diploma cria linhas de crédito especiais com o objetivo de minimizar os danos ocorridos devido a catástrofe, normalmente devido a condições atmosféricas excecionais na atividade comercial, industrial e de serviços. 
As entidades bancárias protocolam os créditos com o IAPMEI. Os empréstimos protocolados beneficiarão de uma bonificaçáo, que consiste no pagamento pelo IAPMEI da totalidade dos encargos de juros, nos moldes referidos no art. ${ }^{\circ}$ 6. ${ }^{\circ}$, bem como dos encargos correspondentes ao imposto de selo.

As empresas localizadas em regiōes que tenham sido atingidas por condiçôes atmosféricas excecionais e que tenham sofrido danos significativos na sua atividade comercial, industrial e de serviços serão contemplados com este apoio. Refira-se ainda que a cobertura dos encargos resultantes da bonificação dos empréstimos é suportada por transferência do Orçamento do Estado para o IAPMEI.

Apresenta-se um exemplo de aplicação objetiva de Linhas de Crédito Bonificado, para socorrer os concelhos de Ferreira do Zêzere, Sertã e Tomar que foram atingidos, no dia 7 de dezembro de 2010, por um tornado que afetou equipamentos públicos e associativos, instalaçôes industriais e comerciais, exploraçóes agrícolas e agropecuárias, habitaçóes e diversos outros bens (fig. 1).

- Decreto-Lei n. ${ }^{\circ}$ 112/2008, de 1 de julho, que definiu a Conta de Emergência, aberta no Instituto de Gestáo da Tesouraria e do Crédito Público, I. P., conta titulada pela Autoridade Nacional de Proteçáo Civil (ANPC).

Esta conta de emergência pode suportar despesas destinadas a pessoas atingidas, nomeadamente na reconstrução e reparação de habitações, unidades de exploração económica e na cobertura de outras necessidades sociais prementes, uma vez que numa situação de catástrofe, em que não só elevados prejuízos materiais e vítimas, mas também em que as condiçóes de vida foram intensamente afetadas e onde o tecido económico foi destruído, seja no comércio, indústria e serviços, e onde houve habitaçôes destruídas de que decorrem graves problemas sociais, esta conta permite dispor um mecanismo que permite adotar medidas de assistência de urgência.

Refira-se que esta cobertura se destina às pessoas que não têm capacidade efetiva para, pelos seus próprios meios, recuperarem os seus bens ou a sua atividade. Ainda é de referir que os danos que sejam cobertos por quaisquer entidades públicas ou privadas não serão cobertos por esta conta.

Para coordenar todas as açôes de necessidade de socorro, comprovar as situaçôes elegíveis e definir os critérios de financiamento será criada, pelo Governo, 
Diário da República, 1 . $^{a}$ série -N. ${ }^{\circ} 242-16$ de Dezembro de 2010

\section{PRESIDÊNCIA DO CONSELHO DE MINISTROS}

\section{Resolução do Conselho de Ministros n. ${ }^{\circ}$ 99/2010}

Os concelhos de Ferreira do Zêzere, Sertã e Tomar — sem excluir outros que venham a ser apurados - foram atingidos, no dia 7 de Dezembro de 2010, por um tornado que afectou equipamentos públicos e associativos, instalações industriais e comerciais, explorações agrícolas e agro-pecuárias, habitações e diversos outros bens.

O sistema de protecção civil e os respectivos agentes, a nível nacional, distrital e municipal, actuando de forma coordenada, conseguiram repor o funcionamento das infra-estruturas e equipamentos essenciais à vida das populações, com a necessária colaboração de todas as entidades responsáveis por cada uma das áreas, nomeadamente nos domínios da energia, abastecimento de água, comunicações e circulação.

Após a primeira fase de resposta, e num quadro de excepcionalidade conferido pela natureza da ocorrência e extensão dos danos, constitui preocupação do Governo criar condições que permitam levar a cabo, de forma adequada e equitativa, a minimização dos prejuízos e recuperação do tecido produtivo, recorrendo para o efeito aos instrumentos legais disponíveis.

As dotações financeiras disponibilizadas para a concretização das medidas agora adoptadas serão fixadas assim que esteja concluída a determinação exacta dos prejuízos em causa. Adecisão sobre os apoios a conceder basear-se-á, necessariamente, na avaliação rigorosa e documentada dos danos e na verificação da incapacidade de os sinistrados, pelos seus próprios meios, incluindo o accionamento de contratos de seguro existentes, superarem, no todo ou em parte, a situação.

Assim:

Nos termos da alínea $g$ ) do artigo $199 .^{\circ}$ da Constituição, o Conselho de Ministros resolve:

1 - Desencadear os procedimentos necessários à minimização dos prejuízos provocados pelo tornado que, em 7 de Dezembro de 2010, atingiu os concelhos de Ferreira do Zêzere, Sertã e Tomar - sem excluir outros que venham a ser apurados —, com recurso aos seguintes instrumentos:

a) Através da Presidência do Conselho de Ministros, relativamente aos danos que afectaram infra-estruturas e equipamentos municipais, autorizar o recurso ao Fundo de Emergência Municipal previsto no artigo $11 .^{\circ}$ do Decreto-Lei n. $.^{\circ} 225 / 2009$, de 14 de Setembro, com dispensa do requisito previsto no artigo $4 .^{\circ}$ do mesmo diploma, atendendo às circunstâncias excepcionais verificadas; b) Através do Ministério da Agricultura, do Desenvolvimento Rural e das Pescas, relativamente aos danos que atingiram explorações agrícolas, agro-pecuárias e florestais, accionar se necessário os apoios no âmbito da Acção n. ${ }^{\circ}$ 1.5.2 do Programa de Desenvolvimento Rural do Continente (PRODER), designada «Restabelecimento do potencial produtivo», que tem por objectivo a manutenção das condições de produção afectadas por catástrofes ou calamidades naturais de elevado impacto;

c) Através dos Ministérios das Finanças e da Administração Pública, da Administração Interna e da Economia, da Inovação e do Desenvolvimento, em relação a actividades económicas não abrangidas pela alínea anterior, proferir despacho conjunto, ao abrigo do disposto no Decreto-Le n. ${ }^{\circ} 38-\mathrm{B} / 2001$, de 8 de Fevereiro, com a redacção que lhe foi dada pelo Decreto-Lei n. ${ }^{\circ} 130 / 2008$, de 21 de Julho, que define o montante global de crédito sob a forma de emprés timo bonificado, até ao limite de $€ 500000$ por operação, a conceder às pequenas e médias empresas no âmbito das linhas de crédito especiais com o objectivo de minimizar os danos resultantes de condições climatéricas excepcionais,

d) Através do Ministério do Trabalho e da Solidariedade Social, relativamente aos danos que afectaram equipamentos sociais, atribuir subsídios eventuais e apoios para recuperação dos equipamentos sociais afectados;

e) Através dos Ministérios das Finanças e da Administração Pública e da Administração Interna, relativamente a outros danos, nomeadamente em habitações, accionar conta de emergência aberta junto do Instituto de Gestão da Tesouraria e do Crédito Público, I. P., e titulada pela Autoridade Nacional de Protecção Civil, para fazer frente a situações de catástrofe ou calamidade, através de despacho conjunto a proferir ao abrigo do disposto no Decreto-Lei n. ${ }^{\circ} 112 / 2008$, de 1 de Julho.

2 - As regras aplicáveis à verificação dos danos e os critérios para a comparticipação e financiamento das despesas elegíveis são os decorrentes de cada um dos instrumentos acima identificados ou, na sua ausência, os que forem estabelecidos por despacho conjunto do Ministro de Estado e das Finanças e do membro do Governo competente em função da matéria.

3 - O disposto na alínea $a$ ) do n. $^{\circ} 1$ da presente resolução produz efeitos a partir de 1 de Janeiro de 2011.

Presidência do Conselho de Ministros, 9 de Dezembro de 2010. - O Primeiro-Ministro, José Sócrates Carvalho Pinto de Sousa

Fig. 1 - Resolução Conselho Ministros n.o 99/2010 de 16 de dezembro (Fonte: Diário da República).

Fig. 1 - RCouncil of Ministers Resolution no. 99/2010 of 16 December (Source: Diário da República/Official Gazette).

uma "Estrutura de Coordenação e Controlo", cuja composição é fixada por Despacho, conforme o n. ${ }^{\circ} 2$ do art. $^{\circ} 1^{\circ}{ }^{\circ}$, do Decreto-Lei n. ${ }^{o} 112 / 2008$, de 1 de julho.

Esta conta de emergência é movimentada pelo Presidente da ANPC e está sujeita à fiscalização do Tribunal de Contas. 
- O Decreto-Lei n. ${ }^{\circ}$ 225/2009, de 14 de setembro, que criou o Fundo de Emergência Municipal em situação de calamidade declarada pelo Governo e que visa conceder auxílios financeiros às autarquias locais para a recuperação de equipamentos públicos da responsabilidade das mesmas, Fundo que é gerido pela Direção-Geral das Autarquias Locais (DGAL).

A Lei das Finanças Locais (LFL) estabelece a possibilidade de concessão de auxílios financeiros às Autarquias Locais em "situação de Calamidade" definida pela Lei n. $27 / 2006$, de 3 julho, alterada pela Lei n.o 80/2015, de 3 agosto, art.o 9o n.o 3, prevendo a necessidade de criação, nesse âmbito, do Fundo de Emergência Municipal.

A concessão de auxílios financeiros regulados no presente Decreto-Lei depende da declaração de Situação de Calamidade. A declaração de "Situação de Calamidade" é da competência do Governo e reveste a forma de Resolução de Conselho de Ministros, nos termos do art. ${ }^{\circ} 19 .^{\circ}$ da Lei n. ${ }^{\circ}$ 80/2015, de 3 agosto.

A Resolução do Conselho de Ministros deve mencionar expressamente (n. ${ }^{\text {s }}$ 1 e 2 , art. ${ }^{\circ} 21 .^{\circ}$, da Lei n. ${ }^{\circ} 80 / 2015$, de 3 agosto):

- A natureza do acontecimento que originou a situação declarada;

- O âmbito temporal e territorial;

- O estabelecimento de diretivas especificas relativas à atividade operacional dos agentes de proteção civil e das entidades envolvidas nas operaçóes de proteção e socorro;

- Os procedimentos de inventariação dos danos e prejuizos provocados;

- Os critérios de concessão de apoios materiais e financeiros;

Pode ainda estabelecer:

- A mobilização civil de pessoas por períodos de tempo determinados;

- A fixação, por razóes de segurança dos próprios ou das operaçóes, de limites ou condicionamentos à circulação de pessoas, outros seres vivos ou veículos;

- A fixação de cercas sanitárias e de segurança;

- A racionalização da utilização dos serviços públicos de transportes, comunicação, abastecimento de água e energia, bem como bens de primeira necessidade.

Os instrumentos financeiros em situação de calamidade visam a resolução de situaçóes excecionais de urgência, devidamente fundamentada e comprovada, podendo celebrar contratos os municípios, as comunidades intermunicipais e as áreas metropolitanas. 
As candidaturas a contratos de auxílio financeiro são apresentadas junto da Comissão de Coordenaçáo e Desenvolvimento Regional (CCDR) da área geográfica correspondente à entidade beneficiária.

O Orçamento de Estado contém anualmente uma autorização de despesa no montante máximo equivalente a $1 \%$ do Fundo de Equilíbrio Financeiro (FEF) dos municípios do continente, do ano em questáo, destinada exclusivamente a auxílios financeiros à administraçáo local, em caso de declaraçáo de calamidade, nos termos do n. ${ }^{\circ} 1$, art. ${ }^{\circ} 13 .^{\circ}$, DL n. ${ }^{\circ}$ 225/2009, de 14 setembro. A gestão do Fundo é da competência da Direçấo Geral das Autarquias Locais (DGAL).

Além dos mecanismos acabados de referir, existentes a nível nacional, existem outros a nível internacional, de que mencionamos os seguintes:

- Fundo de Solidariedade da União Europeia - Regulamento (CE) n. 2012/2002 de 11 de novembro

Para situaçôes de catástrofe de grandes proporçôes a União Europeia, aprovou o Fundo de Solidariedade da Uniáo Europeia-Regulamento (CE) n. ${ }^{\circ}$ 2012/2002, de 11 novembro, para ajudar a populaçáo das regióes afetadas, prestando-lhes um auxílio financeiro que contribua para o rápido restabelecimento de condiçốes de vida normais das regióes afetadas.

É um fundo destinado essencialmente para fazer face aos prejuízos causados por uma catástrofe de grandes proporçôes.

O regulamento define como "Catástrofe de grandes proporçôes" qualquer catástrofe que, em pelo menos um dos Estados abrangidos, provoque prejuízos importantes em termos financeiros superior a 3 mil milhōes de euros (preços de 2002) ou em percentagem do rendimento nacional bruto (RNB) que represente mais de $0,6 \%$ do rendimento nacional bruto (RNB) do Estado em causa.

Em circunstâncias excecionais, mesmo quando os critérios quantitativos, não se encontrem preenchidos, $\mathrm{o}$ Estado membro afetado pode beneficiar do auxílio do "Fundo", em caso de catástrofe de carácter extraordinário, especialmente em catástrofe natural, que afete a maior parte da sua população e tenha repercussóes graves e prolongadas nas condiçôes de vida e na estabilidade económica da região (fig.2). 
Incêndios Proposta do Fundo de Solidariedade será votada no dia 30

\section{Europa dá 50,6 milhões}

\section{Alexandra Figueira}

afigueira@jn.pt

>Portugal deverá receber 50,6 milhões de euros do Fundo de Solidariedade da União Europeia como compensação pelos incêndios florestais do ano passado. A proposta de mobilização do fundo foi aprovada pela Comissão dos Orçamentos do Parlamento Europeu e será votada pelo plenário no próximo dia 30

O Fundo de Solidariedade, criado depois das cheias que arrasaram o centro da Europa em 2002, visa compensar os estados-membros pelos custos suportados com a recuperação de catástrofes naturais. No ano passado, o Governo português entregou um primeiro pedido de compensação após $\mathrm{Pe}$ drógão Grande, a 17 de julho de
2017, e atualizou-o a 13 de outubro e a 14 de dezembro, para contemplar os fogos do outono.

Em resposta, logo em novembro, a Europa concedeu um adiantamento de 1,5 milhões de euros. "Estamos profundamente solidários com Portugal, com os seus habitantes e com os que de forma corajosa e incansável lutam contra as chamas", disse, na altura, a comissária europeia da Política Regional, Corina Cretu.

Ontem, foi aprovada em sede de comissão a atribuição de um

\section{Esta será a quarta vez que Portugal beneficia do fundo}

total de 104 milhões de euros, não só para Portugal mas também para a França (devido aos furações que assolaram as regiões francesas de São Martinho e Guadalupe), Grécia (após o sismo na ilha de Lesbos) e Espanha (pelos incêndios florestais na Galiza).

Hoje, a Comissão do Ambiente vai votar uma proposta sobre o Mecanismo de Proteção Civil da União, que prevê uma reserva europeia de ativos de proteção civil para melhorar a prevenção e a preparação em caso de catástrofe natural, bem como a resposta conjunta a dar.

Esta é a quarta vez que Portugal beneficia do fundo. Já o tinha feito nos incêndios de 2003, no deslizamento de terras que matou 40 pessoas na Madeira em 2010 e nos fogos, na mesma ilha, em 2011.

Fig. 2 - Europa dá 50,6 milhôes (Fonte: JN,16/5/2018).

Fig. 2 - Europe gives 50.6 million euros (Source: JN, 16/5/2018).

O "Fundo" tem por objetivo complementar os esforços dos Estados afetados na realização das operaçôes essenciais de urgência, a seguir indicadas (art. ${ }^{\circ}$ 3. ${ }^{\circ}$ Regulamento (CE) n.o 2012/2002, de 11 de novembro):

- Restabelecimento imediato do funcionamento das infraestruturas e equipamentos nos domínios da energia, do abastecimento de água e das águas residuais, das telecomunicaçóes, dos transportes, da saúde e do ensino;

- Execução de medidas provisórias de alojamento e prestaçóes de serviços de socorro destinados a prover às necessidades imediatas da população atingida;

- Criação imediata de condiçóes de segurança das infraestruturas de prevenção e medidas de proteção imediata do património cultural;

- Limpeza imediata das áreas sinistradas, incluindo zonas naturais.

O Estado afetado deve num prazo máximo de 10 semanas, após a ocorrência da catástrofe apresentar o pedido de apoio à Comunidade Europeia (CE). A subvenção deve ser utilizada no prazo de um ano, após o seu recebimento. 
O Estado membro seis meses após o termo do prazo de um ano tem que apresentar um relatório sobre a execução financeira da subvenção, com um mapa fundamentado das despesas e indicação de todas as outras fontes de financiamento das operaçóes em causa, incluindo reembolsos de seguros e indemnizaçôes obtidas de terceiros.

O relatório deve mencionar as medidas de prevenção decididas e previstas pelo Estado benificiário, a fim de limitar os prejuízos e evitar, a repetição de catástrofes semelhantes. Se o custo da reparação dos prejuízos for posteriormente coberto por terceiros, a Comissão reclamará ao Estado benificiário o reembolso do montante correspondente da subvenção atribuída.

- Auxilio Internacional - Cooperação Bilateral

Os acordos bilaterais têm assumido uma importância fundamental no quadro da Cooperação Portuguesa em matéria de Proteção Civil (ANPC, 2009).

Portugal firmou acordos de cooperação bilateral com os seguintes Países (ANPC, 2009):

- Espanha, desde 1992, protocolo de cooperação técnica e assistência mú-

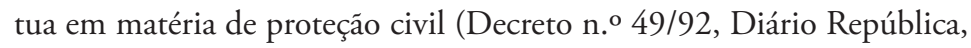
no 291/1992 série I-A, de 18 de dezembro).

- Em 2003 foi assinado um protocolo adicional sobre ajuda mútua em caso de incêndios florestais nas zonas fronteiriças.

- Adicionalmente, em julho de 2007, foi alargada a cooperação a outras situaçôes de emergência em incêndios urbanos e industriais e operações de busca e salvamento, sendo alargada a faixa de $5 \mathrm{~km}$ para $15 \mathrm{~km}$ (Cimeira de Zamora de janeiro de 2009);

- França, desde 1995, realizado acordo entre as duas repúblicas no domínio da Proteção Civil.

- Em 2006, efetuou-se acordo administrativo entre o Ministério da Administração Interna de Portugal e o Ministério do Interior da França sobre a intervenção de meios aéreos bombardeiros de água em situaçóes de assistência mútua em caso de incêndios florestais; 
- Marrocos, desde 1992, acordo de cooperação entre o Reino de Marrocos e o Governo da República Portuguesa em matéria de Proteção Civil;

- Rússia, desde 1999, acordo entre o Governo da República Portuguesa e o Governo da Federação da Rússia sobre a cooperação no domínio da Proteçâo Civil, prevenção e gestão de emergências;

- Cabo Verde, desde 1998, protocolo de cooperação entre o Ministério da Administração Interna de Portugal e o Ministério da Defesa de Cabo Verde em matéria de Proteção Civil.

- Auxílio Internacional - Cooperação Multilateral

Portugal participa ativamente nos trabalhos das seguintes organizações internacionais que desenvolvem açôes no domínio da Proteçáo Civil:

1. Uniâo Europeia (EU);

2. Organização das Naçôes Unidas (ONU);

3. Organização do Atlântico Norte (NATO);

4. Conselho da Europa (CdE);

5. Associação Ibero Americana de Organismos Governamentais de Defesa e Proteção Civil (AIAOGDPC);

6. Organização Internacional de Proteção Civil (OIPC).

- Gabinete Coordenação Assuntos Humanitários (OCHA) da ONU desde 2004

A ONU é uma instituiçấo internacional formada por 192 Estados soberanos e trabalha com o propósito de manter a paz e a segurança no mundo, fomentar relaçôes amistosas entre as naçôes, promover o progresso social, melhorar os padrôes de vida e garantir os elementares direitos humanos.

Não possuindo a ONU uma estrutura específica no Domínio da Proteção Civil, o serviço da ONU com competências nesta área de intervenção é o Gabinete para a Coordenação dos Assuntos Humanitários (UN OCHA), cuja missão é a de coordenar eficazmente os esforços de ação humanitária em parceria com os atores nacionais e internacionais (ANPC, CTPROCIV10,2009).

O Gabinete desenvolve e fornece ferramentas de resposta a emergências, que incluem:

- Equipas no terreno de Avaliação e Coordenação das Nações Unidas (UNDAC); 
As equipas de Avaliação e Coordenação das Naçôes Unidas (UNDAC) assumem um papel central neste sistema. Atuam a pedido de um país afetado e sáo mobilizadas dentro de um curto espaço de tempo, visando realizar uma rápida avaliação das necessidades prioritárias e apoiar as autoridades nacionais e o Coordenador Residente das Naçôes Unidas nos trabalhos de coordenação da ajuda internacional no local.

- Coordenaçáo de operação de busca e salvamento:

- Em harmonia com as orientaçôes INSARAG, definem os procedimentos considerados mais adequados para a coordenação da resposta internacional e nacional quando são utilizadas valências de busca e salvamento em resposta a um desastre de natureza sísmica. Funcionam igualmente como Checlist de requisitos mínimos para a constituição de equipas envolvidas naquelas operaçôes (ANPC, CTPROCIV10,2009).

- Centro de Coordenação Euro-Atlântico de Catástrofes (OTAN/Nato)

A NATO foi criada como uma aliança político-militar para a defesa dos territórios dos aliados e respetivas populaçóes contra ataques militares.

Atualmente, a NATO vê-se envolvida no domínio da Proteção Civil em três tipos de açóes:

- Ajuda aos aliados e aos países associados, nos processos de melhoria da capacidade de resposta;

- Desenvolvimento e disponibilização de uma plataforma de coordenação dos meios nacionais;

- Mobilizaçáo ocasional de recursos para assistência aos aliados e associados.

O domínio da Proteção Civil, no seio da NATO, está integrado no conceito mais alargado de Planeamento Civil de Emergência (PCE), através do qual as atividades de planeamento nacionais são articuladas com vista a:

- Melhor uso dos recursos civis em suporte à concretização dos objetivos da Aliança;

- Melhor uso dos recursos da Aliança no suporte às operaçóes de Proteção Civil.

O fórum principal da NATO neste domínio é o Alto Comité para o Planeamento Civil de Emergência - SCEPC, no âmbito do qual foram criados 8 Comités de Planeamento, entre os quais o Comité de Proteção Civil (CPC). 
O papel atribuído ao CPC é o de coadjuvar os decisores da NATO e dos países aliados e associados no processo de desenvolvimento e manutenção de procedimentos para um efetivo uso dos meios civis e militares em operaçóes de Proteção Civil.

Em Portugal, o órgão que acompanhava os trabalhos ao nível do SCEPC era o Conselho Nacional de Planeamento Civil da Emergência (CNPCE), sendo agora a ANPC que assumiu essa responsabilidade após a extinção do CNPCE. A Comissão Nacional Proteção Civil (CNPC), em 31 de maio de 2010, constituiu-se como "Plataforma Nacional para a Redução do Risco de Catástrofes" e foi reconhecida pela Estratégia Internacional de Redução de Catástrofes das Naçōes Unidas (UNISDR), em abril de 2011, (ANPC, CTPROCIV64,2013).

O Centro de Coordenação Euro-Atlântica para a Resposta a Catástrofes (EADRCC) foi criado em 1998. Trata-se de uma estrutura de reduzida dimensão composta por peritos disponibilizados pelos países aliados e associados e que conta também com um oficial de ligação em permanência do UN OCHA.

As responsabilidades deste Centro, na eventualidade de uma emergência, incluem a coordenação da resposta, em estreita articulação com o UN OCHA e outras organizaçóes internacionais, na sequência de catástrofes ocorridas no território dos países que integram o Conselho para a Parceria Euro-Atlântica (19 aliados e 27 associados).

À semelhança do Centro de Informação e Vigilância da Comissão Europeia (MIC), tem também um papel importante na gestão da informação, isto é, procede à receção e difusão de pedidos e ofertas de assistência internacional.

No que respeita à ativação, o seu mandato dá-lhe plenos poderes para atuar assim que recebe um pedido de um país aliado ou associado (ANPC, CTPROCIV10,2009).

- Mecanismo Comunitário de Proteção Civil

O Mecanismo Comunitário de Proteção Civil é um conjunto de medidas e de procedimentos cuja finalidade é a de facilitar uma cooperação reforçada no quadro das intervençôes de proteção e socorro em situaçôes de ocorrência ou eminência de uma emergência grave, dentro ou fora do espaço europeu (fig. 3). 


\section{Juncker vai repensar proteção civil europeia}

CONSELHO DEESTADO O presiden- ro-ministro, António Costa, o lu- Juncker salientou, por outro te da Comissăo Europeiaja deuins- xemburigus teçấo Civil, Christos Stylianides proteção civil tem "lacunas e fra- ceiros, ao passar de um défice de para que repense o sistema comu- quezas que é preciso remediar" e $11,6 \%$, no pico da crise financeira, nitário de proteçáo civil. Em causa prometeu mais ajuda: "Paremos para $1,4 \%$. Quero aqui homena-

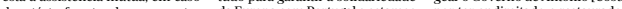
ceu este ano natural comante- da Europa com Portugal e estamos por ter endireitado e restaurado mataram mais de 100 pessoas no proteção civil europeus que po- tuguesas", afirmou. O elogio a nosso pais no verão passado. dem ser melhorados". controlo do défice é relevante $\begin{array}{ccc}\begin{array}{c}\text { Portugal recebeu meios de com- } \\ \text { bate aos incêndios, ao abrigo do }\end{array} & \begin{array}{c}\text { A propósito, enviou as condo- } \\ \text { lencias às vitimas dos incêndios e }\end{array} & \begin{array}{l}\text { atendendo a que, na passada sex- } \\ \text { ta-feira, a Comissão Europeia aler- }\end{array}\end{array}$ $\begin{array}{lll}\text { Mecanismo Europeu de Proteção } & \text { lisse que ele próprio foi afetado, já } & \text { tou } \\ \text { Mou Portugal para os riscos a que a }\end{array}$

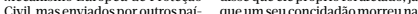
ses, já que a União Europeia não tragédia. No Luxemburgo, recorde$\begin{array}{ll}\text { tem meios próprios. Ontem, de- } & \text { se, os portugueses são um quint } \\ \text { pois de uma reunião com oprimei- } & \text { da populaçăo. }\end{array}$ tou Portugal para os riscos a que as
contas públicas estarão sujeitas contas publicas estarã
este ano e no próximo.

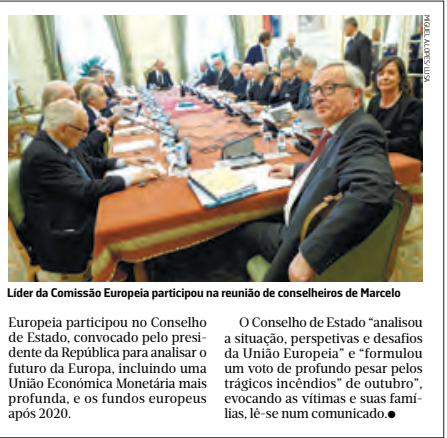

Fig. 3 - Juncker vai repensar proteção civil europeia (Fonte: JN, 31/10/2017.

Fig. 3 - Juncker will rethink European civil protection (Source: JN, 10/31/2017).

Assenta nos seguintes pressupostos:

- Funcionamento de um Centro de Informação e Vigilância, o MIC (do inglês Monitoring and Information Center);

A 15 de maio de 2013 foi inaugurado o Emergency Response Centre (ERC). Funciona 24 horas sobre 24 horas, sendo uma ampliação e melhoria do MIC:

- Constituição e Registo de Peritos e Módulos de Proteção Civil (MPC);

- Um programa de formação complementado por um programa de troca de peritos;

- Um sistema de informação conjunta, o CESIS;

- Identificação prévia de peritos e mobilização de equipas de avaliação e de coordenação do terreno.

Vejamos três exemplos concretos de aplicaçấo destes mecanismos:

\section{Exemplo 1:}

Nos dias 18 e 19 de fevereiro de 2013 o distrito de Lisboa foi afetado, por condiçóes atmosféricas excecionais, que provocaram danos significativos em vários concelhos (Cascais, Loures, Mafra, Oeiras, Vila Franca de Xira e Sintra). 
Foram afetadas essencialmente infraestruturas municipais, mas também propriedades particulares.

Assim, para fazer face a esta situação, foi necessário desenvolver mecanismos de assistência e socorro previstos no Decreto-Lei n. ${ }^{\circ}$ 112/2008, sendo acionada a Conta de emergência através dum despacho do Governo (fig. 4).

Em paralelo à ação das entidades públicas houve a intervenção das seguradoras. Neste temporal, que alastrou a todo o território continental, foram participados 48000 sinistros e cerca de 100 milhôes de euros de indemnizaçóes (fig. 5).

\section{Exemplo 2}

Devido a condiçóes meteorológicas excecionais, em quantidade, duração, intensidade, concentração temporal e distribuição de precipitação na bacia hidrográfica, bem como devido a enormes intervençóes antrópicas (havia barcos e mar onde hoje estão edifícios) e a falhas técnicas, evidenciadas pela ruptura de condutas e coletores, no dia 6

Despacho n. ${ }^{7} 73 / 2009$

A experiéncia tem demonstrado que, en situapióes de catistrofe ou calamidade, e para fazer face a problemas sociais graves gerados por tais sina ples, aos quis nem senpre os mecanismos de solidariedade peblica e privada conseguem dar resposta, pode ser necessirio desenvolver com ungtncia accòes de socorro $c$ assisténcia.

0 distrito de Lisbon foi atingido, nos dias 18 e 19 de Feverciro de 2008, por condigües climatericas excepcionais, que provocaram danos significativos, designadamente nos coecelhos de Cascais, Loures, Ma. fra, Odivelas, Oeiras, Vila Franca de Xita e Sintra. Tais denas ocorre. $\mathrm{ram}$, essencialmentc, em infra-estruturas municipais, mas tumbtm $\mathrm{cm}$ propriedades particulares, predocrinantemente ena estabelecimentos comerciais

ODecreto-Lei n." II2/2008, de I de Julho, veio criar um regime que permite adoptar medidas de assistencia a pessoas atingidas por catistrofes ou calamidades, através da abertura de uma conta de energegencia, accionada por despacho conjunto dos menhtros do Govemo responcivás pelas áreas das finanças $\mathrm{e}$ da administraclo interna.

0 mesmo despacto devc, ainda, fixar a composiçlo da cstrutura de scordenaçio e controlo, à qual cabe o reconhecimento das nesessidades te socorro e assistencia.

Assim:

Nos termos do disposto no n." 2 do artigo I."e no n." 1 do artigo 4." do Decreto-Lein." I12/2008, de I de Julho, manda o Governo, pelos Minis. tros de Essado e das Finanças e da Administraçio Intema, o seguinte:
1-As condiçes cimaténeas excepcioasis, que atingiram odistrito de Lisbou nos dias $18 \mathrm{e} 19$ de Fevercito de 2008, preenchem o conceito de catistrofe, definido no n." 2 do artigo 3." da Lei n." 27/2006, de $3 \mathrm{de}$ Julho (Lei de Bases da Proteccio Civil).

2- Para fazer face aos danos significativos provocados por tal ca. tistrofe, de que resultaram graves problemas sociais a que urge pór cobro, é accionada a conta de emergetencia a que se refere o artigo 1." do mencienado Decreto-Lei n." 112/2008.

3-A estrutura de coordenaçlo $\mathrm{e}$ controlo, indicada no n." I do artigo 4." do mesmo decreto-lei c com as competencias constantes do n." 2 do citado preceito legal, $\dot{c}$ composta por.

Um representante do Ministerio das Finanças e da Administraço Publica:

Um representante do Ministerio da Adrinistraclo Interna:

Un representante do Governo Civil de Libbor;

Um representante designado pelas Cimaras Municipais de Cascais. Loures, Mafra, Odivelas, Oeiras, Vila Franca de Xira e Sintra.

4-0 presente despacho produz efeitos a partir do dia 18 de Feve reiro de 2008 .

30 de Setembro de 2008. - 0 Ministro de Estado e das Finanças. Femando Teiteirs dos Santos. - 0 Ministro da Administraço Interna, Rui Carlas Perina.

Fig. 4 - Despacho n. ${ }^{\circ}$ 733/2009 de 12 de janeiro (Fonte: Diário República). Fig. 4 -Administrative Order no. 733/2009 of 12 January (Source: Diário da República/Official Gazette). 


\begin{tabular}{|c|c|c|c|}
\hline $\begin{array}{l}\text { Temporal do continente } \\
18 \text { e 19 Janeiro } 2013\end{array}$ & \begin{tabular}{|} 
№ de sinistros \\
participados
\end{tabular} & $\begin{array}{l}\text { Custos com } \\
\text { sinistros }\end{array}$ & $\begin{array}{l}\text { Custo médio } \\
\text { porsinistro }\end{array}$ \\
\hline $\begin{array}{l}\text { Acidentes (de Trabalho e } \\
\text { Pessoais, exceto Auto) }\end{array}$ & 35 & $101.835 €$ & $2.910 €$ \\
\hline Incêndio e Outros Danos: & 46.014 & $97.467 .107 €$ & $2.118 €$ \\
\hline - Habitação & 38.201 & $42.045 .714 €$ & $1.101 €$ \\
\hline - Comércio e Indústria & 7.455 & $53.748 .628 €$ & $7.210 €$ \\
\hline - Engenharia & 352 & $1.583 .265 €$ & $4.498 €$ \\
\hline - Agrícola e Pecuário & 6 & $89.500 €$ & $14.917 €$ \\
\hline Automóvel: & 1.303 & $1.700 .564 €$ & $1.305 €$ \\
\hline - Danos Próprios (F. Natureza) & 840 & $1.614 .117 €$ & $1.922 €$ \\
\hline - Outros (RC e Ocupantes) & 463 & $86.447 €$ & $187 €$ \\
\hline $\begin{array}{l}\text { Embarcações marítimas } \\
\text { lacustres e fluviais }\end{array}$ & 100 & $582.103 €$ & $5.821 €$ \\
\hline Responsabilidade Civil Geral & 175 & $254.652 €$ & $1.455 €$ \\
\hline Mercadorias Transportadas & $\mathbf{1}$ & 140.000€ & $140.000 €$ \\
\hline Total Não Vida & 47.628 & $100.246 .261 €$ & $2.105 €$ \\
\hline
\end{tabular}

Fig. 5 - Sinistros ocorridos a 18 e 19 de janeiro em Portugal Continental participados às seguradoras (Fonte: ANPC, 2013c).

Fig. 5 - Accidents that occurred on 18 and 19 January in mainland Portugal reported to insurers (Source: ANPC, 2013c).

de janeiro de 2015, a baixa de Albufeira (Algarve) foi atingida por uma grande inundação urbana, a que se seguiram fortes enxurradas que originaram o pânico e a destruição.

Não foi declarada a situação de calamidade, mas foram implementadas:

- Linhas de Crédito Especiais (Decreto-Lei n. ${ }^{\circ}$ 38-B/2001, de 8 de fevereiro, com a redação do Decreto-Lei n. ${ }^{\circ}$ 130/2008, de 21 julho);

- A Conta de Emergência (Decreto-Lei n. ${ }^{\circ}$ 112/2008, de 1 de julho);

- Fundo de Emergência Municipal (Decreto-Lei n. ${ }^{\circ} 225 / 2009$. de 14 de setembro);

A notícia do JN de 7 de janeiro de 2015, é elucidativa (fig. 6).

Neste contexto, foi criada uma equipa de Coordenação e Controlo para o reconhecimento e avaliação das necessidades de socorro e assistência, inventariando as elegíveis para o uso da Conta de Emergência e outros apoios elegíveis, bem como a intervenção da Segurança Social para os apoios e à reparaçáo de danos a pessoas e famílias em situação de emergência social. 


\begin{abstract}
Estrutura de coordenação
O Governo decidiu ainda criar uma estrutura de coordenação e controlo para o reconhecimento das necessidades de socorro e assistência, com a função de inventariar e comprovar as situações elegíveis para o apoio através da conta de emergência. Já a Segurança Social terá a responsabilidade de adotar os procedimentos necessários à atribuição de apoios e à reparação de danos a pessoas e famílias em situação de emergência social.

Foi ainda constituída uma comissão interministerial de coordenação política, com membros do Governo dos ministérios das Finanças, Administração Interna, Administração Local, Solidariedade e Segurança Social, coordenada pela Administração Interna.

O presidente da Câmara de Albufeira considerou importante que o Governo tenha autorizado o acesso imediato aos fundos de emergência. "É uma decisão importante, pois o Governo reagiu com celeridade com medidas que são positivas para ajudar a enfrentar a calamidade que se abateu sobre o concelho", disse Carlos Silva e Sousa.
\end{abstract}

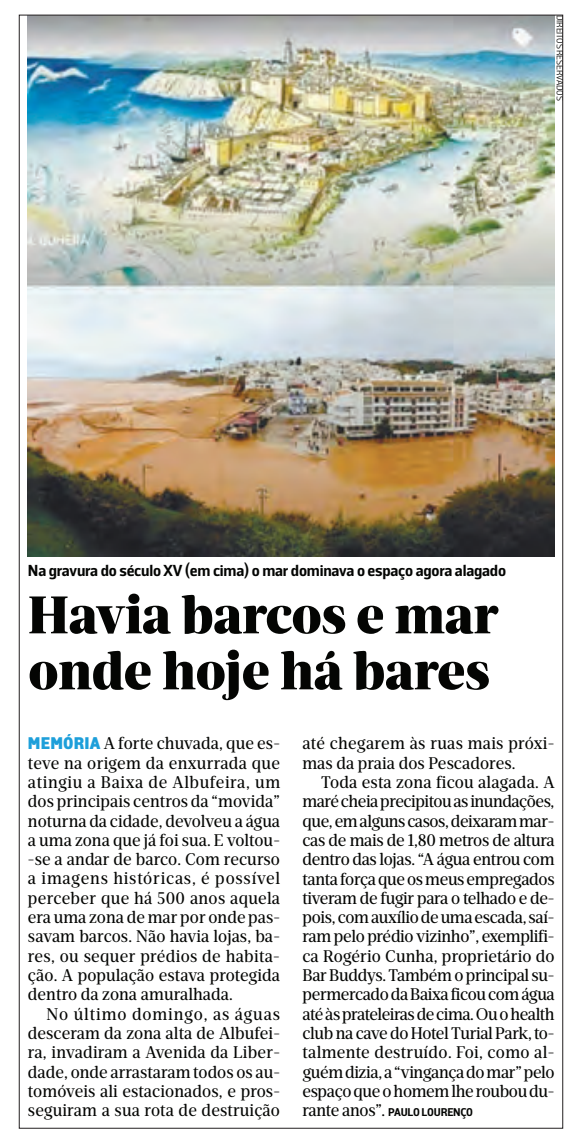

Fig. 6 - Inundação rápida na Baixa de Albufeira (Fonte: Jornal de Notícias 07-11-2015). Fig. 6 - Rapid flooding in downtown Albufeira (Source: Jornal de Notícias 07-11-2015).

\section{Exemplo 3:}

Corresponde a um exemplo de aplicação objetiva da Conta de Emergência, para socorrer os distritos de Leiria, Lisboa e Santarém que foram atingidos, na madrugada de 23 de dezembro de 2009, por condiçôes atmosféricas excecionais que provocaram danos significativos em vários concelhos: Alenquer, Almeirim, Alpiarça, Arruda dos Vinhos, Azambuja, Bombarral, Cadaval, Caldas da Rainha, Chamusca, Golegã, Lourinhã, Mafra, Óbidos, Peniche, Rio Maior, Santarém, Sobral de Monte Agraço, Torres Novas e Torres Vedras (fig. 7). 


\section{Diário da República, $2{ }^{a}$ série - N. ${ }^{\circ} 43-3$ de Março de 2010 \\ MINISTÉRIOS DAS FINANÇAS E DA ADMINISTRAÇÃO PÚBLICA E DA ADMINISTRAÇÃO INTERNA}

\section{Despacho $n .{ }^{\circ} 3834 / 2010$}

Os distritos de Leiria, Lisboa e Santarém foram atingidos, na madrugada de 23 de Dezembro de 2009, por condições climatéricas excepcionais que provocaram danos significativos designadamente nos concelhos de Alenquer, Almeirim, Alpiarça, Arruda dos Vinhos, Azambuja, Bombarral, Cadaval, Caldas da Rainha, Chamusca, Golegã, Lourinhã, Mafra, Óbidos, Peniche, Rio Maior, Santarém, Sobral de Monte Agraço, Torres Novas e Torres Vedras.

O Decreto-Lei n. ${ }^{\circ} 112 / 2008$, de 1 de Julho, veio criar um regime que permite adoptar medidas de assistência, através da abertura de uma conta de emergência junto do Instituto de Gestão da Tesouraria e do Crédito Público, I. P., titulada pela Autoridade Nacional de Protecção Civil e accionada por despacho conjunto dos membros do Governo responsáveis pelas áreas das Finanças e da Administração Interna. Esse despacho deve, também, fixar a composição da estrutura de coordenação e controlo, à qual cabe proceder ao reconhecimento das necessidades de socorro e assistência.

Em Resolução do Conselho de Ministros aprovada em 30 de Dezembro de 2009, foram elencados os instrumentos de apoio aplicáveis à situação em causa, entre os quais se insere o accionamento da referida conta de emergência.

Assim:

Nos termos do disposto no n. ${ }^{\circ} 2$ do artigo $1 .^{\circ}$ e no n. ${ }^{\circ} 1$ do artigo $4 .^{\circ}$, ambos do Decreto-Lei n. ${ }^{\circ} 112 / 2008$, de 1 de Julho, manda o Governo, pelos Ministros das Finanças e da Administração Pública e da Administração Interna, o seguinte:

1 - As condições climatéricas excepcionais que atingiram os concelhos de Alenquer, Almeirim, Alpiarca, Arruda dos Vinhos, Azambuja, Bombarral, Cadaval, Caldas da Rainha, Chamusca, Golegã, Lourinhã, Mafra, Óbidos, Peniche, Rio Maior, Santarém, Sobral de Monte Agraço,
Torres Novas e Torres Vedras, na madrugada de 23 de Dezembro de 2009, justificaram a aprovação, em reunião do Conselho de Ministros que teve lugar em 30 de Dezembro de 2009, de uma resolução que visa desencadear os procedimentos necessários à minimização dos prejuízos. 2 - Para fazer face aos danos provocados, nomeadamente em habitacões, que não estejam abrangidos pelas demais medidas de apoio previstas na citada Resolução do Conselho de Ministros, é accionada a conta tas na citada Resolução do Conselho de Ministros, e accionada a conta . de 1 de Julho, com o objectivo de minoras problemas sociais decorrentes desta situação.

3 - A decisão sobre os apoios a conceder terá em linha de conta uma avaliação rigorosa e documentada dos danos, e a verificação da incapacidade de os sinistrados, pelos seus próprios meios, incluindo o accionamento de contratos de seguro existentes, superarem, no todo ou em parte, o problema.

4 - A estrutura de coordenação e controlo prevista no n. ${ }^{\circ} 1$ do artigo $4{ }^{\circ}$ do mesmo decreto-lei é composta por um representante de cada uma das seguintes entidades:

Ministério das Finanças e da Administração Pública;

Ministério da Administração Interna;

Governo Civil de Leiria;

Governo Civil de Lisboa;

Governo Civil de Santar

5 - O presente despacho produz efeitos a partir desta data.

5 de Janeiro de 2010. - O Ministro de Estado e das Finanças, Fernando Teixeira dos Santos. - O Ministro da Administração Interna, Rui Carlos Pereira.

Fig. 7 - Despacho n. ${ }^{o}$ 3834/2010 de 3 de março (Fonte: Diário da República).

Fig. 7 - Administrative Order no. 3834/2010 of 3 March (Source: Diário da República/Official Gazette).

\section{A recuperação a médio e longo prazo}

A crise instalou-se, aconteceu, houve a plena manifestação do risco. Os mortos foram enterrados (cremados), tratou-se dos feridos e cuidou-se dos vivos.

Depois, após a catástrofe, há 3 aspetos que é fundamental ter em consideração: avaliar, indemnizar e reconstruir.

Assim, depois da emergência, a primeira ação a realizar é a de avaliar o que aconteceu, isto é, procurar estudar os mecanismos, os factos que deram origem à catástrofe. Para levar a efeito esta ação é fundamental haver equipas multidisciplinares experientes, com elevados conhecimentos técnicos e científicos, que farão o seu trabalho.

É uma fase difícil, pois nem sempre se consegue determinar o número de vítimas mortais e avaliar os efeitos sociais e económicos.

Para além destes aspetos essenciais, há sempre muita controvérsia, pois umas vezes são subavaliados, essencialmente devido à ausência de equipas especializadas e da falta de 
organização da Proteção Civil, ou, então, porque os próprios governos escondem os efeitos e não querem ajuda, por "orgulho nacional" causando por isso muito sofrimento às populaçóes (exemplo Chernobyl, ex-URSS, 26 de abril de 1986, onde morreram dezenas de milhares de pessoas e ainda morrem hoje; outro exemplo, as inundaçóes de 25 de novembro de 1967, em Lisboa em que o Governo escondeu o número de mortos, cerca de quinhentos), ou, então, sobrevalorizando as catástrofes, procurando assim obter ajudas nacionais e internacionais, pois não tendo qualquer preparação para resolver a catástrofe e os problemas originados pela catástrofe, o único objetivo é obter ajuda financeira.

O usual em países democráticos, após uma catástrofe, é criar uma "Comissão" ou "Equipa de Coordenação/Investigação" que fará a avaliação e que permitirá passar aos atos seguintes.

A avaliação após a catástrofe é um dos meios mais eficazes para compreender porque é que o risco se transformou numa catástrofe e, depois, criar condiçóes para implementar medidas de prevenção.

Segundo A. Dauphiné et al. (2013), a avaliação tem méritos e deméritos, conforme exemplifica:

- A tendência natural dos indivíduos e das organizaçóes é de atribuir como causas das catástrofes, as açôes externas, mas os inquéritos após as catástrofes revelam sistematicamente, para surpresa geral, que os mecanismos cindínicos são bem mais endógenos que exógenos;

- Os relatórios dizem muito pouco sobre o que desencadeou a catástrofe. Insistem muito como gerir a catástrofe, falam sobre o local, falam das pessoas afetadas e no fundo falam das vulnerabilidades.

Como exemplo do atrás referido refere os acidentes tecnológicos, onde os relatórios falam pouco dos defeitos técnicos mas falam muito sobre a existência ou não dos meios de segurança.

Falam pouco da falta de preparação das populaçóes, dos funcionários quer sejam de uma empresa quer digam respeito a instituiçóes públicas.

O relatório dos incêndios florestais de 2013, em Portugal, pode ser apontado como exemplo. Nesse ano morreram 8 bombeiros, mas, segundo a imprensa, o relatório esteve "escondido" porque concluía que os bombeiros cometeram erros! Para ter acesso ao relatório, o Jornal de Notícias (JN) apresentou queixa contra o MAI na Comissão de Acesso a Documentos Administrativos (CADA) (fig. 8). 


\section{Acesso JN venceu queixa na CADA}

Para ter acesso ao relatório, o JN teve de apresentar uma queixa contra o MAI na Comissão de Acesso aos Documentos Administrativos (CADA), que emitiu um parecer positivo à consulta, com a condição de que não sejam revelados quaisquer nomes referidos no relatório.

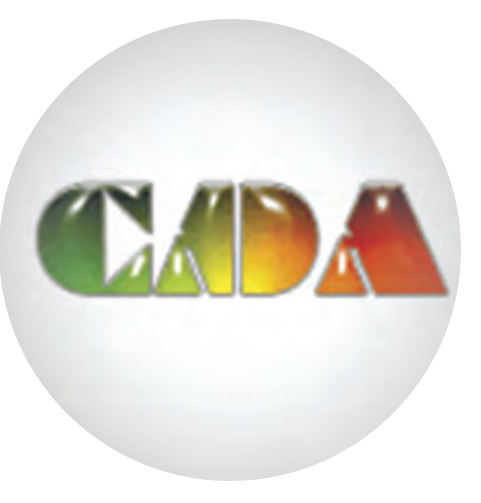

Fig. 8 - Acesso a Relatório Incêndios de 2013 (Fonte: JN de 16 de novembro de 2016). Fig. 8 - Access to the Fires Report of 2013 (Source: Jornal Noticias of November 16, 2016).

Mas haverá algum mal em admitir que se cometeram erros? E foram só os bombeiros a cometer erros?

Será que o insucesso dos bombeiros se deveu unicamente aos "hipotéticos" erros? Será que o trabalho do "Antes da Emergência" foi executado? Será que o relatório também apresenta essa conclusão?

No âmbito do Sistema de Defesa da Floresta Contra Incêndios, será que todos cumpriram com as suas obrigaçoes, dentro do que está definido em lei desde 2004?

Será que o Instituto de Conservação da Natureza e Florestas (ex-Autoridade Florestal Nacional) a quem cabe a coordenaçâo das Açôes de Prevençâo Estrutural, nas vertentes de sensibilização, planeamento, organização do território florestal, silvicultura e infraestruturaçáo, fez o seu trabalho? Este trabalho está devidamente analisado no relatório?

Será que a Guarda Nacional Republicana (GNR) a quem cabe a coordenaçẫo das açóes de prevenção relativas à vertente da vigilância, deteção e fiscalização, cumpriu a sua missão? Essa apreciação está plasmada no referido relatório?

Será que nesse relatório também estáo plasmadas as medidas corretivas para evitar situaçōes no futuro, similares às que deram origem aos incêndios florestais de 2013? 
Um outro exemplo, um bom exemplo, foi a "Recuperação da baixa de Albufeira”, sete meses após a grande enxurrada que destrui a baixa transformando-a num grande lago com todas as lojas destruídas e alagadas (fig. 9).

A notícia diz que está tudo muito bonito, pintado e a cheirar a novo. Revela ter havido 21 milhôes de euros de prejuízos.

Foram milhóes de euros de prejuízos, mas tudo foi recuperado e, de acordo com as palavras do Presidente da Câmara, está em elaboraçáo um Plano de Drenagem, avaliado em 15 milhôes de euros, que evitará situação danosa semelhante à de 1 de novembro de 2015, para implementar em 2017 e com entrada em funcionamento em 2018.

Será que a obra de Engenharia Hidráulica que vai ser construída mitigará os erros urbanísticos cometidos nas décadas de oitenta e noventa do século passado?

\section{Baixa recupera em sete meses}

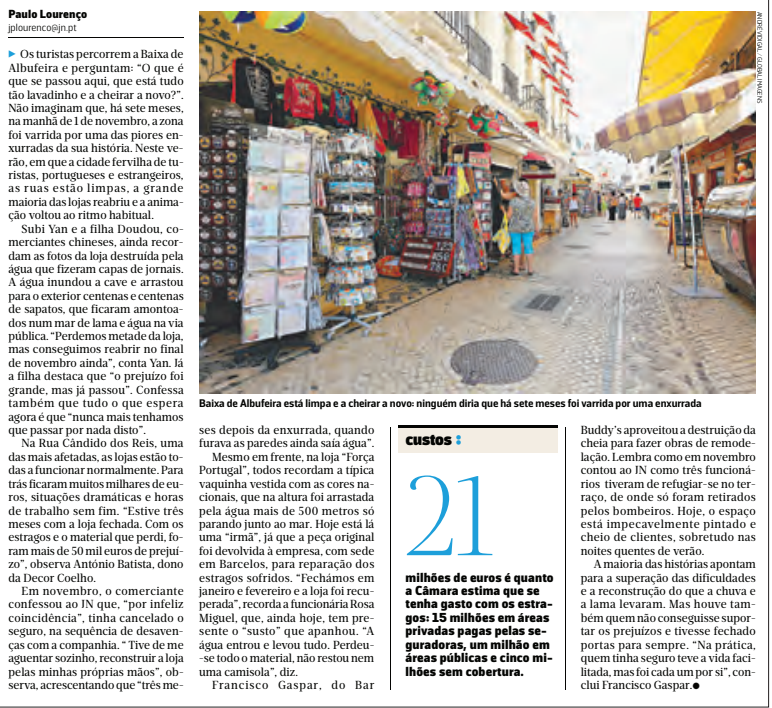

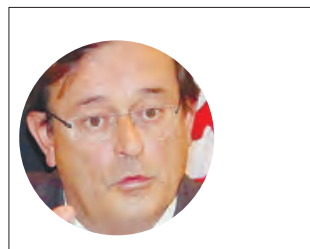

Carlos Silva e Sousa

Presidente da Câmara Municipal de Albufeira

Que fazer agora para evitar a repetição de um fenómeno igual ao que se passou em novembro passado?

Estamos a trabalhar no Plano de Drenagem de Albufeira, avaliado em 15 milhões de euros, que permitirá que a descarga de águas seja feita acima do nível do mar, de forma a evitar situações idênticas. Queremos que esteja em discussão até ao final do ano e que esteja concluído até 2018.

Fig. 9 - Recuperação de Albufeira 7 meses após a catástrofe (Fonte: Jornal de Notícias 24-07-2016).

Fig. 9 - AAlbufeira's recovery 7 months after the disaster (Source: Jornal de Notícias 24-07). 
Estamos em Maio de 2018 e não há qualquer notícia da obra, nem notícia da sua discussão pública. Será que não vai mais chover no Algarve? Será que a obra vai mesmo ser construída? Vamos aguardar a notícia da inauguração!

Após a catástrofe há 3 aspetos que são fundamentais: avaliar, indemnizar e reconstruir". Os incêndios de Pedrógão, segundo a Associação Portuguesa de Seguradoras (APS), originaram um apoio de 3,409 milhôes de euros. Os incêndios que deflagraram em outubro constituíram o maior sinistro de sempre na história da atividade seguradora em Portugal (fig.10).

O que há a fazer de imediato, é a reconstrução das habitaçôes (fig.11), recuperar os equipamentos da atividade industrial e contribuir decisivamente para salvaguarda do ambiente e da vida (fig. 12).

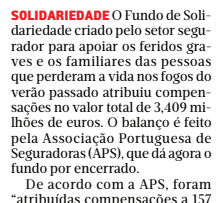

\section{Seguradoras apoiaram vitimas dos incêndios com 3,4 milhões}

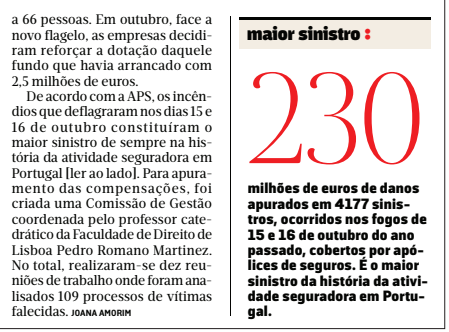

Fig. 10 - Seguradoras apoiaram vítimas dos incêndios (Fonte: JN, 09-03-2018).

\section{Ministro diz que mil casas estão em obras}
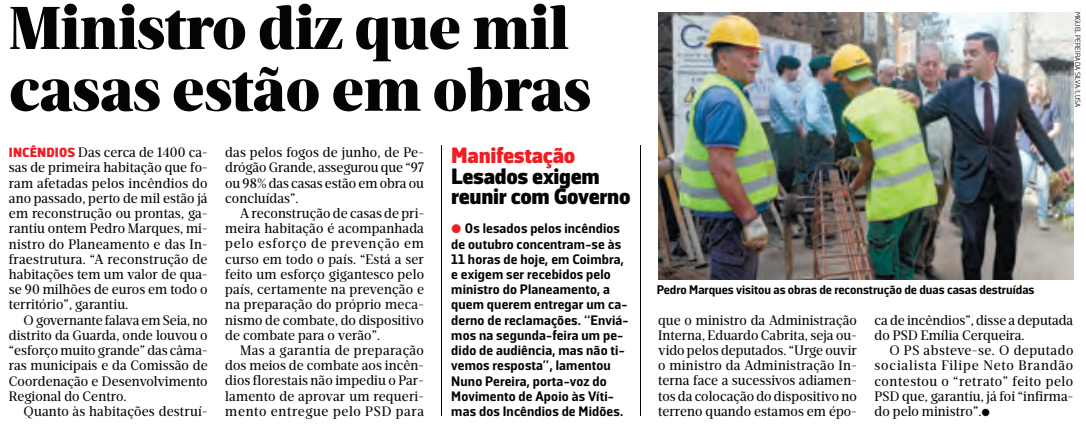

Fig. 11 - Ministro diz que mil casas estão em obras (Fonte: JN, 24-05-2018).

Fig. 11 - Minister says that a thousand houses are under construction (Source: JN, 05-24-2018). 
O trabalho de estabilização dos taludes, responder à erosão dos solos, evitar a contaminação das linhas de água bem como o seu assoreamento deve ser uma prioridade, evidenciada na notícia (fig.12) de acordo cos as palavras do Ministro da Agricultura e do Secretário de Estado das Florestas e Desenvolvimento Rural.

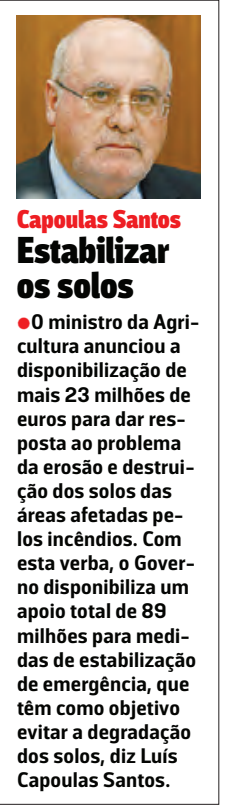

\section{Avião lança sementes sobre zona queimada}

VISEU O secretário de Estado das Florestas e do Desenvolvimento Rural, Miguel Freitas, congratulou-se ontem por, pela primeira vez em Portugal, se estar a fazer trabalhos de estabilização de emergência dos solos no mesmo ano em que ocorrem os incêndios.

"No ano passado, houve incêndios e só se fez estabilização de emergência a partir de março deste ano. É a primeira vez que estamos a fazer tudo no tempo certo", afirmou no aeródromo de Viseu, onde assistiu ao arranque da primeira fase do projeto $\mathrm{Se}$ mear Portugal por Via Aérea.

Um Dromader M-18 levantou voo carregado de sementes de gramíneas e leguminosas, que foram lançadas em Mourilhe (Mangualde), com o objetivo de ajudar a reduzir a erosão e promover a biodiversidade em zonas íngremes fustigadas pelos fogos.

O projeto é da iniciativa da Take C'Air Crew Volunteers e da Replantar Portugal, e, na primeira fase, envolve municípios de Mangualde, Nelas, Gouveia, Oliveira do Hospital, Tondela e Seia.

Fig. 12 - Aviáo lança sementes sobre zona queimada (Fonte: JN, 07-12-2017).

Fig. 12 - Plane drops seeds on burned area (Source: JN, 07-12-2017).

\section{Conclusão}

A desorganização dos espaços e dos territórios é ao mesmo tempo uma causa e uma consequência das catástrofes (A. Dauphiné et al., 2013), sendo a ocorrência de Albufeira um bom exemplo, pois a construçáo ocupava (ocupa) espaços inadequados, o que, associado a condiçóes atmosféricas excecionais, teve como consequência a destruição das infraestruturas que estavam subdimensionadas e a destruição de bens e ainda a necessidade de importantes obras de engenharia para mitigar futuras situaçóes 
Após a catástrofe o que devemos fazer é avaliar, indemnizar e reabilitar/reconstruir.

Não é uma tarefa simples, bem pelo contrário.

A avaliação dos mecanismos que provocaram a catástrofe, seja um incêndio, seja um ciclone, uma cheia e que normalmente provocam milhares de euros de prejuízo, paralisam a atividade económica, provocam mortes, feridos, desalojados, tem normalmente um retorno de experiências, mas este trabalho (avaliação) está semeado de armadilhas (A. Dauphiné et al, 2013).

Será que vamos esquecer a tragédia de Vila Nova da Rainha, concelho de Tondela deflagrou um incêndio urbano na sede da Associação Recreativa Cultural e Humanitária, onde devido ao fumo, proveniente dum incêndio se transformou num local de terror devido à ausência de medidas passivas e ativas e essencialmente devido à ausência de Medidas de Autoproteção, obrigatórias desde 2008 (D.L.220/2008 de 12/11,alterado pelo D.L.224/2015 de 9/10 e Portaria 1532/2008 de 29/12), (fig. 13) morreram nove portugueses e ficaram feridos algumas dezenas?

$O$ alerta para o sinistro foi dado às 20h51. O incêndio foi extinto cerca de uma hora depois. No local, o comandante operacional distrital da Proteção Civil, Miguel Ângelo David, indicou que estavam em Vila Nova da Rainha 168 operacionais e dezenas de meios, entre viaturas de socorro, ambulâncias e ainda três helicópteros do INEM.

A salvaguarda da segurança das pessoas e bens constitui uma função primordial e prioritária do Estado.

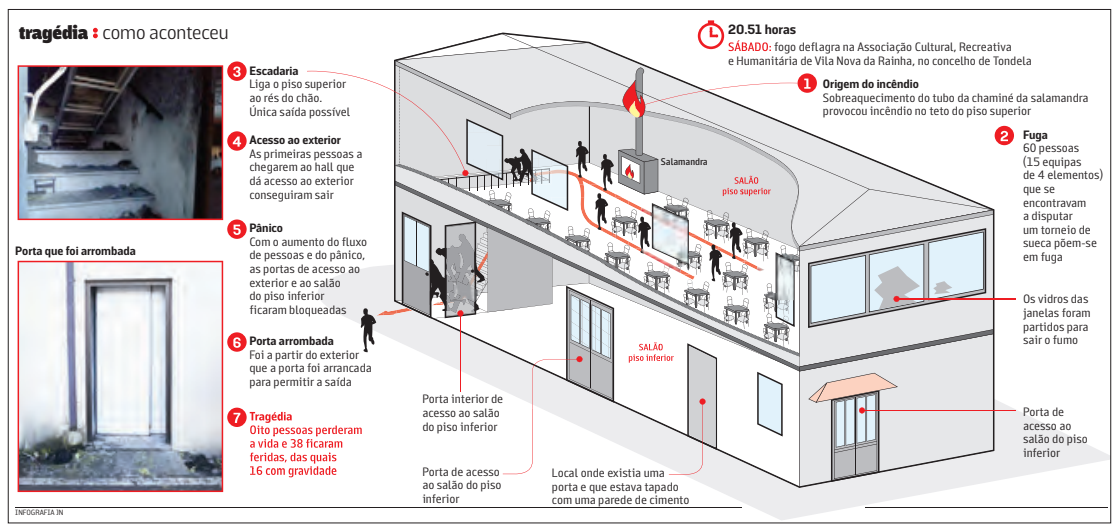

Fig. 13 - O incêndio na Associaçáo Recreativa de Vila Nova da Rainha (JN, 15-01-2018).

Fig. 13 - Fire at the Vila Nova da Rainha Recreation Association (JN, 01-15-2018). 
Assim é publicado a Resolução do Conselho de Ministros n. ${ }^{\circ}$ 13/2018 de 20 Fevereiro, com a obrigatoriedade de realização de uma campanha a nível nacional de divulgação e informação sobre o regime jurídico da segurança contra incêndio em edifícios pela Autoridade Nacional da Proteção Civil (ANPC).

Ainda determinou a Auto verificação do cumprimento das condiçóes de segurança contra incêndio, de acordo com a legislação aplicável, pelas entidades responsáveis ou gestoras dos edifícios, recintos ou estabelecimentos das utilizaçóes-tipo IV «escolares» e $\mathrm{V}$ «hospitalares e lares de idosos», em todas as categorias de risco, e nas utilizaçóes-tipo VI «espetáculos e reunióes públicas»e IX «desportivos e de lazer», nas 2. a $3 .^{\text {a }}$ e $4 .^{a}$ categorias de risco e as entidades previstas no número anterior comunicam, no prazo de 90 dias, à ANPC ou à câmara municipal, enquanto entidades competentes para a fiscalização, consoante o tipo de utilização e categoria de risco, a situação de cumprimento do regime jurídico de segurança contra incêndio (fig.14).

Diário da República, $1 .^{a}$ série-N. ${ }^{o} 36-20$ de fevereiro de 2018

\section{PRESIDÊNCIA DO CONSELHO DE MINISTROS}

\section{Resolução do Conselho de Ministros n. ${ }^{0}$ 13/2018}

A salvaguarda da segurança das pessoas e bens constitui uma função primordial e prioritária do Estado. Neste âmbito, ao longo das últimas décadas foi desenvolvido um conjunto de atos normativos na área da segurança contra incêndio em edifícios, que visam reduzir a probabilidade de ocorrência de incêndios, limitar o desenvolvimento de eventuais incêndios, circunscrevendo e minimizando os seus efeitos, facilitar a evacuação e o salvamento dos ocupantes em risco e permitir a intervenção eficaz e segura dos meios de socorro.

O universo é vasto, abrangendo as operações urbanísticas, onde se incluem os imóveis e o seu uso e, em especial, as atividades desenvolvidas que pela sua natureza, número de ocupantes ou condição destes, envolvem um risco acrescido, como sucede com as creches, lares de idosos, associações recreativas, recintos de espetáculos ou de prática desportiva, entre outros.

O modelo existente de verificação, manutenção e garantia das condições de segurança contra incêndio assenta no princípio da responsabilização das entidades que detêm a propriedade do edifício ou recinto e das entidades que detiverem a exploração do edifício ou recinto, consoante a situação, ou ainda as gestoras no caso de edifícios ou recintos que disponham de espaços comuns, partilhados ou de serviços coletivos.

No entanto, a administração pública, através dos seus serviços e organismos e dos municípios, desempenha uma função fiscalizadora fundamental de assegurar a segurança de pessoas e bens.

Importa, assim, assegurar permanentemente a verificação do cumprimento das condições de segurança contra incêndios em edifícios e recintos, num esforço que envolve os responsáveis e as entidades com competência legal, em especial a Autoridade Nacional da Proteção Civil e os municípios, nos termos do Decreto-Lei n. ${ }^{\circ} 220 / 2008$, de 12 de novembro, na sua redação atual.

Assim:

Nos termos da alínea $g$ ) do artigo $199{ }^{\circ}$ da Constituição, o Conselho de Ministros resolve:

1 - Determinar a realização de uma campanha a nível nacional de divulgação e informação sobre o regime jurídico da segurança contra incêndio em edifícios pela Autoridade Nacional da Proteção Civil (ANPC).

2 - Determinar a autoverificação do cumprimento das condições de segurança contra incêndio, de acordo com a legislação aplicável, pelas entidades responsáveis ou gestoras dos edifícios, recintos ou estabelecimentos das utilizações-tipo IV «escolares» e V «hospitalares e lares de idosos», em todas as categorias de risco, e nas utilizações-tipo VI «espetáculos e reuniões públicas»e IX «desportivos e de lazer», nas $2 .^{\mathrm{a}}, 3$. $^{\mathrm{a}}$ e 4 . $^{\mathrm{a}}$ categorias de risco.

3 - As entidades previstas no número anterior comunicam, no prazo de 90 dias, à ANPC ou à câmara municipal, enquanto entidades competentes para a fiscalização, consoante o tipo de utilização e categoria de risco, a situação de cumprimento do regime jurídico de segurança contra incêndio.

Presidência do Conselho de Ministros, 8 de fevereiro de 2018. - O Primeiro-Ministro, António Luís Santos da Costa.

111140694

Fig. 14 - Resolução conselho Ministros n. ${ }^{\circ} 13 / 2018$ (Fonte: DR n. ${ }^{\circ} 36$ 2002-2018).

Fig. 14 - Council of Ministers Resolution n. ${ }^{\circ} 13 / 2018$ (Source: DR n. ${ }^{\circ} 36$ 2002-2018). 
Será que todos vão responder ou simplesmente ignorar?

Quantas notícias foram publicadas realçando açóes de sensibilização e prevenção? Quantas notícias são publicadas relatando exercícios, treino e açóes de formação das populaçôes? Sim, pois proteger as populaçôes, implica ensiná-las a como proceder no "Antes", "Durante" e "Após" face a um hipotético acidente grave e a uma catástrofe. Não chega dizer que as populaçóes, principalmente às mais isoladas, que têm de saber defender-se, mas importa saber se, face à sua idade e estado de saúde, têm condiçôes físicas para tal.

Os valores que, em minha opinião, devem orientar toda a atividade da Proteção Civil são: a vida, como primado da nossa existência; a confiança, pois sem uma relação próxima e verdadeira não há sociedade; o ambiente, não podemos esquecer que a Terra é a nossa casa; a responsabilidade, cumprir sempre os nossos deveres e assumir as suas consequências; a eficácia, significa com poucos meios fazermos muito; e a solidariedade, sem a qual falar de proteção civil não faz qualquer sentido.

\section{Referências bibliográficas}

ANPC - AUTORIDADE NACIONAL DE PROTEÇĀO CIVIL (2003). Plano Especial de Emergência de Proteção Civil para o Risco Sísmico na Área Metropolitana de Lisboa e Conselhos Limitrofes (PEERS-AMLCL), Carnaxide, ANPC.ANPC - AUTORIDADE NACIONAL DE Europeia, Carnaxi

ANPC - AUTORIDADE NACIONAL DE PROTEÇÃO CIVIL (2009). Caderno Técnico PROCIV, n. 9 Guia para a caracterização do risco no Âmbito da Elaboração de Planos de Emergência de Proteção Civil, Carnaxide, ANPC.

ANPC - AUTORIDADE NACIONAL DE PROTEÇÃO CIVIL (2009). Caderno Técnico PROCIV, n. ${ }^{\circ} 10$ Organizaçôes, Sistemas e Instrumentos Internacionais de Proteção Civil, Carnaxide, ANPC.

ANPC - AUTORIDADE NACIONAL DE PROTEÇÃO CIVIL (2010). Diretiva Operacional Nacional $n .^{\circ}$ 1-DIOPS, Carnaxide, ANPC.

ANPC - AUTORIDADE NACIONAL DE PROTEÇĀO CIVIL (2010). Diretiva Operacional Nacional $n .^{o}$ 3-NRBQ, Carnaxide, ANPC.

ANPC - AUTORIDADE NACIONAL DE PROTEÇĀO CIVIL (2011). Boletim PROCIV, n. ${ }^{\circ} 39$ - Educar e Preparar para os riscos e catástrofes, Carnaxide, ANPC.

ANPC - AUTORIDADE NACIONAL DE PROTEÇĀO CIVIL (2012). Caderno Técnico PROCIV, n. ${ }^{\circ} 23$ - Manual de Apoio à Decisão Política: Situação de Alerta, de Contingência e de Calamidade, Carnaxide, ANPC;

ANPC - AUTORIDADE NACIONAL DE PROTEÇÃO CIVIL (2012a). Boletim PROCIV, n. ${ }^{\circ}$, Carnaxide, ANPC.

ANPC - AUTORIDADE NACIONAL DE PROTEÇÃO CIVIL (2012b). Boletim PROCIV, n. 55, Carnaxide, ANPC. 
ANPC - AUTORIDADE NACIONAL DE PROTEÇÃO CIVIL (2013a). Boletim PROCIV, n. ${ }^{\circ}$ 63, Psicologia de Catástrofe na Gestão de Emergências, Carnaxide, ANPC.

ANPC - AUTORIDADE NACIONAL DE PROTEÇĀO CIVIL (2013b). Boletim PROCIV, n. ${ }^{\circ}$ 64, Plataforma Global para a Redução de Catástrofes, Carnaxide, ANPC.

ANPC - AUTORIDADE NACIONAL DE PROTEÇĀO CIVIL (2013c). Boletim PROCIV, n. ${ }^{\circ}$ 65, A Atividade Seguradora em Acidentes Graves e Catástrofes, Carnaxide, ANPC.

ANPC - AUTORIDADE NACIONAL DE PROTEÇÃO CIVIL (2015a). Boletim PROCIV, n.o 84, Quadro de Ação Sendai, 2015-2030, Carnaxide, ANPC.

ANPC - AUTORIDADE NACIONAL DE PROTEÇĀO CIVIL (2015b). Boletim PROCIV, n. ${ }^{\circ} 87$, Carnaxide, ANPC.

ANPC - AUTORIDADE NACIONAL DE PROTEÇÃO CIVIL (2016a). Boletim PROCIV, n. ${ }^{\circ}$ 91, Carnaxide, ANPC.

ANPC - AUTORIDADE NACIONAL DE PROTEÇÃO CIVIL (2018). Diretiva Operacional Nacional $n .^{o}$ 2-DECIR, Carnaxide, ANPC.

Cruz, C. e Lourenço, L. (2016). A inundação do dia 31 de janeiro de 2015 na bacia inferior do Rio Ceira: contributo para o conhecimento dos riscos e importância da informação para a gestão da emergência. Territorium, (23), 171-190.

Disponível em: http://impactum-journals.uc.pt/territorium/article/view/3808/2993

Dauphiné, A., Provitolo, D. (2013). Risques et catástrofes. Observer, Spatialiser, Comprendre, Gérer, $2^{\mathrm{a}}$ ediçẫo. Paris, Armand Colin, p. 412.

Declaração (extrato) n. 97 / 2007, de 16 de maio, aprovou a Diretiva Operacional relativa ao Estado de Alerta Especial para as organizaçóes integrantes do Sistema Integrado de Operaçóes de Proteção e Socorro (SIOPS).

Decreto no 49/1992, Diário República n. ${ }^{\circ}$ 291/1992, de 18 de dezembro - Aprova o Protocolo sobre Cooperação Técnica e Assistência Mútua em Matéria de Proteção Civil entre a República Portuguesa e o Reino de Espanha

Decreto-Lei n. ${ }^{\circ}$ 38-B/2001 de 8/2, alterado pelo Decreto-Lei n. ${ }^{\circ} 130 / 2008$, de 21/7-Linhas de crédito especial;

Decreto-Lei n. ${ }^{\circ}$ 112/2008, de 1 de junho - Conta de Emergência;

Decreto-Lei n. ${ }^{\circ}$ 225/2009, de 14 de setembro, aprovou o Fundo de Emergência Municipal

Decreto-Lei n. ${ }^{\circ} 84 / 2010$, de 14 de julho, aprovou as normas de funcionamento do Secretariado Permanente do Gabinete Coordenador de Segurança e da respetiva Sala de Situação.

Decreto-Lei n. ${ }^{\circ}$ 62/2011, de 9 de maio, aprovou os procedimentos de identificação e de proteção das infraestruturas críticas.

Decreto-Lei n. ${ }^{\circ}$ 72/2013, de 31 de maio, altera o DL n. ${ }^{o}$ 134/2006 de 25 de julho, aprovou o Sistema Integrado de Operaçóes de Proteção e Socorro (SIOPS).

Decreto-Lei n. ${ }^{\circ}$ 163/2014, de 31 de outubro - lei orgânica da Autoridade Nacional Proteção Civil.

Decreto-Lei n. ${ }^{\circ}$ 150/2015 de 5 de agosto, Estabelece o Regime de Prevenção de Acidentes Graves envolvendo substâncias perigosas e de Limitação das suas consequências para a saúde humana e para o Ambiente.

Despacho n. ${ }^{\circ} 3317-A / 2018$ de 3 de abril, aprovou a revisão do Sistema de Gestão de Operaçóes (SGO).

ENB - ESCOLA NACIONAL BOMBEIROS (2002). Busca e Salvamento. Volume XI. Sintra.

ESCOla NACIONAL DE BOMBEIROS (2001). Comunicaçôes. Seminário Os Bombeiros e o Socorro em Situaçôes de Catástrofe, CNEMA, Santarém, Escola Nacional de Bombeiros, 56 p.

Lei n. ${ }^{\circ}$ 65/2007, de 12 de novembro, aprovou o sistema de Proteção Civil a nível Municipal. 
Lei Orgânica n. ${ }^{\circ}$ 1/2012 de 11 de março, altera a Lei n. ${ }^{\circ}$ 44/86 de 30 de setembro - Regime do Estado de Sítio e Estado de Emergência.

Lei n. ${ }^{0} 59$ /2015, de 24 de junho, aprovou a alteração da Lei n. ${ }^{\circ}$ 53/2008 de 29 de agosto - Aprova a Lei de Segurança Interna.

Lei n. ${ }^{\circ}$ 80/2015, de 3 de agosto, alteração da Lei n. ${ }^{\circ}$ 27/2006 de 3 de julho, Lei de Bases de Proteção Civil.

Lei n. ${ }^{\circ}$ 76/2017 de 17 de agosto, altera o Sistema Nacional de Defesa da Floresta Contra Incêndios, procedendo à $5^{a}$ alteração do DL n. ${ }^{\circ}$ 124/2006 de 28 de junho.

Lourenço, L. (2003). Análise de riscos e gestäo de crises. O exemplo dos incêndios florestais. Territorium, 10 , p. $89-100$.

Disponível em: http://impactum-journals.uc.pt/territorium/article/view/3468/2705

Lourenço, L. (2015). Risco, perigo e crise: pragmatismo e contextualização. Seminário Internacional de Riscos e Desastres Relacionados à Água: aplicabilidade de bases conceituais das Ciências humanas e Sociais para a análise de casos concretos. Disponível em: http://www.uc.pt/fluc/nicif/Publicacoes/ Estudos_de_Colaboradores/PDF/Livros_e_Guias/2015_RiscosDesastres_LL_.pdf

Lourenço, L, Tedim, F. (2014). Realidades e Desafios na Gestäo dos Riscos. Diálogo entre Ciência e Utilizadores. Coimbra: NICIF/FLUC. Disponível em: https://digitalis.uc.pt/pt-pt/livro/realidades_e_desafios_na_gest\%C3\%A3o_dos_riscos_di\%C3\%A1logo_entre_ci\%C3\%AAncia_e_utilizadores

Kervern, G. Y. (1995). Éléments Fondamentaux des Cindyniques, Paris.

Portaria n. ${ }^{\circ}$ 167/2016, de 15 de junho - Definição de Período Critico;

Portaria n. ${ }^{\circ}$ 195/2017, de 22 de junho - definiçáo de Período Critico;

Quarantelli, E. L. (2005). A Social Science Research Agenda for the Disaster of the $21^{\text {st }}$ Century, in Perry R. W., Quaranteelli E.(eds), What is a Disaster? New answers to Old questions, Philadelphia, Xlibris Books.

Rebelo, F. (2003). Riscos Naturais e Ação Antrópica. Estudos e Reflexóes, 2a edição revista e aumenta- da. Coimbra, Imprensa da Universidade, 286 p. (1a edição, 2001). Disponível em: https://digi- talis.uc.pt/pt-pt/ livro/riscos_naturais_e_ac\%C $3 \% \mathrm{~A} 7 \% \mathrm{C} 3 \% \mathrm{~A} 30$ _antr\%C $3 \%$ B3pica_estudos_e_reflex\%C3\%B5es

Rebelo, F. (2005). Uma Experiência Europeia em Riscos Naturais. Coimbra, Minerva Coimbra. Rebelo, F. (2010). Geografia Física e Riscos Naturais. Coimbra, Imprensa da Universidade, 215 p.

Resolução do Conselho de Ministros n. ${ }^{\circ}$ 196/2005 de 22 de dezembro, aprova a Ajuda Humanitária.

Resoluçăo do Conselho de Ministros n. ${ }^{0}$ 17/2014, de 7 de março, aprovou o Conceito Estratégico da Cooperação Portuguesa 2014-2020.

Resoluçáo do Conselho de Ministros n. ${ }^{\circ}$ 65/2015 de 27 de agosto, aprovou as Normas da Ajuda Humanitária.

Saúde, A., Costa, E,m Fernandes, J, J., Esteves, M. J., Amaral, M. L., Almeida, P. e André, T. L. (2015). Referencial de Educação para o Risco - Educaçāo Pré-Escolar, Ensino Básico (1. ${ }^{\circ}, 2^{\circ}$ e 3. ${ }^{\circ}$ ciclos) e Ensino Secundário. Ministério da Educação e Ciência, Lisboa, 114 p.

Smith, K. (2013). Environmental Hazards. Assessing risk and reducing disaster, London and New York. Routledge, 478 p. (6a ediçẫo).

Tedim, F. e Paton, D. (2012). A Dimensäo Social dos Incêndios Florestais, Para Uma Gestäo Integrada e Sustentável, $192 \mathrm{p}$.

Torres, V. N. (2010). Resgate dos 33 Mineiros do Chile. Obra-prima da Engenharia, Ingenium, n. ${ }^{o} 119$, p. 4-6. 
(Página deixada propositadamente em branco) 


\title{
A SOCIALIZAÇÁO PÓS-CATÁSTROFE
}

\author{
POST-DISASTER SOCIALIZATION
}

Norma Valencio

Universidade Federal de São Carlos-UFSCar norma.valencio@ufscar.br

Sumário: Para os grupos afetados nas catástrofes, o tempo social da experiência de sofrimento é maior do que o tempo cronológico no qual a visão operacional é baseada. Para tais, grupos isso gera uma composiçáo mais complexa de elementos objetivos e subjetivos que integram o problema, o qual é frequentemente incompreendido no teor de políticas de resposta e recuperaçáo. A partir de uma abordagem sociológica, há uma discussáo sobre alguns dos aspectos desse desencontro ente tempos e significados bem como recomendaçóes.

Palavras-chave: Sofrimento social, catástrofe, políticas de recuperação.

Abstract: For the groups affected by disasters, the social time of the experience of suffering is greater than the chronological time in which operational view is based. For such groups this generates a more complex composition of objective and subjective elements that form the problem, and this is often misunderstood in the content of response and recovery policies. Using a sociological approach, there is a discussion about some of the aspects of this mismatch between times and meanings, as well as recommendations.

Keywords: Social suffering, disaster, recovery policies. 


\section{Introduçáo}

A vivência de uma catástrofe produz profundas cicatrizes existenciais nas pessoas que passam por essa dolorosa experiência. Por essa razáo, em termos sociológicos, há polêmicas em torno da elaboração sociocultural de uma temporalidade que demarca o momento 'pós' de uma catástrofe.

Sob um prisma sociológico, uma catástrofe pode ser entendida, por um lado, como sendo uma situação, a qual aglutina um acontecimento físico e um estresse coletivo de grande monta (Quarantelli, 1998), suscitando danos e perdas com simultâneas características materiais, sociais e simbólicas. Isso altera a história da vida dos grupos afetados (Quarantelli, 2005), pois as rotinas a vida prática jamais voltarão a ser como eram e tampouco se desenrolaráo conforme aquilo que antes se previa ou se esperava.

Uma catástrofe promove transformaçóes na aparência da localidade que a circunscreveu, nas representaçóes sociais que os grupos afetados têm sobre a mesma bem como no entendimento de si no mundo. Para os sobreviventes, uma catástrofe constitui um conjunto indelével de situaçóes objetiva e subjetivamente perturbadoras, dentre as quais se destacam: o falecimento, o desaparecimento súbito ou ferimentos em pessoas, incluso, naquelas com quem se mantem importantes vínculos sociais; a repentina destruiçáo ou danificaçáo de diferentes objetos, alguns dos quais associados de modo significativo à memória afetiva, à identidade social ou ao exercício de rotinas da vida cotidiana; perda de funcionalidades de instalaçôes públicas e privadas; entre outros.

Em tais circunstâncias, aquilo que o sujeito possa fazer de imediato para se proteger, amparar alguém que esteja em iminente risco de perda da vida, alcançar e recuperar rapidamente um dado objeto de grande valor pessoal é pontualmente relevante, porém insuficiente para deter os estragos maiores e coletivos, do que decorre estados emocionais negativos, como medo, ansiedade, frustração e um certo sentimento de impotência. Se acaso esse ambiente for o da moradia, abrangendo demais porçôes da respectiva comunidade de inserção, ainda maior a intensidade dessa experiência de sofrimento, pois o lugar 
de vivência é um elemento fundamental de definição da identidade social. A pessoa é caracterizada socialmente pelo espaço que ali ocupa e pela forma como ali atua (Bourdieu, 2004).

Saliente-se que, embora se tratando de um episódio penoso e destacado na história individual, familiar ou comunitária, uma catástrofe é um processo, criando elos com as trajetórias pregressas e incidindo no restante do percurso de indivíduos e coletividades. É dizer, embora haja situaçóes de maior visibilidade física - e, sobretudo, midiática - e que serâo discursivamente definidas como o momento culminante de distúrbios e ruturas, as ligaçôes menos aparentes (de natureza econômica, política e cultural) com o antes e o depois desse momento sensível náo devem ser desconsideras para desenhar os contornos temporais que emolduram a densidade social apropriada essa tragédia. Desse enquadramento social depende o acerto das providências públicas para evitar ocorrências similares.

\section{A temporalidade alargada da catástrofe para quem a sofre}

No antes da catástrofe, constituído do passado mais remoto ao mais recente do episódio, há os elementos concretos, as práticas correntes, o habitus e registros - dos oficiais e históricos aos da sutileza da memória social e das impressōes individuais - que caracterizam a dinâmica de funcionamento socioespacial tido como normal. A ideia de catástrofe não se sustenta por si mesma, pois precisa referir-se a esse passado, remoto e imediato, bem como a essa ideia de normalidade para atestar que ali houve distúrbios ou ruturas.

Usualmente, dentro do contexto de normalidade são forjados os sub-processos sorrateiros, socialmente discretos e toleráveis, além de geograficamente insignificantes, os quais suscitam, nalgum ponto adiante, distúrbios de maior magnitude e abrangência territorial. Por seu turno, o depois de um grande distúrbio pode conter outras perturbaçôes socialmente muito significativas para os grupos afetados, lhes exigindo continuados esforços de síntese entre o passado e o presente de suas trajetórias em busca de uma intensiva reelaboração dos sentidos de normalidade e de anormalidade. 
Tal síntese é o que permite que a vida social dos sujeitos envolvidos ancore as suas respectivas práticas de resposta e resistência ante essas incomensuráveis adversidades, mesclando continuidades e descontinuidades de rotinas e práticas. Os fragmentos não estão somente na paisagem devastada. As pessoas afetadas também se ocupam de coletar seus fragmentos de memória - de alegrias e de tristezas - para colarem simbolicamente esses cacos e restituírem um sentido de continuidade dentro da amarga descontinuidade.

As instituiçóes atuam e os sujeitos sociais interagem cotidianamente supondo haver estabilidade e controle ilusório sobre os processos socioambientais nos quais estão imersos; contudo, na contemporaneidade, esses processos têm a sua complexidade própria e se desenrolam de formas surpreendentes e inusitadas, muito além do que as mentes mais precavidas haviam assinalado nos cenários mais adversos de seus planos de contingência. Assim como uma comunidade é um sistema espacial constituído historicamente de variáveis assincrônicas, cuja organizaçáo social tenta obter funcionalidades sincrônicas (Santos, 1998), os grupos técnicos que atuam numa catástrofe precisam ser aptos para decifrar os tempos distintos que estáo contidos não apenas em edificaçôes, mas nas mentalidades e comportamentos das pessoas que compóe o intricado jogo da vida social local.

Em termos sociológicos, esses dois lados complementares da catástrofe vista como situação e como processo - incidem em como os grupos afetados, e seus subgrupos, concebem e demarcam o tempo dessa vivência. $\mathrm{O}$ eminente sociólogo russo que deflagrou os estudos em Sociologia das Catástrofes, P. Sorokin (1942), advertiu que a compreensão mais ampla dessas circunstâncias exige reconhecer que o tempo social desses processos, cujas vítimas estáo no centro, deveria se sobrepor à mensuração meramente cronológica de algum aspecto técnico em particular.

Aquilo que se passaria em termos mais amplos da deflagração e atenuaçáo do sofrimento social é o que deveria balizar a demarcação do começo e do final da tragédia, como, por exemplo, em relação às grandes epidemias, aos que combatem e morrem nas guerras, aos que estão esquálidos nas fomes ou mesmo compelidos a migraçóes compulsórias e a buscar acampamentos de refugiados. Mas, desafortunadamente, conforme o referido autor, os parâmetros 
institucionais adotados para mensurar a duração dessas catástrofes amiúde se contrapóem aos critérios adotados pelos grupos afetados, os quais são mais consoantes à sua vida emocional, à sua cognição sobre o mundo circundante, às dimensôes éticas e religiosas, aos processos vitais, à organizaçáo social e mobilidade, à vida econômica, entre outros. Na perspectiva sociológica, seria um equívoco supor que houvesse uma uniformidade e convergência pacífica entre esses tempos. A subordinaçáo do tempo social dos sofredores ao tempo cronológico da técnica - que, ainda assim, é também um tempo social -, resulta em slow violence (Nixon, 2011), que obriga os primeiros a adotarem e a aceitarem as referências cronológicas das instituiçôes que têm por missão lhes proteger: 'agora, a catástrofe acabou', dita uma voz externa, um comando, não ciente dos vínculos entre pessoas, coisas e lugar; 'agora, inicia a reabilitação; no abrigo, o horário de dormir é $x$, o horário do almoço $y$ e o do banho é $z$ ", dita o gestor público em desconformidade com os tempos fisiológicos, sociais e emocionais das pessoas atendidas.

Sem haver disposição das instituiçôes públicas para abrir uma discussão sobre a complexidade subjacente aos critérios de demarcaçáo do início e do fim de uma catástrofe, os critérios convencionados tecnicamente, que costumam ser mais estreitos, vão sendo replicados. E o pós-catástrofe torna-se, então, um restrito compartimento da açáo técnica, cuja objetividade monológica pode agredir aos atendidos.

Contudo, essa assimetria de visóes sobre os tempos da catástrofe, na qual a perspectiva do meio técnico prepondera sobre a das vítimas, tende a revelar tensôes quando a coletividade atendida - tendo por base as suas normas, as suas crenças, os seus valores, a rotina de sua sociabilidade e os fundamentos psicossociais da sua vida cotidiana - se nega a admitir passivamente a redutibilidade de sua tragédia a uma cronologia de curto alcance que, ao virar rapidamente a página da história, vincula esse rápido 'passado' a medidas de remediação igualmente pequenas e insuficientes.

Numa concepção humanística, a característica essencial de uma catástrofe é a grave falha da cultura da proteçáo na qual, até então, a sociedade depositava a sua plena confiança (Dombrowsky, 1998). Isto é, a catástrofe revela que a 
visão e as práticas das instituições públicas estiveram aquém da tarefa protetiva que lhe confiou a sociedade civil.

Isso as coloca na berlinda, pois é possível haver uma indisposição inicial e justificável daqueles que foram vitimados em relação aos aparatos públicos que, direta ou indiretamente - por meio de serviços prestados, regulaçóes, monitoramento, fiscalização e afins -, foram incapazes de lhes prover a proteção esperada. Tendo sido débeis na prestação de serviços essenciais - devido às incapacidades, insuficiências, inadequaçóes ou omissóes associadas ao transcurso da tragédia -, instala-se uma crise de confiança na qual os argumentos técnicos-operacionais que assentavam a noção de prevenção são colocados em suspeição. Essa crise de confiança, portanto, coloca em discussão as noçôes e as práticas de reabilitação ou recuperação operadas por essas mesmas instituiçôes.

O que subjaz à concepção técnico-operacional de 'pós-catástrofe' é a ideia de que 'o pior já passou'; mas, para as vítimas, por vezes o pior ainda está por vir. Diante tantas perdas múltiplas e simultâneas, que arrancam-lhe o chão existencial, o sujeito se pergunta: 'e agora, o que fazer?'.

As situaçóes deflagradoras de ruturas na vida social poderão deflagrar outras ainda mais penosas que, na perspectiva da experiência das vítimas, estão encadeadas numa só catástrofe e suscitam a sua morte física ou social ou a perda do sentido da vida.

Quem perde a moradia e seus bens móveis, e não conta com alternativas compatíveis de acolhimento, ainda está por passar humilhaçóes e privaçóes em abrigos provisórios ou residência de familiares e amigos; quem perde os seus meios de produção ainda está por passar dificuldades econômicas relacionadas à sobrevivência imediata, às condições de retomada do trabalho, à reposição dos fluxos de estoque e de caixa, à pressão de credores, às restriçóes securitárias e de crédito; quem porventura venha a perder seus entes queridos, ainda está por passar um cotidiano esvaziado em seus papéis sociais substantivos e correspondentes; quem passa por comprometimentos de saúde física e mental no episódio passa a lidar com dificuldades referentes às despesas com medicação, demanda por serviços médicos, ambulatoriais e psicossociais nem sempre disponíveis ou economicamente acessíveis. 
Tudo isso pode ser considerado, pelos organismos governamentais, como sendo apenas os desdobramentos da catástrofe. Uma vez que isso é reiterado nos discursos públicos, esses desdobramentos se tornam passíveis de diluição em outras tantas variáveis, que paulatinamente são desconectados das relaçôes de responsabilização circunscritas à tragédia.

No entanto, como bem lembrou Quarantelli (2005), danos e perdas não são consequências de uma catástrofe, mas a essência da situação como tal. Portanto, não é incomum haver embates e controvérsias acerca do recorte analítico que enquadra a duração e o cenário de uma catástrofe, pois tal recorte diz respeito a abrangência de danos e perdas que ficarão dentro ou deixados de fora do enredo argumentativo sobre a vida social dos afetados. Quanto menor a densidade social do discurso institucional sobre dada catástrofe ocorrida em seu espaço jurisdicional, maiores as dificuldades que as vítimas enfrentarão na garantia de seus direitos de reparaçáo.

Em termos sociais, uma tipificação possível de desfiliação social associada a uma catástrofe poderia considerar cinco diferentes situações:

- A mais radical, aquela na qual o corpo do sujeito subitamente some e não é localizado por algum tempo ou jamais o é (desaparecido), o que deixa em suspenso as relaçóes do mesmo com os demais sujeitos de seus vínculos;

- Em seguida, aquela na qual a vida se esvai do corpo físico (morto), devido a agravos fatais, o que encerra as interaçóes do sujeito com terceiros, os quais reelaboram tal perda e ausência através do luto e da memória;

- Depois há os feridos e enfermos, cuja debilidades adquiridas ou agravadas criam ou aumentam a sua dependência de apoio de terceiros para a satisfação de necessidades mínimas vitais e sociais;

- Os desabrigados, que na ausência de possibilidades de acolhimento por sua rede primária de relaçôes, ficam na tutela do Estado, que organiza abrigos provisórios para os mesmos; e, por fim,

- Os desalojados, cuja perda da moradia os coloca na constrangedora situaçáo de precisar residir com parentes e amigos por um período indeterminado. 
Essas situações não são excludentes para a comunidade ou famílias afetadas numa catástrofe, pois dizem respeito aos dois 'corpos' essenciais da sociabilidade privada, a do corpo físico humano e o da casa antropoformizada e, por fim ao 'corpo' da mais amistosa e relevante sociabilidade pública, a comunidade.

Assim, uma família que esteja circunstancialmente desabrigada, tem esse estresse somado ao fato de ter tido um membro desaparecido, um vizinho morto e seu pequeno estabelecimento comercial arruinado; outra família pode estar desalojada e ter vários membros feridos, enquanto sua igreja colapsou; essas famílias podem estar conectadas por laços de sangue ou de compadrio; e assim por diante, ou seja, as condiçóes do indivíduo e de seu núcleo social, família/ comunidade, podem estar simultaneamente debilitadas, sendo de grande monta o desafio do recomeço da vida social. Nesse quadro, a impaciência de técnicos e voluntários autocentrados aprofunda o sofrimento de quem tem que procurar recursos intersubjetivos para validar novos caminhos diante múltiplas perdas.

Feitas essas consideraçóes preliminares, e a título ilustrativo, elencamos alguns aspectos de reabilitaçáo que deveriam ser levados em conta pelas organizaçôes governamentais competentes e grupos voluntários numa circunstância que envolva a devastaçáo de uma comunidade.

O primeiro deles, reiteramos, é o de que o olhar desses sujeitos externos busca focalizar fragmentos da situação conforme os filtros de sua competência especializada de atuação; no entanto, o repertório do morador local tende a ser mais abrangente, porque é constituído não apenas daquilo que está posto fenomenicamente diante si, mas de representaçôes comunitariamente compartilhadas, que decifram as conexóes dos residentes entre si bem como com certos sistemas de objetos, as suas práticas habituais ou disposiçóes comportamentais.

Mais terrível é a catástrofe vivida quando, ao testemunho da perturbação havida no espaço comunitário, soma-se a destruiçẫo ou danificação da própria moradia. Esse é um espaço crucial no exercício contínuo de humanização, porque é o lugar onde o sujeito elabora as suas referências básicas para o exercício dos múltiplos papéis sociais na tarefa multifacetada do viver; a começar, pelo aprendizado das especificidades das convençóes, princípios, valores e 
afetos que assentam as interaçôes sociais no núcleo de origem, que é família e, em seguida, na preparaçáo para lidar com os desafios da esfera pública, que espreitam para além da porta.

Ademais, a moradia é o espaço do restauro físico, mental e emocional, além do da intimidade e do devaneio. A casa é como um ninho, cuja proteção espacial à sociabilidade mais íntima preserva os sujeitos em sua integridade física e psíquica, sua identidade social e interaçôes mais intensas. Desde quando o sujeito começa a ser moldado socialmente na tenra idade até quando, já na velhice, precisa restaurar-se dos desgastes da vida, a casa é o anteparo frente às rudezas do mundo, tomando afetivamente feiçôes antropoformizadas e, perante à família convivente, vista como depositária da memória de seus moradores, testemunha silenciosa da trajetória evolutiva do grupo em cada um dos cômodos e nas relaçóes destes com certos objetos como com quadros, cofres, armários (Bachelard, 2003).

É ali que os bens materiais auxiliam na mediação da sociabilidade privada e contribuem para a germinação de um universo simbólico próprio (Santos, 1998), o qual servirá de esteio para categorizar as impressóes colhidas do mundo externo e pautar as escolhas e açóes diante do mesmo. Isso explica o porquê de os membros da família - especialmente, as chefes do lar - prostrarem-se diante dos escombros da moradia devastada numa catástrofe. Procuram ali enxergar os resquícios materiais daquele funcionamento cotidiano acolhedor, as memórias dos tempos bons e de desafios vencidos, enfim, indicativos da proteção que esse envoltório deu aos seus membros diante as felicidades e as adversidades comuns da vida social (Valencio, 2014). A casa contém a família e está é a substância da casa (Sarti, 1995) de modo que são forma e conteúdo de uma unidade social.

Essa é uma das razôes pelas quais a principal medida de reabilitação - prover acolhida em local provisório para a família desabrigada - tem alguns desafios dos quais o meio técnico-operacional e o voluntariado pouco se apercebem.

No que concerne ao acesso à comunidade devastada, os vínculos emocionais e simbólicos do grupo com o lugar deveriam ser devidamente considerados pelas equipes que atuam na emergência. Técnicos, por vezes, pensam que colocar máquinas e equipamentos prontamente no local - por vezes, levando abaixo 
os restos de moradias destruídas ou seriamente danificadas - e promover a limpeza rápida dos resquícios da destruição é a maneira de mostrar a eficiência da máquina pública.

No entanto, isso pode agredir os tempos internos que os membros da comunidade precisam para fazer o luto coletivo, examinar em segurança os escombros das suas moradias e realizar derradeiras tentativas de recuperação de objetos de memória (fotos de família, presente de entes queridos, objetos que recordem momentos emblemáticos da vida familiar) e de utilidade prática para recomeçar a vida algures (Valencio et al., 2007).

O resguardo a esse tempo social exigiria que os técnicos auxiliassem a preservar a comunidade do assédio de terceiros, tais como dos meios de comunicação e de voluntários de comportamento invasivo, que exaurem psicologicamente as vítimas, mesmo quando querem auxiliar, pois impedem que elas tenham espaço para seus silêncios e conversas reservadas.

\section{Conclusão}

O reencontro dos moradores com os fragmentos de seu lugar de vinculação fica envolto em muita tristeza e suas memórias, quando acedidas, passam por reelaboraçóes que atendem primordialmente a um tempo intersubjetivo que é inteligível apenas por aqueles que compartilham a mesma trajetória de produção daquele lugar. Isso costuma ser visto como 'perda de tempo' pelos técnicos atuantes na emergência e que supóem que somente os seus afazeres por ali sejam relevantes.

Então, violência maior não há, em termos simbólicos, quando os técnicos tendem a dispersar do 'cenário' essa 'gente que atrapalha' e impor uma hierarquia na qual o seu tempo de trabalho e a sua prática atuação prevalecem; por exemplo, através de priorização das avaliaçóes de engenharia, interdição do local para perícia policial e afins. A racionalidade burocrática é monológica e, assim, desconsidera a necessidade de negociação entre esses diversos tempos e universos de sentido. O que disso resulta é o atropelo do mundo privado 
e comunitário, a violação de direitos pela forma autoritária de imposição de situaçóes inaceitáveis de abrigo e provimentos (Tierney et al., 2006), o que intensifica a dor moral e emocional que envolvem os grupos afetados.

No que se refere às alternativas de acolhimento provisório que os técnicos procuram oferecer às famílias, há que se considerar que as opções, no geral, ficam aquém dos anseios da família para reproduzir o seu modo habitual de funcionamento.

Se a mesma fica obrigada a compartilhar o espaço com terceiros, isso traz grandes constrangimentos aos seus membros, porque já não podem expressar-se espontaneamente e nem interagir uns com os outros do jeito usual.

A inserção num espaço alheio - seja ele um acampamento, um abrigo provisório instalado em equipamentos públicos voltados à outras finalidades rotineiras (escola, ginásio de esportes, estabelecimento religioso ou comunitário etc.), moradia de amigos ou de parentes - subjuga a família ao controle externo dos que detêm o controle desse novo espaço.

A dinâmica da vida privada em torno do exercício dos papéis sociais complementares bem como dos afazeres cotidianos sofre interferências inoportunas que são fonte de estresse para os acolhidos e, ainda, enfraquece as linhas endógenas de autoridade dessa família (por exemplo, dos pais em relação aos filhos).

O compartilhamento de tarefas como as de limpeza do local, cocção, organizaçáo de objetos e afins tem conotaçáo distinta da que tinha na moradia de origem; os procedimentos de execução devem agradar aos gostos de terceiros; manifestaçôes de intimidade são censuradas; o devaneio e o restauro emocional são vistos como ociosidade ou indolência daqueles a quem se impede que dediquem um tempo para mergulhar dentro de si e de seu sofrimento (Valencio et al., 2007).

Ademais, há uma ambígua relação entre indivíduos e famílias, assim como entre essas e as demais que compóem a comunidade de inserção.

De um lado, os indivíduos querem estar juntos de sua família de convivência, seja ela nuclear ou extensiva, para se sentirem emocionalmente melhor amparados - sendo, por isso, uma violência a adoção de critérios técnicos que, ao montar abrigos, separem os membros de uma família por recorte de gênero - mas, ao mesmo tempo, apreciam manter seus espaços íntimos para descanso, quando se trata de casais, adolescentes, jovens e idosos. 
De outro lado, quando uma comunidade é forjada por vínculos fortes entre seus moradores, convém que a montagem de abrigos provisórios leve em conta essas relaçóes de convivência e vizinhança, contudo, preservando a privacidade de cada qual para evitar que haja extrapolaçóes indevidas e inconvenientes de curiosidade e proximidade entre os mesmos.

Esses desafios são aludidos aqui para destacar que, longe de ser algo de fácil equacionamento, a dinâmica de acolhimento das famílias que serão tipificadas como desabrigadas ou desalojadas é problemática, pois impóe uma convivência sempre pública enquanto um imóvel original não for restaurado ou enquanto uma nova moradia não for viabilizada.

Após algum tempo em que técnicos, voluntários e pessoas da rede primária se dedicam ao acolhimento circunstancial da família vitimada, emerge a fadiga da compaixão (Sennett, 2004), na qual o apoio ao infortúnio cede ao cansaço das práticas de solidariedade e as relaçóes entre atendentes e atendidos se deterioram rapidamente.

Conclui-se, assim, que as catástrofes correspondem à perda de elementos indispensáveis para a emancipação humana dos grupos afetados (Valencio et al., 2007) e, portanto, não é trivial requerer-se uma maior amplitude e sensibilidade das visões técnicas em torno da duração desse acontecimento trágico e, por conseguinte, dos procedimentos atinentes àquilo que denominarão como pós-catástrofe. Esse alargamento interpretativo que porventura ocorra incidirá em como os grupos afetados poderão ser apoiados, em seus esforços autônomos, para lidarem com a situação (The Sphere Project, 2000) e na preocupação do Estado para que a assistência complementar prestada esteja em sintonia com os termos socioculturais locais. Incidirá, ainda, no respeito aos requerimentos subjetivos dos afetados, na forma como esses possam se re-apropriar de seus próprios corpos, serem ativos no funcionamento de seus lares provisórios e seguros nos seus relacionamentos públicos retomados; enfim, terem meios que garantam alguma qualidade no restante da vida a ser vivida. 


\section{Referências bibliográficas}

Bachelard, G. (2003). A poética do espaço. (1. Ed., 6.a tiragem) São Paulo: Martins Fontes.

Bourdieu, P. (2004). O poder simbólico. (7.a ed). Rio de Janeiro: Bertrand Brasil.

Dombrowsky, W.R. (1998). Again and again: is a disaster what we call a 'disaster'? In: E.L. Quarantelli (Ed.). What is a Disaster? Perspectives on the Question. London and New York: Routledge, 19- 30.

Nixon, R. (2011). Slow Violence and the Environmentalism of the Poor. Cambridge, MA: Harvard Univ. Press.

Quarantelli, E.L. (1998). Introduction: the basic question, its importance, and how it is addressed in this volume. In: E.L. Quarantelli (Ed.). What is a Disaster? Perspectives on the Question. London and New York: Routledge, 1-7.

Quarantelli, E. L. (2005). A social science research agenda for de disasters of the $21^{\text {st }}$ century: theoretical, methodological and empirical issues and their professional implementations. In: R.W.Perry \& E.L. Quarantelli (Eds.). What is a disaster? New answers to old questions. United States of America: International Research Committee on Disasters, 325-396.

Santos, M. (1998). Técnica, espaço, tempo - globalização e meio técnico-científico informacional. São Paulo: Editora Hucitec.

Sarti, C. A. (1995). A família como espelho. Campinas: Autores Associados.

Sennett, R. (2004). Respeito: a formação do caráter em um mundo desigual. Rio de Janeiro: Ed. Record.

Sorokin, P. A. (1942). Man and society in calamity - the effects of war, revolution, famine and pestilence upon human mind, behavior, social organization and cultural life. New York: E.P. Dutton and Company Inc.

THE SPHERE PROJECT (2000). Carta Humanitária e normas minimas de resposta humanitária em situaçâa de desastre. Oxford: Ox'fam.

Tierney, K., Bevc, C. \& Kuligowsky, E. (2006). Metaphors matter: disaster myths, media frames, and their consequences in hurricane Katrina. Ann. Am. Acad. Polit. Soc. Sci., 604(1), 57-81 (2006). DOI: http://dx.doi.org/10.1177/0002716205285589.

Valencio, N. F. L. D. S., Siena, M., Marchezini, V., \& da Cunha Lopes, D. (2007). O desastre como desafio para construçáo de uma hermenêutica diatópica entre o Estado e os afetados. Cronos, 8, 81-100. Acedido em 10 novembro de $2008 \mathrm{em}$ : http://www.periodicos.ufrn.br/cronos/article/view/3169/2559

Valencio, N. (2014). Desastres: tecnicismo e sofrimento social. Ciência e Saúde Coletiva. 19(9), 3631-3644. DOI: http://dx.doi.org/10.1590/1413-81232014199.06792014. 
(Página deixada propositadamente em branco) 


\section{CONCLUSÃO}

\section{Luciano Lourenço \\ Departamento Geografia e Turismo, CEGOT e RISCOS, \\ Universidade de Coimbra (Portugal) \\ ORCID: 0000-0002-2017-0854 luciano@uc.pt}

A edição desta obra, em conjunto com as que se lhe seguirão sobre Catástrofes, veio colmatar uma lacuna existente na bibliografia cindínica de língua portuguesa, na medida em que, até agora, não havia nenhuma obra de referência que desse uma visão de conjunto dos diferentes riscos e das suas plenas manifestaçóes, as catástrofes.

Ora, do conjunto destes quatro livros, este primeiro apresenta uma profunda reflexão sobre muitos dos aspetos conceptuais usados pelas diferentes ciências que versam sobre aspetos particulares dos riscos, a qual é feita numa perspetiva holística e, por isso, nem sempre estará de acordo com algumas visóes parcelares de um ou outro conceito, pelo que a primeira conclusão a retirar é a de que se abriu uma porta que permitirá fazer uma reflexão sobre o significado de alguns conceitos em uso na língua portuguesa.

Por outro lado, sendo este volume, de certa forma, dedicado à teoria do risco, as questóes metodológicas não podiam deixar de também ser tidas em conta, tanto na análise e avaliação, como na gestão do risco, as quais conduzem à definição das políticas públicas na área da proteção civil e, por conseguinte, aos modelos de prevenção, socorro e reabilitação, sectores que constituem os pilares de sustentação da proteção civil e que, por essa razão não podiam deixar de ser considerados.

De entre eles, foi dada ênfase à gestão, na medida em que ela deverá ser a chave de sucesso das diferentes operaçóes., a começar pela gestão do risco, como medida de prevenção, passando à gestão da catástrofe, como medida de resposta à crise, onde a organização do socorro desempenha um papel fundamental, e terminando com a gestão do pós-catástrofe, não só como medida de proteção e de mitigação da crise, mas também e sobretudo para aumento da resiliência das áreas afetadas.

Qualquer um dos capítulos e subcapítulos desta obra, que se dedica ao tratamento destas matérias, faculta ampla informação sobre os temas apresentados que, certamente, contribuirá para enriquecer o conhecimento de todos aqueles e aquelas 
que se dedicam à investigação destes assuntos, bem como aos intervenientes nas diferentes missóes de prevenção, socorro e reabilitação, e, também, dos cidadãos anónimos que se interessam pela sua proteção individual e pela segurança das comunidades em que se integram. 


\section{SÉRIE \\ RISCOS E CATÁSTROFES}

Títulos Publicados:

$1 \quad$ Terramoto de Lisboa de 1755. O que aprendemos 260 anos depois?

2 Sociologia do Risco;

3 Geografia, paisagem e riscos;

4 Geografia, cultura e riscos;

5 Alcafache. 30 anos depois;

6 Riscos e crises. Da teoria à plena manifestação;

Volume em publicação:

7 Catástrofes naturais. Uma abordagem global;

8 Catástrofes antrópicas. Uma aproximação integral;

9 Catástrofes mistas. Uma perspetiva ambiental. 
(Página deixada propositadamente em branco) 
Luciano Lourenço é doutorado em Geografia Física, pela Universidade de Coimbra, onde é Professor Catedrático.

É Diretor do NICIF - Núcleo de Investigação Científica de Incêndios Florestais, da Faculdade de Letras da Universidade de Coimbra e Presidente da Direção da RISCOS - Associação Portuguesa de Riscos, Prevenção e Segurança.

Exerceu funções de Diretor-Geral da Agência para a Prevenção de Incêndios Florestais, Presidente do Conselho Geral da Escola Nacional de Bombeiros e Presidente da Direção da Escola Nacional de Bombeiros.

Consultor científico de vários organismos e de diversas revistas científicas, nacionais e estrangeiras, coordenou diversos projetos de investigação científica, nacionais e internacionais, e publicou mais de mais de três centenas de títulos, entre livros e capítulos de livro, artigos em revistas e atas de colóquios, nacionais e internacionais.

António Duarte Amaro é Doutorado em Geografia Humana pela Universidade do Porto, Mestre em Sociologia pelo Instituto Superior de Ciências Sociais e Políticas, da Universidade Técnica de Lisboa, Licenciado em Sociologia pelo Instituto Universitário de Lisboa-ICSTE e em Serviço Social, pelo Instituto Superior de Serviço Social de Lisboa.

Foi Diretor e Professor Coordenador da Escola Superior de Saúde do Alcoitão (ESSA). Atualmente, é Diretor do Centro de Investigação Científica Aplicada da Santa Casa de Misericórdia de Lisboa (SCML), Presidente do Conselho Consultivo da Aldeia de Santa Isabel e seu fundador em 1985 .

Colabora ainda, na qualidade de Professor Catedrático Convidado, com a Universidade Lusófona, e como Professor Associado Convidado com a Faculdade de Direito da Universidade Nova de Lisboa e com o Instituto de Estudos Superiores Militares.

É vice-presidente da Associação Portuguesa de Riscos, Prevenção e Segurança (RISCOS) e Editor Associado da Revista "Territorium" e Diretor Ajunto da Revista de Direito e Segurança. 


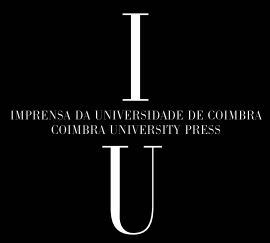

$R / 5 C 05$ 